JULIANA CAROLINE DE ALENCAR DA SILVA

\title{
BACIAS HIDROGRÁFICAS URBANIZADAS: \\ RENATURALIZAÇÃO, REVITALIZAÇÃO E RECUPERAÇÃO. UM ESTUDO DA BACIA DO JAGUARÉ.
}

São Paulo

2017

Av. Prof. Almeida Prado, trav. 2, $n^{\circ} 271$-Cidade Universitária - Butantã CEP. 05508-900 - São Paulo - Capital

Tel.: 3091-5444 Fax: 3091-5423 


\section{BACIAS HIDROGRÁFICAS URBANIZADAS: RENATURALIZAÇÃO, REVITALIZAÇÃO E RECUPERAÇÃO. UM ESTUDO DA BACIA DO JAGUARÉ.}

Tese de doutorado apresentada à Escola Politécnica da Universidade de São Paulo para obtenção do título de Doutora em Ciências.

Área de Concentração: Engenharia Hidráulica e Ambiental

Orientadora: Prof ${ }^{a}$ Dra $^{a}$ Monica Ferreira do Amaral Porto.

São Paulo

2017

Av. Prof. Almeida Prado, trav. 2, $n^{\circ} 271$-Cidade Universitária - Butantã CEP. 05508-900 - São Paulo - Capital

Tel.: 3091-5444 Fax: 3091-5423 
Este exemplar foi revisado e alterado em relação à versão original, sob responsabilidade única do autor e com a anuência de seu orientador.

São Paulo, 21 de agosto de 2017

Assinatura do autor

Assinatura do orientador

FICHA CATALOGRÁFICA

Silva, Juliana Caroline de Alencar da

Bacias Hidrográficas Urbanizadas: Renaturalização,

Revitalização e Recuperação. Um Estudo da Bacia do Jaguaré / J.C.A. da Silva. -versão corr- São Paulo, 2017. $310 \mathrm{p}$.

Tese (Doutorado) - Escola Politécnica da Universidade De São Paulo. Departamento de Engenharia Hidráulica e Ambiental.

1. Hidrologia urbana 2. Cursos d'água urbanos I. Universidade de São Paulo. Escola Politécnica. Departamento de Engenharia Hidráulica e Ambiental II. t. 


\section{AGRADECIMENTOS}

Como todo trabalho de pesquisa, este é fruto de uma jornada que não foi trilhada sozinha, me acompanharam nela muitos profissionais que ao longo do processo se tornaram também meus amigos, não só pelo companheirismo, mas também por compartilhar o sonho de desfrutar um dia de cidades que convivam de forma harmônica com as águas. Sou infinitamente grata a eles.

Faz parte deste grupo de profissionais minha orientadora Monica que não poderia deixar de receber um agradecimento especial por ser a orientadora fantástica que é. Cada experiência passada e cada oportunidade proporcionada foram decisivas para a formação da profissional que sou hoje. Muito obrigada.

Estes últimos seis anos e meio de vida acadêmica, do mestrado ao doutorado, não se limitaram somente à leitura de artigos e atividades de laboratório, foram constituídos também de visitas a diversos cursos d'água pelo Brasil e pelo mundo, que foram definitivas para o amadurecimento da minha percepção sobre as águas urbanas. Agradeço aos financiamentos de viagem recebidos para participação em eventos e estágios que me proporcionaram a chance de vivenciar estas experiências (PROAP, FAPESP, CNPQ e CAPES).

E no meio de todo esse processo eu me tornei mãe. Antes eu lutava por um mundo melhor. Hoje eu luto por um mundo melhor pra você Mumu. Mamãe te ama. Obrigada por dar ainda mais sentido para tudo isso. E por falar em filhos amados, um agradecimento especial à minha quase filhinha Dani, que é meu orgulhinho e parceira de viagens.

E como encontrar palavras para agradecer a você Julio... Obrigada meu amor, por ser meu parceiro de todas as horas, sem você certamente essa jornada teria sido muito mais difícil. 


\section{RESUMO}

A urbanização traz consigo diversos desafios, dentre eles, o manejo das águas, o qual se destaca por englobar aspectos de diversas áreas do conhecimento $\mathrm{e}$ demandar soluções multidisciplinares, o que nem sempre é fácil de alcançar. O presente estudo se dedicou à analise dos principais aspectos e desafios envolvidos no processo de requalificação de corpos d'água em áreas urbanas. Discute-se a renaturalização, a revitalização e a recuperação, e suas dificuldades, como o controle efetivo das cargas poluidoras na bacia hidrográfica, o reestabelecimento das funções ecossistêmicas dos corpos d'águas e a promoção da integração da população no processo a fim de garantir sua efetividade e durabilidade. Este estudo compreende a análise crítica das principais técnicas existentes de manejo da água no meio urbano; das metodologias de tratamento de canais atualmente empregadas; das novas técnicas de drenagem, consideradas sustentáveis; e das estruturas utilizadas para controle de cargas poluidoras. Para tanto as técnicas estudadas foram aplicadas em uma proposta de requalificação da bacia hidrográfica do córrego Jaguaré, situada na zona oeste do município de São Paulo, a fim de auxiliar estudos futuros no melhor entendimento dos processos envolvidos e na escolha da melhor técnica de manejo (renaturalização, revitalização ou recuperação) a ser empregada para distintos cenários. A bacia do córrego Jaguaré conta com uso do solo heterogêneo, possuindo desde áreas verdes bem preservadas, até remanescentes industriais e rodovias e, portanto, apresenta diversos problemas e usos conflituosos do espaço, o que garante a ela um campo fértil para estudos relativos ao manejo das águas. Para validar a proposta de requalificação foi realizada ainda uma consulta pública junto aos moradores da bacia a fim de compreender as demandas da sociedade.

PALAVRAS-CHAVE: Renaturalização de corpos d'água; Revitalização de corpos d'água; Recuperação de corpos d'água; Drenagem sustentável; Infraestrutura verde; Qualidade da água; Recursos hídricos. 


\begin{abstract}
Urbanization brings with it several challenges, among them water management that stands out because it involves aspects of several areas of knowledge and demands multidisciplinary solutions, which is not always easy to achieve. The present study was devoted to the analysis of the main aspects and challenges involved in the process of urban watercourses requalification. The restoration, revitalization and recovery, and their difficulties, such as the effective pollution control in the watershed, the reestablishment of the ecosystem functions of the watercourses and the population integration in order to ensure the process effectiveness and durability. This study includes the critical analysis of the main existing water management techniques, such as methodologies of channels treatment currently employed, sustainable drainage, and structures used for pollutant control. The techniques studied were applied in a proposal for the Jaguaré watershed requalification, located in the western zone of São Paulo city, in order to help future studies to better understand the processes involved. Besides that it helps to choose the best management techniques (Restoration, revitalization or recovery) to be used for different scenarios. The Jaguaré watershed has a heterogeneous land occupation, preserving green areas, residential use, industrial remnants, and highways. Therefore, it presents several problems and conflicting land uses, which ensures it is a fertile field for water management studies. In order to validate the requalification proposal, a public consultation was also held with the watershed residents, in order to understand the society's demands.
\end{abstract}

KEYWORDS: River restoration; River revitalization; River recovery; Sustainable drainage; Green infrastructure; Water quality; Water resources. 


\section{LISTA DE ILUSTRAÇÕES}

Ilustração 01- Tributário do córrego Jaguaré. Desafios para o manejo das águas em áreas urbanas. Fonte: Foto da autora.

Ilustração 02- Caminho do Rio Pinheiros em 1930 e suas manchas de inundação naturais nas cotas $735,730,725$ e 720 . Fonte: Elaborado pela autora a partir de EMPLASA e SARA Brasil.

Ilustração 03- Tipos de ocupação em áreas várzea. Fonte: Fotos da autora. 38

Ilustração 04- Autodepuração em corpos d'água. Fonte: Guia ecológico (s/d).

Ilustração 05- Evolução da Demanda Bioquímica de Oxigênio (DBO) no período de 01/01/2007 a 01/01/2012 nos córregos da Zona Oeste pertencentes ao programa "Córrego Limpo" e comportamento da precipitação neste período. Fonte: Elaborado pela autora a partir de Córrego Limpo (s/d) e SAISP (2012).

Ilustração 06- Esgotamento de soleiras negativas em fundos de vale. Fonte: Elaborado pela autora.

Ilustração 07- Fontes de Poluição no Meio Urbano. Fonte: Elaborado pela autora a partir de Walesh (1989)

Ilustração 08- Componentes da carga difusa. Fonte: Elaborado pela autora.

Ilustração 09- Córrego do Sapé antes e depois de uma precipitação no verão de 2012. Fonte: Fotos da autora.

Ilustração 10- Dragagem do rio Pinheiros na foz do córrego Pirajussara em junho de 2015. Fonte: Fotos da autora.

Ilustração 11- Exemplo de canalização. Fonte:Elaborado pela autora. 52

Ilustração 12- Revestimentos flexíveis. Fonte: Adaptado de Brighetti et al.(1999).

Ilustração 13- Proteções rígidas. Fonte: Fonte: Adaptado de Brighetti et al.(1999). 
Ilustração 14- Tipos de intervenções em corpos d'água. Fonte: Adaptado de Findlay \& Taylor (2006)

Ilustração 15- Equilibrio do processo de intervenção em corpos d'água. Fonte: Adaptado de Findlay \& Taylor (2006).

Ilustração 16- Metodologia multicriterial para orientação de processos decisórios em cursos d'água urbanos. Fonte: Cardoso e Baptista (2013).

Ilustração 17- Zona de intersecção dos projetos de revitalização de corpos d'água mais eficazes. Fonte: Adaptado de Palmer et al. (2005)

llustração 18- Filtro de fluxo vertical. Fonte: Global wetlands (s/d).

Ilustração 19- Espécies vegetais utilizadas em Wetlands para tratamento de efluentes. Fonte: Discovery life (s/d). 76

Ilustração 20- Filtro de fluxo vertical. Fonte: Philippi et al. (2007). 76

Ilustração 21- Funcionamento do filtro percolador. Fonte: Hoffmann et al. (2004). . 77

Ilustração 22- Esquema de funcionamento do Reator Sequencial por Batelada. Fonte: Hoffmann et al. (2004).

llustração 23- Bacia de evapotranspiração (BET). Fonte: Benjamin (2013).

Ilustração 24- Exemplos de ETE's compactas. Fonte: Flipper (s/d). 80

Ilustração 25- Técnica de infraestrutura verde adotadas em Freiburg. Fonte: Adaptado de Herzog e Rosa (2010).

Ilustração 26- Exemplo de um sistema tradicional de drenagem. Fonte: Elaborado pela autora. .84

Ilustração 27- Hidrograma de uma bacia rural e depois de urbanizada. Fonte: Tucci (2008).

Ilustração 28- Engenharia rígida x Engenharia flexível. Fonte: UACDC (2010). 86 
Ilustração 29- LID aplicado a um sistema viário. Fonte: Adaptado pela autora a partir de UACDC (2010).

Ilustração 30- LID aplicado a um estacionamento. Fonte: Adaptado pela autora a partir de UACDC (2010).

Ilustração 31- LID aplicado a um fundo de vale. Fonte: Adaptado pela autora a de UACDC (2010).

Ilustração 32- Técnicas do LID e seus índices de qualidade e quantidade. Fonte: UACDC (2010).

Ilustração 33- Exemplo de wetland na Nova Zelândia. Fonte: DOC (s/d). 92

Ilustração 34- Espécies adotadas em wetlands. Fonte: Discovery life (s/d).

llustração 35- Wetland para tratamento da drenagem proveniente de tipologias comerciais e industriais em Los Angeles. Fonte: Fotos da autora.

Ilustração 36- Water Square na ausência de precipitações. Fonte: Urbanisten (s/d).

Ilustração 37- Water Square na ocorrência de precipitações de baixas intensidades. Fonte: Urbanisten (s/d). .98

llustração 38- Water Square na ocorrência de precipitações de elevadas intensidades. Fonte: Urbanisten (s/d). .98

Ilustração 39- Projeto do Córrego Antonico. Fonte: Galeria da Arquitetura (s/d). Esquema do Antes e depois da implantação do canal de águas controladas. Fonte: Elaborado pela autora.

Ilustração 40- Limpeza de bocas de lobo na cidade de São Paulo. Fonte: PMSP $(\mathrm{s} / \mathrm{d})$. 101

Ilustração 41- Funcionamento do SCS. Fonte: Adaptado de Das Neves \& Tucci (2003). 102

Ilustração 42- Funcionamento do SEPT - Fonte: Das Neves \& Tucci (2003). 102 
Ilustração 43- Monitoramento realizado em Cape Town - Fonte: Das Neves \& Tucci (2003).

Ilustração 44- Grade móvel na entrada das bocas de lobo em Los Angeles, Califórnia. Fonte: Fotos da autora. 104

Ilustração 45- Cesto no interior das bocas de lobo em Los Angeles, Califórnia. Fonte: Fotos da autora. 104

Ilustração 46- Cesto de retenção de resíduos sólidos. Fonte: PMSP (s/d). 105

llustração 47- Redes de aço no interior das galerias antes do lançamento nos corpos d'água em Los Angeles, Califórnia. Fonte: Fotos da autora. 105

Ilustração 48- Barreira flutuante e central de armazenamento de resíduos no rio Los Angeles, Califórnia. Fonte: Fotos da autora. Ecobarreira no Arroio Dilúvio, Porto Alegre. Fonte: www.ecobarreiradiluvio.com.br. 106

Ilustração 49- Varrição mecanizada em Los Angeles, Califórnia. Fonte: Fotos da autora. 106

llustração 50- Exemplo de bacia de sedimentação. Fonte: USDA (2010). 107

llustração 51- Exemplo de bacia de sedimentação no Tennessee. Fonte: TNEPSC (s/d). 107

Ilustração 52- Aspectos construtivos e operacionais de uma bacia de sedimentação. Fonte: DWSUD (2005). 108

Ilustração 53- Compartimentos dos ecossistemas aquáticos continentais. Fonte: Adaptado de Esteves (2011). 110

Ilustração 54- Medidas para reintegração de rios e riachos - A e B: Obstaculos ao longo do corpo d'água para promoção de micro habitats; C e D: conteções. artificiais para controle da erosão; E: Estruturas cobertas para abrigos artificiais; F: bacias artificiais rasas para desenvolvimento vegetal. Fonte: Pereira (2001). 113

Ilustração 55- Sistema de tratamento ecológico para recuperação de rios poluídos. Fonte: Biomatrix (s/d). 
Ilustração 56- Detalhes da implantação do MacSoil. Fonte: Maccaferri (s/d).

Ilustração 57- Rio Isar revitalizado. Fonte: Cengiz (2013).

Ilustração 58- Rio Besos revitalizado. Fonte: Ajuntament de Santa Coloma de

Gramenet (2015). 128

Ilustração 59- Rio Porsuk (Foto A) e Bartin (Foto B e C) revitalizados. Fonte: Cengiz (2013).

Ilustração 60- Rio Mississipi revitalizado. Fonte: Cengiz (2013). 130

Ilustração 61- Rio Trinity (Foto A e B) e Onondaga (Foto C e D) revitalizados. Fonte: Cengiz (2013).

Ilustração 62- Rio San Antonio revitalizado. Fonte: Cengiz (2013). 132

Ilustração 63- Rio Gwynns revitalizado. Fonte: ESA, 2010. 132

Ilustração 64- Rio Los Angeles. Fonte: Tetra Tech (2007). 133

Ilustração 65- Rio Los Angeles. Foto A: trecho parcialmente acessível dentro do parque Griffith. Foto B: Trecho acessível somente ao departamento de manutenção no bairro de Long Beach. Fonte: Fotos da autora.

Ilustração 66- Proposta de revitalização do rio Los Angeles. Fonte: Tetra Tech (2007). 134

Ilustração 67- Rio Nine Mile revitalizado. Fonte: Cengiz (2013). 135

Ilustração 68- Avenida e via expressa elevada sobre o rio Cheonggyecheon. Fonte: Nam-choon (2005). 136

Ilustração 69- Rio Cheonggyecheon revitalizado. Fonte: Cengiz (2013). 137

Ilustração 70- Rio Itachi antes/1981 (Foto A) e depois/1993 (Foto B) do projeto de revitalização. Fonte: Nakamura, Tockner e Amano (2006). 138

Ilustração 71- Rio Tama antes/1974 (Foto A) e depois/2002 (Foto B) do projeto de revitalização. Fonte: Nakamura, Tockner e Amano (2006). 139 
llustração 72- Rio Donghao Chung na China antes (Foto A) e depois (Foto B) do projeto de revitalização. Fonte: Schneider (2015).

llustração 73- Córrego Cruzeiro antes (Foto A) e depois (Foto B) do projeto de revitalização. Fonte: Córrego Limpo (s/d).

llustração 74- Exemplos de recuperação e revitalização de corpos d'água no Brasil Córrego das Corujas. Fonte: De Oliveira et al. (2012).

llustração 75- Córrego Piranungaua - Afluente do Riacho Ipiranga - antes (Foto A) Fonte: Condepefi (s/d) e após sua revitalização (Foto B) Fonte: Fotos da Autora. .144

llustração 76- Campanha de monitoramento da qualidade da água e Seminários técnicos do "Projeto Jaguaré". Fonte: Projeto Jaguaré (s/d).

llustração 77- "Projeto Jaguaré" traçados preliminares. Fonte: Projeto Jaguaré (s/d).

llustração 78- Córrego $1^{\circ}$ de Maio em Belo Horizonte, antes (Foto A) e depois (Foto B) da revitalização. Fonte: DRENURBS (2013). 146

Ilustração 79- Projeto do parque linear Capibaribe. Fonte: UFPE (s/d). 147

llustração 80- Bacia do Canal Inferior do Rio Pinheiros. Fonte: Elaborado pela autora. 150

llustração 81- Bacia do córrego Jaguaré, seus afluentes e suas principais vias de acesso. Fonte: Elaborado pela autora.

llustração 82- Trechos da bacia do Jaguaré - Fotos A a D. Fonte: Fotos da autora. 154

llustração 83- Trechos da bacia do Jaguaré - Fotos F a H. Fonte: Fotos da autora. 155

llustração 84- Trechos da bacia do Jaguaré - Fotos I a M. Fonte: Fotos da autora. 156

Ilustração 85- Localização dos pontos referentes ao memorial fotográfico. Fonte: Elaborado pela autora. 157 
llustração 86- Uso e ocupação do solo na bacia do córrego Jaguaré. Fonte: Elaborado pela autora. 158

llustração 87- Macrozonas na Bacia do Jaguaré. Fonte: PDESP (2014). 159

llustração 88- Evolução do crescimento populacional na bacia do Jaguaré. Fonte: Projeto Jaguaré (2017). 160

llustração 89- Precipitação média na Bacia do Jaguaré. Fonte: Elaborado pela autora a partir de SAISP (s/d). 161

llustração 90- Pontos de alagamento na bacia do Jaguaré no período chuvoso de 2016. Fonte: Fotos da autora. 162

Ilustração 91- Estudo da mancha de inundação no trecho do rio Pinheiros que compreende a foz do Jaguaré. Fonte: PDMAT 3 (2013). 163

llustração 92- Corpos d'água abertos (Azul claro) e em galeria subterrânea (Azul escuro) na bacia do Jaguaré. Fonte: Elaborado pela autora 164

Ilustração 93- Nascentes na bacia do Jaguaré. Fonte: Fotos da autora. 165

Ilustração 94- Nascentes ocultas na bacia do Jaguaré. Fonte: Fotos da autora....165 llustração 95- Estrutura geológica das nascentes. Fonte: Adaptado de Davis \& DeWiest (1996). 167

llustração 96- Trechos ilustrativos do sistema de esgotamento sanitário na bacia do córrego Jaguaré. Fonte: Fotos da autora. 168

Ilustração 97- Sistema de esgotamento sanitário existente na bacia do córrego Jaguaré. Fonte: Elaborado pela autora. 169

llustração 98- Coletores tronco existentes e propostos na bacia do Jaguaré. Fonte: Adaptado do Plano Diretor Estratégico do município de São Paulo (2014). 170

llustração 99- Coleta de lixo mecanizada na bacia do Jaguaré. Fonte: Fotos da autora.

llustração 100- Setor piloto de coleta de lixo mecanizada na bacia do Jaguaré. Fonte: Adaptado de LOGA (s/d). 172 
llustração 101- Resíduos de construção civil nas ruas da bacia do Jaguaré. Fonte: Fotos da autora.

llustração 102- Ecoponto na bacia do Jaguaré. Fonte: Foto da autora. 173

llustração 103- Pontos viciados de acumulo de resíduos de grande volume na bacia do Jaguaré. Fonte: Projeto Jaguaré (2017).

Ilustração 104- Áreas contaminadas na bacia do córrego Jaguaré. Fonte: Elaborado pela autora a partir de informações levantadas junto à CETESB e à SVMA. 175

llustração 105- Áreas verdes na bacia do Jaguaré. Fonte: Fotos da autora. 176

llustração 106- Remanescentes vegetais na bacia do Jaguaré foco de atenção da SVMA. Fonte: Elaborado pela autora a partir de informações da SVMA 178

llustração 107- Mapa geológico da região metropolitana de São Paulo. Fonte: Adaptado de Monteiro et al. (2012) 182

llustração 108- Frentes envolvidas na requalificação de cursos d'água em bacias hidrográficas urbanizadas no âmbito da renaturalização, recuperação e revitalização. Fonte: Elaborado pela autora 185

llustração 109- Sistema de esgotamento sanitário existente na bacia do córrego Jaguaré. Fonte: Elaborado pela autora 189

Ilustração 110- Bacias não esgotadas para o coletor tronco SABESP existente na bacia do córrego Jaguaré. Fonte: Elaborado pela autora. 190

llustração 111- Configuração do sistema de esgotamento sanitário da bacia com a implantação dos coletores troncos previstos pela SABESP. Fonte: Elaborado pela autora. 194

Ilustração 112- Vila Nova Esperança na Bacia 3. Fonte: Adaptado de Google Earth e Foto da autora. 195

llustração 113- Efluente sanitário correndo em canaletas na Vila Nova Esperança na Bacia 3. Fonte: Fotos da autora.

llustração 114- Proposta de esgotamento da Bacia 4 196 
Ilustração 115- Lançamento de esgotos no córrego Jaguaré no trecho do CEU Uirapuru.

Ilustração 116- Esgotamento da Bacia 8. ...................................................... 198

Ilustração 117- Esgotamento da Bacia 10 .............................................. 199

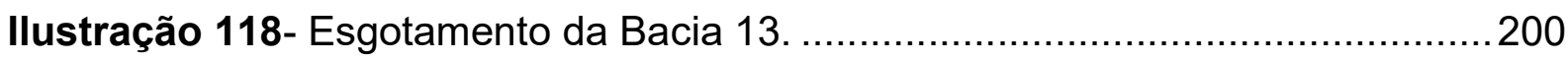

Ilustração 119- Demanda de infraestrutura sanitária na Favela para esgotamento da

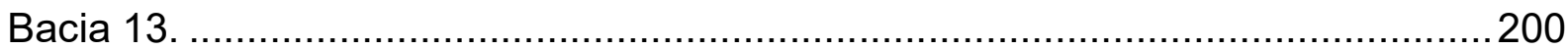

Ilustração 120....................................................................- Esgotamento da Bacia 16.201

Ilustração 121- Demanda de infraestrutura sanitária na Favela para esgotamento da

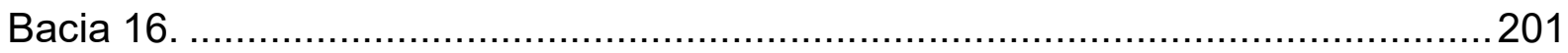

Ilustração 122- Pontos para aplicação de técnicas de esgotamento não convencionais na Bacia 16....................................................................202

Ilustração 123- Utilização de técnicas não convencionais para esgotamento da

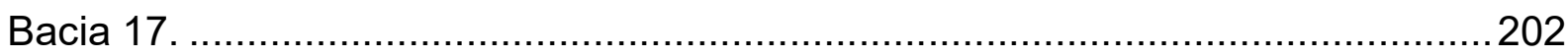

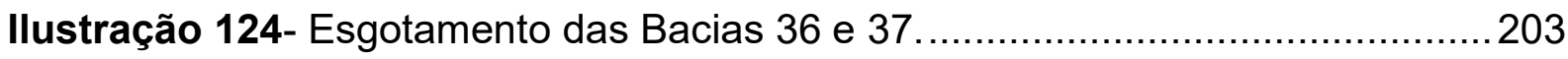

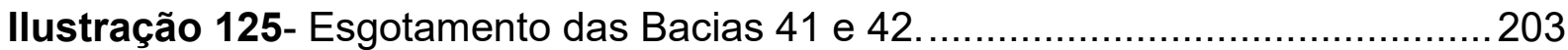

llustração 126- Utilização de técnicas não convencionais para esgotamento da

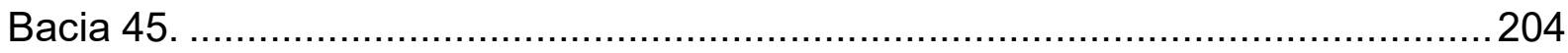

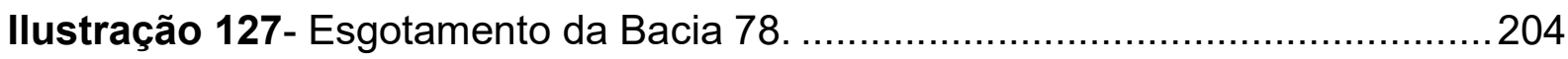

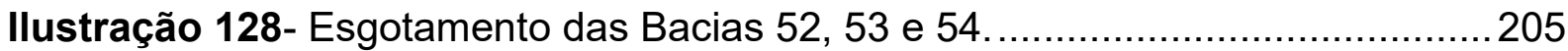

Ilustração 129- Esgotamento e demanda de infraestrutura sanitária na Favela para

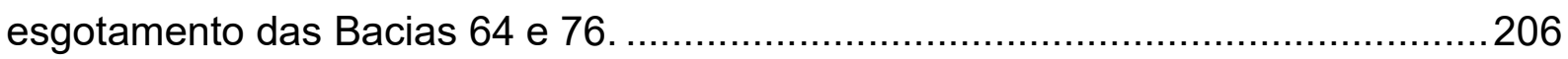

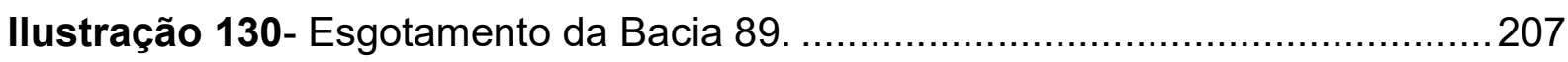

Ilustração 131- Demanda de infraestrutura sanitária na Favela para esgotamento da Bacia 89. 207 
llustração 132- Soluções propostas para a universalização do esgotamento sanitário na bacia do Jaguaré . Fonte: Elaborado pela autora.

llustração 133- Bacias de geração de carga difusa na bacia do córrego Jaguaré. Fonte: Elaborado pela autora.

Ilustração 134- Modelo de bacia de sedimentação. Fonte: MDEQ NPS BMP (2014).

llustração 135- Bacias com maior potencial de geração de carga difusa nos eventos chuvosos durante o tempo seco. Fonte: Elaborado pela autora. 218

Ilustração 136- Bacias com maior potencial de geração de carga difusa nos eventos chuvosos durante o tempo chuvoso. Fonte: Elaborado pela autora. 219

llustração 137- Pontos propostos para adoção de bacias de sedimentação. Fonte: Elaborado pela autora.

llustração 138- Sistema de controle da entrada de resíduos em dispositivos de captação do escoamento superficial. Fonte: Environment LA Sanitation.

222

llustração 139- Medidas de controle adotadas na bacia do Jaguaré. Laranja: Barreiras Flutuantes; Verde: Redes de aço em galerias da microdrenagem e em canais da macrodrenagem que encontram-se em galerias subterrâneas; Roxo: Zonas com alto potencial de geração de resíduos que demandam maior frequência de varrição.

llustração 140- Wetlands propostas para o controle de cargas provenientes de tipologias comerciais e industriais. Fonte: Elaborado pela autora. 226

llustração 141- Solução proposta para controle de cargas provenientes de tipologias comerciais e Industriais. Fonte: Elaborado pela autora. 227

llustração 142- Sistema proposto para controle de resíduos provenientes de feiras livres. Fonte: Elaborado pela autora 229

llustração 143- Solução proposta para áreas de feira livre. Fonte: Elaborado pela autora 230

llustração 144- Classificação do potencial de intervenção dos corpos d'água na bacia do Jaguaré. Fonte: Elaborado pela autora. 
Ilustração 145- Localização das bacias objetos de estudo para propostas de renaturalização, revitalização e recuperação na bacia do Jaguaré. Fonte: Elaborado pela autora.

Ilustração 146- Localização das nascentes do córrego Itaim no Parque Tizo. Fonte: Elaborado pela autora a partir de Google Earth Pro.

Ilustração 147- Trechos da nascente do córrego Itaim no Parque Tizo. Fonte: Fotos da autora.

llustração 148- Corte do cenário existente e proposto para a nascente do córrego Itaim no Parque Tizo. Fonte: Elaborado pela autora. 238

Ilustração 149- Proposta para renaturalização das nascentes do Itaim no Parque Tizo. Fonte: Elaborado pela autora. 239

Ilustração 150- Localização da praça Evandro Valério na bacia do córrego Jaguaré. Fonte: Elaborado pela autora a partir de Google Earth Pro. 242

Ilustração 151- Praça Evandro Valério na bacia do córrego Jaguaré. Fonte: Fotos da autora. 243

Ilustração 152- Córrego canalizado sob a Praça Evandro Valério na bacia do córrego Jaguaré. Fonte: Fotos da autora.

Ilustração 153- Nascente na Praça Evandro Valério na bacia do córrego Jaguaré. Fonte: Fotos da autora.

Ilustração 154- Proposta de revitalização do córrego da nascente - Planta de implantação. Fonte: Elaborado pela autora. 246

Ilustração 155- Referências das estruturas previstas na proposta. Fonte: Maine/ Hargreaves/ Ramsar/ Itishk/ Otanabee.

Ilustração 156- Localização do córrego canalizado sob a Avenida Corifeu de Azevedo Marques. Fonte: Elaborado pela autora a partir de Google Earth Pro......251

Ilustração 157- Córrego canalizado sob a Avenida Corifeu de Azevedo Marques na bacia do córrego Jaguaré. Fonte: Fotos da autora 
llustração 158- Sistema coletor da bacia do córrego sob a Av. Corifel de Azevedo Marques. Fonte: Elaborado pela autora a partir do cadastro SABESP.

llustração 159- Localização dos trechos do córrego Jaguaré e dos cortes dos cenários existentes e propostos. Fonte: Elaborado pela autora

llustração 160- Trechos do córrego Jaguaré e dos cortes dos cenários existentes e propostos. Fonte: Elaborado pela autora.

llustração 161- Seções estudadas na bacia do Jaguaré. Fonte: Elaborado pela autora. 255

llustração 162- Corte AA - Repensando a várzea do Jaguaré. Fonte: Elaborado pela autora. 256

llustração 163- Corte BB - Repensando a várzea do Jaguaré. Fonte: Elaborado pela autora.

llustração 164- Corte CC - Repensando a várzea do Jaguaré. Fonte: Elaborado pela autora.

llustração 165- Corte DD - Repensando a várzea do Jaguaré. Fonte: Elaborado pela autora.

llustração 166- Corte EE - Repensando a várzea do Jaguaré. Fonte: Elaborado pela autora. 260

llustração 167- Corte FF - Repensando a várzea do Jaguaré. Fonte: Elaborado pela autora 261

llustração 168- Remanescentes vegetais protegidos e desprotegidos na bacia do Jaguaré. Fonte: Elaborado pela autora

llustração 169- Locais de avistamento de avifauna no parque Tizo. Fonte: SVMA, 2012 270

Ilustração 170- Proposta de infraestrutura verde e azul. Fonte: Elaborado pela autora. 271

llustração 171- Estrutura de biorretenção. Fonte: Adaptado de Moura, Pellegrino e Martins, 2014 
Ilustração 172- Tipos de viário na bacia do Jaguaré. Fonte: Elaborado pela autora. .273

Ilustração 173- Tratamento típico do viário. Fonte: Elaborado pela autora. 274

llustração 174- Perfil dos entrevistados. Fonte: Elaborado pela autora. 279

Ilustração 175- Resultados questionário específico: parte 1. Fonte: Elaborado pela autora. 280

Ilustração 176- Resultados questionário específico: parte 2. Fonte: Elaborado pela autora 281

Ilustração 177- Resultados questionário específico: parte 3. Fonte: Elaborado pela autora.

Ilustração 178- Resultados questionário específico: parte 4. Fonte: Elaborado pela autora.

Ilustração 179- Consulta pública realizada na bacia do córrego Jaguaré. Fonte: Fotos da autora 283 


\section{LISTA DE TABELAS}

Tabela 1- Custo do tratamento da água em bacias com diferentes índices de cobertura vegetal. Fonte: Adaptado de Postel \& Barton (2005).

Tabela 2- Efeitos da urbanização sobre canais. Fonte: Chin e Gregory. (2005).

Tabela 3- Impactos das intervenções e seus indicadores. Fonte: Adaptado de Cardoso e Baptista (2011). 63

Tabela 4- Medidas estruturais para controle de cargas difusas. Fonte: Elaborada pela autora a partir de Souza (2000), Tomaz (2006) e USEPA (s/d).

Tabela 5- Atuação das medidas estruturais. Fonte: UDFCD (2011).

Tabela 6- Técnicas de construção de wetlands. Fonte: Elaborada pela autora a partir de Salati (2003).

Tabela 7- Impactos e serviços ambientais em áreas urbanas. Fonte: Mendiondo (2008).

Tabela 8- Usos do solo na bacia do Jaguaré. Fonte: Elaborado pela autora. 157

Tabela 9- Classificação de nascentes segundo sua vazão. Fonte: Adaptado de Davis \& DeWiest (1966). 166

Tabela 10- Espécies vegetais presentes no fragmento florestal do parque Tizo. Fonte: Elaborado pela autora a partir de Costa (2006).

Tabela 11- Qualidade da água na bacia do Jaguaré. Fonte: Elaborado pela autora a partir do monitoramento da CETESB. 180

Tabela 12- Estudo da vazão de esgoto na Bacia do Jaguaré. Fonte: Elaborado pela autora. 188

Tabela 13- Vazão por bacia de esgotamento. Fonte: Elaborado pela autora. 188 
Tabela 14- Situação de cada bacia de esgotamento sanitário com a implantação dos coletores troncos previstos pela SABESP. Fonte: Elaborado pela autora.

Tabela 15- Coeficientes de exportação de cargas. Fonte: SMA/Primer, 2015.

Tabela 16- Coeficientes de exportação de cargas adaptados para os usos do solo na bacia. Fonte: Adaptado de SMA/Primer, 2015.

Tabela 17- Composição dos usos do solo por sub bacia. Fonte: Elaborado pela autora.

Tabela 18- Cargas geradas por sub-bacia. Fonte: Elaborado pela autora. 215

Tabela 19- Micro bacias de drenagem com significativas parcelas comerciais e industriais. Fonte: Elaborado pela autora.

Tabela 20- Feiras livres na bacia do Jaguaré. Elaborado pela autora com base em informações da PMSP.

Tabela 21- Renaturalização, revitalização e recuperação. Fonte: Elaborado pela autora

Tabela 22- Matriz de pontuação para avaliação do potencial para renaturalização, revitalização e recuperação de corpos d'água. Fonte: Elaborado pela autora 232

Tabela 23- Classificação do corpo d'água e potencial para intervenção. Fonte: Elaborado pela autora.

Tabela 24- Espécies higrófitas nativas do município de São Paulo. Fonte: Elaborado pela autora a partir de Barbedo et al., 2011

Tabela 25- Resultados obtidos para os cenários estudados. Fonte: Elaborado pela autora.

Tabela 26- Avifauna avistada no Parque Villa Lobos. Fonte: Addaptado de komesu (2012).

Tabela 27- Composição do sistema viário na bacia. Fonte: Elaborado pela autora. 
Tabela 28- Volumes retidos com a implantação da infraestrutura verde. Fonte: Elaborado pela autora. 275

Tabela 29- Proposta de retenção com infraestrutura verde. Fonte: Elaborado pela autora. 276

Tabela 30- Custo de implantação de estruturas de biorretenção. Fonte: Elaborado pela autora com base em PMSP, 2016 276

Tabela 31- Custo de implantação de passeio permeável. Fonte: Elaborado pela autora com base em PMSP, 2016 277

Tabela 32- Custo de implantação de viário permeável. Fonte: Elaborado pela autora com base em PMSP, 2016 277

Tabela 33- Custo de implantação das medidas de infraestrutura ver e de um piscinão. Fonte: Elaborado pela autora 277

Tabela 34- Resultado da pesquisa de campo. Fonte: Elaborado pela autora. 


\section{LISTA DE ABREVIATURAS E SIGLAS}

ANA Agência Nacional de Águas

ANMMA Associação Nacional de Órgãos Municipais de Meio Ambiente APP Área de Proteção Permanente

BMP Best Management Practices

CETESB Companhia de Tecnologia de Saneamento Ambiental

CME Concentração Média de Evento

CONAMA Conselho Nacional do Meio Ambiente

DAEE Departamento de Águas e Energia Elétrica

DBO Demanda Bioquímica de Oxigênio

DQO Demanda Química de Oxigênio

IBGE Instituto Brasileiro de Geografia e Estatística

MNAC Modelo dos Níveis de Ação Colaborativa

OD Oxigênio Dissolvido

OMS Organização Mundial da Saúde

PMSP Prefeitura do Município de São Paulo

PNUD Programa das Nações Unidas para o Desenvolvimento

SABESP Companhia de Saneamento Básico do Estado de São Paulo

SEHAB Secretaria de Habitação do Município de São Paulo

SDT Sólidos Dissolvidos Totais

Tr Tempo ou Período de Retorno

UC Unidade de Carga

UNICEF Fundo das Nações Unidas para a Infância

USEPA United States Environmental Protection Agency 


\section{ÍNDICE}

\section{Capítulo 1}

1 Introdução 26

1.1 Objetivos 30

\section{Capítulo 2}

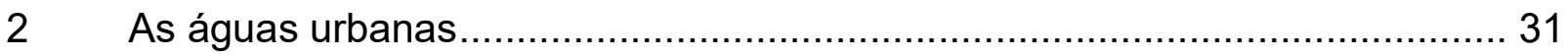

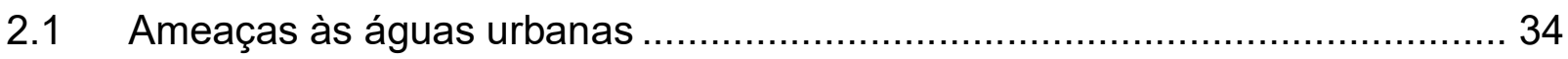

2.1.1 Ocupação das áreas de várzea e mudanças no uso e ocupação do solo....... 36

2.1.2 Lançamento de cargas poluidoras.......................................................... 40

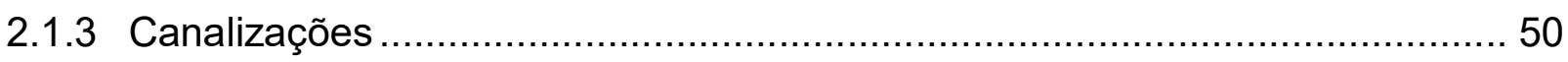

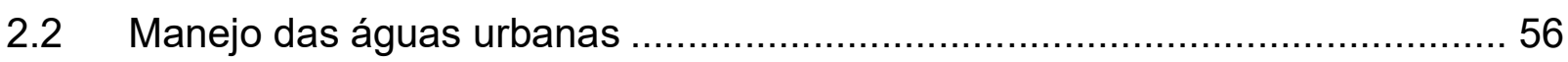

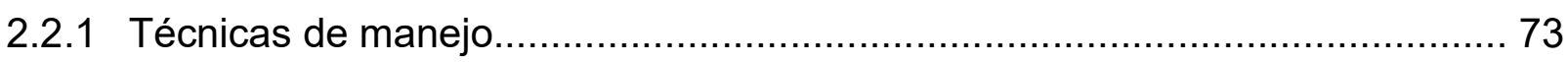

2.2.2 Exemplos de aplicação das técnicas de manejo ........................................ 124

\section{Capítulo 3}

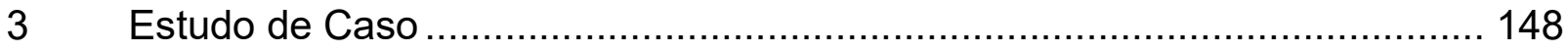

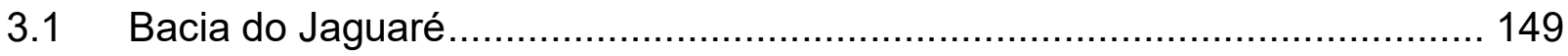

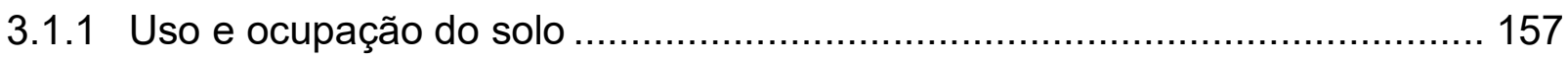

3.1.2 Características hidráulicas e hidrológicas............................................ 161

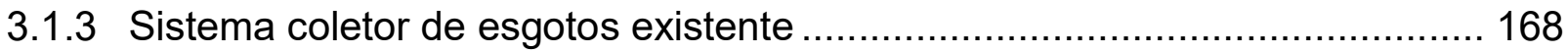

3.1.4 Sistema coletor existente de resíduos sólidos ........................................ 171

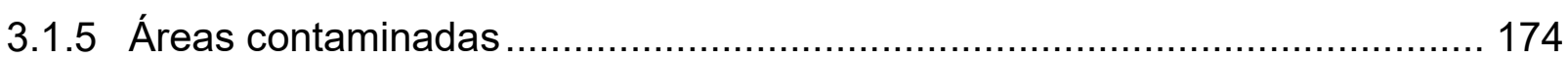

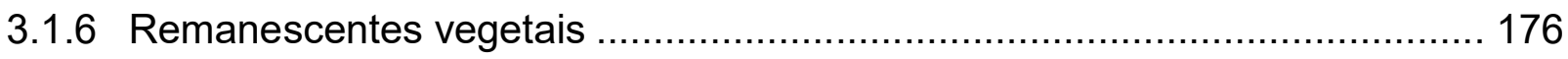

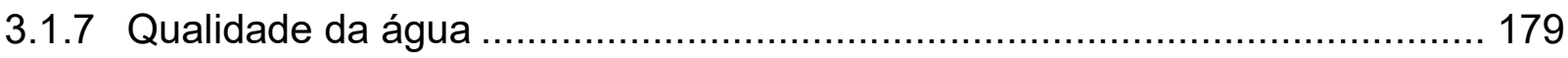

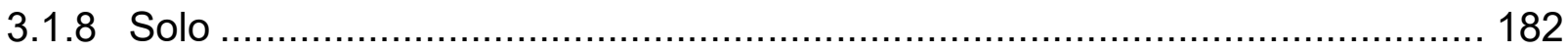




\section{Capítulo 4}

$4 \quad$ Proposta de manejo para a bacia do Jaguaré ............................................. 183

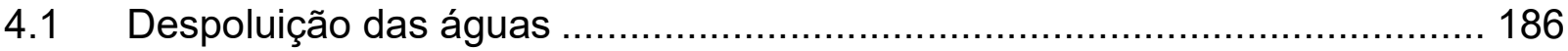

4.1.1 Consolidação do sistema de esgotamento sanitário...................................... 186

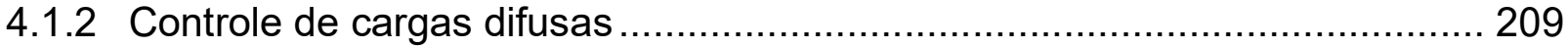

4.2 Reintegração das áreas de várzea ...................................................... 231

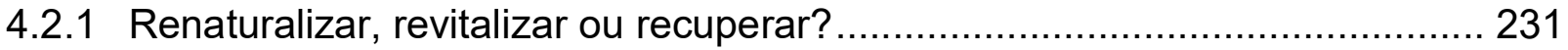

4.2.2 Renaturalizando, Revitalizando e Recuperando...................................... 235

4.2.3 Repensando as várzeas do córrego Jaguaré .......................................... 254

4.3 Impacto da perda de áreas verdes na bacia do córrego Jaguaré................... 264

4.4 Infraestrutura verde e azul na bacia do córrego Jaguaré ............................. 269

4.4.1 Infraestrutura verde e azul: Escala da bacia............................................. 269

4.4.2 Infraestrutura verde e azul: Escala do sistema viário ................................. 272

4.5 Percepção da população sobre a água em áreas urbanas ......................... 278

4.6 Percepção da população sobre uma proposta de revitalização para as várzeas

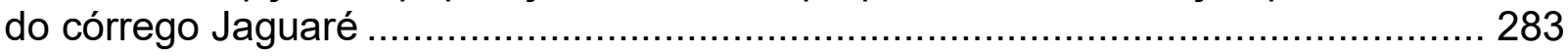

\section{Capítulo 5}

5 Conclusões 285

\section{Capítulo 6}

6 Referências bibliográficas.

\section{Capítulo 7}

$7 \quad$ Anexos. 307 


\section{Capítulo 1}

\section{Introdução}

A relação do homem com a água é complexa, pois extrapola a dependência no nível da sobrevivência biológica, uma vez que a sociedade se moldou com base no seu uso e depende dele também para a geração de energia, sua locomoção, seus processos produtivos e o lazer. Desta forma, a água se torna um recurso essencial para o desenvolvimento da sociedade, no entanto o que se vê na prática não traduz a dimensão desta importância e o acesso à água não é uma realidade unânime em todo o mundo. Todos os objetivos específicos propostos neste estudo foram cumpridos, conforme resumido a seguir. Foram estudadas as melhores práticas para 
recuperação ambiental de bacias hidrográficas em áreas urbanas através da revisão bibliográfica; Foi proposta uma metodologia para consolidação do esgotamento sanitário aliando técnicas convencionais à técnicas complementares aplicada à bacia do Jaguaré; Foi realizado o estudo das melhores medidas de controle de cargas difusas (Estruturais e não estruturais) para redução do potencial poluidor, sendo realizado uma proposta de controle aplicada à bacia do Jaguaré; Foi proposta uma metodologia para identificação da melhor técnica para requalificação do corpo d'água em função das características da bacia hidrográfica em estudo; Foi realizada a verificação da relevância da manutenção de áreas verdes em bacias hidrográficas e da importância do emprego da infraestrutura verde no controle da vazão de pico, através do estudo da bacia do Jaguaré; Foi feito um estudo junto à população visando integra-la às propostas feitas para a bacia. Por fim todos estes estudos resultaram em um plano de manejo completo para a bacia do córrego Jaguaré.

Os corpos d'água desde o inicio da formação das grandes civilizações foram tidos como sinônimo de fartura, por serem eles os provedores dos recursos que permitiam o seu desenvolvimento, sendo essas sociedades chamadas apropriadamente de hidráulicas devido à relação direta com as águas. Os históricos rios Tigre e Eufrates na Mesopotâmia, Nilo no Egito, Ganges na Índia, Indo no Paquistão e Huang-Ho na China e os contemporâneos Tâmisa em Londres, Sena em Paris, Tibre em Roma, Vltava em Praga, Danúbio em Budapeste, Hudson em Nova York, Yeşilırmak, Porsuk, Meriç e Tigre na Turquia e Yarra na Austrália são alguns dos exemplos dessa intima relação histórica entre o homem e a água (Cengiz, 2013). Apesar dessa importância histórica, na maioria dos países em desenvolvimento, para a maior parte da população nas áreas urbanas os corpos d'água representam apenas fontes de problemas, que foram na verdade resultado do processo de urbanização não planejado.

Segundo Cengiz (2013), os corpos d'água tem muitas funções e dentre elas se destaca a de promover a conexão entre a paisagem e as comunidades e a de promover a criação de um conceito de meio ambiente sustentável. Para Postel \& Barton (2005) bacias hidrográficas tem como atributo especial a promoção da conexão entre o ambiente terrestre e o aquático, seja ele de água doce ou costeiro, 
promovendo uma série de serviços ambientais valiosos como a reciclagem da água, a manutenção da biota e a regulação do clima através do sequestro de carbono. Para a economia ecológica, bacias hidrográficas são importantes capitais naturais que proporcionam fluxo de bens e serviços para a sociedade. A falha em incorporar o valor dos recursos naturais em decisões sobre a gestão das bacias faz com que seja reduzido o valor líquido do recurso e o que se vê na prática é um estágio avançado de degradação, que resulta na diminuição da sua capacidade ecológica.

Mas se por um lado as atividades humanas têm alto potencial de modificar a paisagem, por outro é acelerado o desenvolvimento das ciências que se dedicam a melhor compreender os processos afetados pelo desenvolvimento humano e que buscam medidas para mitigar estes impactos gerados.

O reconhecimento dos desafios envolvidos na gestão de bacias hidrográficas cresce com o aumento das cargas poluidoras geradas no meio urbano que são lançadas nos corpos d'água e dos impactos gerados pela canalização destes. Pesquisas demonstram que canais em áreas urbanas podem ter suas dimensões aumentadas em até oito vezes, este aumento se dá como resposta ao aumento do escoamento superficial devido à impermeabilização do solo e também ao excesso de sedimentos trazido pelo sistema de drenagem para o corpo d'água. É necessário reconhecer os padrões espaciais e temporais existentes em bacias localizadas em áreas urbanas para que seja possível categorizar e caracterizar estes padrões para uma gestão mais adequada (Chin et al., 2005).

Às intervenções realizadas nos diversos canais em áreas ocupadas pelo homem levaram ao avanço das pesquisas voltadas para o melhor entendimento do processo, e os resultados destas são hoje usados como subsídio para a gestão adequada dos corpos d'água. Com o avanço desta ciência surgem ao menos oito pontos que podem ser destacados: 1) Maior consciência das variações existentes ao longo do canal; 2) Maior consciência das heterogeneidades existentes na bacia; 3) Demanda por métodos para identificação e analise de tais padrões espaciais; 4) Análise das alternativas existentes para tratamento e gestão de canais; 5) Utilização, sempre que possível, de métodos menos extremos, priorizando o uso de soluções que promovam o retorno do corpo d'água para um estágio mais natural; 6) Necessidade de compreender o que é considerado "natural" quando buscamos 
recuperar um corpo d'água e a importância do envolvimento da comunidade no processo; 7) Gestão e revitalização do canal planejadas dentro de um contexto holístico; 8) Gestão do canal compatível e integrada com a gestão de bacias hidrográficas (Chin et al., 2005).

Por muito tempo o uso humano foi predominante sobre os demais usos possíveis para os corpos d'água, portanto um dos desafios envolvidos no manejo da água em ambientes urbanos é o de integrar a maior quantidade de usos possíveis para o corpo d'água, ou seja, deve se estabelecer usos que levem em conta os aspectos sociais, econômicos, estéticos e ecológicos. Onde especial atenção deve ser dada aos aspectos ecológicos, que por tanto tempo foram renegados (Cengiz, 2013). 


\subsection{Objetivos}

O presente estudo tem como objetivo geral o desenvolvimento de melhores práticas para o manejo adequado de corpos d'água em áreas urbanas. Através da revisão bibliográfica, pretende-se conhecer o histórico do desenvolvimento deste problema no Brasil e no mundo, bem como estudar as técnicas de planejamento e gestão existentes para melhor compreensão dos desafios envolvidos no processo.

Através do estudo de caso na bacia do Jaguaré, pretende-se elaborar uma proposta para o manejo de bacias hidrográficas que integre os aspectos de segurança hidrológica, recuperação da qualidade da água, recomposição biológica e integração paisagística. Portanto são objetivos específicos desta pesquisa:

- O estudo das melhores práticas para recuperação ambiental de bacias hidrográficas em áreas urbanas;

- Proposta de metodologia para consolidação do esgotamento sanitário aliando técnicas convencionais à técnicas complementares;

- O estudo das melhores medidas de controle de cargas difusas (Estruturais e não estruturais) para redução do potencial poluidor;

- A proposição de uma metodologia para identificação da melhor técnica para tratamento do corpo d'água em função das características da bacia hidrográfica em estudo;

- Verificação da relevância da manutenção de áreas verdes em bacias hidrográficas;

- Verificação da importância do emprego da infraestrutura verde no controle da vazão de pico;

- O estudo da importância da integração da população no processo de manejo de bacias hidrográficas; e

- A proposição de um plano de manejo para a bacia do córrego Jaguaré. 


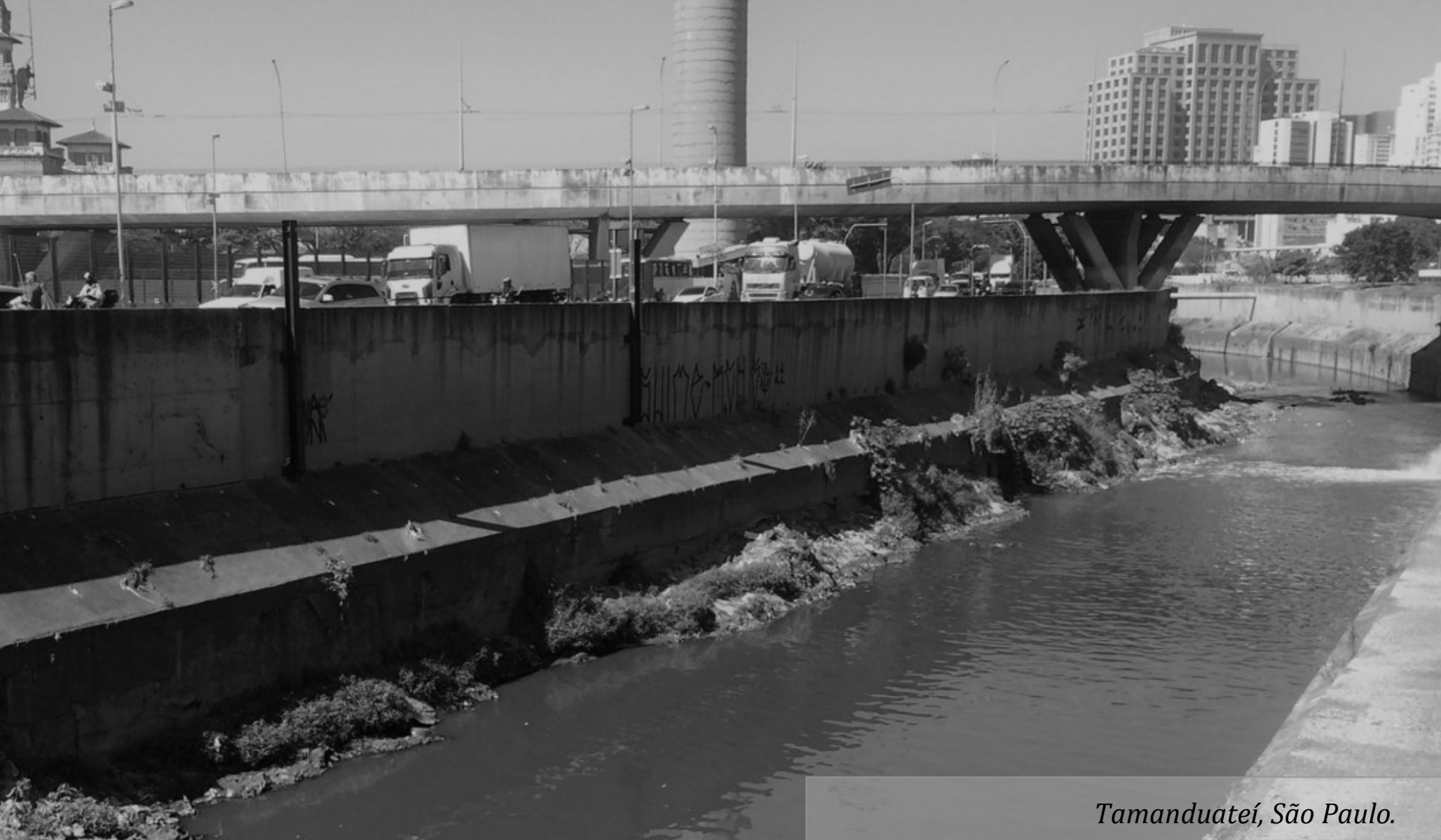

\section{Capítulo 2}

2 As águas urbanas

Por muito tempo os corpos d'água em áreas urbanas sofreram diversas intervenções que condenaram sua biota, encontrando-se muitos deles atualmente, com suas funções naturais inexistentes, principalmente devido às ações voltadas ao controle de suas enchentes regulares. Na Europa e nos Estados Unidos o reconhecimento da importância da função ecológica dos rios só ocorreu depois que a indústria e a agricultura provocaram grandes danos a estes ambientes. Desta forma, muitos ecologistas, nos países temperados, foram privados de realizarem estudos nestes ecossistemas antes destas intervenções (Bayley, 1995), análogo ao que ocorre no Brasil em áreas urbanas. 
A capacidade que as bacias hidrográficas têm de reciclar a água é um de seus serviços mais valiosos, uma vez que a perda da qualidade da água resulta em danos à saúde humana, redução da produtividade de culturas e diminuição do potencial de geração de energia em países dependentes da energia hidroelétrica, o que resulta por sua vez em uma sobrecarga para a parcela mais carente da população. Os países industrializados têm dependido cada vez mais de processos sofisticados para a remoção de contaminantes da água em virtude da diminuição da qualidade de seus mananciais, fazendo com que a água tenha elevado custo. Considerando um cenário em que o aumento da demanda pela água é crescente, bacias hidrográficas saudáveis são capitais naturais de elevado valor (Postel \& Barton, 2005).

Uma das principais causas da crise hídrica que atinge as áreas urbanas no Brasil é a degradação dos corpos d'água, uma vez que inviabiliza o uso deste recurso para satisfazer a demandas internas (Teixeira \& Porto, 2008). Grandes cidades brasileiras como São Paulo, por exemplo, precisam aduzir boa parte da água para o abastecimento da cidade de bacias hidrográficas distantes (Segundo dados do DAEE, para atender a região metropolitana de São Paulo a SABESP realiza a transposição de $33 \mathrm{~m}^{3} / \mathrm{s}$ de água das bacias dos Rios Piracicaba e Juqueri para a bacia do Alto Tietê), devido ao elevado grau de degradação dos corpos d'água dentro da cidade, que não atendem se quer o padrão de qualidade da água exigido para corpos d'água classe 4, que segundo a CONAMA 357, são aqueles destinados à navegação e à harmonia paisagística. As águas provenientes de bacias hidrográficas próximas, como o caso dos reservatórios Billings e Guarapiranga, ainda que estejam em melhor estado, estão sujeitas a degradação devido ao lançamento de cargas poluidoras resultado da ocupação irregular em suas margens, elevando o custo do tratamento da água.

Segundo pesquisa realizada nos EUA, as águas provenientes de bacias com $60 \%$ de florestas, que atuam no controle de cargas poluentes, custam 3 vezes menos para serem tratadas do que as provenientes de bacias urbanizadas com apenas 10\%, conforme mostrado na Tabela 1 (Postel \& Barton, 2005). 
Tabela 1 - Custo do tratamento da água em bacias com diferentes índices de cobertura vegetal. Fonte: Adaptado de Postel \& Barton (2005).

\begin{tabular}{|c|c|c|c|}
\hline $\begin{array}{l}\% \text { de área } \\
\text { florestada }\end{array}$ & $\begin{array}{c}\text { Custo do } \\
\text { Tratamento por } \\
3,785 \mathrm{~m}^{3}\end{array}$ & $\begin{array}{c}\text { Custo médio } \\
\text { anual do } \\
\text { Tratamento }\end{array}$ & $\begin{array}{l}\text { Aumento dos custos } \\
\text { sobre a cobertura } \\
\text { florestal de } 60 \%\end{array}$ \\
\hline $60 \%$ & $\$ 37$ & $\$ 297,110$ & - \\
\hline $50 \%$ & $\$ 46$ & $\$ 369,380$ & $24 \%$ \\
\hline $40 \%$ & $\$ 58$ & $\$ 465,740$ & $57 \%$ \\
\hline $30 \%$ & $\$ 73$ & $\$ 586,190$ & $97 \%$ \\
\hline $20 \%$ & $\$ 93$ & $\$ 746,790$ & $151 \%$ \\
\hline $10 \%$ & $\$ 115$ & $\$ 923,450$ & $211 \%$ \\
\hline
\end{tabular}

Um caso extremo de degradação de mananciais é o da cidade de Mombasa no Kenya, onde a degradação foi tão elevada que resultou no encarecimento do tratamento a tal ponto que o sistema foi simplesmente abandonado. Apesar das zonas úmidas serem eficientes no processo de reciclagem da água, as mesmas dependem das condições do entorno para manter seu ponto ótimo, portanto alterações nas taxas de uso do solo podem comprometer este serviço prestado pela bacia hidrográfica (Postel \& Barton, 2005).

Bogotá na Colômbia tem boa parte de sua demanda por água potável atendida graças ao ecossistema úmido de montanha chamado páramo, que fornece água de excelente qualidade graças ao processo de filtração natural das águas. A água bruta captada demanda em boa parte do ano apenas cloração, nos demais períodos, quando há aumento pontual da turbidez ocasionado por chuvas fortes, a adição de filtros de areia já é suficiente para incrementar o tratamento, portanto a manutenção da condição natural do páramo faz com que haja grande economia no processo de tratamento da água, tornando a mesma mais barata. As nascentes que alimentam as captações que atendem Bogotá estão protegidas estrategicamente dentro do Parque Nacional Chinganza, a fim de garantir que estas não sejam degradadas, a exemplo do que ocorre em outras partes do páramo andino que tem sido constantemente degradado pela ação antrópica (Postel \& Barton, 2005).

Além disso, é notória a importância do controle da qualidade da água não só objetivando o aproveitamento para o abastecimento da população, mas também visando a melhoria da qualidade de vida no ambiente urbano. Yamamoto (2006) destaca a importância de corpos d'água em áreas urbanas como promotores de 
"caminhos de vento" que resultam na melhoria do micro clima e amenizando os efeitos de ilha de calor em centros urbanos, como foi verificado pela autora em Tokyo, Osaka e em Seul.

Nas últimas décadas foram propostas diversas políticas para garantir a gestão participativa e descentralizada dos recursos naturais e do território no Brasil, como por exemplo a criação do Sistema Nacional do Meio Ambiente criado pela Política Nacional do Meio Ambiente (Lei Federal 6938/81) e do Sistema Nacional de Gerenciamento de Recursos Hídricos criado pela Política Nacional de Recursos Hídricos (Lei 9433/97). Neste contexto as ações de planejamento territorial que visam o ganho de quantidade e qualidade de espaços protegidos em áreas urbanas ganham destaque, como por exemplo, a infraestrutura verde que surge para contribuir para a manutenção e criação de espaços de valorização social e ambiental. Para a proteção dos recursos hídricos é necessário transpor a lacuna existente entre a gestão da água e o planejamento do uso e ocupação do solo na bacia (Travassos \& Schuit, 2013). A água é um recurso natural demandado por diversas atividades humanas e que recebe diversas cargas poluentes, e por ser essencial à vida necessita de intensa investigação científica e manejo adequado (Freire \& Castro, 2014).

\subsection{Ameaças às águas urbanas}

O processo de urbanização de uma bacia resulta em diversos impactos sobre seus corpos d'água, que são ainda mais acentuados quando esta urbanização não é planejada. A Tabela 2 mostra os principais efeitos da urbanização sobre canais, às respostas e os métodos de mitigação segundo Chin e Gregory. (2005).

Tabela 2 - Efeitos da urbanização sobre canais. Fonte: Chin e Gregory. (2005).

\begin{tabular}{ccc}
\hline Efeitos da urbanização & Resposta do canal & Mitigação \\
\hline $\begin{array}{c}\text { Aumento da produção de } \\
\text { sedimentos, principalmente durante o } \\
\text { desenvolvimento da construção civil. }\end{array}$ & $\begin{array}{c}\text { Assoreamento do canal } \\
\text { devido a cargas elevadas } \\
\text { de sedimento. }\end{array}$ & $\begin{array}{c}\text { Controle do sedimento } \\
\text { produzido na bacia. }\end{array}$ \\
\hline $\begin{array}{c}\text { Alteração da qualidade da água } \\
\text { devido à poluição. }\end{array}$ & $\begin{array}{c}\text { Aumento de espécies } \\
\text { oportunistas e diminuição } \\
\text { das endêmicas. }\end{array}$ & $\begin{array}{c}\text { Criação de bacias de } \\
\text { detenção e lagoas. }\end{array}$ \\
\hline $\begin{array}{c}\text { Aumento da vazão de pico devido ao } \\
\text { aumento do escoamento superficial, } \\
\text { devido à impermeabilização. }\end{array}$ & $\begin{array}{c}\text { Alargamento, } \\
\text { aprofundamento e erosão } \\
\text { do canal. }\end{array}$ & $\begin{array}{c}\text { Criação de canais de } \\
\text { compensação. Proteção } \\
\text { das margens. }\end{array}$ \\
\hline
\end{tabular}


A partir da análise da imagem apresentada na llustração 01 a seguir de um curso d'água na RMSP, especificamente na bacia do córrego Jaguaré, é possível observar os principais desafios envolvidos no manejo de cursos d'água nas áreas urbanas brasileiras e também de outros países em desenvolvimento.

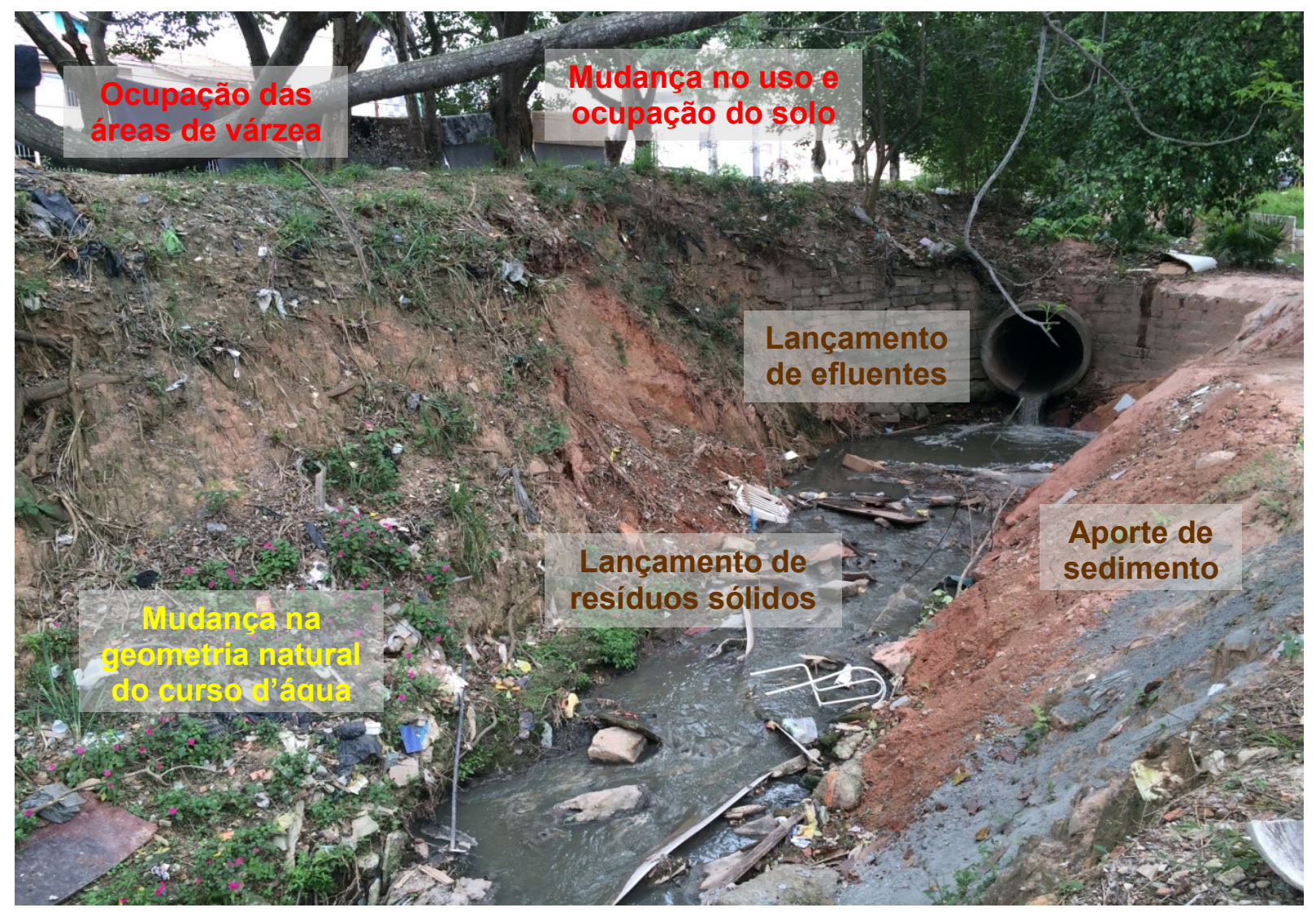

llustração 01 - Tributário do córrego Jaguaré. Desafios para o manejo das águas em áreas urbanas. Fonte: Foto da autora.

Podemos então classificar estes impactos apresentados na llustração anterior em três categorias, que serão melhor detalhas nos itens seguintes:

- A primeira referente ao processo de ocupação das áreas de várzea e da mudança do uso e ocupação do solo na bacia;

- A segunda agrupa os impactos gerados pelo lançamento de cargas poluidoras; e

- A terceira que agrupa os impactos resultantes das intervenções físicas realizadas no corpo d'água, ou seja, canalizações, retificações e o uso de tratamentos artificiais nas margens e fundo. 
fins imobiliários e rodoviaristas. É possível observar este cenário em diversas grandes cidades do Brasil, onde os rios foram gradualmente perdendo seus elementos vivos e se tornando barreiras ao desenvolvimento. A llustração 02 a seguir, mostra o traçado do rio Pinheiros em 1930 (Em azul), quando o rio ainda possuía boa parte de seus meandros naturais; observa-se ainda na llustração as curvas de nível próximas ao rio, mostrando as possíveis manchas de inundação do canal, que marcam sua extensa área de várzea, que hoje é ocupada por importantes centros comerciais, como o da Faria Lima, Pinheiros, Berrini e Vila Olímpia.

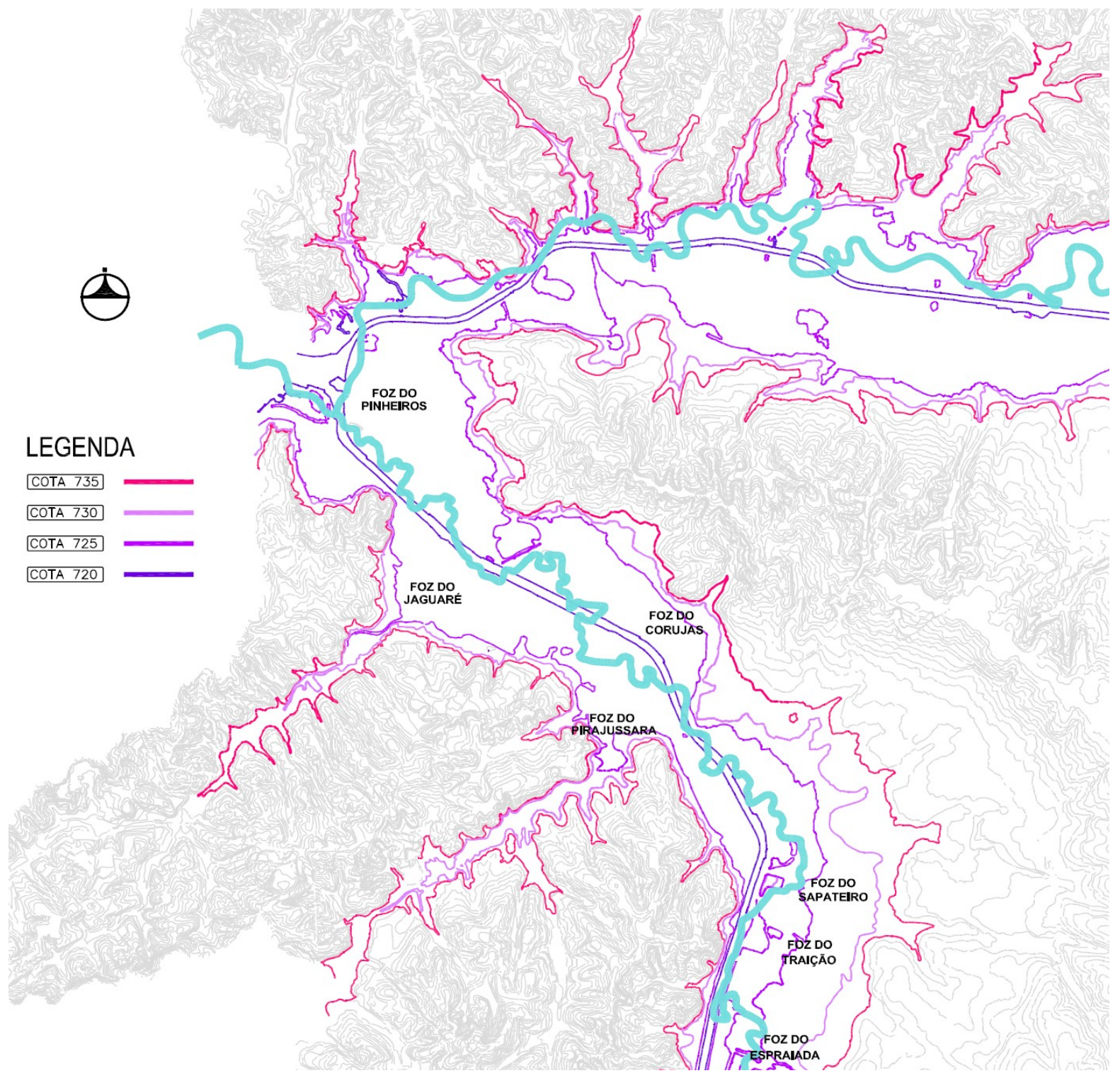

Ilustração 02 - Caminho do Rio Pinheiros em 1930 e suas manchas de inundação naturais nas cotas 735, 730, 725 e 720 . Fonte: Elaborado pela autora a partir de EMPLASA e SARA Brasil.

A interação dinâmica entre água e terreno é a principal responsável pelos diversos processos que mantém a diversidade dos habitats. Os organismos que 
compõem o ecossistema aquático, em sistemas lóticos, são adaptados ao pulso de inundação natural que ocorre de forma gradual entre as estações secas e chuvosas, portanto ao impedir que este processo ocorra, provoca-se um grande impacto sobre este ecossistema. Os micros habitats formados ao longo das várzeas sazonalmente alagadas resultam em grande diversidade biológica, graças a dinâmica particular de transporte de sedimentos e a formação de lagoas rasas temporárias que propiciam uma intensa atividade vegetal, devido à maior influência solar (Bayley, 1995). A ocupação das áreas de várzea, portanto, resulta na perda da complexa relação equilibrada existente entre ambiente aquático e terrestre, resultando em diversos impactos sobre a biota do corpo d'água.

A llustração 03 mostra diferentes tipos de ocupação das áreas de várzea nos corpos d'água de São Paulo, ilustrando como foi construída a relação da cidade com seus rios.
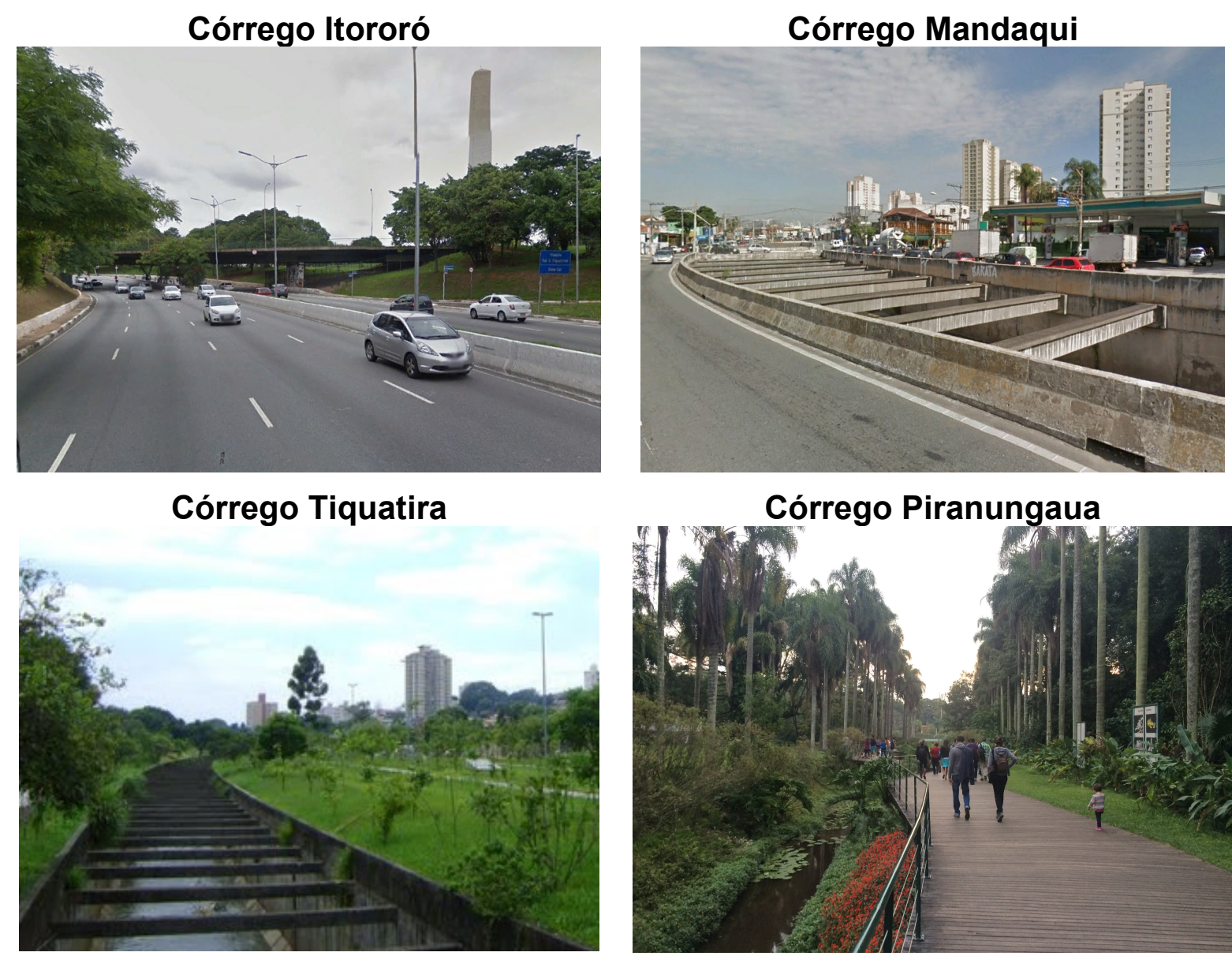

Ilustração 03 - Tipos de ocupação em áreas várzea. Fonte: Fotos da autora.

É possível observar casos drásticos, e que infelizmente são os mais comuns, como o caso do córrego Itororó totalmente oculto sob a Avenida 23 de Maio e do 
córrego Mandaqui que apesar de aberto, perdeu toda sua várzea e encontra-se engessado na Avenida Engenheiro Caetano Álvares. No entanto existem também tratamentos mais amenos, como o caso do córrego Tiquatira, que apesar do engessamento do canal em uma seção retangular de concreto, preserva em suas margens um parque linear muito utilizado pela população para o lazer; e do córrego Piranungaua dentro do Jardim Botânico de São Paulo, que por muito tempo permaneceu tamponado, mas que após o processo de revitalização, concluído em 2008 , foi totalmente remodelado e reintegrado à paisagem.

O conceito de desenho ambiental remete à ideia de conceber projetos que levem em conta outros aspectos além dos funcionais. Tal conceito surge no póssegunda guerra, quando a crise ambiental culminou em uma nova geração de arquitetos e urbanistas voltados para uma visão ecológica do mundo. Agrega-se, portanto na ciência do desenho ambiental a ideia de mega-entropia inserida na ciclagem de recursos, a preservação e a conservação ambiental. O conceito de desenho ambiental incorpora a proposição de uma alternativa viável de deslocamento que não negue, mas que reduza a importância do sistema viário sobre o desenho e planejamento de áreas urbanas, portanto prevê o alargamento de calçadas para o transito de pedestres e a implantação de ciclovias que sejam alternativas ao excesso viário (De Oliveira et al., 2012).

Considerando o grau de ocupação das áreas de várzea em áreas urbanas e o valor elevado do $\mathrm{m}^{2}$ nas grandes cidades, a recuperação das mesmas se apresenta como um grande desafio, mas que à medida que o ônus dessa ocupação passa a ser cada vez mais elevado, a viabilidade desse processo vem aumentando. Desta forma, é preciso criar elementos que assegurem incentivem a recuperação destas áreas e não ocupação das ainda livres, como por exemplo, através da criação de instrumentos legais.

O corpo d'água é reflexo dos processos que ocorrem em suas bacias hidrográficas, portanto o manejo adequado da dinâmica de uso e ocupação do solo na mesma é de grande importância para controle dos processos que geram cargas poluentes para o corpo d'água bem como dos processos que resultam em incrementos significativos no escoamento superficial. 
enquadrado nas seguintes classes: classe especial, classe 1, 2, 3 ou 4, em ordem de restrição da classe, ou seja, classe especial tem usos mais restritos e classe 4 mais flexíveis (Calmon et al., 2014). Uma bacia que ainda não teve seus corpos d'água enquadrados segundo os critérios da CONAMA 357/2005 é considerada de classe 2 (Freire \& Castro, 2014).

No processo de enquadramento é possível estabelecer metas intermediárias e verificar a evolução do atendimento das mesmas cruzando as informações do percentual de atendimento do sistema de esgotamento sanitário na bacia com as curvas de permanência de qualidade e de cargas remanescentes totais, além disso é possível simular diferentes condições de eficiência do tratamento para estas metas intermediárias, sendo possível definir quais bacias são de atuação prioritária para que se atinja os objetivos previstos (Calmon et al., 2014). Apesar da existência desta ferramenta de gestão, muitas bacias brasileiras ainda não tiveram seus corpos d'água enquadrados por um plano de manejo, além disso, a situação precária do saneamento na maioria das áreas urbanas torna o processo um grande desafio.

A poluição que chega a um corpo d'água pode ser caracterizada em dois tipos: pontuais, que é o tipo de fonte passível de ser caracterizada e rastreada, como por exemplo, esgotos domésticos e efluentes industriais; e difusas, que são aquelas geradas de forma distribuída ao longo da bacia contribuinte, sendo elas produzidas por inúmeros agentes poluidores, que afluem aos corpos d'água por ocasião dos eventos de chuvas.

\subsubsection{Cargas Pontuais}

As cargas pontuais carregam uma grande quantidade de matéria orgânica, desta forma, quando lançadas no corpo d'água há imediatamente o aumento do consumo de oxigênio pelos organismos decompositores, ou seja, há o aumento da DBO (Demanda Bioquímica de Oxigênio). O lançamento contínuo desta carga orgânica faz com que haja a proliferação destes organismos decompositores aeróbios, levando à extinção do oxigênio dissolvido na água, o que leva a morte destes e dos demais organismos dependentes de oxigênio. Na etapa seguinte há o aumento de organismos decompositores anaeróbios, que são favorecidos pelo ambiente anóxico e pela falta de concorrência por outros recursos demandados por 
seu metabolismo. Se o lançamento não for cessado a situação se mantém, resultando na completa degradação do corpo d'água no trecho em questão (Andrade, 2010).

A llustração 04 a seguir mostra o processo de autodepuração em um corpo d'água esquemático, onde se podem identificar cinco zonas, a de águas limpas, ponto anterior ao lançamento; a de degradação, onde se encontra o lançamento e onde há o processo de decomposição ocorrendo; a de decomposição ativa, onde há maior concentração de matéria orgânica e por sua vez também a faixa de maior consumo de oxigênio; a zona de recuperação, onde a matéria orgânica já foi degradada e o corpo d'água volta a se oxigenar; e a de águas limpas, onde graças à autodepuração o corpo d'água já se encontra recuperado. Este processo é observado nos principais rios em áreas urbanas brasileiras, como por exemplo, na cidade de São Paulo nos Rios Pinheiros, Tietê e Tamanduateí. Apesar de sem vida no trecho que corta a área urbana, o Rio Tiete passa por um processo de autodepuração que torna suas águas limpas novamente a jusante da região metropolitana de São Paulo.

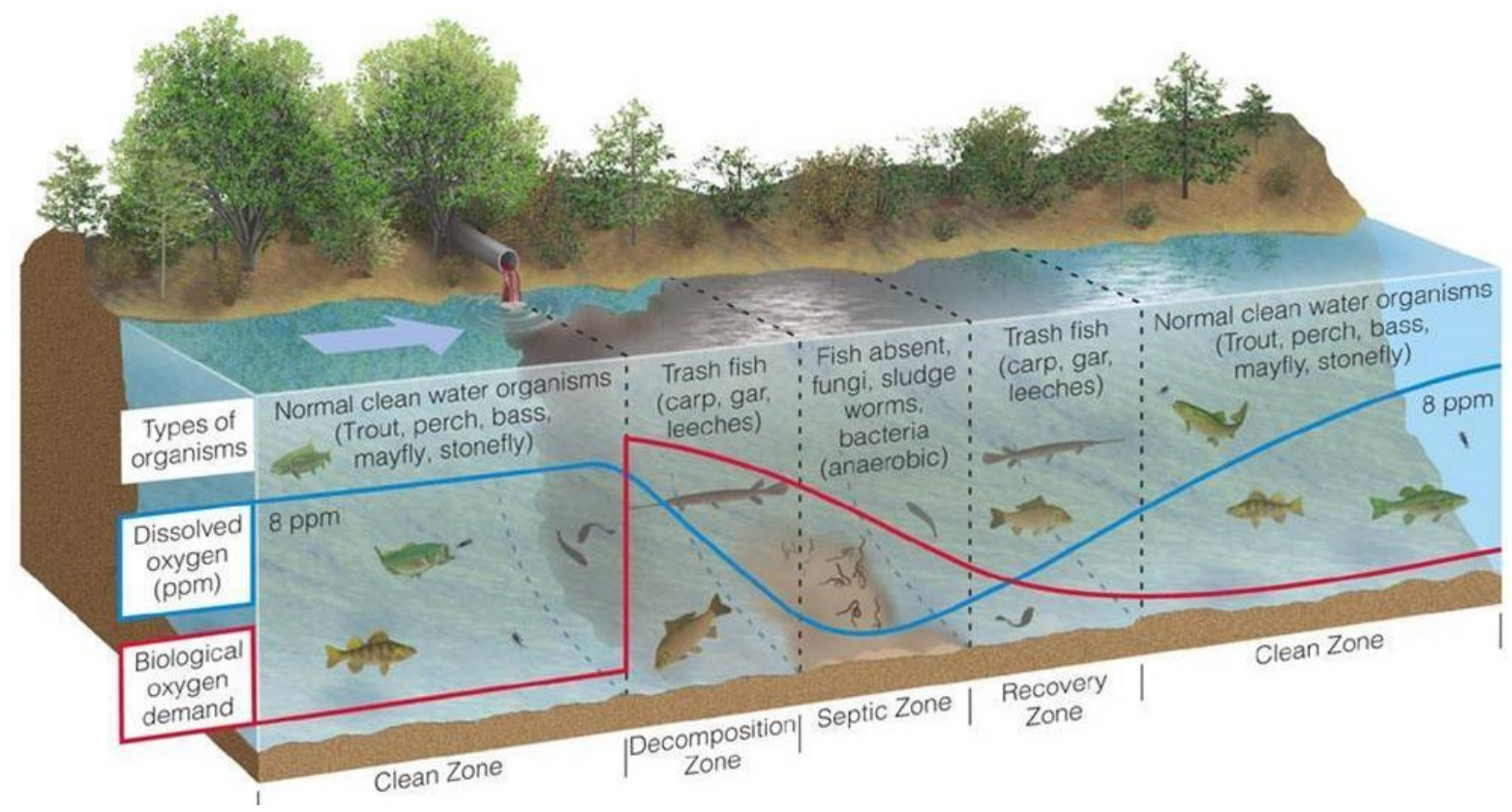

Ilustração 04 - Autodepuração em corpos d'água. Fonte: Guia ecológico (s/d).

Quando se remove o lançamento de cargas pontuais de um corpo d'água, há naturalmente um processo de autodepuração, havendo o reestabelecimento de sua DBO gradativamente. O Gráfico da llustração 05 mostra a evolução da DBO nos córregos do programa "Córrego Limpo" pertencentes à Zona Oeste do município de 
São Paulo. O programa atua na recuperação de corpos d'água através do controle de cargas pontuais, ou seja, há a realização de diversas intervenções no sistema de esgotamento sanitário a fim de retirar lançamentos de esgotos do corpo d'água. Pode-se observar no gráfico a redução notória da DBO dos corpos d'água que foram contemplados pelas ações do programa, mostrando o quão eficiente é o processo de autodepuração com relação às cargas pontuais.

Precipitação (mm) x DBO (mg/L) (2007-2012) - Zona Oeste

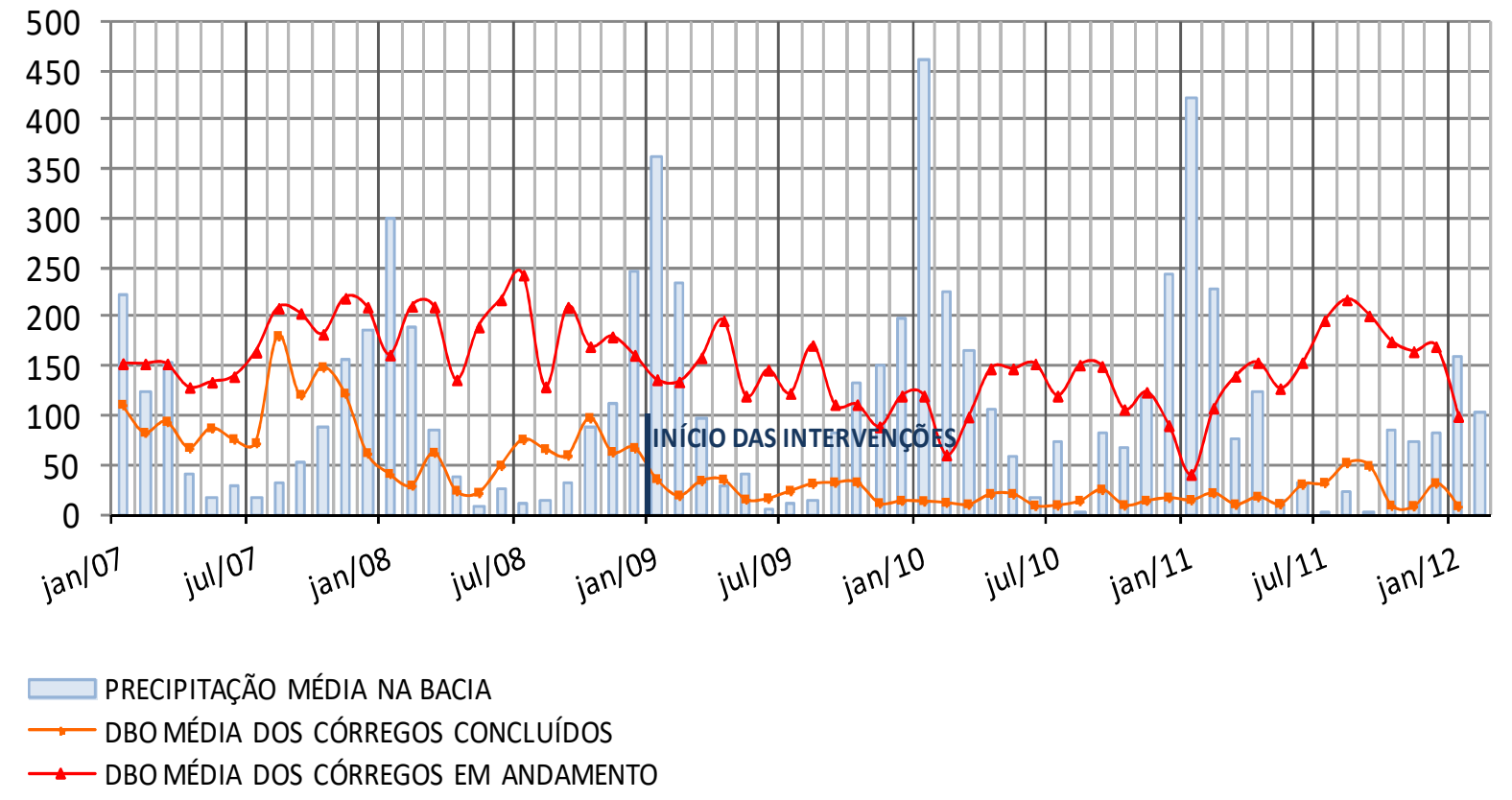

Ilustração 05 - Evolução da Demanda Bioquímica de Oxigênio (DBO) no período de 01/01/2007 a 01/01/2012 nos córregos da Zona Oeste pertencentes ao programa "Córrego Limpo" e comportamento da precipitação neste período. Fonte: Elaborado pela autora a partir de Córrego Limpo (s/d) e SAISP (2012).

Quando se trata de cargas pontuais, além do problema da ausência de sistema de coleta e tratamento de esgotos, um dos grandes desafios encontrados é o esgotamento de fundos de vale, pois o escoamento utilizado em redes de esgotos públicas no Brasil se dá principalmente em condutos livres, ou seja, condutos que dependem da gravidade para escoar os fluidos transportados, portanto todo o esgotamento de uma bacia tende naturalmente a ser direcionado para o canal de drenagem, ou seja, o corpo d'água. Habitações localizadas próximas ao canal, por tratar-se na maioria das vezes de soleiras negativas (Residências que tem sua instalação predial de esgotos orientada naturalmente para o fundo do lote), são de difícil esgotamento, pois demandam a implantação de coletores de fundo de vale que nem sempre são de fácil execução, e a ausência destes coletores resulta no lançamento dos esgotos das residências nesta situação diretamente no canal. 
Uma das ações do programa "Córrego Limpo", contempla a execução de redes coletoras nas margens e até mesmo dentro dos corpos d'água, a fim de interceptar os lançamentos de esgoto das soleiras negativas. Tal medida apesar de não normatizada (As normas das concessionárias, bem como a NBR 9649, preveem somente a implantação de redes coletoras em passeios e no viário), tem propiciado a recuperação ambiental dos corpos d'água do programa, se mostrando uma solução viável para o esgotamento de vazões de fundo de vale, o que ressalta a importância da normatização da solução nestes casos específicos. A llustração 06 exemplifica a situação complexa do esgotamento de fundos de vale e um coletor tronco implantado dentro do córrego Ibiraporã pelo programa "Córrego Limpo".
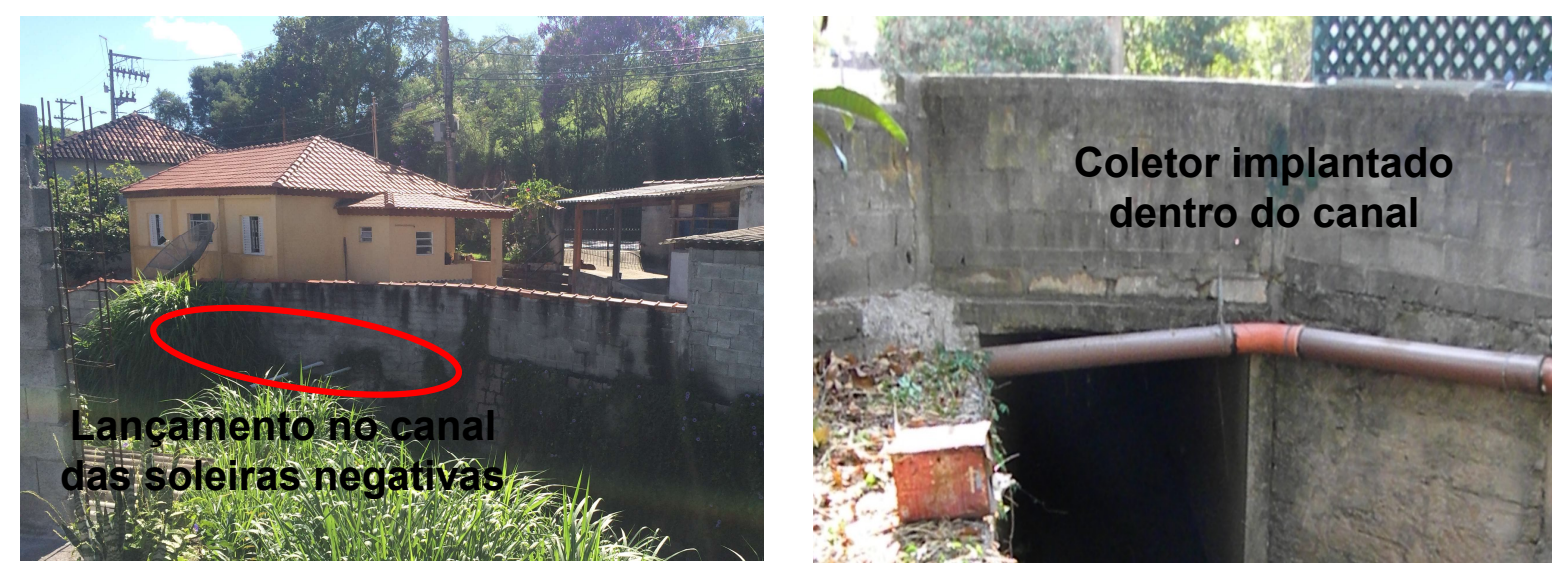

Ilustração 06 - Esgotamento de soleiras negativas em fundos de vale. Fonte: Elaborado pela autora.

\subsubsection{Cargas Difusas}

A poluição difusa é aquela que é depositada na superfície da bacia hidrográfica e é carreada para o corpo d'água devido aos eventos chuvosos que lavam a superfície da bacia. Segundo Novotny (2003) os primeiros $40 \%$ de escoamento superficial podem conter $60 \%$ dessa carga poluidora. Este tipo de poluição está diretamente relacionada com o tipo de uso e ocupação do solo, já que os mesmos resultam na geração de diferentes poluentes.

Em áreas urbanas a carga difusa tem papel significativo na poluição dos corpos d'água, de modo que é estimado que mesmo que $100 \%$ dos efluentes da região metropolitana de São Paulo fossem coletados e tratados, o rio Tietê ainda seria poluído em $25 \%$ devido à poluição difusa proveniente do escoamento pluvial urbano. 
A llustração 07 apresenta as principais fontes geradoras de carga difusa no meio urbano e tipos de poluentes.

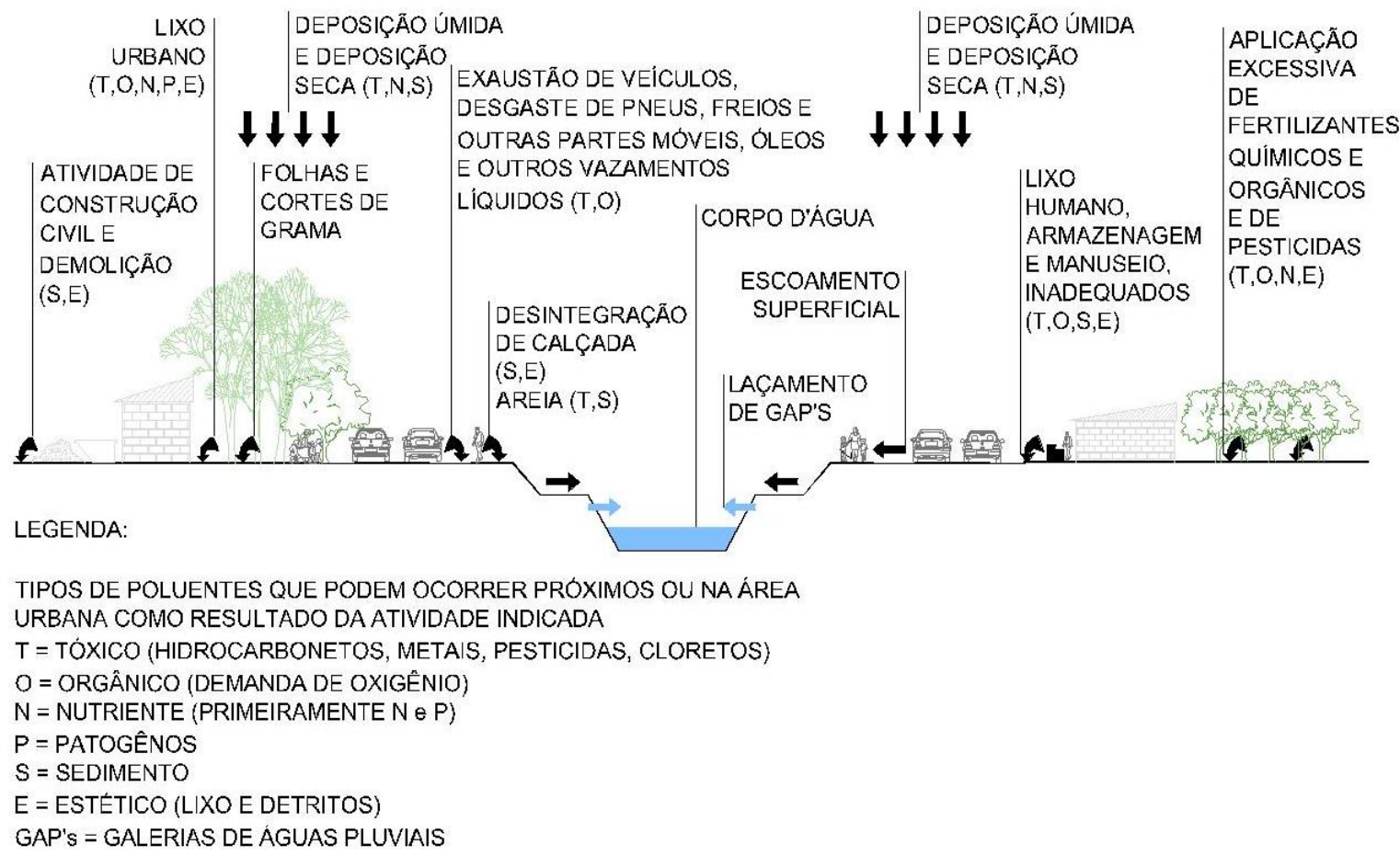

Ilustração 07 - Fontes de Poluição no Meio Urbano. Fonte: Elaborado pela autora a partir de Walesh (1989).

A carga difusa por ser ainda dividida em três parcelas, uma vez que apesar de possuírem como característica comum afluírem aos cursos d'água via evento chuvoso, cada uma possui características especificas no que se refere à forma de geração, disposição na superfície da bacia e estratégias para seu controle e tratamento.

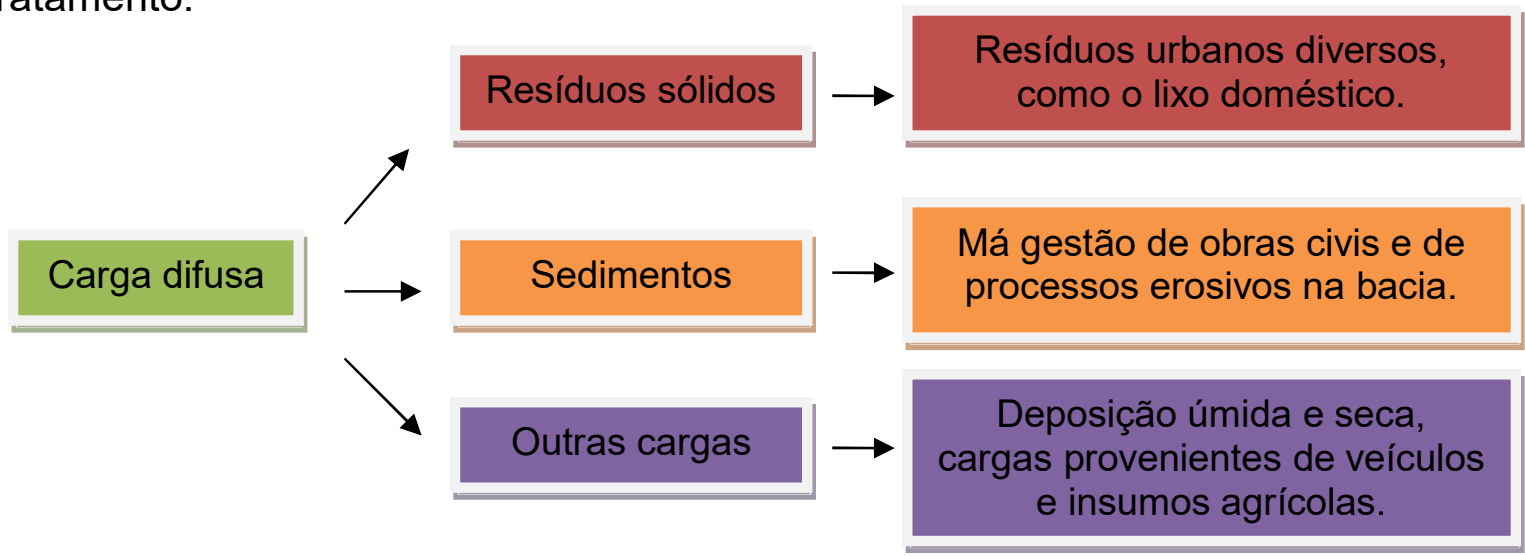

Ilustração 08 - Componentes da carga difusa. Fonte: Elaborado pela autora.

A primeira parcela é constituída pelos resíduos sólidos gerados na bacia, que devido à gestão inadequada da operadora do serviço (que pode ser a prefeitura ou uma empresa terceirizada) ou do usuário do serviço, podem afluir aos cursos 
d'água. A gestão inadequada da operadora do serviço se dá devido à ausência da universalização do atendimento, ou seja, não há o atendimento de $100 \%$ da população ou ainda pela prestação de serviço inadequado, como por exemplo, no caso de falhas no processo de coleta e armazenagem. Já a gestão inadequada por parte do usuário se da principalmente na disposição inadequada dos resíduos na bacia, seja no lançamento de resíduos na superfície da bacia e diretamente no sistema de drenagem, ou na não observância das regras para acondicionamento e disposição dos resíduos domésticos para coleta. Um usuário que dispõe seus resíduos, ainda que adequadamente acondicionados, fora do horário estabelecido pela operadora do serviço de coleta, expõe o resíduo à ação de animais que podem violar a embalagem expondo o material na superfície da bacia ficando o mesmo sujeito a ser carreado no evento de chuva para o curso d'água.

A geração desta parcela é mais significativa nos locais onde a população desconhece a importância de gerenciar bem seus próprios resíduos sólidos, desta forma, fica evidente a importância da educação no processo (Tomaz, 2006).

Segundo o Plano de gestão integrada de resíduos sólidos da cidade de São Paulo (2014), somente com a limpeza de Bocas de lobo e bueiros são gastos 5,65 milhões de reais por mês. A llustração 09 mostra o córrego do Sapé, afluente do córrego Jaguaré na bacia do rio Pinheiros, antes e depois de uma precipitação, onde podem ser observados os resíduos trazidos pelo sistema de drenagem.
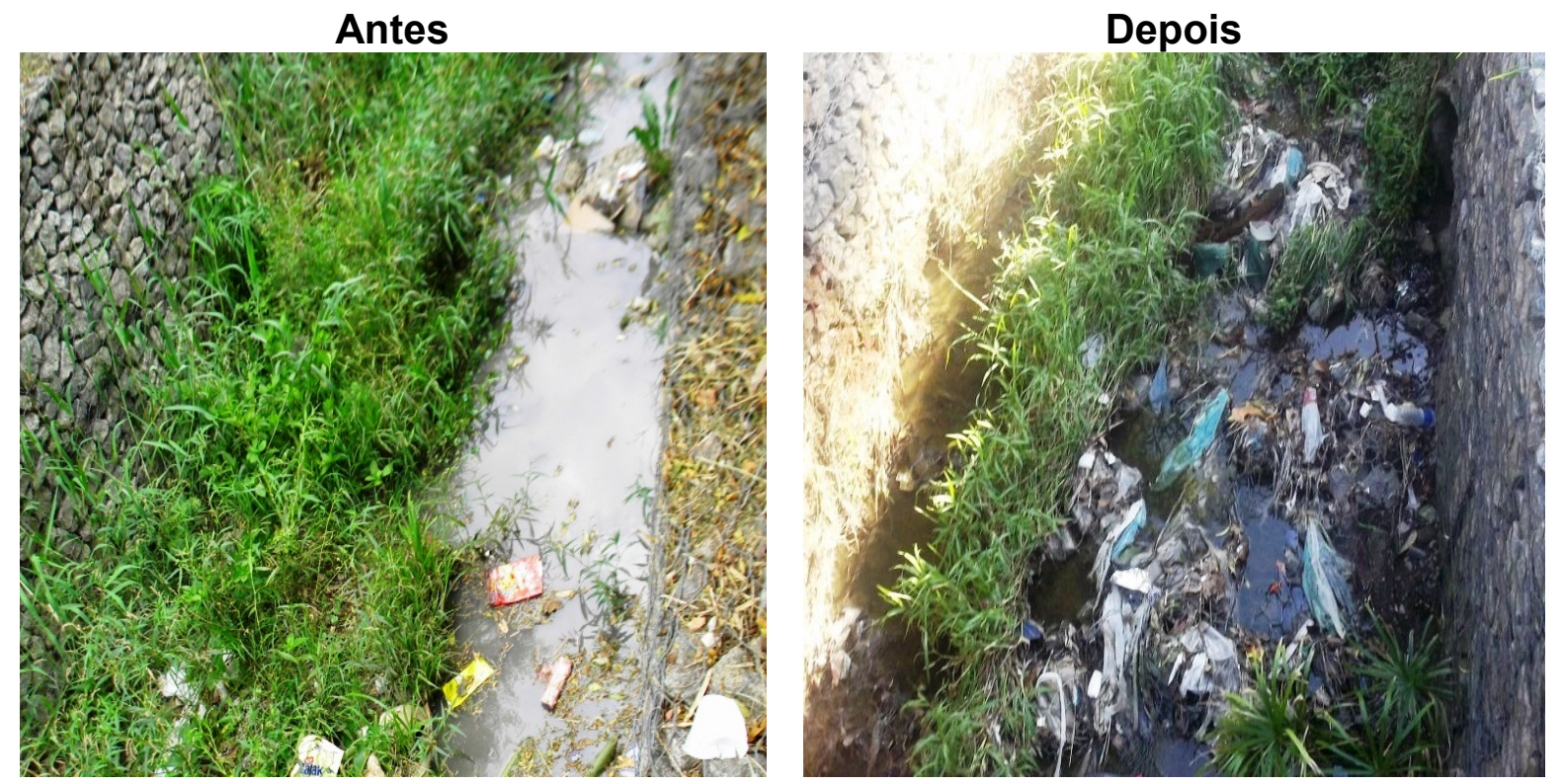

llustração 09 - Córrego do Sapé antes e depois de uma precipitação no verão de 2012. Fonte: Fotos da autora. 
Atualmente, os paulistanos mostram um índice insatisfatório quanto à poluição nas ruas da cidade. Com referência nos dados obtidos pelo Instituto Informe, três em cada quatro paulistanos consideram São Paulo uma cidade suja (Ferraz, 2012).

A segunda parcela da carga difusa são os sedimentos gerados na bacia hidrográfica, que podem ser provenientes principalmente de duas fontes, da atividade da construção civil na bacia ou devido ao desmatamento e ocupação de encostas que tornam o solo mais suscetível à erosão.

Segundo Findlay \&Taylor (2006) o processo geomorfológico de maior interesse em bacias hidrográficas são os de sedimentação e erosão. Cidades em construção são grandes geradoras de sedimentos devido às obras ao longo da bacia, estes sedimentos são carreados para os corpos d'água resultando em grandes prejuízos à biota, devido ao depósito de sedimento no fundo do canal e aumento da turbidez que prejudica o processo de fotossíntese aquática.

O carreamento de poluentes das superfícies se dá pela ação da precipitação e do escoamento superficial, que são transportados pelo sistema de drenagem até os corpos d'água (Poleto et al., 2011). Além disso, os sedimentos acabam se acumulando devido à diminuição da declividade e da capacidade de transporte o que leva à diminuição da seção e por consequência ao comprometimento da utilização hidráulica da estrutura, aumentando o risco de inundações na bacia drenada, desta forma os canais de drenagem em áreas urbanas demandam dragagens constantes, o que eleva o custo da manutenção do sistema.

Cidades como São Paulo gastam grandes quantidades de recursos públicos com a dragagem constante de seus corpos d'água, segundo a PMSP são retiradas 4,5 toneladas de resíduos de corpos d'água e 56,6 toneladas dos piscinões por dia na cidade de São Paulo. A llustração 10 mostra as atividades de dragagem no rio Pinheiros na foz do córrego Pirajussara, responsável pelo carreamento de grande quantidade de sedimento para o rio. 

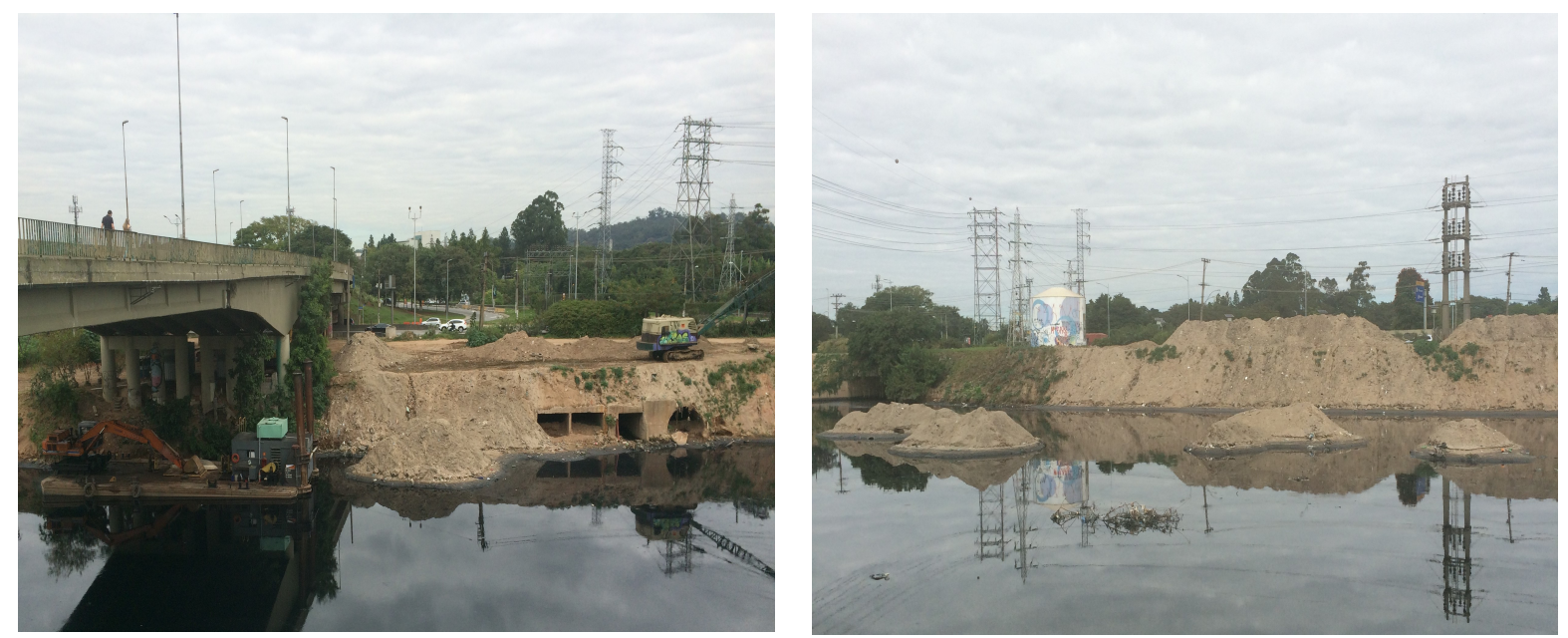

Ilustração 10 - Dragagem do rio Pinheiros na foz do córrego Pirajussara em junho de 2015. Fonte: Fotos da autora.

Por fim, a terceira parcela se refere às demais contribuições, que constituem a parcela mais discreta da carga difusa, como por exemplo a fuligem, óleos e graxas, metais, material proveniente de desgaste de peneus, fertilizantes, pesticidas, deposição seca e úmida, produto da lavagem da atmosfera pelas chuvas, etc.

Em áreas agrícolas o principal problema ligado às cargas difusas é o do uso indiscriminado de fertilizantes e produtos químicos para controle de pragas, pois além de serem fontes de contaminação das águas subterrâneas, ao serem transportados pelo escoamento superficial podem afluir aos corpos d'água e resultar em sua degradação pelo excesso de nutrientes disponíveis (Pinheiro et al., 2008). Esse processo é observado também em áreas urbanas onde há o uso excessivo destes insumos para tratamento de gramados e jardins, como ocorre em muitas cidades nos estados unidos, sendo foco de atenção nestas áreas.

A capital de Honduras, Tegucigalpa, por exemplo, tem sido fortemente afetada nos últimos anos pela redução da qualidade da água de seus mananciais devido ao aumento das taxas de ocupação da bacia, que tem resultado em maiores cargas de Nitrogênio e Fósforo devido às cargas difusas provenientes da agricultura e das cargas pontuais resultantes das moradias sem sistema de coleta e tratamento de esgotos. Além disso, a ocupação das encostas tem resultado no aumento da erosão, o que resulta, segundo algumas estimativas, na redução de cerca de $2 \%$ do potencial de armazenamento dos mananciais (Postel \& Barton, 2005). 
Segundo estudo realizado por Gebler et al. (2012) os diferentes tipos de cobertura do solo tem diferentes potenciais de retenção de contaminantes. Trabalhando com cargas de fósforo em parcelas de solo com vegetação natural (E1), árvores + solo exposto (D1), árvores + palha (C1), árvores + aveia (B1) e árvores + capina (A1) obtiveram como resultado que a concentração de fósforo no escoamento se dá na seguinte ordem: E1>D1>A1>C1>B1.

O estudo de Freire \& Castro (2014), analisou 13 sub-bacias contribuintes da bacia hidrográfica do rio Itapemirim no Espírito Santo, a fim de estabelecer a correlação entre o uso e ocupação do solo e a qualidade da água nestas sub-bacias, visando determinar qual uso e ocupação resulta em maior impacto sobre a qualidade da água. As bacias estudadas possuíam diferentes usos e ocupação do solo, incluindo áreas urbanas, atividades agrícolas, pastagens, solo exposto e fragmentos florestais. Utilizando a análise das correlações canônicas proposta por Hotelling (1936) os autores obtiveram como resultado, como já previsto, que as bacias com maior atividade humana geravam maior impacto sobre o corpo d'água e ainda que este impacto foi maior em bacias com maiores porcentagem de área ocupada por solo exposto e pastagem.

A qualidade da água é um fator limitante para a biota, portanto alterações resultantes do lançamento de poluentes, por exemplo, pode resultar na redução da diversidade no ecossistema aquático. Além disso, alterações na qualidade da água geram limitações para o uso humano, por exemplo, águas poluídas não permitem o uso recreativo e demandam técnicas avançadas de tratamento para o consumo. A cidade de Sidney na Austrália sofreu por muito tempo com os efeitos das vazões de pico que colocavam as águas contaminadas da cidade em contato com a população. Tal problema foi sanado com investimentos maciços na implantação de estações de tratamento de esgoto por toda a cidade e de bacias de detenção. Além disso, para o controle de cargas difusas, foram implementadas diversas ações visando a redução da geração através da conscientização da população e de algumas estruturas para remoção da mesma no sistema de drenagem (Findlay \&Taylor, 2006). 


\subsubsection{Canalizações}

A prática da regularização de canais através de canalizações tem seu primeiro registro no século $\mathrm{XVI}$, quando houve a regularização do Rio Amarelo na China através da sua canalização e aterramento de sua várzea, já a prática moderna começou na Europa no século XIX, impulsionada pela demanda de espaço urbano e aumento da profundidade dos rios para garantir sua navegabilidade, resultado da revolução industrial. Há ainda o aperfeiçoamento da técnica de tratamento de canais urbanos e o surgimento das primeiras técnicas de revitalização, com os trabalhos de Frederick Law Olmsted no final do século XIX, inaugurando uma nova tendência 
seguida pelos atuais movimentos de revitalização americanos (Pereira, 2008). No Brasil, tais intervenções em corpos d'água devem estar de acordo com os critérios ambientais estabelecidos pela legislação e são autorizadas mediante concessão de uma outorga emitida pelo órgão competente.

Países que sofrem com inundações, têm sua principal fonte de intervenções nos corpos d'água, aquelas realizadas nos canais a fim de conte-las, como por exemplo, através da realização de obras para o aumento da seção de escoamento do canal; já países onde há estações secas bem marcadas, a principal intervenção se dá devido às obras hidráulicas para regularização da vazão para captação de água para abastecimento ou para geração de energia, através da implantação de barragens (Newson et al., 2006). No Brasil há os dois tipos de intervenções.

O processo de urbanização acarreta na diminuição da capacidade de retenção de água no solo. Desta forma, há a mudança no balanço hídrico na bacia, de modo que a água que outrora infiltrava, passa a escoar superficialmente, resultando por fim no aumento da vazão de pico no canal. Para ampliar a capacidade hidráulica do canal, a fim de que este suporte o incremento de vazão, evitando o alagamento de áreas marginais, são realizadas as canalizações. Canalizações são intervenções feitas em corpos d'água, que podem contemplar a estabilização de suas margens e fundos, retificação de seu traçado, aumento das dimensões de suas seções bem como mudanças nas declividades de seus trechos. Este tipo de regularização traz como beneficio imediato um aumento da segurança no que se refere ao risco de alagamentos, ou seja, procura-se disciplinar o pulso natural existente (Enchentes: aumento temporário do nível d'água do canal de ocorrência sazonal), a fim de evitar danos à população, limitando as inundações (Extravasamento do NA máximo do canal) a ocorrência de chuvas de maior intensidade do que foi utilizado para o dimensionamento da nova seção do canal. A llustração 11 mostra um exemplo de regularização do canal, a fim de evitar o alagamento de zonas marginais. 


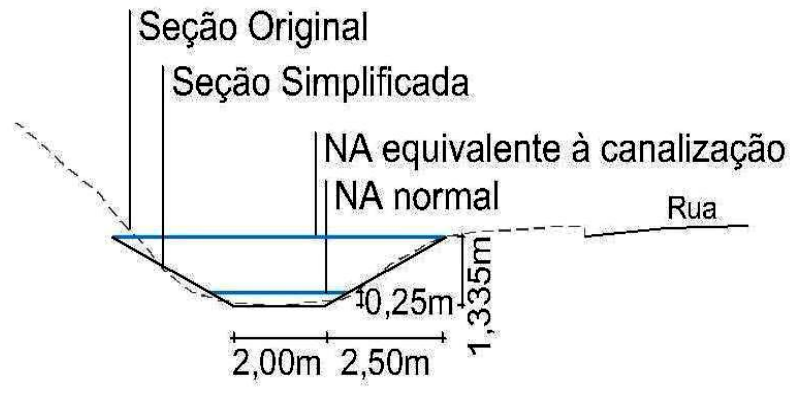

Seção Trapezoidal:

$$
\text { Área }=((B+b) / 2) \times h
$$$$
\text { Área }=((2,00+7,00) / 2) \times 1,335=6,00 \mathrm{~m}^{2}
$$

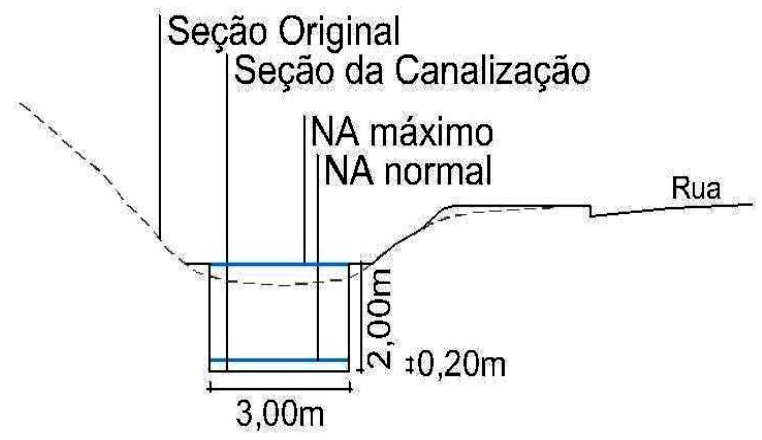

Seção Retangular:

Área $=\mathrm{b} \times \mathrm{h}$

Área $=3,00 \times 2,00=6,00 \mathrm{~m}^{2}$

Ilustração 11 - Exemplo de canalização. Fonte:Elaborado pela autora.

A mudança na configuração do corpo d'água com a implantação da canalização interfere no processo natural de modelagem de margens e fundos a partir da dinâmica de sedimentos na bacia, o que requer algumas medidas a fim de assegurar a estabilidade da estrutura e para tanto podem ser adotados diferentes métodos. Segundo Brighetti et al. (1999), para realizar a estabilização e proteção das margens e do fundo de canais pode se adotar duas alternativas, a utilização de revestimentos flexíveis ou proteções rígidas. A escolha destas duas alternativas se dá em função das características topográficas, do solo e da ocupação das margens do canal.

A escolha do tipo de tratamento empregada nas margens e fundos do canal influencia diretamente a qualidade ambiental do curso d'água, uma vez que o material empregado pode ser mais ou menos restritivo à colonização da biota. Revestimentos flexíveis tendem a ser mais permissíveis que revestimentos rígidos, no entanto nem sempre a realidade das várzeas permite a adoção destes revestimentos.

Os revestimentos flexíveis contemplam a utilização de proteção com enrocamentos, colchões, revestimentos vegetais naturais ou consolidados, gabiões de caixa e elementos do tipo saco de areia (Brighetti et al., 1999). Geralmente são utilizados quando a faixa adjacente ao canal permite certo recalque, como por exemplo, faixas de solo com vegetação, situação pouco encontrada em áreas 
densamente ocupadas como a região metropolitana de São Paulo, onde grandes avenidas ocuparam os fundos de vale. A llustração 12 a seguir mostra os principais tipos de revestimentos flexíveis.

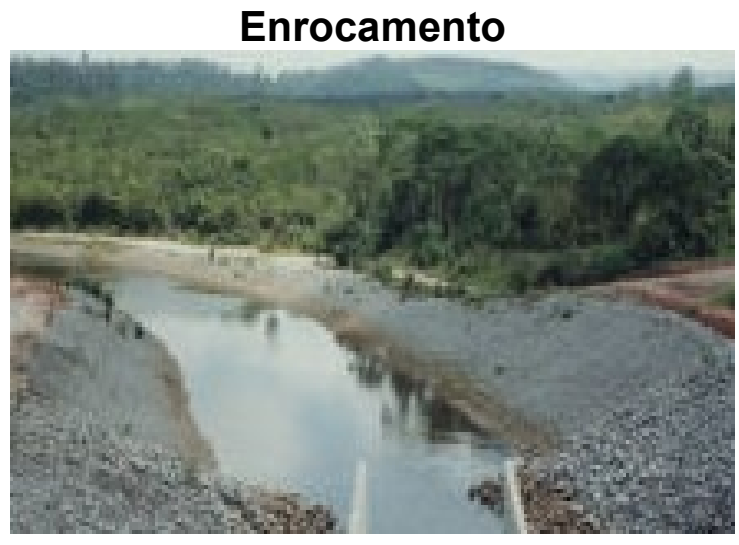

Colchão de concreto articulado
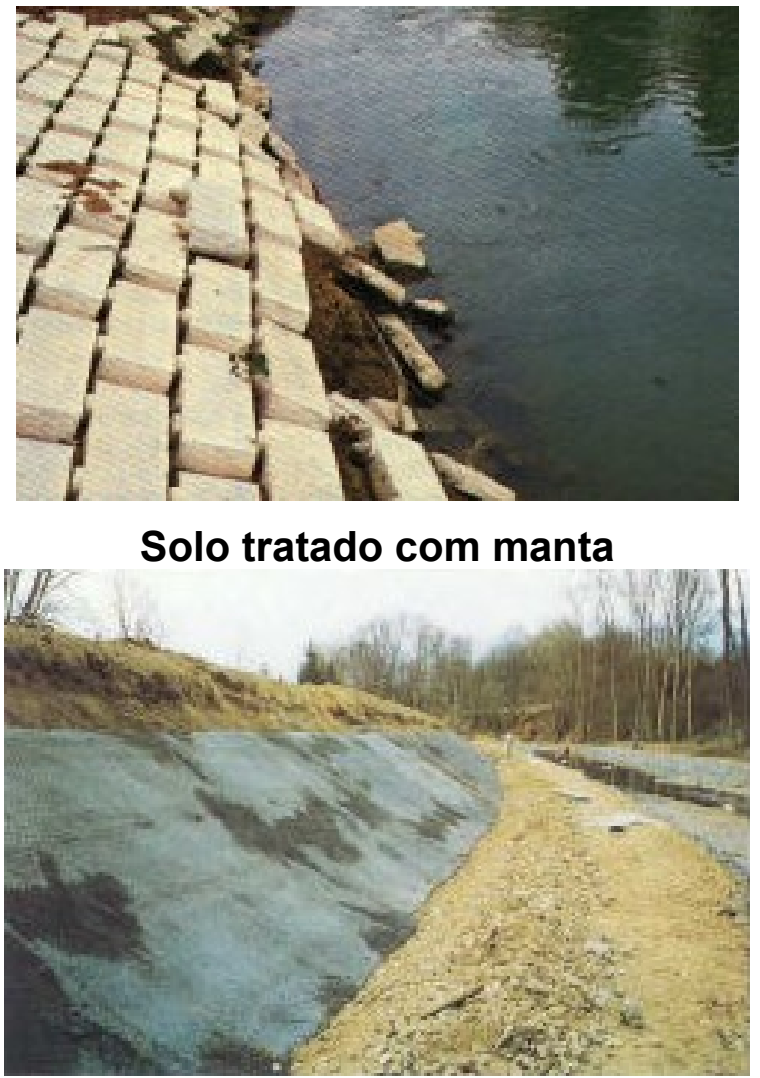

\section{Colchão de enrocamento}

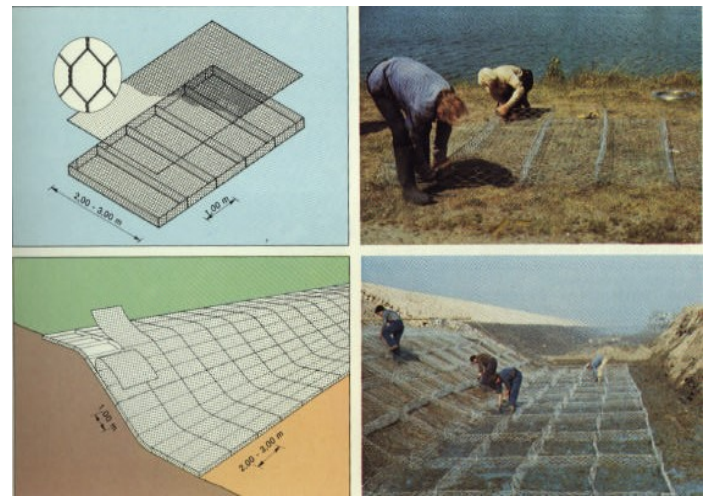

Caixa gabião

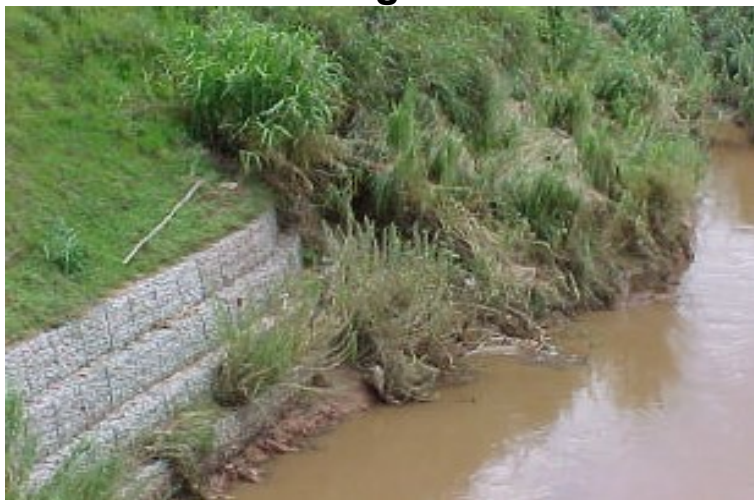

Saco de concreto

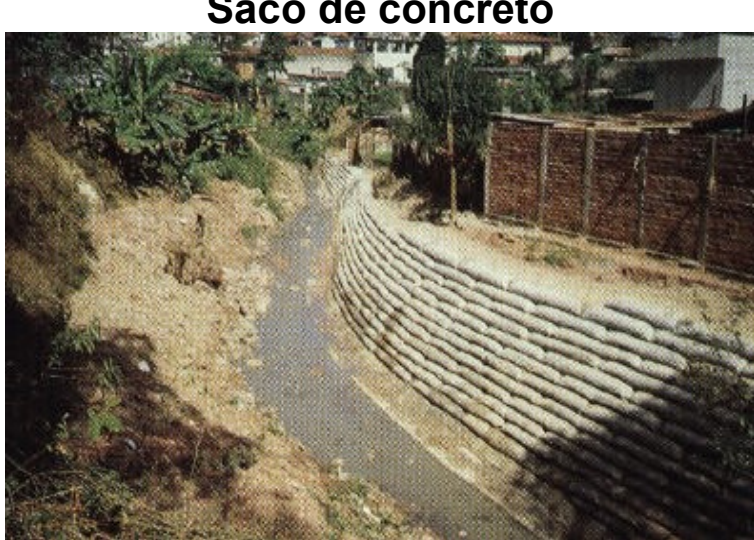

Ilustração 12 - Revestimentos flexíveis. Fonte: Adaptado de Brighetti et al.(1999).

A principal vantagem da utilização de proteções flexíveis é que elas são mais permissivas à colonização vegetal, o que garante maior naturalidade ao canal. O estudo realizado no Rio das Velhas, afluente do Rio São Francisco, no trecho situado na divisa dos municípios de Belo Horizonte e Sabará, mostrou a eficiência da aplicação de solo envelopado com base em enrocamento, que permite o crescimento de vegetação, sem comprometer sua função de estabilização das 
margens. No entanto, a ocupação deste substrato pela vegetação deve ser assistida, ou seja, as espécies devem ser previamente selecionadas e seu plantio deve ser acompanhado por equipes botânicas para não haver o comprometimento da estrutura de contenção. Após a intervenção realizada, houve redução significativa do processo erosivo na margem direita tratada (Pereira, 2008).

As proteções rígidas contemplam painéis de concreto armado, cortinas atirantadas, muros de gravidade e placas pré-moldadas de concreto (Brighetti et al., 1999). Geralmente são utilizados quando a faixa adjacente ao canal não permite recalque do maciço contido, como por exemplo, quando o canal esta limitado diretamente por viário, cujo recalque resultaria em fraturas no pavimento, situação mais comumente encontrada em áreas urbanas. A llustração 13 a seguir a seguir mostra tipos de proteções rígidas.
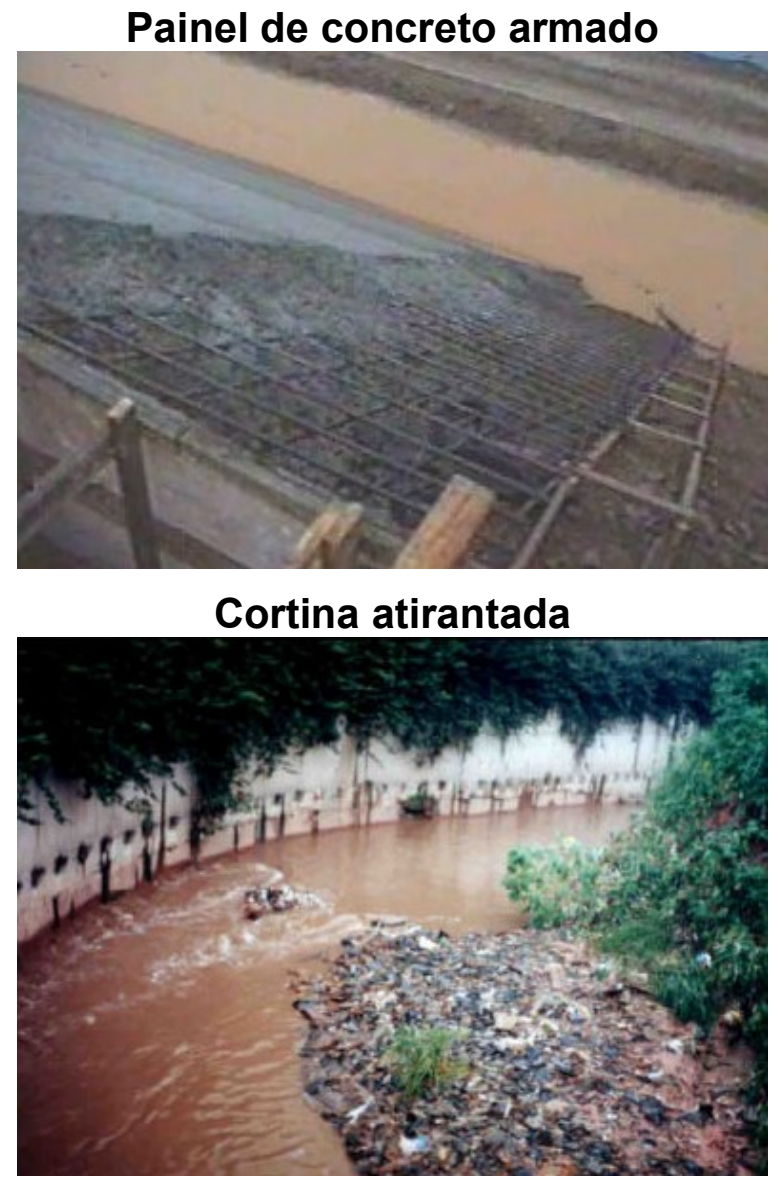
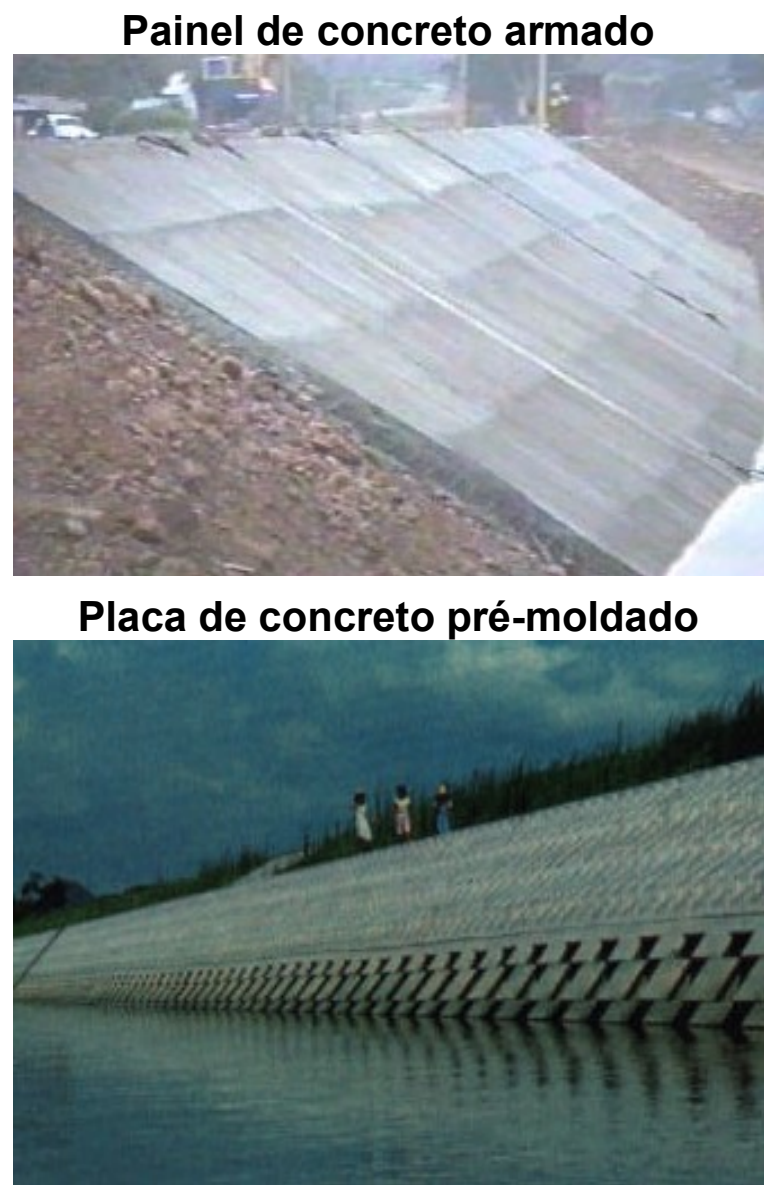

Ilustração 13 - Proteções rígidas. Fonte: Fonte: Adaptado de Brighetti et al.(1999).

Segundo agentes da prefeitura e do programa "Córrego Limpo", do ponto de vista da manutenção e limpeza, o pior tratamento do fundo de canais é o colchão, pois retém material grosseiro que fica preso às suas grades, impedindo também que 
os agentes de limpeza utilizem ferramentas auxiliares, limitando sua ação à limpeza manual. Com relação a isto, o tratamento mais indicado seria a laje de concreto, uma vez que permite a mecanização da limpeza. No entanto, do ponto de vista ambiental o resultados são diferentes, pois o uso da laje de concreto dificulta a manutenção de ecossistemas aquáticos diversos, uma vez que os organismos têm poucos lugares abrigados para colonizar. Já no caso do colchão, a grade acaba retendo resíduos, aumentando a matéria orgânica disponível, que acaba favorecendo a ação de organismos decompositores e diminuindo o oxigênio dissolvido disponível, que é um fator limitante à vida aquática. Uma situação intermediária para os dois casos é o uso de enrocamento, pois permite maior versatilidade na manutenção e possibilita um ecossistema aquático mais diverso, uma vez que cria distintos micro habitats para a fauna aquática.

O estudo de Silva e Porto (2014) que realizou a avaliação da qualidade ambiental através da aplicação de um indicador de riqueza biológica, com base na comunidade bentônica, de dois trechos do córrego Ibiraporã na zona oeste de São Paulo, o primeiro trecho com fundo tratado com enrocamento e o segundo com o fundo tratado com colchão, revelou uma maior riqueza, no período seco e chuvoso, no trecho com enrocamento, atestando os benefícios deste tipo de técnica.

A ciência dos rios surge em um primeiro momento com os engenheiros hidráulicos, com o intuito de disciplinar as águas, o que resultou na canalização e retificação de muitos rios em áreas urbanas; em um segundo momento os engenheiros hidráulicos passam a compreender a importância dos rios possuírem traçados mais orgânicos e neste ponto surge a preocupação com a conservação e recuperação de seus meandros; já em um terceiro momento há o envolvimento de outros profissionais como por exemplo ecólogos e hidrogeólogos trazendo para a discussão novas abordagens; Portanto o grande desafio da atualidade é a integração de todos os aspectos envolvidos a fim de garantir um manejo adequado das águas (Palmer e Bernhardt, 2006). 

No Brasil a estruturação do sistema viário se deu com a ocupação dos fundos de vale, constituindo as conhecidas avenidas sanitárias, no entanto as canalizações realizadas não têm se mostrado satisfatórias do ponto de vista hidrológico, uma vez que as mudanças na ocupação do solo fizeram com que a eficiência de sua seção fosse comprometida, e também do ponto de vista ambiental, uma vez que tais canais constituem estruturas de concreto sem vida alguma. A degradação dos corpos d'água urbanos vem ressaltando a importância da requalificação destes e da importância da preservação dos sistemas naturais remanescentes (Cardoso \& Baptista, 2011).

No que se refere à concepção de sistemas de drenagem, houve o entendimento de que a premissa passada de aumentar a condutividade hidráulica do canal não é a concepção mais efetiva, uma vez que sobrecarrega o sistema a jusante, portanto a ideia ultrapassada de retificar e canalizar vem sendo substituída por outras que priorizam o retardo das águas (Travassos \& Schuit, 2013). Visando o retardo da vazão de pico das chuvas, houve nos últimos anos a implantação de diversos reservatórios de detenção na RMSP, os conhecidos piscinões, no entanto, tais estruturas, apesar de garantir ao sistema certa segurança com relação à ocorrência de inundações, do ponto de vista ambiental e social, representam um grande retrocesso, uma vez que da forma que são concebidos não agregam valor à paisagem e não trazem benefício ambiental ao corpo d'água. Os piscinões hoje são pontos de acúmulo de resíduos e de desvalorização paisagística.

Nas últimas décadas tem sido adotado um enfoque mais abrangente em muitos dos projetos que envolvem intervenções em corpos d'água, incluindo as questões sociais e ambientais das áreas de várzeas em conflito com a urbanização, no entanto, ainda que o conceito tenha evoluído, o que se observa muitas vezes na prática é uma série de intervenções incompletas, como é o caso da implantação de parques lineares em áreas onde há a manutenção de rios poluídos (Travassos \& Schuit, 2013).

A cidade de Fountain Hills, Arizona, nos EUA, oferece um bom exemplo de manejo adequado do sistema de drenagem para contenção de inundações. No início do desenvolvimento da cidade três medidas de planejamento importantes foram tomadas e impactaram definitivamente os processos hidrológicos e geomorfológicos. 
Primeiro, foram identificados o caminho do fluxo de chuvas para medidas de controle de tempestades e prevenção de enchentes; Segundo, áreas de várzeas foram impedidas de serem ocupadas e terrenos próximos destas áreas de inundação naturais dos corpos d'água, sofreram taxações elevadas a fim de conter a ocupação, foram também criados critérios de ocupação específicos para evitar a ocupação densa dos espaços urbanos; Terceiro, as ruas foram projetadas para funcionar como canais de drenagem que conduzem a água de chuva para as áreas onde elas tenham condições de se infiltrar e gerar menor impacto sobre o canal (Chin e Gregory, 2005).

Cengiz (2013) divide em três áreas os princípios para um desenho ecologicamente córrego para áreas de várzea, sendo eles: Princípios gerais, onde há a previsão de metas ecológicas e de desenvolvimento econômico, a proteção e restauração das características naturais dos rios, restauração da comunidade ribeirinha, promoção de medidas que atraiam a população para próximo do corpo d'água, como atividade de lazer ao ar livre e o envolvimento desta comunidade no processo de planejamento. Princípios de planejamento, onde é previsto a consolidação da relação entre a comunidade ribeirinha e o rio, conhecimento do ecossistema do rio, devido ao dinamismo dos rios minimizar o desenvolvimento humano nas várzeas, fornecer acesso público e recreação, promoção de eventos para a comemoração da história ambiental do rio a fim de criar uma relação entre o rio e a sociedade. Princípios do desenho, onde é prevista a proteção da função natural do rio, criação de zonas de proteção para áreas sensíveis, restauração das moradias dos ribeirinhos, uso de alternativas não estruturais para gestão dos recursos hídricos, reduzir as construções impermeáveis, priorizar o uso de abordagens não estruturais e a instalação de equipamentos de lazer de forma segura para o usuário.

Em função da preocupação com a questão das inundações em áreas urbanas, Cengiz (2013) elenca possíveis usos para as áreas de várzea para diferentes manchas de inundação para cada período de retorno considerado, para que haja a integração entre interesses sociais, econômicos e ambientais. A mancha de inundação alcançada por uma chuva com período de retorno de meio ano, fica destinada a reservas naturais, parques infantis e jardins; Já a mancha para o período de retorno de um ano, fica reservada para estacionamentos temporários, 
estradas de baixa circulação e construções de uso intermitente resistentes à água; Para um período de retorno de 25 anos, permite-se estradas de maior circulação, parques de estacionamento e edificações com pavimento térreo mas de uso intermitente; E a mancha atingida pelo período de retorno de 100 anos, permite por fim grandes áreas urbanas, exceto hospitais e outros serviços essenciais.

Segundo Cengiz (2013), é possível dividir o manejo das águas em diferentes ambitos, sendo eles:

- Restauração ou naturalização: Restabelecer as relações entre o corpo d'água e a paisagem de modo a retornar o corpo d'água a condição natural, ou o mais próximo possível da condição natural.

- Reabilitação ou recuperação: que visa o reestabelecimento das condições físicas, químicas e biológicas do corpo d'água, de modo a reestabelecer as condições sanitárias deste.

- Revitalização: Restabelecer as relações entre o corpo d'água e a paisagem de forma funcional, ou seja, reintroduzir o canal dando novamente vida a este, sem privar outros usos.

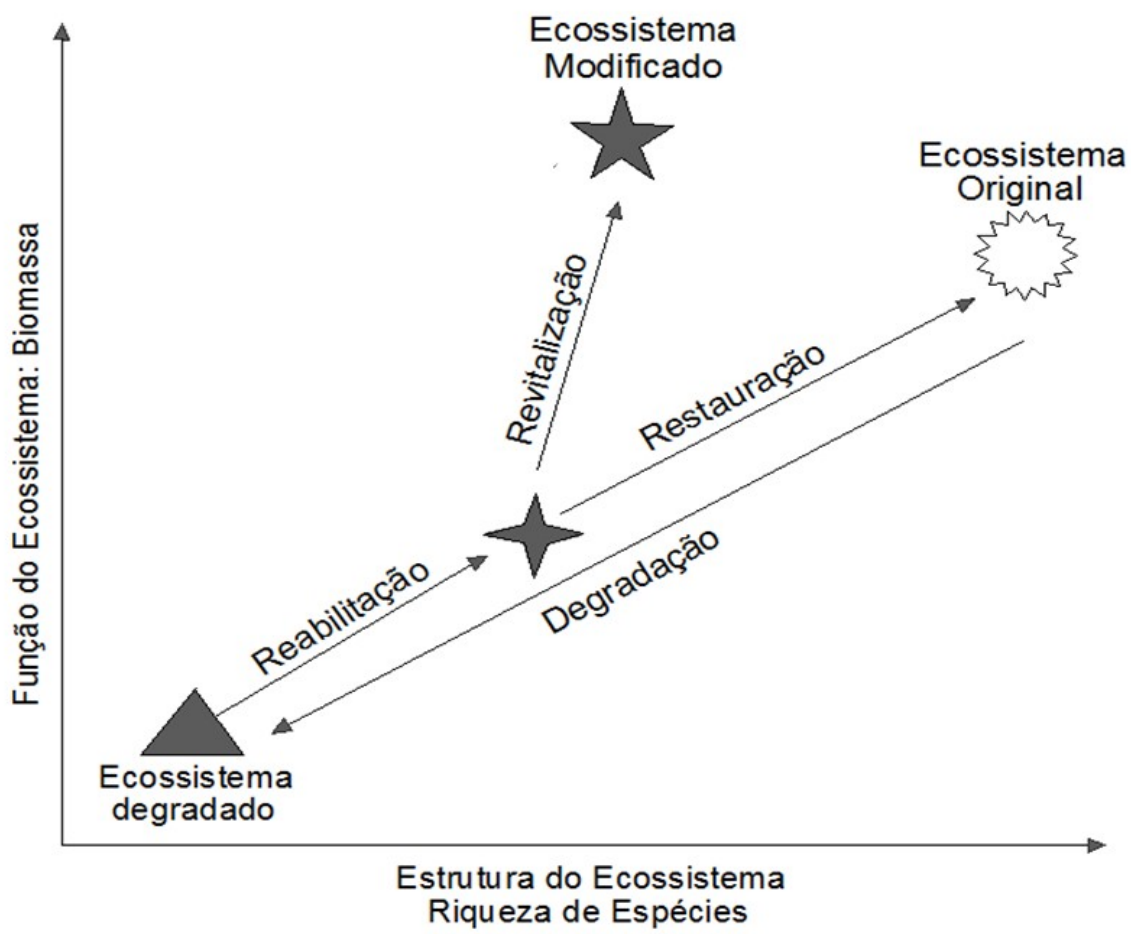

Ilustração 14 - Tipos de intervenções em corpos d'água. Fonte: Adaptado de Findlay \& Taylor (2006). 
A revitalização pode ser ainda considerada como um passo intermediário em um processo de restauração ou renaturalização, já que pode-se estabelecer em um intervalo curto de tempo uma nova condição de equilíbrio no sistema que visa no longo prazo a restauração completa do mesmo.

Para Findlay e Taylor (2006) restaurar ou renaturalizar um corpo d'água significa retorna-lo a uma condição original, o que inclui reestabelecer todas suas características físicas, químicas e biológicas; Já o processo de reabilitar ou recuperar significa reestabelecer algumas características, ou seja, uma situação intermediária entre a degradação e a restauração; Por fim, para os autores o processo de revitalizar implica em reestabelecer algumas funções originais e criar outras novas, fazendo com que o corpo d'água atinja uma condição de equilíbrio nova. O processo de recuperação e revitalização são mais realistas dentro de um contexto urbano, uma vez que dificilmente consegue-se reestabelecer as condições originais do corpo d'água, já que o processo demandaria elevado investimento financeiro e inviabilizaria a maioria dos usos da água, como por exemplo a recreação e transporte.

Baker e Eckerberg (2013) apud Hull e Robertson (2000) detalham três definições possíveis de naturalidade do sistema considerando a restauração ecológica: Naturalidade associada a um estado do ambiente em um momento anterior conhecido, onde a restauração visa a reconstrução fiel deste estado; Naturalidade como um estado do ambiente na ausência de intervenções humanas, onde a restauração visa reestabelecer um estado semelhante; e por fim a naturalidade como uma condição de equilíbrio ecológico que atingida de forma lenta e natural, onde a restauração atue de modo a assegurar as funções ecológicas do ecossistema. Tais definições devem ser abordadas com atenção pois podem criar um distanciamento da compreensão da importância da reconstrução de um ecossistema saudável via projetos de restauração ecológica.

A revitalização de corpos d'água em áreas urbanas esbarra em 3 questões, as sociais e políticas, as econômicas e as ambientais, que servem de embasamento para justificar o porque revitalizar um corpo d'água. Para reestabelecer a integridade de corpos d'água é necessário pensar em componentes como a ecologia, a 
hidrologia, a geomorfologia e a qualidade da água de forma integrada (Findlay \&Taylor, 2006).

Projetos de revitalização tem como diferencial não se limitar somente à condição sanitária do corpo d'água, sendo aqueles que se preocupam em integrar um conjunto de variáveis, como por exemplo as naturais, urbanísticas, sociais e de gestão no processo de decisão (Cardoso \& Baptista, 2013). A abordagem dos programas de revitalização deve manter uma visão holística que leve em conta a integração dos processos que ocorrem na bacia, no corpo d'água e nas zonas ripárias (Ward et al., 2001). Além disso, não é possível realizar uma intervenção duradoura em um corpo d'água sem um forte suporte público (Petts, 2007).

Findlay \&Taylor (2006) citam como uma das principais causas do sucesso dos programas de revitalização de corpos d'água na Austrália, a ampla participação da comunidade no processo. Os projetos de maior sucesso foram aqueles que implantaram nas margens de seus canais estruturas para controle de inundações que eram associadas a áreas de recreação para a comunidade. Além disso, a população mostrou-se mais favorável às soluções que passavam uma imagem mais natural do canal, que incluíam a previsão de vegetação nas margens. As áreas no entorno dos canais reabilitados no município de Perth, tiveram seu valor imobiliário aumentado em 17\%. Segundo os autores existem diversas razões para revitalizar um corpo d'água, algumas são mais evidentes como as que envolvem a qualidade da água e os fenômenos erosivos, no entanto há também motivos mais discretos, como os sociais e econômicos, portanto é necessário estabelecer um equilíbrio entre os diversos aspectos envolvidos, como mostrado no diagrama da llustração 15 .

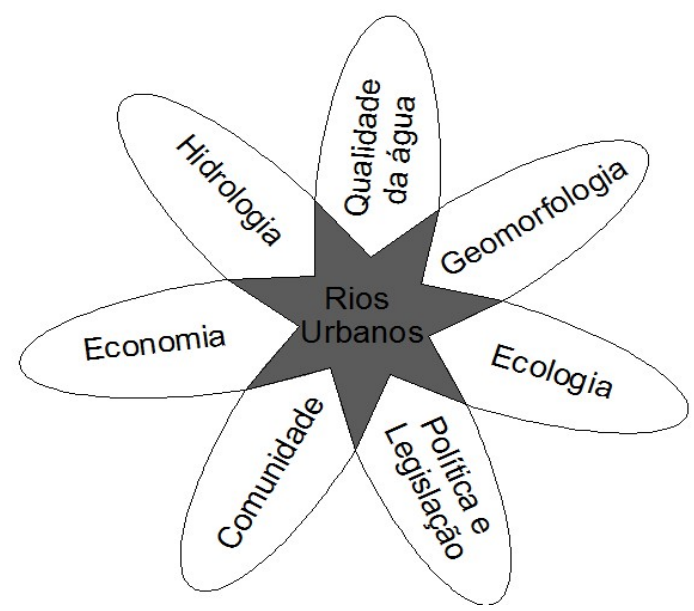

Ilustração 15 - Equilibrio do processo de intervenção em corpos d'água. Fonte: Adaptado de Findlay \& Taylor (2006). 
Segundo Chin e Gregory (2005) é possível identificar cinco categorias para o potencial de recuperação de um corpo d'água: 1) Intactos: operando de forma em que pequenas perturbações são auto ajustadas facilmente garantindo a manutenção do meio equilibrado; 2) Aptos à recuperação: se recuperam com facilidade de um eventual distúrbio, mantendo suas características essenciais em equilíbrio, ou seja, são moderadamente resistentes; 3) Pré-degradados: em processo de ajuste frente à perturbação e em estado de deterioração progressiva; 4) Ponto de viragem: em transição para um estágio de degradação, neste ponto os canais podem se recuperar ou se degradar por completo; 5) Degradado: Estágio em que o corpo d'água não se auto recupera, sendo necessárias intervenções diretas, ou seja, não basta cessar a fonte do impacto. A classificação funciona como instrumento de identificação de áreas com potencial maior para recuperação e que por sua vez demanda menores investimentos para tanto.

Cardoso e Baptista (2011) propõem um indicador para avaliar intervenções necessárias em corpos d'água urbanos, a metodologia se baseia em doze parâmetros, sendo eles: Forma/sinuosidade; Leito e margens; Condições de inundação no local; Impacto sobre as vazões de jusante; Processo de erosão e assoreamento; Diversidade de habitats; Áreas verdes adjacentes ao corpo d'água; Impacto paisagístico; Proliferação de insetos; Áreas e equipamentos urbanos de lazer; Desapropriação, remoção e reassentamento da população; e Valorização financeira da área.

A aplicação do indicador de Cardoso e Baptista (2011) consiste em delimitar a área de influência do corpo d'água, identificação das alternativas, avaliação das alternativas e comparação destas. A identificação das alternativas deve ser realizada dentro da premissa de buscar-se a manutenção do curso d'água nas condições mais naturais possíveis. $\mathrm{Na}$ avaliação das alternativas o método propõe a atribuição de uma pontuação seguindo a seguinte escala: Grande piora (-2); Pequena piora (-1); Indiferente (0); Pequena melhora (+1); e Grande melhora (+2). Portanto a avaliação de cada alternativa se da pela soma da avaliação de qualitativa de cada um dos indicadores. Indicadores como o proposto pelos autores tem grande importância como ferramenta de gestão e auxiliam na sistematização da escolha da metodologia de tratamento empregada. A Tabela 3 a seguir, mostra o impacto das intervenções e seus indicadores, onde é possível observar seus respectivos pesos. 
Tabela 3 - Impactos das intervenções e seus indicadores. Fonte: Adaptado de Cardoso e Baptista (2011).

\begin{tabular}{|c|c|c|}
\hline \multicolumn{3}{|c|}{ Impactos das intervenções e seus indicadores } \\
\hline $\begin{array}{l}\text { Impacto da } \\
\text { Intervenção }\end{array}$ & Indicador & Peso \\
\hline \multirow{2}{*}{$\begin{array}{l}\text { Impactos no } \\
\text { curso d'água }\end{array}$} & 1) Forma / sinuosidade & 8,0 \\
\hline & 2) Leito e margens & 9,5 \\
\hline \multirow{2}{*}{$\begin{array}{l}\text { Impactos no } \\
\text { curso d'água }\end{array}$} & 3) Condições de vulnerabilidade e inundações do local & 14,5 \\
\hline & 4) Vazões de jusante & 11,5 \\
\hline \multirow{4}{*}{$\begin{array}{l}\text { Impactos } \\
\text { ambientais }\end{array}$} & 5) Processos de erosão e assoreamento & 9,0 \\
\hline & 6) Diversidade de habitats & 5,3 \\
\hline & 7) Áreas verdes adjacentes ao corpo d'água & 6,5 \\
\hline & 8) Impacto paisagístico & 5,2 \\
\hline $\begin{array}{l}\text { Impactos } \\
\text { sanitários }\end{array}$ & 9) Proliferação de insetos & 8,0 \\
\hline \multirow{3}{*}{$\begin{array}{l}\text { Impactos } \\
\text { sociais }\end{array}$} & 10) Áreas e equipamentos urbanos e de lazer & 9,8 \\
\hline & 11) Remoção da poluição & 8,2 \\
\hline & 12) Valorização financeira da área & 4,5 \\
\hline Total & & 100 \\
\hline
\end{tabular}

Cardoso e Baptista (2013), propõem ainda uma metodologia multicriterial para orientação de processos decisórios em cursos d'água urbanos, baseada em quatro etapas: concepção, análise, comparação e seleção de alternativas. Os autores demonstraram a aplicação da metodologia para o Córrego Engenho Nogueira, dentro do Campus da UFMG, obtendo resultados eficientes na análise de quatro alternativas de intervenção para a área, auxiliando no processo de seleção. A llustração 16 mostra o fluxograma para aplicação da metodologia proposta. 


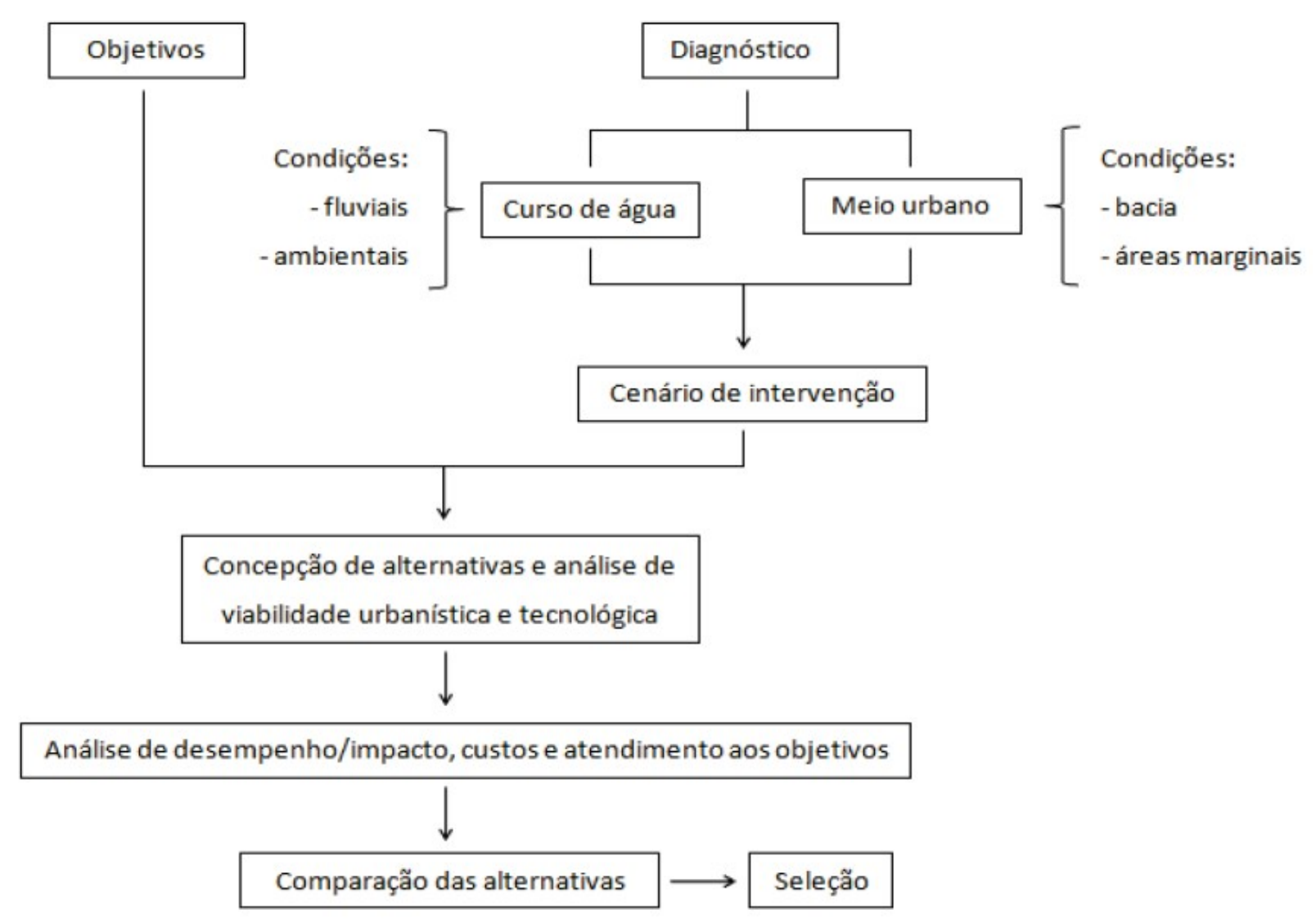

llustração 16 - Metodologia multicriterial para orientação de processos decisórios em cursos d'água urbanos. Fonte: Cardoso e Baptista (2013).

Pereira (2001), com base nos princípios descritos pela USEPA, elenca alguns princípios indispensáveis para que um projeto de renaturalização seja bem sucedido, sendo eles:

- A preservação e proteção dos recursos aquáticos, uma vez que a existência de ecossistemas intactos são peças chave para a recuperação de sistemas degradados;

- Restauração e integridade ecológica, que refere-se à estrutura, composição e processos naturais da biota e das variáveis físico-químicas;

- Restauração da estrutura física natural, muitos dos problemas de corpos d'água degradados se devem às alterações na configuração do canal resultante de canalizações e retificações, que por sua vez resultam na degradação do ecossistema aquático, dos fluxos hidráulicos e dos processos de transporte de sedimento; 
- Restauração da função, a fim de garantir a sustentabilidade do processo;

- Trabalhar a restauração no contexto da bacia hidrográfica e da paisagem, uma vez que estas são responsáveis por moldar o corpo d'água;

- Apontar continuamente as causas da degradação, uma vez que uma rápida resposta à degradação resulta em um processo de mitigação mais eficiente; e

- Monitoramento, antes e depois do processo para a consolidação do mesmo e verificação do atendimento dos objetivos.

Já Petts (2007) elenca para um efetivo processo de revitalização de corpos d'água em áreas urbanas os seguintes elementos:

- A qualidade da água deve ser adequada para a manutenção da biota;

- Em zonas críticas de inundação, deve-se envolver as pessoas nos estudos de concepção para manejo da água na área;

- Envolver a comunidade no processo de planejamento da bacia hidrográfica;

- Não permitir construções nas áreas de várzea;

- Sempre tornar as áreas de várzeas interessantes à população;

- Criar oportunidades ao longo do rio para atividades de educação ambiental sobre o rio e sobre sua biota;

- Quando houver a remodelagem do canal, aproveitar a oportunidade para realizar a remoção das construções existentes nas áreas de várzea;

- Sempre que possível priorizar traçados que permitam que o rio tome sua forma sinuosa natural, permitindo que a água flua livremente;

- Aumentar as possibilidades de acesso seguro ao rio, tendo em conta as necessidades das crianças e dos portadores de necessidades especiais;

- Havendo terreno disponível e condições adequadas, promover a criação de zonas úmidas; 
- Promover ao longo do rio, áreas para que as pessoas possam realizar atividades de lazer, como pistas de caminhadas e estruturas esportivas; e

- Gerir os resíduos de forma eficiente para que não haja nenhum lixo no rio e ao longo das margens.

E Palmer et al. (2007), elenca com base na análise de diversos projetos em andamento nos EUA e na entrevista de consultores que atuam nestes projetos as seguintes recomendações para a realização de projetos de revitalização:

- Os projetos devem ser baseados no grau de degradação da bacia e desenvolvidos em escala adequada, a fim de viabilizar sua aplicação;

- O projeto deve observar as características especificas da bacia, como o uso do solo, a hidrologia e o meio biótico, a fim de assegurar que o projeto não demande grandes intervenções futuras para manutenção de seus resultados, ou seja, que a revitalização seja autorregulada;

- O projeto deve ser acompanhado de um programa de monitoramento, a fim de garantir que as metas estabelecidas na etapa de planejamento sejam cumpridas;

- Devem ser estabelecidos mecanismos de financiamento e regulamentação, a fim de assegurar a implantação total do projeto; e

- Deve-se envolver a população em todas as etapas do projeto, a fim de tornar os resultados permanentes.

Na América do Norte, projetos de revitalização tem alguns objetivos comuns, como a melhoria das áreas ripárias e a melhoria dos habitats, para tanto são necessárias ações voltadas para o replantio de vegetação, eliminação da pecuária das áreas de várzea e manutenção da mata ciliar. A revitalização esta muito atrelada ao tipo de usos pretendidos, por exemplo, nos rios da América do Norte há uma grande preocupação em manter à integridade do ecossistema devido ao uso dos rios para a pesca de Truta e Salmão; Já na Europa a preocupação esta muito voltada para o controle no transporte de sedimentos e assoreamento dos rios, uma vez que há uma grande demanda para a navegação (Pereira, 2001). Nestes países 
a revitalização constituiu uma atividade importante para reestabelecer a identidade dos corpos d'água, possibilitando o uso múltiplo das águas (Kondolf, 2006).

A legislação europeia exige que os projetos de revitalização sejam interdisciplinares e que integrem a geomorfologia, a hidrologia, a hidráulica e a ecologia pluvial, no entanto esta integração se torna difícil quando o intuito é definir o que é a revitalização de um corpo d'água, já que cada ciência tem suas prioridades e seu conceito de projetos viáveis. A definição de "Natural" sofre variação em função da ciência em que o termo esta sendo considerado, no entanto quando tratamos da revitalização de corpos d'água o mais palpável é que um corpo d'água revitalizado seja aquele que esteja reintegrado à paisagem e à população e não necessariamente aquele que retornou a uma condição original (Newson et al., 2006).

O estado da Califórnia é um dos estados americanos que mais investe na requalificação de rios, seu programa de revitalização CALFED Bay-Delta investiu entre 1996 e $2005 \$ 500$ milhões em projetos. Analisando o banco de dados do estado, composto por 4023 projetos, os focos de projeto mais comuns encontrados foram: a qualidade da água (20\%), o manejo da mata ciliar (15\%) e a estabilização das margens (13\%). Além disso, $22 \%$ dos projetos no banco de dados possuíam um programa de monitoramento (Kondolf et al, 2007).

Em São Paulo, o Programa de Recuperação Ambiental de Cursos D'água e Fundos de Vale, previsto pelo Plano Diretor Estratégico, idealizado para constituir uma parceria entre a Secretaria Municipal do Planejamento (SEMPLA), a Secretaria Municipal do Meio Ambiente (SMMA) e a Secretaria Municipal da Habitação (SEHAB), prevê a integração das áreas de várzea através da implantação de parques lineares como ferramenta fundamental para a consolidação destas áreas como espaços públicos. O município possui 1637 áreas de interesse social, onde cerca de 1/3 destas estão situadas total ou parcialmente sobre áreas de várzea, portanto a questão da revitalização de corpos d'água na cidade, que reflete a realidade de outros centros urbanos no Brasil, esta intimamente atrelada à questão habitacional (Travassos \& Schuit, 2013).

Segundo Macedo e Magalhães (2011), a velha concepção de tratamento de canais em áreas urbanas está tão consolidada na percepção da população, que 
mesmo que as novas soluções sejam eficientes, a população se mantém temerosa. Um das alegações mais comuns é a de que a ausência de manutenção das estruturas pode levar a problemas sanitários no futuro, o que não deixa de ser uma preocupação pertinente, uma vez que um dos grandes problemas dos sistemas de drenagem urbana brasileiros é a falta de manutenção ou sua realização inadequada. Ainda segundo os autores, a mudança no uso da água de um uso puramente sanitário para outros ligados ao lazer, criando condições estéticas mais favoráveis, promove uma maior integração do corpo d'água com a paisagem e a vida urbana, fazendo com que a população volte a se identificar com o corpo d'água.

Petts (2007) a fim de compreender melhor a importância do envolvimento da população no processo de revitalização de rios urbanos, realizou um estudo com um grupo de pessoas, sem formação especifica na área, envolvidas no processo de revitalização de um rio urbano, onde foi identificado que ao envolver a população no processo, essa passa a agregar conhecimentos específicos, passa a estabelecer uma conexão com o corpo d'água e a atuar ativamente na comunidade, representando um grande ganho para o processo como um todo. Os mesmos agentes, quando perguntados sobre o que consideravam essencial em um projeto de revitalização, apontaram a presença de espaços públicos abertos à comunidade, onde a população possa realizar atividades ligadas à recreação e onde os jovens possam criar uma identidade positiva e até mesmo afetiva com as águas.

O encorajamento para que a sociedade como um todo se envolva no processo de revitalização de corpos d'água deve ser realizado com cautela, uma vez que a fusão do público com o acadêmico não necessariamente resulta em programas sustentáveis, já que muitas vezes o envolvimento político pode dar ênfase nos ganhos em curto prazo, descaracterizando os projetos de revitalização que acabam se tornando "falsos naturais", ou seja, imitando formas naturais para garantir a estética e retirando os elementos que tornam o projeto realmente sustentável (Newson et al., 2006).

Através da utilização de pesquisas amostrais (surveys) para avaliação da percepção social e das mudanças de comportamento em relação aos cursos d'água após as intervenções do "Programa de Recuperação Ambiental e Saneamento dos Fundos de Vale e dos Córregos em Leito Natural em Belo Horizonte", conhecido 
como Drenurbs, na bacia do córrego Baleares, observou-se que há um baixo envolvimento da população no processo de revitalização, cerca de $9 \%$ dos entrevistados residentes na bacia indicaram alguma participação. Segundo pesquisa realizada no Córrego Baxter, na Califórnia, onde foi analisada somente a participação dos moradores que vivem de frente ao curso d'água, $42 \%$ dos entrevistados apontaram sua participação nas ações de revitalização (Macedo e Magalhães, 2011).

Quando perguntados sobre as obras realizadas no Córrego Baleares, $50 \%$ da população indicaram a preferência por uma avenida sanitária, ao invés das ações de revitalização, e o argumento mais citado (44\%) para justificar sua rejeição foi o de que uma avenida sanitária melhoraria o acesso viário. Outras causas citadas foram que a avenida resultaria na redução de vetores (20\%), protegeria o córrego da poluição (14\%), geraria maior valorização da área (10\%), que cobriria o córrego $(8 \%)$, o parque seria perigoso $(3 \%)$ e que a avenida resultaria na proteção contra enchentes (3\%) (Macedo e Magalhães, 2011). A maioria das alegações apresentadas é equivocada, indicando a importância da conscientização da população sobre a gestão de recursos hídricos em áreas urbanas.

Sempre que há uma alteração na paisagem, cuja população já esta familiarizada, há uma contestação por parte desta, ainda mais se tais alterações resultem em alterações na acessibilidade da área, portanto o envolvimento da população residente na fase de projeto é de grande importância, para que haja a aceitação da intervenção. Importância ainda deve ser dada à heterogeneidade existente dentro da população envolvida, a fim de garantir que a maior parcela possível da população seja integrada no processo decisório (Seidl e Stauffacher, 2013). Segundo Palmer et al. (2007), que realizou uma revisão dos projetos de revitalização de rios nos EUA, os projetos que obtiveram melhores resultados foram aqueles onde havia o envolvimento da população residente na bacia no projeto.

A consulta pública sobre as iniciativas de revitalização do delta rio Reno realizada no estudo de Buijs (2009) revelou que a população se mostra mais envolvida e favorável ao projeto, quando este tem potencial de valorização paisagística e respeita os valores culturais da região. Aspectos ligados a questões ecológicas não se mostraram atrativos à população entrevistada. O autor ressalta a 
necessidade de criar alianças locais durante processo de elaboração do projeto de revitalização, a fim de envolver os cidadãos comuns para que compreendam a importância das ações do projeto, contrabalanceando grupos críticos que tenham interesse nas terras para outros usos.

O estudo realizado por Seidl e Stauffacher (2013), onde foi aplicado um questionário para avaliar a percepção dos moradores da bacia do Rio Thur na Suiça sobre a revitalização do mesmo, revelou que há uma relação entre a idade do entrevistado e a sua tendência a aceitação do projeto. O índice de aceitação do projeto foi maior entre pessoas mais jovens, enquanto na parcela mais velha dos entrevistados indicou com maior frequência que "Os seres humanos tem direito de modificar a natureza em beneficio próprio" e que "A natureza não deve obstruir o desenvolvimento econômico". Tal resultado revela que na população esta em curso uma mudança de mentalidade, onde a natureza vem ganhando maior importância.

Os moradores de áreas próximas a zonas alagadas da Nova Escócia no Canadá quando questionados sobre estas áreas, indicaram elas como parte integrante do bairro e como zonas promotoras de áreas de lazer, indicaram ainda que acreditam que estas áreas elevam o valor dos imóveis devido à beleza paisagística (Manuel, 2003). A manutenção destes espaços como áreas saudáveis é o elemento chave para a criação de um vínculo entre os mesmos e a população.

Palmer et al. (2005) elenca cinco passos para um programa de revitalização de corpos d'água de sucesso. O primeiro inclui a criação de uma imagem de referência para o corpo d'água que considere as características dinâmicas relacionadas às características ecológicas, hidrológicas e geomorfológica, traçando os objetivos a serem alcançados e os valores referência para as variáveis consideradas; O segundo inclui a seleção de um conjunto de indicadores, seja da qualidade da água como também da melhoria do regime do canal, que sirvam para avaliar se as metas de melhoria do canal estão sendo atingidas; O terceiro estipula que o projeto deve priorizar a criação de um canal resiliente, que em longo prazo demande poucas intervenções para sua manutenção e que absorva bem os pequenos impactos; $O$ quarto prevê que haja o monitoramento do canal mesmo após a conclusão das intervenções a fim de verificar se a condição se mantém estável; e por fim o quinto prevê a avaliação do processo para checagem das etapas concluídas com sucesso. 
O diagrama apresentado na llustração 17 a seguir, mostra o ponto de integração das variáveis consideradas no processo de revitalização de corpos d'água, ou seja, o processo mais efetivo é aquele que encontra um ponto de equilíbrio entre elas.

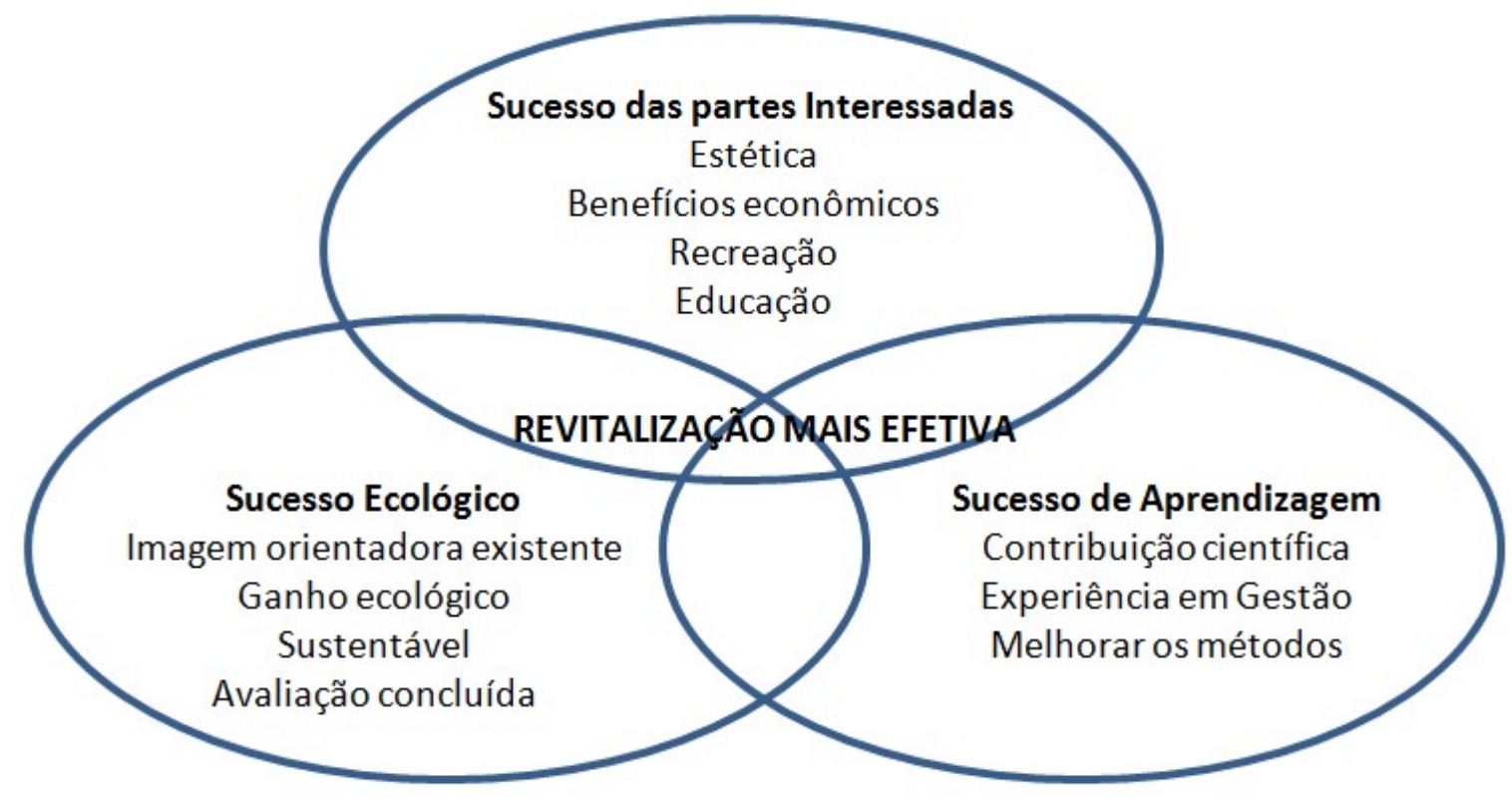

Ilustração 17 - Zona de intersecção dos projetos de revitalização de corpos d'água mais eficazes. Fonte: Adaptado de Palmer et al. (2005).

Segundo Baker e Eckerberg (2013) em sua análise política do processo de restauração ecológica, apesar da ideia de que o processo deve ser multidisciplinar, poucos estudos dão atenção à importância das políticas públicas na consolidação do mesmo. A política tem a função de organizar os interesses de diferentes atores da sociedade de forma a balizar os interesses envolvidos, uma vez que apesar de haver órgãos específicos que cuidam dos interesses ambientais, como ministérios do meio ambiente e dos recursos hídricos, estes dependem de outros setores para seu bom funcionamento, como energia, agricultura, transporte, etc, portanto a existência de políticas que organizem a relação entre eles é de grande importância (Baker e Eckerberg, 2013).

A elaboração de uma política para programas de interesse ambiental segue uma série de estágios, como a definição de uma agenda (Propostas e foco do programa), formulação da política (Definição da escala espacial e temporal e das fontes de financiamento), implementação (Identificação das características da área, dos aspectos técnicos e investigação junto aos agentes envolvidos) e avaliação (Técnica, histórica, ecológica, social e econômica) (Baker e Eckerberg, 2013). 
A restauração ecológica pode ser aplicada em diferentes sistemas, incluindo áreas urbanas e rurais, podendo ainda ser aplicada em diversas escalas, desde a remediação de pequenas áreas, até grandes projetos como a revitalização do rio Kissimmee na Florida. Ao escolher a escala de intervenção em uma bacia um dos principais desafios é lidar com casos em que há a transposição de limites fronteiriços, já que cada unidade de gestão possui suas próprias legislações, bem como interesses particulares e impedimentos financeiros. Como exemplo, o que ocorre na bacia do rio Colorado nos Estados Unidos e México e no lago OhridPrespa na Grécia e Macedônia (Baker e Eckerberg, 2013). A escolha de áreas menores acaba minimizando este tipo de problema e garantindo maior sucesso para o projeto.

À crescente preocupação com as mudanças climáticas tem potencializado o interesse em projetos de revitalização, uma vez que as projeções indicam uma mudança significativa nos regimes de chuva em todo o globo, e quando se trata de áreas urbanas pequenas mudanças podem resultam em consequências catastróficas. Desta forma muito tem se discutido sobre a importância da criação de sistemas resilientes, que sejam capazes de absorver tais alterações sem impactar significativamente a população, contrário dos sistemas usuais, que dependem de manutenções constantes e não tem flexibilidade para suportar sobrecargas (Palmer et al., 2007). 


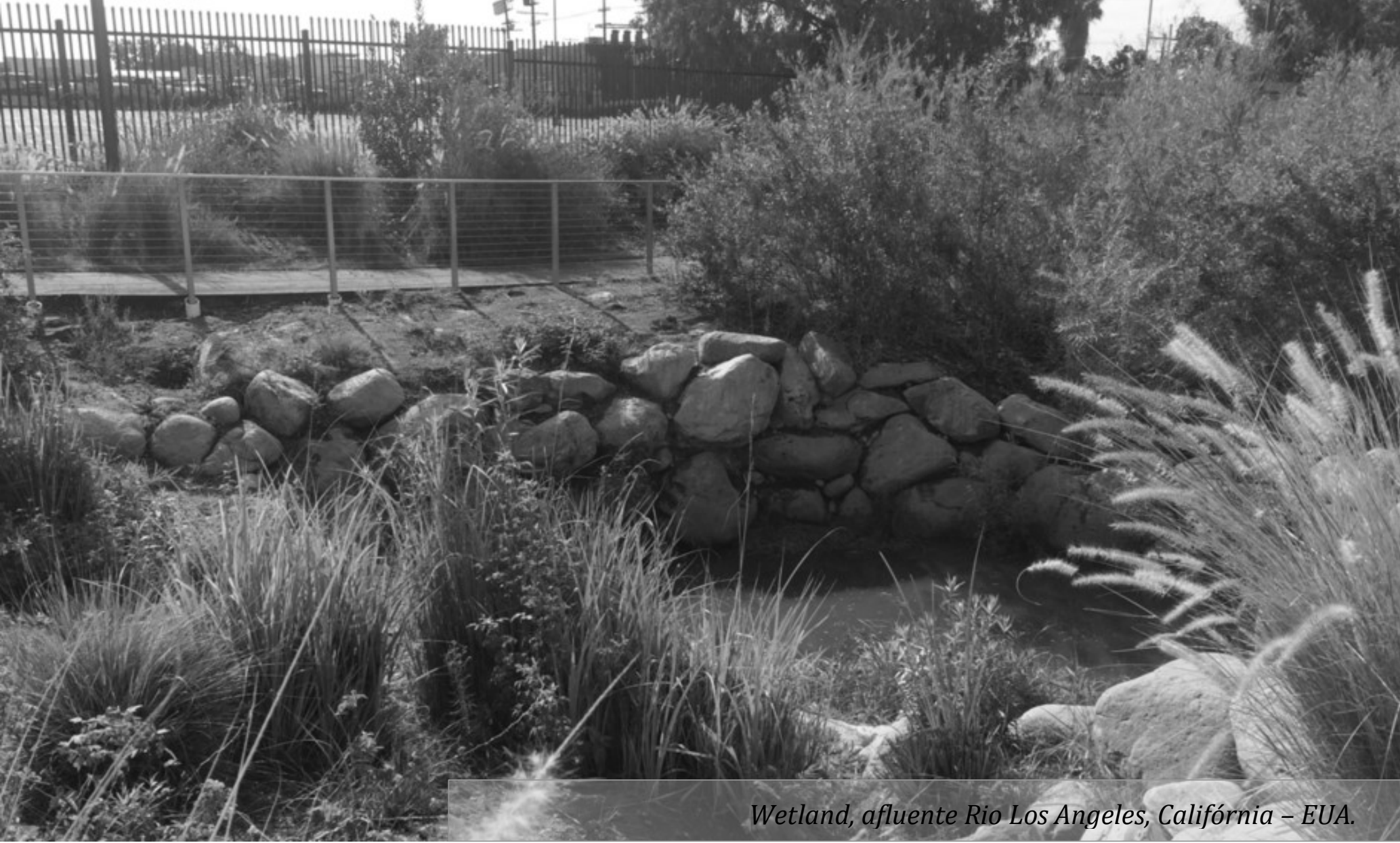

\subsubsection{Técnicas de manejo}

O estudo dos sistemas urbanos atuais demonstra que as técnicas convencionais, apesar de importantes, não são suficientes para sanar por completo os problemas ambientais, hidrológicos e paisagísticos existentes em uma bacia hidrográfica, sendo necessária a utilização de técnicas complementares. Os itens seguintes abordam diversas metodologias e técnicas complementares aos sistemas urbanos convencionais que visam cobrir as lacunas existentes aumentando sua eficácia e promovendo um funcionamento mais integrado. 


\subsubsection{Sistemas complementares para controle da carga pontual}

Sabendo que as cargas pontuais são a fonte de poluição mais significativa para o corpo d'água, estas devem ser prioritárias em programas de despoluição. No entanto a consolidação de sistemas de esgotamento nem sempre é uma tarefa trivial, devido à existência de pontos de difícil esgotamento, desta forma surge a necessidade da adoção de técnicas de tratamento complementares que promovam o tratamento local dos efluentes e que viabilizem a consolidação do sistema.

O sistema de esgotamento sanitário tradicional se baseia no conceito de sistemas centralizados, onde as estações de tratamento de esgotos são de grande porte e recebem efluentes de diversas bacias de esgotamento, sendo necessários órgãos e dispositivos que promovam a transposição de bacias, como estações elevatórias, e que conduzam os efluentes por longas distancias. No entanto, vem ganhando força um novo modelo chamado de descentralizado, que dentro dos princípios da sustentabilidade prioriza a descentralização dos serviços, visando a redução do consumo de recursos e o tratamento dos resíduos próximo à fonte.

O Water Supply and Sanitation Collaborative Council concebeu o conceito de saneamento ambiental domiciliar, para viabilizar o atendimento total da população por serviços sanitários, desta forma mesmo pequenos municípios e povoados, adotando técnicas locais, poderiam destinar adequadamente seus efluentes sem impactar o meio ambiente. Considerando o porte da cidade de São Paulo, pode-se tratar seus bairros como pequenos municípios, descentralizando os serviços a fim de consolida-los (Samuel, 2011).

Segundo Hoffmann et al. (2004) os sistemas descentralizados seguem os seguintes princípios básicos: Baixos custos de investimento, baixos custos de operação, operação e manutenção simplificada e boa eficiência de tratamento. $O$ autor elenca três técnicas para o tratamento descentralizado de efluentes: filtros de areia plantados (Wetlands), filtro percolador e reator sequencial por batelada.

Os filtros de areia plantados, as conhecidas wetlands, implantados como canteiros de fluxo vertical, tem capacidade para remoção de DBO e DQO e também a nitrificação total, possibilitando uma eliminação efetiva de coliformes fecais. Segundo a experiência europeia, o sistema atinge taxas de coliformes fecais abaixo 
do exigido pela portaria de balneabilidade (1000 coliformes fecais/L). O sistema possui como vantagem ainda a não geração de lodo, que é mineralizado nos canteiros (Hoffmann et al., 2004). O estudo de Trein et al. (2015) revelou a remoção mínima de $75 \%$ da DQO e $88 \%$ da DBO em sistemas de filtro de areia plantados.

O funcionamento do filtro se dá pela percolação do efluente em diferentes camadas filtrantes que funcionam como um reator. A llustração 18 mostra as etapas do processo: Os efluentes são recepcionados em um tanque (1) e direcionados através de bombeamento (2) caso seja necessário, ou diretamente por gravidade para o filtro através de uma tubulação perfurada (4) que dispersa o efeluente na camada filtrante com camadas de diferentes granulometrias (5) até chegar ao fundo do filtro composto por carvão ativado (6), a fase líquida do efluente tratado é coletada no fundo do tanque através de uma segunda linha de tubulação perfurada e direcionada a uma caixa de inspeção (7) e na sequência lançada no corpo d'água. Sobre o filtro realiza-se o plantio de espécies vegetais adequadas (3) para a remoção de nutrientes (Global wetlands, s/d).

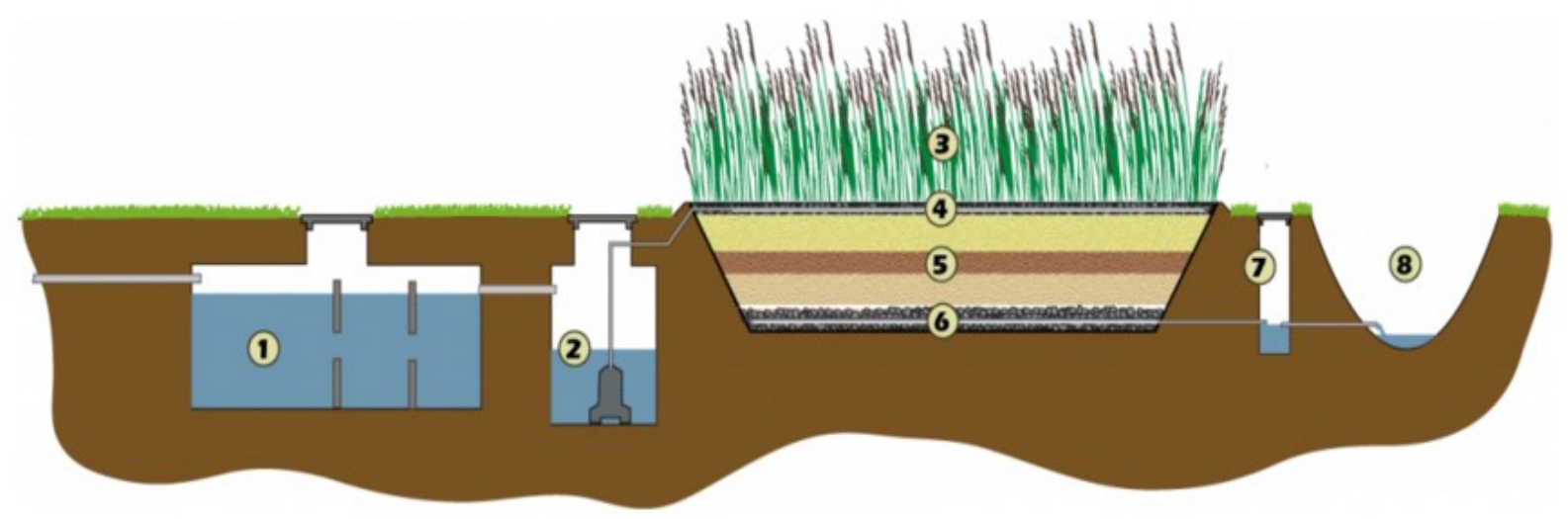

Ilustração 18 - Filtro de fluxo vertical. Fonte: Global wetlands (s/d).

Segundo o GESAD (Grupo de estudos em sistemas wetlands construídos aplicados ao tratamento de águas residuárias), as principais espécies utilizadas para o tratamento de efluentes são: Juncus spp, Oryza sativa (Arroz), Zizaniopsis spp, Cyperus papyrus, Eleocharis spp, Cynodon spp, Brachiaria spp e Typha spp. 

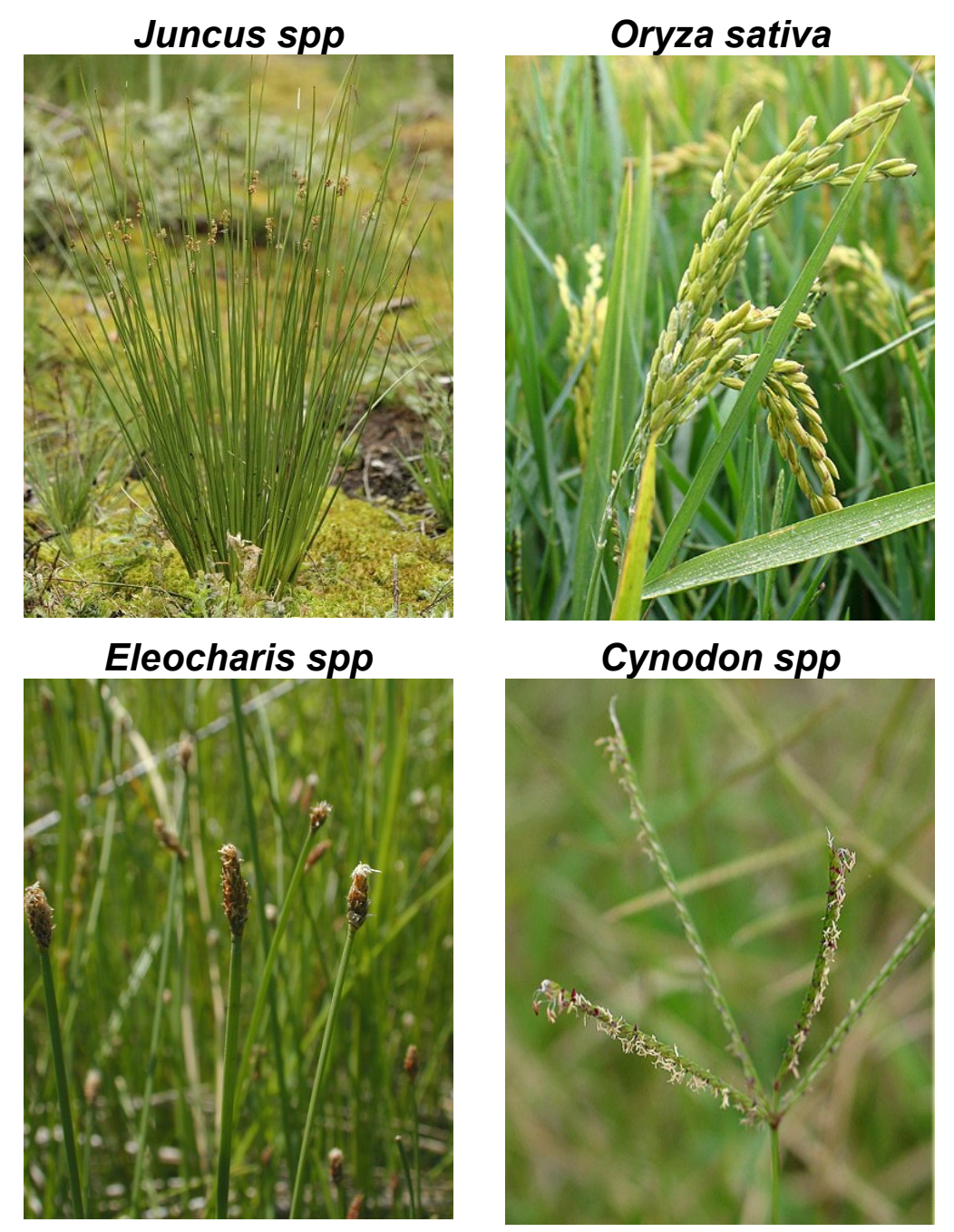

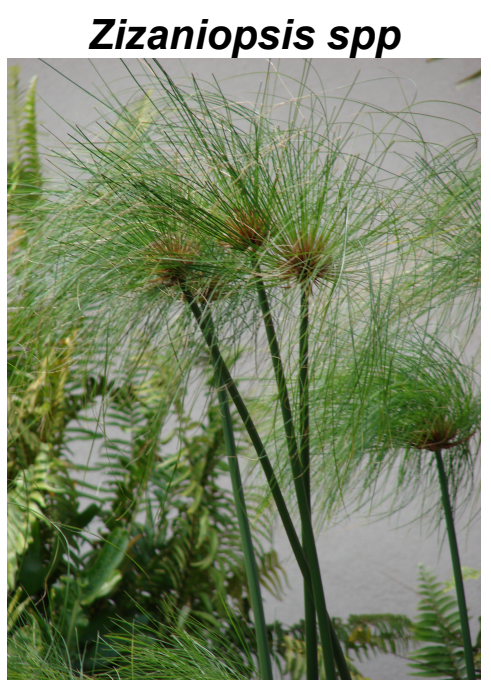

Brachiaria spp

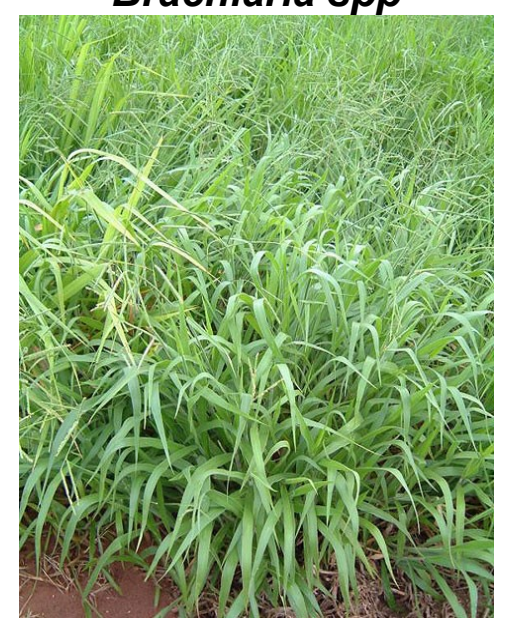

Ilustração 19 - Espécies vegetais utilizadas em Wetlands para tratamento de efluentes. Fonte: Discovery life (s/d).

A digestão dos efluentes no sistema de raízes das espécies vegetais ocorre da seguinte forma: Há a formação de um biofilme nas raízes das plantas constituído por uma comunidade de organismos aeróbios e anaeróbios que irão atuar na depuração da matéria orgânica e nos processos de nitrificação e desnitrificação, como exemplificado na llustração 20 a seguir (Philippi et al., 2007).
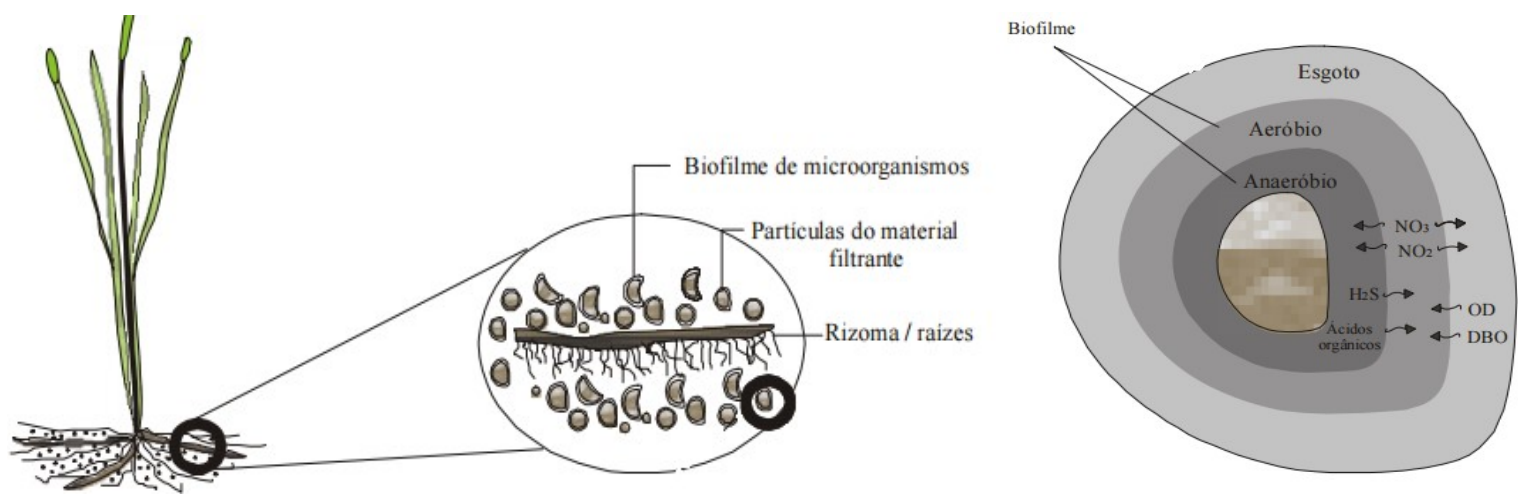

Ilustração 20 - Filtro de fluxo vertical. Fonte: Philippi et al. (2007). 
Em climas frios, onde o processo de tratamento é mais lento, recomenda-se 2,5 $\mathrm{m}^{2}$ de filtro por pessoa atendida, podendo este valor ser adotado como uma referência conservadora para o caso brasileiro. Para a construção da camada filtrante deve ser utilizado somente solos não coesivos (Areias). A operação do sistema demanda apenas o controle do estado de colmatação do solo, para a viabilidade do crescimento da vegetação e distribuição homogênea do efluente, e a lavagem anual dos drenos de superfície e de fundo (Hoffmann et al., 2004).

O sistema de filtro percolador é um método antigo de tratamento, onde o efluente é depositado sobre um leito de material de enchimento que pode ser sintético ou de rochas vulcânicas que permite a formação de um biofilme que atua na degradação da matéria orgânica. O efluente passa por gravidade por todo o filtro, atingindo o fundo do tanque, sendo coletado por uma caixa de decantação onde o clarificado será separado do lodo. O excesso de biofilme formado no material de enchimento é desprendido e segue junto ao efluente para a caixa de decantação. Apesar de poder apresentar uma elevada eficiência na remoção da DBO (Até $90 \%$ ), o sistema não realiza a desnitrificação da material e não remove fósforo, sendo necessárias unidades adicionais para cumprir este propósito (Hoffmann et al., 2004).

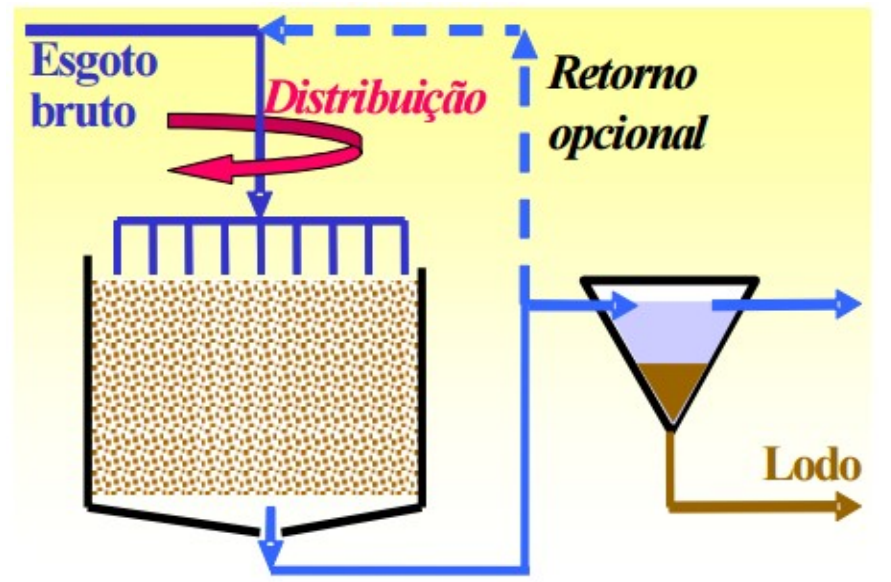

llustração 21 - Funcionamento do filtro percolador. Fonte: Hoffmann et al. (2004).

O sistema de tratamento por reator sequencial por batelada, que tem todas etapas do tratamento realizadas em um único tanque, sendo uma forma especial do processo de lodo ativado, tem sido o mais adotado para pequenas populações no mundo. O sistema possui as seguintes etapas de tratamento: Enchimento, onde é realizada a biodesfosfatação (Absorção de fósforo por bactérias heterotróficas, em condições alternadas de aerobiose e anaerobiose, que é eliminado junto com o lodo 
gerado) e desnitrificação do efluente; Aeração, para nitrificação; Decantação, para separação da fase líquida da fase sólida (Lodo ativado); e Descarga do clarificado (fase líquida tratada) e do lodo. O sistema tem eficiência tanto para o tratamento individual como para pequenas comunidades (Hoffmann et al., 2004). Segundo Cybis, Santos e Gehling (2004) o estudo da eficiência de tratamento de um RSB avaliado foi de $88 \%$ para remoção de nitrogênio e $90 \%$ para remoção da DQO.

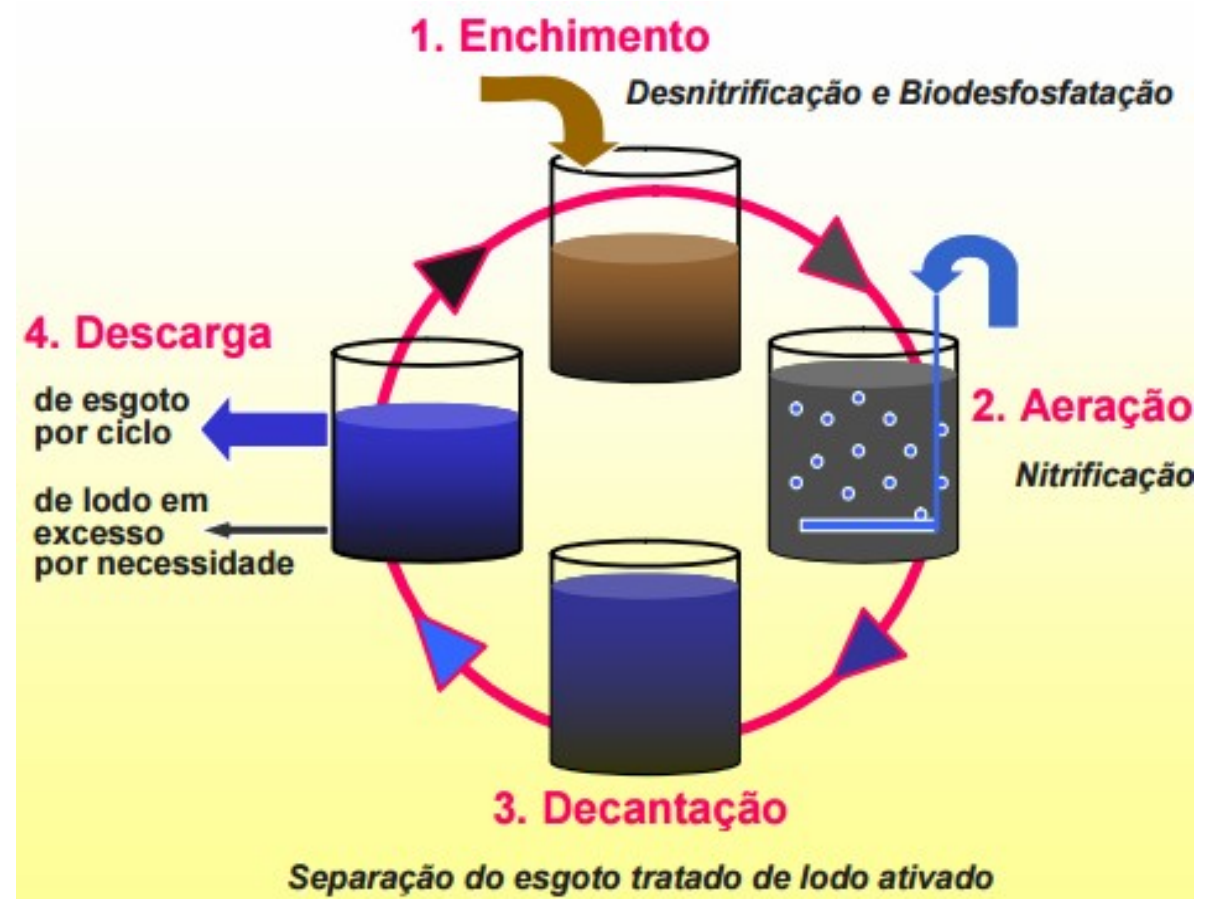

Ilustração 22 - Esquema de funcionamento do Reator Sequencial por Batelada. Fonte: Hoffmann et al. (2004).

Outra alternativa para o tratamento local de efluentes é o tanque séptico. $\mathrm{O}$ tanque séptico é uma estrutura que reúne as funções de sedimentação, remoção de materiais flutuantes e biodigestão da matéria orgânica. $O$ tanque pode ser construído como uma câmera única ou com câmeras em série, onde ocorrem os processos de flotação, decantação e biodigestão. Sua eficiência para remoção da DBO é de até $65 \%$, baixa se comparada aos outros métodos, no entanto constitui um sistema simplificado que pode ser aplicado para o tratamento individual de residências (Philippi et al., 2007).

Tonetti et al. (2010) testou a eficiência de um tratamento alternativo aplicado a uma comunidade de 8 mil habitantes na cidade de Limeira no interior de São Paulo; O sistema consistiu em um filtro anaeróbio com reator composto por anéis de bambu, de $0,04 \mathrm{~m}$ de diâmetro e $0,05 \mathrm{~m}$ de comprimento, da espécie Bambusa 
tuldoides, aliado a um filtro de areia. O sistema, apesar de ter tido pouco efeito sobre a densidade de $E$. Coli se mostrou eficiente na remoção da DBO e do fósforo, apresentando-se como uma alternativa viável para pequenas comunidades.

Um sistema conhecido como ecológico utilizado para tratamento individual de efluentes é o da bacia de evapotranspiração (BET). O sistema é uma técnica de permacultura, constituído por um canteiro preenchido por areia, brita, pedregulho e pneus, que alimenta um sistema vegetal composto majoritariamente por bananeiras. O sistema através dos processos de percolação, digestão anaeróbia e evapotranspiração, promove a degradação da matéria orgânica presente no efluente. Recomenda-se que a bacia tenha 1 metro de profundidade no mínimo e uma área de $2 \mathrm{~m}^{2}$ de BET por habitante na residência (Benjamin, 2013). A llustração 23 mostra o esquema de uma BET.

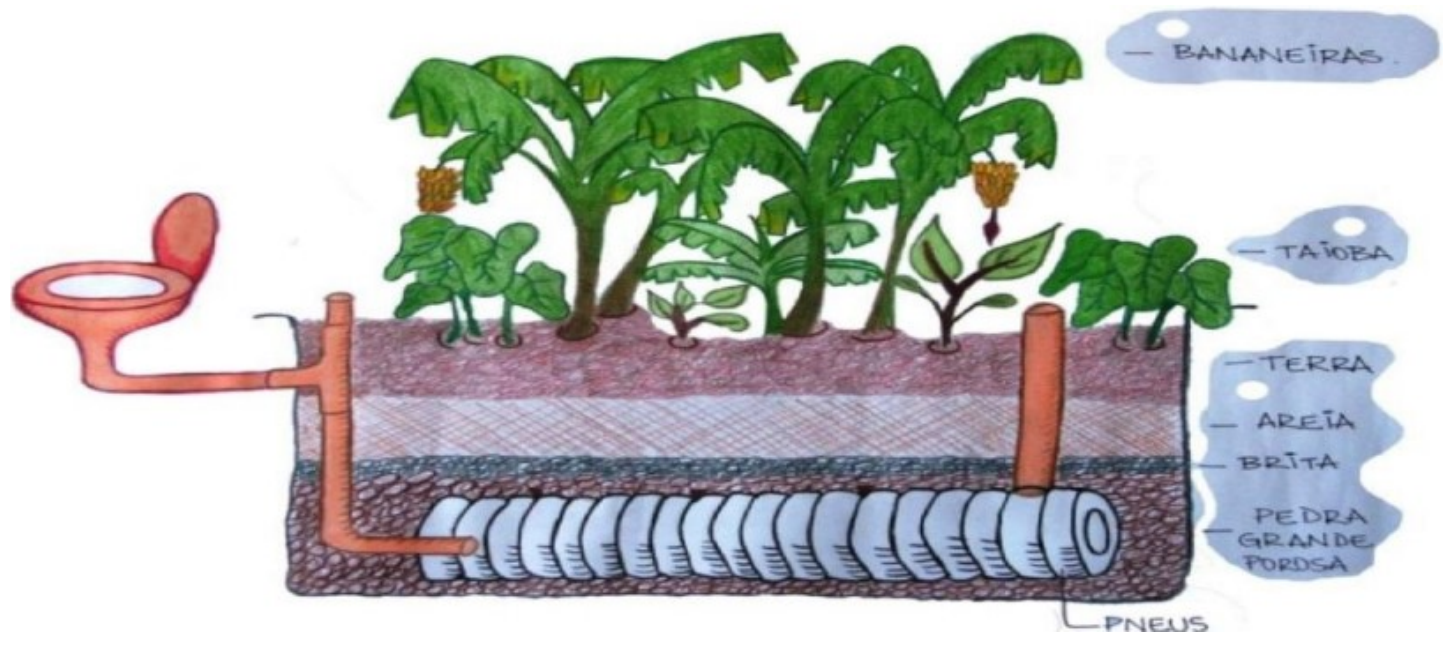

Ilustração 23 - Bacia de evapotranspiração (BET). Fonte: Benjamin (2013).

Benjamin (2013) avaliou a eficiência da estrutura no tratamento de efluentes provenientes de uma residência, onde se constatou que a estrutura é eficiente no tratamento promovendo ainda a fertilidade do solo. Foi ainda avaliada pelo autor a presença de coliformes totais, termotolerantes e salmonela no solo, folhas e frutos produzidos pelo sistema, não sendo constatada a presença dos mesmos nas amostras monitoradas.

Existe ainda a possibilidade de se trabalhar com estações de tratamento de esgotos compactas que possuem como vantagem demandarem pequena área para implantação e apenas licenciamento ambiental simplificado. Segundo a resolução CONAMA 377 de outubro de 2006, para fins de licenciamento ambiental 
simplificado, enquadram-se as estações de tratamento descentralizadas, aquelas que possuam vazão menor ou igual a $50 \mathrm{~L} / \mathrm{s}$ ou que atendam até 30 mil habitantes. Atualmente o sistema tem sido amplamente adotado para o tratamento de esgotos em condomínios que não são atendidos pelo sistema público e existem no mercado diversas empresas que fornecem equipamentos, montagem e operação da estação.
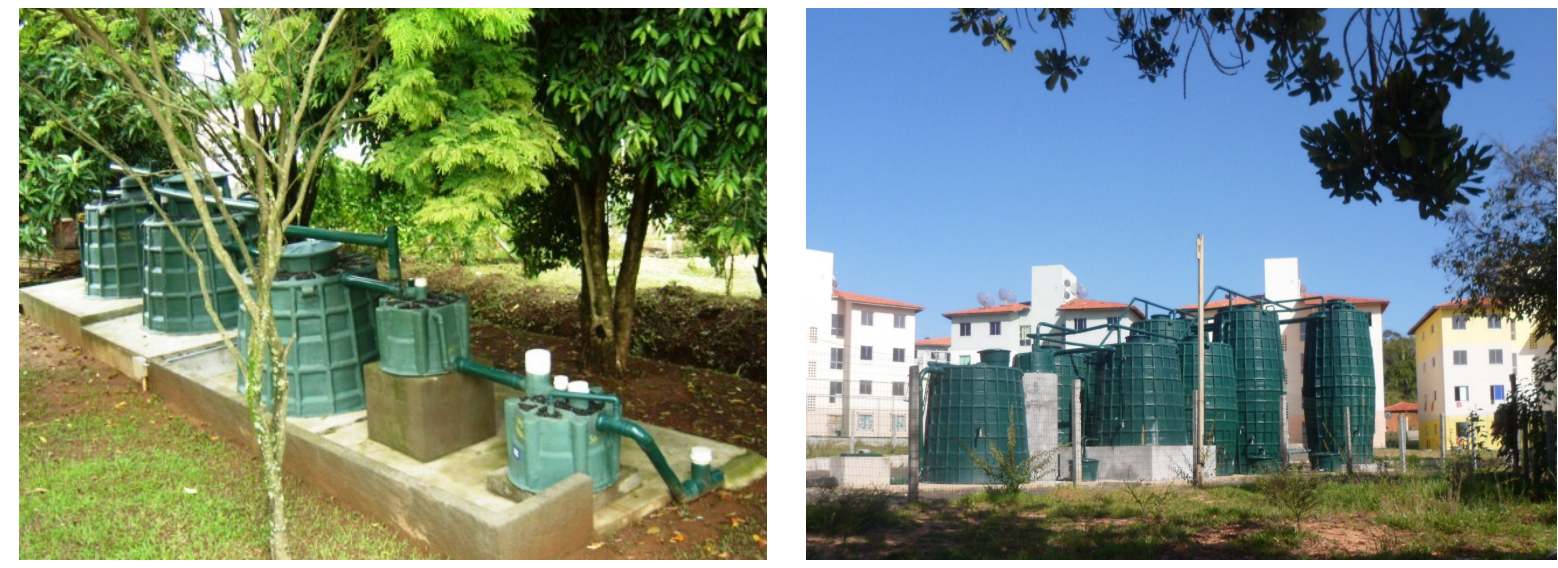

Ilustração 24 - Exemplos de ETE's compactas. Fonte: Flipper (s/d).

\subsubsection{Controle qualitativo e quantitativo do escoamento superficial} através da infraestrutura verde e azul

É sabido que o processo de urbanização resulta em alterações no balanço hídrico da bacia fazendo com que haja aumento das taxas de escoamento superficial e da velocidade deste escoamento, e em contraponto há a diminuição do processo de infiltração. Além dos impactos gerados na dinâmica do escoamento das águas, estas novas vazões de pico no corpo d'água resultam em modificações nos processos geomorfológicos, ecológicos e na qualidade da água (Findlay \&Taylor, 2006). Tal processo pode ser amenizado através da adoção na bacia de medidas que retardem a vazão de pico, sendo essa uma das premissas da infraestrutura verde e azul.

Benedict e McMahon (2006) classificam o uso dos elementos vegetais formando uma teia multifuncional dentro das cidades a fim de auxiliar no controle da qualidade do ar, água e solo, como técnicas da infraestrutura verde. A infraestrutura verde consiste na requalificação e enriquecimento das áreas verdes urbanas a fim de reestabelecer os processos naturais que prestam importantes serviços para a cidade, baseando se nos conceitos da ecologia da paisagem que emergem em 
meados dos anos 90. Segundo Forman (1995) o foco da ecologia da paisagem é estudar as relações espaciais entre os ecossistemas e os elementos da paisagem; estudar os fluxos de energia, nutrientes e minerais; e estudar a dinâmica ecológica dos mosaicos de paisagem.

As técnicas da infraestrutura verde têm sido discutidas como alternativa para auxiliar no controle quantitativo e qualitativo do escoamento superficial. Consiste, portanto em uma rede de áreas abertas naturais que são fundamentais para o funcionamento ecológico do território. Conceito que vai além do conceito original de paisagismo para o embelezamento da cidade. A infraestrutura verde, além de incorporar a rede interconectada de áreas verdes, incorpora também elementos naturais que não se restringem à vegetação, como corpos d'água e a atmosfera, sendo, portanto, um agente importante na regulação da qualidade da água e do ar, resultando em uma ampla variedade de benefícios para a população (De Oliveira et al., 2012). A incorporação dos elementos azuis da paisagem, as águas nas suas diversas formas, fez com que esse grupo de técnicas passasse a ser chamado por alguns autores de infraestrutura verde e azul, termo utilizado neste estudo.

O conceito de infraestrutura verde tem sido adotado no Brasil através da implantação de parques lineares. Os parques lineares vem do conceito de Green Ways que visa a criação de áreas verdes ao longo dos corpos d'água, que atendam tanto a demanda por serviços à população, como também possibilite a convivência com as cheias periódicas do corpo d'água. No Brasil parques lineares são áreas lindeiras aos corpos d'água associadas ao tráfego de pedestres, que tenha a função primordial de recuperar os ecossistemas lindeiros, controlarem enchentes promover áreas para o lazer. No município de São Paulo exige-se que estes caminhos verdes sejam providos de calçadas permeáveis em pelo menos $60 \%$ da área (De Oliveira et al., 2012).

A cidade de Freiburg na Alemanha adotou diversas técnicas da Infraestrutura verde e azul em duas escalas, na escala urbana, que consiste em uma rede de áreas de conservação e agrícolas que permeiam a área urbana; e na escala local junto aos proprietários dos lotes a fim de integrar as propriedades à escala urbana (Herzog e Rosa, 2010). A Ilustração 25 mostra algumas técnicas adotadas na cidade. 

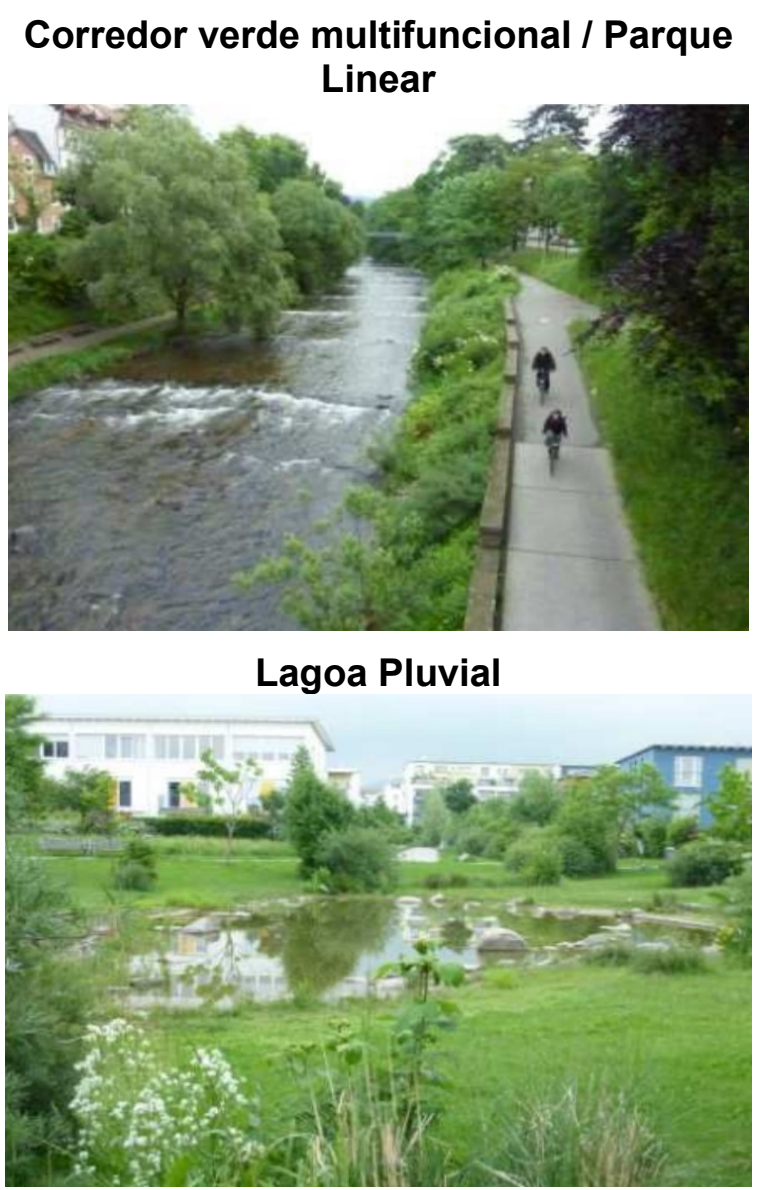

VLT em canteiro vegetado

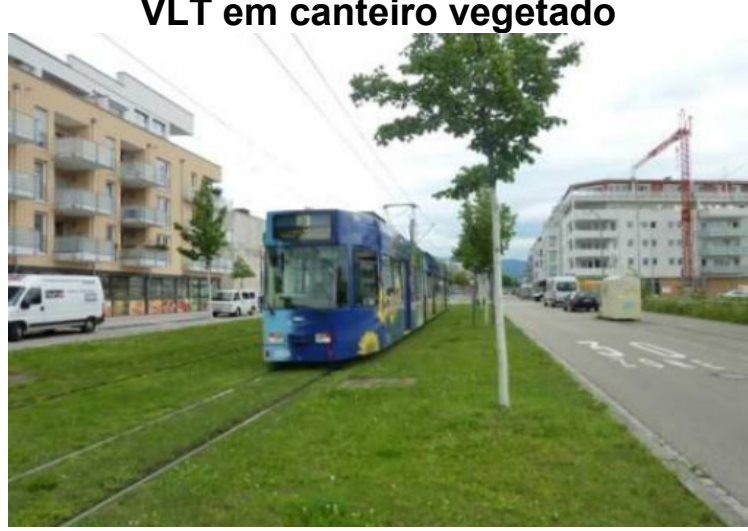

Passeios com pavimento drenante

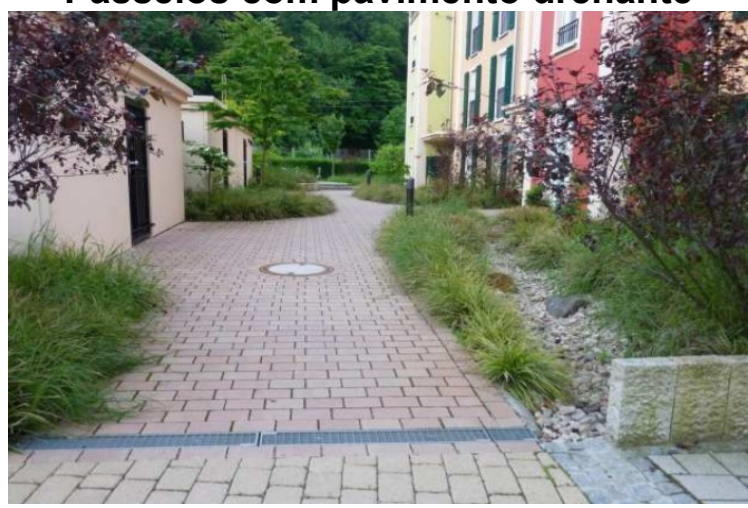

Estacionamento e passeio com pavimento drenante

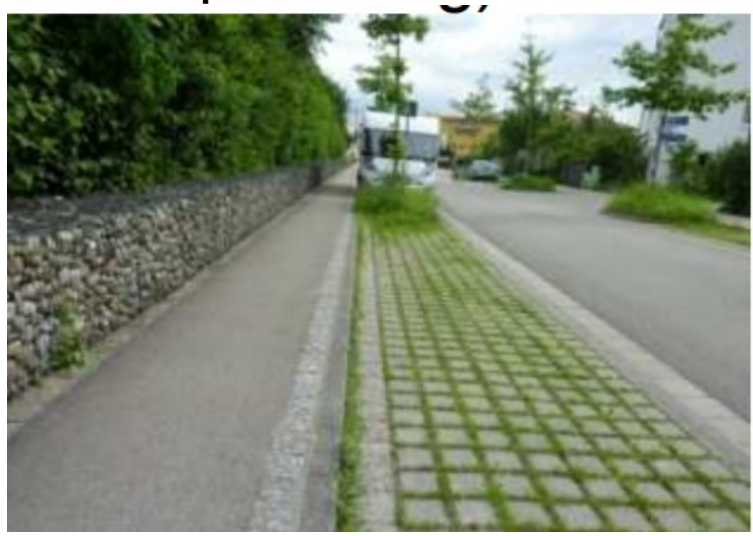

Lagoa seca ou de infiltração

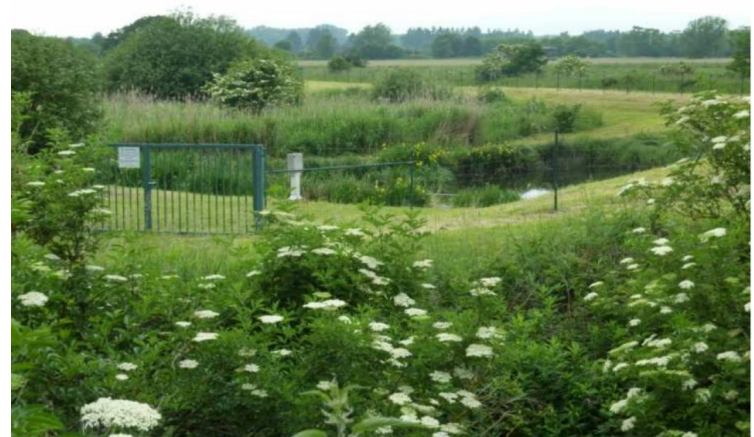

Canteiro pluvial

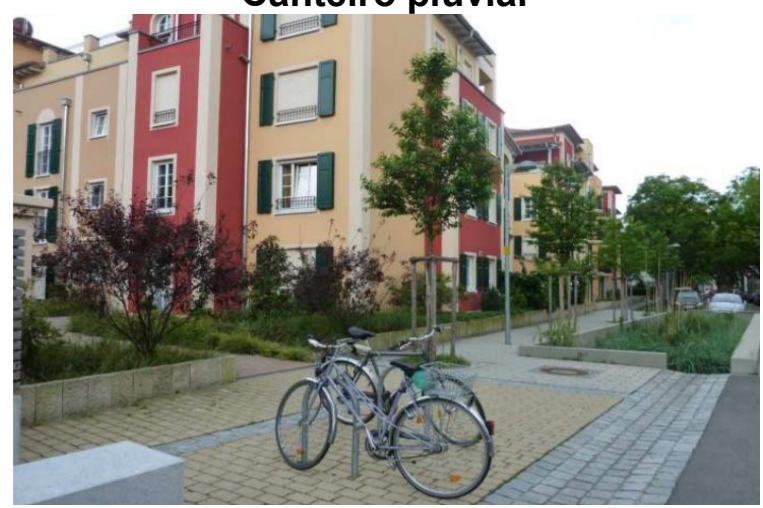

Ruas com fluxos de água visíveis

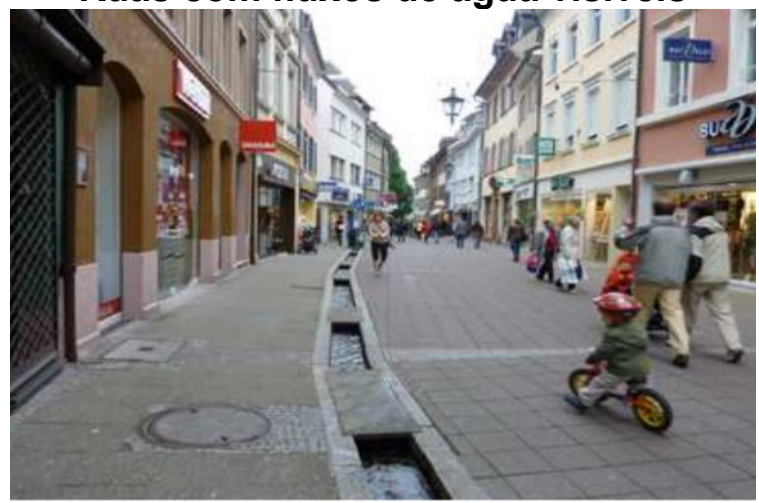

Ilustração 25 - Técnica de infraestrutura verde adotadas em Freiburg. Fonte: Adaptado de Herzog e Rosa (2010). 
Moura, Pellegrino e Martins (2014) ressaltam a importância de novas estratégias para a drenagem de áreas urbanas uma vez que os efeitos das mudanças climáticas globais têm feito com que os eventos chuvosos extrapolem o que foi previsto em projeto de forma que as estruturas convencionais têm tido sua capacidade saturada com maior frequência. Os autores citam a iniciativa do plano de macrodrenagem para a RMSP que prevê a implantação de 134 piscinões a fim de controlar as vazões de pico, mas que estão associados a inúmeros inconvenientes, uma vez que juntamente com o escoamento superficial o sistema tradicional carreia para estas estruturas as cargas difusas na bacia que acabam se acumulando gerando mau cheiro e aspecto desagradável, resultando em rejeição da estrutura pela população. Neste contexto, os conceitos de drenagem sustentável ganham força, trazendo formas alternativas de como lidar com estes eventos chuvosos extremos.

Quando se trata das formas de como lidar com as águas em áreas urbanas, temos a divisão em medidas estruturais e não estruturais, onde as estruturais são aquelas medidas referentes às estruturas hidráulicas, como diques, barragens, reservatórios de detenção e canalizações; e as não estruturais que são o conjunto de medidas que visam ordenar o uso e a ocupação do solo, como por exemplo, o controle de ocupação de áreas de várzea e programas de educação ambiental (Tucci, 1995). A drenagem sustentável, que é uma das técnicas da infraestrutura verde e azul, prioriza a adoção de medidas que atuem na fonte e que demandem menos manutenção para seu funcionamento, funcionando de forma integrada aos sistemas naturais.

Um sistema tradicional de drenagem é composto pelas seguintes estruturas: dispositivo de direcionamento do escoamento superficial (Canaletas, sarjetões, guias e sarjetas), dispositivos de captação do escoamento superficial (Bocas de leão, boca de lobo e caixas com grelha), condução subterrânea das águas coletadas (Galerias e poços de inspeção) e dispositivos que realizam o lançamento das águas pluviais coletadas nos corpos d'água (Muros de ala e dissipadores de energia). Tal sistema tradicional segue a lógica da rápida dissipação das águas precipitadas, além disso, as galerias de drenagem promovem uma ligação direta entre as áreas impermeabilizadas e os canais, ignorando a função das zonas ripárias de não só amortecer a velocidade do escoamento, como promover a retenção de poluentes 
(Groffman et al., 2003). A llustração 26 mostra um exemplo de um sistema tradicional de drenagem.

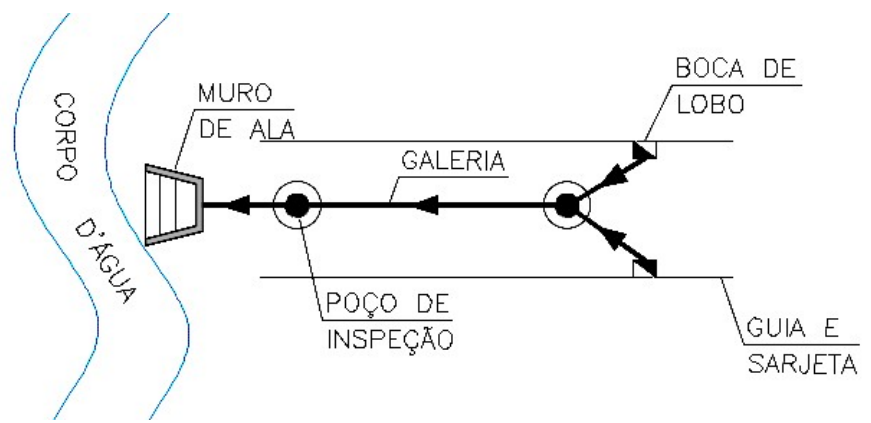

Ilustração 26 - Exemplo de um sistema tradicional de drenagem. Fonte: Elaborado pela autora.

Já um sistema baseado no conceito de drenagem sustentável, prioriza a instalação de dispositivos que retardem a chegada das águas no corpo d'água resultando na redução da sua vazão de pico. Segundo Tucci (2008), o processo de urbanização resulta em uma mudança significativa no hidrograma da bacia, que passa a ter uma vazão de pico maior e mais localizada no inicio do hidrograma. Desta forma, as medidas adotadas pela drenagem sustentável visam abater ao menos parte deste volume excedente, a fim de evitar inundações e proteger as áreas adjacentes ao corpo d'água. A llustração 27 exemplifica em um hidrograma hipotético as mudanças ocorridas na vazão de pico em uma bacia inicialmente rural que foi posteriormente urbanizada, e que teve diminuídas as taxas de infiltração e aumentadas as de escoamento superficial.

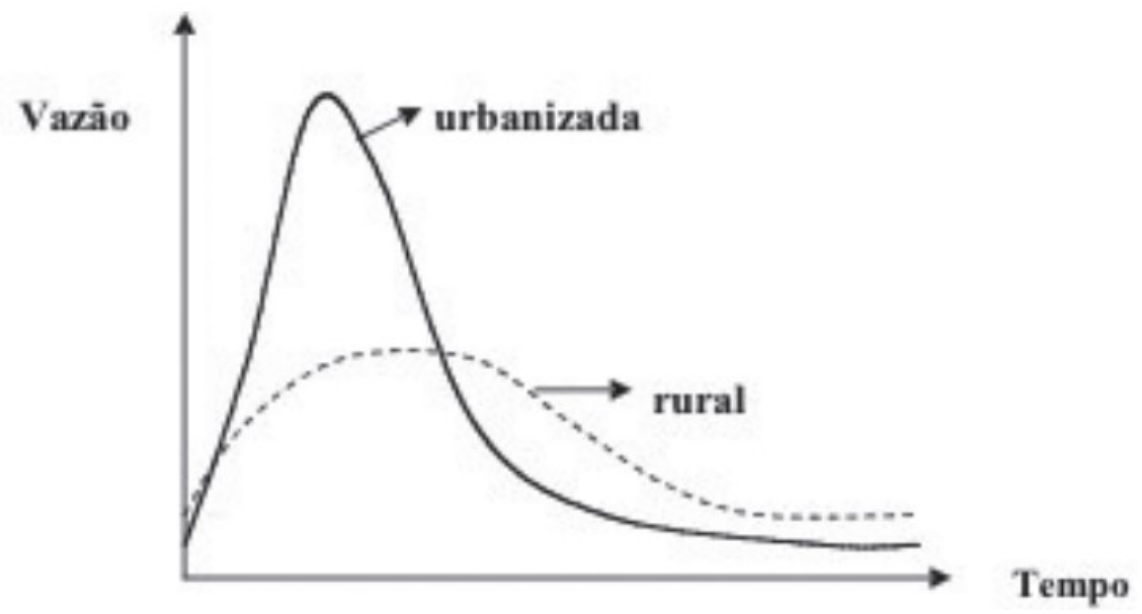

Ilustração 27 - Hidrograma de uma bacia rural e depois de urbanizada. Fonte: Tucci (2008).

Além disso, a drenagem sustentável prevê a implantação de dispositivos que promovam o controle de poluentes provenientes do escoamento superficial. $O$ controle de poluentes no sistema de micro drenagem, através da implantação de 
estruturas que promovam a filtragem das águas, tem se apresentado como solução mais eficiente no controle da qualidade da água dos corpos d'água, se comparado ao tratamento no sistema de macro drenagem (Walsh, Fletcher e Ladson, 2005).

Walsh, Fletcher e Ladson (2005) avaliaram o impacto do lançamento de cargas poluentes provenientes do escoamento superficial em corpos d'água por dispositivos de drenagem tradicionais, ou seja, micro drenagem conectada diretamente no corpo d'água. Os autores monitoraram 15 córregos com semelhantes bacias e condições físicas em Melbourne na Austrália, utilizando na avaliação organismos indicadores, como por exemplo, macro invertebrados bentônicos, algas e diatomáceas, e constataram que o impacto das cargas sobre o ecossistema aquático é mais exacerbado nos eventos de precipitação de menor intensidade, ou seja, houve maior variação negativa nos índices ecológicos (Riqueza, Diversidade, Equitabilidade, etc) nestes eventos.

O reconhecimento de que o conceito de promover o escoamento rápido das águas era falho resultou no surgimento de uma nova abordagem técnica que recebem diferentes denominações em função do local onde foram desenvolvidas, mas que partilham as mesmas premissas, como o Low Impact Development (LID), nos EUA e Canadá; Sustainable Urban Drainage Systems (SUDS), no Reino Unido; Water Sensitive Urban Design (WSUD), na Austrália; e Low Impact Urban Design and Development (LIUDD), na Nova Zelândia. As primeiras iniciativas voltadas a implantação destas técnicas foram realizadas na Suécia e na Noruega, onde foram implantados pavimentos porosos, faixas gramadas e telhados verdes (Poleto, 2011).

O manual apresenta o conceito de "hard engineering" e "soft engineering", onde a engenharia rígida é aquela baseada no sistema tradicional, que depende de manutenções constantes para o perfeito funcionamento, e onde pequenas falhas são pouco absorvidas, ou seja, o sistema é pouco resiliente; já a engenharia flexível é aquela baseada nos sistemas naturais, criando soluções resilientes, que são capazes de absorver pequenas falhas e se auto regularem. A junção das duas formas de engenharia da origem às técnicas LID. A llustração 28 mostra esquemas que ilustram o conceito de "hard engineering" e "soft engineering". 

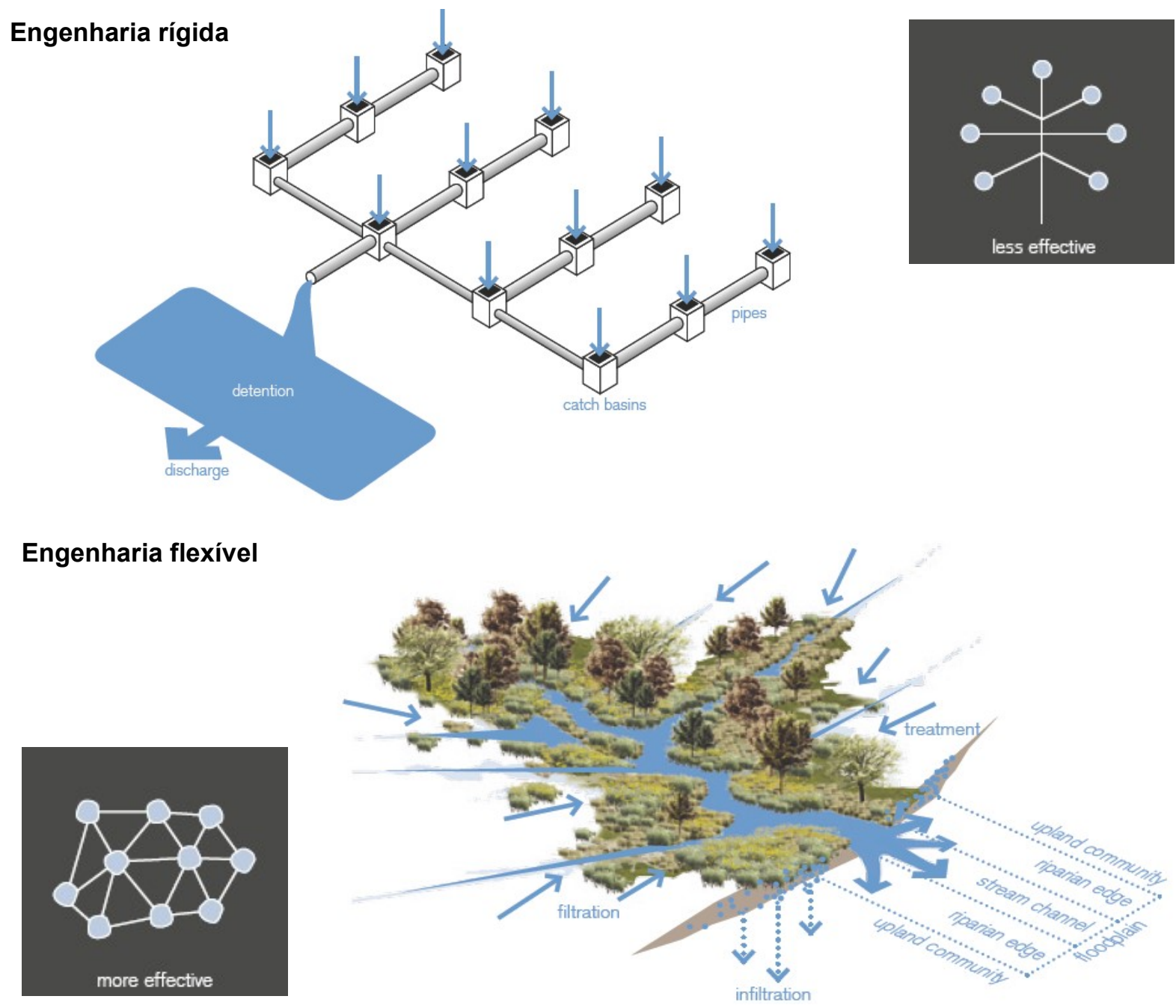

Ilustração 28 - Engenharia rígida x Engenharia flexível. Fonte: UACDC (2010).

O conceito de LID prevê a utilização de estruturas que promovam o amortecimento das vazões de pico na bacia, como por exemplo, pavimentos permeável e semipermeável; reservatórios de detenção e retenção; trincheiras de infiltração; valas e poços de infiltração; microrreservatórios; telhados reservatório; telhados verdes; bacias subterrâneas; e faixas gramadas (Poleto, 2011). Estas estruturas, além da função de controle da vazão, atuam também na melhoria da qualidade das águas do escoamento superficial, sendo medidas também utilizadas para controle de cargas difusas. A aplicação dos conceitos de LID no sistema de drenagem urbana é exemplificada na sequência de ilustrações apresentadas a seguir para diferentes situações, um sistema viário, um estacionamento e um fundo de vale com residências. 


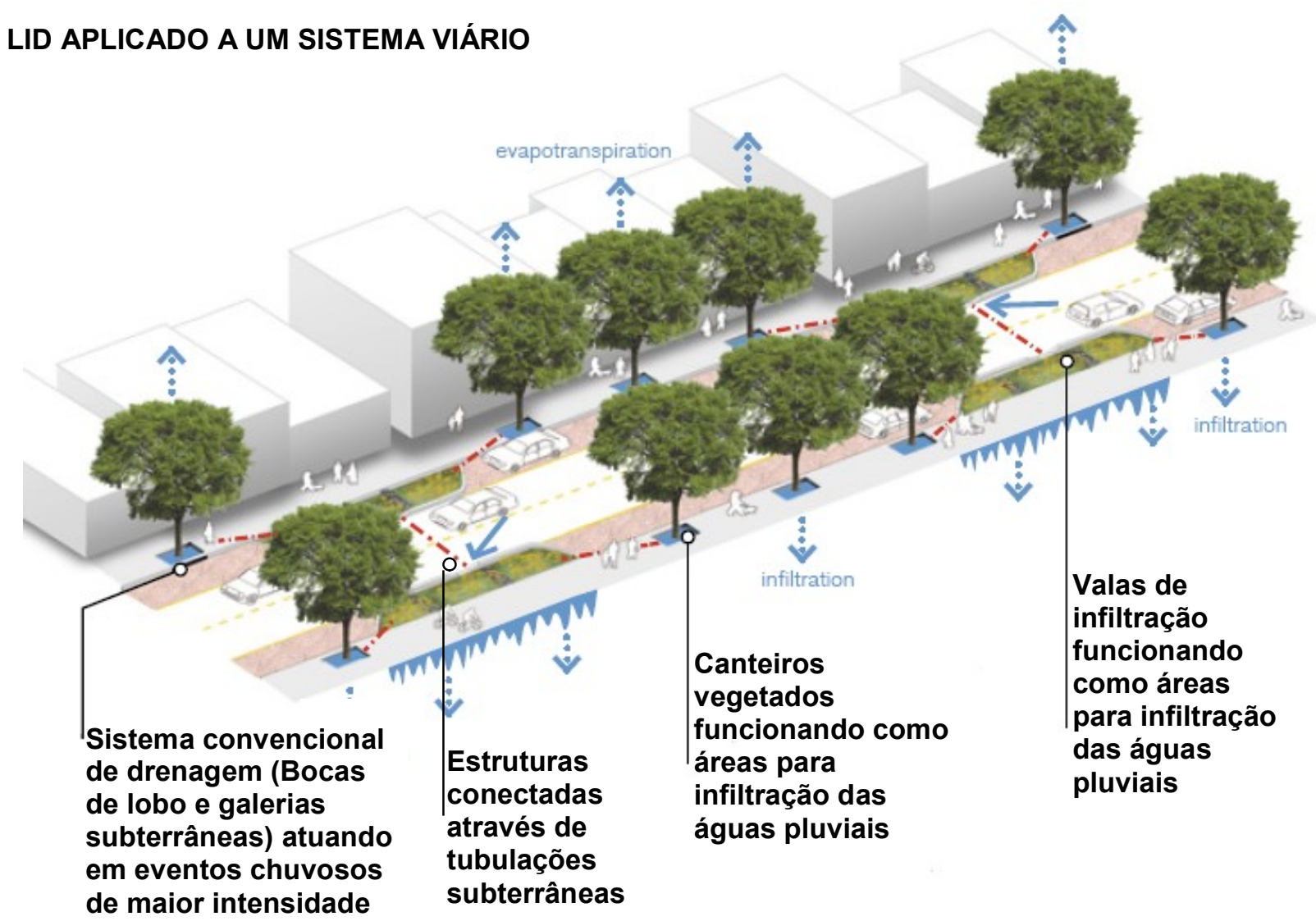

Ilustração 29 - LID aplicado a um sistema viário. Fonte: Adaptado pela autora a partir de UACDC (2010).

\section{LID APLICADO A UM ESTACIONAMENTO}

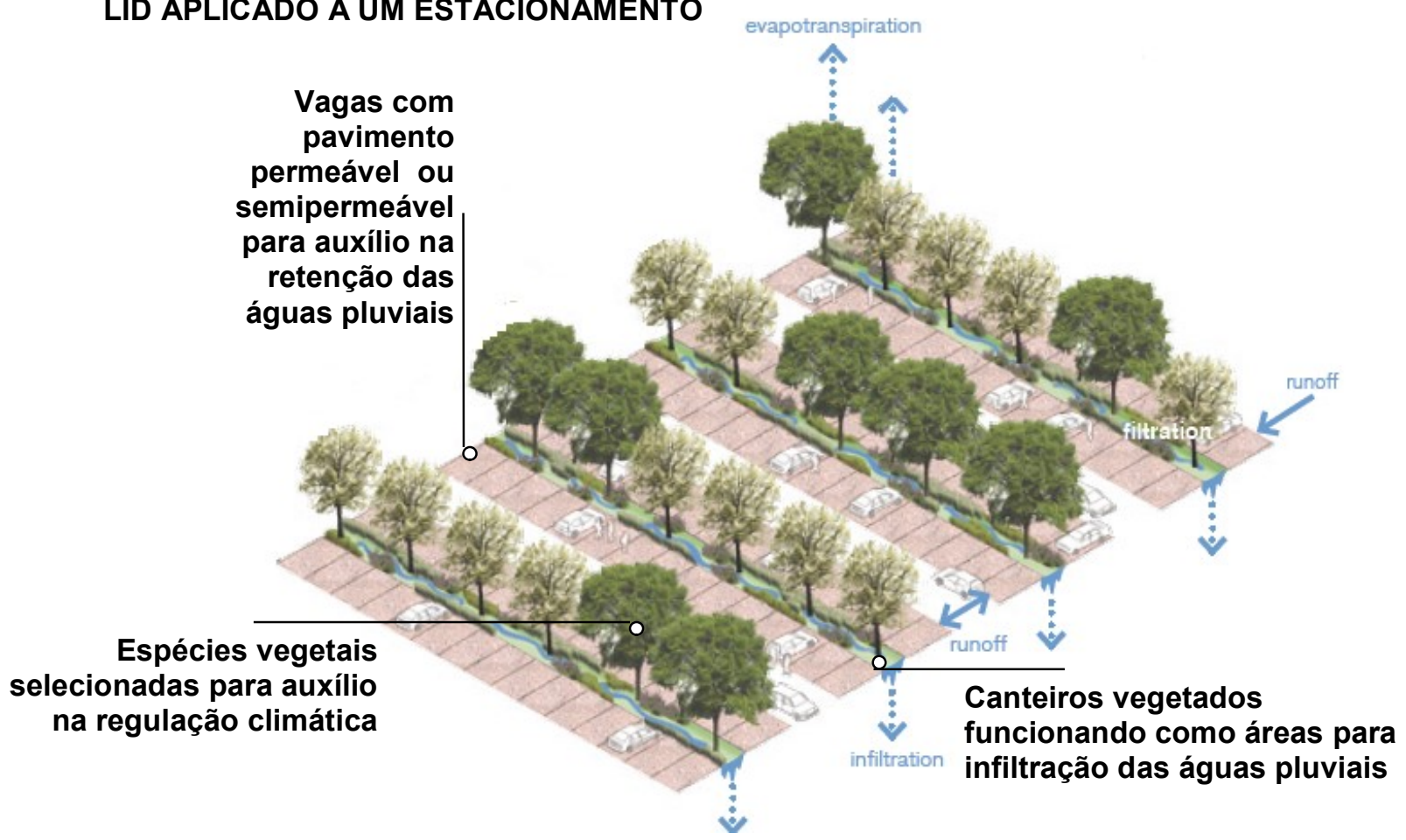

Ilustração 30 - LID aplicado a um estacionamento. Fonte: Adaptado pela autora a partir de UACDC (2010). 


\section{LID APLICADO A UM FUNDO DE VALE COM RESIDÊNCIAS}

Zona tampão para amortecimento das vazões de pico e retenção de cargas poluidoras

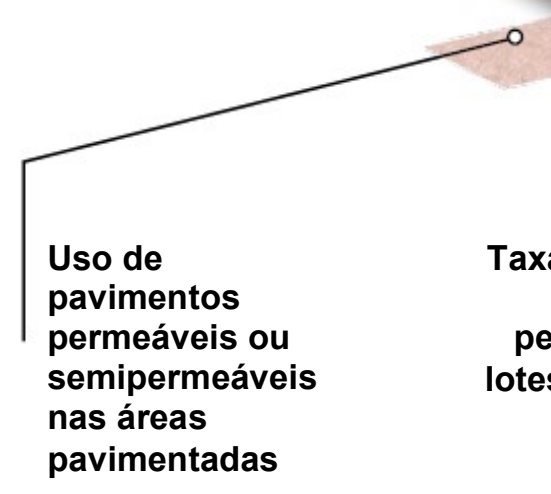
permeáveis nos pavimentadas

\section{Uso do fundo de vale para hortas comunitárias}
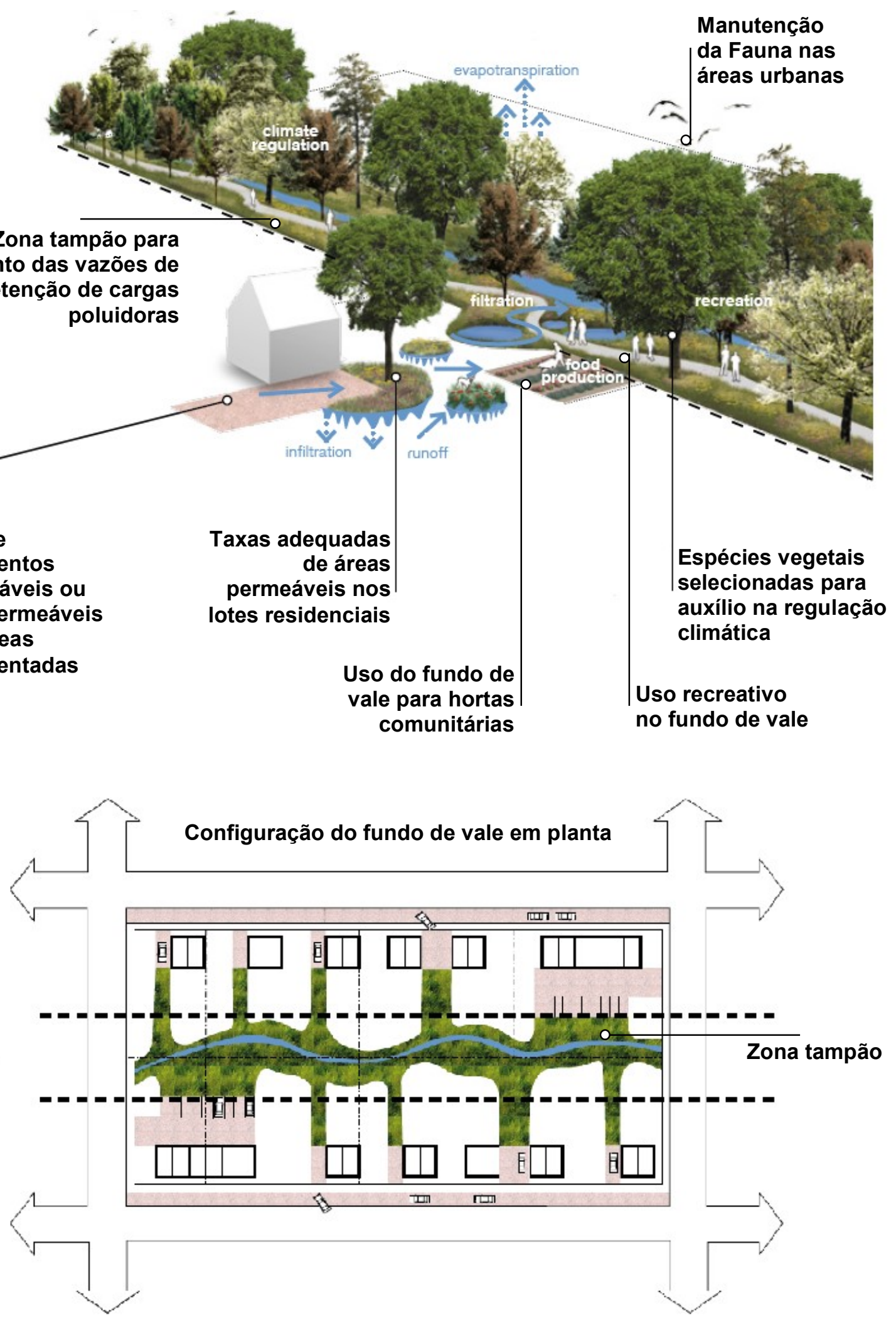

Ilustração 31 - LID aplicado a um fundo de vale. Fonte: Adaptado pela autora a de UACDC (2010). 
O manual "Low Impact Development: a design manual for urban areas" ilustra a aplicação de diversos dispositivos e dá recomendações para a implantação e manutenção dos mesmos, além disso, classifica as técnicas em função da sua atuação na melhoria da qualidade da água (Qualidade) e no controle da vazão de pico (Quantidade), desta forma a técnica 1 oferece menos serviços de tratamento, enquanto a técnica 21 oferece mais serviços de tratamento, conforme mostrado na llustração 32 a seguir.

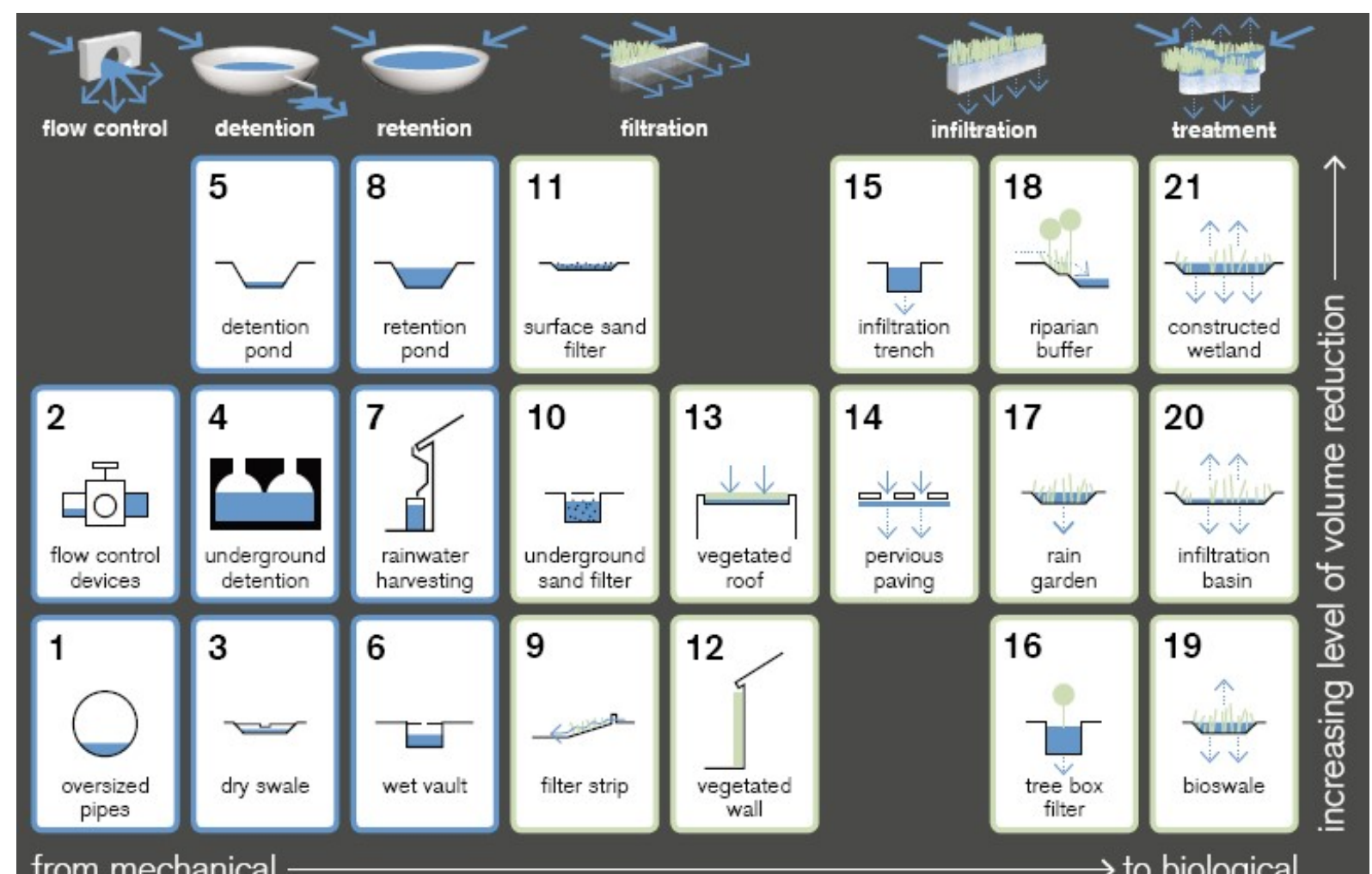

from mechanical

$\rightarrow$ to biological

Ilustração 32 - Técnicas do LID e seus índices de qualidade e quantidade. Fonte: UACDC (2010).

Nos EUA vem sendo empregadas técnicas LID a fim de aproximar os sistemas de drenagem urbana dos sistemas naturais, sendo as técnicas norteadas por manuais, com destaque para os manuais municipais de Portland no Oregon e de Seattle em Washington. A cidade de Portland conseguiu uma redução de 35\% no escoamento superficial com a implantação de telhados verdes, valas de infiltração, faixas gramadas, pavimento poroso e a educação da população, contando hoje com 500 ruas ecológicas distribuídas pela cidade. Já em Seattle, a adoção das mesmas medidas, resultou em uma economia de $25 \%$ com os gastos com a poluição, recomposição de asfalto e calçadas e conseguiu obter uma retenção de $37 \%$ do volume de água precipitado nos eventos de chuva. Na Escócia, a adoção das 
técnicas SUDS tem sido utilizada para evitar acidentes nas vias, já que as técnicas resultam na absorção rápida da água pelo pavimento evitando a formação de gelo nas rodovias (Poleto, 2011).

Segundo Novotny e Olem (1994) o controle da carga difusa pode ser realizado através de medidas não estruturais e estruturais. As medidas não estruturais, conhecidas como Best Management Practices - BMP's - são caracterizadas como sendo medidas de baixo custo, pois não exigem a implantação de estruturas físicas e localizadas, mas sim ações de gestão e gerenciamento por toda bacia. As principais medidas não estruturais são aquelas que visam organizar a participação da população da bacia, garantindo uma eficiente gestão de resíduos; controlem o uso e ocupação do solo, prevenindo a ocupação de áreas sensíveis; e que promovam a manutenção de áreas permeáveis, promovendo a infiltração e resultando na redução da vazão de pico. Já as medidas estruturais estão ligadas a implantação de dispositivos na bacia que promovam a coleta e o tratamento das cargas difusas através da interceptação do escoamento superficial. A Tabela 4 mostra alguns dispositivos adotados e suas funções. 
Tabela 4 - Medidas estruturais para controle de cargas difusas. Fonte: Elaborada pela autora a partir de Souza (2000), Tomaz (2006) e USEPA (s/d).

\begin{tabular}{|c|c|}
\hline Estrutura & Função \\
\hline $\begin{array}{l}\text { Pavimento } \\
\text { drenante }\end{array}$ & $\begin{array}{l}\text { Pavimento que promova a infiltração de parcela do escoamento } \\
\text { superficial, como os modulares (Intertravados), porosos (Concreto ou } \\
\text { asfalto sem agregados finos) e as britas; }\end{array}$ \\
\hline $\begin{array}{l}\text { Trincheiras } \\
\text { de } \\
\text { infiltração }\end{array}$ & $\begin{array}{l}\text { Valas rasas, revestida por mata geo-têxtil e preenchidas com material } \\
\text { granular que atuam como sistema de drenagem, fazendo com que a } \\
\text { carga difusa fique retida no solo; }\end{array}$ \\
\hline Filtro grama & $\begin{array}{l}\text { Faixa de vegetação ao longo das margens dos canais da bacia a fim } \\
\text { de promover a infiltração do escoamento superficial, filtração do } \\
\text { material particulado e diminuição do runoff; }\end{array}$ \\
\hline $\begin{array}{l}\text { Bacias de } \\
\text { retenção } \\
\text { alagadas } \\
\text { (wet } \\
\text { reservoir) }\end{array}$ & $\begin{array}{l}\text { Lagos permanentes, que retém as águas das chuvas durante todo o } \\
\text { ano a fim de promover o amortecimento das vazões de pico e a } \\
\text { melhoria da qualidade da água através da remoção de poluentes por } \\
\text { atividade biológica e por decantação no fundo do lago; }\end{array}$ \\
\hline $\begin{array}{l}\text { Bacias de } \\
\text { detenção }\end{array}$ & $\begin{array}{l}\text { reservam a água por determinado período e a liberam logo após o } \\
\text { evento de chuva. Um exemplo de aplicação destas estruturas são os } \\
\text { piscinões brasileiros; }\end{array}$ \\
\hline $\begin{array}{l}\text { Filtros de } \\
\text { areia de } \\
\text { superfície }\end{array}$ & $\begin{array}{l}\text { Destinado ao tratamento dos primeiros instantes de chuva, que } \\
\text { carregam a maior parte da carga difusa, possuindo quatro elementos } \\
\text { principais, um regulador de fluxo que conduz o fluxo para o sistema } \\
\text { de tratamento; um sistema de pré-tratamento que retém folhas e } \\
\text { material grosseiro, sedimentos, óleos e graxas; Tratamento do } \\
\text { material fino; e uma estrutura para regulação da saída. Esta estrutura } \\
\text { deve ser construída preferencialmente off-line, ou seja, sem conexão } \\
\text { direta com o corpo d'água; }\end{array}$ \\
\hline Wetlands & $\begin{array}{l}\text { São áreas permanentemente alagadas, ou seja, saturadas. Podem } \\
\text { ser naturais, como brejos, mangues, várzeas e pântanos; ou artificiais, } \\
\text { construídas pelo homem com duas finalidades possíveis, a primeira } \\
\text { aplicada ao tratamento secundário de esgotos; já a segunda aplicada } \\
\text { no controle da carga difusa. }\end{array}$ \\
\hline
\end{tabular}

O Urban Drainage and Flood Control District em seu manual de drenagem avalia a ação de diversas BMP's no que se refere à segurança hidrológica e tratamento da qualidade das águas pluviais, essa avaliação é mostrada em resumo na Tabela 5 a seguir. 
Tabela 5 - Atuação das medidas estruturais. Fonte: UDFCD (2011).

\begin{tabular}{|c|c|c|c|c|c|c|c|c|}
\hline & \multicolumn{3}{|c|}{ Hydrologic Processes } & \multicolumn{5}{|c|}{ Treatment Processes } \\
\hline & Peak & & lume & & hysical & & Chemical & Biological \\
\hline UDFCD BMP & $\begin{array}{c}\text { Flow } \\
\text { Attenuation }\end{array}$ & Infiltration & $\begin{array}{c}\text { Evapo- } \\
\text { transpiration }\end{array}$ & Sedimentation & Filtration & Straining & $\begin{array}{l}\text { Adsorption/ } \\
\text { Absorption }\end{array}$ & $\begin{array}{c}\text { Biological } \\
\text { Uptake }\end{array}$ \\
\hline Grass Swale & I & $\mathrm{S}$ & I & $\mathrm{S}$ & S & $\mathrm{P}$ & S & $\mathrm{S}$ \\
\hline Grass Buffer & I & S & I & $\mathrm{S}$ & S & $\mathrm{P}$ & S & $\mathrm{S}$ \\
\hline $\begin{array}{l}\text { Constructed } \\
\text { Wetland Channel } \\
\end{array}$ & I & N/A & $\mathrm{P}$ & $\mathrm{P}$ & $\mathrm{S}$ & $\mathrm{P}$ & $\mathrm{S}$ & $\mathrm{P}$ \\
\hline Green Roof & $\mathrm{P}$ & S & $\mathrm{P}$ & N/A & $\mathrm{P}$ & N/A & I & $\mathrm{P}$ \\
\hline $\begin{array}{l}\text { Permeable } \\
\text { Pavement Systems } \\
\end{array}$ & $\mathrm{P}$ & $\mathrm{P}$ & N/A & $\mathrm{S}$ & $P$ & N/A & N/A & N/A \\
\hline Bioretention & $\mathrm{P}$ & $\mathrm{P}$ & S & $\mathrm{P}$ & $\mathrm{P}$ & S & $\mathrm{S}^{1}$ & $\mathrm{P}$ \\
\hline $\begin{array}{l}\text { Extended } \\
\text { Detention Basin } \\
\end{array}$ & $\mathrm{P}$ & I & I & $\mathrm{P}$ & N/A & $\mathrm{S}$ & $\mathrm{S}$ & I \\
\hline Sand Filter & $\mathrm{P}$ & $\mathrm{P}$ & I & $\mathrm{P}$ & $\mathrm{P}$ & N/A & $S^{1}$ & N/A \\
\hline $\begin{array}{l}\text { Constructed } \\
\text { Wetland Pond } \\
\end{array}$ & $\mathrm{P}$ & I & $\mathrm{P}$ & $\mathrm{P}$ & $\mathrm{S}$ & $\mathrm{s}$ & $\mathrm{P}$ & $\mathrm{P}$ \\
\hline Retention Pond & $\mathrm{P}$ & I & $\mathrm{P}$ & $\mathrm{P}$ & N/A & N/A & $\mathrm{P}$ & $\mathrm{S}$ \\
\hline $\begin{array}{l}\text { Underground } \\
\text { BMPs }\end{array}$ & Variable & N/A & N/A & Variable & Variable & Variable & Variable & N/A \\
\hline
\end{tabular}

Notes:

$\mathrm{P}=$ Primary; $\mathrm{S}=$ Secondary, $\mathrm{I}=$ Incidental; N/A = Not Applicable

${ }^{1}$ Depending on media

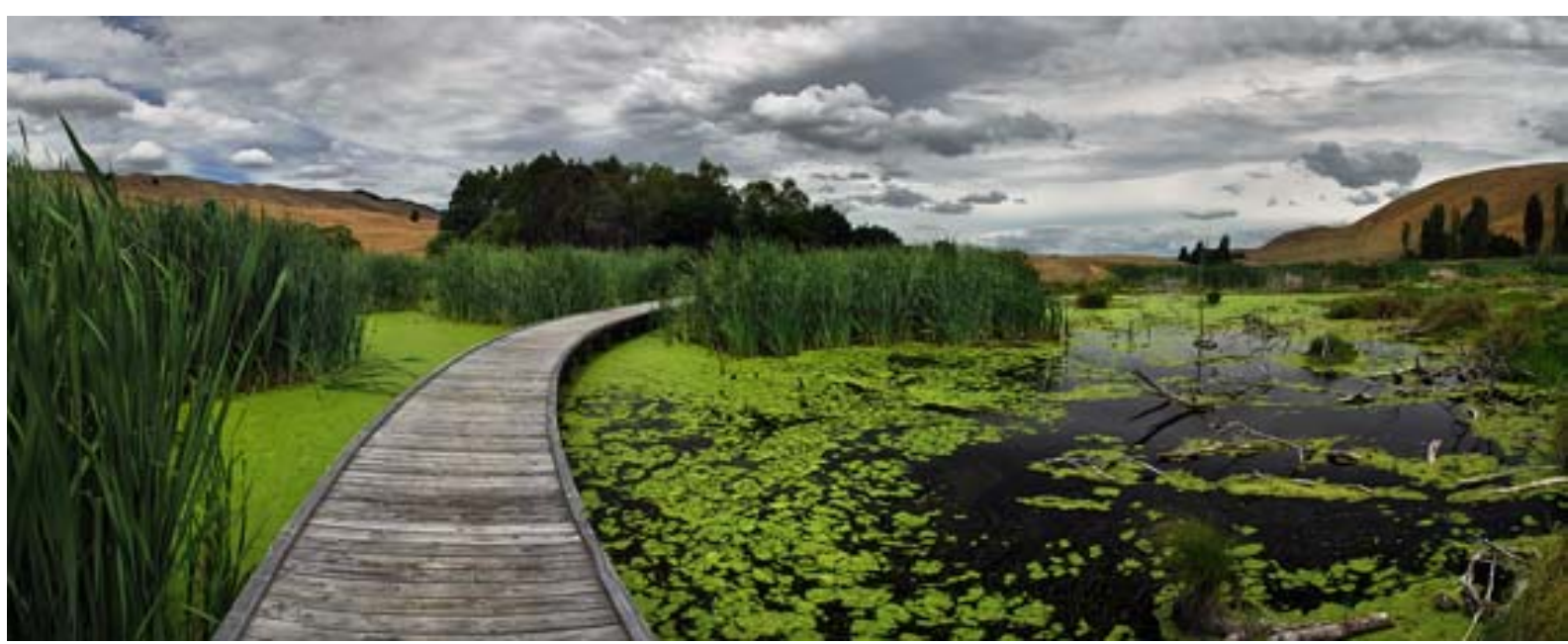

Ilustração 33 - Exemplo de wetland na Nova Zelândia. Fonte: DOC (s/d).

Dentre as medidas estruturais, as wetlands têm sido amplamente utilizadas na Europa e nos EUA como estruturas para retenção e tratamento das cargas poluidoras. São estruturas que interceptam o sistema de drenagem, promovendo o tratamento das águas através do uso de espécies de interesse que recriem 
condições naturais de depuração de nutrientes, além da retenção de sedimentos que se depositam no fundo da estrutura (Salati, 2003).

Existem diversas técnicas para construção de wetlands, que variam em função da carga de poluentes que será recebida e eficiência na remoção de determinados nutrientes, podendo ser classificadas como: wetlands com plantas flutuantes, com plantas emergentes, com macrófitas fixas submersas, com solos filtrantes (Sistema DHS) ou com técnicas combinadas (Salati, 2003). As principais características de cada técnica são descritas na Tabela 6 e a llustração 34 mostra exemplos de espécies vegetais utilizadas em wetlands para controle da carga difusa.

Tabela 6 - Técnicas de construção de wetlands. Fonte: Elaborada pela autora a partir de Salati (2003).

\begin{tabular}{|c|c|}
\hline Técnica & Características \\
\hline $\begin{array}{l}\text { Wetlands com } \\
\text { plantas } \\
\text { flutuantes }\end{array}$ & $\begin{array}{l}\text { Mais utilizada em canais relativamente rasos, com a aplicação de } \\
\text { macrófitas flutuantes, visando a remoção de fósforo e nitrogênio } \\
\text { que são incorporados em sua biomassa, além da redução da DBO } \\
\text { e DQO. Principal espécie utilizada nestes sistemas é a Eichornia } \\
\text { crassipes*, graças à sua robustez e grande capacidade de }_{\text {crescimento vegetativo. }}\end{array}$ \\
\hline $\begin{array}{l}\text { Wetlands com } \\
\text { plantas } \\
\text { emergentes }\end{array}$ & $\begin{array}{l}\text { O sistema utiliza plantas que tem seu sistema radicular preso ao } \\
\text { sedimento, mantendo caule e folhas parcialmente submersos. As } \\
\text { espécies mais utilizadas tem sido Phragmites australis*, a Typha } \\
\text { latifolia* e a Scirpus lacustris. }\end{array}$ \\
\hline
\end{tabular}

$\begin{array}{ll}\text { Wetlands com } & \text { O sistema utiliza plantas que permanecem com suas partes } \\ \text { macrófitas } & \text { vegetativas submersas, que tem grande capacidade de oxigenação } \\ \text { fixas } & \text { das águas. As espécies mais utilizadas tem sido Isoetes Lacustris*, } \\ \text { submersas } & \text { Lobelia Dortmanna*, Egéria } s p^{*} \text { e Elodea Canadensis. }\end{array}$

\begin{tabular}{ll}
\hline & O sistema utiliza diferentes camadas de solo, com diferentes \\
Wetlands com granulometrias a fim de promover o tratamento das águas, & $\begin{array}{l}\text { solos filtrantes } \\
\text { mesclando função de tratamento mecânico, físico-químico e } \\
\text { microbiológico }\end{array}$ \\
\hline
\end{tabular}

Wetlands com técnicas combinadas

O sistema usa a combinação das demais técnicas descritas, a fim de potencializar o tratamento das cargas poluentes afluentes.

\footnotetext{
* Espécies citadas de ocorrência natural no Brasil, segundo pesquisa no banco de dados do Discovery life.
} 

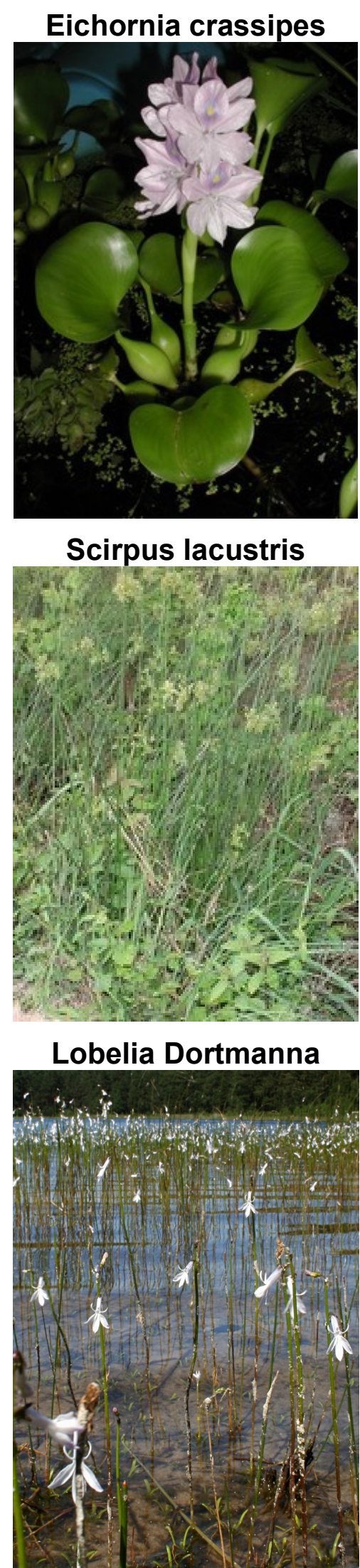
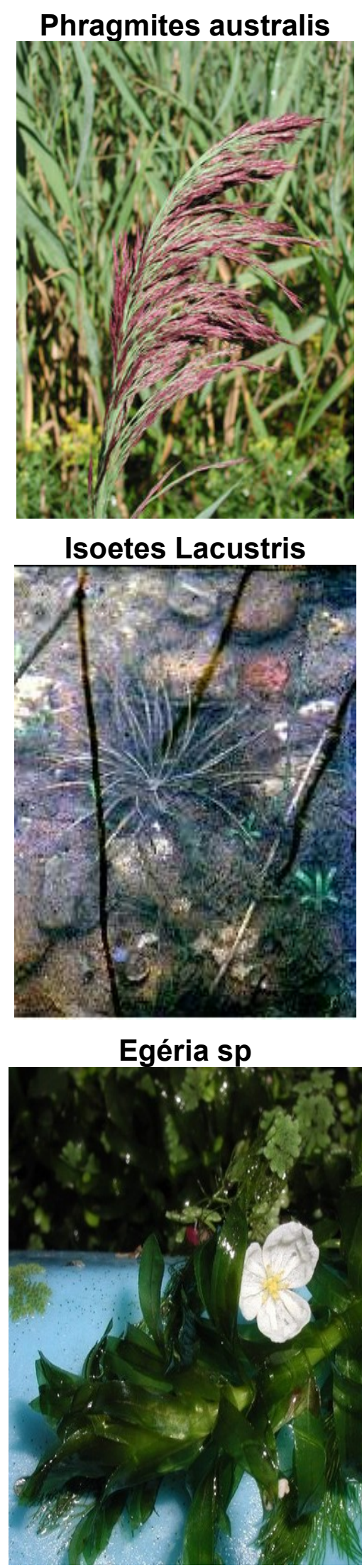
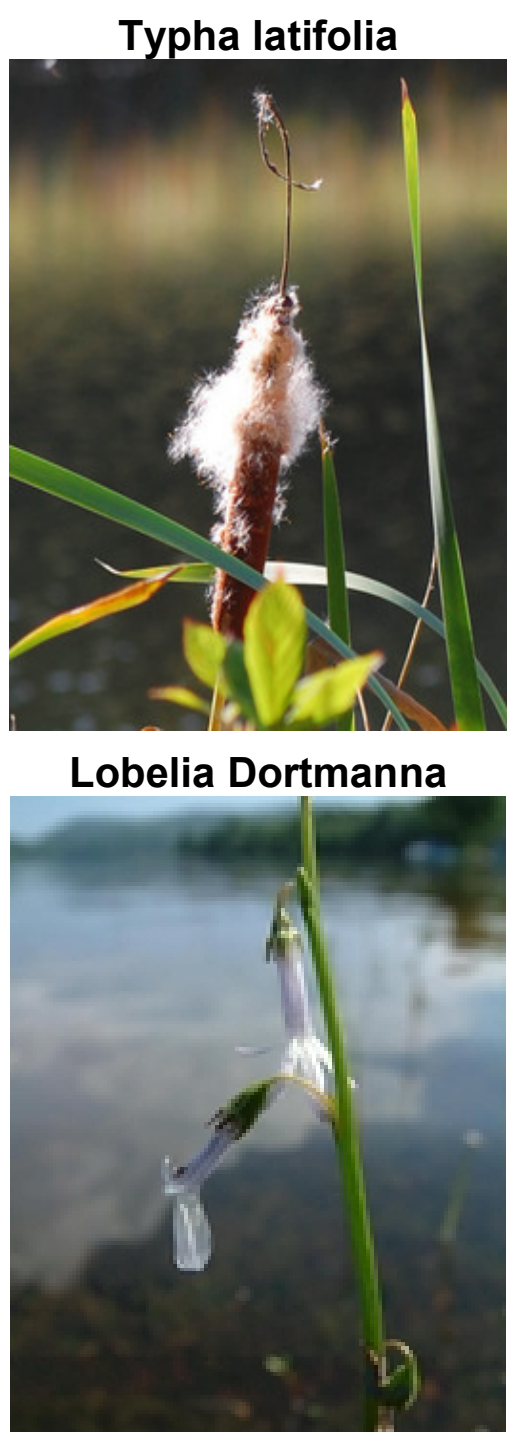

Elodea Canadensis

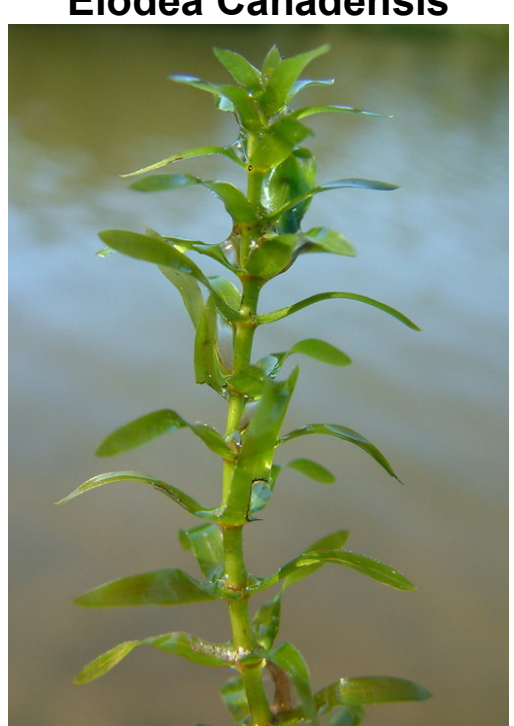

Ilustração 34 - Espécies adotadas em wetlands. Fonte: Discovery life (s/d).

A cidade de Los Angeles adota no sistema de drenagem, nas parcelas que coleta tipologias comerciais e industriais um sistema de wetlands para tratamento de 
cargas difusas, a fim de controlar os poluentes que afluem para o rio Los Angeles. $O$ sistema de microdrenagem coleta as águas do escoamento superficial nas tipologias e as reúne em um ponto de lançamento comum onde estas águas passam por um processo de tratamento biológico, sendo lançadas nos corpos d'água da bacia com as cargas orgânica e de metais reduzidas. Além disso, a área da Wetland é utilizada como área de lazer pela população, possuindo travessias sobre as zonas alagadas, bancos e equipamentos de lazer. A llustração 35 a seguir mostra um exemplo do sistema implantado em uma zona comercial de Los Angeles.

\section{Sistema de tratamento de cargas difusas de tipologias comerciais e} industriais em Los Angeles
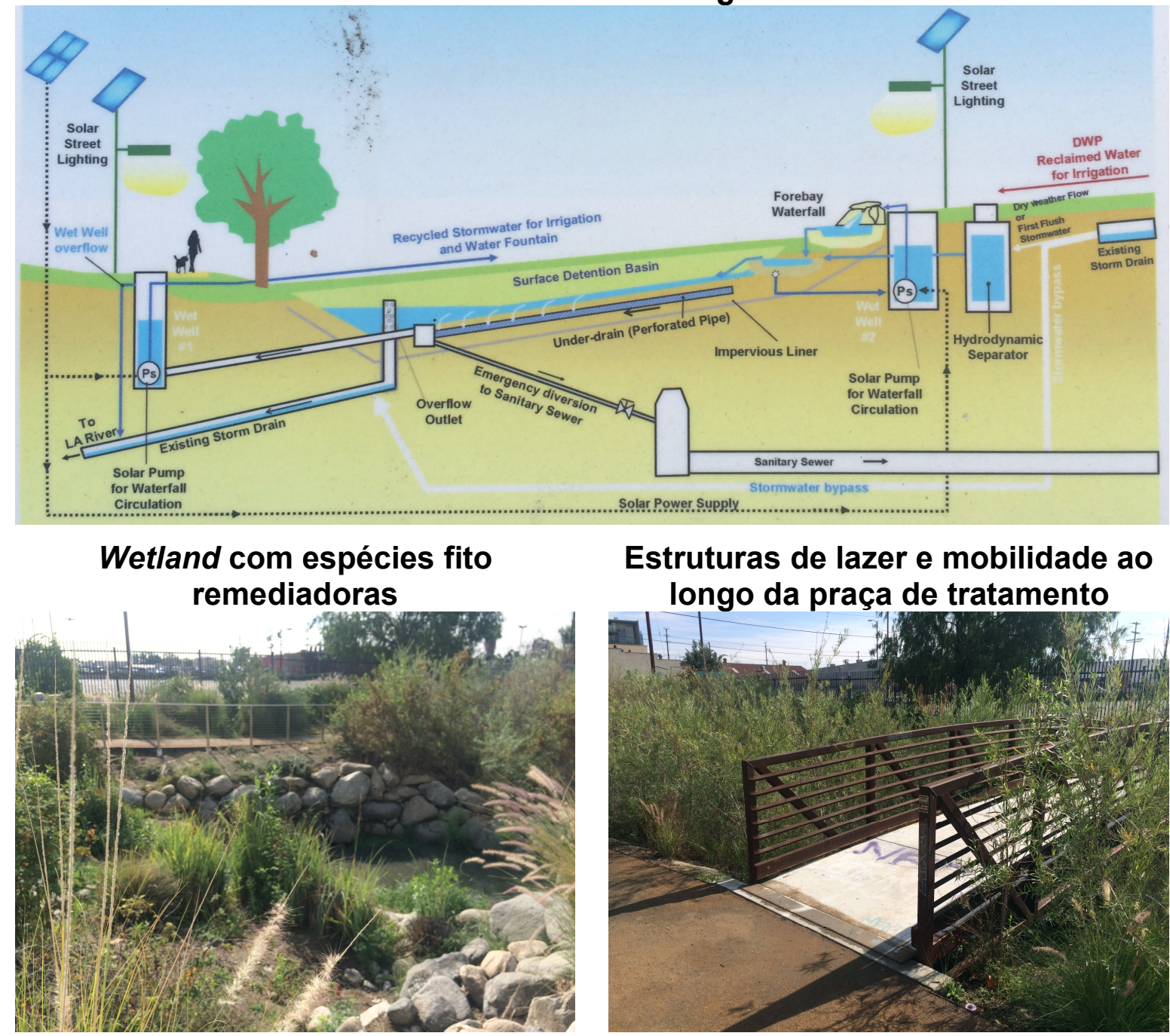

Estruturas de lazer e mobilidade ao longo da praça de tratamento

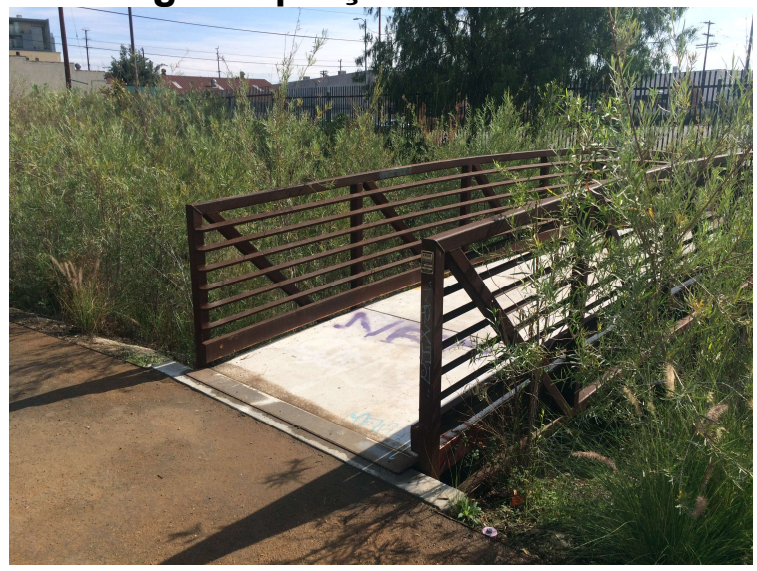

Ilustração 35 - Wetland para tratamento da drenagem proveniente de tipologias comerciais e industriais em Los Angeles. Fonte: Fotos da autora.

A bacia do rio Mississipi nos EUA tem um longo histórico de degradação devido às cargas difusas que recebem provenientes majoritariamente do uso de fertilizantes nitrogenados na bacia, de uma pequena parcela de lançamentos de efluentes 
domésticos e industriais e de excrementos proveniente da criação de animais, o que resulta em um processo de hipóxia em sua foz no Golfo do México, sendo as maiores taxas de degradação encontradas no período chuvoso; Além disso, a bacia perdeu nos últimos 200 anos cerca de $80 \%$ de seus alagados naturais. A fim de calcular a área de wetlands necessária para mitigar os impactos desses lançamentos, foram estudadas 50 áreas para construção destas estruturas. O estudo revelou a necessidade de $22 \mathrm{mil} \mathrm{km}^{2}$ de wetlands na bacia do rio Mississipi, que possui 3,2 milhões de $\mathrm{Km}^{2}$ de área de drenagem, alternativa viável considerando que mesmo em um cenário otimista onde haja a redução dos lançamentos e do uso de fertilizantes, ainda assim não seria o suficiente para controlar a degradação do corpo d'água (Mitsch e Day, 2006).

No estudo realizado por Cha et al. (2009) na bacia do rio Gwangju na Coreia, foi proposta uma Wetland para controle da qualidade da água no corpo d'água. As modelagens realizadas no QUAL2E revelaram que uma Wetland no canal resultaria na redução significativa da carga orgânica, além disso, a estrutura apresentou elevada eficiência, $80 \%$, na remoção de E. Coli, constituindo assim uma ferramenta importante de melhoria de qualidade da água no projeto de revitalização.

A empresa holandesa Urbanisten apresenta um exemplo interessante de drenagem sustentável, as Water Squares, onde há a previsão do uso das áreas reservadas à retenção de águas pluviais, pela população através da previsão de estruturas de lazer, promovendo assim a integração da população com a água. Vale ressaltar que a proposta original da Urbanisten só pode ter seu propósito atingido se a água armazenada atenda os padrões mínimos sanitários, para que seja possível a recreação de contato primário, onde há contato direto e prolongado com a água, tais como natação e mergulho, na qual a possibilidade do banhista ingerir água é elevada. Como a aplicação da proposta depende de águas de boa qualidade, pois coloca o usuário em contato direto com a água, para o caso brasileiro, a mesma poderia ser implantada em um primeiro momento com estruturas que limitem o usuário ao contato secundário, ou seja, aquele em que o contato com a água é esporádico ou acidental e a possibilidade de ingerir água é pequena, conforme a resolução CONAMA 357 de 2005, e em um segundo momento poderiam ser implantadas estruturas que promovessem o contato primário. 
A retenção das águas pluviais pode atender diferentes períodos de retorno, onde as águas podem ocupar parcialmente ou totalmente a praça, o que modifica as possibilidades de uso das estruturas pela população. A sequência de ilustrações a seguir, mostra o projeto de uma Water Square projetada para a cidade de Roterdã, onde se observa as estruturas sob influência de diferentes intensidades de chuva. A llustração 36 mostra a praça na ausência de precipitação, onde a totalidade das estruturas de lazer podem ser utilizadas pela população, podendo ser implantados bancos para contemplação, chafarizes, quadras esportivas, rampas para skates e brinquedos para crianças.

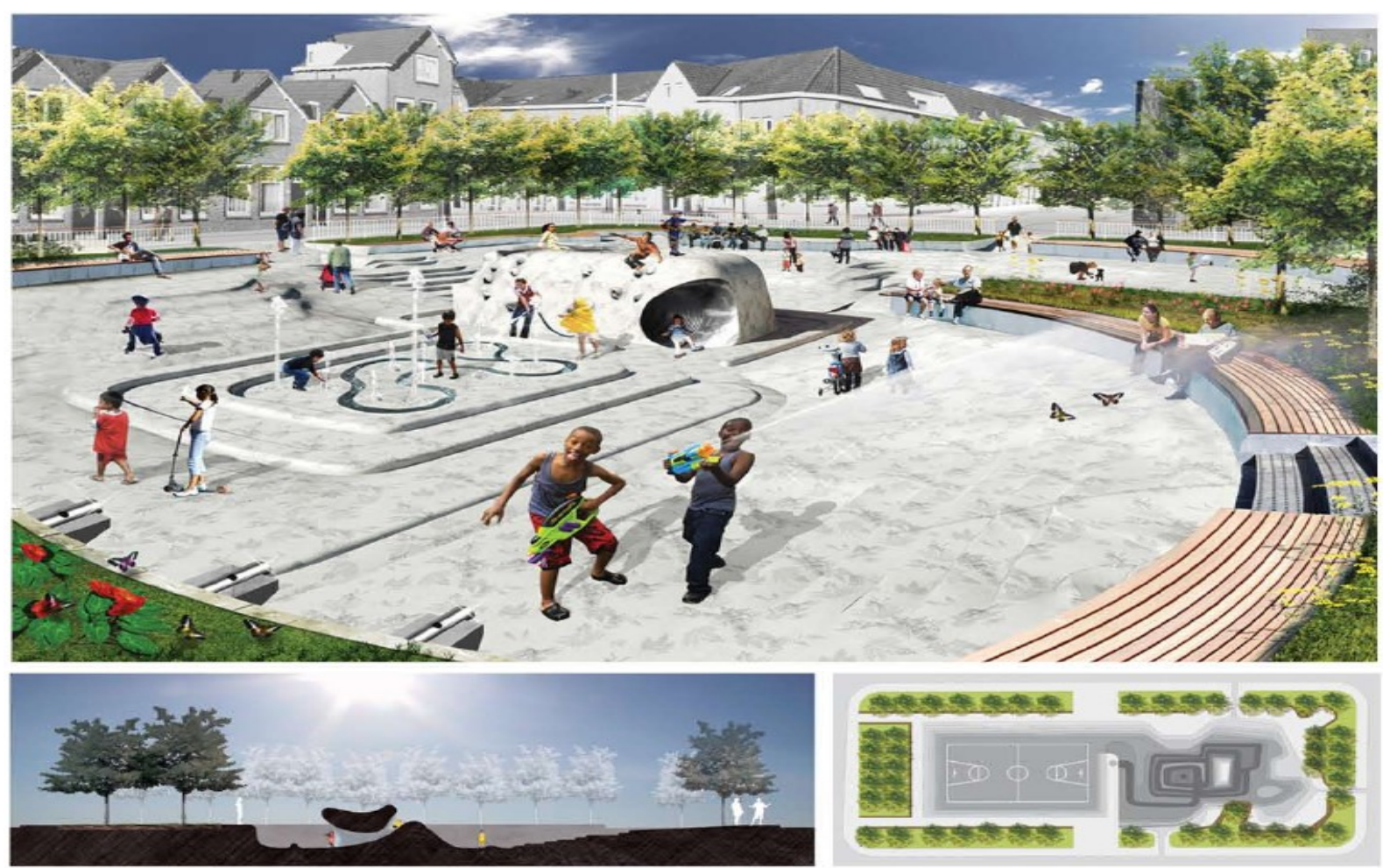

Ilustração 36 - Water Square na ausência de precipitações. Fonte: Urbanisten (s/d).

Já a llustração 37 mostra a praça sobre influência de precipitações de baixa intensidade, onde há o aumento do nível d'água e ocupação pela água de parte da praça, mas ainda assim permitindo o uso de algumas estruturas de lazer; por fim a llustração 38 mostra a utilização da praça em seu nível de água máximo, onde há a ocupação de toda a área da praça pela água e obstrução temporária da maioria das estruturas de lazer. 


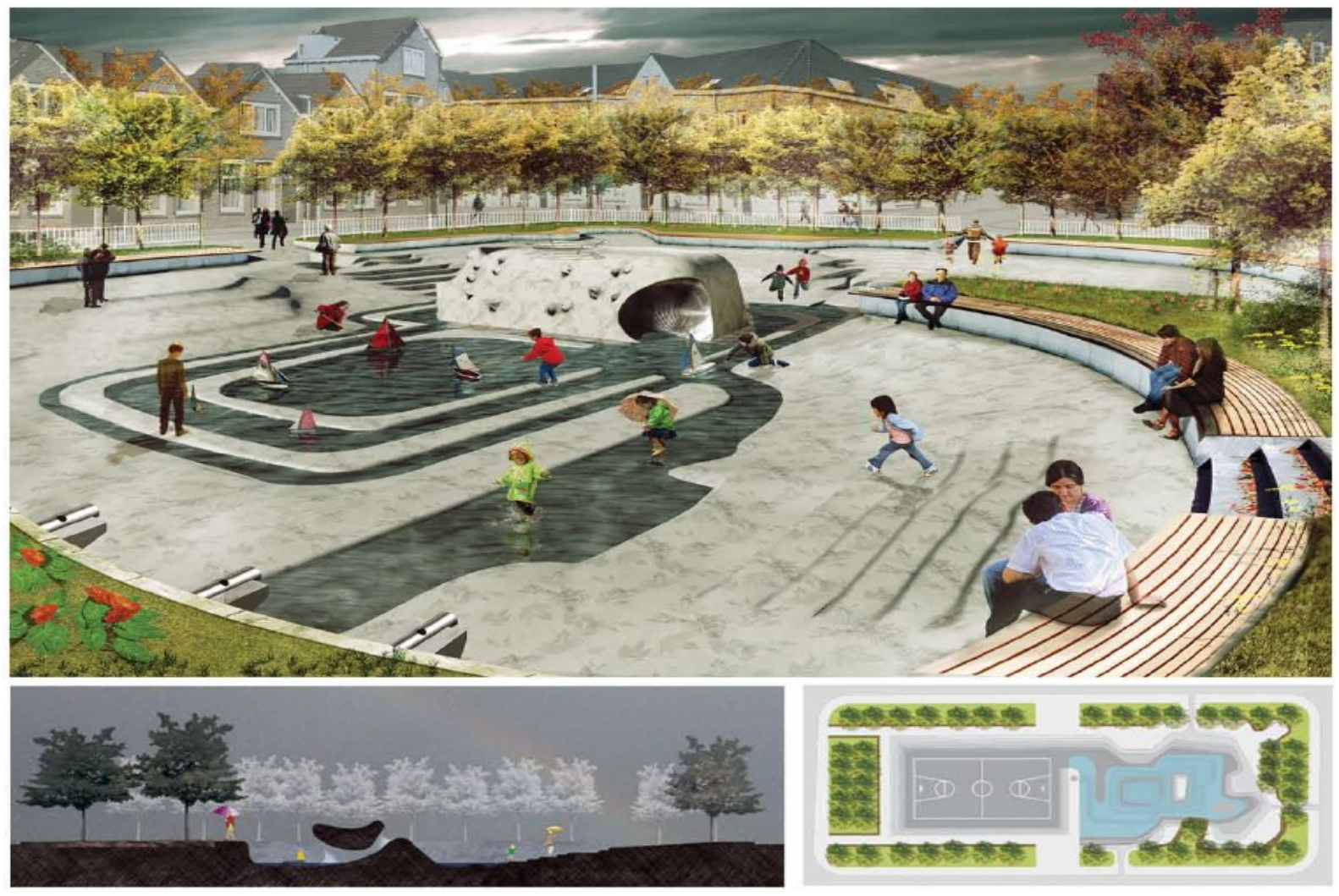

Ilustração 37 - Water Square na ocorrência de precipitações de baixas intensidades. Fonte: Urbanisten (s/d).
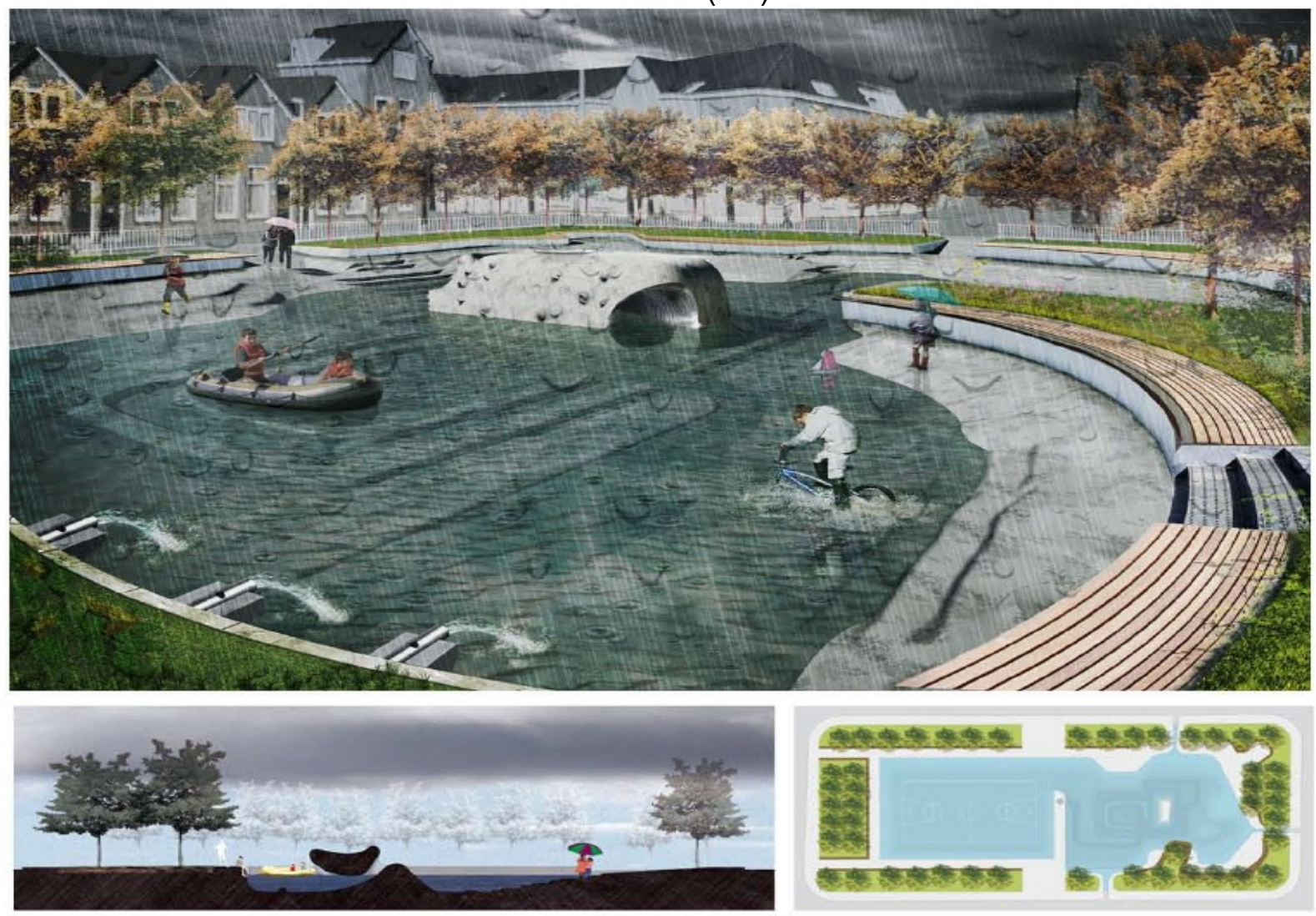

Ilustração 38 - Water Square na ocorrência de precipitações de elevadas intensidades. Fonte: Urbanisten (s/d). 
No Brasil, um exemplo de solução para o controle da qualidade da água e reabertura de canalização foi a adotada no projeto do Córrego do Antonico na Favela de Paraisópolis em São Paulo. No projeto foram considerados dois canais, um que receberá as águas sem controle de qualidade, coletadas pelo sistema de drenagem convencional e outro que receberá águas controladas, como as provenientes de nascentes, de reservatórios de detenção (Piscininha) e de outras fontes de qualidade controlada, a fim de proporcionar uma fonte segura de contato com a água para a comunidade. A llustração 39 mostra a solução adotada.
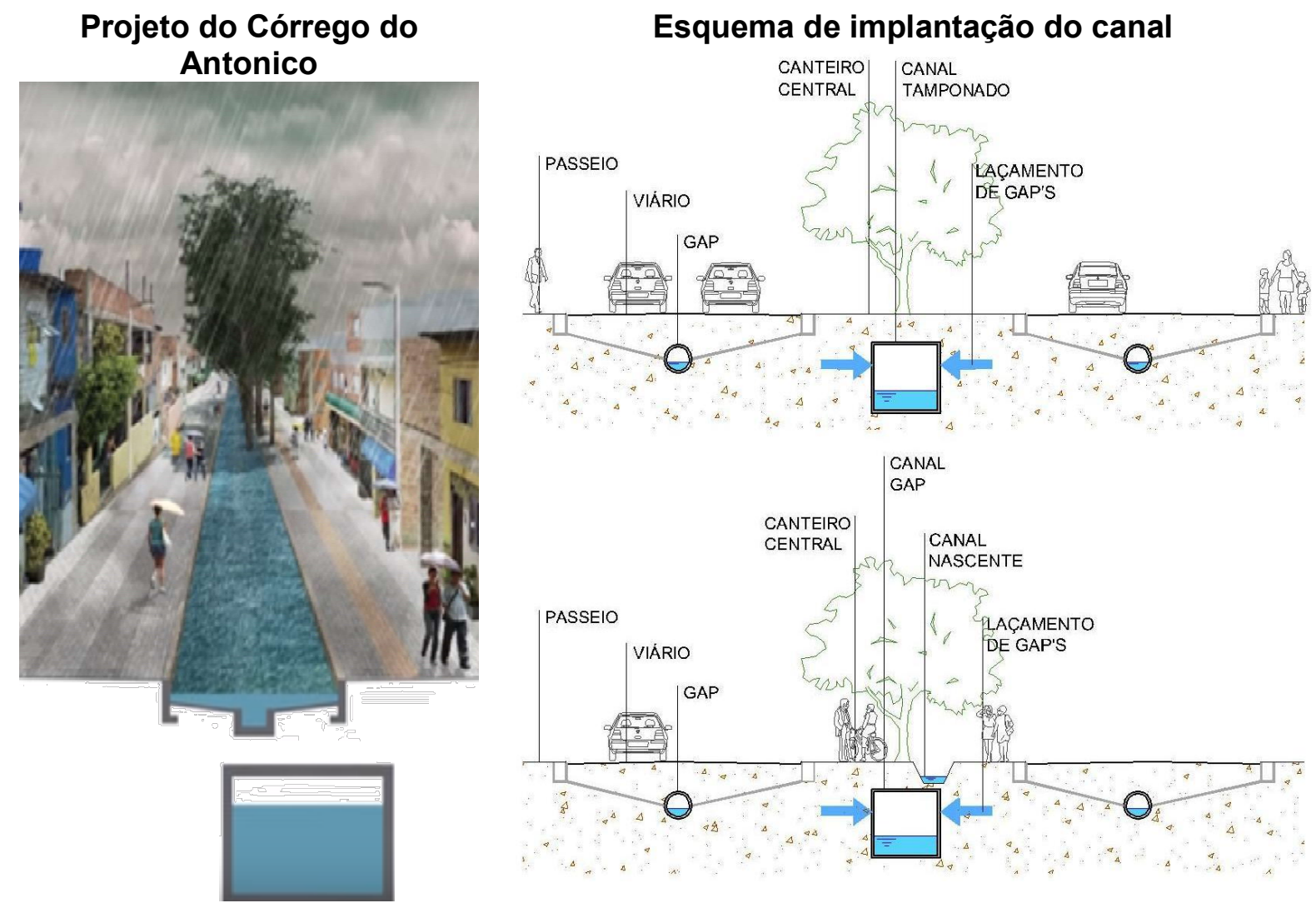

Ilustração 39 - Projeto do Córrego Antonico. Fonte: Galeria da Arquitetura (s/d). Esquema do Antes e depois da implantação do canal de águas controladas. Fonte: Elaborado pela autora.

Em Porto Alegre o modelo de controle do escoamento no município considera duas situações: O controle Corretivo (CC), que atua em bacias que já possui algum tipo de intervenção, atuando no sistema de drenagem existente para aumentar sua eficiência hidráulica; e o Controle Preventivo (CP), que considera o amortecimento do escoamento superficial desde a etapa de implantação do parcelamento do solo. O estudo de Cruz e Tucci (2008) apontou que o custo de implantação de infraestrutura do tipo CP é de $R \$ 36500 /$ ha, já para a implantação de infraestrutura 
do tipo CC é de $R \$ 198161,50 /$ ha, ou seja, o controle corretivo custa 2,7 vezes mais que o preventivo, e segundo os autores o custo de CC pode ser ainda maior se considerados os gastos com desapropriações maiores que os considerados, interrupções no tráfego viário e desgastes políticos envolvidos neste tipo de intervenção.

Um dos grandes desafios que o sistema de drenagem enfrenta é a entrada de resíduos sólidos no sistema de micro drenagem que quando é transportado para o sistema de macro drenagem resulta na degradação dos corpos d'água e quando fica retido nos dispositivos de captação como bocas de lobo e de leão, resulta em pontos de alagamento.

Segundo o Plano de gestão integrada de resíduos sólidos da cidade de São Paulo (2014), são dispostas nos aterros 2,2 mil toneladas por dia de resíduos provenientes da limpeza de bocas e lobo, limpeza de córregos e de piscinões. Somente com a limpeza de Bocas de lobo e bueiros são gastos 5,65 milhões de reais por mês, portanto tal sistema é grande demandador de soluções técnicas que tornem o processo mais eficiente e menos oneroso.

Atualmente a limpeza das Bocas de lobo é realizada com a única finalidade de desobstruir os dispositivos e evitar pontos de alagamento, a prefeitura de São Paulo realiza esta manutenção de duas formas, manualmente com auxílio de pás ou através de caminhões providos de equipamentos de alta potência para sucção de detritos, que retiram os resíduos retidos nos dispositivos e os encaminha para os aterros sanitários da cidade, realidade que se repete para a maioria dos municípios brasileiros (PGIRSSP, 2014). A llustração 40 mostra o processo de limpeza de bocas de lobo na cidade de São Paulo. 

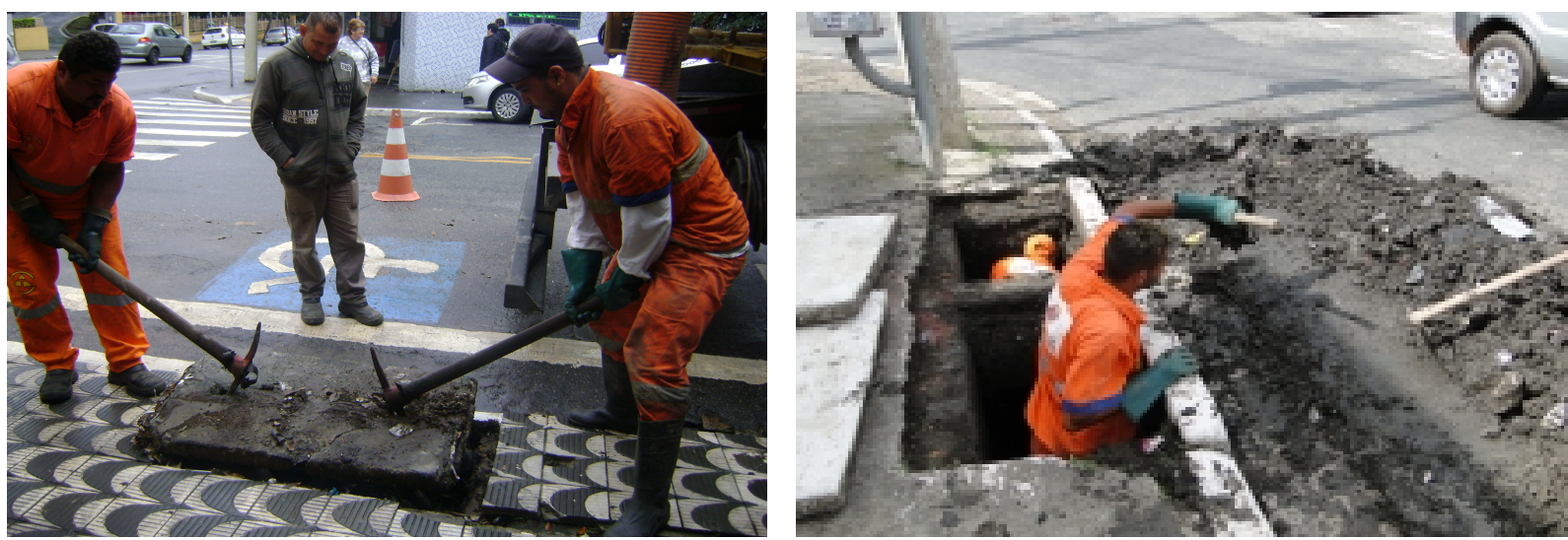

Ilustração 40 - Limpeza de bocas de lobo na cidade de São Paulo. Fonte: PMSP (s/d).

Segundo Tucci (2002), a produção de lixo para a drenagem em cidades onde há uma boa gestão de resíduos, como a cidade de San José na Califórnia, que utiliza o sistema de coleta por contêineres individuais, foi estimada em 1,8 $\mathrm{Kg} / \mathrm{hab} / \mathrm{ano}$, mas a taxa para o perfil brasileiro tende a ser maior, uma vez que os resíduos são mal geridos na bacia e o sistema de drenagem é utilizado como receptor destes poluentes.

Visando o controle de cargas difusas, um novo conceito vem ganhando força, o de controle na entrada do sistema, através da adição de dispositivos de captação, ou seja, estruturas que impeçam que os resíduos sejam direcionados ao corpo d'água, que segundo Righetto (2009), devem ser incorporados abaixo da cota inferior da entrada da boca de lobo e o material retido deve ser coletado periodicamente de modo a evitar o entupimento da estrutura e a atração de vetores.

Um exemplo de estrutura simples e razoavelmente eficiente é a SCS (Stormwater Cleaning Systems), utilizada em Springs, África do Sul. A função da estrutura é forçar o escoamento sobre o vertedor e através de um gradeamento inclinado, a interceptação do resíduo pelo gradeamento os força a cair em um compartimento, como mostrado na llustração 41 (Neves \& Tucci, 2003). 


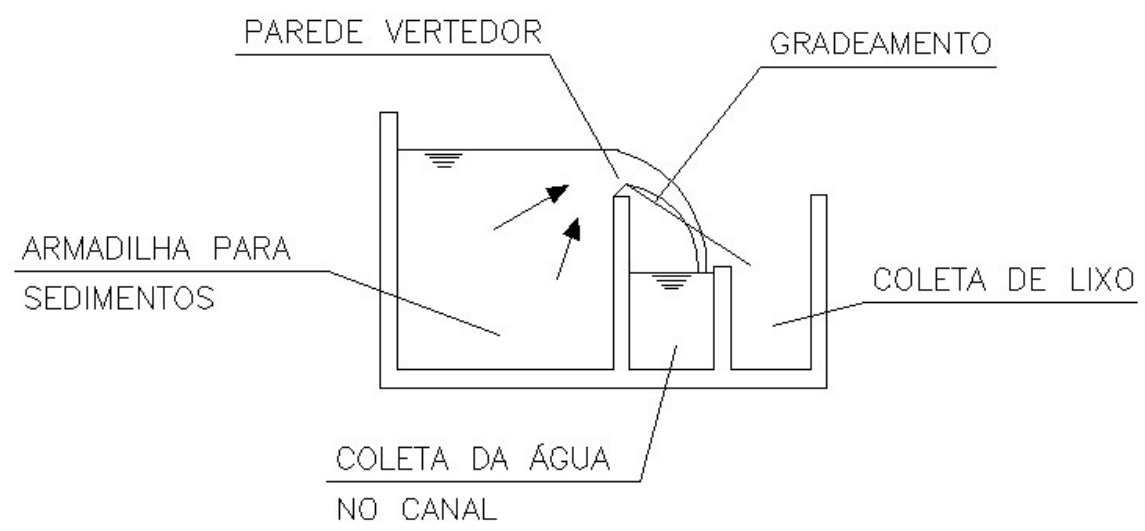

Ilustração 41 - Funcionamento do SCS. Fonte: Adaptado de Das Neves \& Tucci (2003).

Outra estrutura é a chamada SEPT (Side-Entry Pit Trap), utilizada em Melbourne, Austrália. São cestas acopladas à entrada de bocas de lobo, com malha de $5-20 \mathrm{~mm}$, onde há a retenção dos resíduos, que são removidos pela equipe de manutenção manualmente ou através do uso de um sugador de grande diâmetro. Uma vez bloqueados os poros, a água se acomoda na cesta e verte sobre a parte posterior da mesma (Das Neves \& Tucci, 2003).

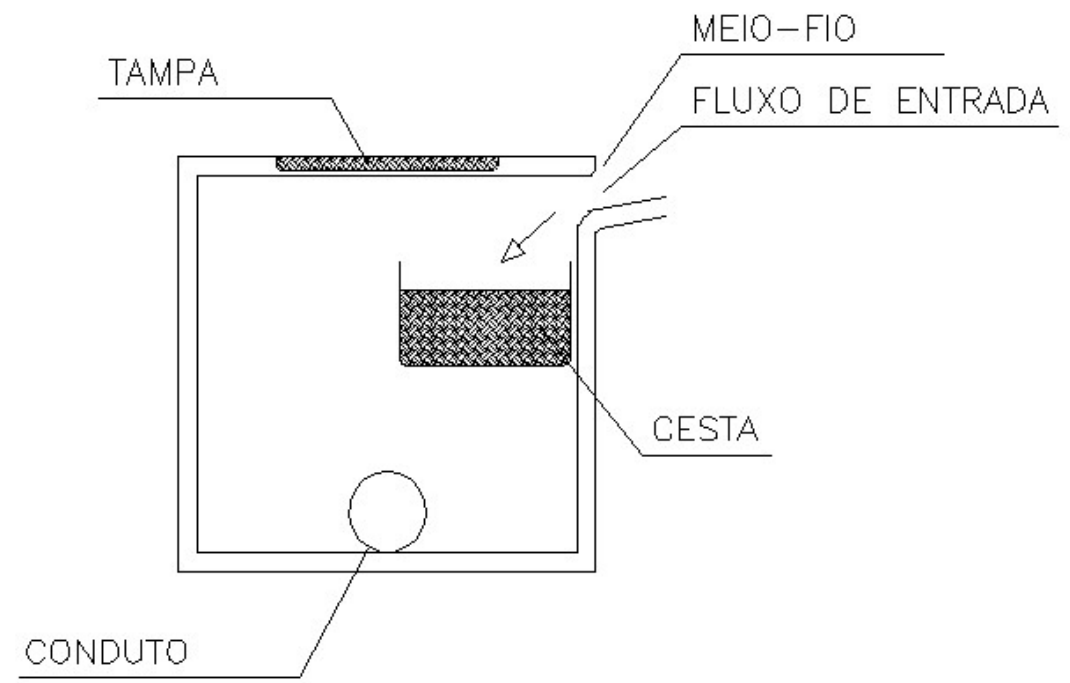

Ilustração 42 - Funcionamento do SEPT - Fonte: Das Neves \& Tucci (2003).

O monitoramento dos dispositivos instalados em Melbourne indicou que as cestas podem capturar até $85 \%$ da carga de resíduos sólidos secos e até $75 \%$ da carga total, ou seja, resíduos secos mais matéria orgânica. O estudo apontou ainda que as bocas de lobo sem grade na entrada contribuíram com cerca do dobro de cargas (Neves \& Tucci, 2003). 
Em Auckland, na Nova Zelândia e em Cape Town foram adotadas redes de nylon e de aço para controle de resíduos em lançamentos de sistemas de drenagem, mostrando ser outra ferramenta efetiva (Neves \& Tucci, 2003).
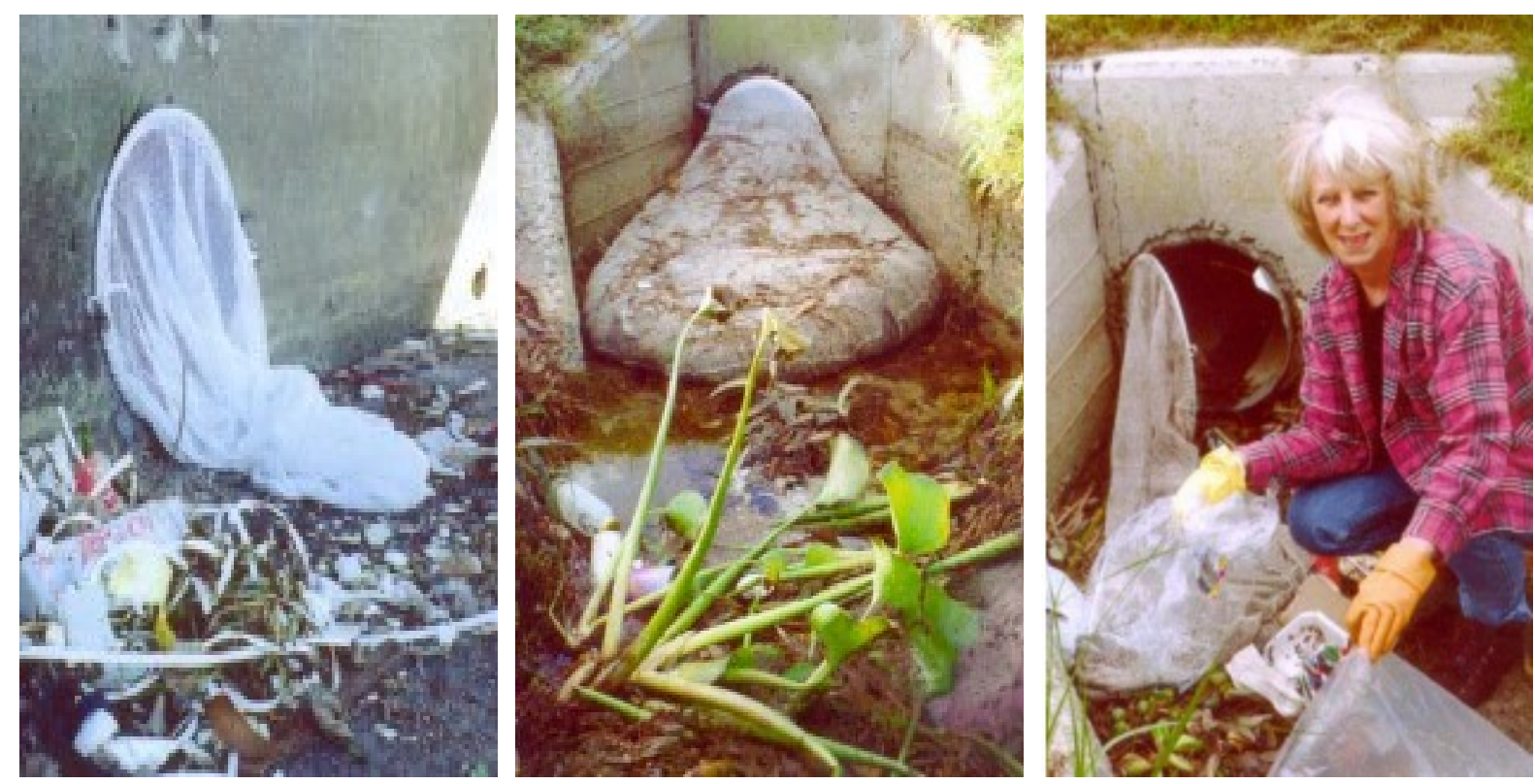

Ilustração 43 - Monitoramento realizado em Cape Town - Fonte: Das Neves \& Tucci (2003).

A cidade de Los Angeles vem realizando nos últimos 20 anos um grande esforço para o controle de resíduos em seu sistema de drenagem, para tanto foram instalados diversos dispositivos para garantir que os resíduos gerados na cidade não atinjam seus corpos d'água, uma vez que o destino final destes resíduos são as praias de Los Angeles, através do rio Los Angeles. As praias de Los Angeles têm grande importância para o turismo, sendo a preservação das mesmas de grande interesse para a cidade. Desta forma, foram instalados em todas as bocas de lobo da cidade dois dispositivos, o primeiro consiste em uma grade móvel que impede a entrada de resíduos na boca de lobo, sendo aberta somente em casos de chuvas de grande intensidade, onde a grande vazão de entrada força sua abertura (llustração 44 ); e o segundo consiste em cestos implantados dentro dos dispositivos que impedem que os resíduos, que por ventura consigam entrar na boca de lobo, sejam levados para a galeria de drenagem (llustração 45 ). 

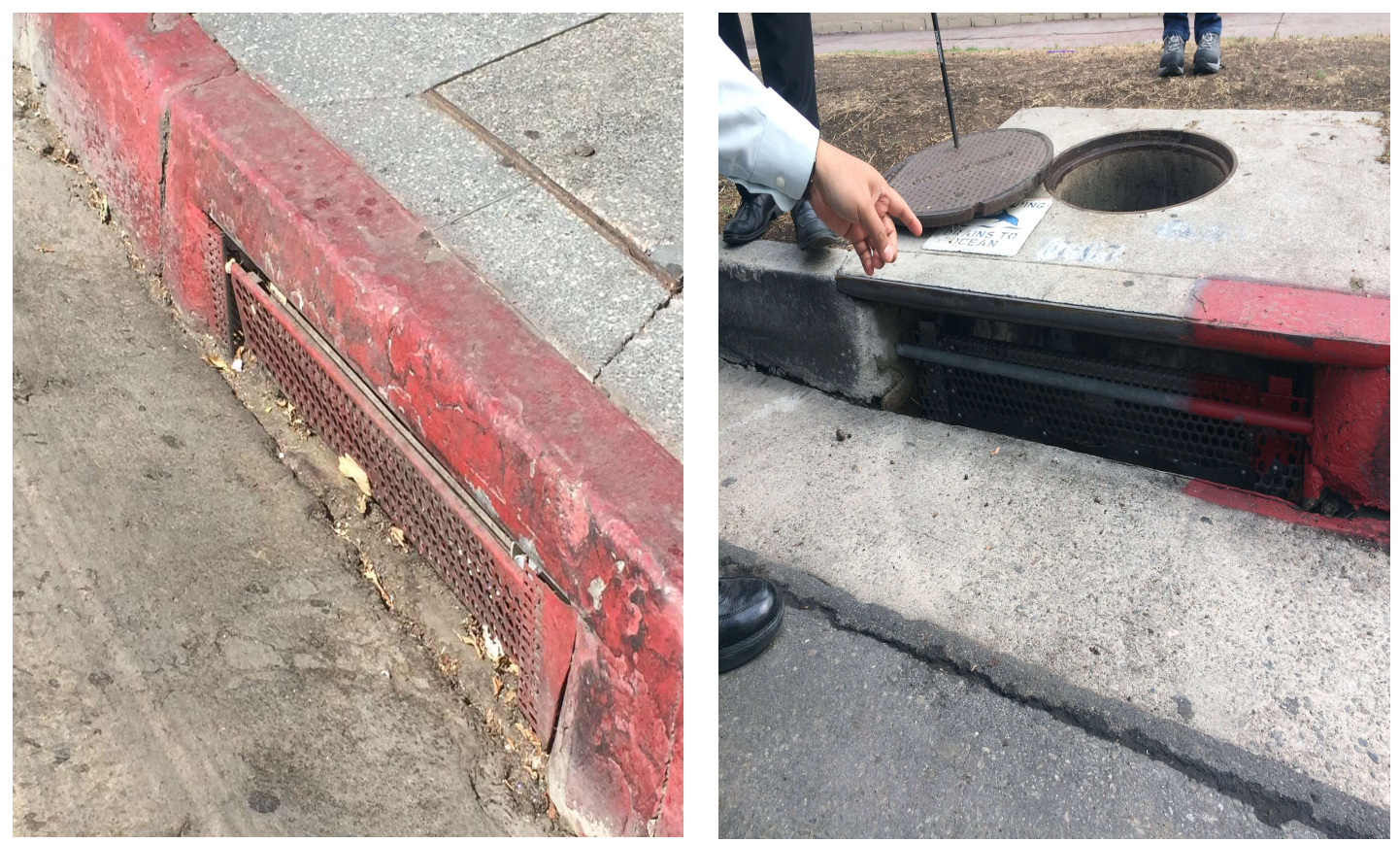

Ilustração 44 - Grade móvel na entrada das bocas de lobo em Los Angeles, Califórnia. Fonte: Fotos da autora.
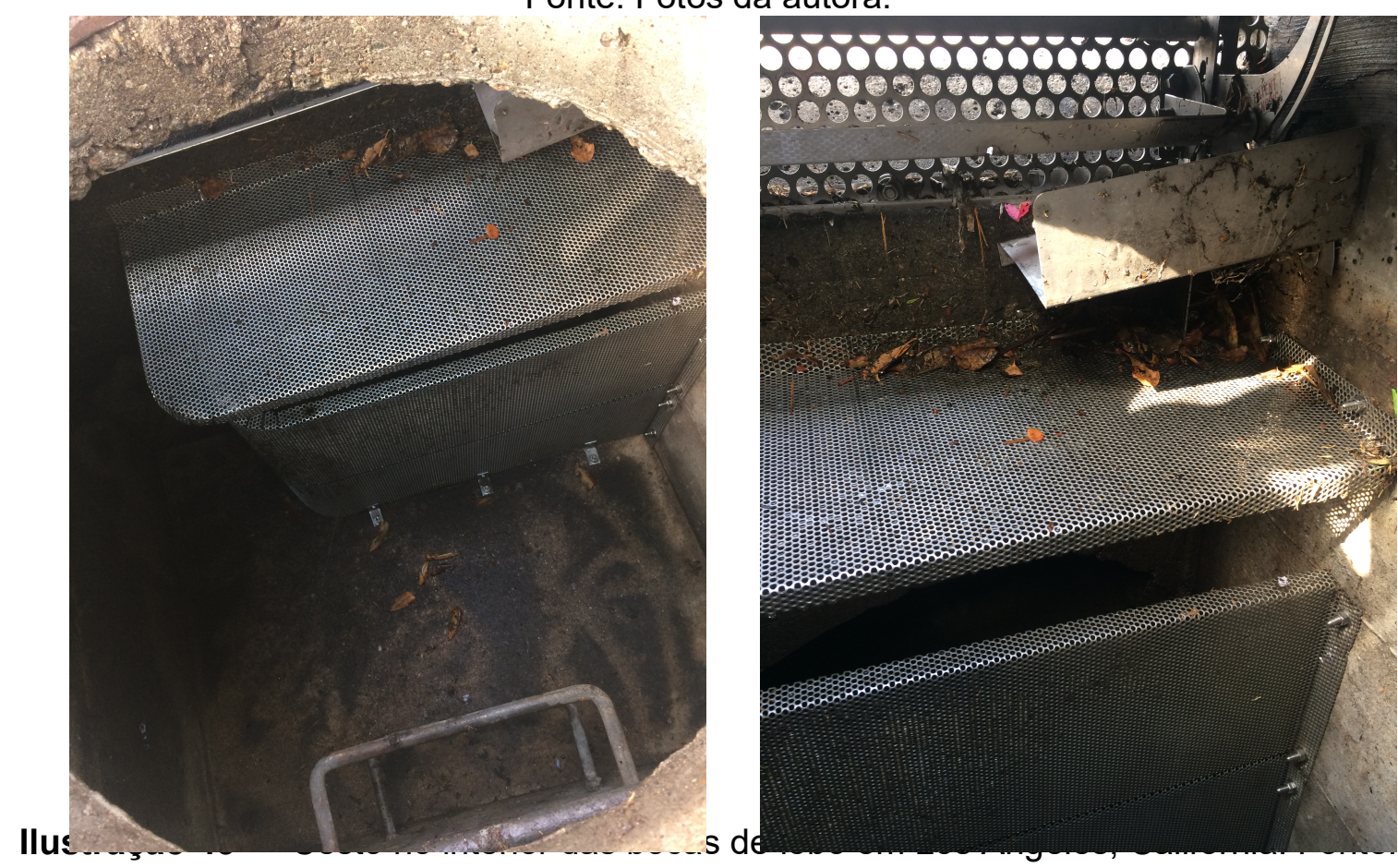

Fotos da autora.

Em algumas cidades brasileiras têm sido instalado em algumas bocas de lobo, caixas removíveis, que atuam na retenção de materiais grosseiros, a fim de auxiliar no controle do entupimento destes dispositivos e de galerias de águas pluviais. Algumas dessas iniciativas constituem adaptações de caixotes de feira, mas há no mercado também algumas empresas que fornecem de forma industrializada uma caixa filtrante que é acompanhada de um sensor para monitoramento do nível da caixa e de um software para gestão do sistema. A cidade de São Paulo instalou de 
forma piloto 400 cestos em bocas de lobo em pontos estratégicos da cidade, a fim de avaliar a viabilidade de utilizar a tecnologia em todo o sistema (PMSP, s/d).
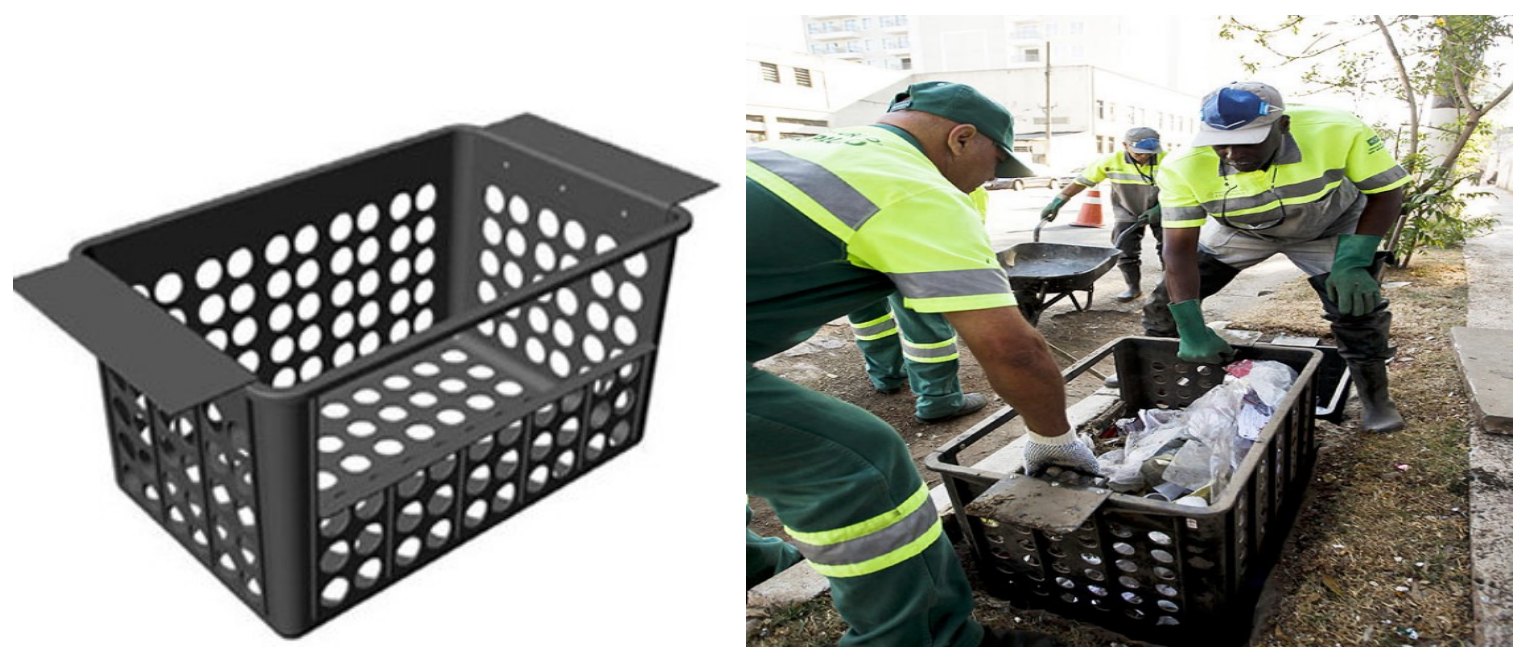

llustração 46 - Cesto de retenção de resíduos sólidos. Fonte: PMSP (s/d).

Além disso, a cidade de Los Angeles adota no desemboque das galerias de drenagem nos corpos d'água da cidade, dispositivos de retenção de resíduos, constituídos de grandes redes de aço, como mostrado na llustração 47 , para retenção dos resíduos que não tenham sido retidos nos dispositivos de captação do escoamento superficial. Para tanto é necessária a construção de um poço de manutenção, que será utilizado para retirada dos resíduos retidos e manutenção técnica da estrutura.
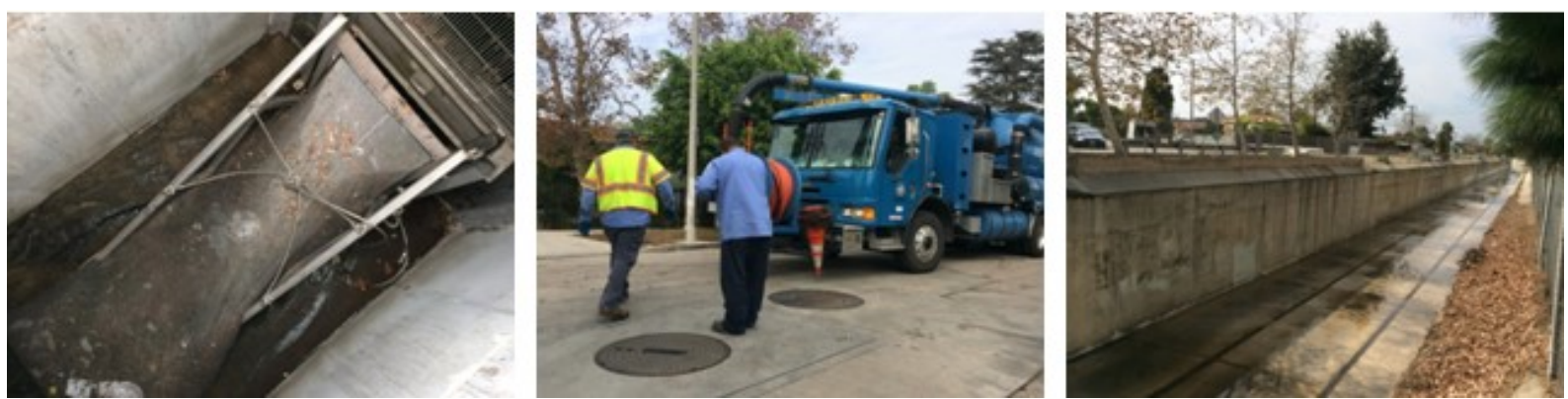

Ilustração 47 - Redes de aço no interior das galerias antes do lançamento nos corpos d'água em Los Angeles, Califórnia. Fonte: Fotos da autora.

Por fim, adotam no rio Los Angeles, próximo à sua foz uma barreira flutuante que realiza a retenção final de resíduos. Os resíduos retidos na barreira são coletados, prensados e armazenados em contêineres onde são transportados até a central de resíduos da cidade. No Brasil, em Porto Alegre, tem sido adotada uma medida parecida, conhecida como ecobarreira no Arroio Dilúvio. A llustração 48 mostra a barreira flutuante e a central de processamento adjacente à barreira onde 
os resíduos são acondicionados em Los Angeles e a Ecobarreira instalada no Arroio Dilúvio.

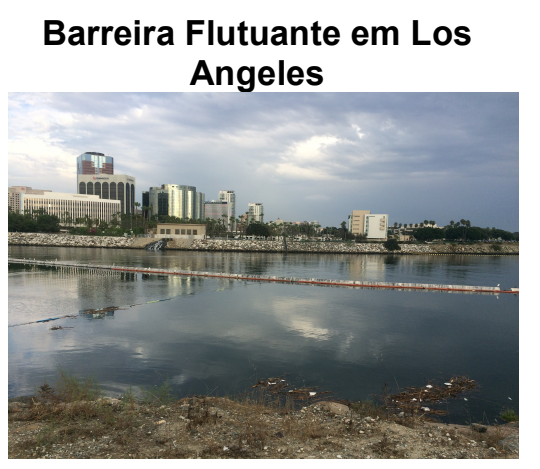

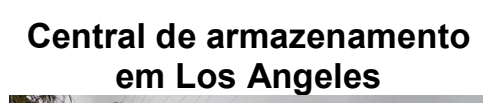

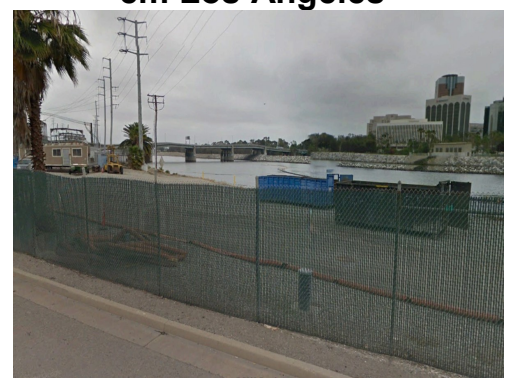

Eco Barreira no Arroio Dilúvio

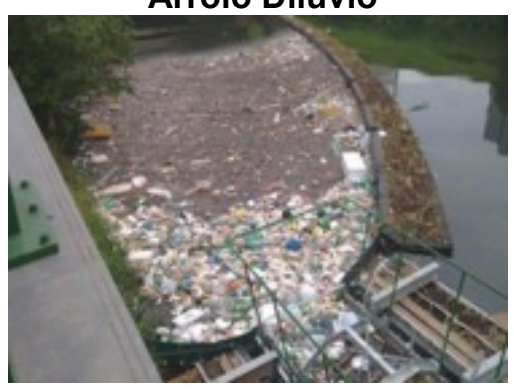

Ilustração 48 - Barreira flutuante e central de armazenamento de resíduos no rio Los Angeles, Califórnia. Fonte: Fotos da autora. Ecobarreira no Arroio Dilúvio, Porto Alegre.

Fonte: www.ecobarreiradiluvio.com.br

Los Angeles possui um programa rigoroso de limpeza de logradouros públicos, através de varrição mecanizada periódica (sinalizada por placas que alertam os moradores sobre o horário em que o caminhão de varrição fará a manutenção da via), o que reduz o aporte de resíduos para os dispositivos instalados na micro e macro drenagem.
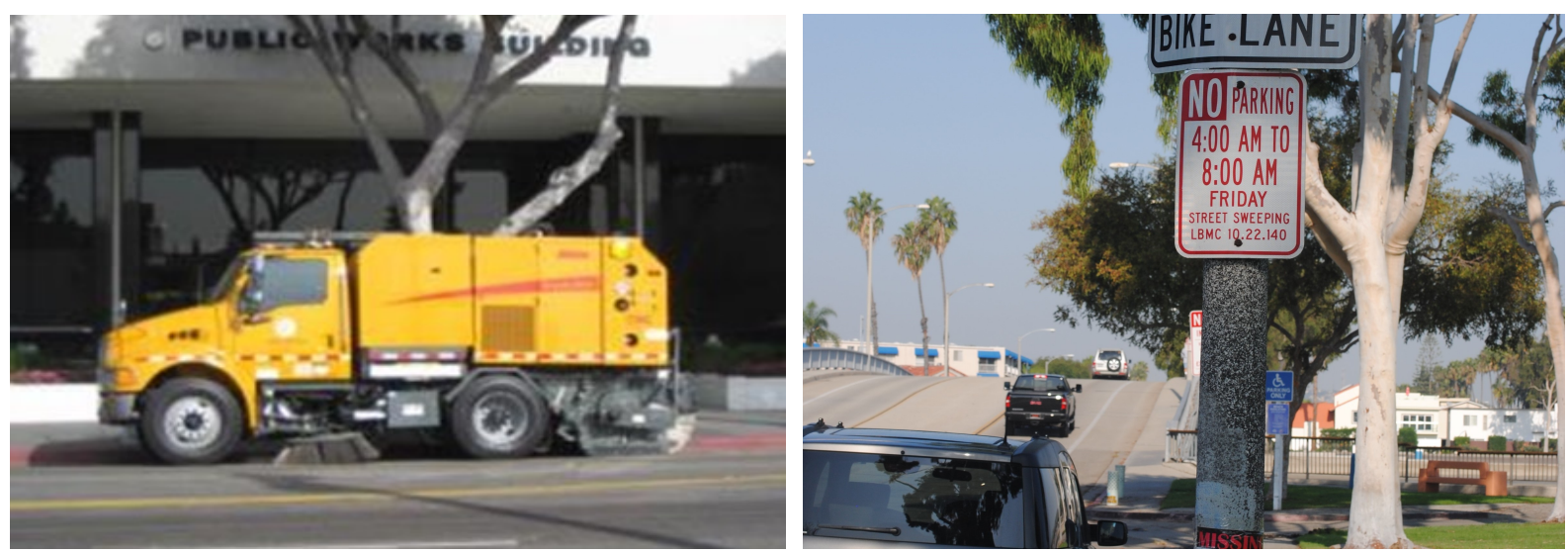

Ilustração 49 - Varrição mecanizada em Los Angeles, Califórnia. Fonte: Fotos da autora.

Para controle de sedimento nos canais da macro drenagem podem ser adotadas bacias de sedimentação, que provocam a redução da velocidade do escoamento forçando o acumulo de sedimentos que devem ser removidos de forma periódica. O departamento de agricultura dos Estados Unidos propõe como bacia de sedimentação a estrutura mostrada a seguir, que funciona como um barramento que retém o escoamento superficial, formando um ambiente propicio ao processo de decantação, desta forma o sedimento fica depositado no fundo da estrutura e as águas pluviais são direcionadas para a macrodrenagem com auxilio de um vertedor 
do tipo tulipa. A llustração 50 a seguir mostra um esquema de uma bacia de sedimentação e a llustração 51 mostra um exemplo no Tennessee.

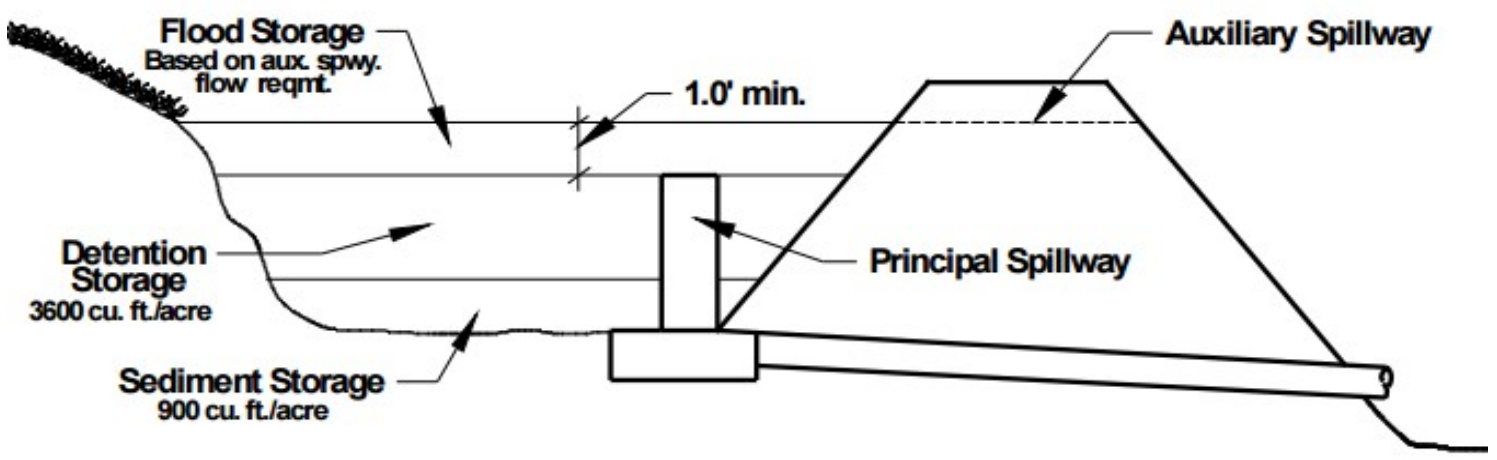

Ilustração 50 - Exemplo de bacia de sedimentação. Fonte: USDA (2010).

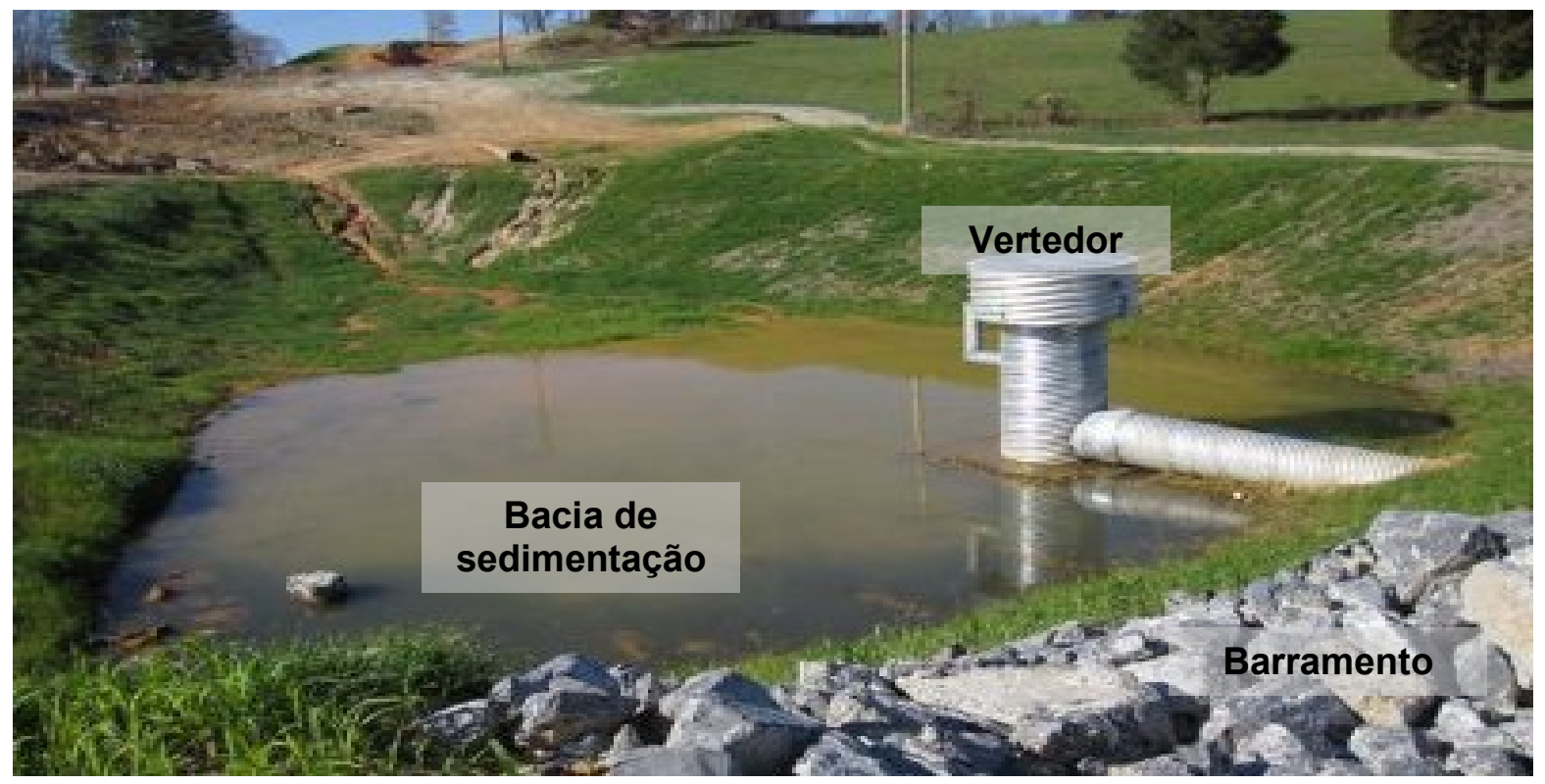

Ilustração 51 - Exemplo de bacia de sedimentação no Tennessee. Fonte: TNEPSC (s/d).

Segundo o Wisconsin Department of Natural Resources o dimensionamento da estrutura deve levar em conta a vazão afluente e as características do sedimento afluente, como tamanho da partícula e velocidade de sedimentação. Além disso, segundo o "Draft Water Sensitive Urban Design, Engineering Guidelines" de Brisbane na Austrália, a configuração da bacia deve permitir fácil acesso para manutenção da estrutura, ou seja, retirada periódica de sedimentos do leito da estrutura e os desemboques das galerias do sistema de microdrenagem devem possuir dissipadores de energia a fim de evitar processos erosivos no interior da bacia. 


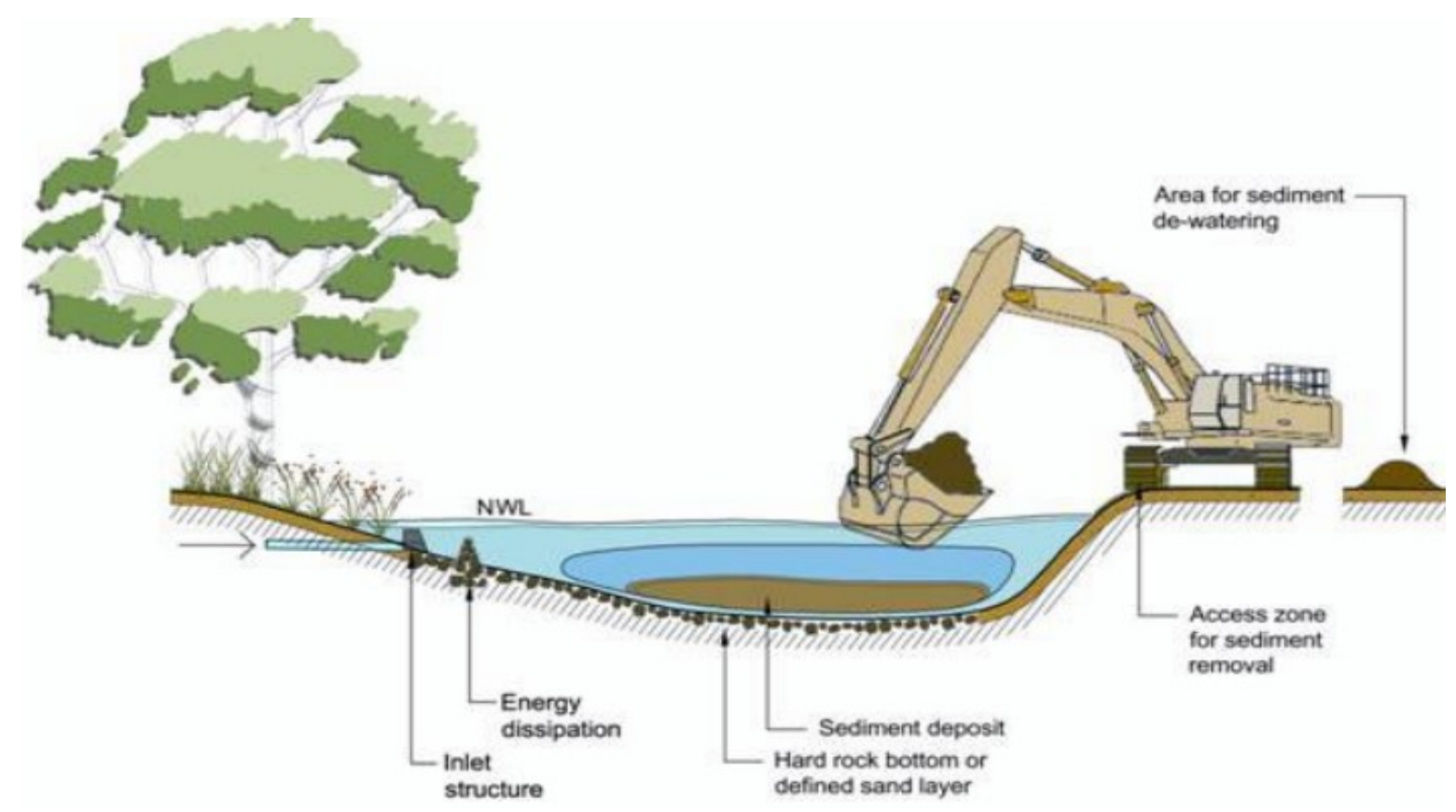

Ilustração 52 - Aspectos construtivos e operacionais de uma bacia de sedimentação.

Fonte: DWSUD (2005).

Segundo o manual de drenagem do Estado de Michigan nos EUA (2014) o volume da bacia de sedimentação deve ser de no mínimo $25,171 / \mathrm{m}^{2}$ de área contribuinte. O departamento de agricultura dos Estados Unidos recomenda ainda que no caso de uso da bacia de sedimentação pela fauna, deve ser priorizado o uso de espécies vegetais nativas na composição do espaço a fim de prover alimentação e abrigo para estas espécies.

Além das medidas estruturais, a gestão dos processos geradores de sedimento na bacia que contribuem para o sistema de drenagem é de fundamental importância, ou seja, o controle na fonte deve ser prioritário. Os dois principais processos geradores de sedimentos na bacia são as obras de construção civil e a ocupação irregular de encostas. Ambos os processos podem ser evitados se houver atuação eficiente de agentes fiscalizadores na bacia, no entanto a gestão de sedimentos adequada pode ser garantida com o incentivo do poder público para a adoção de certificações ambientais em empreendimentos, como por exemplo, o selo AQUA. 


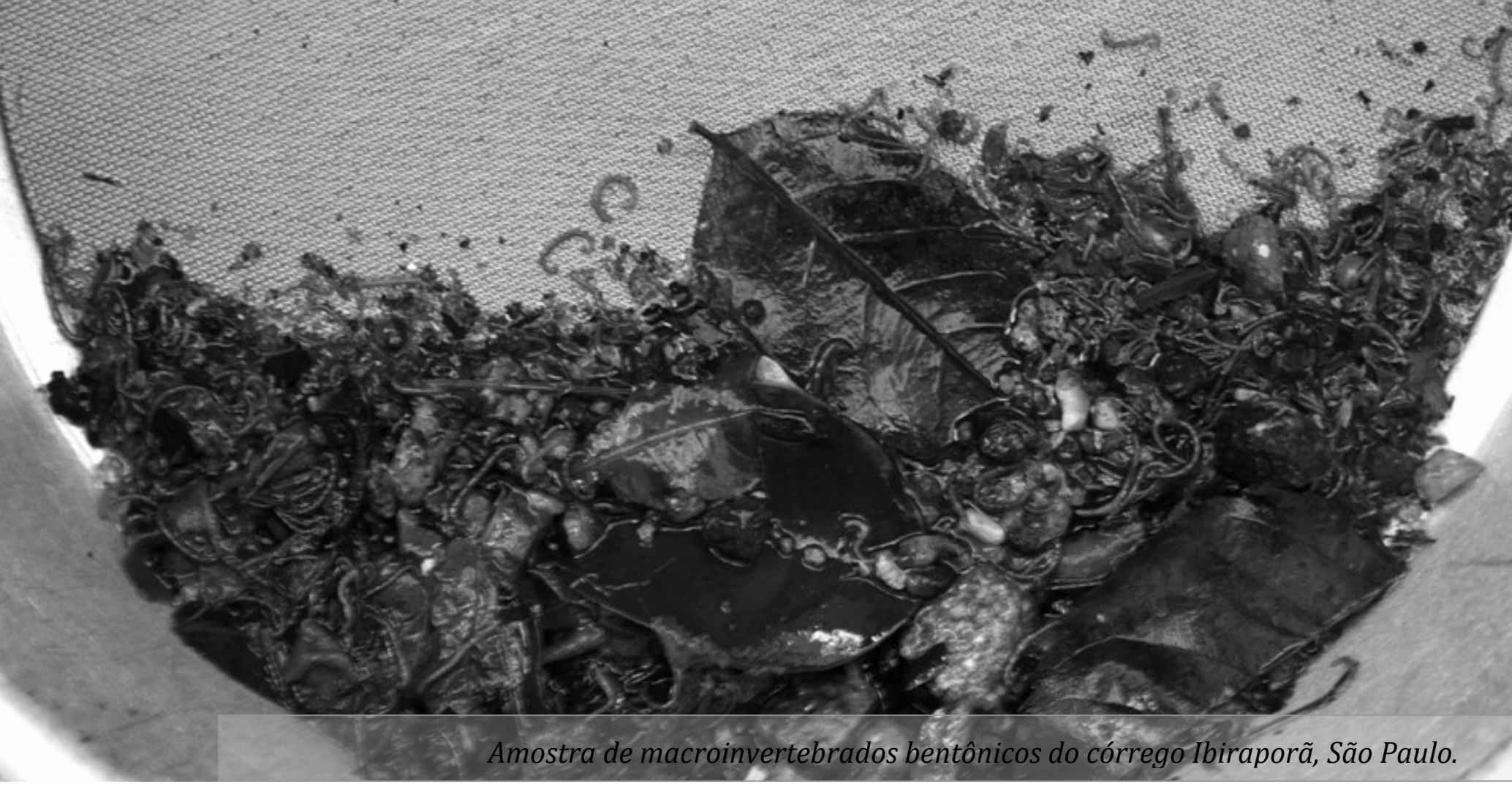

\subsubsection{Recomposição do ecossistema aquático}

Os ecossistemas aquáticos continentais podem ser compartimentalizados didaticamente nas seguintes regiões: região ripária, limnética ou pelágica, bentônica e interface água-ar. A região ripária corresponde à porção em contato direto com o ecossistema terrestre, sua característica principal é a densa colonização por vegetação (Macroalgas, briófitas, pteridófitas e plantas superiores), este compartimento é considerado uma região de transição entre o ecossistema aquático e terrestre (Esteves, 2011). As zonas ripárias, conhecidas áreas de várzea, são áreas de grande importância ecológica, pois abrigam uma série de interações biológicas que propiciam a saúde tanto do ecossistema aquático, como do terrestre. O processo de urbanização trouxe a ocupação destas áreas, principalmente nos núcleos urbanos, havendo a perda das importantes funções fornecidas por este ambiente, dentre elas a importante função de atuar como zona tampão entre as águas e as zonas altas (Groffman et al., 2003). A llustração 53 mostra os compartimentos dos ecossistemas aquáticos continentais. 


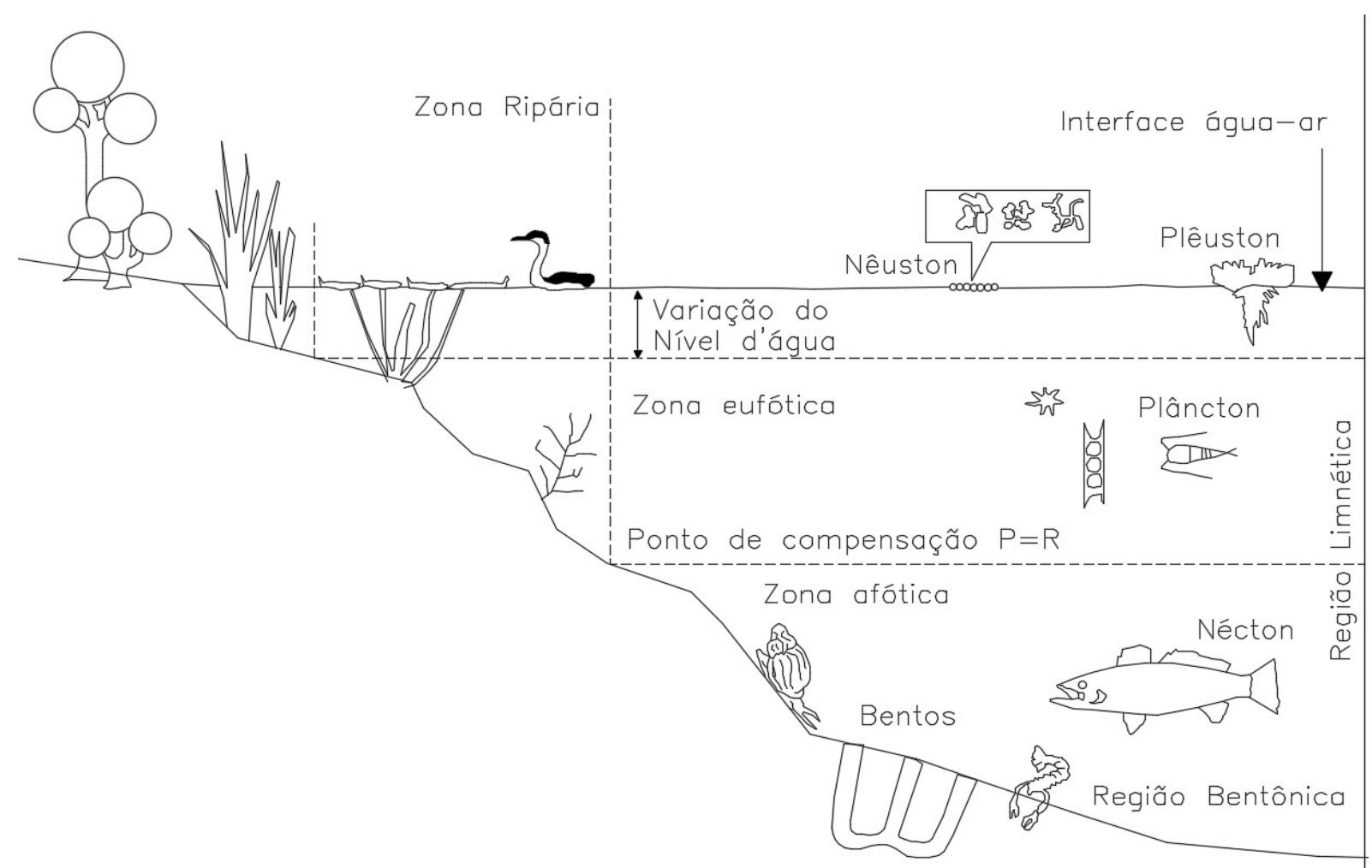

Ilustração 53 - Compartimentos dos ecossistemas aquáticos continentais. Fonte: Adaptado de Esteves (2011).

Além disso, o processo de urbanização tende a rebaixar o nível do lençol freático nas áreas de várzea, tornando a região mais seca e mudando completamente sua composição vegetal. Estudos no rio Gwynns em Baltimore demonstraram que depois do processo de urbanização da bacia, houve o avanço da colonização das espécies típicas das planícies secas sob a área que outrora era ocupada por espécies de típicas das áreas de várzea. Além disso, observa-se em zonas ripárias sob influência urbana uma alteração no balanço entre nitrificação (Processo microbiano que produz NO3-) e desnitrificação (Processo anaeróbio que consome NO3-), havendo maior produção de nitrato, funcionando como uma fonte ao invés de sumidouro, como ocorre em bacias florestadas (Groffman et al., 2003).

A vegetação é um importante elemento para determinar os fluxos da água no solo e para a gestão da erosão e transporte de sedimentos para os rios, sendo importante na modelagem da paisagem, além disso, tem importante papel na sustentação da riqueza de habitats para a fauna (Cengiz, 2013). Além da existência de vegetação nas margens do corpo d'água a distribuição das áreas vegetadas é importante para a conservação dos ecossistemas aquáticos, uma vez que áreas contínuas resultam em maior ganho ambiental do que fragmentos isolados (Ward et 
al., 2001). No Rio Ohio, as técnicas de revitalização adotadas para recuperação do corpo d'água foram pautadas na recomposição da comunidade vegetal do canal, a fim de melhorar as taxas de sequestro de carbono, que foram consideradas essenciais para a viabilidade das estratégias de conservação (Ward et al., 2001).

Segundo Bayley (1995), as várzeas possuem uma dinâmica particular devido ao pulso natural de inundação dos rios, que faz com que haja a formação de micro habitats ao longo delas, portanto projetos que visem a recuperação de corpos d'água devem se atentar a esta dinâmica, e ainda que não seja possível reestabelecer a dinâmica original, é possível criar outras artificiais a fim de promover a recomposição da biota. $O$ autor ressalta a importância de modelos da dinâmica dos pulsos de inundação elaborados em rios tropicais, pois os mesmos podem ser utilizados como modelos gerais a serem aplicados para rios temperados, uma vez que se perdeu em muitos casos a chance se estudar o processo nestas regiões em função da ocupação mais antiga do território (Bayley, 1995).

A maioria dos corpos d'água já canalizados foi pensada dentro da concepção antiga de retificação de canais, portanto revitalizar envolve reestabelecer um pouco da dinâmica antiga do canal através da recuperação de seus meandros, o que torna o processo ainda mais complexo. Rios Sinuosos são vistos como mais saudáveis, no entanto, é necessário ponderar o quão significativo é o ganho ambiental da reestruturação dos meandros frente ao impacto social gerado, uma vez que o processo envolve grandes intervenções imobiliárias. Além disso outras técnicas podem ser incorporadas no projeto agregando ganho ambiental equivalente, como por exemplo a implantação de estruturas ao longo do canal e das margens que propiciem a redução da velocidade e abrigo para a biota (Kondolf, 2006). A recriação de meandros é mais comumente adotada em projetos de renaturalização, onde se tenta recriar as condições originais do corpo d'água. Kondolf (2006) cita duas iniciativas fracassadas de recriação de meandros, nos rios Cuneo e Uvas no estado da Califórnia nos EUA, como o processo natural de formação de meandros é complexo e depende das características geomorfológicas da região, houve em diversos trechos erosão excessiva e em outros soterramentos de estruturas por depósito excessivo de sedimentos. 
Segundo Palmer, Menninger e Bernhardt (2010), o aumento da heterogeneidade no sistema aquático, promove o aumento da biodiversidade, portanto a inserção de estruturas físicas que recriem as condições de meandros e corredeiras dentro do corpo d'água trás grandes benefícios para o ecossistema aquático, no entanto os autores destacam que em projetos de revitalização, em um primeiro momento mais importante que a inserção destas estruturas é a eliminação dos agentes que geram estresse no ambiente, como por exemplo, o lançamento de cargas poluidoras, pois a eficiência das estruturas físicas para aumento da biodiversidade depende da qualidade das águas no corpo d'água. Os autores avaliaram 113 artigos que tratavam da revitalização de corpos d'água e constataram uma baixa eficiência no aumento da riqueza de invertebrados aquáticos no pósrevitalização, concluindo que em áreas sob grande influência antrópica é difícil garantir o restabelecimento de uma biota diversificada, portanto recomendam a seguinte sequência de ações em projetos de revitalização: Proteger habitats críticos; melhorar a qualidade da água e os processos hidrológicos na bacia; e por fim melhorar o ecossistema aquático através da inserção de estruturas físicas no canal.

Mendiondo (2008) destaca seis elementos a serem tratados quando se visa o reestabelecimento da saúde de um curso d'água: 1) A evolução do curso d'água, que se refere aos meandros do rio e sua estrutura física especifica; 2) O perfil longitudinal do curso d'água, que se refere às edificações transversais, as tubulações que afluem ao curso d'água, à existência de remansos e a variação do fluxo ao longo da sua extensão; 3) O substrato do leito, que se refere à qualidade do material encontrado no leito do curso d'água e sua interação com a biota aquática; 4) O perfil da seção transversal, que se refere ao tipo de perfil do canal, profundidade e o transporte hidráulico existente; 5) A estrutura das margens, que se refere ao tipo de ocupação das margens, ou seja, se há elementos naturais ou se as mesmas foram ocupadas no processo de urbanização. Estes elementos podem auxiliar na avaliação do curso d'água para o emprego de técnicas de bioengenharia para recomposição do ecossistema aquático.

Para ajudar na reestruturação do ecossistema aquático é possível a adoção de técnicas de bioengenharia como: Melhoria da velocidade da correnteza, com a instalação, por exemplo, de pequenas estruturas que reduzam a velocidade da água e permitam a colonização de organismos aquáticos através da criação de novos 
micros habitats (Pequenas barragens de enrocamento ou com troncos ao longo do canal) (Esquema A e B); Proteção artificial das margens a fim de controlar a erosão, priorizando o uso de materiais que permitam a colonização vegetal (Esquema C e D); Instalação de coberturas e outras estruturas para promoção de refúgios artificiais para a fauna aquática (Esquema E); e Criação de bacias artificiais rasas que permitam uma maior incidência solar, propiciando o desenvolvimento vegetal (Esquema F) (Pereira, 2001).
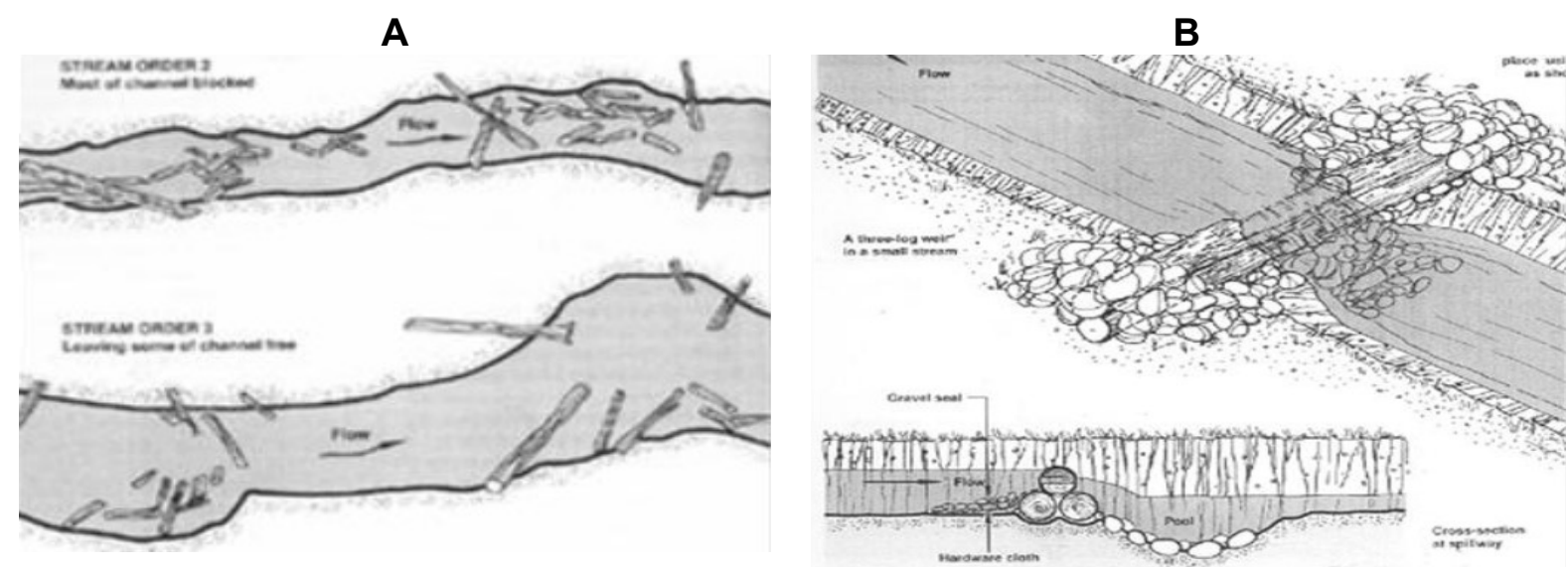

C

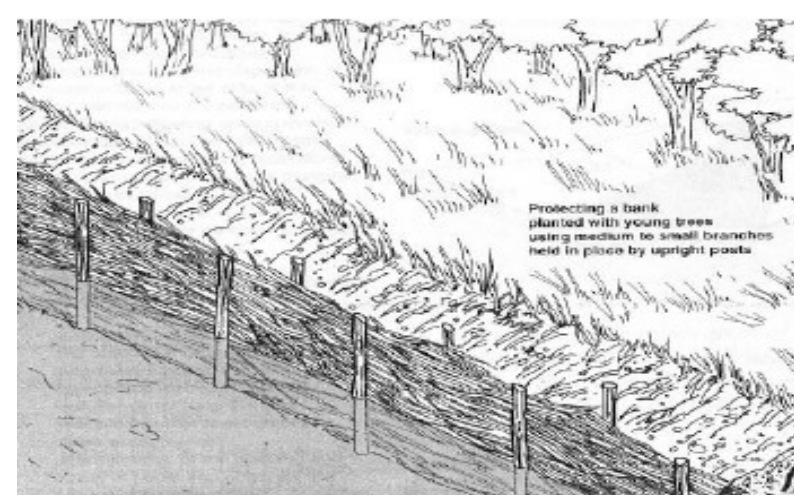

D

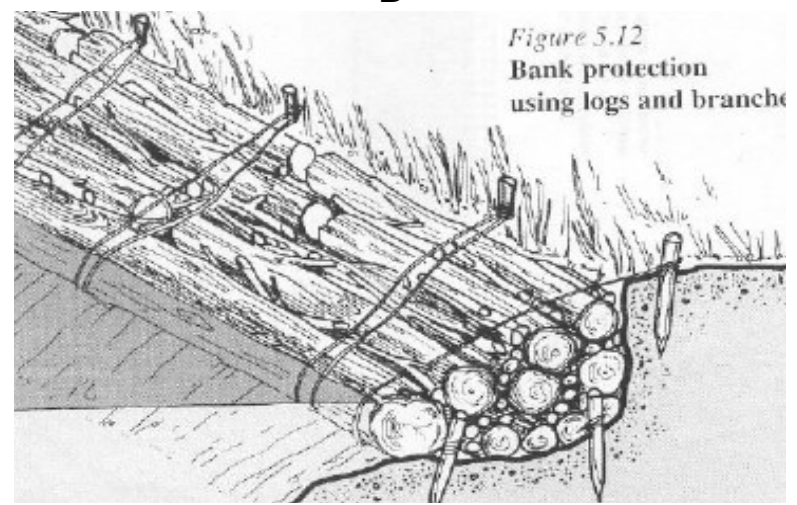

E
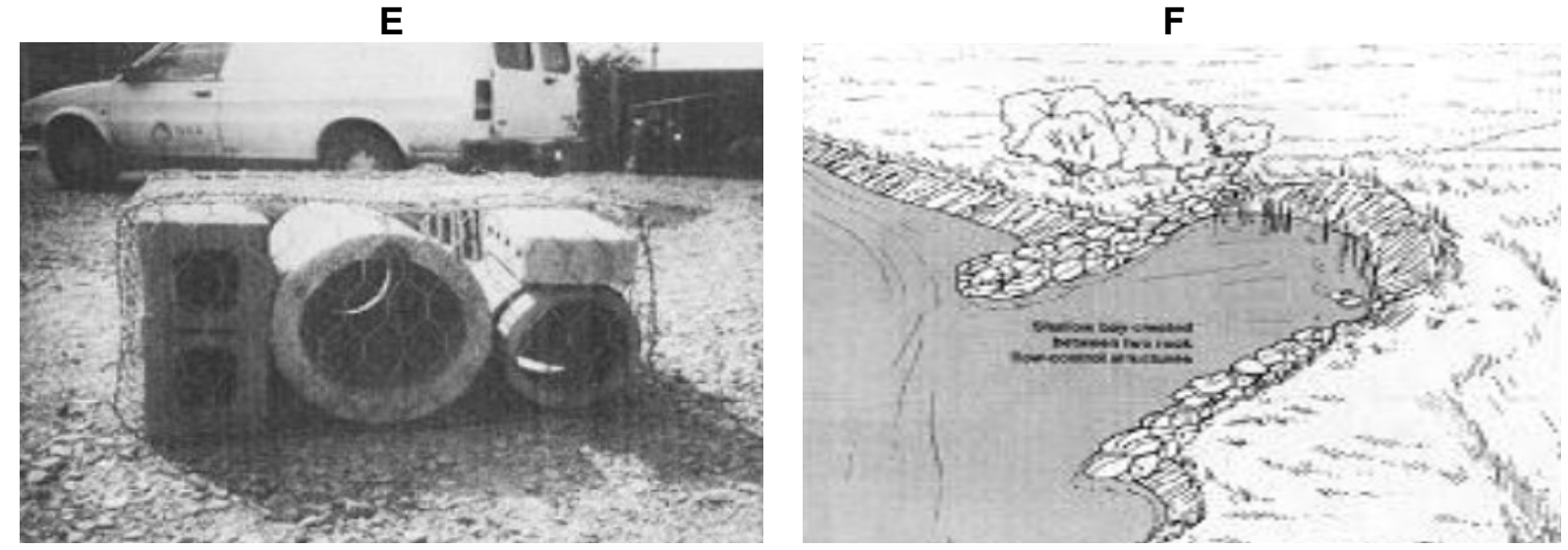

Ilustração 54 - Medidas para reintegração de rios e riachos - A e B: Obstaculos ao longo do corpo d'água para promoção de micro habitats; C e D: conteções. artificiais para controle da erosão; E: Estruturas cobertas para abrigos artificiais; F: bacias artificiais rasas para desenvolvimento vegetal. Fonte: Pereira (2001). 
Stromberg (2001) aponta como principais causas para o fracasso de programas de recuperação de zonas ripárias a incapacidade de implementar ou sustentar as mudanças necessárias; o não seguimento das recomendações científicas necessárias, como por exemplo através do uso de espécies inadequadas; e a não eliminação dos fatores que causam degradação das águas, como por exemplo o lançamento de cargas poluentes.

Nos EUA, as técnicas de recomposição da vegetação na zona ripária tem sido amplamente adotadas em corpos d'água de interesse pesqueiro, uma vez que o processo de degradação das margens e ocupação da bacia resultou nas ultimas décadas na redução da quantidade de espécies de interesse comercial e recreativo no país. O reestabelecimento das zonas ripárias tem auxiliado no reestabelecimento do fluxo de base e no controle da erosão nas margens do canal, que por sua vez tem resultado no aumento do número das espécies de interesse, a exemplo do que tem sido observado no rio Gorge Owens na Califórnia, que após o processo de reabilitação das zonas ripárias pelo qual o rio tem passado desde 1991, teve reabastecidas suas taxas de truta marrom e de outros animais selvagens na região (Hill e Platts, 1998).

Outra técnica interessante para requalificação de corpos d'água é o sistema Biomatrix criado na Inglaterra, o sistema alia o processo de despoluição a reintrodução de uma paisagem natural. O sistema consiste na instalação de estruturas flutuantes de baixo custo na superfície de ecossistemas aquáticos poluídos, como lagos, reservatórios e canais contaminados, provendo assim sua recuperação e propiciando habitat para que a nova fauna se desenvolva, como por exemplo fornecendo abrigo para pássaros. O sistema foi aplicado com sucesso na cidade de Manila, nas Filipinas, no canal Paco, onde foi instalado um sistema de ilhas de cerca de $100 \mathrm{~m}^{2}$ (Biomatrix, s/d). A llustração 55 apresentada a seguir, mostra a construção e implantação do sistema na cidade de Manila, onde na Foto $\mathrm{A}$ é possível observar a condição do corpo d'água antes da implantação do sistema Biomatrix; na Foto B a confecção das ilhas flutuantes pela população; na Foto C o sistema sendo transportado para instalação no canal; na Foto $D$ as ilhas implantadas no canal; na Foto $\mathrm{E}$ as ilhas já consolidadas com a flora desenvolvida; e na Foto $\mathrm{F}$ o resultado final com a implantação do sistema. 
Foto A

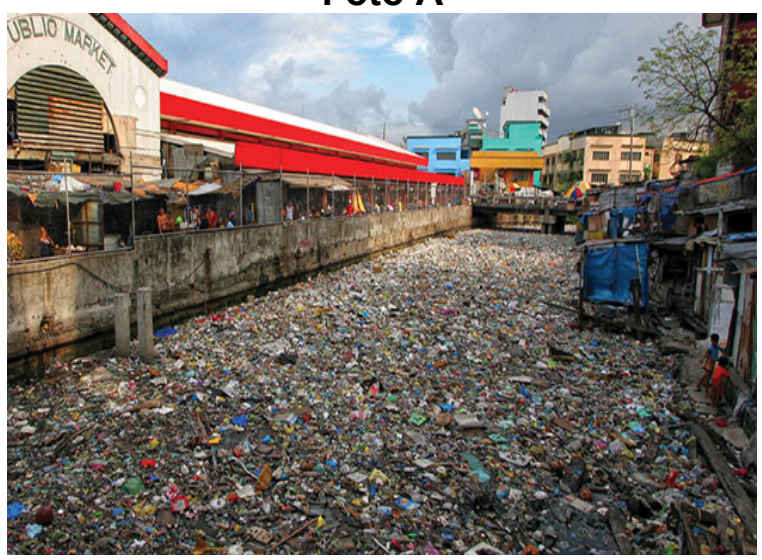

Foto C
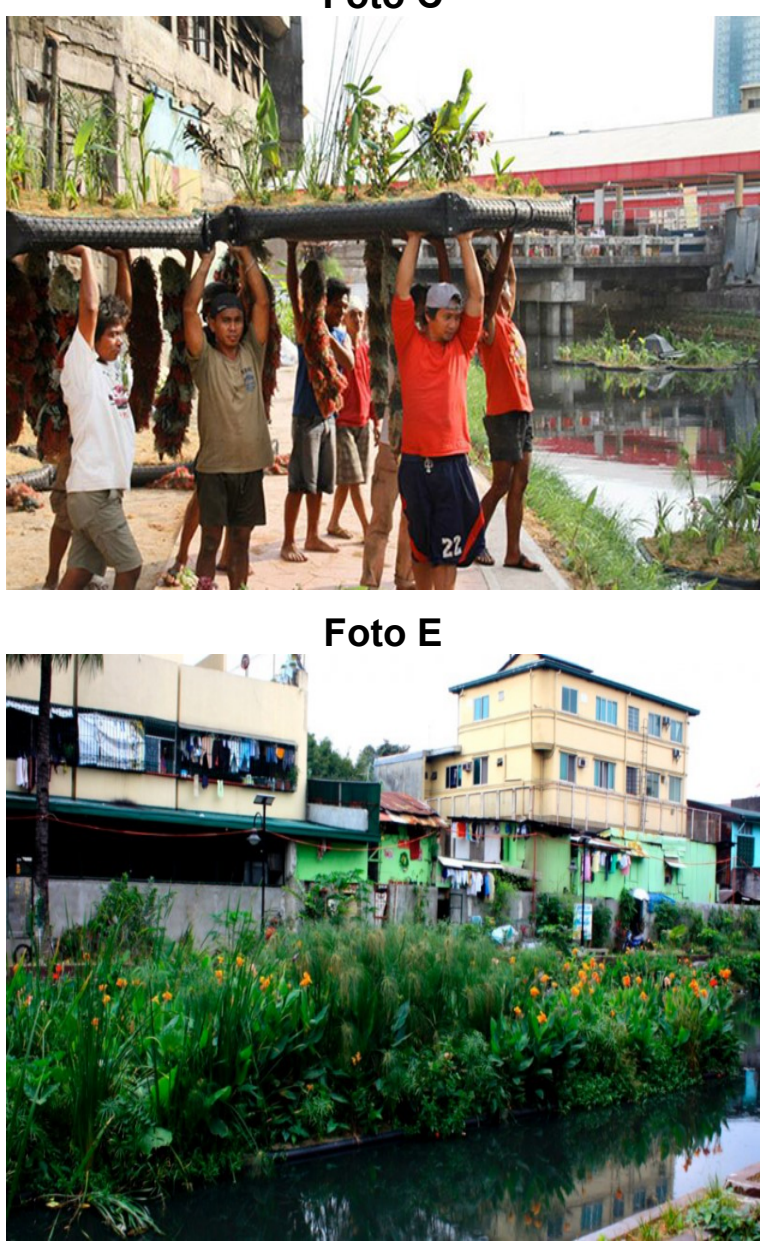

\section{Foto B}

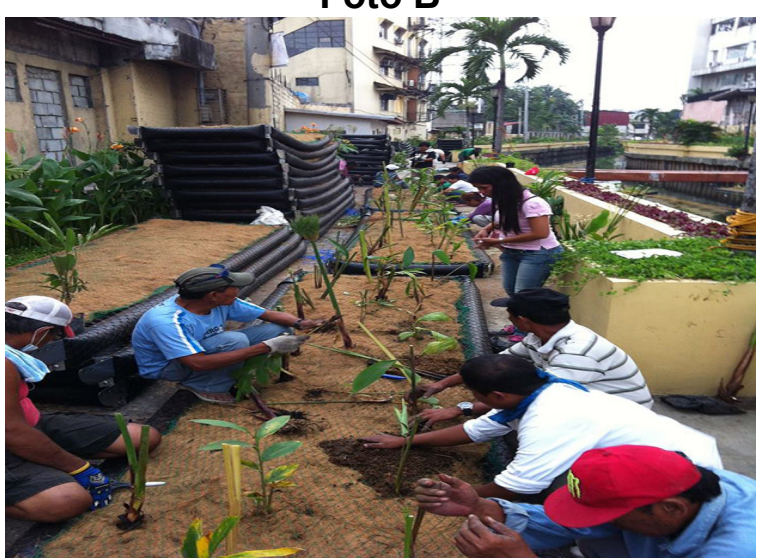

\section{Foto D}

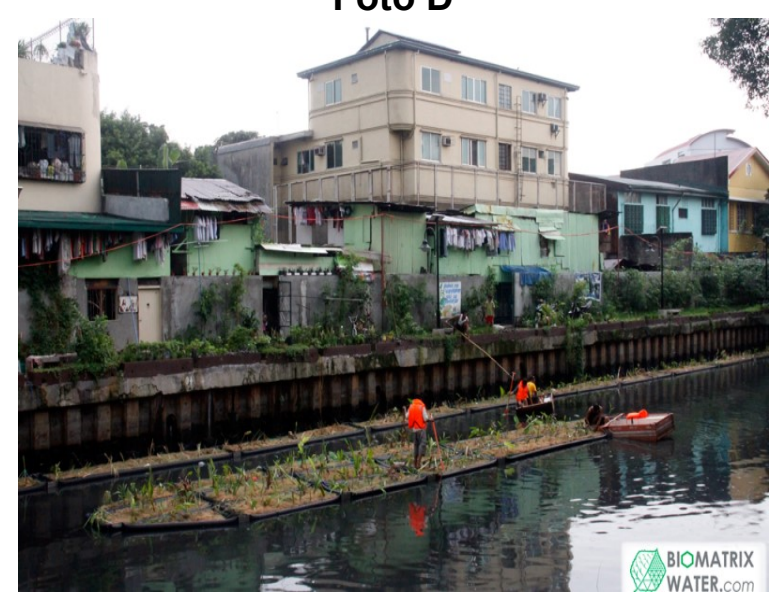

Foto F

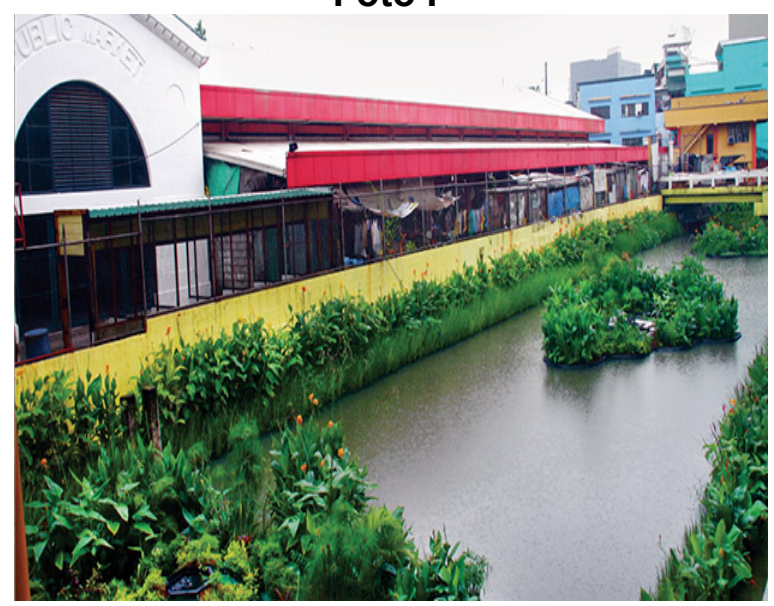

Ilustração 55 - Sistema de tratamento ecológico para recuperação de rios poluídos. Fonte: Biomatrix (s/d).

Apesar do processo de urbanização, a fim de garantir os usos de navegação e controle de cheias, acabar resultando em canais estreitos com paredes verticais reforçadas, restringindo o dinamismo dos sistemas fluviais naturais que são essenciais para manutenção das comunidades ripárias, foi observado que as estruturas artificiais como, por exemplo, as paredes de concreto podem abrigar 
comunidades vegetais, sendo comparáveis a superfícies rochosas verticais. A diversidade de espécies que estas estruturas podem abrigar varia em função das suas características, como: Dimensões vertical e horizontal da parede; inclinação; material (Relacionado com o número de fendas e tipo de juntas); Idade (Relacionada à decomposição dos materiais); Nutrientes disponíveis (Relacionada à quantidade de sedimentos carreados); Umidade; Microclima (Vento, radiação e precipitação); Acessibilidade (Espécies vetores de dispersão); e Manutenção da estrutura (Relacionada a remoção de vegetação e aplicação de produtos) (Francis e Hoggart, 2009).

O estudo realizado por Francis e Hoggart (2009) no Rio Tamisa, a fim de avaliar a eficácia das paredes deste rio urbano na manutenção de espécies ripárias revelou que os trechos de parede em pedra e tijolos são mais amigáveis ás plantas do que os trechos em concreto. Dentro do contexto da revitalização, o estudo ressalta a importância de integrar as funções estruturais às funções ecológicas na escolha dos materiais empregados em canalizações. Quando trata-se da revitalização de um corpo d'água refere-se à reintegração deste à paisagem urbana, promovendo a melhoria da qualidade ambiental e da qualidade de vida da população, sendo portanto necessária a adoção de tecnologias que visem o equilíbrio dos sistemas existentes e o uso múltiplo da estrutura.

A Maccaferri possui um produto chamado MacSoil, que foi desenvolvido para promover a recomposição de taludes e margens através da construção de estruturas de contenção e revestimento com paramento frontal vegetado. A estrutura pode ser preenchida com solo, ou materiais reutilizados, como resíduos de construção e demolição, constituindo uma estrutura sustentável e resultando em baixo impacto ambiental. A estrutura promove a integração da estrutura ao meio e possibilita diversas composições paisagísticas e arquitetônicas, uma vez que permite o uso de vegetação ornamental em sua face. Seu paramento frontal é composto por células preenchidas com solo vegetal, contidas por um geocomposto MacMat, que retém o material fino e propicia o desenvolvimento vegetal (Maccaferri, s/d). A llustração 56 a seguir mostra Fotos de detalhes da instalação do MacSoil. 
Foto A: Instalação do painel de MacSoil.

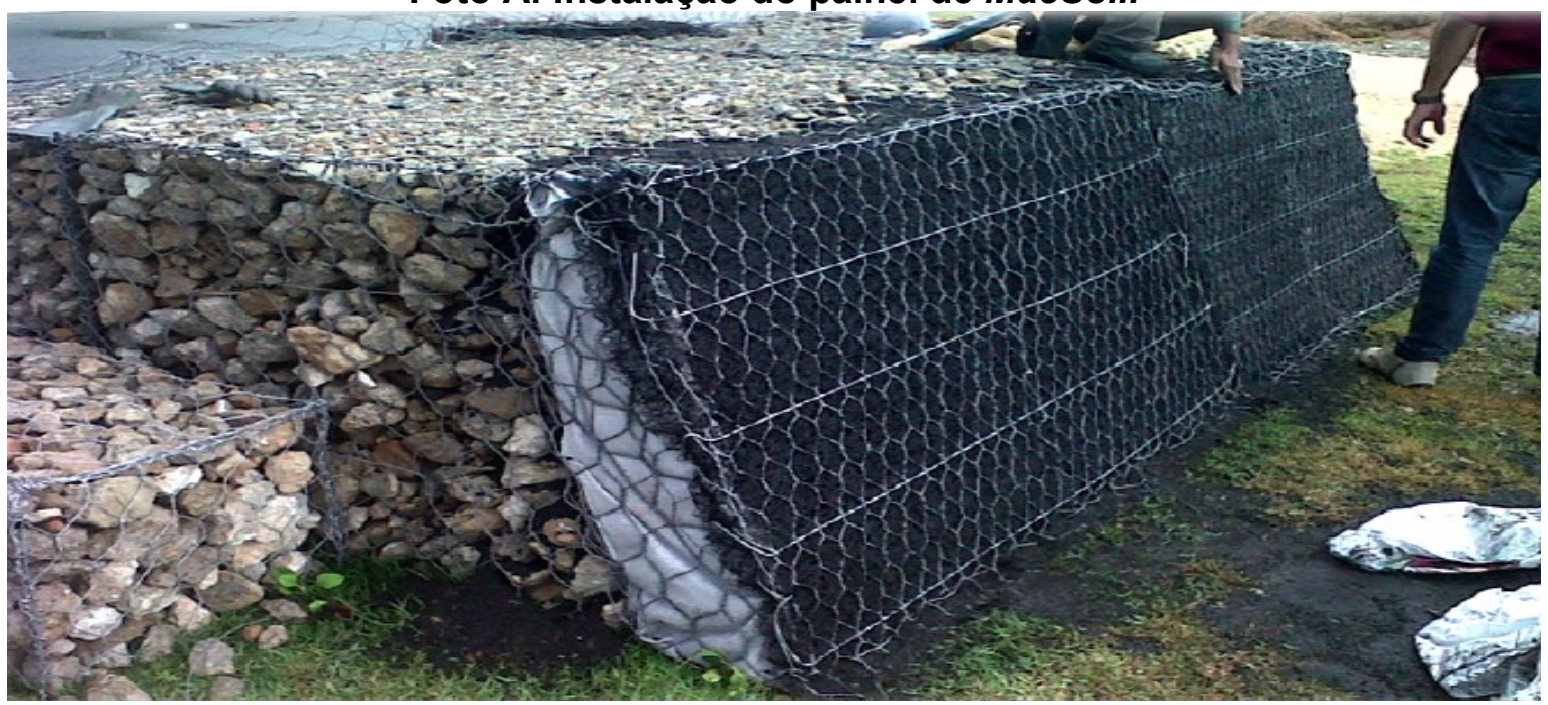

Foto B: Instalação da vegetação no painel de MacSoil.

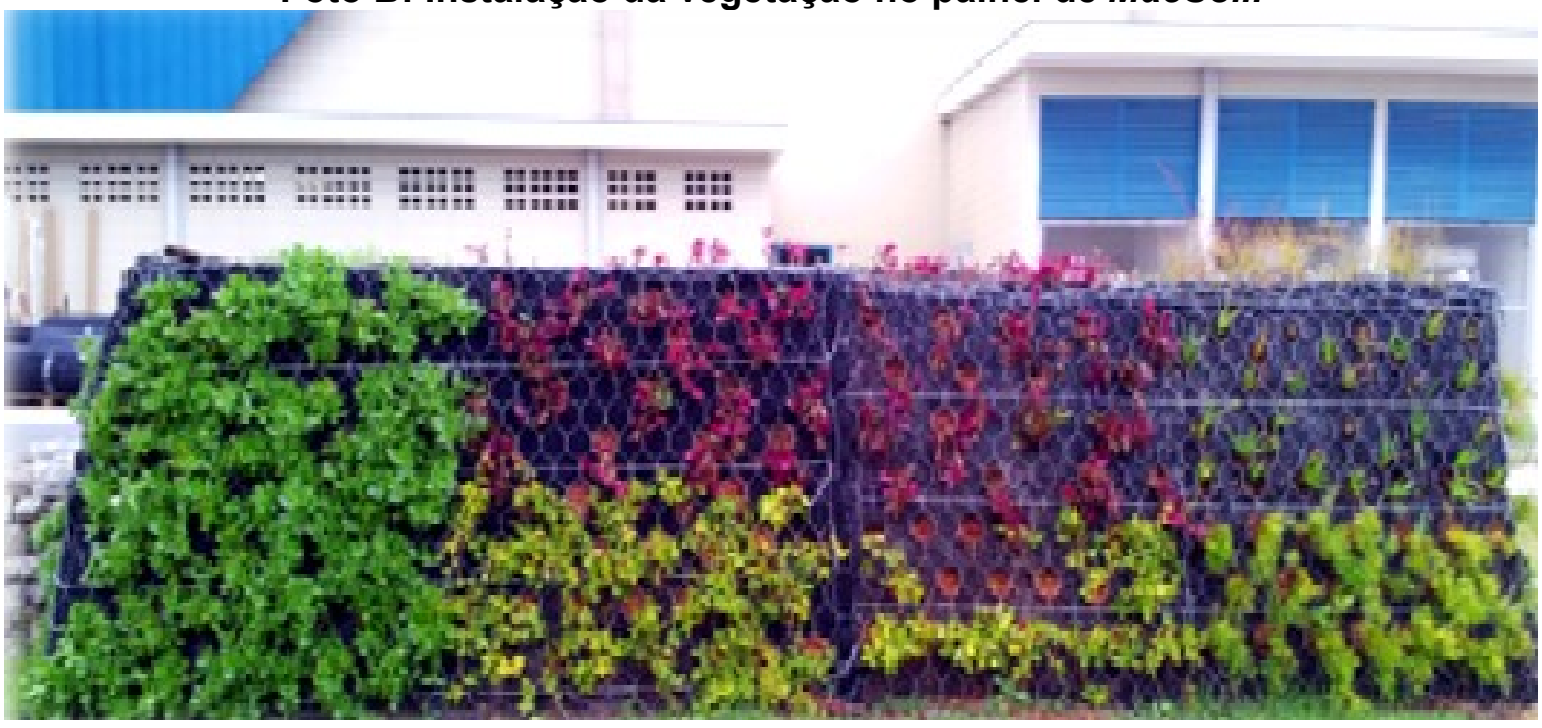

Foto C: Estabelecimento da vegetação no painel de MacSoil.

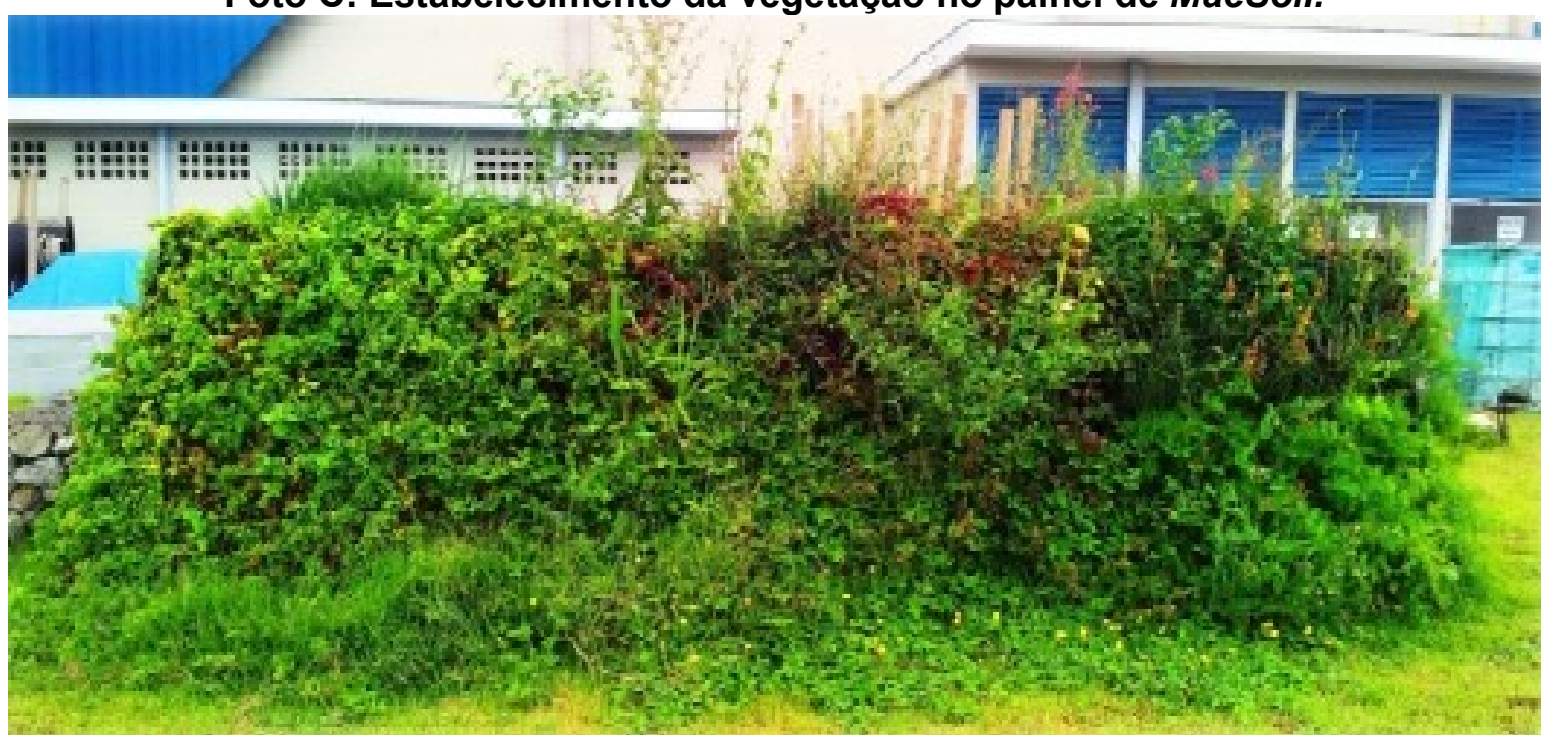

Ilustração 56 - Detalhes da implantação do MacSoil. Fonte: Maccaferri (s/d). 
Ao percorrer uma cidade de grande porte como São Paulo é possível encontrar diversos tipos de tratamentos adotados em seus corpos d'água, sendo o mais radical a canalização subterrânea em galerias de concreto, onde o corpo d'água é totalmente excluído da paisagem, se tornando apenas um elemento de afastamento das águas. Tal concepção ainda que totalmente na contramão da nova concepção de drenagem sustentável, ainda tem sido adotada nos centros urbanos, sendo necessário ainda um intenso trabalho de conscientização de projetistas e órgãos outorgadores destas intervenções para que tais soluções deixem de ser adotadas.

\subsubsection{Monitoramento da evolução da qualidade da água}

Dentro de programas de manejo das águas uma etapa fundamental é o monitoramento da qualidade das águas, antes, durante e depois da conclusão das atividades do programa a fim de identificação o grau de degradação inicial do corpo d'água e acompanhar a evolução do processo de recuperação das águas. Após o corpo d'água ser recuperado o monitoramento funciona como indicador de atividades irregulares na bacia que resultam em degradação, sendo, portanto um importante instrumento de controle.

A avaliação da qualidade da água pode ser realizada através do monitoramento de diversos componentes que compõe o ecossistema, podendo ser classificados em variáveis físicas, químicas, microbiológicas, hidrobiológicas, ecotoxicológicas. Segundo Mendes \& Oliveira (2004) durante muito tempo a avaliação física e química de um corpo d'água era a maneira mais rotineira de deteç̧ão de poluição, mas hoje com o avanço das técnicas para emprego de indicadores biológicos, houve uma mudança no padrão de monitoramento da qualidade da água, havendo uma integração maior entra as ciências exatas e biológicas no processo.

A avaliação biológica de um corpo d'água é indispensável, uma vez que a biota consegue detectar e apresentar respostas mesmo sob influência de pequenas concentrações de poluentes, além disso, as avaliações físicas e químicas são um retrato da qualidade da água no ponto de amostragem e no instante da amostragem, enquanto a avaliação biológica faz um filme da situação do corpo d'água, já que a comunidade aquática é capaz de refletir no presente as alterações geradas em 
momentos anteriores, bem como acumular resposta de diversas alterações (Cortes et al., 2002).

O estudo de Silva et al. (2015) comparou a classificação da qualidade do corpo d'água Ibiraporã em São Paulo utilizando três indicadores, o indicador da SABESP com base na DBO, o Índice de Qualidade da Água da CETESB e o Índice de Família de Hilsenhoff com base na comunidade bentônica. Obteve-se com a aplicação da classificação segundo a DBO a classificação "Condições Boas" e "Condições Naturais"; Já com a classificação segundo o Índice de Qualidade da Água da CETESB "Condições boas"; e por fim, segundo o Índice de Família de Hilsenhoff o corpo d'água foi classificado como "Pobre", ressaltando a importância de se trabalhar com diferentes indicadores em programas de monitoramento.

\subsubsection{Pagamento por Serviços Ambientais (PSA)}

A economia do ambiente, dentro da visão de Georgescu-Roegen, considera a $2^{a}$ Lei da termodinâmica, a Lei da Entropia, onde toda transformação energética gera calor que tende a se dissipar, portanto, os sistemas produtivos não podem ser tidos como fechados, sempre haverá uma parcela da energia que será perdida. Portanto, tal visão reforça a ideia de que os recursos naturais são finitos e que os processos devem ser bem geridos a fim de garantir o suprimento das futuras gerações (Cechin e Veiga, 2010). A economia do ambiente é responsável por criar uma ponte entre a economia e as ciências ambientais, auxiliando na recuperação dos ecossistemas, aumentando a biodiversidade e gerando serviços ecossistêmicos que beneficiem o homem e a natureza. O ser humano é parte integral do ecossistema e portanto tem como responsabilidade o gerenciamento do mesmo para manutenção de sua saúde (Blignaut e Aronson, 2014).

A valoração ambiental é definida como o ato de dar valor a um bem ou serviço ambiental (Pearce \& Turner, 1990), já o serviço ambiental ou ecossistêmico é definido como todo benefício fornecido pela natureza de forma direta ou indireta (Marques \& Comunne, 1995). Segundo Guedes \& Seehusen (2011), há quatro categorias de serviços ambientais: Serviços de provisão, relacionados à capacidade do ecossistema de prover bens, como alimentos e matéria prima; Serviços reguladores, relacionados aos processos naturais que regulam condições 
ambientais, que são a base de sustentação da vida humana, como a regulação do clima e a ciclagem da água; Serviços culturais, associados à capacidade do ecossistema em prover benefícios ligados à recreação, educação, espiritualidade e estética; e Serviços de suporte, relacionados aos processos de suporte aos demais serviços, como a ciclagem de nutrientes e a formação do solo.

Os valores atribuídos aos serviços ambientais podem ser divididos em três tipos: Valores intrínsecos, que corresponde à manutenção da saúde de um ecossistema ou de uma espécie que independe de dos interesses humanos, esses valores são baseados em questões éticas, não sendo possível atribuir valor monetário; Valores de uso, que podem ser de uso direto, onde o agente se beneficia diretamente (Serviços de provisão e culturais), ou de uso indireto, onde o agente se beneficia indiretamente (Serviços reguladores e de suporte); e Valores de não uso, podendo ser de existência, como por exemplo, com a manutenção de determinadas espécies em seus ecossistemas, ou de legado, como por exemplo, na manutenção de determinado serviço para as futuras gerações. Ao mensurar o valor econômico dos serviços ambientais é possível entender com melhor clareza os ganhos e perdas envolvidos no sistema em questão, ou seja, entender os conflitos de escolha (Tradeoffs) (Guedes \& Seehusen, 2011).

São quatro as categorias básicas de serviços ecossistêmicos fornecidos por bacias hidrográficas: Purificação da água; regulação do fluxo; controle de sedimentos; e preservação de habitats (Postel \& Barton, 2005). Desta forma, conhecido os serviços ecossistêmicos fornecidos pelo sistema, é possível valorar estes serviços e instituir o pagamento por serviços ambientais (PSA).

Mendiondo (2008) lista na Tabela 7 a seguir os impactos sofridos (positivos, negativos ou constantes) e os serviços ambientais promovidos pelos ecossistemas aquáticos em áreas urbanas, onde é possível observar sua importância na regulação do clima, controle de processos erosivos, redução da ocorrência de inundações, melhoria na qualidade de vida da população e ganhos ecológicos. 
Tabela 7 - Impactos e serviços ambientais em áreas urbanas. Fonte: Mendiondo (2008).

\begin{tabular}{|c|c|c|}
\hline $\begin{array}{c}\text { Ecosystem } \\
\text { service }\end{array}$ & $\begin{array}{c}\text { Environmental good/ } \\
\text { service }\end{array}$ & Impacts on environmental goods/services \\
\hline Supporting & $\begin{array}{l}\text { Ecological processes and } \\
\text { biodiversity }\end{array}$ & Forests as ecological corridors ( $\boldsymbol{\Lambda})$ and preserving headwaters $(\boldsymbol{\Lambda})$. \\
\hline Provisioning & $\begin{array}{l}\text { Groundwater and surface } \\
\text { water supply }\end{array}$ & $\begin{array}{l}\text { All urban people, with collapse risk in public water supply ( } \mathbf{\nabla}) \\
\text { Correlation between forest and water quality and quantity ( }\end{array}$ \\
\hline \multirow[t]{2}{*}{ Regulating } & Climatic regulation & $\begin{array}{l}\text { Urban temperature rising (heat islands) influence rainfall patterns } \\
\text { and lead to heavy urban floods }(\mathbf{\nabla}) \text {. }\end{array}$ \\
\hline & $\begin{array}{l}\text { Soil protection and run- } \\
\text { off regulation }\end{array}$ & Revitalized forests prevent soil erosion and minimize floods $(\boldsymbol{\Lambda})$ \\
\hline Cultural & Social use & $\begin{array}{l}\text { Lack of green areas ( } \mathbf{\Delta}) \text { invokes peri-urban belts as an alternative } \\
\text { for the population to be contact with healthier environment }(\boldsymbol{\Delta}) \text {. }\end{array}$ \\
\hline
\end{tabular}

Impacts (positive $\boldsymbol{\Lambda}$, negative $\mathbf{\nabla}$ or constant

Quito obtém $80 \%$ de sua água potável de áreas protegidas, que abrangem $520 \mathrm{mil} \mathrm{Ha}$ de florestas de altitude, que embora formalmente protegidas, também tem sido utilizadas para outros fins, como para a pecuária e extração de madeira, representando um grande desafio. A solução encontrada por Quito no Ecuador foi a criação de um fundo fiduciário para pagamento por serviços ambientais a fim de proteger as águas que abastecem a cidade. Assim estabeleceram-se algumas áreas protegidas, como por exemplo, através da proteção do parque Nacional La Tigra que ajuda a salvaguardar $40 \%$ do abastecimento de água da capital. Apesar da criação destas áreas protegidas, as terras permitem usos controlados por comunidades locais que realizam agricultura tradicional, pastagem e coleta de lenha, sem comprometer a função de abastecimento de água. O fundo, proposto em 1997 pela Fundación Antisana (uma ONG ambientalista com sede em Quito) e estabelecido em 2000, com o apoio da The Nature Conservancy e da Agência dos Estados Unidos para Desenvolvimento Internacional (USAID), vem como resposta a este desafio, a fim de financiar medidas para a proteção da bacia. Quando questionados sobre o pagamento por serviços ambientais para promover a qualidade da bacia, boa parte da população se mostrou favorável (Postel \& Barton, 2005).

Na Costa Rica a solução para a proteção das fontes de abastecimento foi a adoção de um regime de proteção da floresta através da criação de uma política de Biodiversidade que recomenda aos beneficiários dos recursos o pagamento de uma variedade de serviços ambientais. Houve a criação de um fundo para PSA, o Fundo Florestal Nacional (FONAFIFO), que oferece aos proprietários diversos contratos, que incluem a preservação de florestas existentes e também o reflorestamento de áreas impactadas. Os pagamentos são ligeiramente acima do custo de conversão se 
comparado aos outros usos. Há ainda iniciativas para o estabelecimento de parcerias com as empresas de geração de energia, uma vez que as mesmas são dependentes da manutenção do potencial hidrológico da bacia. O programa tem sido bem sucedido, uma vez que o PSA é mais rentável para o usuário do que o uso da terra para outros fins, no entanto os analistas tem se mostrado preocupados com a equidade e a sustentabilidade do programa, uma vez que apenas os proprietários privados com escrituras das terras tem acesso ao programa, o que muitas vezes exclui os pequenos proprietários, como pequenas comunidades tradicionais, que muitas vezes não tem condições de arcar com os custos do processo e com a burocracia do mesmo (Postel \& Barton, 2005).

Houve no caso da Costa Rica a criação de uma ponte entre os prestadores de serviços ecossistêmicos e os beneficiários, a cidade negociou os serviços ambientais fornecidos pelos proprietários de terra e pelas comunidades a montante com os usuários a jusante, portanto há uma ligação direta entre os mantenedores do recurso a montante com os tomadores do recurso a jusante. A cidade optou portanto em investir na proteção de suas áreas geradoras de água ao invés de investir em sofistificação do tratamento de águas degradadas (Postel \& Barton, 2005).

Cidades como Bogotá, Boston e Nova lorque tem obtido economia com o tratamento da água para abastecimento através da adoção de medidas para melhoria da qualidade da água na bacia, o que prova que tais iniciativas são uma alternativa viável (Postel \& Barton, 2005). Existem ainda grande desafios para a aplicação prática e econômica do PSA, que incluem o estabelecimento do direito de propriedade, execução de contratos, adoção de métodos para avaliação do desempenho e a formação de um mercado (Blignaut e Aronson, 2014).

No Brasil o PSA tem sido empregado em áreas rurais, onde os proprietários recebem pela preservação dos recursos naturais existentes em suas propriedades. A ferramenta tem se mostrado de grande importância na preservação de áreas de interesse ambiental, o que envolve diretamente a preservação dos recursos hídricos, ainda que não haja um corpo d'água dentro da propriedade, já que a manutenção de áreas verdes tem papel importante na manutenção do equilíbrio do ciclo hidrológico através da recarga dos aquíferos subterrâneos.

Em áreas urbanas pouco se trabalha o PSA, no entanto esta ferramenta traria grandes benefícios, uma vez que auxiliaria na manutenção das áreas permeáveis 
dentro da cidade resultando no controle das vazões de pico no sistema de drenagem. Os terrenos em áreas urbanas tem o valor de seu $\mathrm{m}^{2}$ elevado, portanto há pouco interesse por parte dos proprietários na manutenção destas áreas como áreas verdes, o que se observa é que os remanescentes vegetais nas áreas urbanas têm sido convertidos em loteamentos, o que muda as taxas de infiltração e escoamento superficial sobrecarregando ainda mais o sistema de drenagem municipal que na maioria dos casos já se encontra no limite.

Obras nos sistemas de macro drenagem para ampliação da capacidade de transporte das águas são de custo elevado, pois envolvem a implantação de novas estruturas físicas e movimento de terra; além disso, geram diversos transtornos à cidade devido a interrupções no tráfego e outros malefícios ligados às obras civis. Portanto, a manutenção dos remanescentes vegetais na bacia acaba resultando na economia com adequações nos sistemas municipais, desta forma seria possível mensurar esta economia e revertê-la em incentivos financeiros para que os proprietários destas áreas as mantenham com seus remanescentes vegetais e até mesmo recuperem trechos degradados. É necessário, portanto identificar os serviços ecossistêmicos que essas áreas são capazes de prover para a cidade e os gastos resultantes da eliminação destas áreas, a fim de arquitetar um programa de PSA em áreas urbanas. 


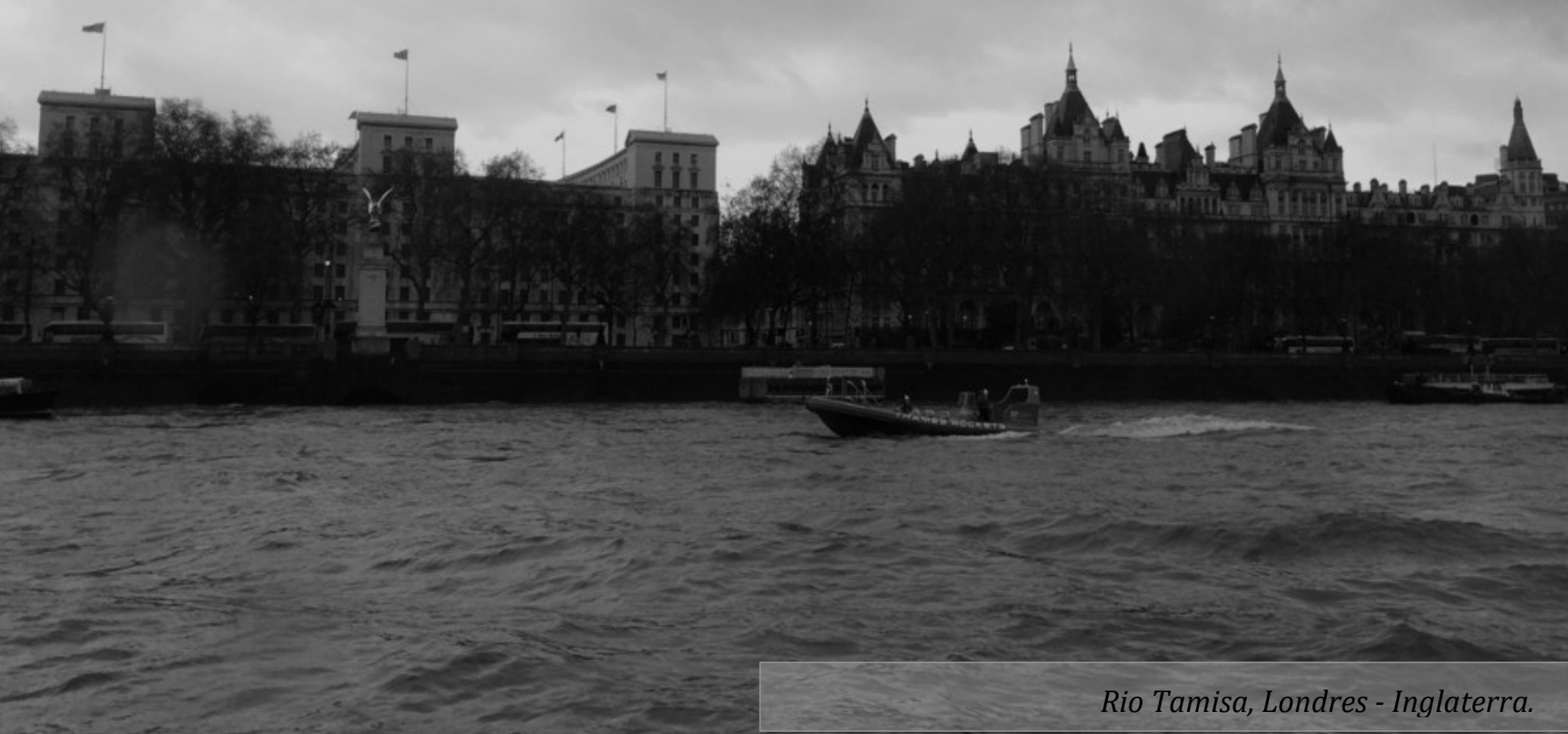

\subsubsection{Exemplos de aplicação das técnicas de manejo}

\subsubsection{Experiência internacional}

A preocupação com a restauração ecológica tem crescido de forma acelerada nos últimos tempos, tal fenômeno se deve principalmente com o aumento da preocupação a cerca dos impactos resultantes das mudanças climáticas bem como no crescente interesse nos serviços ambientais que os ecossistemas degradados poderiam prover (Nilsson e Aradóttir, 2013). Na Europa e nos EUA as iniciativas para restauração de ambientes aquáticos são tomadas principalmente por entidades públicas com base no planejamento participativo, incluindo a população no processo, por outro lado no Japão as ONG's são as grandes responsáveis por estas iniciativas (Seidl e Stauffacher, 2013). 
Hagen et al. (2003) identifica para os países nórdicos na Europa vários tipos de degradação ecológica, dentre eles destaca o desmatamento, a drenagem de zonas úmidas, a canalização de rios, a expansão do pasto, a urbanização e a introdução de espécies exóticas, portanto dois dos tipos de degradação identificados são ligados às águas. Tais degradações sempre foram preocupantes tendo em vista que o ciclo de recuperação dos ambientes nórdicos é mais lento, devido às suas características naturais como ciclo vegetativo curto, renovação lenta de nutrientes e longos invernos que tendem a criam restrições ao desenvolvimento da biota (Nilsson e Aradóttir, 2013).

Na Dinamarca, devido à conversão das florestas em pastos e áreas para cultivo agrícola, as áreas alagadas foram drenadas e os rios canalizados para aumentar o aproveitamento do uso do solo, o que resultou em diversos impactos, com destaque para a eutrofização das águas devido ao uso de insumos agrícolas, desta forma, os principais esforços para restauração ecológica no país estão voltados para o reflorestamento e o controle da eutrofização em rios e lagos, a fim de retomar a biodiversidade aquática. O maior projeto de restauração da Dinamarca é o do Rio Skjern, rio que corta o território da Dinamarca passando por áreas agrícolas e pequenos núcleos urbanos. $O$ projeto visa o restabelecimento dos processos naturais de retenção de nitrogênio e fósforo no corpo d'água a fim de recuperar sua qualidade ambiental.

$\mathrm{Na}$ Islândia, metade das áreas úmidas do território foi drenada no século $\mathrm{XX}$ para aproveitamento na agricultura e ocupação urbana, havendo hoje grandes problemas com relação aos processos erosivos, sendo a maioria dos projetos de restauração voltados para o controle da erosão. Já na Suécia, o uso histórico dos rios foi para escoamento de toras provenientes da exploração de madeira das florestas nativas e para geração de energia. Hoje há predomínio do reflorestamento e os rios não são mais usados para escoamento de toras, mas ainda há grande importância no uso dos mesmos, para geração de energia, o que muitas vezes cria empecilhos para projetos de restauração ecológica. As principais ações de restauração em rios no país são voltadas para conservação de espécies migratórias de peixes, que necessitam transpor as barragens existentes nos rios do país (Hagen et al,2003). 
Nos países nórdicos a atenção especial está na recuperação das áreas úmidas que foram drenadas para propiciar outros usos, o que representa um grande desafio, já que contrário da restauração de rios que se concentra no reestabelecimento das condições físico-químicas da água propiciando o reestabelecimento das condições biológicas, a renaturalização de áreas alagadas depende de reestabelecer primeiramente o regime hidrológico da área, o que torna o processo ainda mais complexo. Quando se trata de intervenções em áreas degradadas, o conceito de renaturalização só é bem aceito e de fato empregado quando há pouco interesse utilitário da área, já áreas que possuem importância cultural, geralmente recebem uma abordagem no sentido de revitalizar e não renaturalizar (Hagen et al,2003).

Na Suíça, no início do século XIX diversas intervenções para o controle das inundações foram realizadas, impactando severamente o ecossistema aquático, havendo a perda da maioria das áreas alagadas do país. No entanto, nas últimas décadas houve uma mudança de mentalidade e os corpos d'água têm passado por programas de revitalização para reestabelecimento das suas funções naturais, sem deixar de atender os interesses técnicos relativos à segurança contra inundações. Tais projetos tem garantido maior espaço para os rios e sua capacidade de descarga, ou seja, tem unificado as funções de drenagem com as ecológicas (Seidl e Stauffacher, 2013).

O rio Isar, que corta a cidade de Munique na Alemanha, foi chamado por ambientalistas na década de 80 de rio morto, mas o processo foi revertido graças a um amplo programa de revitalização nas décadas seguintes que visou reabilitar o rio para os usos necessários à cidade, de navegação, manancial de captação de água, geração de energia e lazer (Cengiz, 2013). A llustração 57 a seguir mostra um trecho do rio Isar em Munique após sua revitalização. 


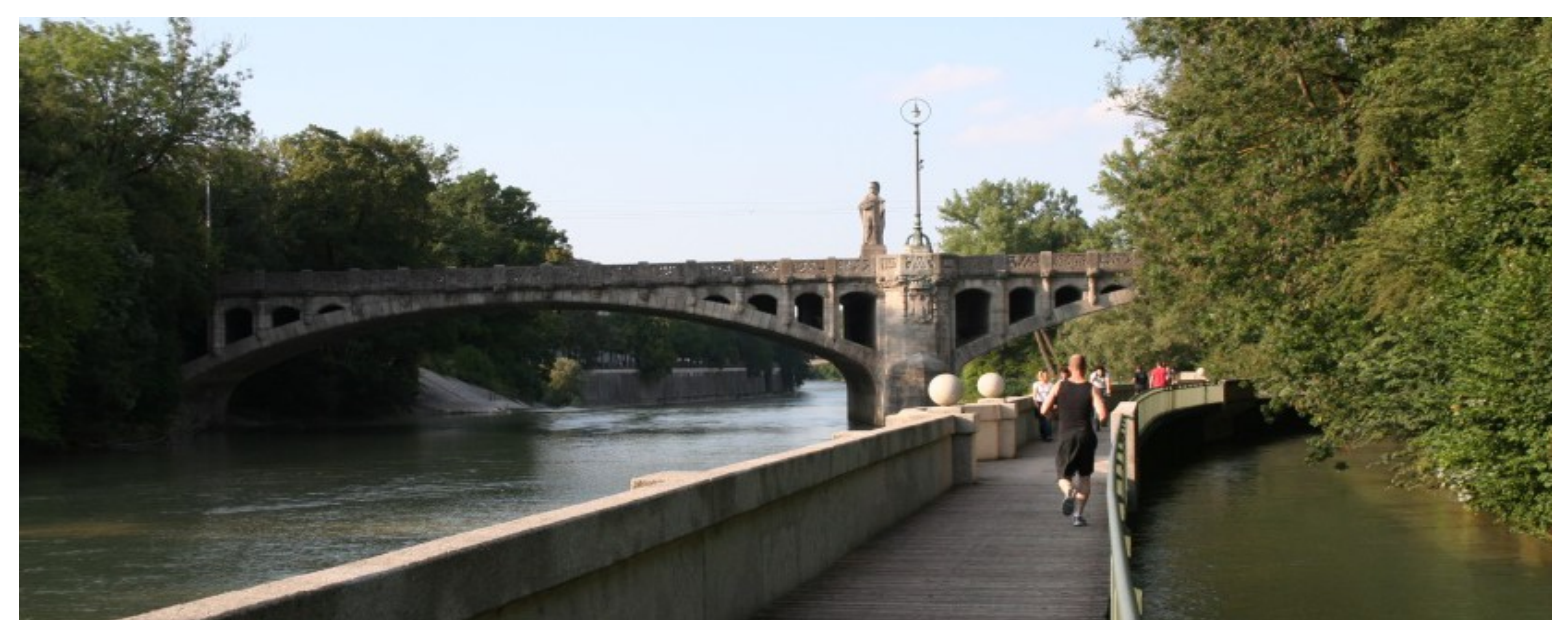

Ilustração 57 - Rio Isar revitalizado. Fonte: Cengiz (2013).

O rio Besos em Barcelona sofreu um intenso processo de degradação no século XIX, encontrando-se, na década de 90 , totalmente poluído por esgotos domésticos e industriais, além de resíduos urbanos. O rio sofreu inundações importantes que resultaram em diversos danos à cidade, com perda de patrimônio e a morte de pessoas, devido a isso diversas intervenções foram adotadas, resultando na retificação da calha do rio com tratamento em concreto, convertendo o finalmente em um canal de escoamento de esgotos. Com perspectiva da realização dos jogos Olímpicos em Barcelona em 1992, o poder público definiu como meta a revitalização do rio Besos, obtendo um financiamento de 20 milhões de dólares para execução do projeto de revitalização (Martín-vide, 1999).

A revitalização do rio Besos contemplou um trecho de $6 \mathrm{~km}$, cortando dois municípios, Montcada a montante e Santa Coloma a jusante, e neste ponto houve duas visões de projeto diferentes, pois a montante havia grande disponibilidade de parques que eram utilizados pela polução, havendo menor demanda de áreas de lazer junto ao canal, contrário do que ocorria a jusante, onde a demanda por áreas de lazer era maior. Portanto a montante, as áreas adjacentes ao canal foram utilizadas para implantação de Wetland's, colonizadas com espécies adequadas para promover a retenção de nutrientes das águas residuárias, a fim de promover a melhoria da qualidade das águas do canal, enquanto a jusante, as áreas adjacentes abrigaram um parque para uso da população, equipado de rampas e escadarias de acesso e de alarmes de alerta de inundação para evacuação do parque, atendendo assim os dois usos pretendidos inicialmente: qualidade das águas e recreação (Martín-vide, 1999). 
A montante foi adotado um traçado mais meandrante, uma vez que as margens era menos demandadas e no trecho a jusante, foi mantido um traçado mais retilíneo para comportar o parque instalado em suas margens. As características hidráulicas dos dois trechos foram modeladas para entender a dinâmica do aporte de sedimentos e o comportamento do canal diante das vazões de pico revelando a forma adotada para os dois trechos era adequada, demandando apenas algumas ações de manutenção para controle da retenção de sedimentos nos meandros. por fim, a revitalização do canal foi considerada um sucesso, pois atingiu os objetivos pretendidos, tanto no que se refere à qualidade da água, pois houve melhoria significativa da mesma, bem como no que se refere à recreação, pois houve uma aceitação significativa do parque pela população (Martín-vide, 1999). A llustração 58 a seguir mostra um trecho do rio Besos após sua revitalização.

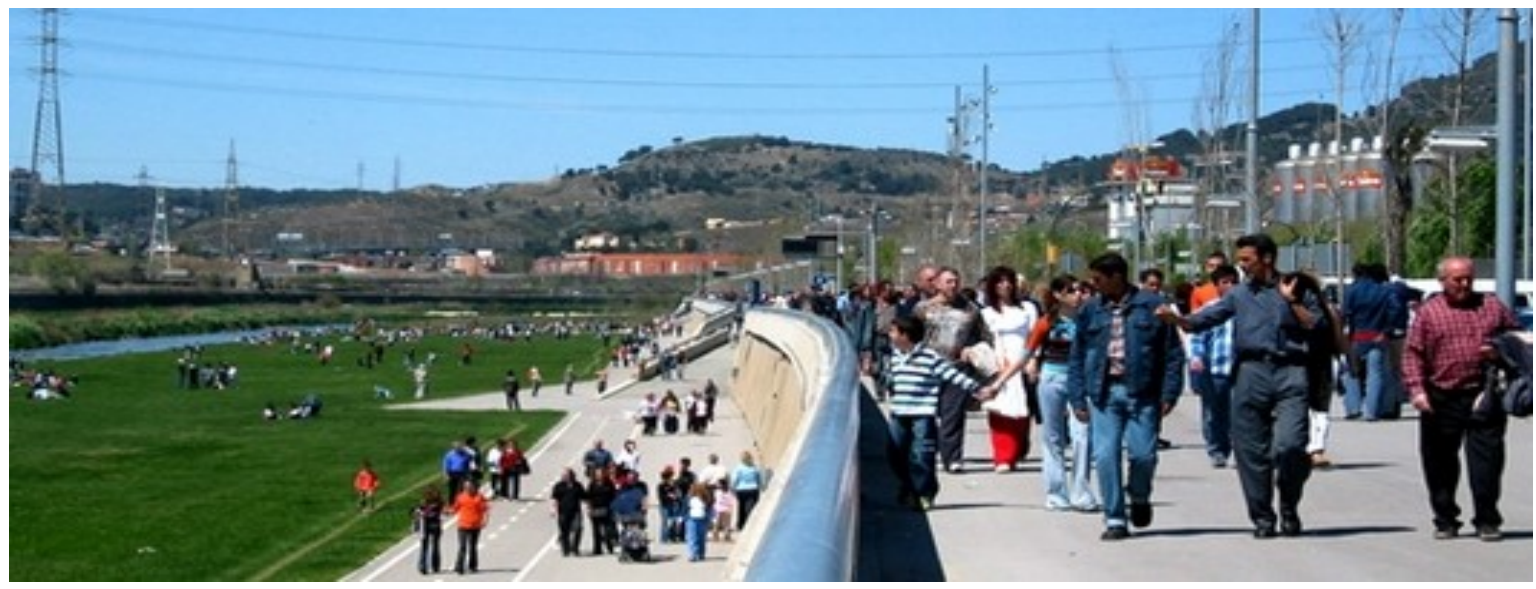

Ilustração 58 - Rio Besos revitalizado. Fonte: Ajuntament de Santa Coloma de Gramenet (2015).

Na Turquia o projeto de revitalização do rio Porsuk (Foto A), que historicamente tem grande importância na irrigação, foi pautado na despoluição orgânica e na criação de cinturões verdes e áreas de lazer ao longo de suas margens; Já o rio Bartin (Foto B e C) sob forte pressão da urbanização teve seu projeto de revitalização atrelado à necessidade de conter as inundações que afetavam as áreas urbanas, o projeto fez amplo uso do Sistema de Informações Geográficas (SIG) para nortear o planejamento do corpo d'água a fim de reduzir o risco de inundações, melhorar o transporte e conectar os ambientes naturais, culturais e históricos (Cengiz, 2013). A llustração 59 mostra foto dos dois rios após o processo de revitalização. 


\section{Foto A}

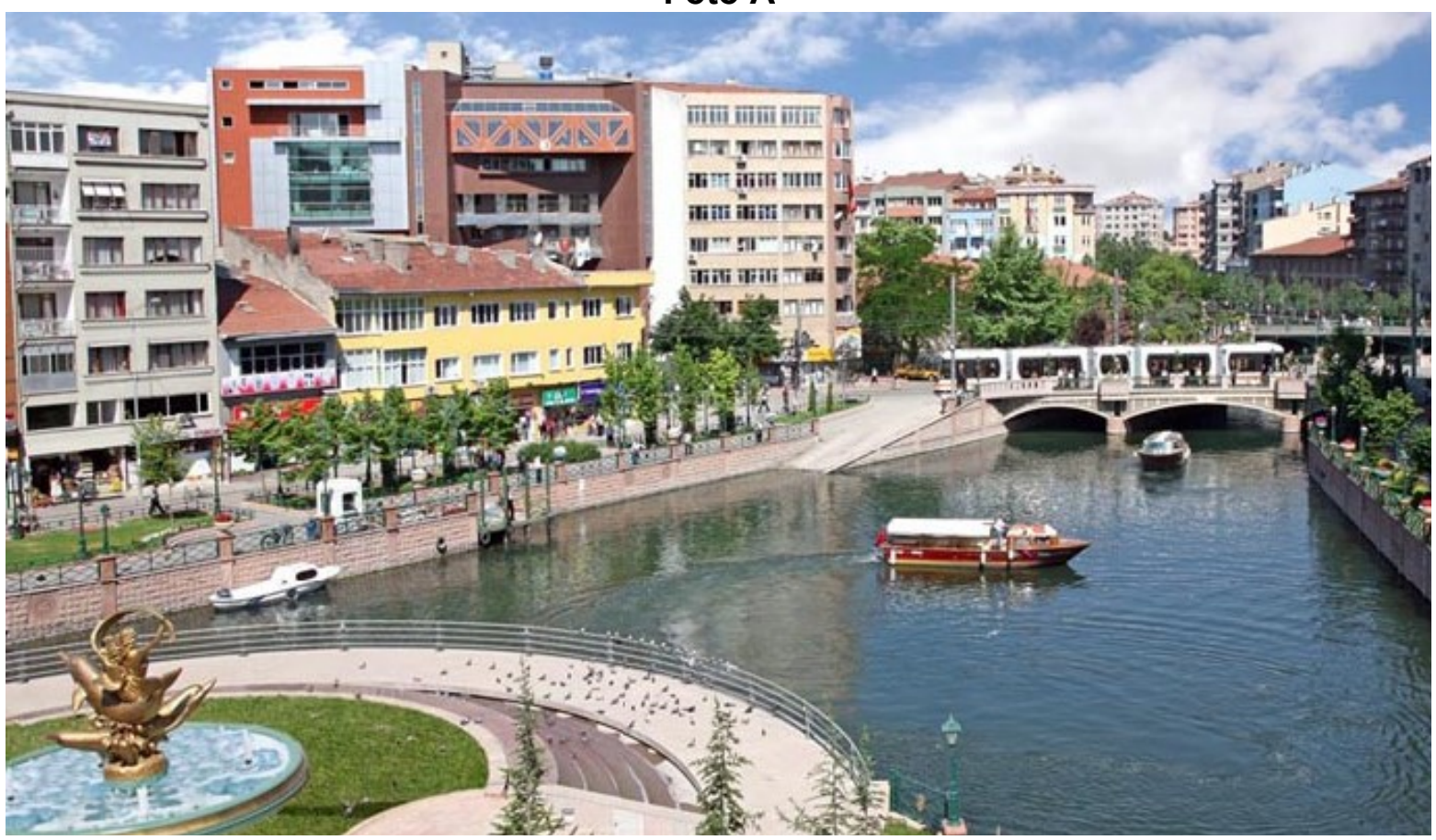

\section{Foto B}

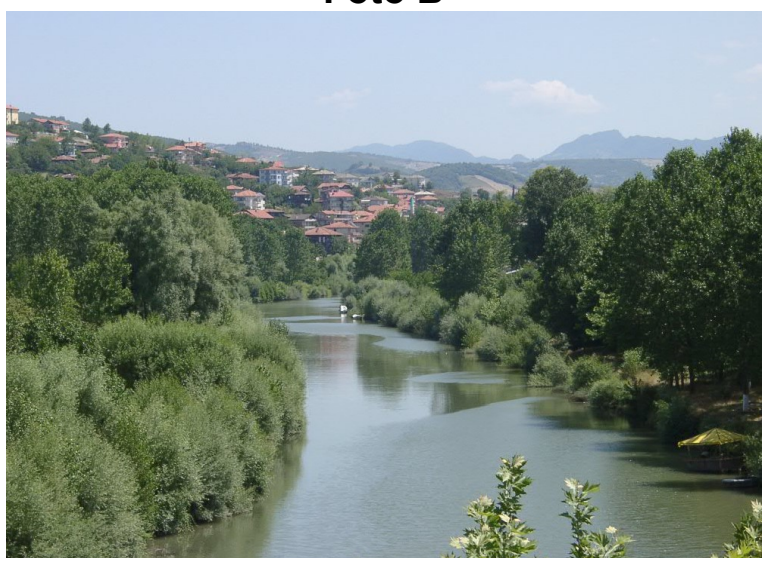

Foto C

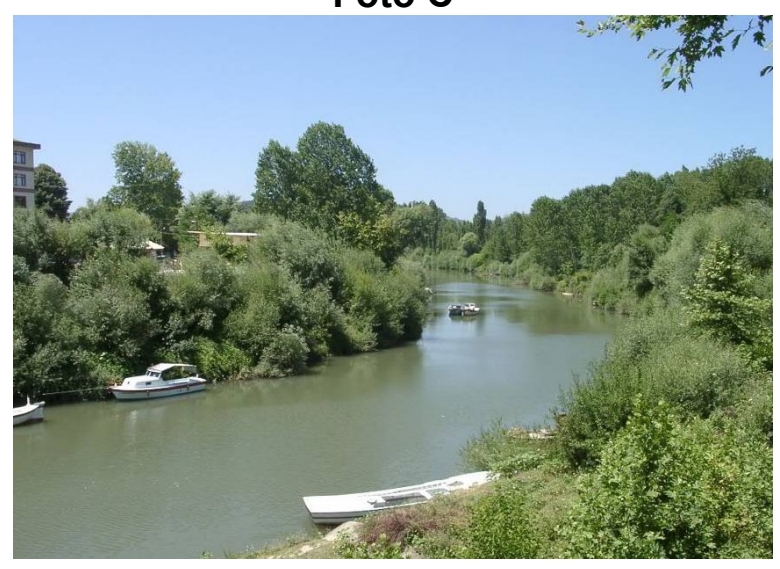

Ilustração 59 - Rio Porsuk (Foto A) e Bartin (Foto B e C) revitalizados. Fonte: Cengiz (2013).

O rio Tamisa que corta o centro de Londres é um exemplo famoso de revitalização. O rio sofreu um intenso processo de degradação ao desenvolvimento industrial e urbano durante os séculos XIX e XX, além de ter seu canal estreitado e aprofundado para navegação e defesa contra cheias. Em 1957 o rio foi declarado morto. Hoje o rio encontra-se despoluído e é considerado um dos rios urbanos mais limpos da Europa, graças a um intenso processo de controle de cargas poluidoras, apresentando alterações pontuais na qualidade de suas águas associadas ao lançamento de esgotos devido à ocorrência de chuvas extremas (Francis e Hoggart, 2009). 
Nos EUA $79 \%$ dos rios encontram-se sob influência de atividades humanas e $19 \%$ abrigam reservatórios, restando apenas $2 \%$ em condições naturais. Além disso, cerca de $70 \%$ da mata ciliar ao longo dos rios foram perdidas e um terço dos rios são considerados poluídos (Palmer et al., 2007). O reconhecimento da importância dos serviços ecossistêmicos perdidos com a degradação destes ambientes, faz com que os EUA seja um dos países mais ativos em programas de revitalização e renaturalização de rios - segundo Palmer et al. (2007) há 37 mil projetos em andamento - sendo referência mundial no assunto.

Um projeto importante é o da revitalização do rio Mississipi (Ilustração 60 ), o rio corta grande parte do território dos Estados Unidos, sendo historicamente usado para navegação e recreação. Passou por um processo de recuperação e revitalização na década de 30 , e hoje tem suas águas despoluídas, possuindo em suas margens diversas estruturas de lazer, como parques e feiras de exposição.
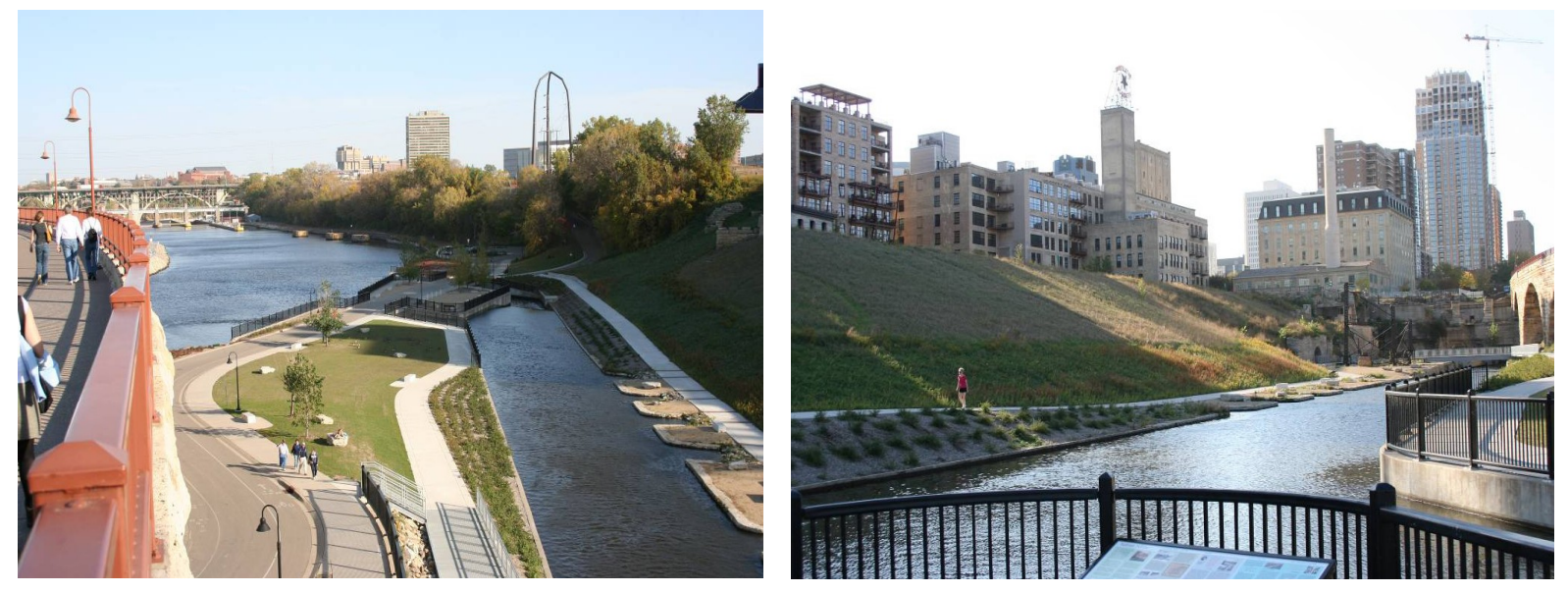

Ilustração 60 - Rio Mississipi revitalizado. Fonte: Cengiz (2013).

A revitalização do Rio Trinity (Fotos A e B) em Dallas contemplou 5 etapas: proteção contra inundações; gestão ambiental; recreação; transporte e desenvolvimento socioeconômico. Para tanto foram construídas wetlands, diques, áreas de lazer dentro das zonas de inundação, trilhas para caminhada e cinturões verdes. Já o plano de revitalização do Rio Onondaga (Fotos C e D) em Nova York com forte componente comunitário forneceu as orientações para aumentar as oportunidades sociais, ambientais e econômicas. Os principais problemas enfrentados foram a redução da qualidade da água devido às cargas difusas, as mudanças nos habitats e o limitado acesso público. Desta forma, foram executadas pistas de caminhadas nas margens, mirantes ao longo do rio, pontos de comércio e 
ainda obras de estabilização das margens para redução da carga de sedimentos (Cengiz, 2013). A llustração 61 mostra fotos dos dois rios após o processo de revitalização.
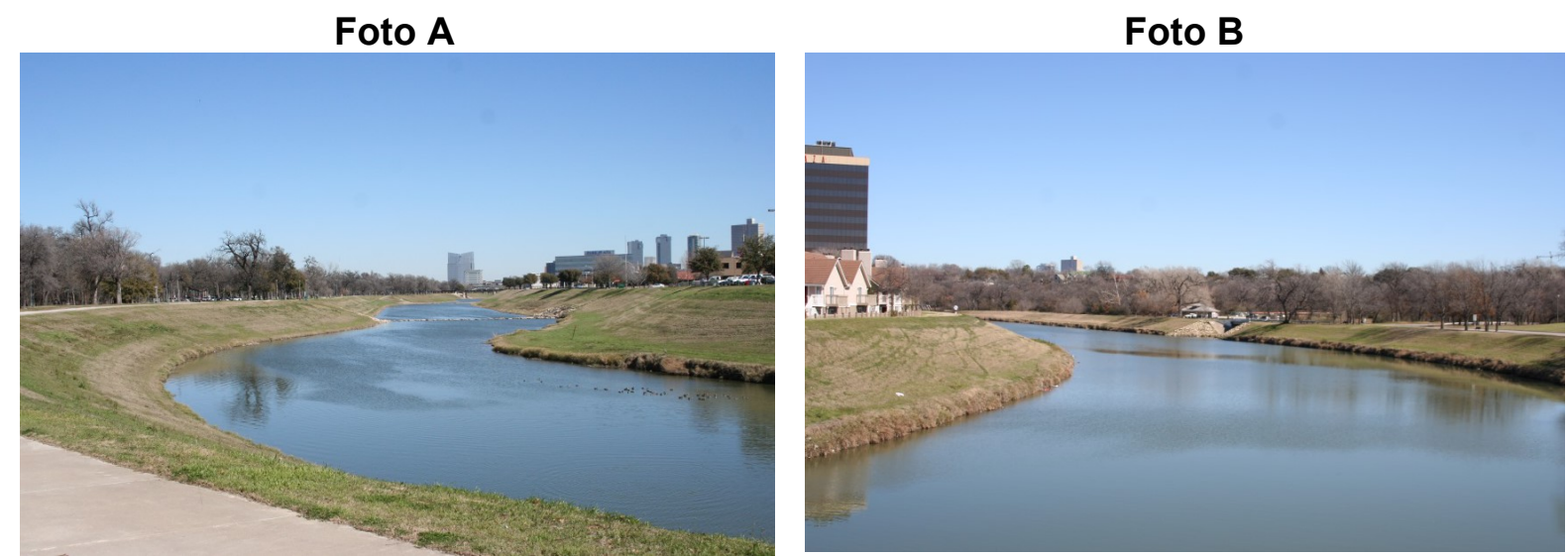

\section{Foto C}
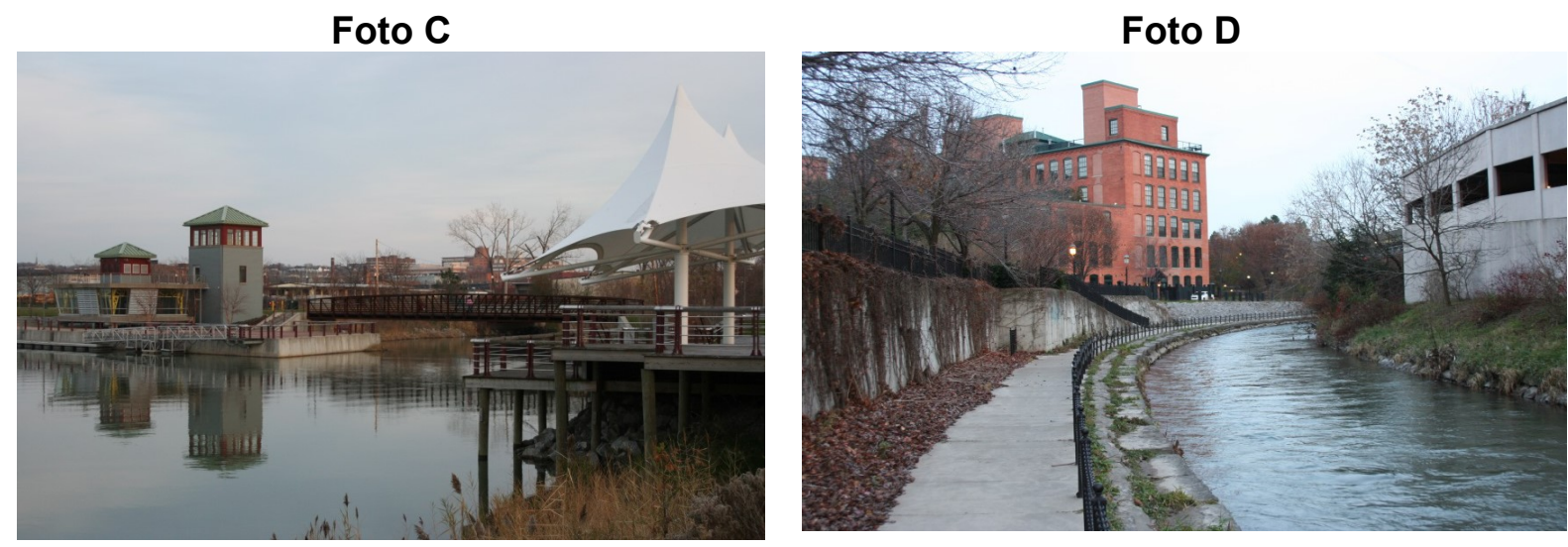

Ilustração 61 - Rio Trinity (Foto A e B) e Onondaga (Foto C e D) revitalizados. Fonte: Cengiz (2013).

O Rio San Antonio (Ilustração 62 ), no Texas, após sofrer uma terrível inundação na década de 20, foi foco de um grande estudo para contenção de inundações que mais tarde foi aprimorado para abranger sua recuperação e revitalização. Na época a população foi consultada sobre a proposta e 96,6\% indicou que a iniciativa seria uma excelente ferramenta para aumentar a atratividade turística da bacia. Hoje o projeto encontra-se totalmente implantado e a área é chamada de pequena Amsterdã (Cengiz, 2013). 

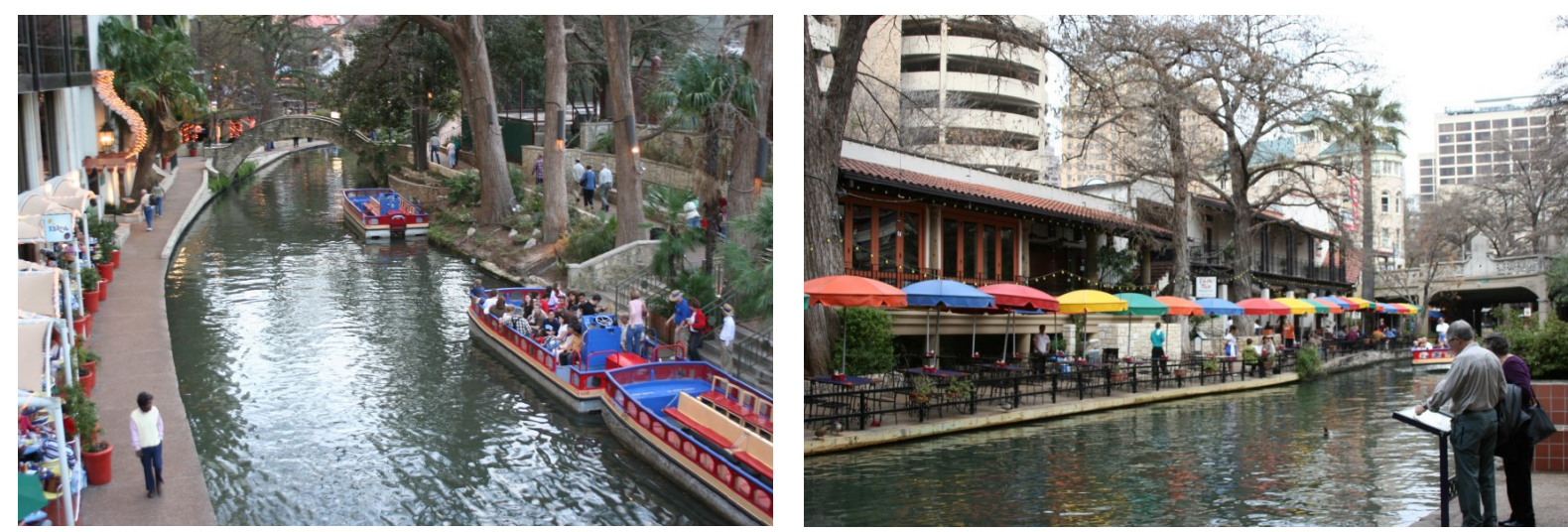

Ilustração 62 - Rio San Antonio revitalizado. Fonte: Cengiz (2013).

O rio Gwynns em Baltimore (llustração 47, Foto A), sofreu um intenso processo de degradação desde o século XVII, suas várzeas foram convertidas em áreas agrícolas, industriais e em núcleos urbanos, que resultaram também no lançamento de diversas cargas poluidoras diretamente no rio, comprometendo severamente a qualidade das suas águas. Somente no início do século $X X$, com o enfraquecimento do uso industrial e agrícola na região, houveram as primeiras iniciativas para revitalização do rio Gwynns, que se basearam no tratamento das cargas poluidoras, a fim de recuperar a qualidade de suas águas e com a implantação de um parque que se estende desde suas nascentes até os limites da cidade de Baltimore (Groffman et al., 2003).

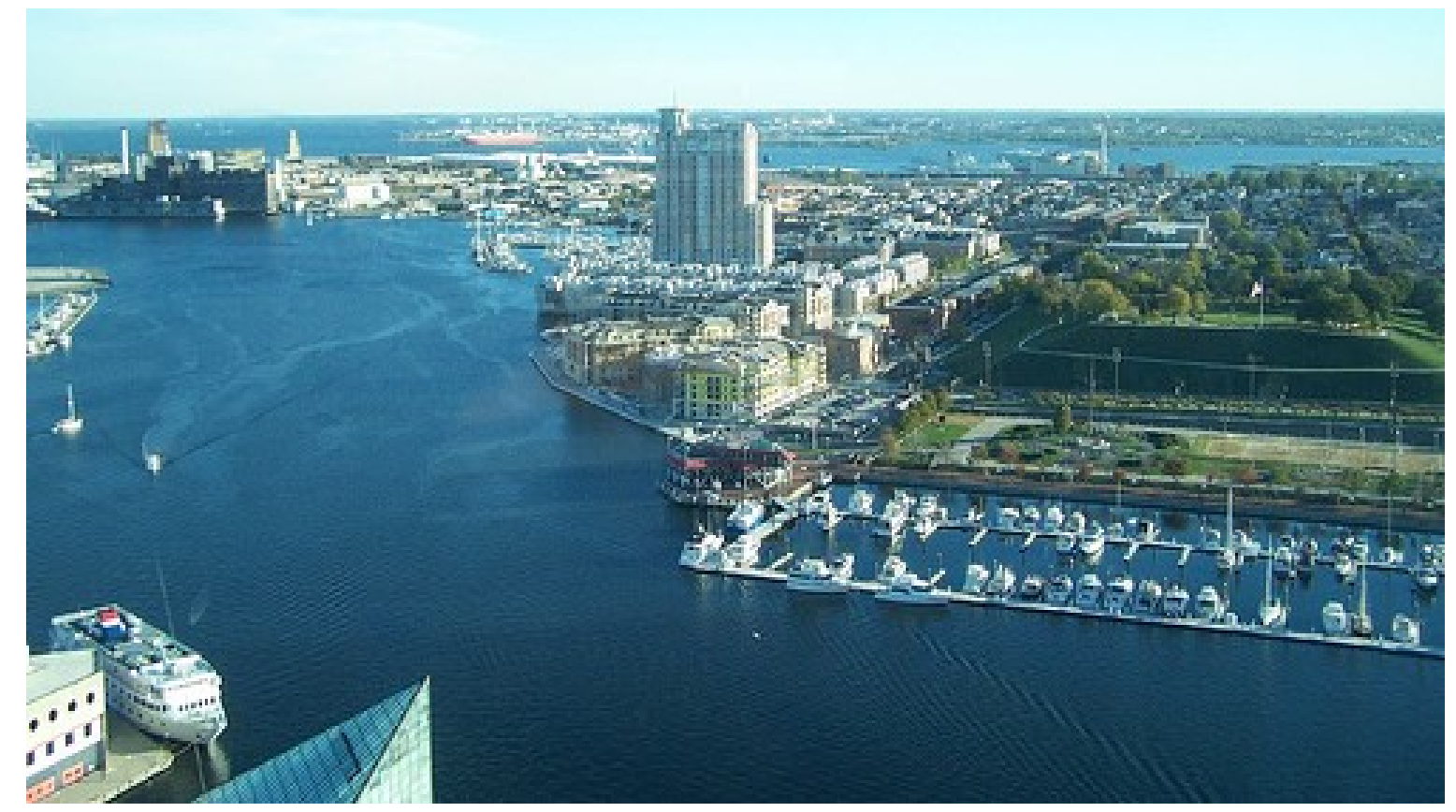

Ilustração 63 - Rio Gwynns revitalizado. Fonte: ESA, 2010. 
O rio Los Angeles (Ilustração 47, Foto B), em Los Angeles na Califórnia, passou por diversas intervenções a partir de 1938 que resultaram na conversão de $82 \mathrm{~km}$ de rios e córregos de sua bacia em canais de concreto, a fim de garantir o rápido escoamento de suas águas, no entanto esse processo aliado ao lançamento de cargas poluidoras resultou na perda da qualidade de suas águas prejudicando a jusante importantes praias da costa da California. Em 1990 foi elaborado um plano diretor para a bacia cujo objetivo foi a criação de uma rede de parques ao londo dos corpos d'água da bacia, providos de vegetação, com trilhas e ciclovias, a fim de recuperar a qualidade de suas águas. O grande diferencial do projeto foi a previsão de importantes parques mesmo em áreas densamente ocupadas, para isso contam com ajuda do poder público para realização de desapropriações e mudanças no tráfego (Otto, McCormick e Leccese, 2004).

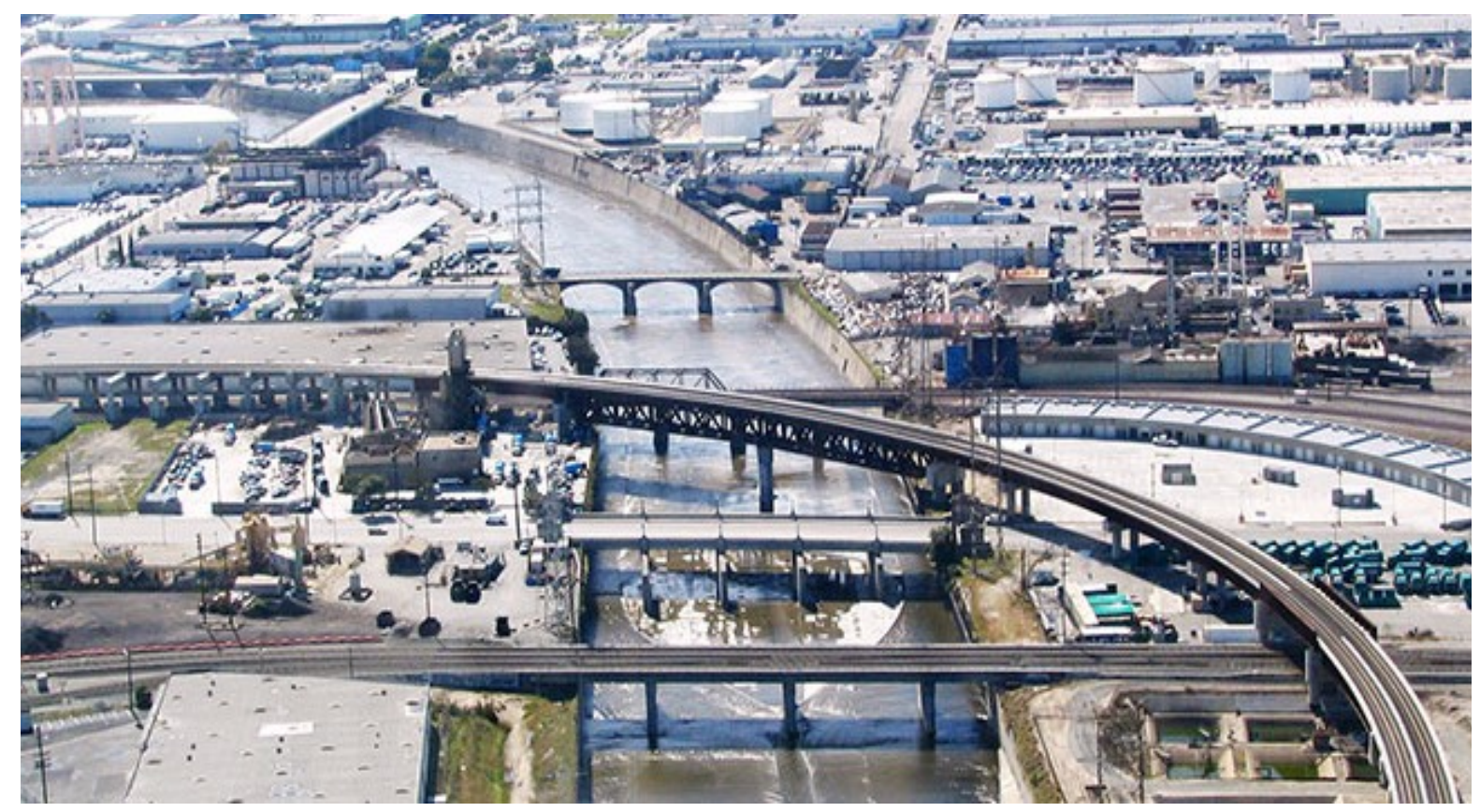

Ilustração 64 - Rio Los Angeles. Fonte: Tetra Tech (2007).

O rio apesar de despoluido, graças ao rigoroso programa de controle de resíduos sólidos e da consolidação do sistema de esgotamento sanitário, ainda encontra-se com poucos pontos de acesso à população, limitados aos parques na periferia da cidade, sendo o rio cercado por rodovias urbanas e linhas de trem. Além disso, o canal no trecho que corta a área urbana de Los Angeles, encontra-se confinado em uma galeria de concreto, a canalização foi realizada visando a segurança hidrológica da bacia, no entanto tal tratamento limita o desenvolvimento da fauna e flora aquática. 
Foto A

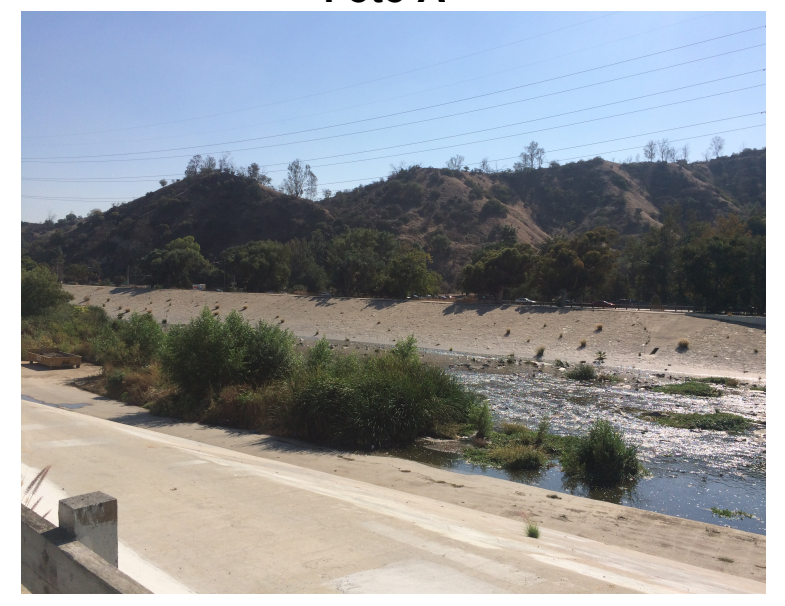

Foto B

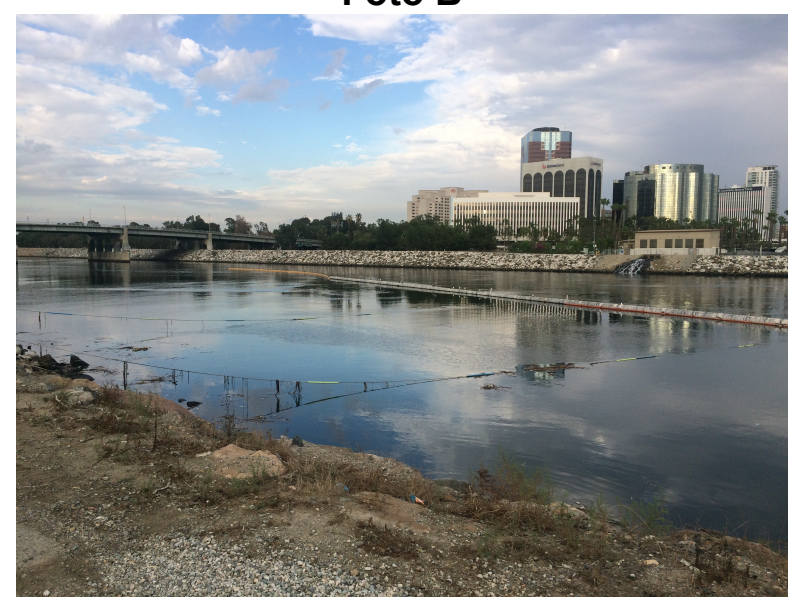

Ilustração 65 - Rio Los Angeles. Foto A: trecho parcialmente acessível dentro do parque Griffith. Foto B: Trecho acessível somente ao departamento de manutenção no bairro de Long Beach. Fonte: Fotos da autora.

O projeto contempla ainda a revitalização de córregos da bacia com a desconstrução dos canais de concreto a fim de promover o reestabelecimento da biota e promoção da integração da população com o corpo d'água. Muitas comunidades carentes estão localizadas ao longo dos corpos d'água da bacia, portanto a revitalização dos mesmos será muito importante para melhorar a qualidade de vida da população, fortalecer ecomias locais, conscientizar a população sobre a importância do patrimônio natual, aumentar a disponibilidade hídrica local, aumentar o uso da bicicleta e expandir oportunidades de lazer (Otto, McCormick e Leccese, 2004).

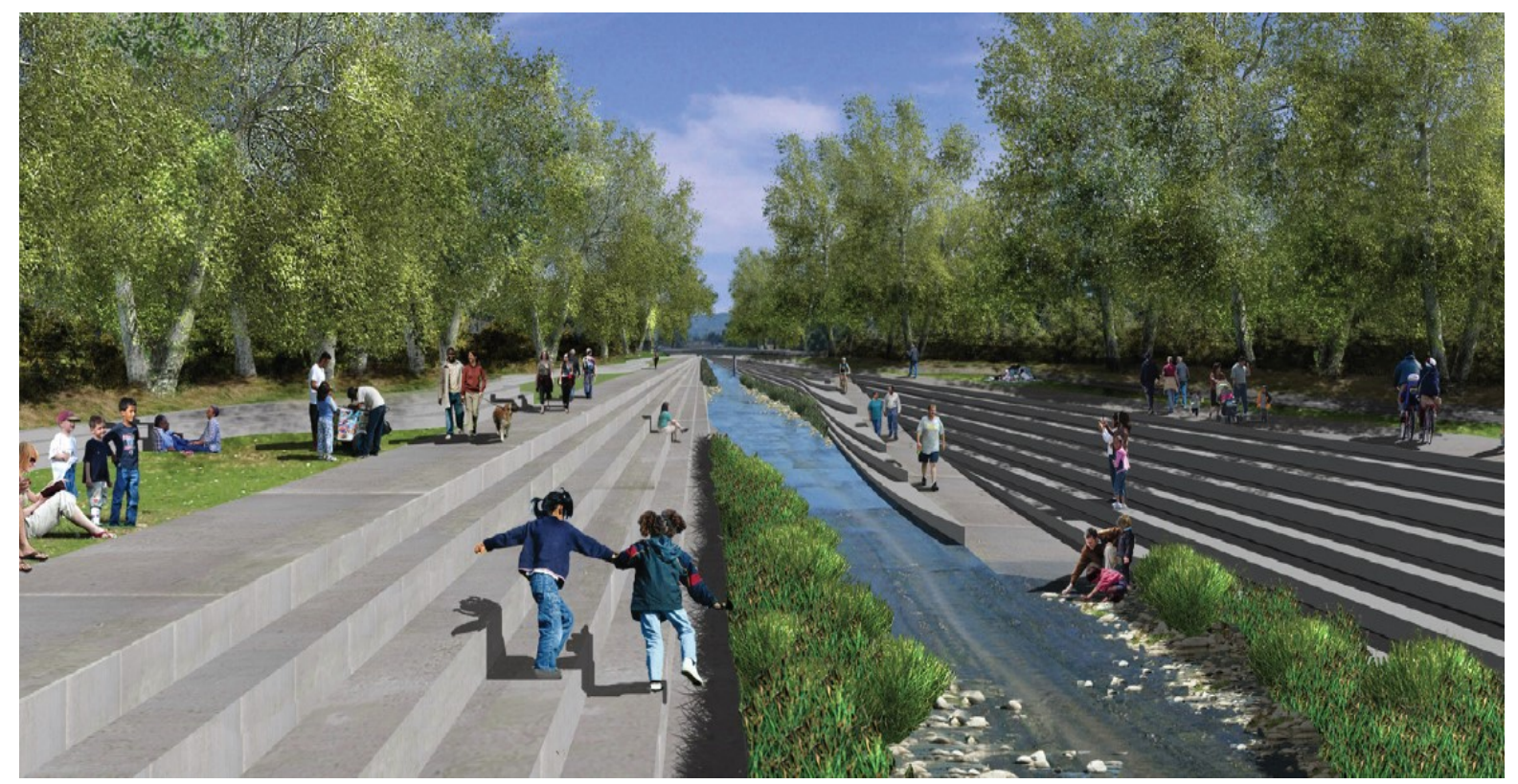

Ilustração 66 - Proposta de revitalização do rio Los Angeles. Fonte: Tetra Tech (2007). 
No Canadá um projeto importante é o da revitalização do rio Nine Mile, na província da Nova Escócia, que possui enorme potencial pesqueiro e é foco constante de atenção das agências de proteção ambiental por possuir um habitat ideal para ocorrências de trutas. Para revitalização do rio foram implantadas diversas wetlands que desempenham importante papel na proteção da qualidade da água. Atualmente há diversas ações para manejo a fim de conciliar os usos da água existentes em sua bacia e de educação ambiental para conservação dos ambientes aquáticos (Cengiz, 2013). A llustração 67 mostra o rio revitalizado.
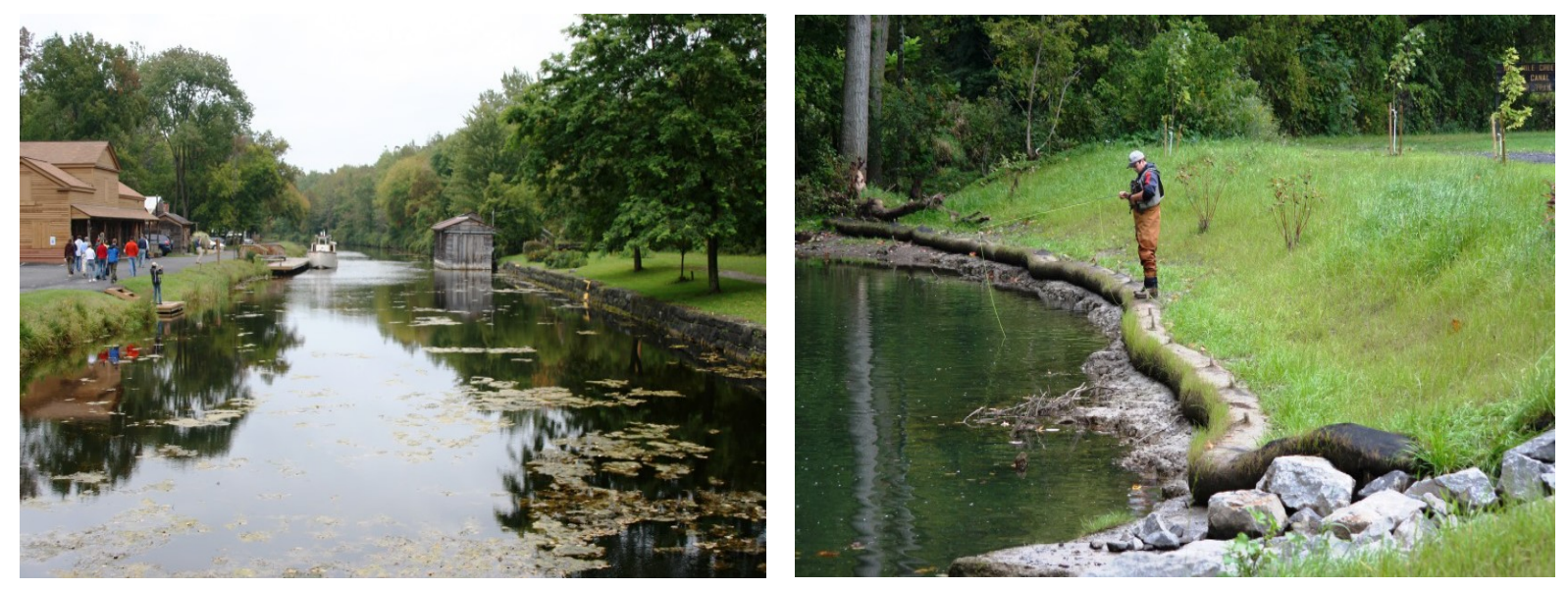

Ilustração 67 - Rio Nine Mile revitalizado. Fonte: Cengiz (2013).

$\mathrm{Na}$ Coréia, tem sido adotada uma série de medidas objetivando a sustentabilidade no país, sendo propostos quatro planos de restauração e preservação: Plano de revisão dos critérios para construção de estradas; Plano de revisão das leis nacionais sobre conservação ambiental; Plano para emprego de especialistas ambientais; e por fim o Plano de promoção e valorização de espaços verdes em áreas urbanas. Dentro deste ultimo, está inserido o programa de revitalização de rios, do qual faz parte o projeto de revitalização do rio Cheonggyecheon (Nam-choon, 2005).

O projeto de revitalização do rio Cheonggyecheon fez parte do novo planejamento urbano de Seul na Coréia que teve o intuito de reviver o patrimônio histórico e cultural. O rio sofreu uma série de intervenções ao longo de sua história junto à cidade que fizeram com que ele fosse usado como canal de escoamento de esgotos e em determinado período fosse totalmente ocultado da paisagem pela construção de uma avenida sobre o rio e de uma via expressa elevada, conforme mostrado na llustração 68 (Cengiz, 2013). 

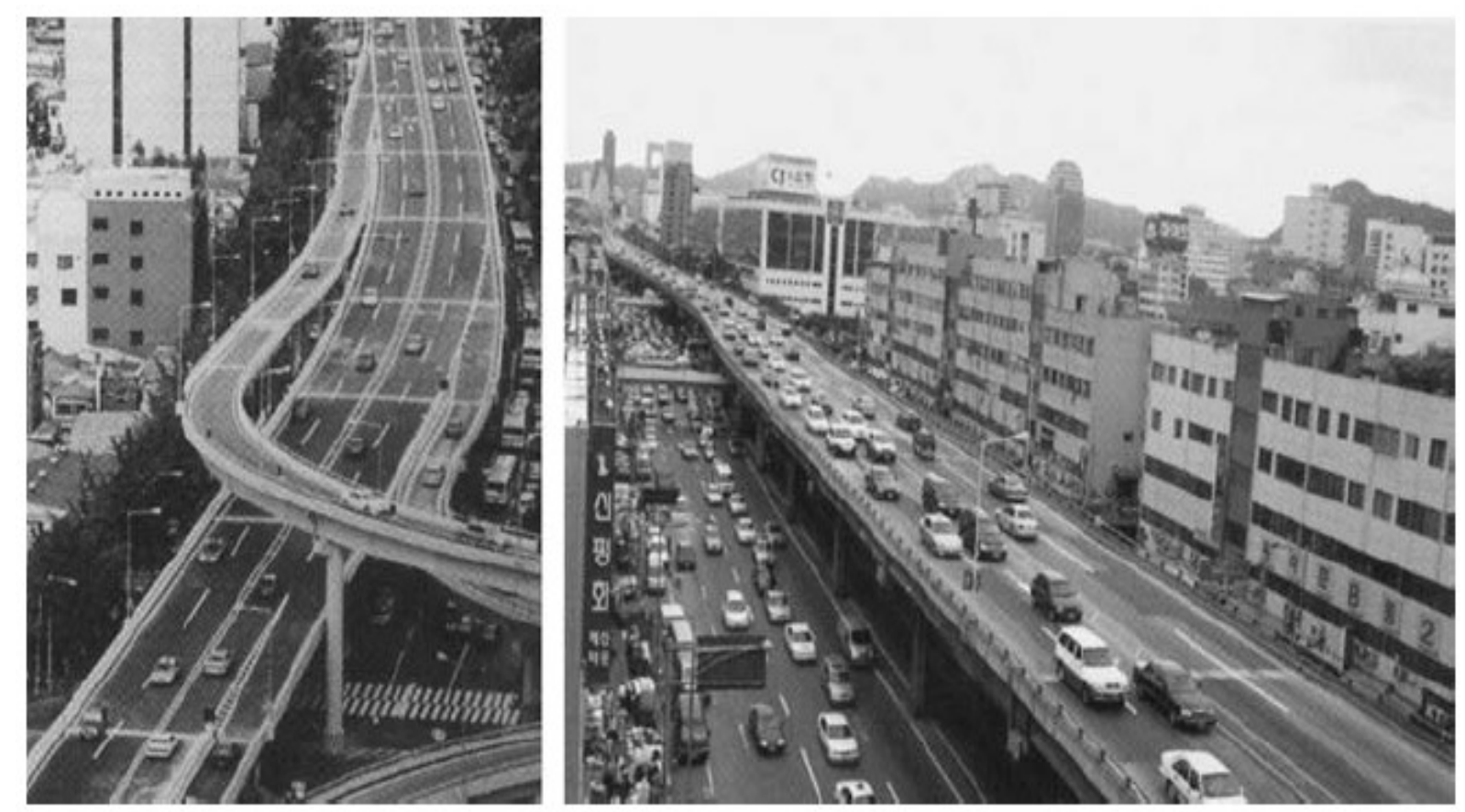

Ilustração 68 - Avenida e via expressa elevada sobre o rio Cheonggyecheon. Fonte: Namchoon (2005).

O projeto de revitalização do rio Cheonggyecheon foi norteado pelas seguintes premissas: Resolver os problemas ligados ao congestionamento do tráfego; Melhorar a qualidade do ar e diminuir o ruído; Criar uma identidade regional; Aumento da segurança; Criação de um espaço favorável ao meio ambiente; Melhoria da qualidade de vida da população; e Melhoria da imagem cultural da cidade. Para tanto, demandou a remoção de uma via expressa elevada, que havia sido construída sobre a avenida que cobria o rio e a demolição desta avenida, resultando na abertura do rio. Além disso, para garantir uma lâmina d'água no canal ao longo do ano, foi necessário criar um sistema de bombeamento de água de um curso d'água vizinho (Lee, 2005). A revitalização do rio foi um processo custoso e trabalhoso, mas que teve como resultado a integração do corpo d'água novamente à paisagem dando a ele novas funcionalidades e o integrando à população de Seul, que o hoje usa as áreas de lazer instaladas ao longo de suas margens. $O$ projeto representou um grande ganho paisagístico para a cidade bem como trouxe um grande incremento à qualidade de vida da população (Cengiz, 2013). 


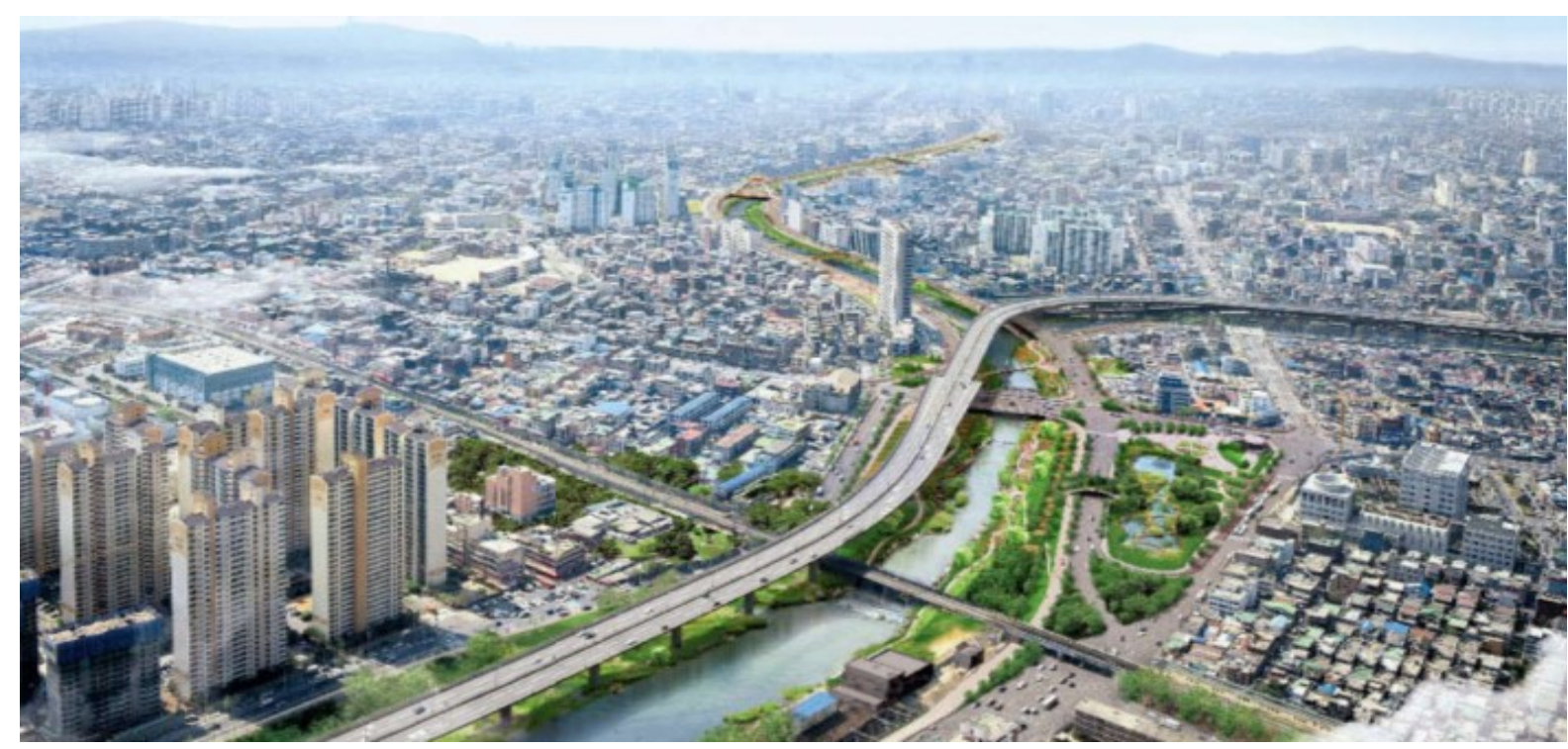

Ilustração 69 - Rio Cheonggyecheon revitalizado. Fonte: Cengiz (2013).

Na Austrália, a análise dos 2247 projetos de restauração revelou que o foco mais comum foi a recomposição da mata ciliar, seguido pela estabilização de margens e recomposição do ambiente aquático. Destes projetos, apenas 14\% incluíram algum programa de monitoramento (Brooks, S. S.; Lake, 2007).

O Japão vem investindo grandes esforços na revitalização de seus rios desde 1990, o país possui como agravante ao processo uma elevada taxa de densidade populacional nas áreas urbanas, o que torna o processo um grande desafio nestas áreas. Os rios no Japão têm como característica particular o fato de serem em sua grande maioria, devido às características naturais da topografia da ilha, íngremes, pouco extensos e com elevado dinamismo de sedimentos, além disso, apresentam elevada diversidade biológica com a elevada ocorrência de espécies endêmicas, o que eleva a importância ecológica destes ambientes (Nakamura, Tockner e Amano, 2006).

No inicio do século $X X$ o Japão sofreu com diversas chuvas fortes que resultaram na morte de cerca de 20 mil pessoas no país, fazendo com que o governo considera-se a questão da elaboração de um plano de controle de cheias como prioridade. Além disso, com o grande crescimento econômico no país entre 1950 e 1970, houve a degradação da qualidade das águas nas áreas urbanas. No início dos anos 70 houve o aumento da demanda por áreas de lazer dentro das cidades e o aumento da preocupação com a qualidade de vida e a área dos rios 
foram as poucas áreas livres que restaram para suprir esta demanda. Desta forma a frase "Brincando com a água" se tornou a moda no Japão, iniciando um período de intensa ligação entre a população e as águas (Nakamura, Tockner e Amano, 2006).

O rio Itachi, em Yokohama, em 1981 encontrava-se em um estado totalmente artificial, contido em um canal em seção trapezoidal, sem nenhum valor paisagistico e recreativo. A partir de 1990 foi dado inicio a um programa de revitalização no rio que mudou sua presença na paisagem, como mostrado na llustração 70 a seguir (Nakamura, Tockner e Amano, 2006).

Foto A

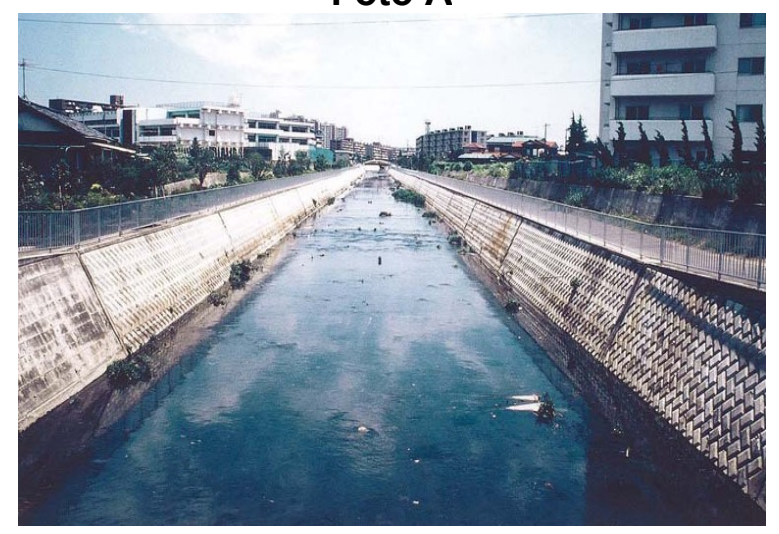

Foto B

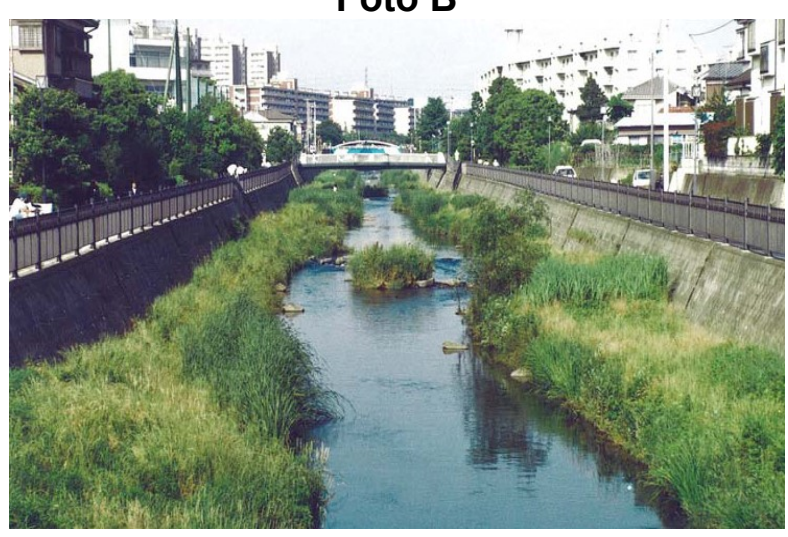

Ilustração 70 - Rio Itachi antes/1981 (Foto A) e depois/1993 (Foto B) do projeto de revitalização. Fonte: Nakamura, Tockner e Amano (2006).

Uma importante medida adotada no Japão juntamente com os projetos de revitalização é o envolvimento da sociedade no processo. O Ministério da educação, cultura, esportes, ciência e tecnologia reconheceu nos projetos de revitalização de rios uma excelente oportunidade para educação ambiental e promove um programa de integração para estudantes de escolas primárias, fazendo com que os estudantes participem do processo de revitalização, se tornando com isso agentes atuam na conscientização da sociedade (Nakamura, Tockner e Amano, 2006).

O projeto de revitalização do rio Tama na região de Tokyo oferece um ótimo exemplo das dificuldades encontradas na revitalização de rios em áreas urbanas, uma vez que apresenta os problemas típicos de rios urbanos, como o elevado grau de urbanização, a presença de barragens de regularização de vazão, o elevado aporte de sedimentos e a colonização de espécies exóticas. A revitalização do rio incluiu o tratamento de todo o leito do canal com cascalho, a fim de propiciar novamente a colonização da fauna e flora dentro do canal (Nakamura, Tockner e Amano, 2006). 
Foto A
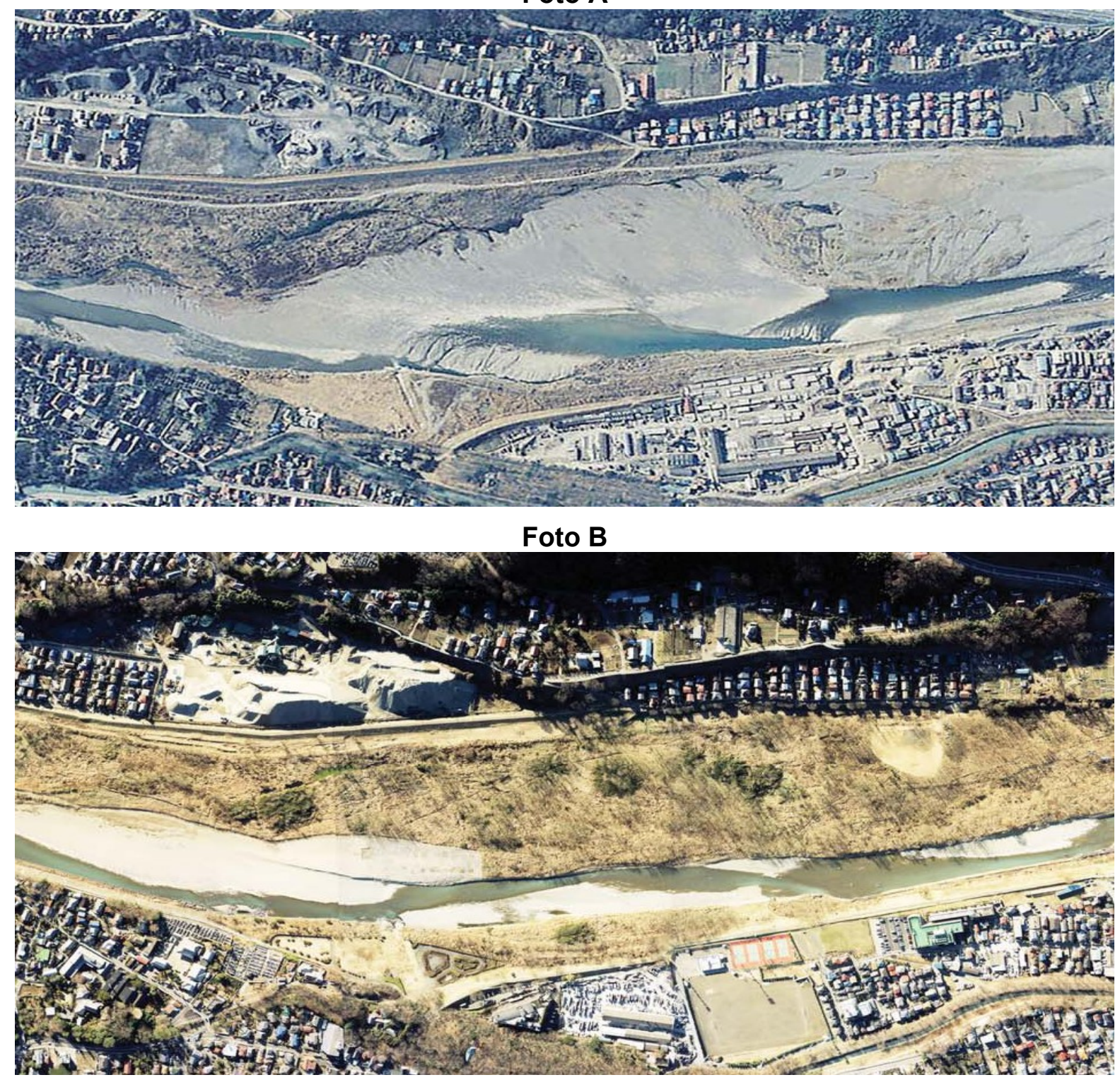

Ilustração 71 - Rio Tama antes/1974 (Foto A) e depois/2002 (Foto B) do projeto de revitalização. Fonte: Nakamura, Tockner e Amano (2006).

Além dos projetos de revitalização em áreas urbanas, há diversos projetos no Japão dedicados ao reestabelecimento da conectividade das espécies aquáticas, uma vez que o Japão esta em quarto lugar dentre os países com maior densidade de barragens no mundo, desta forma, nos últimos anos houve um grande investimento na instalação de estruturas nas barragens que permitissem a migração de peixes (Nakamura, Tockner e Amano, 2006).

Outro exemplo interessante é o do rio Donghao Chung em Guangzhou na China, que foi convertido de um canal de escoamento de águas de chuva misturadas com esgotos, a um rio aberto com tratamento urbanístico que atrai a 
população para perto do mesmo (Schneider, 2015). Pensando na realidade brasileira, a solução urbanística adotada para o canal é de grande relevância para os rios brasileiros que possuem como característica comum a ocupação de suas várzeas por edificações, bem como ocorre no rio Donghao Chung.
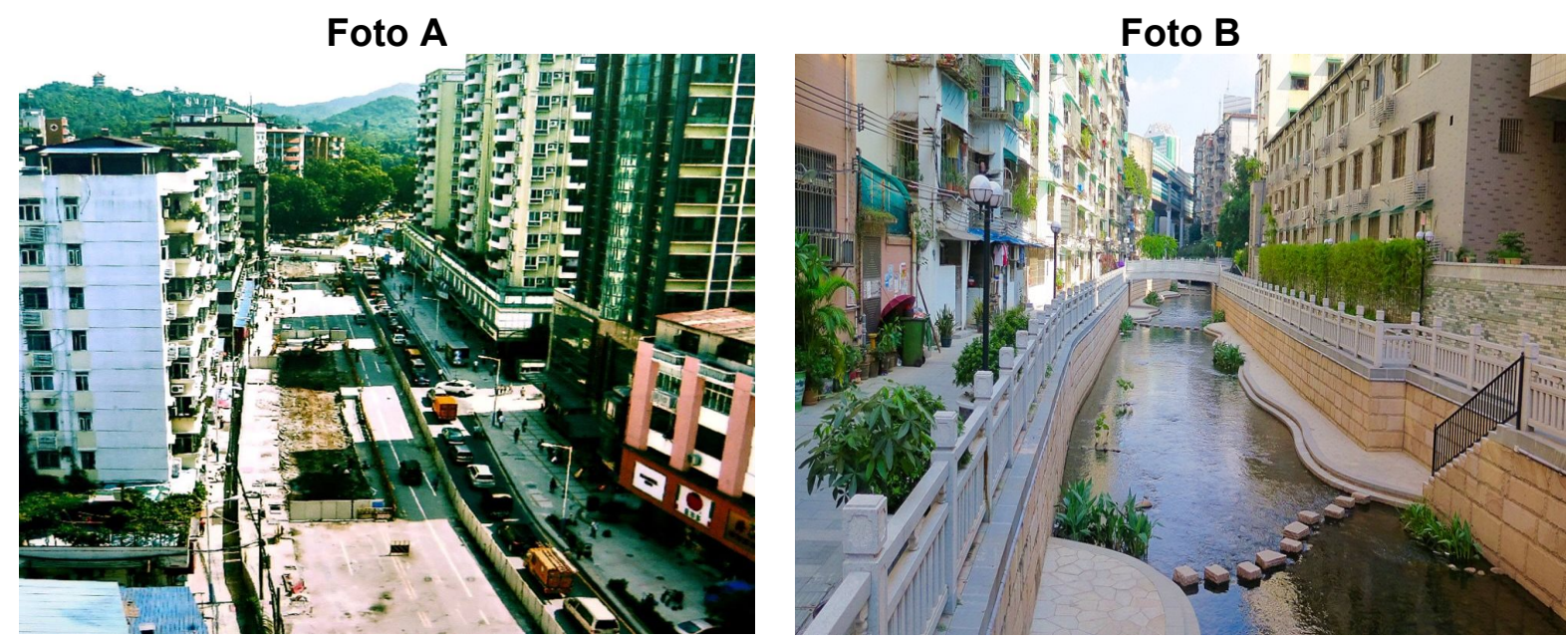

Ilustração 72 - Rio Donghao Chung na China antes (Foto A) e depois (Foto B) do projeto de revitalização. Fonte: Schneider (2015).

Os projetos internacionais apresentam como principal ponto em comum a recuperação da qualidade da água através do controle de cargas pontuais e difusas, a reintegração do corpo d'água à paisagem e principalmente o envolvimento da população no processo, o que garante que mesmo seja duradouro. Mesmo naqueles que fazem uso de soluções radicalmente artificiais, como no caso do rio Cheonggyecheon, que depende de águas de outros canais e de aquíferos subterrâneos para operar, as soluções são bem sucedidas por envolver a população no processo e reintegrar o corpo d'água na paisagem como um elemento de lazer para a população.

O contexto internacional, onde em muitos casos já se encontra consolidado o sistema de esgotamento sanitário, as intervenções são mais facilitadas, uma vez que os efluentes são a carga poluente mais predominante no corpo d'água, desta forma os programas de despoluição são voltados para o controle de cargas difusas. Além disso, muitas vezes a disponibilidade financeira para execução destes projetos garante que o processo de implantação seja mais rápido e mais efetivo. 


\subsubsection{Experiência nacional}

No Brasil, como o controle das cargas pontuais ainda é pouco eficaz, os projetos que atuam em bacias hidrográficas sempre foram mais voltados à questão do controle de efluentes a fim de garantir a melhoria da qualidade das águas. No entanto, têm sido cada vez mais comuns projetos que adotam uma abordagem mais abrangente, que incluem em seu escopo de trabalho o controle de cargas difusas, a drenagem sustentável e a infraestrutura verde. Apesar da deficiência comum no sistema de saneamento básico, apresentada pelas diversas bacias hidrográficas brasileiras, devido à grande heterogeneidade do território, tanto climática com geopolítica, estas bacias apresentam também desafios particulares a serem vencidos, que serão abordados neste item.

Em São Paulo, a SABESP, em parceria com a prefeitura, iniciou em setembro de 2004 o programa "Córrego Limpo", que consiste na recuperação de córregos através da ampliação das redes coletoras de esgoto e condução dos efluentes para o tratamento, eliminação de ligações clandestinas, de lançamentos em galerias pluviais, reestruturação da calha do corpo d'água e manutenção da vegetação no canal. A llustração 73 mostra o córrego Cruzeiro, onde o programa atuou em paralelo com a urbanização da favela em suas margens.
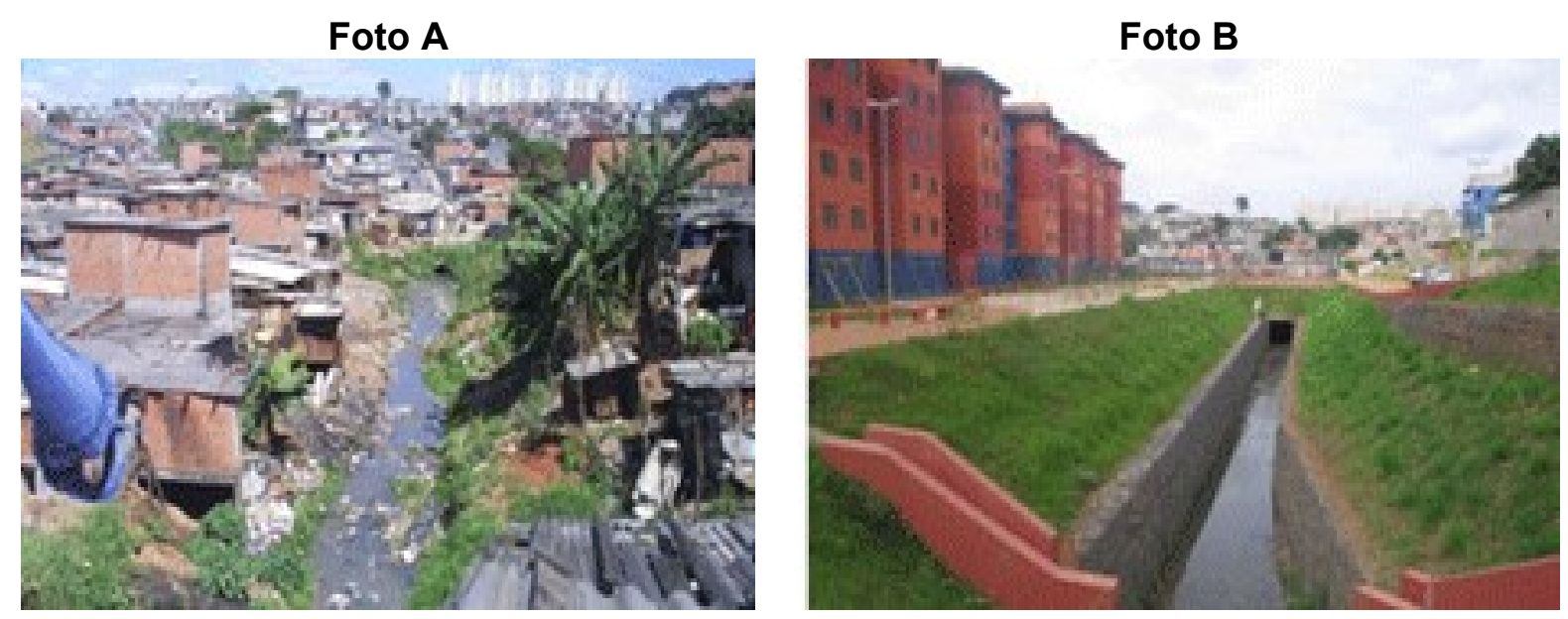

llustração 73 - Córrego Cruzeiro antes (Foto A) e depois (Foto B) do projeto de revitalização. Fonte: Córrego Limpo (s/d).

Além dessas ações e dentro do conceito de Best Management Practices, o programa "Córrego Limpo" realiza a capacitação de técnicos que atuam em algumas bacias do programa de forma piloto, a fim de tornar efetivas as ações de 
recuperação, nas bacias onde foi adotada a governança colaborativa o programa obteve resultados mais duradouros e concretos (Córrego Limpo, s/d).

A estratégia de governança colaborativa adotada pelo programa faz uso do "Modelo dos Níveis de Ação Colaborativa" (MNAC). O modelo proposto pelo professor Mark Imperial, da Universidade da Carolina do Norte, foi testado em bacias norte-americanas, que apesar de maiores, apresentavam os mesmos desafios, abordando a questão da colaboração em três níveis: operacional (Que trata de intervenções como implantação de infraestrutura, processos educativos, monitoramento e avaliação, portanto envolve, na maior parte, serviços governamentais), de formulação de políticas (Que tem caráter orientador, incrementando a comunicação entre os atores, coordenando ações e integrando políticas para alavancar os objetivos coletivos) e institucional (Atividades que influenciam, restringem, incrementam e promovem as ações no nível operacional e formulação de política) (Córrego Limpo, s/d).

O programa "Córrego Limpo" tem foco na despoluição do canal, portanto muitos dos córregos em que o programa atuou não tiveram intervenções mais abrangentes visando, por exemplo, a drenagem sustentável, dependendo de programas auxiliares para tanto, a exemplo do que ocorreu no córrego das Corujas, que teve as ações do programa para recuperação da qualidade das águas aliadas à reestruturação do canal seguindo uma visão pioneira no Brasil de desenho ambiental e infraestrutura verde.

O córrego das Corujas possui cerca de $3 \mathrm{~km}$ de extensão e encontra-se na Zona Oeste do município de São Paulo, foi retificado na década de 40, e encontrase hoje quase que completamente tamponado, com exceção do trecho que corta a Praça Dolores Ibarruri e o recém criado Parque das Corujas. A praça e o parque foram objeto de estudos paisagísticos que tiveram como diferencial fundamental a ampla participação da comunidade na concepção, implantação e manutenção do projeto, o que tornou o processo de integração do corpo d'água com a população e com a paisagem mais consolidado. As intervenções resultaram na diminuição de alagamentos pontuais nas proximidades, o aumento da circulação de moradores e visitantes na área que passaram a utilizar os elementos da praça para o lazer (De Oliveira et al., 2012). 

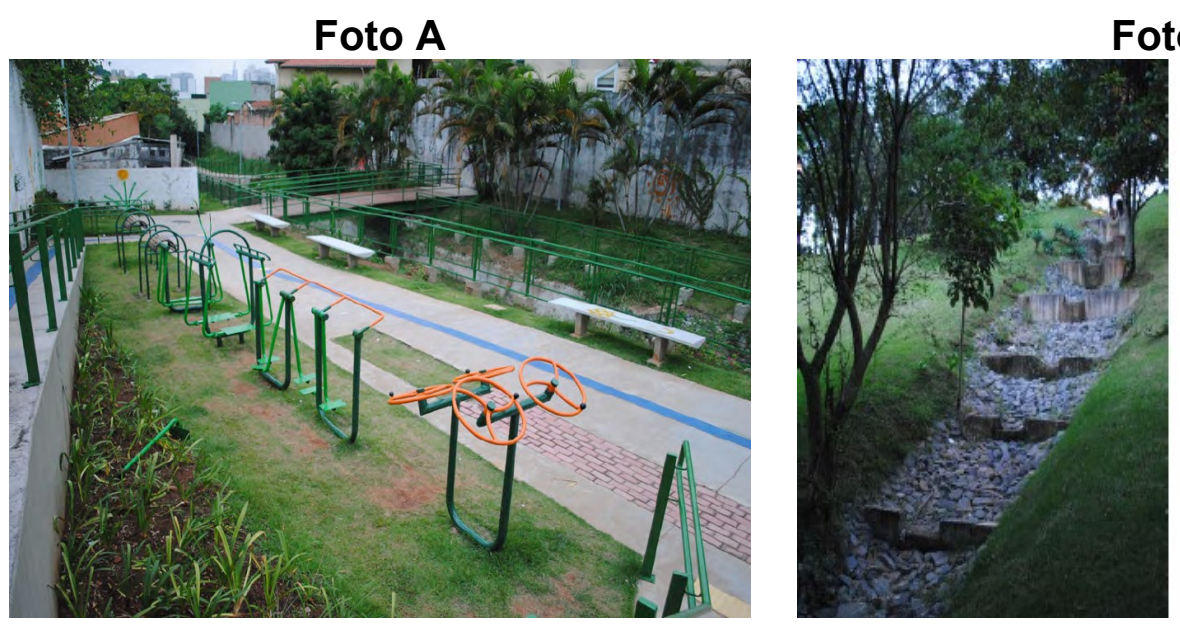

Foto B

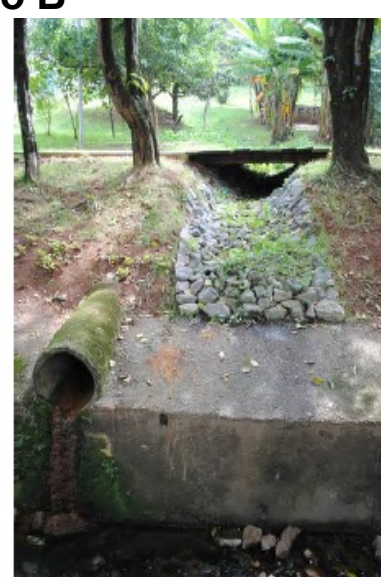

Ilustração 74 - Exemplos de recuperação e revitalização de corpos d'água no Brasil Córrego das Corujas. Fonte: De Oliveira et al. (2012).

$\mathrm{Na}$ implantação das intervenções na praça e no parque encontraram-se alguns desafios com relação ao que foi previsto no projeto de drenagem e o que foi executado, havendo as seguintes mudanças: Algumas das biovaletas previstas não foram executadas ou foram executadas na forma de valetas simples de concreto; As lagoas de retenção previstas para controle da vazão de pico e de cargas difusas não foram executadas; As espécies vegetais previstas no projeto não foram respeitadas, sendo substituídas por outras; e em alguns trechos as calçadas não foram adequadas para direcionar o fluxo para as biovaletas previstas. A não observância do projeto resultou no assoreamento de trechos do corpo d'água, solapamento com exposição da armação das margens; e acumulo de sedimento no piso drenante. Além disso, a ausência das lagoas resultou no aumento da lâmina máxima do canal em relação ao que foi previsto no projeto. No entanto, mesmo diante destes entraves, o projeto mostrou-se significativamente positivo, trazendo grandes ganhos ambientais e sociais (De Oliveira et al., 2012).

Um exemplo importante de intervenção em corpo d'água foi a revitalização do córrego Piranungaua no interior do Jardim Botânico de São Paulo. Apesar de estar dentro de uma área preservada, o córrego desde 1940 até 2007 encontrava-se canalizado em uma galeria subterrânea no trecho da entrada do parque, somente após a conclusão do projeto de revitalização do córrego, concluído em 2008, o córrego foi devolvido à paisagem e despoluído, ganhando pontes para travessia de pedestres, decks para contemplação e regeneração da vegetação de suas margens 
(Condepefi, s/d). A llustração 75 mostra o corpo d'água antes e depois do processo de revitalização.
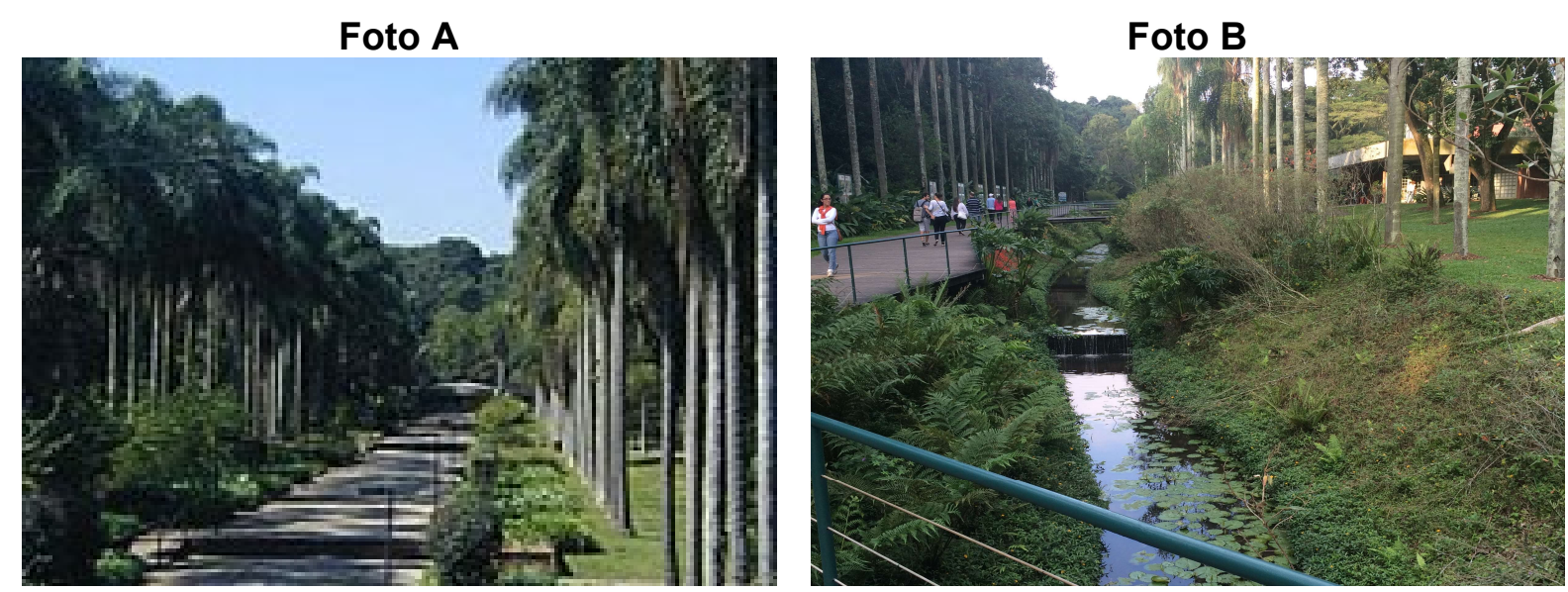

Ilustração 75 - Córrego Piranungaua - Afluente do Riacho Ipiranga - antes (Foto A) Fonte: Condepefi (s/d) e após sua revitalização (Foto B) Fonte: Fotos da Autora.

Atualmente esta em curso o "Projeto Jaguaré", coordenado pela ONG Águas Claras do Rio Pinheiros e desenvolvido pela Fundação do Centro de Hidráulica (FCTH) da USP com apoio do LabVerde da FAU-USP, da CETESB, da SABESP e do IPT, e financiamento do Fundo Estadual de Recursos Hídricos (FEHIDRO), o projeto inova por ter como objetivo a gestão adequada das águas a fim de atender as demandas de qualidade e quantidade da água na bacia dentro do principio de gestão integrada. O produto final do projeto é uma proposta para controle de cargas poluentes na bacia, controle de inundações e integração da população com a água. Para tanto foram realizados estudos na escala da bacia e na escala piloto através de um estudo detalhado das nascentes do córrego Jaguaré. A llustração 76 a seguir mostra fotos da campanha de monitoramento da qualidade da água e de um dos seminários técnicos realizados pelo projeto.
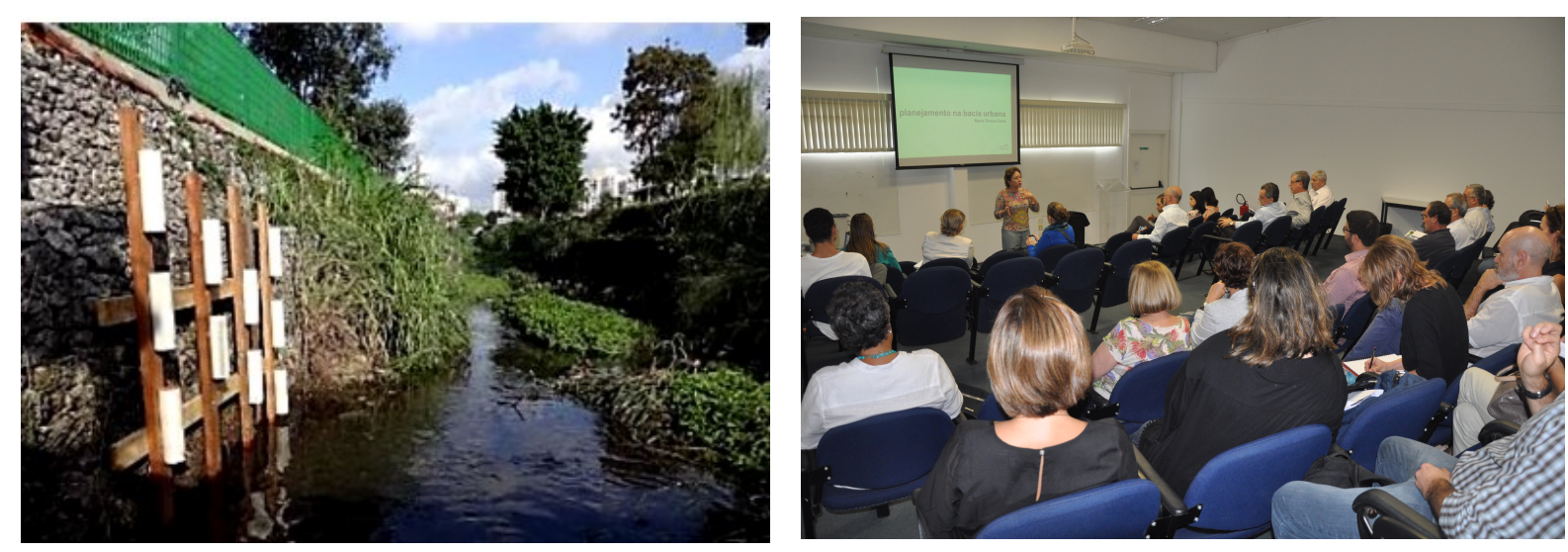

llustração 76 - Campanha de monitoramento da qualidade da água e Seminários técnicos do "Projeto Jaguaré". Fonte: Projeto Jaguaré (s/d). 
O "Projeto Jaguaré" prevê a aplicação das técnicas da infraestrutura verde na bacia a fim de auxiliar no controle da vazão de pico da bacia, como mostrado, no traçado preliminar proposto pela equipe do projeto, na llustração 77 a seguir.

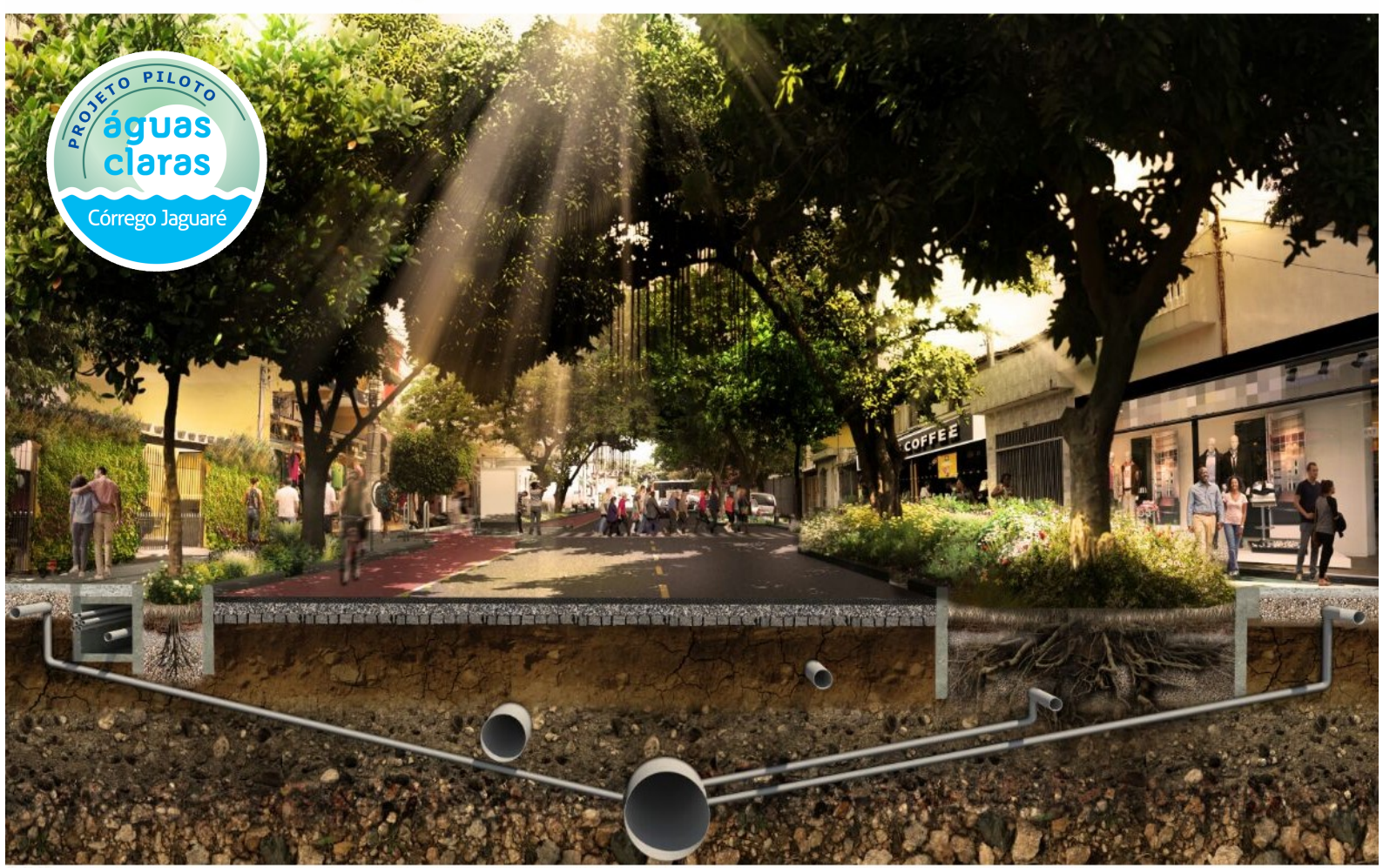

Ilustração 77 - "Projeto Jaguaré" traçados preliminares. Fonte: Projeto Jaguaré (s/d).

Em Minas Gerais, a Universidade Federal desenvolve um projeto chamado Manuelzão que se dedica a promover iniciativas de preservação e recuperação de rios. O projeto tem grande atuação nas bacias hidrográficas do estado, com destaque para a bacia do rio das Velhas, onde tem desenvolvido uma série de estudos que envolvem monitoramento da qualidade das águas, bem como propostas para revitalização dos trechos do corpo d'água mais degradados devido à ocupação humana. O projeto se destaca ainda por incluir diversas ações voltadas para o envolvimento da população a fim de promover a gestão participativa na bacia. Diversas obras de saneamento foram implantadas nos últimos anos que resultaram na melhoria da qualidade das águas do corpo d'água, constatada pela melhoria apresentada no monitoramento das variáveis físico-químicas (Machado et al., 2010).

Outra iniciativa mineira importante é o Programa DRENURBS. O programa foi criado pela extinta Secretaria Municipal de Política Urbana em Belo Horizonte a fim de promover a despoluição, o controle das inundações, da produção de sedimentos e a integração das águas ao ambiente urbano. O programa tem adotado medidas 
inovadoras para solução de problemas de drenagem, como as adotadas na revitalização do córrego $1^{\circ}$ de Maio apresentado na llustração 78 (DRENURBS, 2013).

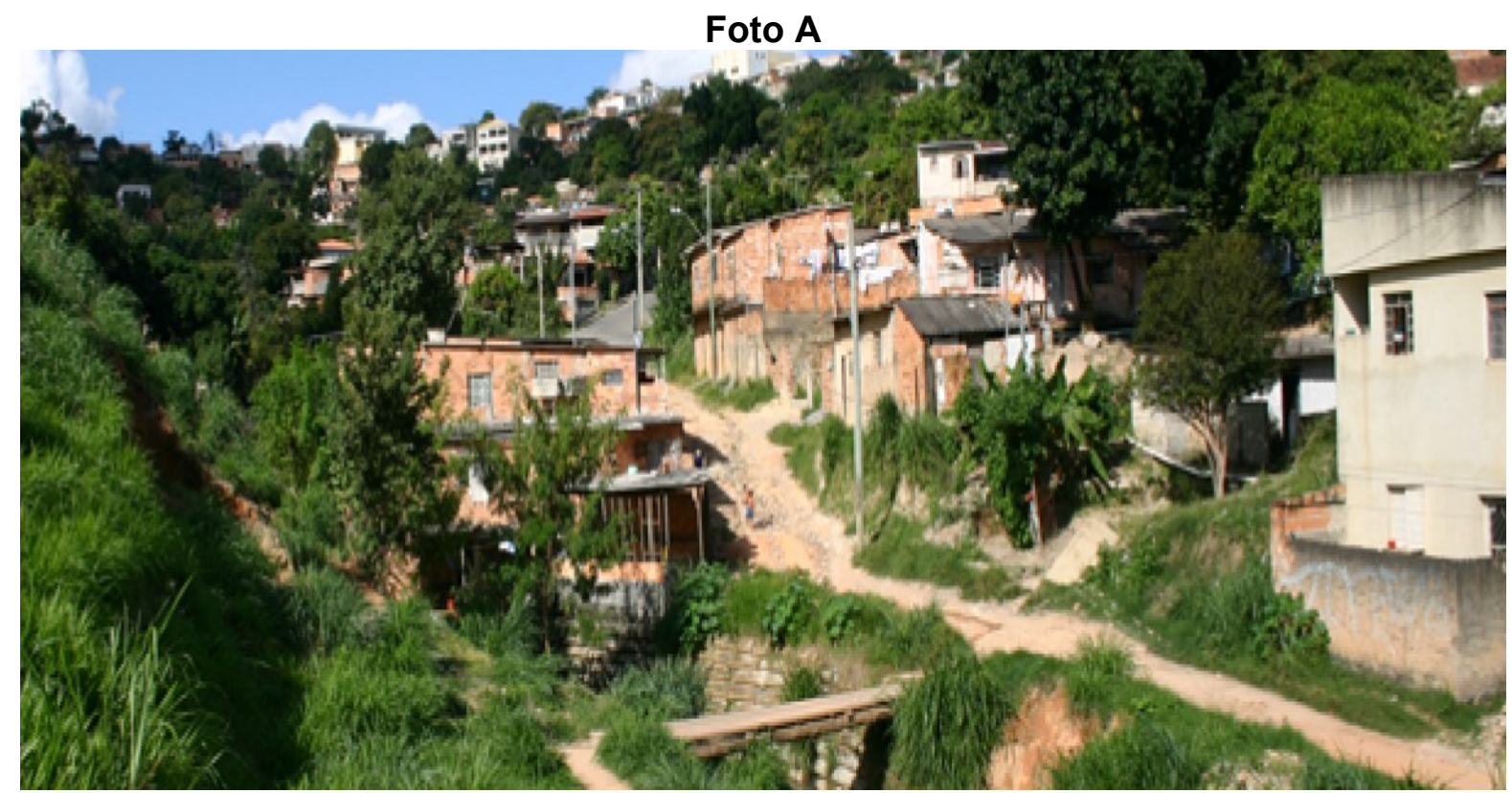

Foto B

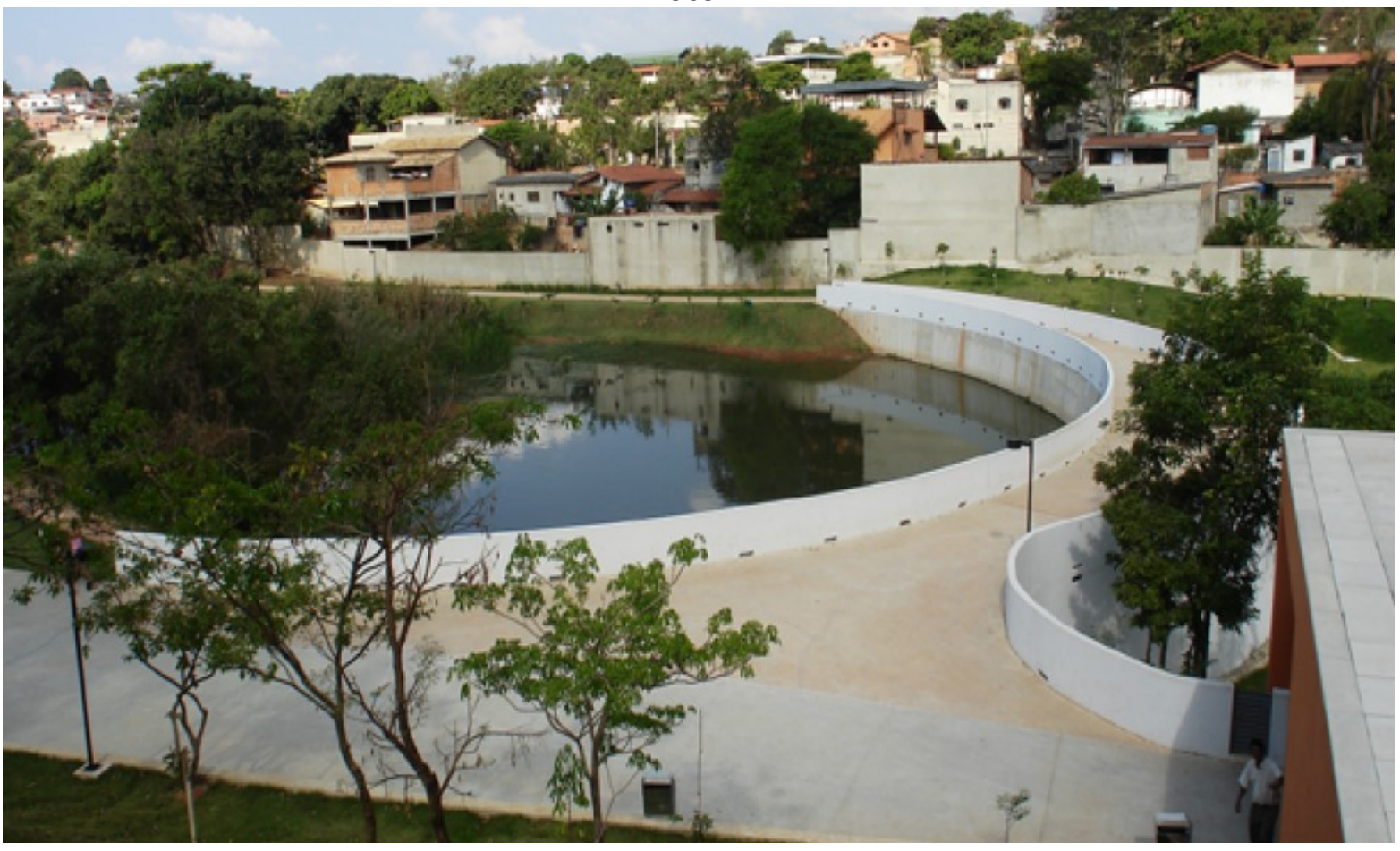

Ilustração 78 - Córrego $1^{\circ}$ de Maio em Belo Horizonte, antes (Foto A) e depois (Foto B) da revitalização. Fonte: DRENURBS (2013).

Em Recife, a Universidade Federal de Pernambuco tem trabalhado no projeto de revitalização do rio Capibaribe. O projeto em andamento, tem como pretensão a criação de espaços de integração entre o rio e a população de Recife, como 
passarelas sobre o rio, alamedas, píeres, espaços de contemplação, ciclovias, equipamentos públicos e ainda áreas de refúgio para fauna por uma extensão de 30 quilômetros do rio. O projeto prevê a redução do tráfego nas avenidas que margeiam o rio a fim de priorizar o pedestre através da implantação de novas calçadas e jardins (UFPE, s/d).

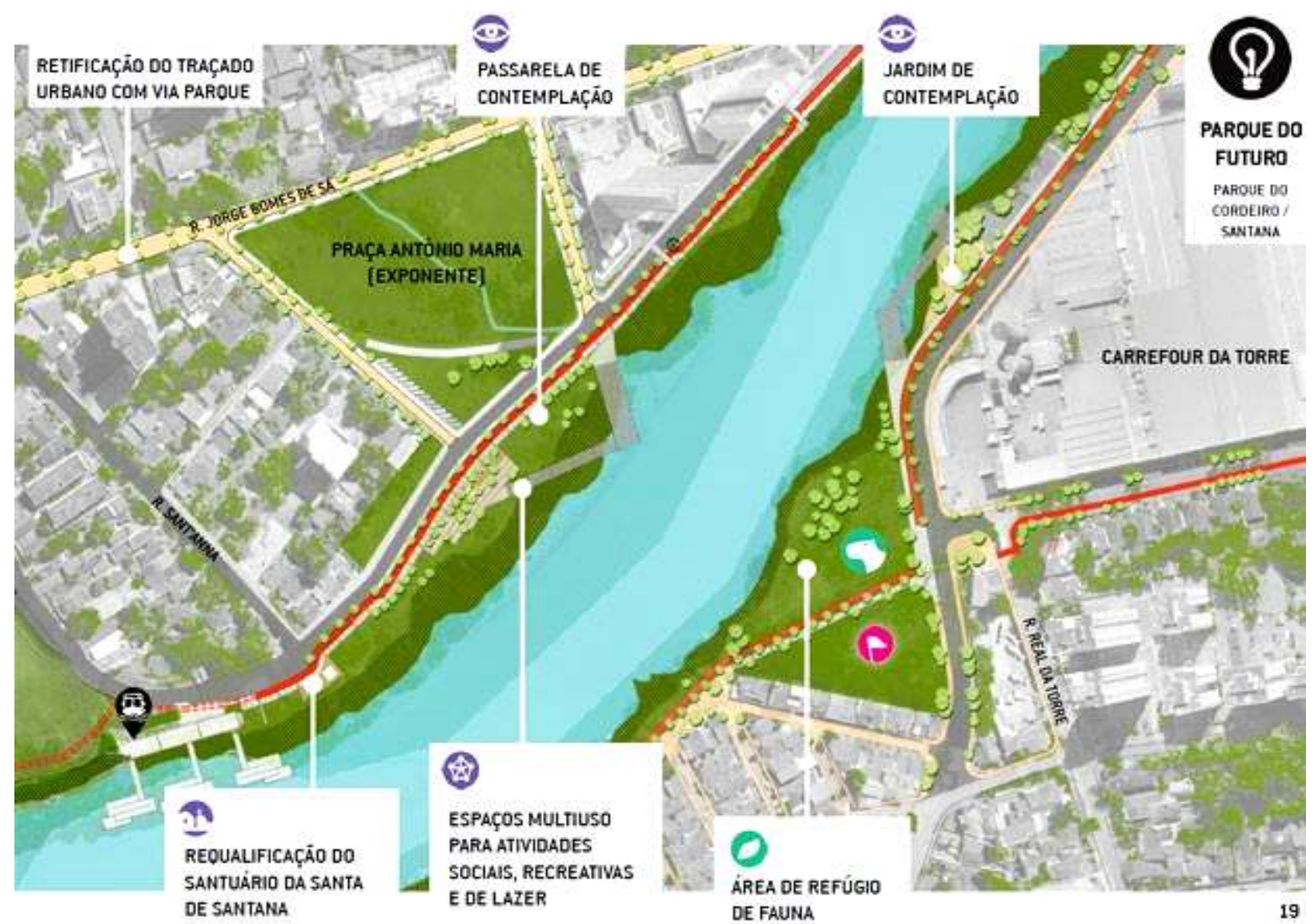

Ilustração 79 - Projeto do parque linear Capibaribe. Fonte: UFPE (s/d).

As iniciativas para revitalização de corpos d'água em áreas urbanas no Brasil esbarram na maioria das vezes na falta de recursos, como é o caso do projeto de revitalização do Arroyo Dilúvio em Porto Alegre que teve seu plano de ação elaborado pela UFRGS e pela PUCRS e entregue à prefeitura em 2012, mas que ainda não foi executado por falta de recursos (Projeto Arroyo Dilúvio, s/d).

Além disso, a maioria dos corpos d'água que demandam projetos de revitalização, são aqueles que se encontram sob forte influência da ocupação irregular e, portanto demandam ações de cunho social, que muitas vezes tornam o processo um grande desafio, pois envolve a remoção e reassentamento da polução em situação de risco. 


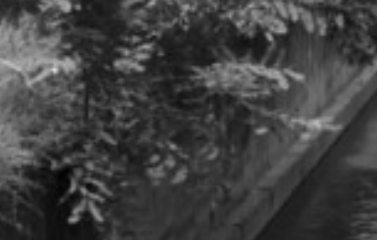

\section{Capítulo 3}

\section{Estudo de Caso}

Para aplicação dos conceitos vistos na revisão bibliográfica foi escolhida uma bacia hidrográfica que reunisse características propicias para a aplicação das diversas técnicas estudadas, a fim de propiciar a elaboração de uma proposta de metodologia para revitalização de bacias hidrográficas em áreas urbanas. Desta forma foi escolhida a bacia do córrego Jaguaré que é afetada pelos três grupos de impactos detalhados neste estudo, impactos referentes à ocupação das áreas de várzea e as mudanças no uso e ocupação do solo, lançamentos de cargas poluidoras e modificações na geometria natural dos cursos d'águas, conforme detalhado nos itens seguintes. 


\subsection{Bacia do Jaguaré}

A bacia do Jaguaré esta localizado na Bacia do Alto Tietê, na sua Sub-bacia denominada Penha - Pinheiros. A bacia do Alto Tietê possui uma área de cerca de 6 mil km², abrangendo 35 municípios, sendo $37 \%$ de sua área ocupada por zonas urbanas. A bacia tem este nome por ser a cabeceira do Rio Tietê, portanto tem como característica possuir cursos d'água de pequeno porte, onde esta característica natural aliada à grande concentração populacional na mesma resulta em uma baixa disponibilidade hídrica na bacia, sendo comparável às da região nordeste do Brasil (Silva \& Porto, 2003).

A bacia do Alto Tietê tem uma taxa de crescimento elevada e devido à situação social da cidade, a população de baixa renda é levada a ocupar as áreas periféricas que em boa parte inclui importantes áreas de proteção de mananciais, e ainda ocupar áreas de várzeas outrora desocupadas. Essa ocupação resulta em um grave problema no que se refere aos recursos hídricos, uma vez que estas áreas são ocupadas sem planejamento e sem a infraestrutura sanitária necessária, resultando em degradação ambiental e problemas de saúde pública, havendo ainda o agravamento da crise hídrica, uma vez que essa degradação da qualidade das águas dos mananciais utilizados para abastecimento da cidade contribui para diminuição da disponibilidade hídrica. Portanto há nessas áreas uma grande demanda por investimentos em habitação e infraestrutura básica (Silva \& Porto, 2003).

O plano da bacia do Alto Tietê desenvolvido pela Fundação Universidade de São Paulo inclui uma série de iniciativas para controle da poluição na fonte, que é uma importante ferramenta para a gestão de recursos hídricos em bacias urbanizadas. O plano foi desenvolvido com base em uma visão integrada de gestão, a fim de garantir que os objetivos de qualidade e de quantidade sejam indissociáveis (Silva \& Porto, 2003).

O Jaguaré é tributário do canal inferior do rio Pinheiros, que compreende o trecho que parte da barragem da traição até sua foz no rio Tietê. A barragem da traição foi inaugurada em 1940 com o intuito de bombear as águas do rio Pinheiros para o reservatório Billings e em seguida para o reservatório do rio das pedras para 
garantir a geração de energia na usina de Henry Borden (EMAE, s/d). Atualmente, devido ao elevado grau de degradação das águas do rio Pinheiros, a reversão de seu fluxo só é realizada para controle de inundações (Extravasamento do NA máximo do canal) em São Paulo, a fim de preservar a qualidade das águas do reservatório Billings. O canal inferior do rio Pinheiros tem como característica principal uma alta densidade demográfica, abrigando em suas margens, áreas comerciais e de elevado valor imobiliário. Os principais tributários do canal neste trecho são os córregos Água espraiada, Traição, Sapateiro, Sumidouro, Corujas, Pirajussara e Jaguaré. Grande parte da malha hídrica da bacia encontra-se canalizada em galerias subterrâneas. A llustração 80 mostra o canal inferior do rio Pinheiros e seus tributários.

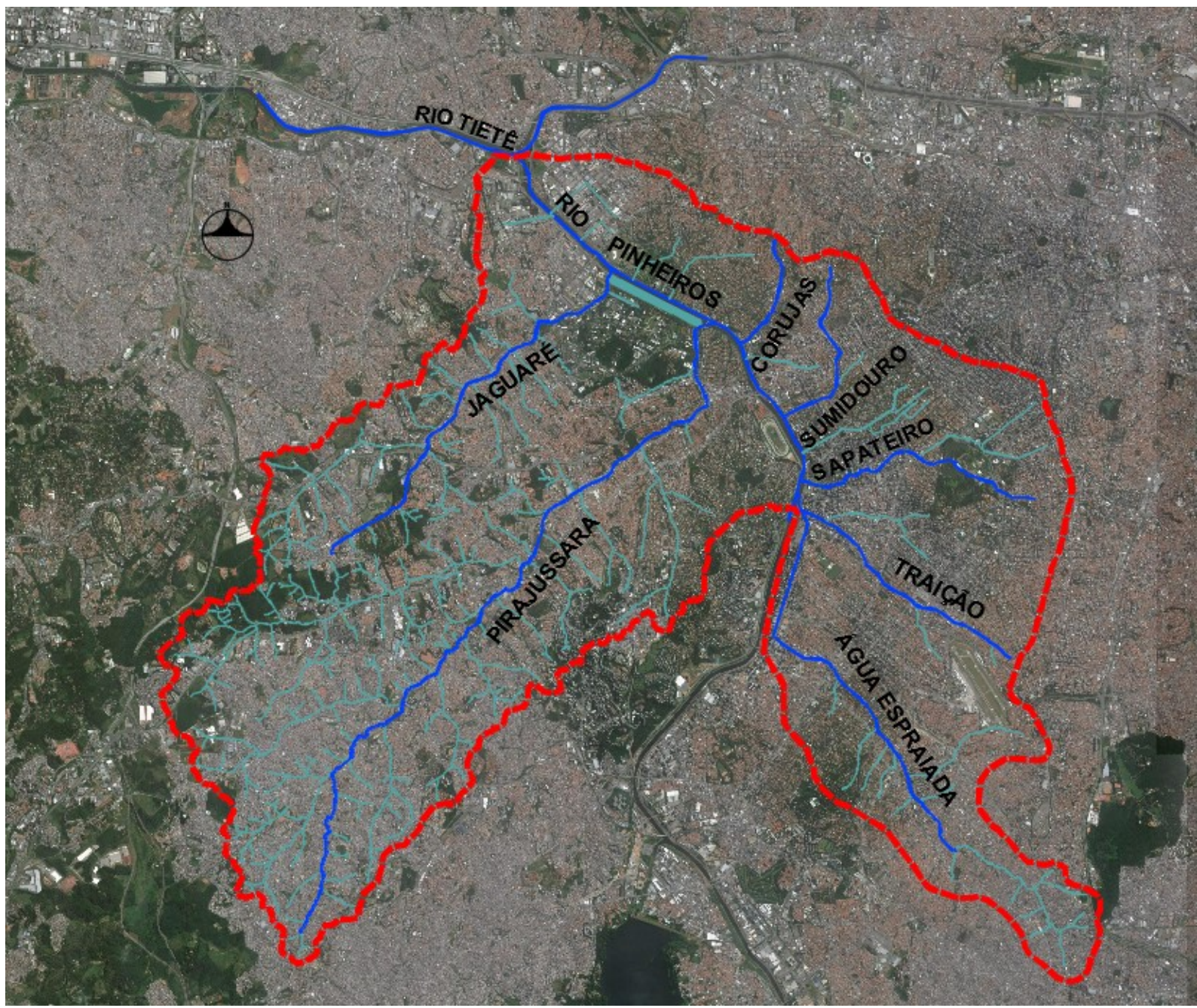

Ilustração 80 - Bacia do Canal Inferior do Rio Pinheiros. Fonte: Elaborado pela autora.

As bacias dos córregos Jaguaré e Pirajussara são bacias de grande porte e de grande importância sob vários aspectos. Do ponto de vista ambiental, as cabeceiras destas duas bacias apresentam canais em relativo bom estado de conservação, com 
importantes remanescentes vegetais. Já do ponto de vista hidrológico, tais bacias contribuem com uma parcela importante da vazão que aflui pelo canal inferior do rio Pinheiros, sendo o manejo de suas águas de extrema importância para o controle de inundações no trecho. $\mathrm{O}$ foco deste estudo será a bacia do Jaguaré. A motivação da escolha se deve principalmente às características geopolíticas da bacia, já que a mesma encontra-se totalmente inserida no município de São Paulo, o que facilita a busca por dados que alimentem o estudo, além de estar situada quase que em sua totalidade na Subprefeitura do Butantã, o que facilita o processo de gestão da bacia.

A bacia do Córrego Jaguaré conta com uma área de contribuição de aproximadamente $28 \mathrm{Km}^{2}$, tendo como principais vias de acesso a Avenida Marginal do Rio Pinheiros e a Rodovia Raposo Tavares. O uso e ocupação do solo predominante é o residencial, havendo ainda uso comercial e uma pequena parcela de indústrias devido à proximidade com a Rodovia Raposo Tavares que é importante via de ligação com o interior e o litoral sul do estado de São Paulo e com o sul do país. A llustração 81 mostra a localização da bacia, suas principais vias de acesso e os principais tributários do córrego Jaguaré.

A bacia do córrego Jaguaré foi objeto do "Projeto piloto para revitalização da bacia do Jaguaré" coordenado pela ONG Águas Claras do Rio Pinheiros e desenvolvido pela Fundação do Centro Tecnológico de Hidráulica da USP (FCTHUSP), com financiamento do Fundo Estadual de Recursos Hídricos (FEHIDRO) durante o ano de 2016, e os dados obtidos no projeto foram utilizados como base em algumas análises desenvolvidas neste estudo.

O córrego Jaguaré atualmente pode ser dividido em três trechos, em função configuração de seu canal, onde neste estudo serão aplicadas diferentes metodologias para revisão do desenho de seu canal e de seus tributários. Os três trechos serão detalhados a seguir. 


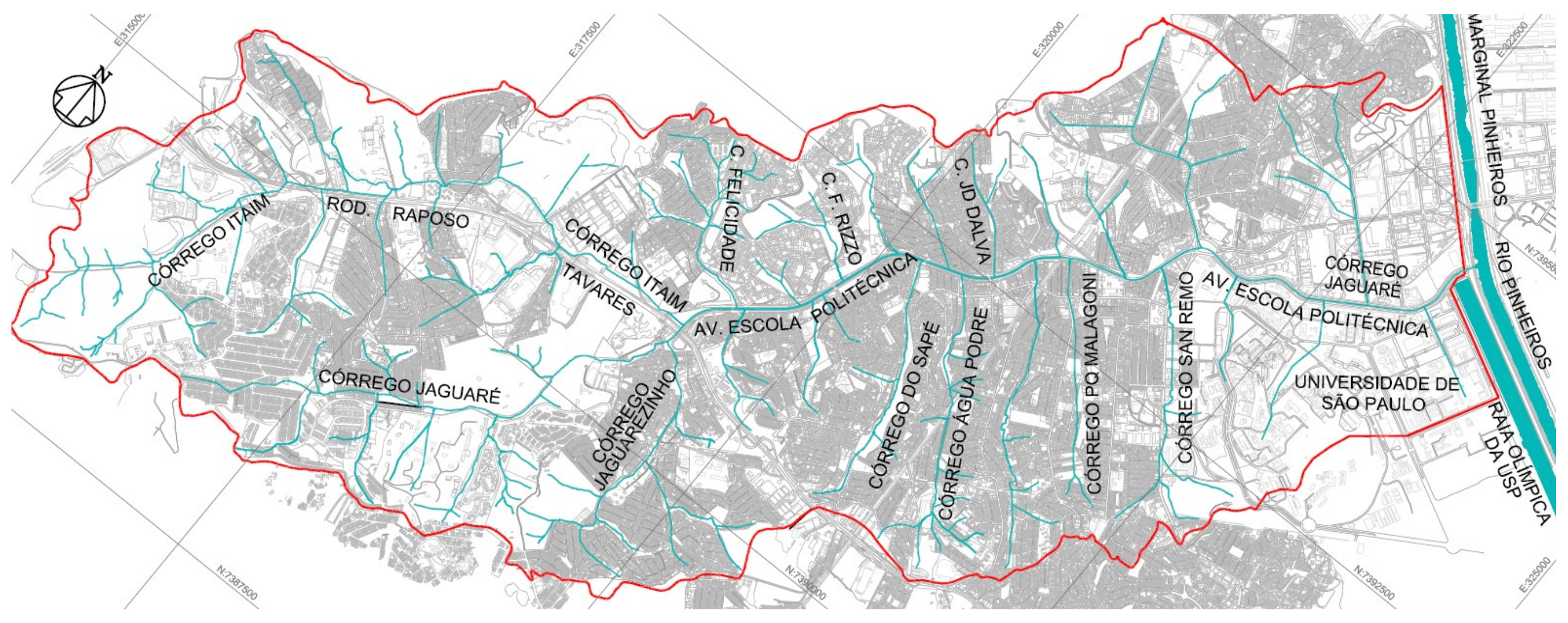

Ilustração 81 - Bacia do córrego Jaguaré, seus afluentes e suas principais vias de acesso. Fonte: Elaborado pela autora. 
O primeiro trecho (Em verde na llustração 85 ) compreende sua cabeceira, que vai até a travessia da Rodovia Raposo Tavares, neste trecho o córrego Jaguaré e seus tributários se encontram em condições menos artificiais, no entanto esta parcela da bacia tem o saneamento básico menos consolidado e os corpos d'água recebem uma elevada carga de poluentes de origem doméstica, como os esgotos de muitas residências não atendidas pelo sistema público de coleta de esgotos, o lançamento de redes coletoras não conectadas a coletores tronco e resíduos sólidos mal geridos na bacia.

A foto A mostra o canal no ponto em que corta o CEU Uirapuru, onde o mesmo encontra-se sem tratamento nas margens e fundo e com vegetação em suas margens; o canal apesar de cortar o terreno do CEU, fica isolado do contato com a população através da presença de muros e grades. Segundo a direção do CEU, o muro e as grades foram instalados para evitar que as crianças que frequentam o CEU não entrem em contato com as águas poluídas; com isso perde-se uma grande oportunidade de utilização do corpo d'água como ferramenta de educação ambiental e reforça-se a ideia de canal de escoamento de esgotos. A foto B mostra o canal no ponto próximo ao cemitério Israelita, onde o mesmo apresenta neste trecho tratamento de seu talude em caixa gabião, revestido de concreto; Neste ponto há a ocorrência constante do extravasamento do NA máximo do canal, resultando no alagamento das casas próximas ao canal, conforme relatado pelos moradores.

A região das nascentes dos tributários do Jaguaré possui áreas bem preservadas, como é o caso da área próxima à Cohab Educandário (Foto $\mathrm{C}$ ) que recentemente foi convertida em parque. A área possui mata densa em que se encontram tributários do Jaguaré em situação preservada e com águas de boa qualidade. Outra importante área é a parcela do Parque Tizo que corresponde à bacia do Jaguaré (Foto D1 e D2). O parque foi criado em 2006 e tem grande importância ambiental, pois protege uma grande área de remanescente de mata atlântica, abrigando diversas espécies vegetais e animais. No limite do parque há uma área de interesse social, a Vila Nova Esperança, cuja população não é atendida por redes coletoras de esgoto, representando um grande risco para a qualidade ambiental dos corpos d'água no interior do parque. A Foto $E$ mostra a ocupação irregular recente (Barracos de madeira) sobre o Córrego Itaim. 

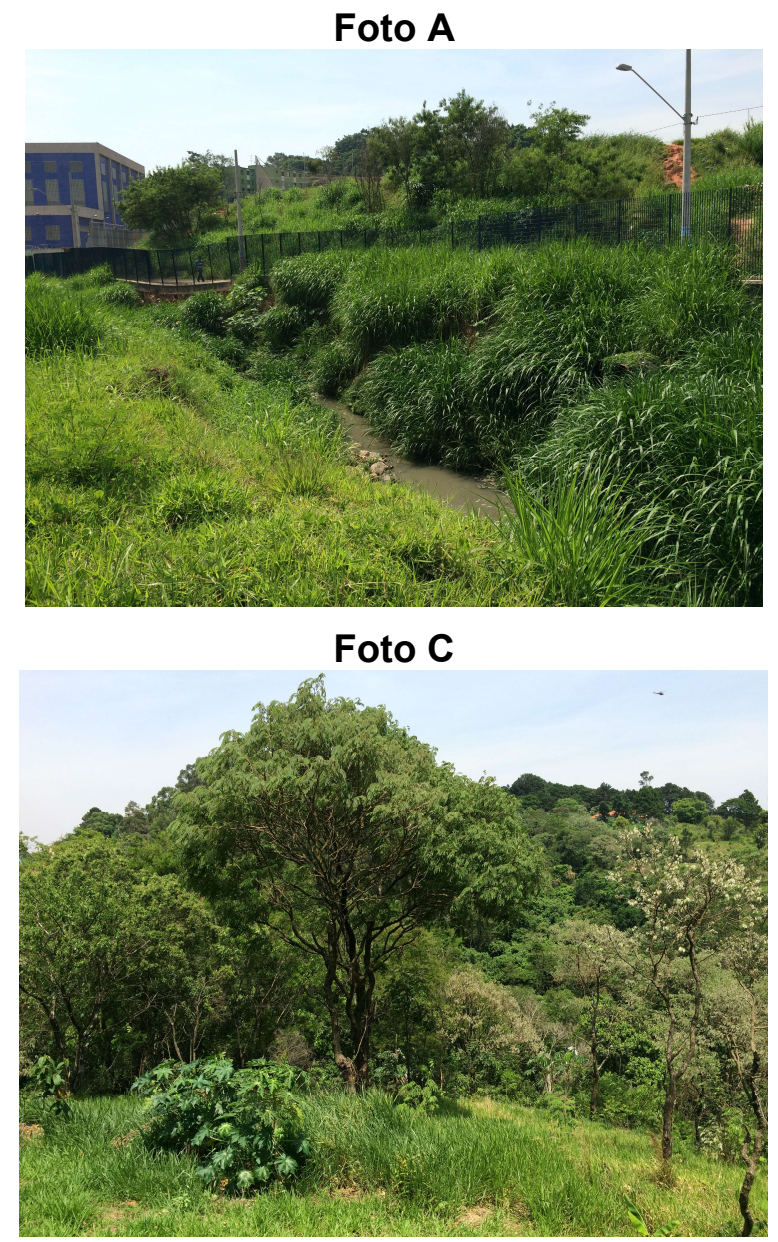

Foto D2

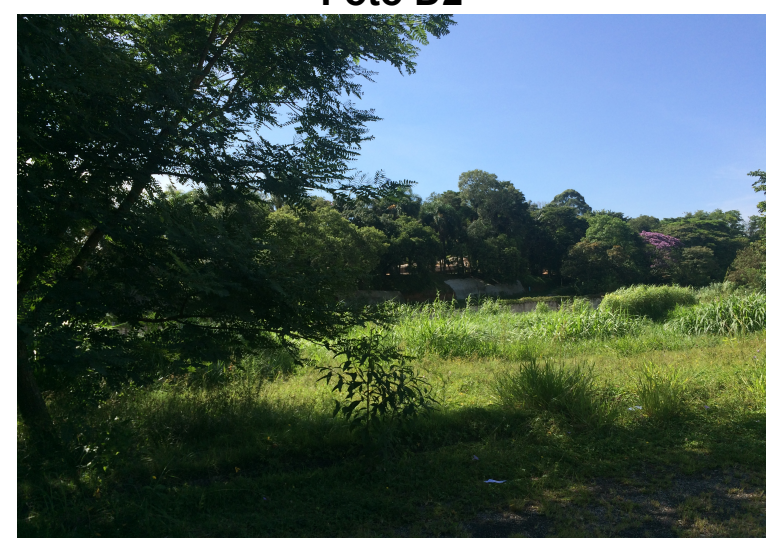

Foto B

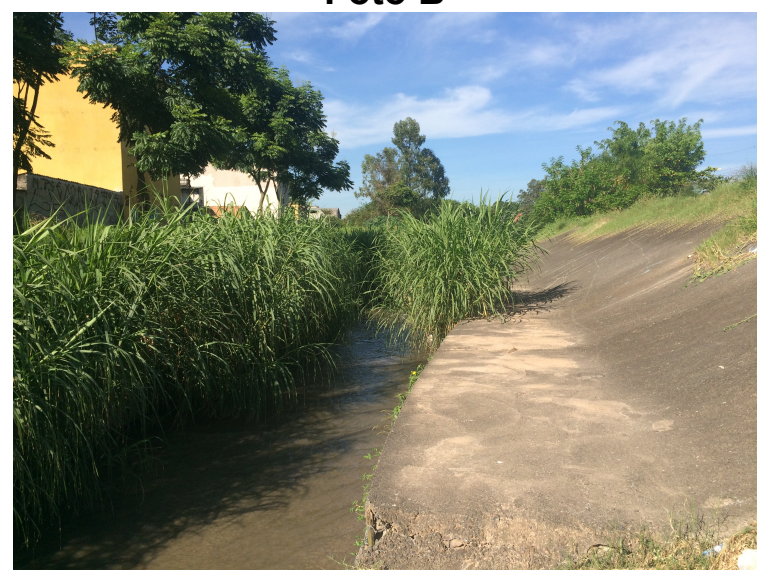

Foto D1

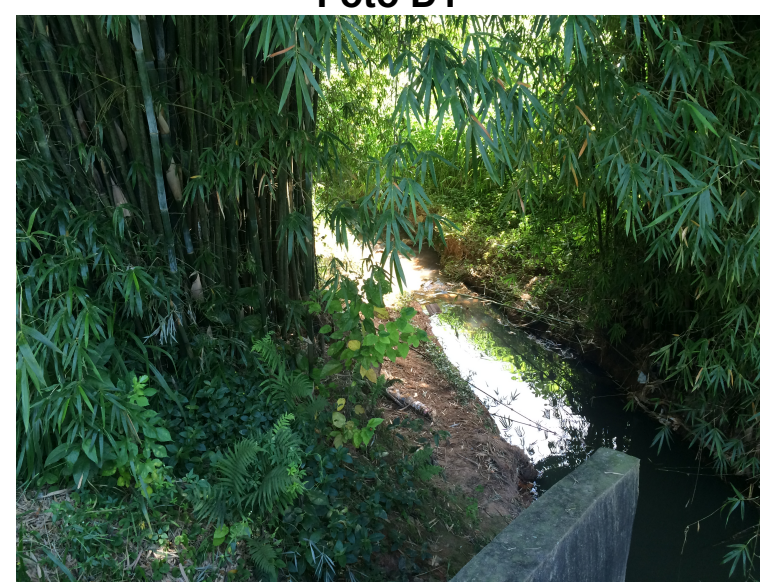

Foto $\mathrm{E}$

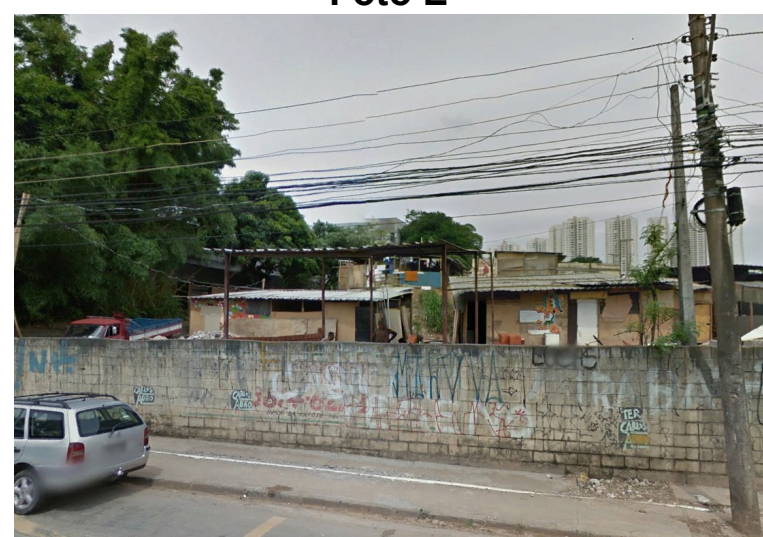

Ilustração 82 - Trechos da bacia do Jaguaré - Fotos A a D. Fonte: Fotos da autora.

O segundo trecho (Em vermelho na llustração 85 ), compreendido desde a travessia da Rodovia Raposo Tavares até pouco antes do cruzamento da Avenida Politécnica com a Avenida Corifeu de Azevedo Marques, se encontra aberto, mas canalizado em uma galeria retangular de concreto, com canteiro arborizado em suas margens, conforme mostrado nas fotos F e G. Neste trecho a bacia tem a ocupação mais consolidada, com redes coletoras de esgotos recepcionadas em sua grande 
maioria por coletores tronco que conduzem os efluentes para estação de tratamento de Barueri e sistema de coleta de lixo mecanizado através da disposição de caçambas ao longo da bacia. Os tributários deste trecho encontram-se em sua grande maioria canalizados em galerias subterrâneas, com exceção de alguns córregos que encontram-se abertos, mas sob forte influência de ocupações irregulares em suas margens (Fotos $\mathrm{H} 1$ e H2), como é o caso do córrego Água podre, Pq. Malagoni e San Remo.

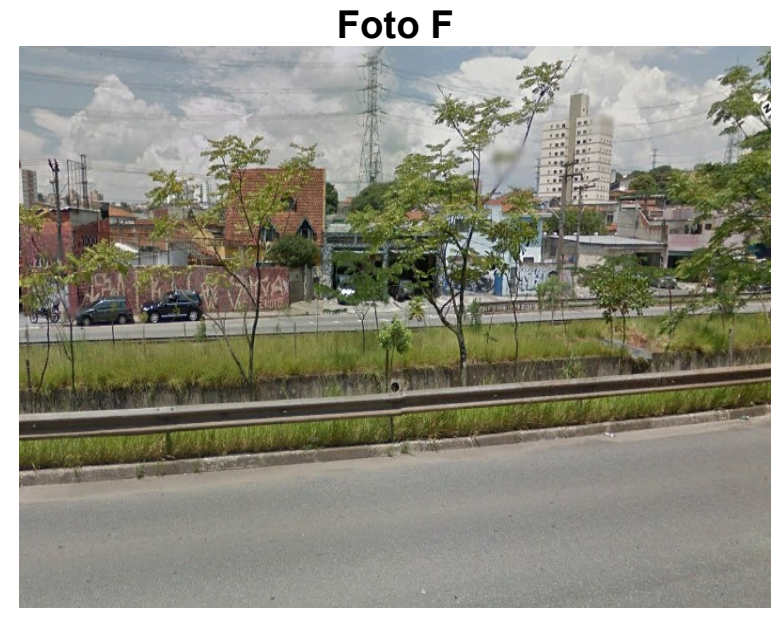

Foto $\mathrm{H} 1$

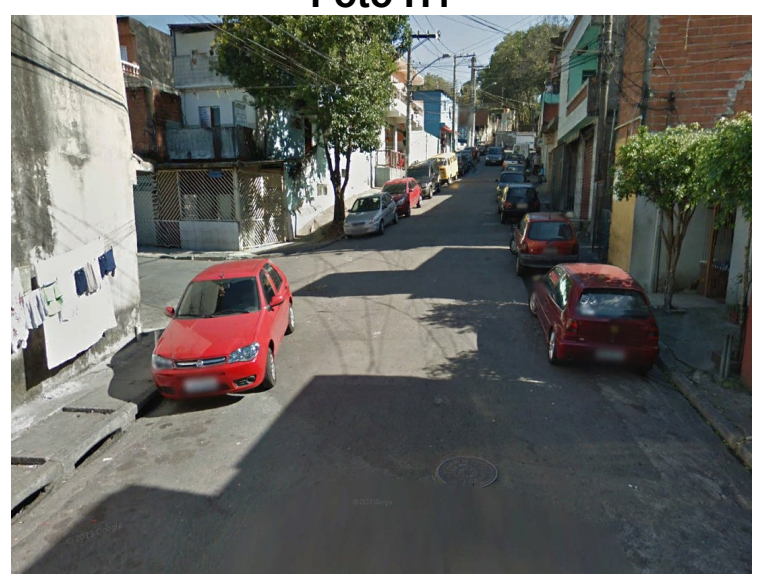

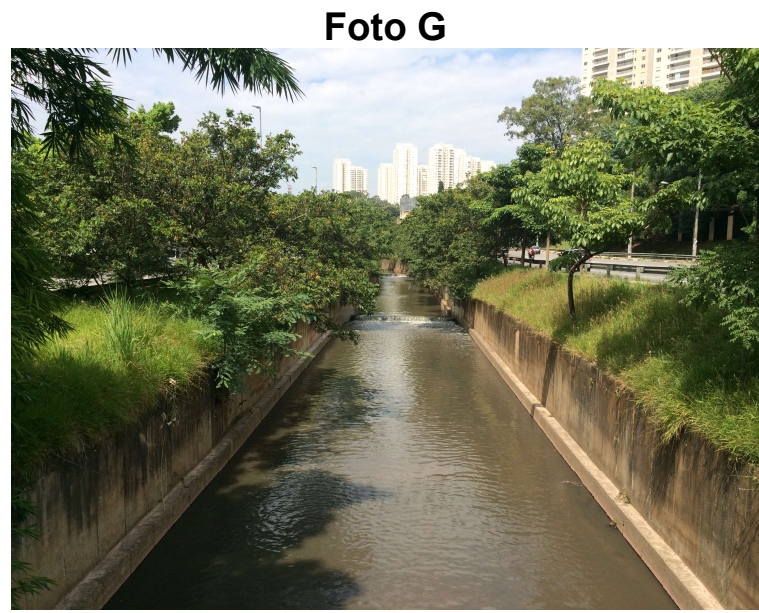

Foto $\mathrm{H} 2$

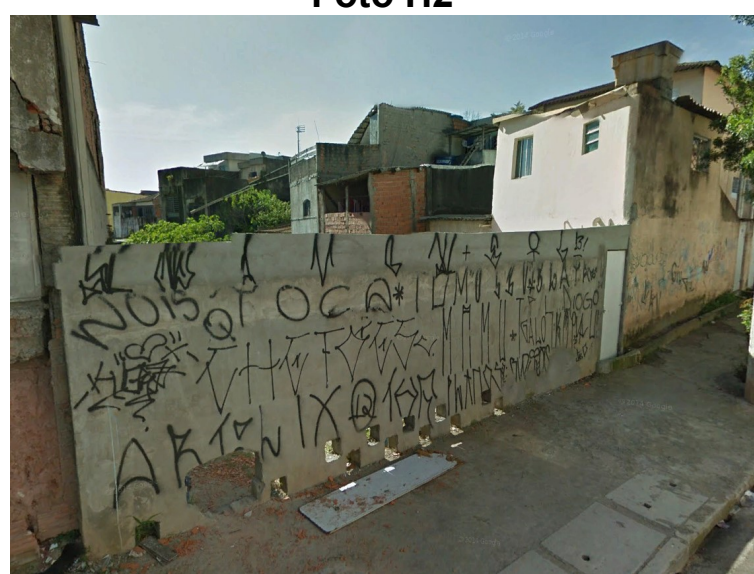

Ilustração 83 - Trechos da bacia do Jaguaré - Fotos F a H. Fonte: Fotos da autora.

Por fim, no terceiro trecho (Em laranja na llustração 85 ) o canal encontra-se fechado em galeria de concreto retangular até sua foz no Rio Pinheiros, a área do canal é ocupada por um canteiro central arborizado, que abriga desde 2015 uma ciclovia, que garante alguma circulação de ciclistas e pedestres pela área, conforme mostrado nas fotos J1, J2. Na Foto I é mostrado o trecho que compreende a rotatória do Extra Jaguaré, que apesar de bem arborizada apresenta pouco uso pela população. A Foto $L$ mostra um dos acessos para manutenção do córrego, que são 
ocupados muitas vezes por moradores de rua. Por fim as Fotos M1 (Vista da Av. Escola Politécnica) e M2 (Vista da Ciclovia da Marginal Pinheiros) mostram a foz do Jaguaré. A bacia neste trecho tem ocupação mais antiga, com remanescentes industriais e comerciais que nos últimos anos tem dado lugar a grandes empreendimentos imobiliários residenciais, além disso, a quase totalidade de seus tributários encontra-se canalizados em galerias subterrâneas. A llustração 85 mostra a localização do memorial fotográfico na bacia.

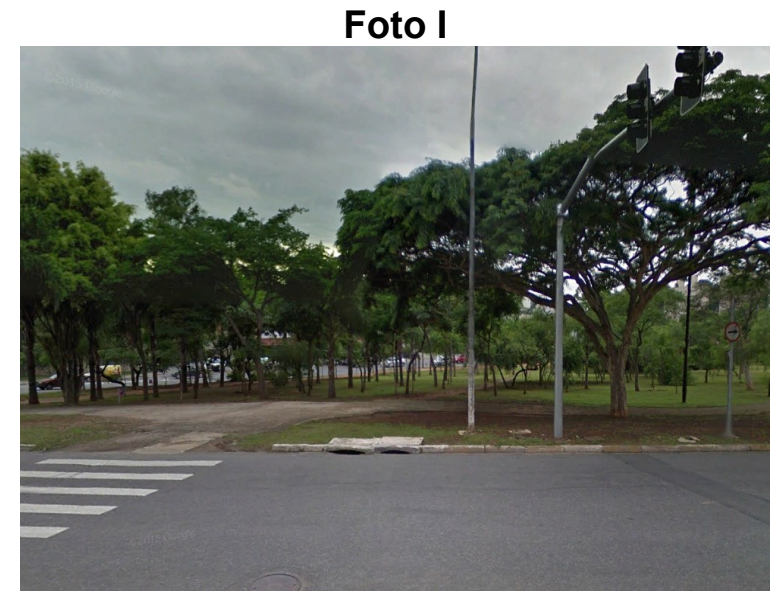

Foto J2

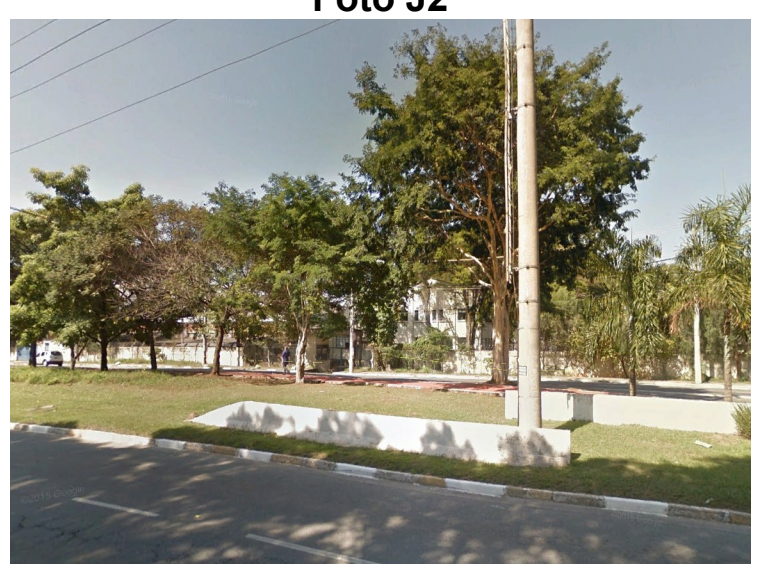

Foto M1

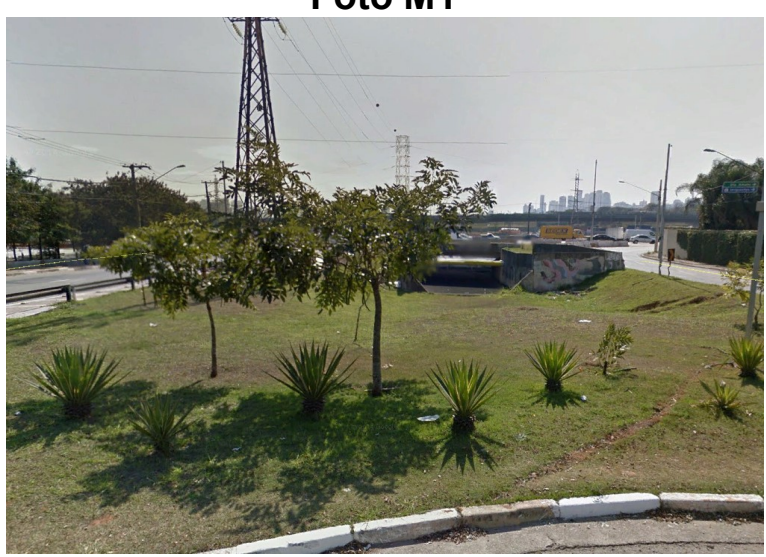

Foto J1

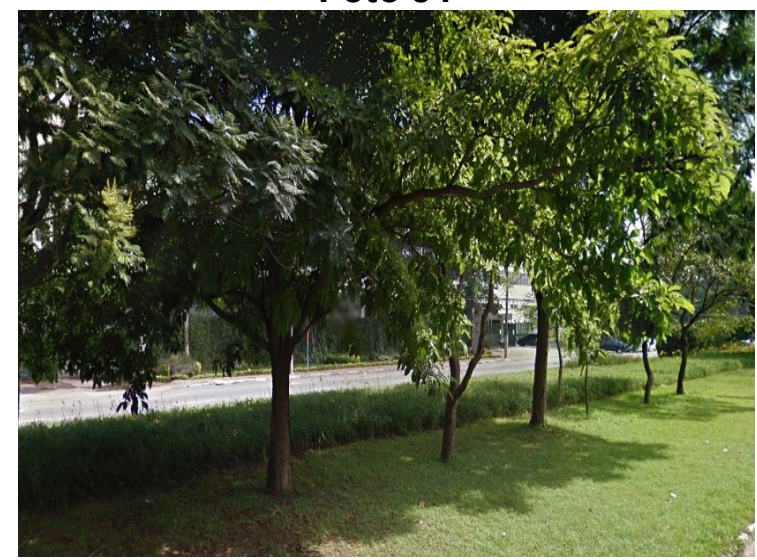

Foto L

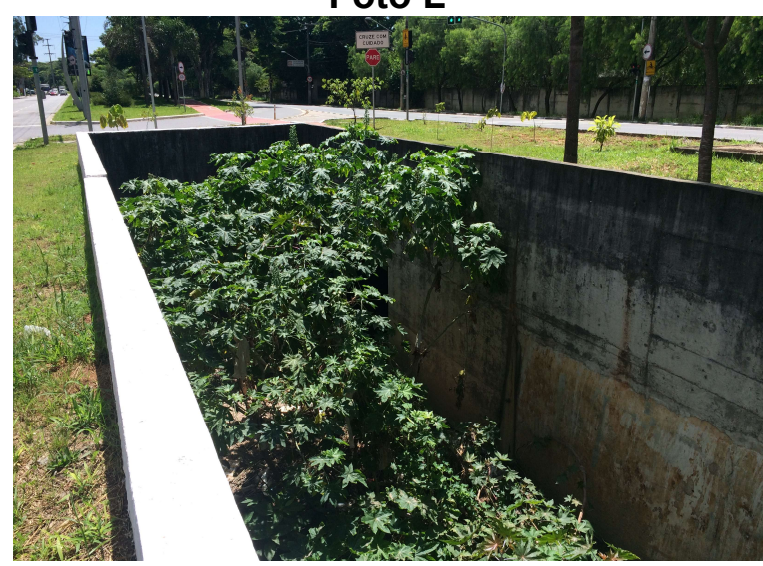

Foto M2

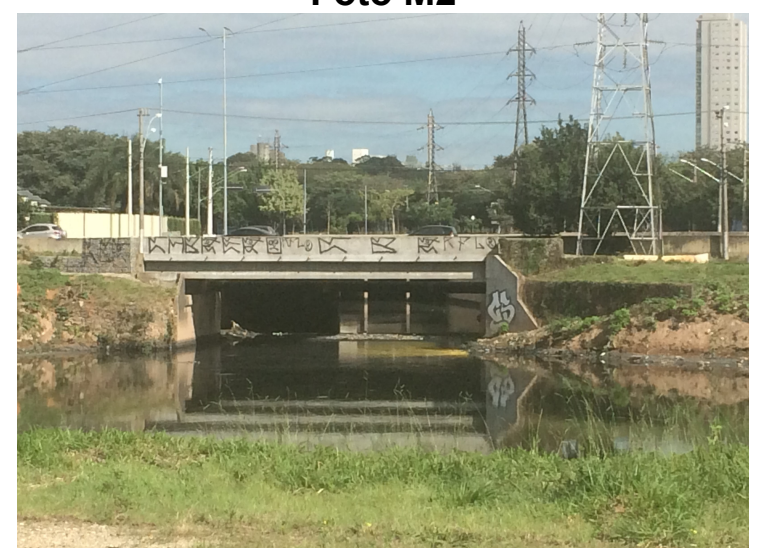

Ilustração 84 - Trechos da bacia do Jaguaré - Fotos I a M. Fonte: Fotos da autora. 


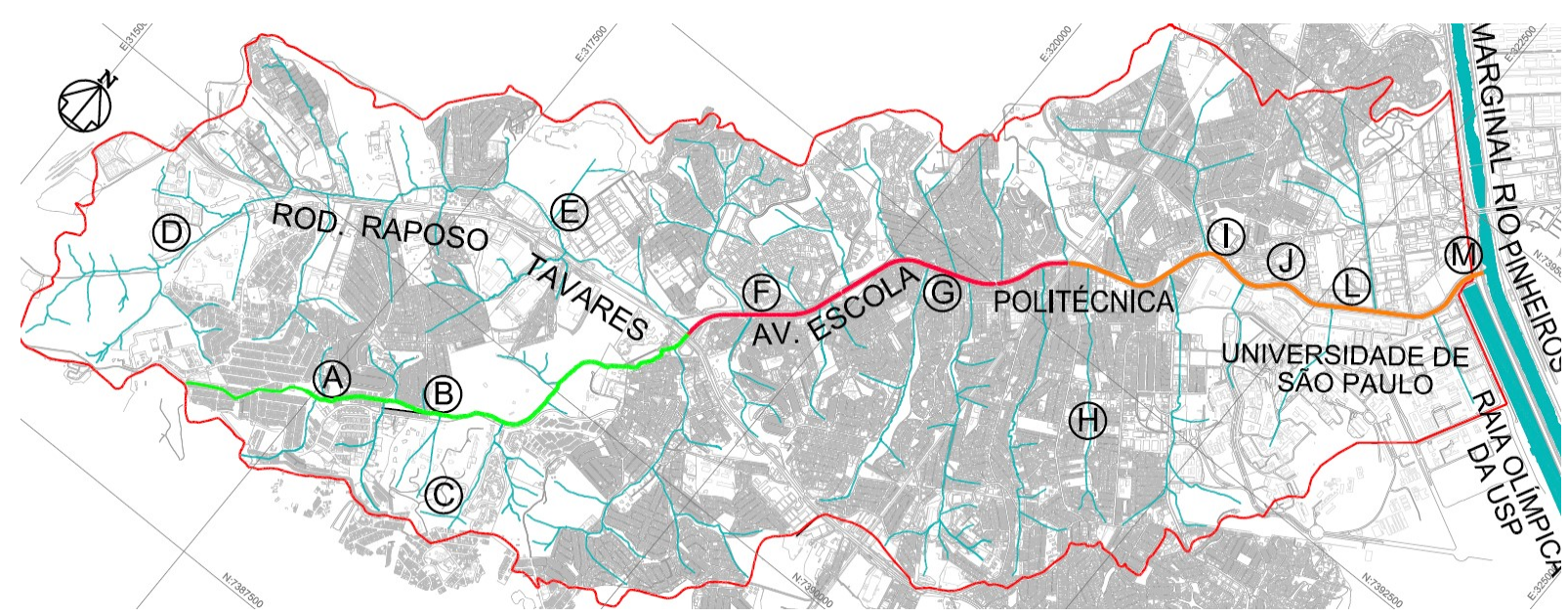

Ilustração 85 - Localização dos pontos referentes ao memorial fotográfico. Fonte:

Elaborado pela autora.

\subsubsection{Uso e ocupação do solo}

A partir de imagens aéreas de março de 2016 e da classificação de uso do solo da EMPLASA, foi produzido o mapa de uso e ocupação do solo da bacia que dará suporte ao estudo da produção de carga difusa nas parcelas. Foram identificados os seguintes usos do solo na bacia: Residencial (Subdividido em: Favelas, prédios, casas contínuo e descontínuo; Comercial (Subdividido em: Contínuo e Descontínuo); Industrial (Subdividido em: Contínuo e Descontínuo); Espaços verdes urbanos; e Rede viária, conforme mostrado na llustração 86 a seguir. De forma geral a bacia possui a seguinte composição dos usos levantados, apresentada na Tabela 8 . Adotou-se contínuo quando não havia espaços permeáveis no interior dos lotes e descontínuo quando havia.

Tabela 8 - Usos do solo na bacia do Jaguaré. Fonte: Elaborado pela autora.

\begin{tabular}{|c|c|c|}
\hline Descrição & Área $\left(\mathrm{Km}^{2}\right)$ & $\%$ \\
\hline Espaços Verdes Urbanos & 7,576 & 26,9 \\
\hline Prédios & 1,698 & 6,0 \\
\hline Casas - Contínuo & 2,250 & 8,0 \\
\hline Casas - Descontínuo & 6,467 & 22,9 \\
\hline Favelas & 0,780 & 2,8 \\
\hline Comércio e Serviços - Contínuo & 0,499 & 1,8 \\
\hline Comércio e Serviços - Descontínuo & 2,998 & 10,6 \\
\hline Industrial - Contínuo & 1,150 & 4,1 \\
\hline Industrial - Descontínuo & 1,149 & 4,1 \\
\hline Viário & 3,646 & 12,9 \\
\hline Bacia total & 28,213 & $\overline{100,0}$ \\
\hline
\end{tabular}




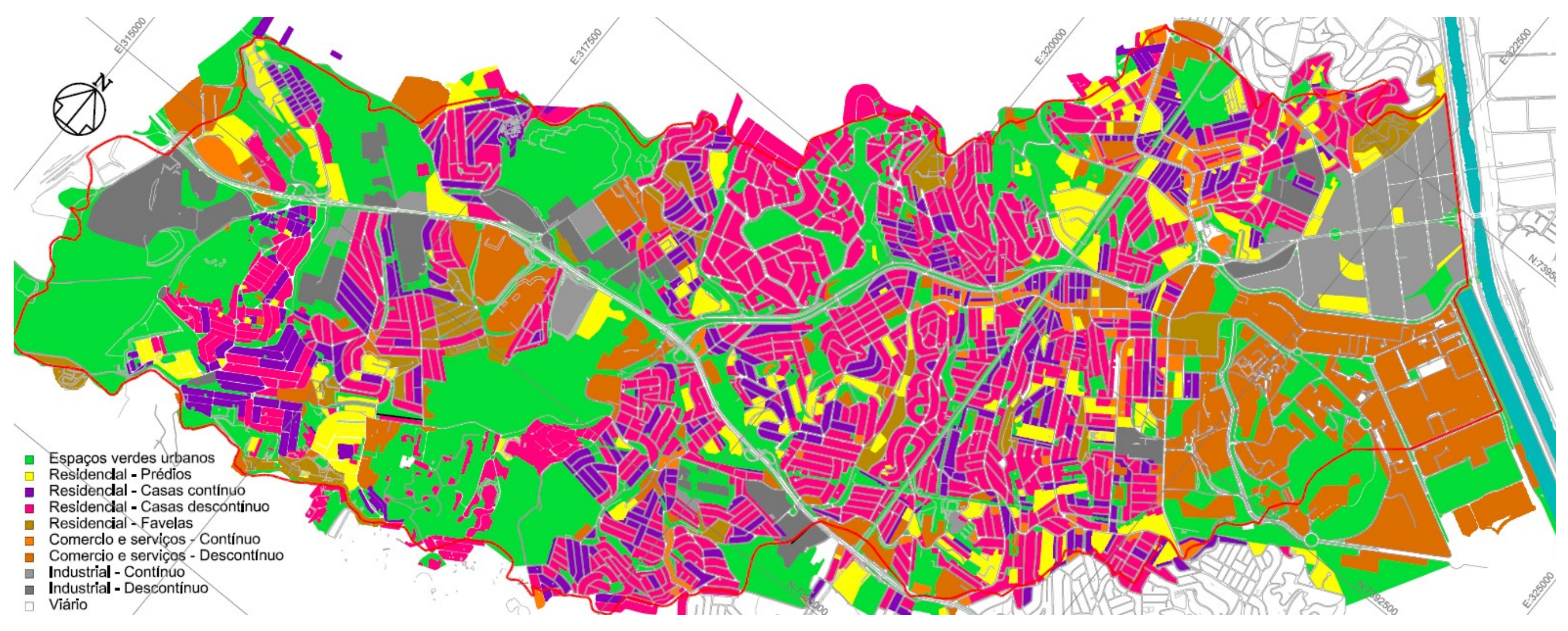

Ilustração 86 - Uso e ocupação do solo na bacia do córrego Jaguaré. Fonte: Elaborado pela autora. 
Constata-se que a bacia é predominantemente residencial, com 39,7\% de uso residencial (Prédios, casas e favelas); Além disso, há uma parcela importante de espaços verdes urbanos de $26,9 \% ; 8,1 \%$ de uso industrial; $12,4 \%$ de comércio e serviços e $12,9 \%$ de viário. A presença de taxa tão elevada de espaços verdes na bacia, garante à mesma um elevado potencial para implantação de estruturas não convencionais para amortecimento da vazão de pico. No entanto essas áreas demandam atenção especial já que estão constantemente ameaçadas pela especulação imobiliária e por ocupações irregulares. O Plano Diretor Estratégico de São Paulo define a zona das cabeceiras da bacia como macrozona de proteção e recuperação ambiental e classifica as macroáreas como de controle e qualificação urbana e ambiental e de vulnerabilidade urbana e de recuperação ambiental, para que esse zoneamento se cumpra é necessária ação constante da prefeitura.

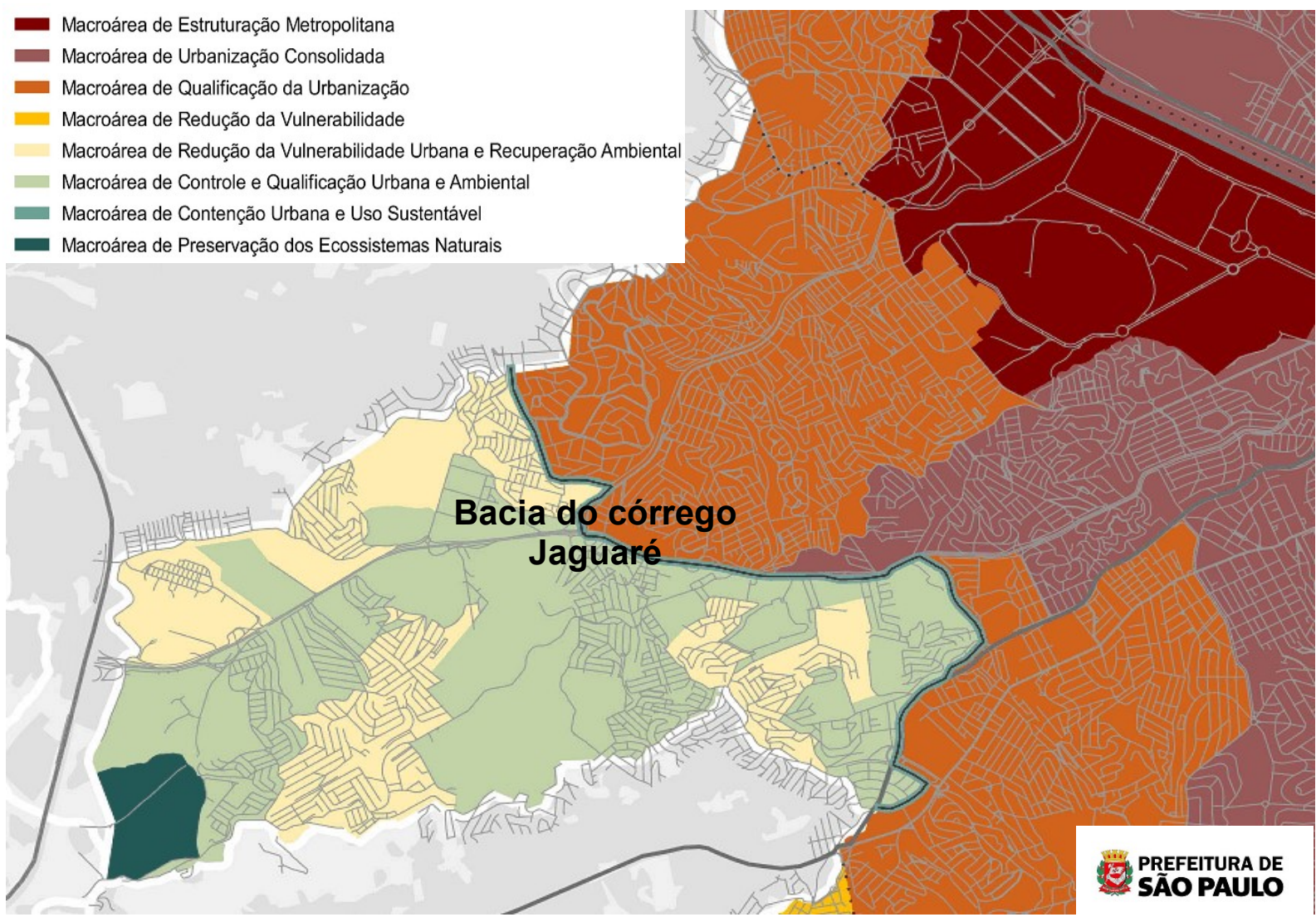

Ilustração 87 - Macrozonas na Bacia do Jaguaré. Fonte: PDESP (2014).

Apesar da classificação do PDESP, no âmbito do "Projeto Jaguaré" foi realizada a caracterização da distribuição da população na bacia e a projeção do crescimento populacional, mostrados na llustração 88 , que revelou uma tendência de adensamento populacional na bacia principalmente nas suas cabeceiras na projeção para 2050. 


\section{População atual}
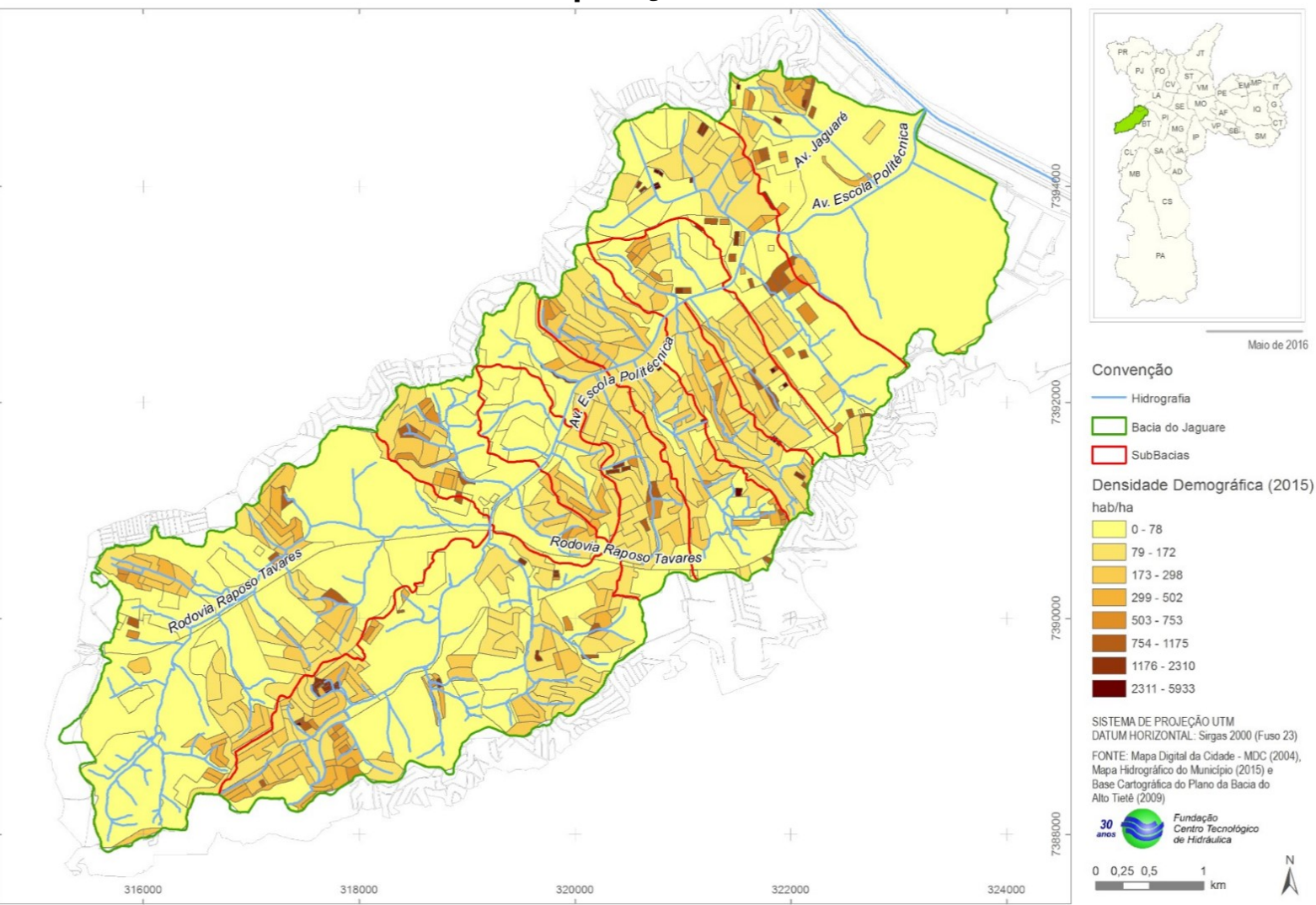

Projeção para 2050

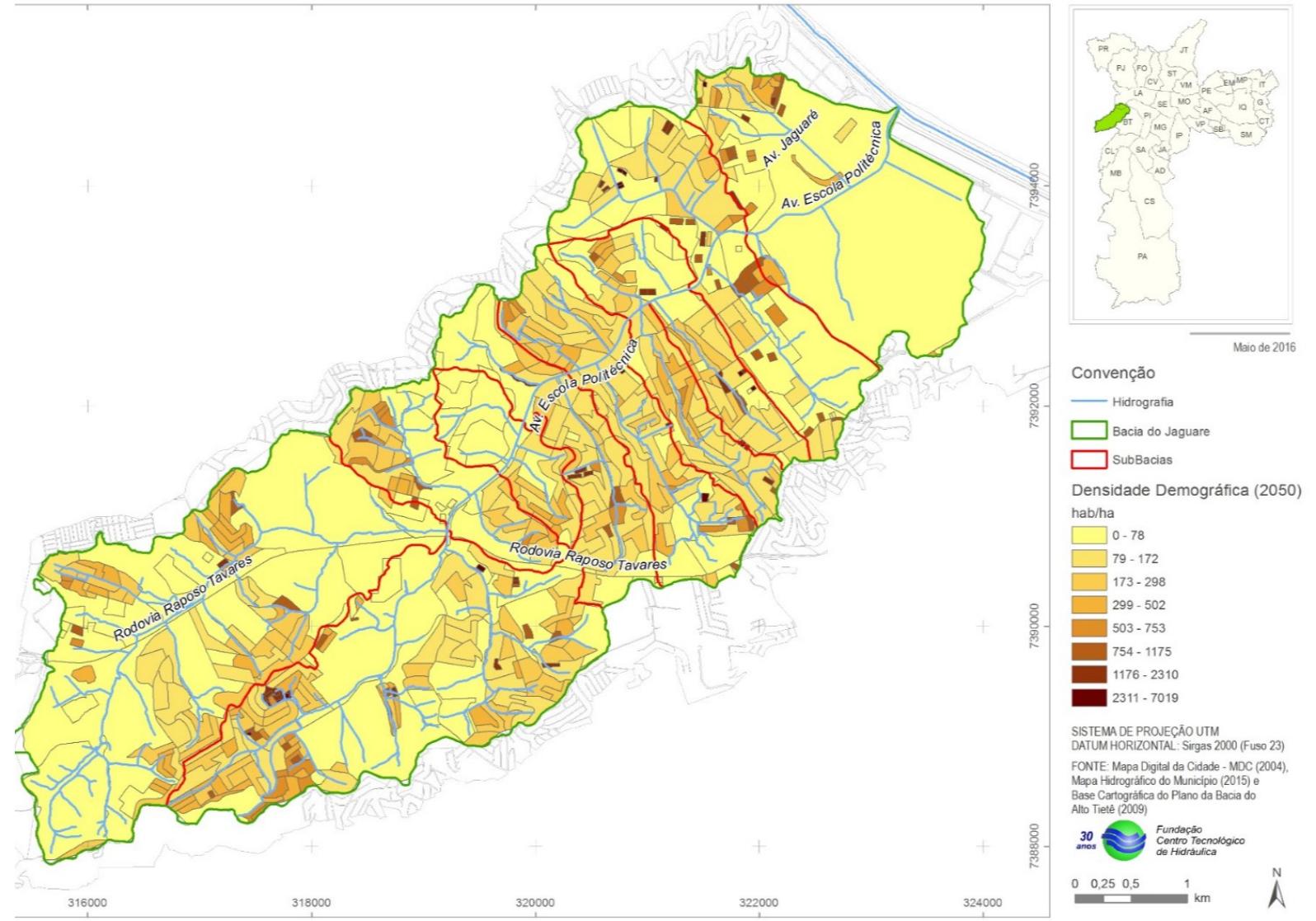

Ilustração 88 - Evolução do crescimento populacional na bacia do Jaguaré. Fonte: Projeto Jaguaré (2017). 


\subsubsection{Características hidráulicas e hidrológicas}

A bacia do Jaguaré encontra-se inserida na zona subtropical, com verões quentes e chuvosos e invernos frios e secos. A análise da precipitação média na bacia, obtida junto ao Sistema de Alerta a Inundação de São Paulo (SAISP), revela que as precipitações máximas na bacia são registradas entre novembro e fevereiro e as mínimas entre maio e julho, conforme mostrado na llustração 89 que mostra a precipitação média registrada nos postos da bacia entre janeiro de 2009 e fevereiro de 2012.

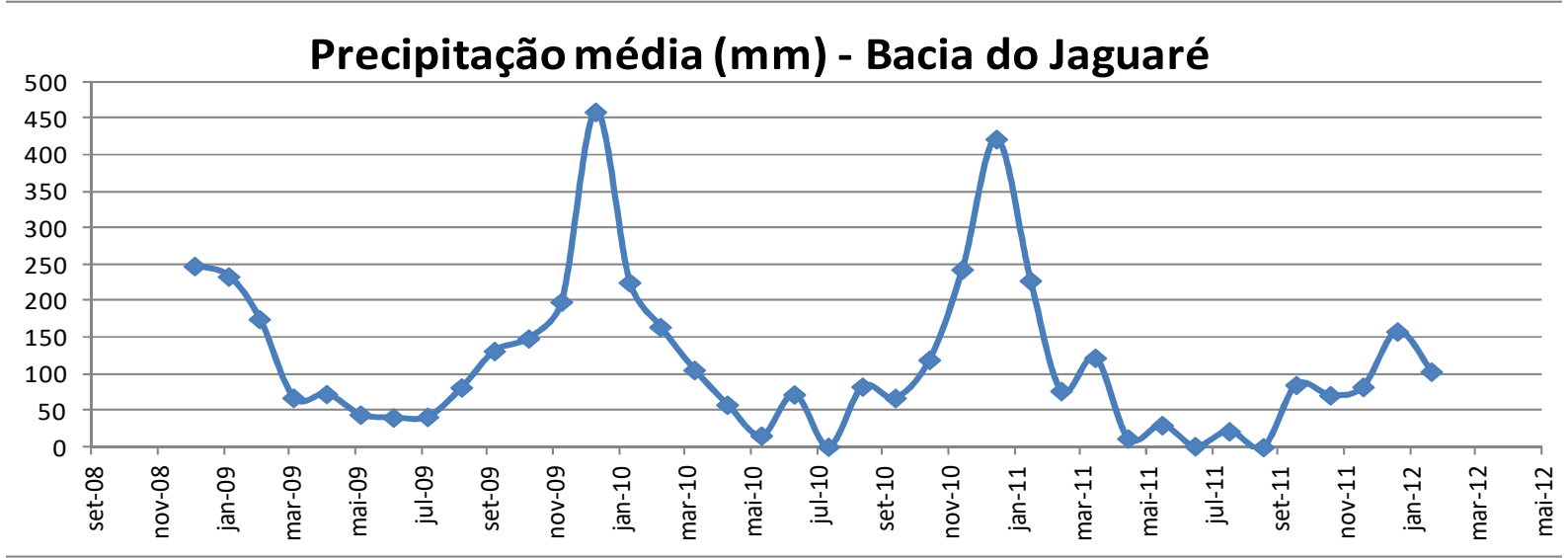

Ilustração 89 - Precipitação média na Bacia do Jaguaré. Fonte: Elaborado pela autora a partir de SAISP (s/d).

Devido ao excesso de áreas impermeáveis e às características naturais de concentração da precipitação no verão, a bacia sofre com a inundação de alguns canais e alagamento de ruas devido à saturação do sistema de drenagem (Fenômeno que é ainda mais exacerbado devido à entupimentos nos dispositivos de drenagem devido à má gestão de resíduos sólidos na bacia), demandando estudos específicos para a bacia que resultem em soluções para estes pontos vulneráveis. A llustração 90 mostra dois eventos de alagamento em dois pontos da bacia no período chuvoso de 2016. 


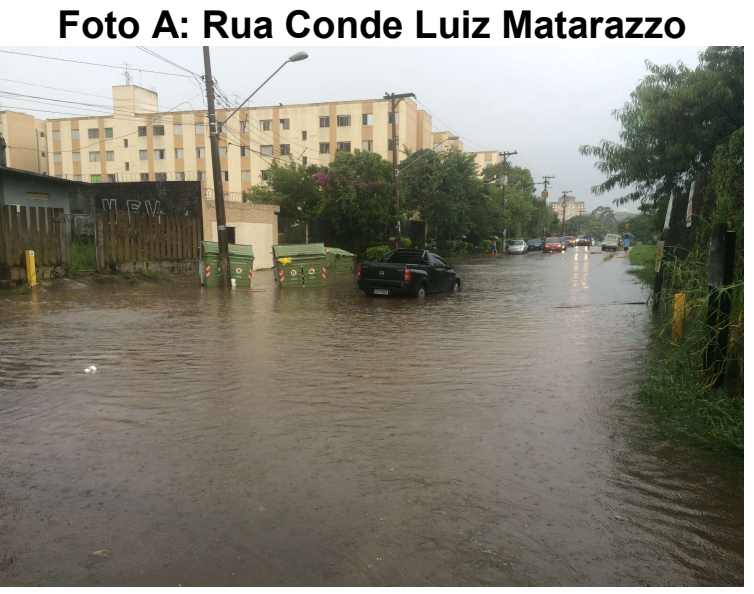

Foto B: Rua Pe. Francisco Libermann

Ilustração 90 - Pontos de alagamento na bacia do Jaguaré no período chuvoso de 2016. Fonte: Fotos da autora.

Foi elaborado em 2013 o terceiro Plano Diretor de Macrodrenagem da Bacia do Alto Tietê (PDMAT 3), onde foi realizado o estudo do atual sistema de macrodrenagem da bacia do Alto Tietê a fim de identificar os pontos vulneráveis do sistema e propor um conjunto de soluções para redução dos efeitos das cheias para um horizonte de projeto de cinco, dez e vinte anos. A llustração 91 mostra os resultados obtidos no plano para diferentes manchas de inundação no rio Pinheiros próximo à foz do córrego Jaguaré.

As soluções propostas seguem dois eixos, ações estruturais e não estruturais. Nas ações estruturais estão agrupadas as seguintes intervenções: Bacias de detenção (Piscinões), reservatórios subterrâneos, desvio de excedente de vazão através de túnel, alargamento da seção de canal, pôlderes e aumento da declividade de cursos d'água. Já nas ações não estruturais estão agrupadas as seguintes intervenções: controle da taxa de ocupação e impermeabilização, promoção de áreas livres e da arborização, aproveitamento das águas pluviais e controle da produção de sedimento (PDMAT3, 2013).

Segundo o PDMAT3 (2013), a calha do rio Pinheiros funciona como um grande reservatório durante os eventos de precipitação intensa, portanto as intervenções previstas se baseiam no aumento da capacidade de bombeamento das estações elevatórias de Pedreira e Traição. Além disso, estudou-se no plano a bacia do córrego Pirajussara, sendo propostas intervenções em sua calha. 


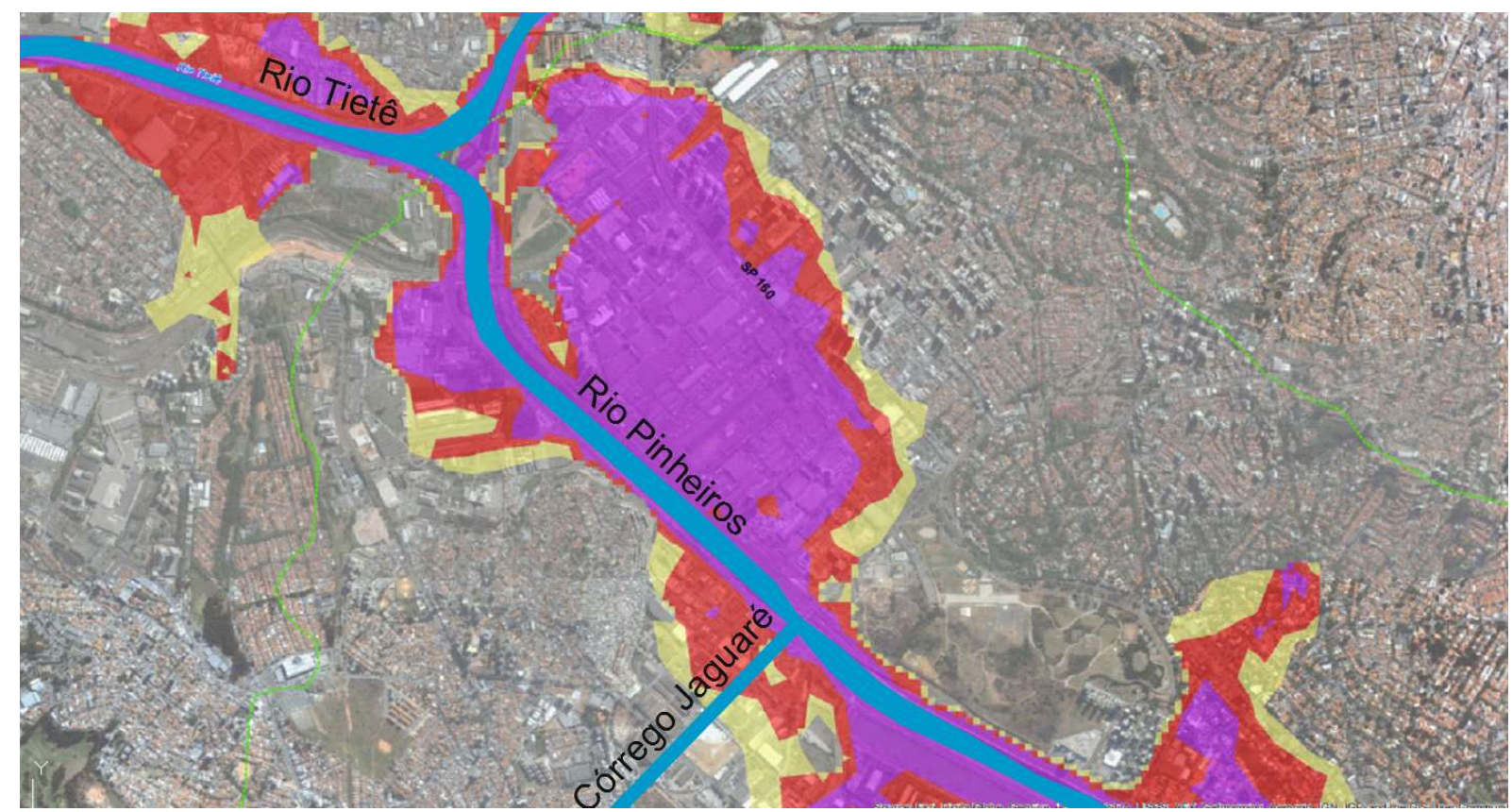

\section{LEGENDA}

Niveis de Alerta

\begin{tabular}{|c|c|}
\hline Aviso & Profundidades inferiores a $0,5 \mathrm{~m}$ e velocidades inferiores a $0,5 \mathrm{~m} / \mathrm{s}$; \\
\hline Salvamento & $\begin{array}{l}\text { Profundidades iguais ou superiores a } 0,5 \mathrm{~m} \text { e iguais ou inferiores } \\
\text { a } 1,5 \mathrm{~m} \text {, ou velocidades iguais ou superiores a } 0,5 \mathrm{~m} / \mathrm{s} \text { e iguais } \\
\text { ou inferiores a } 1,5 \mathrm{~m} / \mathrm{s} \text {; }\end{array}$ \\
\hline Remoção & Profundidades superiores a $1,5 \mathrm{~m}$ ou velocidades superiores a $1,5 \mathrm{~m} / \mathrm{s}$. \\
\hline
\end{tabular}

Ilustração 91 - Estudo da mancha de inundação no trecho do rio Pinheiros que compreende a foz do Jaguaré. Fonte: PDMAT 3 (2013).

A bacia do Jaguaré possui uma rica malha hídrica, no entanto boa parte dos corpos d'água encontram-se canalizados em galerias subterrâneas, principalmente os pequenos tributários. Segundo levantamento realizado, da malha hídrica de 95km, 65\% encontra-se canalizada em galerias subterrâneas e dos 35\% restante, somente uma pequena parcela, dentro dos remanescentes vegetais, encontra-se em condições próximas as naturais, a grande maioria dos canais abertos encontram-se em condições artificiais, com suas calhas tratadas com diferentes materiais, como gabião, concreto e manta.

A llustração 92 mostra a situação da malha hídrica na bacia com relação ao tratamento apresentado pelos canais, em azul claro os canais abertos e em azul escuro os canais em galeria subterrânea; além disso, é possível observar os pontos de monitoramento de precipitação operados pelo SAISP. 


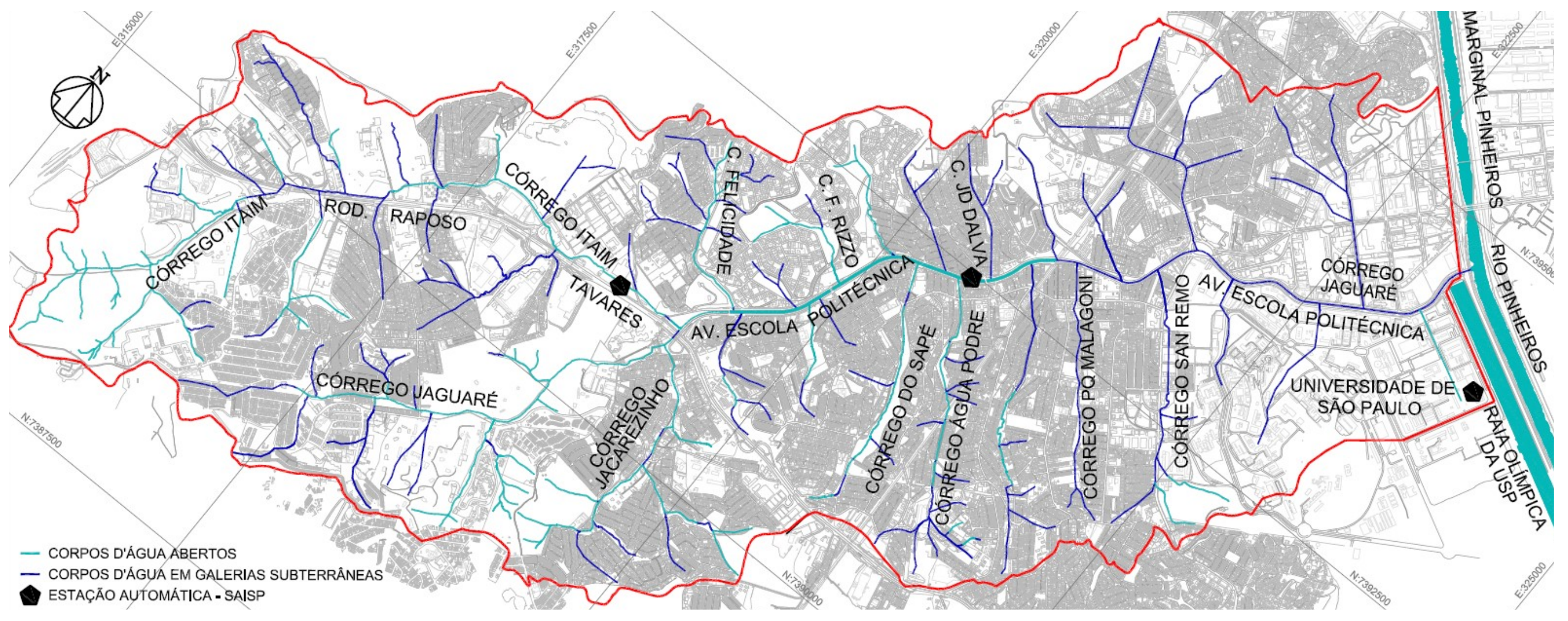

llustração 92 - Corpos d'água abertos (Azul claro) e em galeria subterrânea (Azul escuro) na bacia do Jaguaré. Fonte: Elaborado pela autora. 
Além disso, na bacia existem diversas nascentes, sendo muitas delas utilizadas pela população para diversas finalidades, como recreação, lavagem de automóveis e coleta de água para usos residenciais não potáveis, se tornando uma importante fonte de atenção no que se refere à doenças de veiculação hídrica. A llustração 93 a seguir exemplifica tal realidade ao mostrar dois exemplos de nascente na bacia.
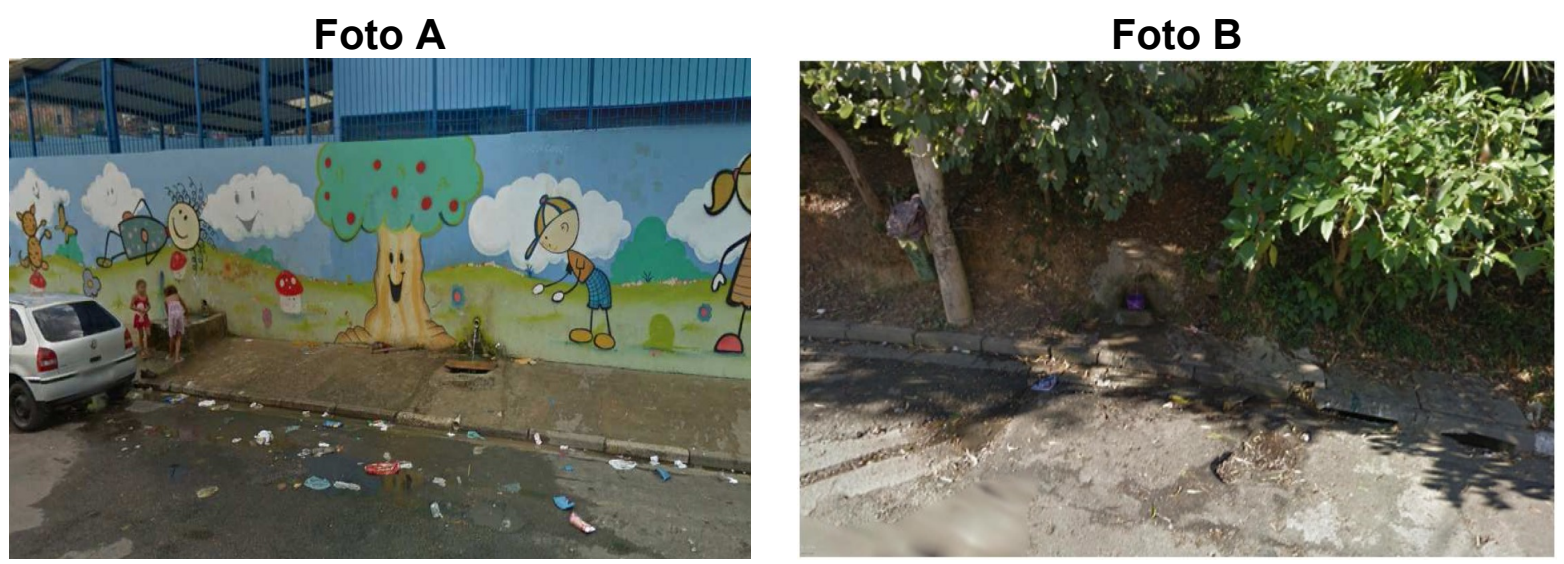

Ilustração 93 - Nascentes na bacia do Jaguaré. Fonte: Fotos da autora.

Atualmente as águas que fluem destas nascentes escoam livremente pelas sarjetas sendo coletadas pelas galerias de águas pluviais e direcionadas para os corpos d'água da bacia, ou seja, as águas das nascentes, de melhor qualidade, se juntam às águas contaminadas por cargas pontuais e difusas. Apesar de a população fazer uso de muitas destas nascentes, há muitas outras que no processo de ocupação da bacia foram aterradas, causando danos constantes ao pavimento, demandando manutenção constante por parte da prefeitura, como ocorre com a nascente que aflora na Rua Wlademir Pereira, como mostrado na llustração 94 na Foto $A$ seu afloramento e Foto $B$ danos no pavimento à jusante do afloramento da nascente.
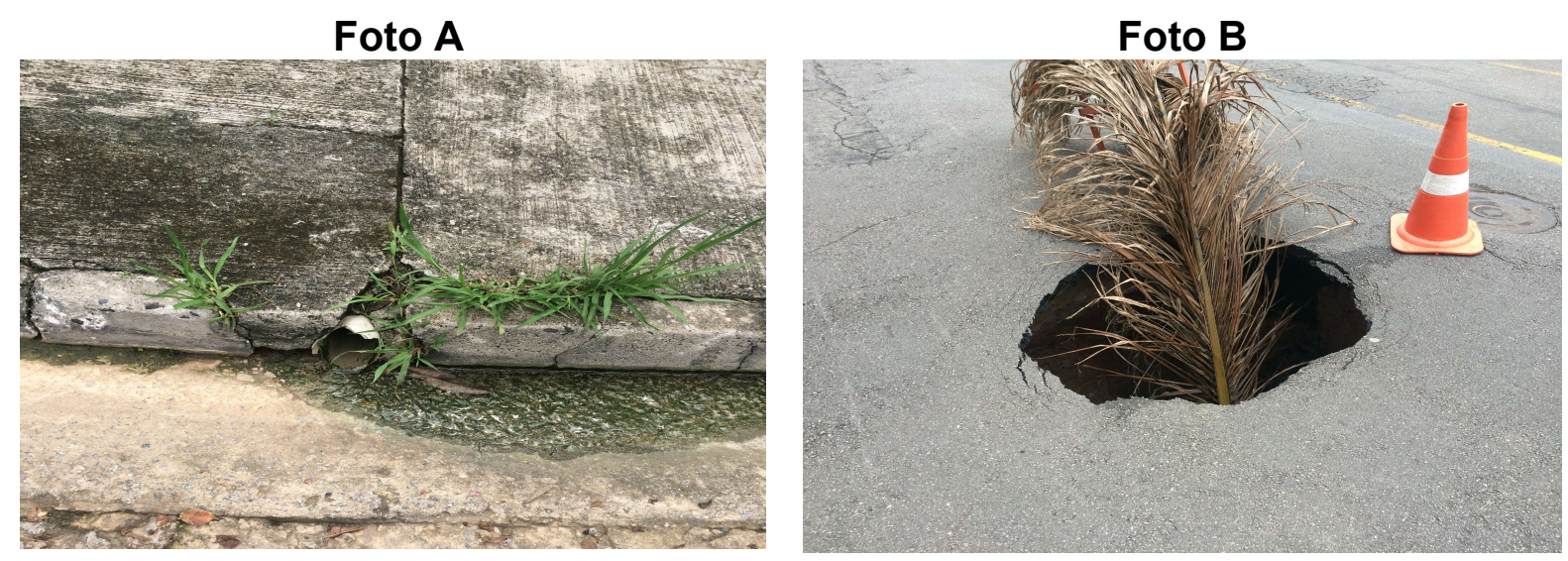

Ilustração 94 - Nascentes ocultas na bacia do Jaguaré. Fonte: Fotos da autora. 
Segundo Davis \& DeWiest (1966), nascente é qualquer descarga realizada pelo aquífero na superfície, que resulte na formação de um fluxo visível, sendo possível classificar estes fluxos segundo sua vazão de descarga, características hidráulicas, estrutura geológica do solo onde ocorre a descarga, qualidade e temperatura da água, sendo mais citadas as classificações segundo sua estrutura geológica e vazão. Segundo a vazão, tais fluxos de água podem ser classificados de primeira a oitava ordem, conforme mostrado na Tabela 9 a seguir.

Tabela 9 - Classificação de nascentes segundo sua vazão. Fonte: Adaptado de Davis \& DeWiest (1966).

\begin{tabular}{cc}
\hline \multicolumn{2}{c}{ Classificação de nascentes segundo sua vazão } \\
\hline Classificação & Vazão \\
\hline Primeira ordem & Maior que $10 \mathrm{~m}^{3} / \mathrm{s}$ \\
\hline Segunda ordem & 1 a $10 \mathrm{~m}^{3} / \mathrm{s}$ \\
\hline Terceira ordem & 0,1 a $1 \mathrm{~m} / 3$ \\
\hline Quarta ordem & 10 a $100 \mathrm{~L} / \mathrm{s}$ \\
\hline Quinta ordem & 1 a $10 \mathrm{~L} / \mathrm{s}$ \\
\hline Sexta ordem & 0,1 a $1 \mathrm{~L} / \mathrm{s}$ \\
\hline Sétima ordem & 10 a $100 \mathrm{~cm}^{3} / \mathrm{s}$ \\
\hline Oitava ordem & Menor que $10 \mathrm{~cm}^{3} / \mathrm{s}$ \\
\hline
\end{tabular}

Além disso, seguindo a estrutura geológica do terreno, as nascentes podem aflorar em: depressões no terreno que acaba expondo o lençol freático $(A)$; no sopé de escarpas, com a passagem do fluxo de água por regiões com material permeável (B); ao final de uma camada permeável que sobrepõe uma camada impermeável do solo (C); em uma falha geológica, que resulta no encontro de camadas permeáveis e impermeáveis de solo, interrompendo o fluxo subterrâneo (D); através de falhas nas rochas impermeáveis, resultando no afloramento de lençóis subterrâneos de água (E); e por fim através de rochas fraturadas que permitem a infiltração e extravasam esse fluxo em suas depressões $(F)$, conforme mostrado na llustração 95 a seguir. 
A

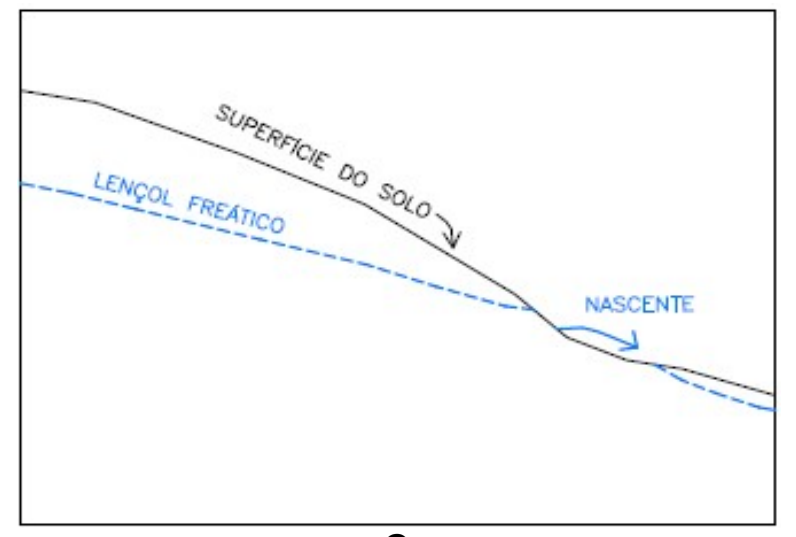

C

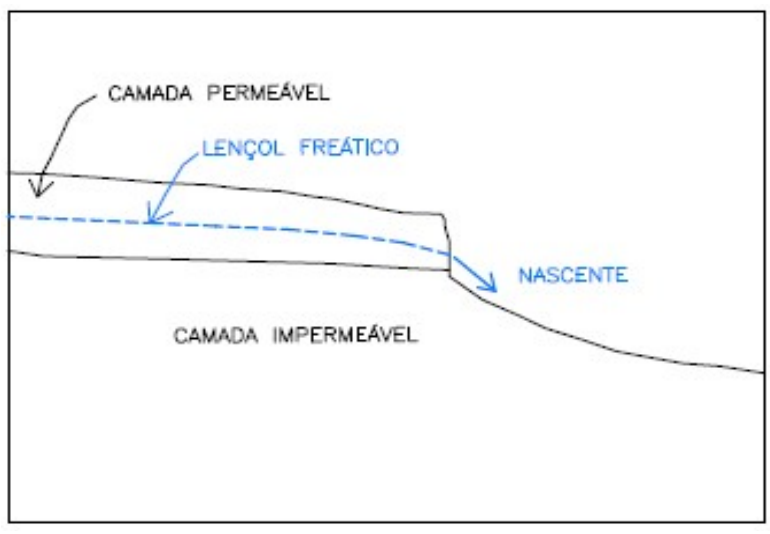

E

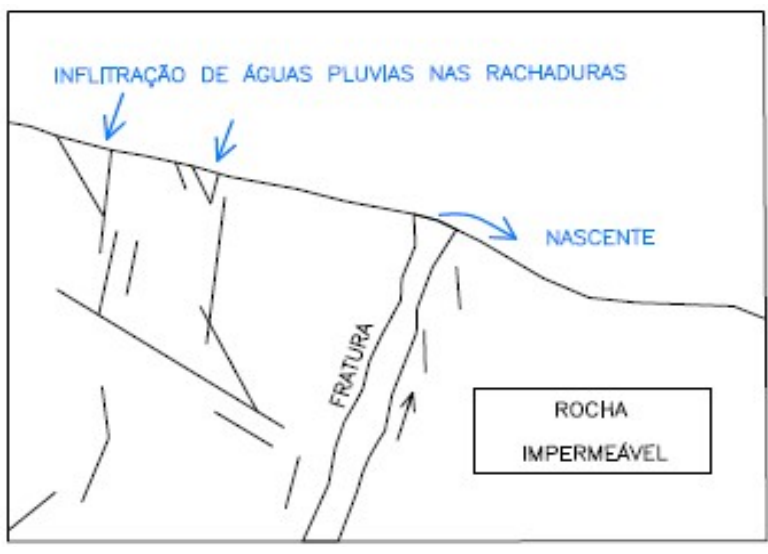

B

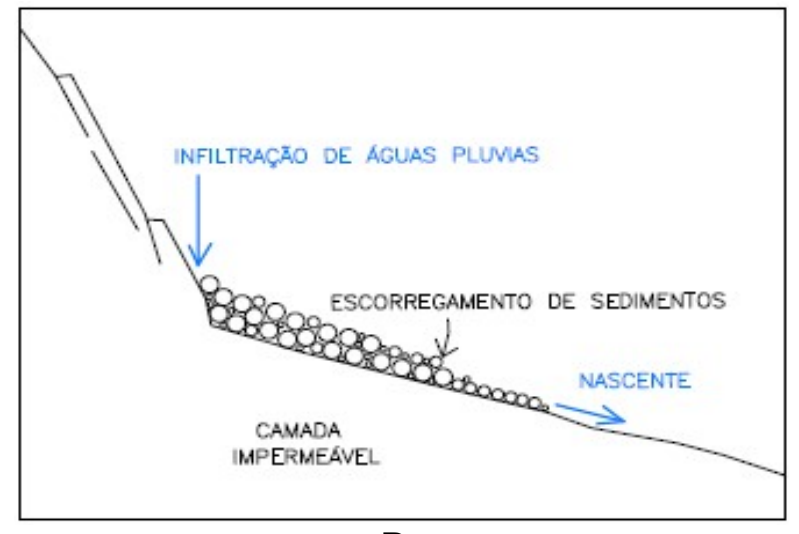

D

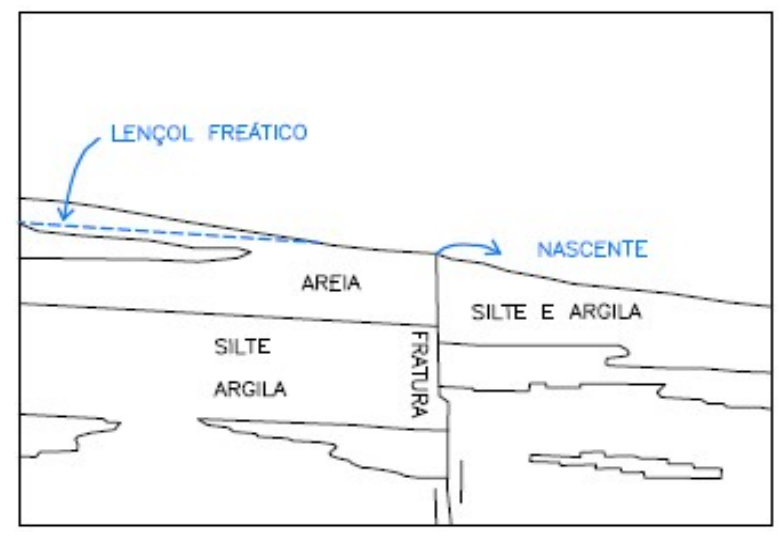

$\mathbf{F}$

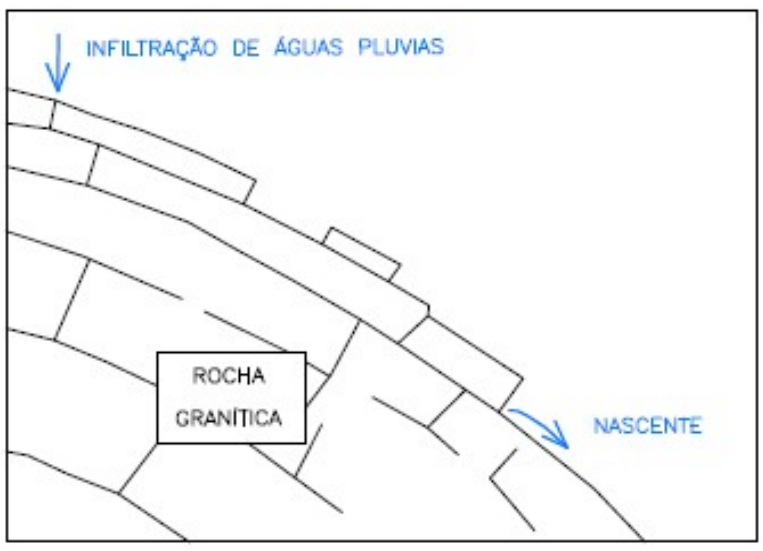

Ilustração 95 - Estrutura geológica das nascentes. Fonte: Adaptado de Davis \& DeWiest (1996).

A alimentação de nascentes pode ser proveniente de fontes de água subterrâneas (Aquíferos subterrâneos) e subsuperficiais (Lençol freático), portanto aquelas que são alimentadas por fontes subterrâneas se mantém na paisagem mesmo nos períodos de estiagem. Com a demanda cada vez maior pelo recurso água em áreas urbanas as águas provenientes destas nascentes poderiam ser aproveitadas pela população através da recuperação e revitalização das mesmas, devendo ser foco de atenção em programas de manejo de bacias hidrográficas. 


\subsubsection{Sistema coletor de esgotos existente}

A bacia do Jaguaré possui uma situação não homogênea com relação ao seu sistema de esgotamento sanitário. Na sua cabeceira, a bacia que possui ocupação mais recente e apresenta um sistema coletor menos consolidado, que lança os efluentes coletados no sistema de drenagem devido a inexistência de coletores tronco. Segundo o plano estratégico da SABESP, está previsto para a este trecho da bacia a implantação de coletores tronco para o ano de 2016, estes coletores farão a conexão dos esgotos coletados nas ao coletor tronco já implantado a jusante, na Av. Escola Politécnica, que conduz os efluentes da bacia até a estação de tratamento de esgotos da SABESP de Barueri. Apesar desta previsão, devido à crise hídrica pela qual a RMSP tem passado, os esforços da concessionária tem se voltado para o setor de abastecimento de água, o que resultou no atraso das ações referentes à implantação dos coletores tronco, de forma que a conclusão dos coletores para 2016 ficará prejudicada, segundo relatos de agentes da SABESP atuantes na bacia. A llustração 96 mostra um exemplo da situação dos canais nesta parcela da bacia, sob forte influência de efluentes domésticos (Foto $A$ ) e um ponto de lançamento de esgotos diretamente no solo em uma das áreas com ocupação irregular (Foto $B$ ).

Foto A

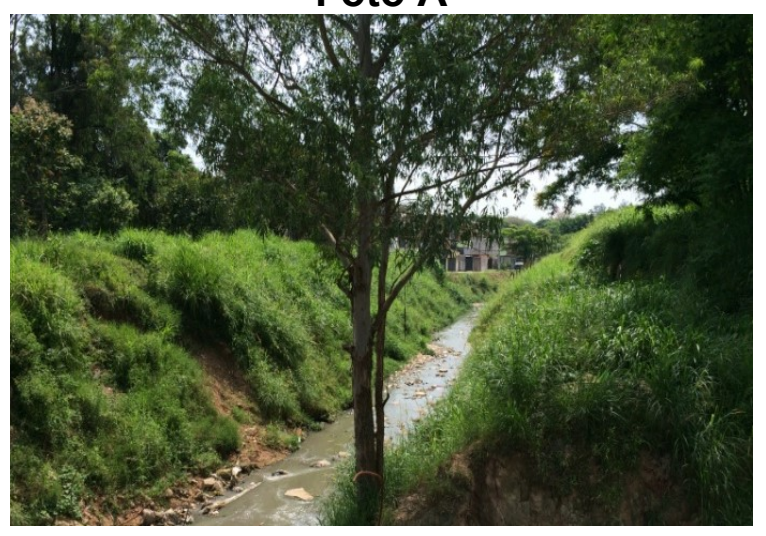

Foto B

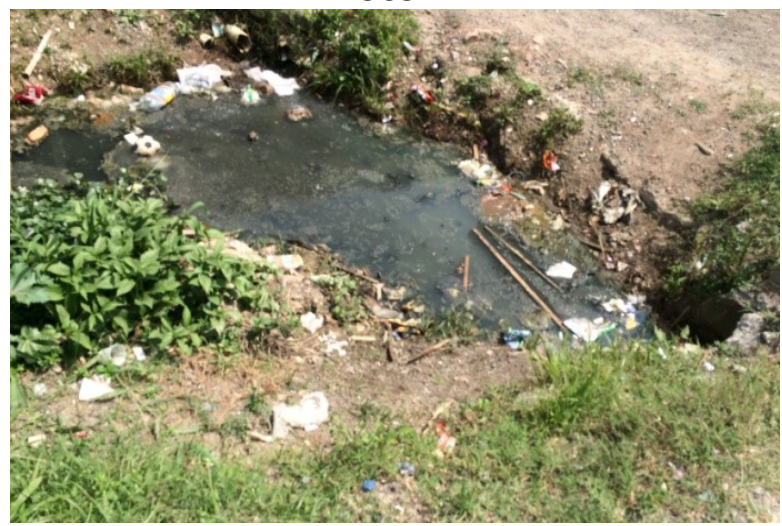

llustração 96 - Trechos ilustrativos do sistema de esgotamento sanitário na bacia do córrego Jaguaré. Fonte: Fotos da autora.

O trecho médio e baixo do canal possui o sistema de coleta mais consolidado, com boa parte dos efluentes recepcionados pelo coletor tronco da Av. Escola Politécnica que foi concluído em meados de 2014. 


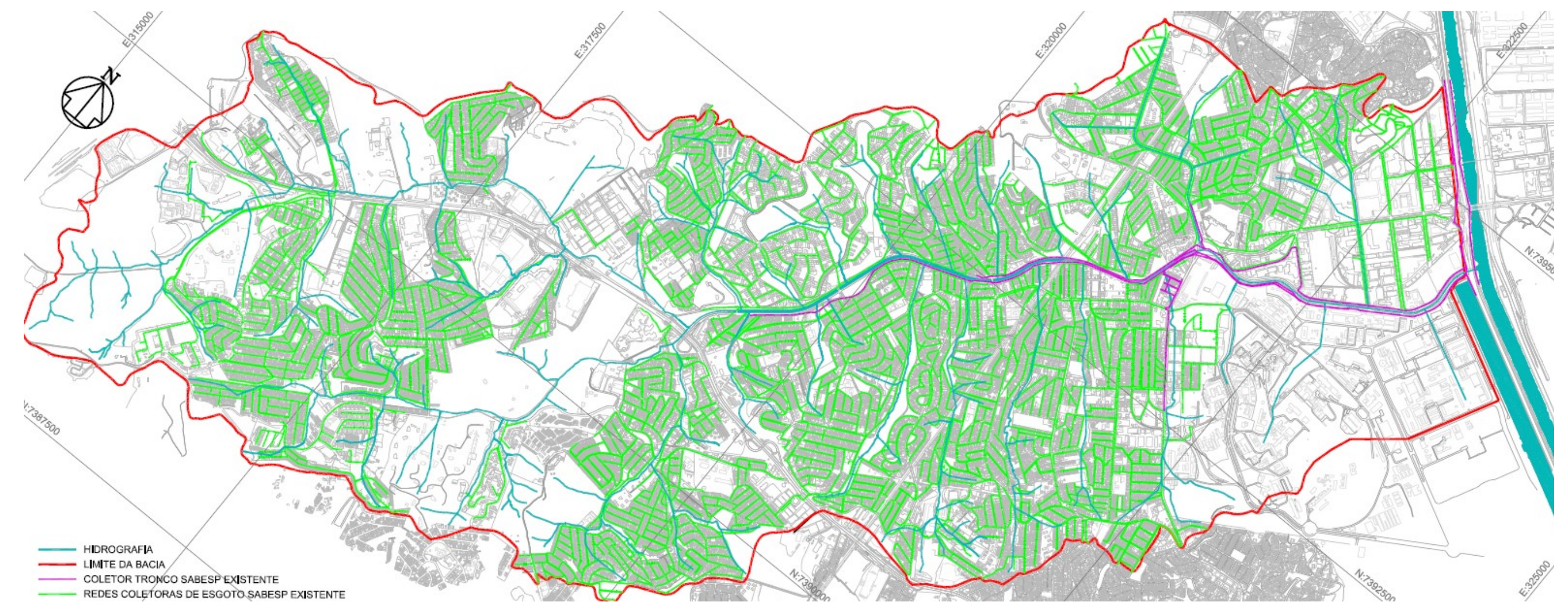

Ilustração 97 - Sistema de esgotamento sanitário existente na bacia do córrego Jaguaré. Fonte: Elaborado pela autora. 
A llustração 97 , mostra o sistema de esgotamento de esgotos existente, onde observa-se em cinza as redes recepcionadas pelos coletores tronco e em colorido as não conectadas, ou seja, que lançam os efluentes coletados nas galerias de drenagem e corpos d'água da bacia.

O plano diretor estratégico do município de São Paulo prevê para consolidação do sistema de esgotamento sanitário na bacia, a implantação de coletores troncos, principalmente na cabeceira da mesma, em duas etapas 2015 e 2018, no entanto nenhuma das duas etapas foi iniciada ainda. A llustração 98 mostra a previsão do caminhamento dos coletores na bacia. Em roxo contínuo se observa os coletores tronco no trecho médio e baixo da bacia que foram concluídos em 2014; Em rosa tracejado coletores planejados para 2015, com um eixo importante nas margens do córrego Itaim, maior tributário do córrego Jaguaré; e por fim em marrom tracejado trechos de coletor na bacia do córrego Sapé, Água Podre, Jaguarézinho e Nascente do Jaguaré planejados para 2018, consolidando a coleta de esgotos formais na bacia. Considerando como esgotos não formais, aqueles provenientes de ligações clandestinas e o de áreas onde não é possível realizar o escoamento sem recursos adicionais do sistema tradicional, como sistemas de bombeamento e linhas de recalque.

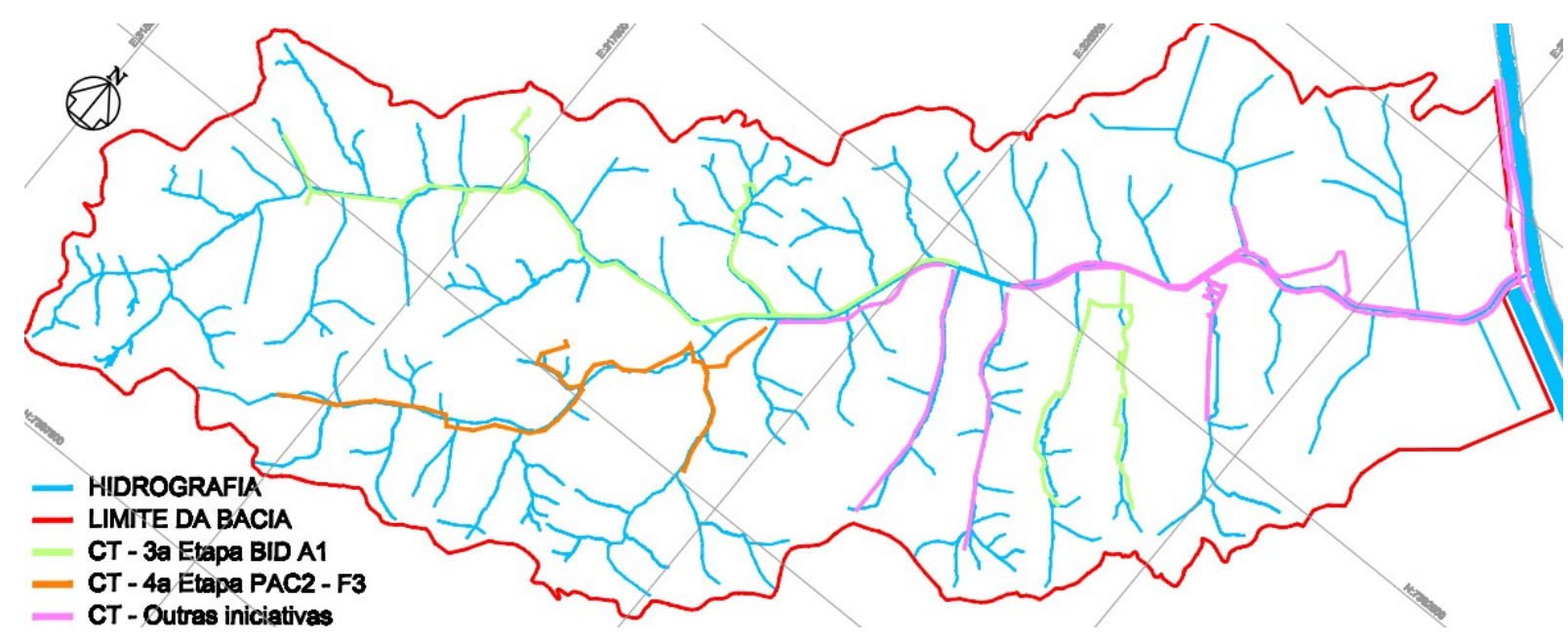

Ilustração 98 - Coletores tronco existentes e propostos na bacia do Jaguaré. Fonte: Adaptado do Plano Diretor Estratégico do município de São Paulo (2014). 


\subsubsection{Sistema coletor existente de resíduos sólidos}

Atualmente a bacia do Jaguaré conta com sistema de coleta de resíduos sólidos majoritariamente do tipo convencional, ou seja, onde o usuário deposita seus resíduos ensacados na frente do lote nos horários permitidos, sendo os mesmos recolhidos pelo caminhão do serviço de coleta. Esse sistema já vem sendo há muito tempo abandonado nos EUA e na Europa, uma vez que o mesmo possui elevado potencial poluidor. Esta modalidade de coleta representa um grande risco à saúde da população e dos corpos d'água, já que os sacos de resíduos estão sujeitos à ação da precipitação enquanto ficam depositados nas ruas à espera dos caminhões, além de poderem ser violados por animais, aumentando o risco de contaminação.

Buscando otimizar a coleta de resíduos no município, a prefeitura de São Paulo iniciou um projeto piloto de coleta mecanizada em 2014, através da adoção de caçambas de lixo em alguns bairros do município, como por exemplo no bairro do Butantã, que inclui quase que a totalidade da bacia do Jaguaré (Fernandes, 2014). O sistema de coleta mecanizada é operado pela empresa Loga - Logística Ambiental de São Paulo, que foi a pioneira na Capital paulista nesta solução diferenciada, visando proporcionar a retirada de resíduos das ruas de forma mais inteligente. A coleta é realizada por um caminhão automatizado que utiliza braços mecânicos para elevar o contêiner, esvaziar o seu interior e retorna-lo a sua posição inicial. Finalizada a coleta, o contêiner é lavado com auxílio do caminhão higienizador (Loga, 2014). A llustração 99 mostra dois pontos de coleta mecanizada na bacia do Jaguaré.

Foto A: Rua Conde Luiz Matarazzo

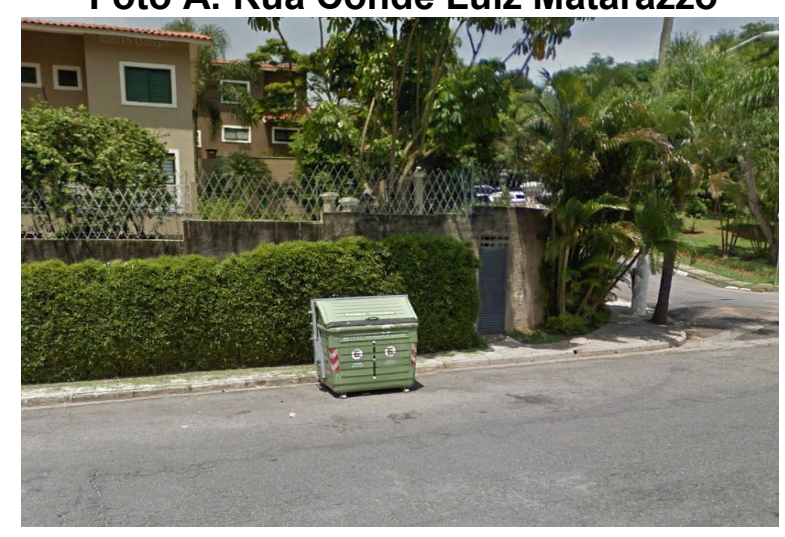

Foto B: Rua General Syzeno Sarmento

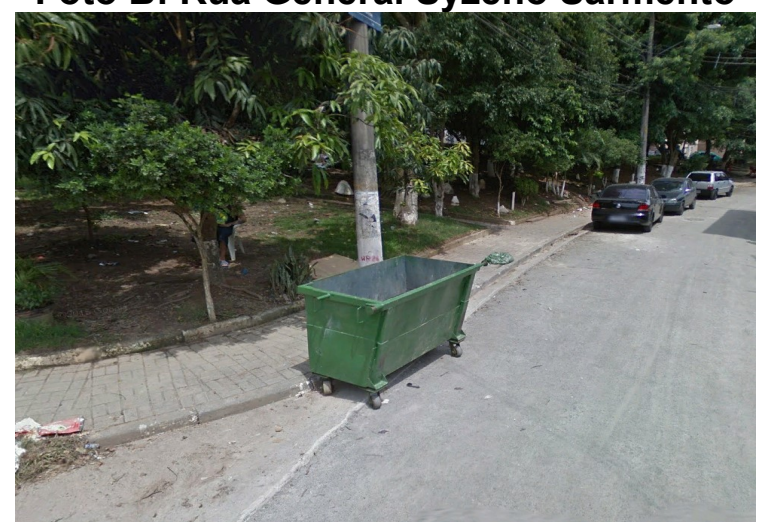

Ilustração 99 - Coleta de lixo mecanizada na bacia do Jaguaré. Fonte: Fotos da autora. 


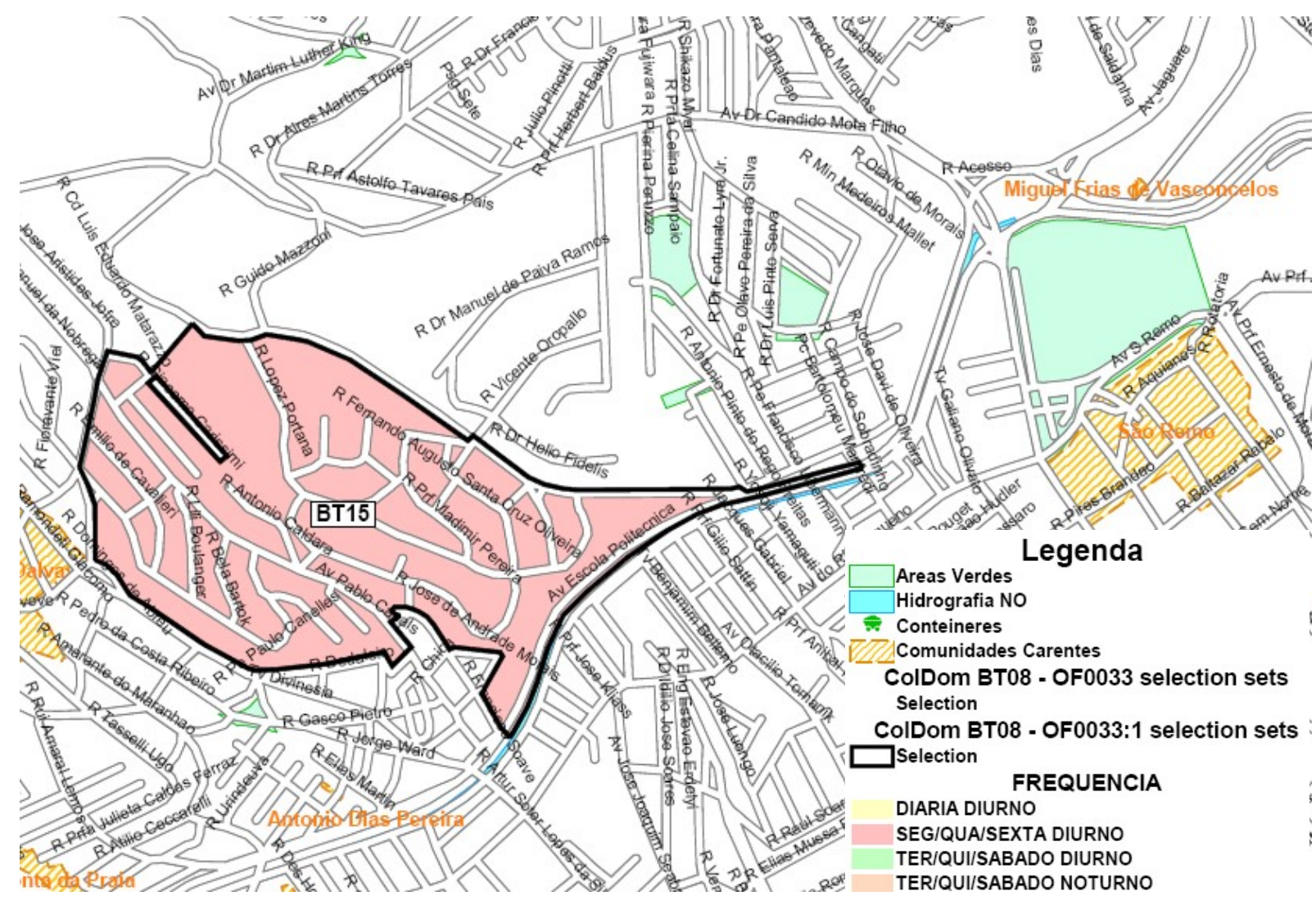

Ilustração 100 - Setor piloto de coleta de lixo mecanizada na bacia do Jaguaré. Fonte: Adaptado de LOGA (s/d).

Este novo modelo, adotado em boa parte dos países europeus, já existe em algumas cidades brasileiras, como Itu, Sorocaba, Passo Fundo, Santos, Campinas, Duque de Caxias e Salvador, onde vem obtendo resultados positivos no controle de resíduos na superfície da bacia (Contemar, 2014).

É possível destacar as seguintes vantagens do sistema de coleta mecanizada: a flexibilidade no horário do depósito do resíduo sólido dentro dos contêineres, a atenuação do mau cheiro e da poluição visual, a diminuição da dispersão ocasionada pelo contato por animais ou catadores informais, a redução dos índices de insetos e animais transmissores de doenças e a preservação do sistema de drenagem, que deixa de receber esses resíduos sólidos durante os episódios de precipitação (Loga, 2014).

Um grave problema na bacia esta ligado à má gestão de resíduos sólidos proveniente da construção civil, cenário comum nos grandes centros urbanos e que se repete em outras bacias da RMSP, demandando um plano de gestão mais eficiente, com aumento da fiscalização e incentivos para o gerenciamento adequado 
destes resíduos. A llustração 101 mostra dois exemplos de disposição inadequada de resíduos de construção civil na bacia do Jaguaré em duas escalas, obras de pequeno porte (Casas) e de grande porte (Edifícios).

\section{Foto A}

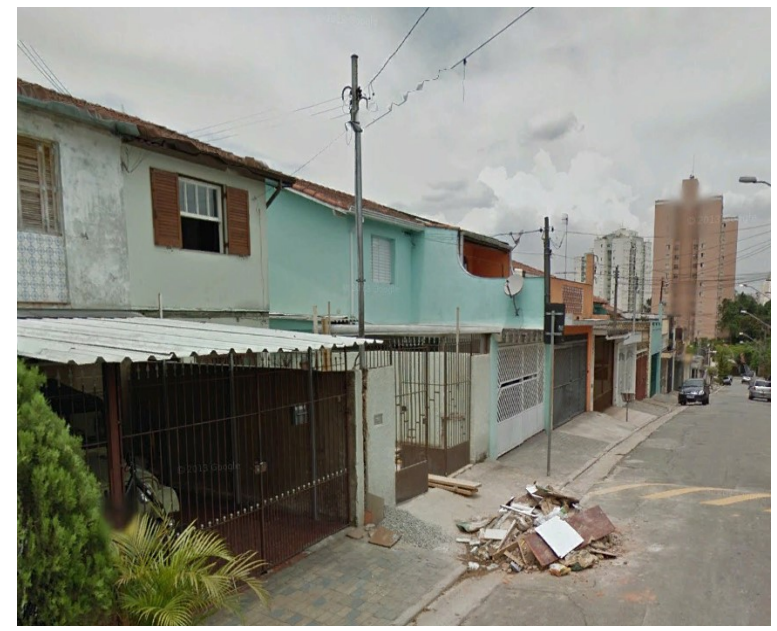

\section{Foto B}

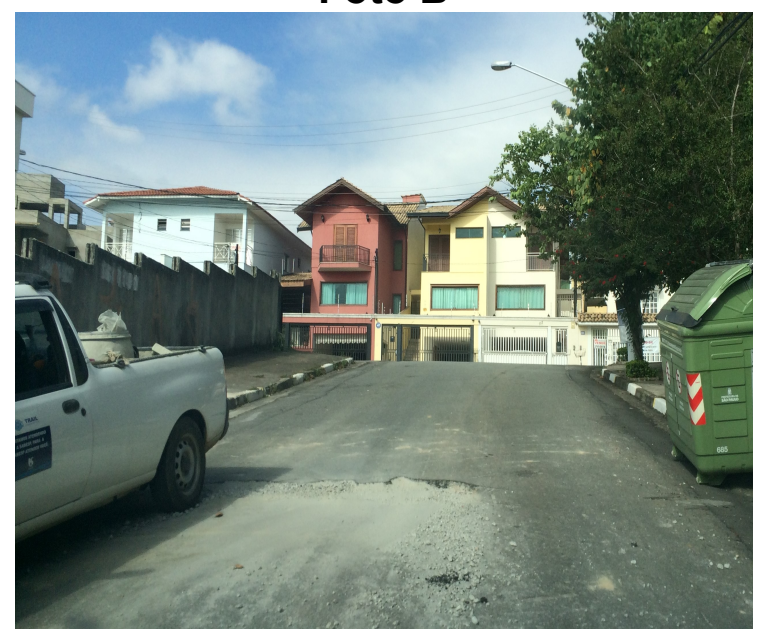

Ilustração 101 - Resíduos de construção civil nas ruas da bacia do Jaguaré. Fonte: Fotos da autora.

A bacia do Jaguaré abriga o Ecoponto Politécnica, na Praça Nilton Vieira de Almeida. Os Ecopontos são pontos disponibilizados pela prefeitura do município de São Paulo à população para coleta de resíduos. Os resíduos são coletados separadamente em contêineres e destinados à reciclagem. A llustração 102 mostra o Ecoponto da Politécnica.

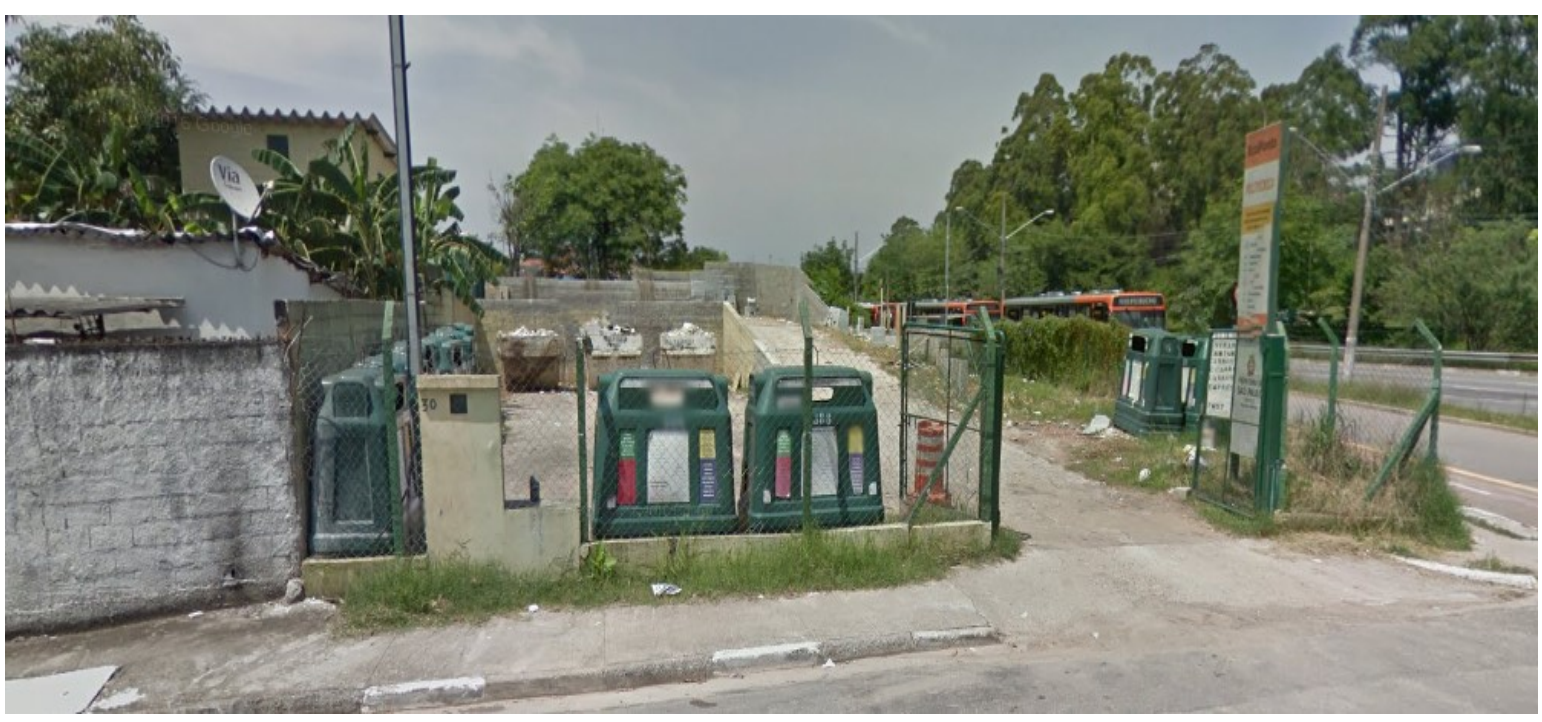

Ilustração 102 - Ecoponto na bacia do Jaguaré. Fonte: Foto da autora. 
No âmbito do "Projeto Jaguaré" foram levantados os pontos viciados de acumulo de resíduos de grande volume na superfície da bacia, o que resultou no mapa da llustração 103 a seguir, onde os pontos amarelos representam os pontos viciados levantados nas vistorias de campo realizadas na bacia.

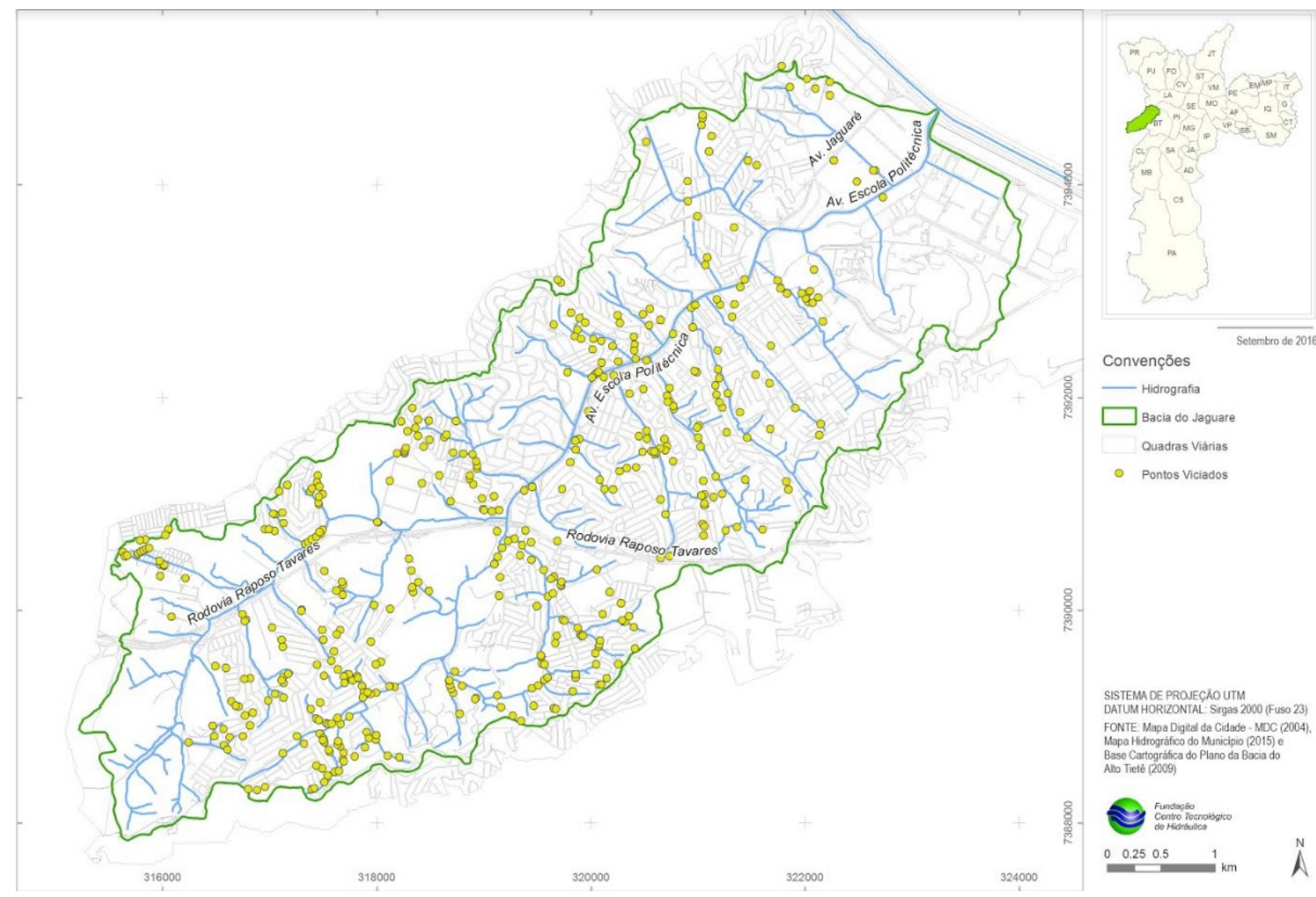

Ilustração 103 - Pontos viciados de acumulo de resíduos de grande volume na bacia do Jaguaré. Fonte: Projeto Jaguaré (2017).

\subsection{5 Áreas contaminadas}

As áreas contaminadas na bacia estão ligadas às antigas atividades industriais e a postos de combustíveis. Segundo cadastro da CETESB existe na bacia 43 áreas contaminadas e segundo cadastro da SVMA 15, muitas delas associadas a atividades de postos de combustível, conforme mostrado na llustração 104 a seguir. 


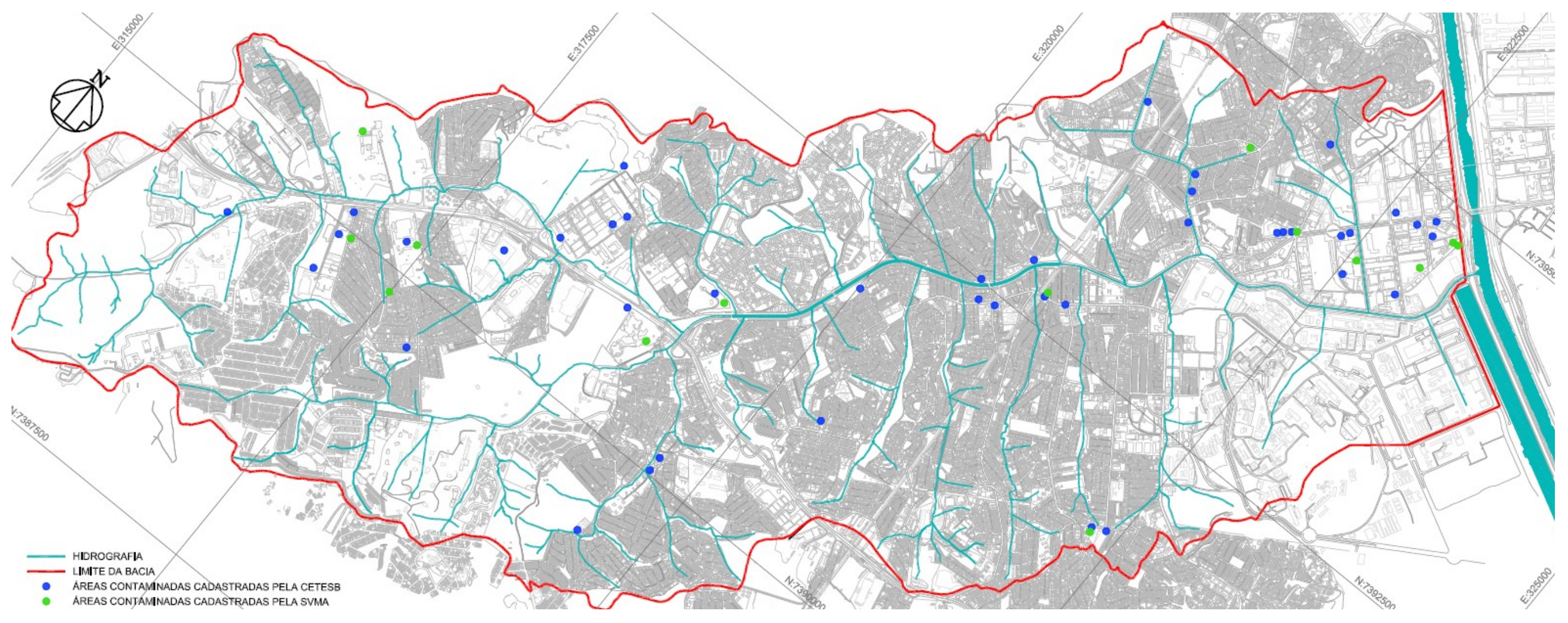

Ilustração 104 - Áreas contaminadas na bacia do córrego Jaguaré. Fonte: Elaborado pela autora a partir de informações levantadas junto à CETESB e à SVMA. 


\subsubsection{Remanescentes vegetais}

A bacia do Jaguaré contrária de muitas outras bacias hidrográficas em áreas urbanas, ainda possui um significativo remanescente vegetal e em diferentes estágios de conservação; Desde áreas sob maior intervenção humana, como o caso de canteiros e praças, até áreas que possuem elevado interesse ecológico, como os fragmentos florestais remanescentes ou em estágio de recuperação de mata atlântica no parque Tizo e no Parque Vila São Francisco. A llustração 105 mostra diferentes exemplos de áreas verdes na bacia do Jaguaré, como a Praça Evandro Valério, que possui equipamentos de lazer improvisados pela população; $O$ canteiro da Avenida Escola Politécnica na sua intersecção com a Rodovia Raposo Tavares, que foi recentemente arborizado pela SVMA; O parque Tizo, com significativo remanescente vegetal de mata atlântica em estágio de regeneração; e O parque Vila São Francisco, reserva legal do condomínio Vila São Francisco que foi transformado em parque público, com estruturas de lazer para uso da população.

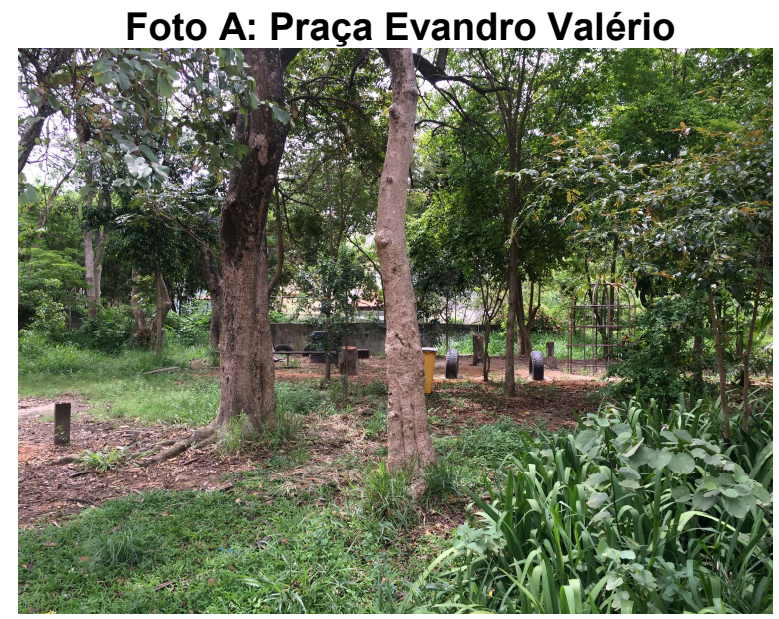

Foto C: Parque Tizo

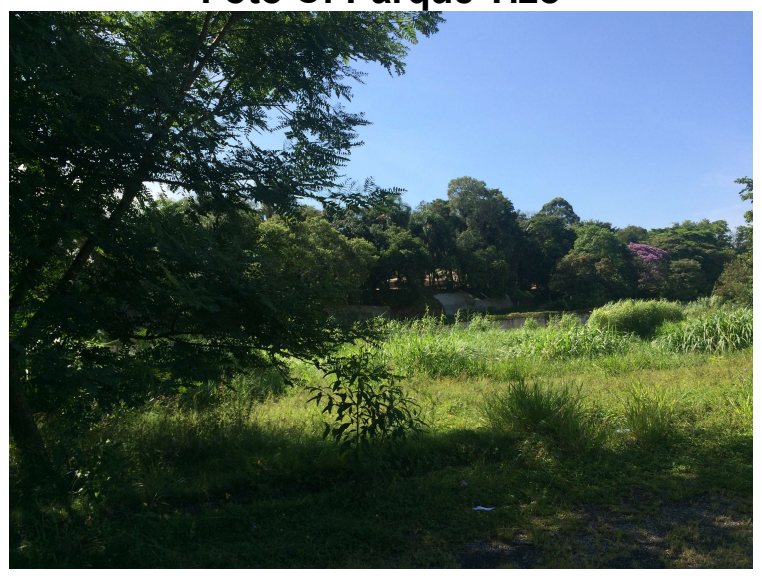

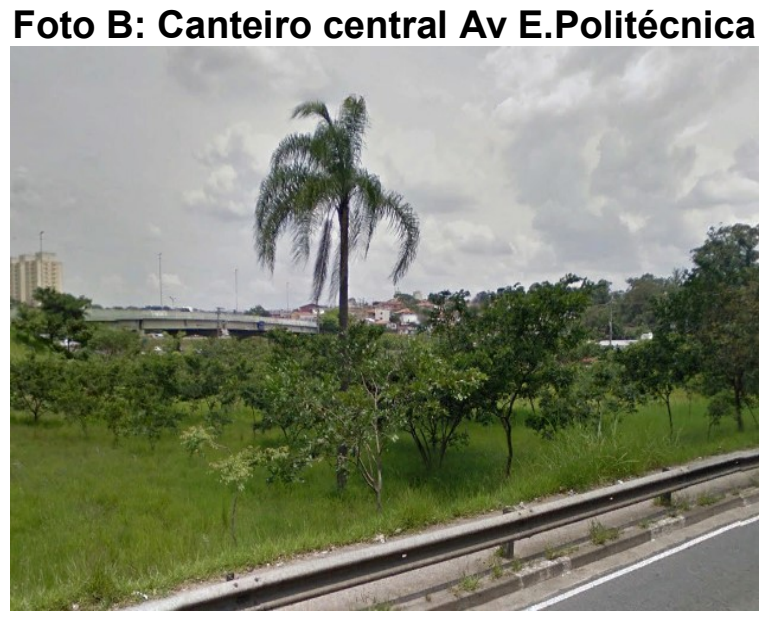

Foto D: Parque Vila São Francisco

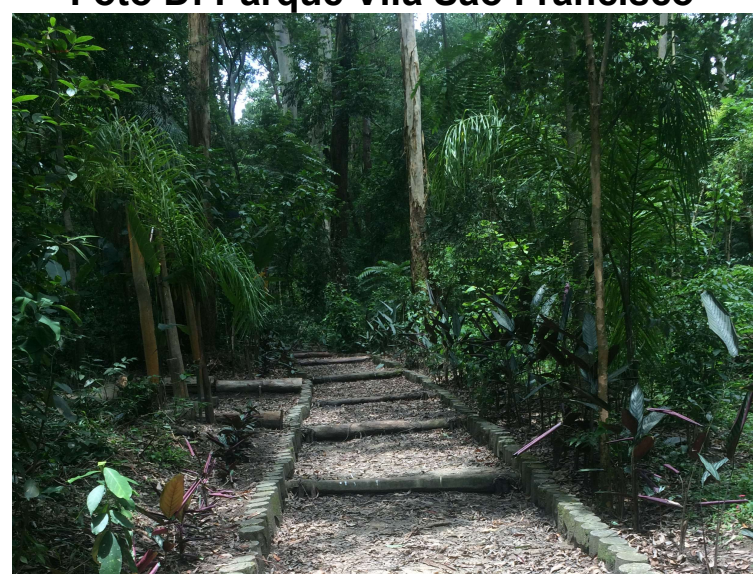

llustração 105 - Áreas verdes na bacia do Jaguaré. Fonte: Fotos da autora. 
Costa (2006) identificou no fragmento florestal do parque Tizo importantes representantes da mata atlântica, destacando a importância destas áreas como mantenedoras da biodiversidade deste bioma. A Tabela 10 mostra as espécies amostradas pelo autor no fragmento, servindo de referência para programas de recomposição vegetal na região.

Tabela 10 - Espécies vegetais presentes no fragmento florestal do parque Tizo. Fonte: Elaborado pela autora a partir de Costa (2006).

\begin{tabular}{l|l|l|l}
\hline \multicolumn{5}{c}{ Espécies vegetais } \\
\hline Aegiphila obducta & Croton macrobothrys & Miconia valtherii & Psychotria suterella \\
\hline Albertia myrciifolia & Cupania emarginata & Mollinedia schottiana & Psychotria vellosiana \\
\hline Alchornea triplinervia & Cupania oblongifolia & Mollinedia triflora & Pterocarpus rohrii \\
\hline Allophylus edulis & Cupania vernalis & Myrcia fallax & Rapanea ferruginea \\
\hline Allophylus petiolatus & Endlicheria paniculata & Nectandra oppositifolia & Rapanea umbellata \\
\hline Amaioua intermedia & Eugenia cerasiflora & Nectandra oppositifolia & Rollinia sylvatica \\
\hline Andira anthelmia & Eugenia involucrata & Ocotea aciphylla & Roupala brasiliensis \\
\hline Aspidosperma olivaceum & Eugenia sp 1 & Ocotea Cf. pulchella & Rudgea gardenioides \\
\hline Bathysa australis & Guapira opposita & Ocotea dispersa & Rudgea jasminoides \\
\hline Brosimum glaziovii & Guarea macrophylla & Ocotea elegans & Schefflera angustissima \\
\hline Cabralea canjerana & Guatteria australis & Ocotea glaziovii & Sebastiana serrata \\
\hline Campomanesia eugenioides & Heisteria silvianii & Ocotea lanata & Sloanea guianensis \\
\hline Campomanesia guaviroba & Hirtella hebeclada & Ocotea puberula & Sloanea monosperma \\
\hline Capsicum mirabile & Ilex amara & Ocotea silvestris & Solanum cinnamomeum \\
\hline Casearia obliqua & Jacaranda puberula & Ocotea sp 1. & Solanum rufescens \\
\hline Casearia sylvestris & Machaerium nyctitans & Ocotea venulosa & Tetrorchidium rubrivenium \\
\hline Cecropia hololeuca & Machaerium villosum & Pera glabrata & Tibouchiia pulchra \\
\hline Cedrella fissilis & Matayba elaeagnoides & Piptadenia gonocantha & Tovomitops paniculata \\
\hline Clethra scabra Pers & Matayba guianensis & Pseudobambax grandiflorum & Vitex polygama \\
\hline Coccoloba warmingii & Maytenus salicifolia & Psichotria suterella & Vochysia magnifica \\
\hline Cordia sellowiana & Miconia cabussu & Psidium sp. & Xylosma ciliatifolium \\
\hline Croton floribundu & Miconia inconspicua & Psychotria cephalantha & \\
\hline
\end{tabular}

A SVMA tem atuado ativamente na bacia para que tais áreas sejam preservadas e para que haja conexões entre as mesmas através da criação de parques lineares por toda a bacia. Atualmente a SVMA tem trabalhado especificamente em 17 áreas na bacia, seja através da implantação de medidas para a conservação e recuperação das mesmas, como através da adoção de planos de gestão participativa junto à comunidade na bacia a fim de tornar as ações mais efetivas. A llustração 106 mostra as 17 áreas de atuação da SVMA. 


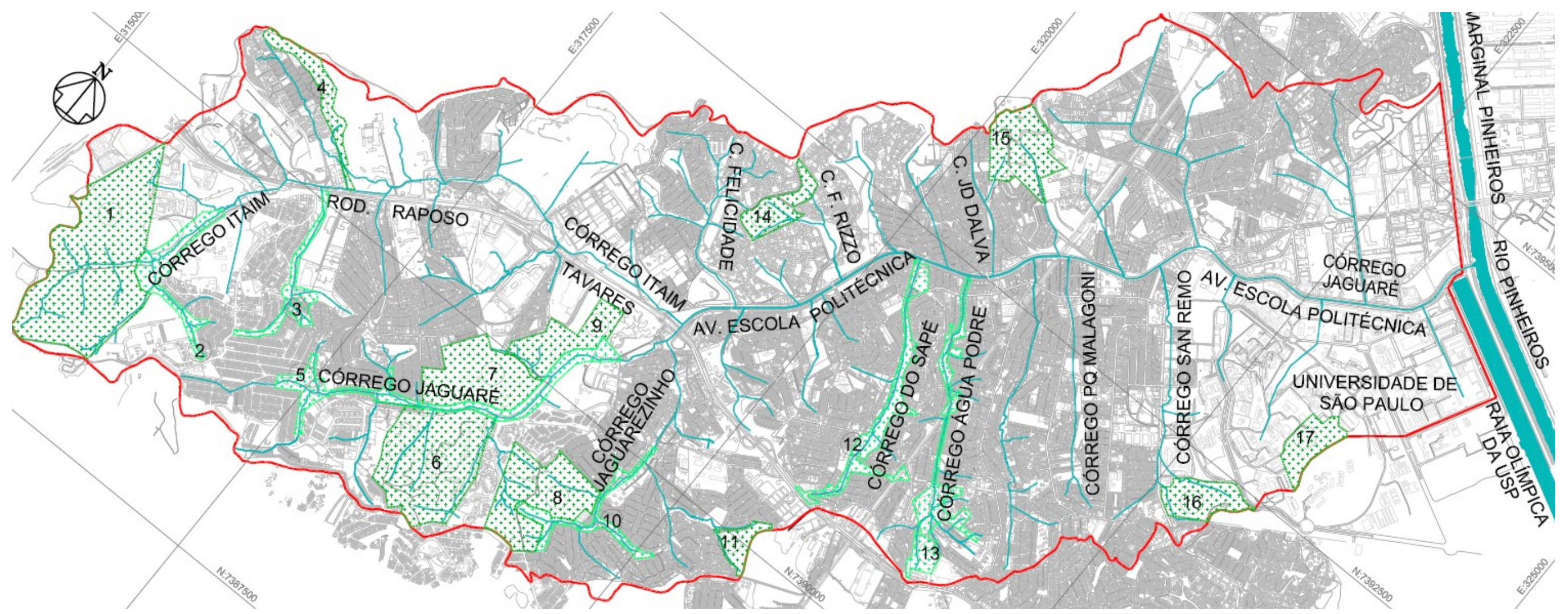
1 PQ. TIZO
7 CEMITÉRIO ISRAELITA
2 PQ. LINEAR ITAIM
8 ÁREA PARTICULAR
3 PQ. LINEAR PASSAGEM GRANDE
4) PQ. JULIANA
5 PQ. LINEAR NASCENTES JAGUARÉ
6 PQ. EDUCANDÁRIO
9 ÁREA PARTICULAR
10 PQ. LINEAR JACAREZINHO
11 PQ. RAPOSO TAVARES
12 PQ. LINEAR DO SAPÉ

\begin{abstract}
13 PQ. LINEAR ÁGUA PODRE
14 PQ. DOS PRÍNCIPES

$15 \mathrm{PQ}$. VILA SÃO FRANCISCO

16 ÁREAS VERDES DA USP

17 ÁREAS VERDES DA USP
\end{abstract}

Ilustração 106 - Remanescentes vegetais na bacia do Jaguaré foco de atenção da SVMA. Fonte: Elaborado pela autora a partir de informações da SVMA. 
Tais áreas, além de serem importantes do ponto de vista da manutenção da biota, são também importantes do hidrológico, uma vez que funcionam como zonas de recarga subterrânea, atenuando a vazão de pico na bacia, já que permitem que as águas precipitadas sobre estas tenham elevadas taxas de infiltração, contrário do que ocorre nas áreas densamente urbanizadas, onde a água escoa rapidamente para os canais de drenagem. A perda destas parcelas permeáveis na bacia, potencialmente resultaria em um incremento na vazão de pico significante que elevaria a ocorrência de inundações da calha atual do córrego Jaguaré. Tal fenômeno será ensaiado e discutido adiante neste estudo.

\subsubsection{Qualidade da água}

A Companhia de Tecnologia de Saneamento Ambiental, CETESB, mantém um ponto permanente de monitoramento de qualidade da água na bacia do Jaguaré na Avenida Politécnica com a Rua Jorge Waard. A CETESB monitora o ponto a cada dois meses desde janeiro de 2012, avaliando as seguintes variáveis: DBO, OD, turbidez, $\mathrm{pH}$, sólidos dissolvidos totais, nitrogênio amoniacal, temperatura, fósforo total, alumínio, cobre, ferro, mercúrio, arsênio, bário, cádmio, chumbo, cromo, manganês, níquel, zinco, estireno, benzeno, etilbenzeno, tolueno, óleos e graxas e nitrogênio Kjedahl, como mostrado na Tabela 11 a seguir. A observação da série monitorada revela que o corpo d'água encontra-se sob forte influência de cargas poluidoras, principalmente provenientes do lançamento de efluentes, evidenciada pela elevada carga de DBO, que atinge valores da ordem de $100 \mathrm{mg} / \mathrm{L}$ no período seco, quando a redução da vazão do corpo d'água resulta no aumento da concentração dos poluentes. Observa-se também uma elevada carga de nutrientes como fósforo, e nitrogênio, indicadores da presença de matéria orgânica. A presença de metais se manteve abaixo dos limites previstos para um corpo d'água classe 3 e em alguns períodos abaixo dos limites da classe 1 (CONAMA 357). Além disso, observa-se uma presença notória de tolueno nas águas do corpo d'água, possivelmente resultado das áreas contaminadas na bacia por postos de combustível, como já mostrado na llustração 104 no item "Áreas contaminadas na bacia". 
Tabela 11 - Qualidade da água na bacia do Jaguaré. Fonte: Elaborado pela autora a partir do monitoramento da CETESB.

\begin{tabular}{|c|c|c|c|c|c|c|c|c|c|c|c|c|c|c|c|c|c|}
\hline Data & $\begin{array}{c}\text { DBO } \\
(5,20) \\
\mathrm{mg} / \mathrm{L}\end{array}$ & $\begin{array}{c}\text { Oxigênio } \\
\text { Dissolvido } \\
\text { mg/L }\end{array}$ & $\begin{array}{c}\text { Turbidez } \\
\text { UNT }\end{array}$ & $\begin{array}{c}\text { pH } \\
\text { U.pH }\end{array}$ & \begin{tabular}{|c|} 
Sólido \\
Dissolvido \\
Total \\
mg/L \\
\end{tabular} & $\begin{array}{c}\text { Nitrogênio } \\
\text { Amoniacal } \\
\text { mg/L }\end{array}$ & $\begin{array}{c}\text { Temperatura } \\
\text { da água } \\
\text { oc }\end{array}$ & $\begin{array}{c}\text { Fósforo } \\
\text { Total } \\
\mathrm{mg} / \mathrm{L}\end{array}$ & & $\begin{array}{c}\text { Alumínio } \\
\text { Dissolvido } \\
\text { mg/L }\end{array}$ & & $\begin{array}{c}\text { Cobre } \\
\text { Dissolvido } \\
\text { mg/L }\end{array}$ & $\begin{array}{c}\text { Ferro } \\
\text { Dissolvido } \\
\mathrm{mg} / \mathrm{L}\end{array}$ & & $\begin{array}{c}\text { Mércurio } \\
\text { Total } \\
\text { mg/L }\end{array}$ & & $\begin{array}{l}\text { Arsênio } \\
\text { Total } \\
\text { mg/L }\end{array}$ \\
\hline $30 / 01 / 2012$ & 37 & 2,5 & 17,9 & 7,6 & 258 & 14,2 & 22,1 & 3,5 & $<$ & 0,1 & & 0,12 & 0,33 & $<$ & 0,0002 & $<$ & 0,01 \\
\hline $26 / 03 / 2012$ & 36 & 0,5 & 34,3 & 7,7 & 274 & 15,9 & 27,4 & 0,137 & $<$ & 0,1 & & 0,01 & 0,4 & $<$ & 0,0002 & $<$ & 0,01 \\
\hline $10 / 05 / 2012$ & 102 & 2,1 & 86,7 & 7,5 & 278 & 22,2 & 22,8 & 3,09 & $<$ & 0,1 & & 0,02 & 0,62 & $<$ & 0,0002 & $<$ & 0,01 \\
\hline $30 / 07 / 2012$ & 58 & 2,1 & 176 & 7,7 & 304 & 22,5 & 19,2 & 2,51 & $<$ & 0,1 & $<$ & 0,009 & 0,59 & $<$ & 0,0002 & $<$ & 0,005 \\
\hline $24 / 09 / 2012$ & 63 & 0,8 & 65 & 7,4 & 326 & 23,3 & 22,6 & 2,23 & & 0,11 & & 0,03 & 0,65 & $<$ & 0,0002 & $<$ & 0,005 \\
\hline $12 / 11 / 2012$ & 15 & 7,09 & 68,1 & 7,58 & 118 & 1,46 & 22,7 & 0,204 & & 0,21 & $<$ & 0,009 & 0,13 & $<$ & 0,0002 & & \\
\hline $21 / 01 / 2013$ & 26 & 1,07 & 12,2 & 7,55 & 260 & 16,9 & 22,3 & 1,9 & $<$ & 0,1 & & 0,05 & 0,43 & $<$ & 0,0002 & $<$ & 0,005 \\
\hline $18 / 03 / 2013$ & 38 & 3,68 & 17,6 & 7,52 & 228 & 12,3 & 21,46 & 1,38 & $<$ & 0,1 & & 0,01 & 0,4 & $<$ & 0,0002 & $<$ & 0,005 \\
\hline $06 / 05 / 2013$ & 115 & 1,09 & 102 & 7,66 & 303 & 22,7 & 21,09 & 3,27 & & 0,11 & & 0,01 & 0,68 & $<$ & 0,0002 & $<$ & 0,005 \\
\hline $15 / 07 / 2013$ & 67 & 1,42 & 43,8 & 7,01 & 230 & 21,6 & 20,97 & 2,88 & $<$ & 0,1 & & 0,04 & 0,65 & $<$ & 0,0002 & $<$ & 0,01 \\
\hline 09/09/2013 & 187 & 0,5 & 32 & 7,46 & 346 & 26,7 & 22,29 & 4,37 & $<$ & 0,1 & & 0,01 & 0,1 & $<$ & 0,0002 & $<$ & 0,01 \\
\hline $25 / 11 / 2013$ & 36 & 5,21 & 16,7 & 7,9 & 280 & 18 & 22,4 & 1,91 & $<$ & 0,1 & & 0,02 & 0,47 & $<$ & 0,0002 & $<$ & 0,01 \\
\hline $30 / 01 / 2014$ & 100 & 0,91 & 37,2 & 7,42 & 272 & 18,5 & 27,76 & 2,73 & $<$ & 0,1 & & 0,01 & 0,64 & $<$ & 0,0002 & $<$ & 0,01 \\
\hline $17 / 03 / 2014$ & 27 & 4,18 & 15,8 & 7,76 & 266 & 17,9 & 25,54 & 1,59 & $<$ & 0,1 & & 0,04 & 0,34 & $<$ & 0,0002 & $<$ & 0,01 \\
\hline $28 / 05 / 2014$ & 80 & 0,3 & 24,5 & 7,61 & 276 & 19,2 & 18,3 & 1,79 & $<$ & 0,1 & & 0,02 & 0,52 & $<$ & 0,0002 & $<$ & 0,01 \\
\hline $02 / 07 / 2014$ & 77 & 1,92 & 40,2 & 7,64 & 222 & 25,5 & 19,2 & 3,04 & $<$ & 0,1 & & 0,01 & 0,63 & $<$ & 0,0002 & $<$ & 0,01 \\
\hline $18 / 09 / 2014$ & 113 & 0,39 & 48,3 & 7,66 & 306 & 30,7 & 25,1 & 3,98 & $<$ & 0,1 & $<$ & 0,009 & 0,71 & $<$ & 0,0002 & $<$ & 0,01 \\
\hline $17 / 11 / 2014$ & 53 & 2,19 & 31,4 & 7,77 & 308 & 22,9 & 21,8 & 2,97 & $<$ & 0,1 & & 0,08 & 0,5 & $<$ & 0,0002 & $<$ & 0,01 \\
\hline $29 / 01 / 2015$ & 112 & 0,39 & 22,2 & 7,71 & 326 & 21,4 & 26,97 & 2,42 & $<$ & 0,1 & & 0,01 & 0,53 & $<$ & 0,0002 & $<$ & 0,01 \\
\hline $31 / 03 / 2015$ & 76 & 1,3 & 15,1 & 7,61 & 342 & 19,7 & 25,1 & 2,23 & $<$ & 0,1 & & 0,02 & 0,51 & $<$ & 0,0002 & $<$ & 0,01 \\
\hline $05 / 05 / 2015$ & 79 & 0,21 & 28,7 & 7,37 & 344 & 32,1 & 21,8 & 3,3 & $<$ & 0,1 & $<$ & 0,009 & 0,61 & $<$ & 0,0002 & $<$ & 0,01 \\
\hline $15 / 07 / 2015$ & 101 & 0,21 & 22,2 & 7,63 & 324 & 27,8 & 21,1 & 3,83 & $<$ & 0,1 & & 0,01 & 0,43 & $<$ & 0,0002 & $<$ & 0,01 \\
\hline $10 / 09 / 2015$ & 55 & 0,63 & 119 & 7,52 & 350 & 17,2 & 21,81 & 2,6 & $<$ & 0,1 & $<$ & 0,009 & 0,33 & $<$ & 0,0002 & $<$ & 0,01 \\
\hline $25 / 11 / 2015$ & 30 & 0,77 & 17,7 & 7,6 & 250 & 19,6 & 22,8 & 1,98 & $<$ & 0,1 & $<$ & 0,009 & 0,4 & $<$ & 0,0002 & $<$ & 0,01 \\
\hline
\end{tabular}


Tabela 11 (continuação) - Qualidade da água na bacia do Jaguaré. Fonte: Elaborado pela autora a partir do monitoramento da CETESB.

\begin{tabular}{|c|c|c|c|c|c|c|c|c|c|c|c|c|c|c|c|c|c|c|c|c|c|c|}
\hline Data & $\begin{array}{l}\text { Bário } \\
\text { Total } \\
\mathrm{mg} / \mathrm{L}\end{array}$ & & $\begin{array}{l}\text { Tádmio } \\
\text { Total } \\
\text { mg/L }\end{array}$ & & $\begin{array}{c}\text { Chumbo } \\
\text { Total } \\
\mathrm{mg} / \mathrm{L}\end{array}$ & & $\begin{array}{l}\text { Cromo } \\
\text { Total } \\
\mathrm{mg} / \mathrm{L}\end{array}$ & $\begin{array}{c}\text { Mangânes } \\
\text { Total } \\
\mathrm{mg} / \mathrm{L}\end{array}$ & & $\begin{array}{l}\text { Víquel } \\
\text { Total } \\
\mathrm{mg} / \mathrm{L}\end{array}$ & $\begin{array}{l}\text { Zinco } \\
\text { total } \\
\mathrm{mg} / \mathrm{L}\end{array}$ & & $\begin{array}{l}\text { tireno } \\
\mu \mathrm{g} / \mathrm{L}\end{array}$ & & $\begin{array}{l}\text { nzeno } \\
\mu \mathrm{g} / \mathrm{L}\end{array}$ & & $\begin{array}{c}\text { Etilbenzeno } \\
\mu \mathrm{g} / \mathrm{L}\end{array}$ & & $\begin{array}{l}\text { lueno } \\
\mu \mathrm{g} / \mathrm{L}\end{array}$ & & $\begin{array}{l}\text { leos e } \\
\text { Sraxas } \\
\mathrm{mg} / \mathrm{L}\end{array}$ & $\begin{array}{c}\text { Nitrogênio } \\
\text { Kjedahl } \\
\text { mg/L }\end{array}$ \\
\hline $30 / 01 / 2012$ & 0,1 & $<$ & 0,0005 & & 0,008 & $<$ & 0,02 & 0,27 & $<$ & 0,02 & 0,07 & $<$ & 2,5 & $<<<$ & 2,5 & $<$ & 2,5 & $<$ & 2 & $<$ & 10 & 18,2 \\
\hline $26 / 03 / 2012$ & 0,11 & $<<$ & 0,0005 & $<$ & 0,005 & $<$ & 0,02 & 0,25 & $<<$ & 0,02 & 0,04 & & & & & & & & & $<$ & 10 & 19,3 \\
\hline $10 / 05 / 2012$ & 0,15 & $<$ & 0,0005 & & 0,02 & $<$ & 0,02 & 0,31 & $<$ & 0,02 & 0,1 & & & & & & & & & & 11 & 33,3 \\
\hline $30 / 07 / 2012$ & 0,11 & $<$ & 0,0007 & $<$ & 0,009 & $<$ & 0,02 & 0,29 & $<$ & 0,02 & 0,08 & & & & & & & & & $<$ & 10 & 28,1 \\
\hline $24 / 09 / 2012$ & 0,1 & $<$ & 0,0002 & & 0,005 & & 0,03 & 0,24 & $<$ & 0,02 & 0,04 & & & & & & & & & $<$ & 10 & 29,6 \\
\hline $12 / 11 / 2012$ & 0,02 & $<$ & 0,0007 & & 0,03 & $<$ & 0,02 & 0,06 & $<$ & 0,02 & 0,13 & $<$ & 2,5 & $<$ & 2,5 & $<$ & 2,5 & $<$ & 2 & & 10 & 3,98 \\
\hline $21 / 01 / 2013$ & 0,12 & $<$ & 0,0007 & $<$ & 0,009 & $<$ & 0,02 & 0,27 & $<$ & 0,02 & 0,04 & $<$ & 2,5 & $<$ & 2,5 & $<$ & 2,5 & $<$ & 2 & $<$ & 10 & 20,6 \\
\hline $18 / 03 / 2013$ & 0,1 & $<$ & 0,0007 & $<$ & 0,009 & $<$ & 0,02 & 0,2 & $<$ & 0,02 & 0,03 & & & & & & & & & $1<$ & 10 & 17,5 \\
\hline $06 / 05 / 2013$ & 0,13 & $<$ & 0,0007 & $<$ & 0,009 & $<$ & 0,02 & 0,24 & $<$ & 0,02 & 0,13 & $<$ & 2,5 & $<$ & 2,5 & $<$ & 2,5 & & 11 & & 16 & 25,3 \\
\hline $15 / 07 / 2013$ & 0,12 & $<$ & 0,0007 & $<$ & 0,009 & $<$ & 0,02 & 0,26 & $<$ & 0,02 & 0,03 & $<$ & 2,5 & $<$ & 2,5 & $<$ & 2,5 & $<$ & 2 & $<$ & 10 & 28,7 \\
\hline $09 / 09 / 2013$ & 0,14 & $<$ & 0,0007 & & 0,01 & $<$ & 0,02 & 0,25 & $<$ & 0,02 & 0,07 & & & & & & & & & & 27 & 36,3 \\
\hline $25 / 11 / 2013$ & 0,11 & $<$ & 0,0007 & $<$ & 0,009 & $<$ & 0,02 & 0,25 & $<$ & 0,02 & \begin{tabular}{|l|l|}
$<$ & 0,02 \\
\end{tabular} & 14 & 2,5 & $<$ & 2,5 & $<$ & 2,5 & $<$ & 2 & $<$ & 10 & 21,5 \\
\hline $30 / 01 / 2014$ & 0,12 & $<$ & 0,0007 & $<$ & 0,009 & $<$ & 0,02 & 0,21 & $<$ & 0,02 & \begin{tabular}{|l|l|}
$<$ & 0,02 \\
\end{tabular} & $<$ & 5 & $<$ & 2,5 & $<$ & 2,5 & & 4,32 & $<$ & 10 & 27 \\
\hline $17 / 03 / 2014$ & 0,11 & $<$ & 0,0007 & $<$ & 0,009 & $<$ & 0,02 & 0,26 & $<$ & 0,02 & 0,04 & & & & & & & & & $<$ & 10 & 21,1 \\
\hline $28 / 05 / 2014$ & 0,12 & $<$ & 0,0007 & $<$ & 0,009 & $<$ & 0,02 & 0,21 & $<$ & 0,02 & \begin{tabular}{|l|l|}
$<$ & 0,02 \\
\end{tabular} & $<$ & 5 & $<<$ & 2,5 & $<$ & 2,5 & $<$ & 2 & $<$ & 10 & 20,6 \\
\hline $02 / 07 / 2014$ & 0,13 & $<$ & 0,0007 & $<$ & 0,009 & $<$ & 0,02 & 0,23 & & 0,03 & \begin{tabular}{|l|l|}
$<$ & 0,02 \\
\end{tabular} & $<$ & 5 & $<$ & 2,5 & $<$ & 2,5 & & 13,4 & & 15 & 27,3 \\
\hline $18 / 09 / 2014$ & 0,11 & $<$ & 0,0007 & $<$ & 0,009 & $<$ & 0,02 & 0,24 & $<$ & 0,02 & 0,05 & & & & & & & & & & 21 & 40,9 \\
\hline $17 / 11 / 2014$ & 0,1 & $<$ & 0,0007 & $<$ & 0,009 & $<$ & 0,02 & 0,23 & $<$ & 0,02 & 0,02 & $<$ & 5 & $<$ & 2,5 & $<$ & 2,5 & $<$ & 2 & & 10 & 29,5 \\
\hline $29 / 01 / 2015$ & 0,1 & $<$ & 0,0007 & $<$ & 0,009 & $<$ & 0,02 & 0,23 & $<$ & 0,02 & 0,03 & $<$ & 5 & $<$ & 2,5 & $<$ & 2,5 & & 2,33 & & 17 & 27 \\
\hline $31 / 03 / 2015$ & 0,11 & $<$ & 0,0007 & $<$ & 0,009 & $<$ & 0,02 & 0,29 & $<$ & 0,02 & 0,03 & & & & & & & & & & 14 & 25,8 \\
\hline $05 / 05 / 2015$ & 0,13 & $<$ & 0,0007 & $<$ & 0,009 & $<$ & 0,02 & 0,28 & $<$ & 0,02 & 0,03 & $<$ & 5 & $<$ & 2,5 & $<$ & 2,5 & & 3,89 & & 29 & 35,1 \\
\hline $15 / 07 / 2015$ & 0,13 & $<$ & 0,0007 & $<$ & 0,009 & $<$ & 0,02 & 0,27 & $<$ & 0,02 & 0,04 & $<$ & 5 & $<$ & 2,5 & $<$ & 2,5 & $1<$ & 2 & & 12 & 32,1 \\
\hline $10 / 09 / 2015$ & 0,12 & $<$ & 0,0007 & $1<$ & 0,009 & $<$ & 0,02 & 0,29 & $<$ & 0,02 & 0,02 & & & & & & & & & & 20 & 23,2 \\
\hline $25 / 11 / 2015$ & 0,1 & $<$ & 0,0007 & 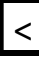 & 0,009 & $<$ & 0,02 & 0,28 & $<$ & 0,02 & 0,02 & $<$ & 5 & $<$ & 2,5 & $<$ & 2,5 & & 2 & & 10 & 22,6 \\
\hline
\end{tabular}




\subsubsection{Solo}

A bacia possui quatro unidades geológicas, Granitoides intrusivos, na porção das nascentes do Jaguaré; Grupo Votuverava, na porção correspondente ao córrego Itaim; Sedimentos paleógenos e neógenos, nas bacias afluentes no trecho mais a jusante na sua margem esquerda; e Depósitos aluvionares, na sua foz junto ao rio Pinheiros, conforme mostrado na llustração 107 adaptada do mapa geológico da RMSP.

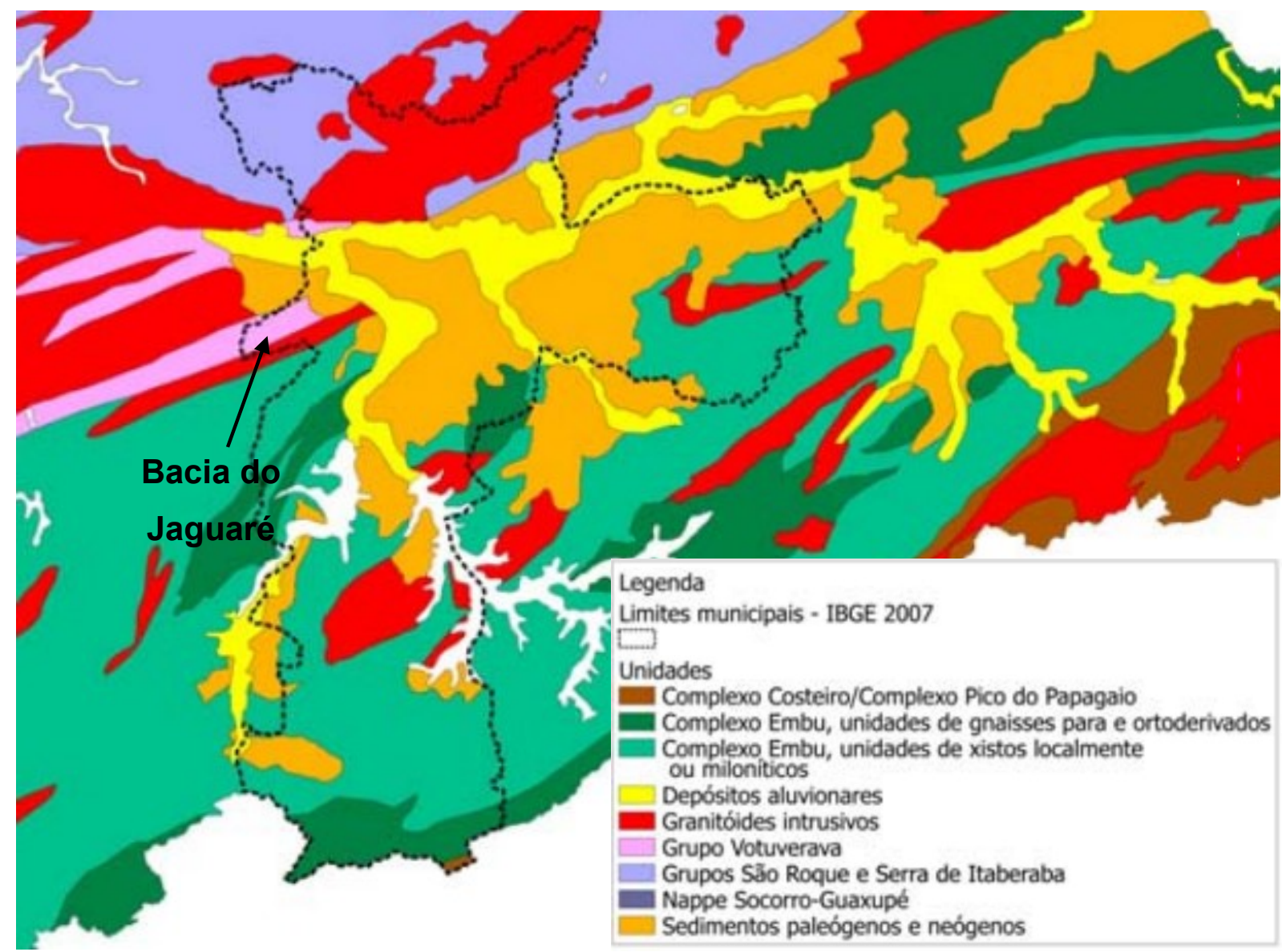

Ilustração 107 - Mapa geológico da região metropolitana de São Paulo. Fonte: Adaptado de Monteiro et al. (2012).

O registro de sondagens, constante no banco de dados da CPRM, revela que as primeiras camadas do solo nas unidades "Sedimentos paleógenos e neógenos" e "Depósitos aluvionares" é do tipo argilo arenoso, apresentando boas condições de permeabilidade; já as unidades "Granitoides intrusivos" e "Grupo Votuverava" apresentam uma camada rasa de solo argiloso orgânico seguido por rochas migmáticas alteradas, o que garante a estas unidades baixa capacidade de recarga subterrânea. 
- Despoluição das águas: Neste item foram detalhadas medidas estruturais e não estruturais para sanar os problemas existentes na bacia relativos às cargas pontuais (Consolidação do sistema de coleta e tratamento de efluentes) e às cargas difusas (Resíduos sólidos, sedimentos e demais cargas poluentes associadas ao escoamento superficial);

- Reintegração das áreas de várzea: Neste item foram detalhadas as medidas que visaram a requalificação dos corpos d'água da bacia no âmbito da "Renaturalização", da "Recuperação" e da "Revitalização", visando o uso múltiplo das águas, de forma a garantir não só a segurança hidrológica da bacia, mas também propiciar o uso das águas para atividades recreativas, a manutenção da biodiversidade, a valorização paisagística dos fundos de vale e aumentar a qualidade de vida da população dando à mesma acesso a um ambiente urbano mais saudável. Desta forma, neste item foram incorporados os grupos de impactos relativos à ocupação das áreas de várzea e modificações na geometria natural do canal;

- Os item "Impacto da perda das áreas verdes" e "Infraestrutura verde e azul" se destinam à verificação da relevância da presença de remanescentes na bacia para a segurança hidrológica da mesma, bem como a relevância dos mesmos na manutenção da biodiversidade, além disso, é foco destes itens a proposição de medidas para enriquecimento destas áreas verdes a fim de garantir melhoria da qualidade e da quantidade da água;

- Por fim o item "Percepção da População" avaliou a percepção da população sobre a água no ambiente urbano através dos resultados obtidos da aplicação de um questionário.

Todas as análises realizadas neste estudo visaram o atendimento de todas as frentes envolvidas na requalificação de corpos d'água em bacias hidrográficas urbanizadas, no âmbito da renaturalização, recuperação e revitalização, em função da realidade e demandas de uso dos recursos hídricos existentes na bacia em questão. A llustração 108 a seguir resume as frentes envolvidas na requalificação de cursos d'água em bacias hidrográficas urbanizadas no âmbito da renaturalização, recuperação e revitalização. 


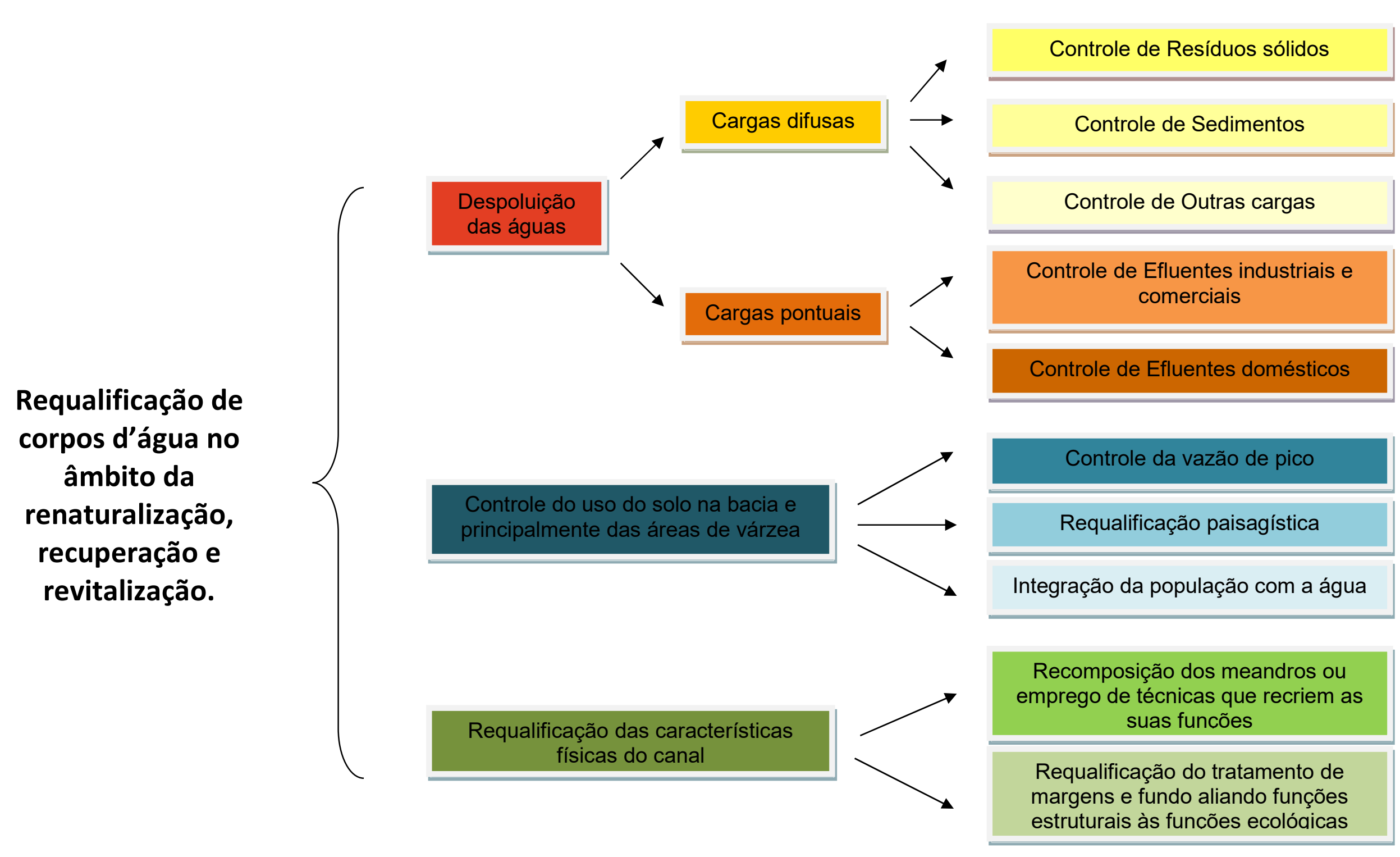

Ilustração 108 - Frentes envolvidas na requalificação de cursos d'água em bacias hidrográficas urbanizadas no âmbito da renaturalização, recuperação e revitalização. Fonte: Elaborado pela autora. 


\subsection{Despoluição das águas}

Quando falamos do processo de despoluição de um corpo d'água estamos nos referindo especificamente à retirada de tudo aquilo que atua na degradação da qualidade da água, ou seja, cargas pontuais e difusas. Desta forma, com base na análise do sistema existente, foram propostas uma série de medidas para consolidação do sistema de esgotamento sanitário e para controle de cargas difusas na bacia.

\subsubsection{Consolidação do sistema de esgotamento sanitário}

A partir do cadastro do sistema de esgotos existente na bacia da SABESP, do Cadastro das galerias de drenagem e da malha hidrográfica da prefeitura do município de São Paulo, foi possível identificar os cruzamentos entre os dois sistemas que resultam em pontos de lançamento de esgotos nas águas pluviais. Obteve-se da análise do sistema existente que atualmente $52 \%$ da rede coletora lança os efluentes no sistema de drenagem, totalizando 93 pontos de lançamento, conforme indicado por pontos vermelhos na llustração 109 .

A partir do levantamento dos pontos de lançamento, na malha de rede coletora de esgotos e na população residente na bacia, foi possível estimar a vazão destes lançamentos, seguindo a metodologia descrita a seguir:

a) Determinação da vazão média teórica de esgotos na bacia:

É possível determinar a vazão teórica de esgotos de uma bacia através da população residente na mesma, do seu consumo de água e da taxa convencionada de retorno de esgotos.

Segundo a Subprefeitura do Butantã (2010) a densidade populacional na bacia é de 7633 habitantes por $\mathrm{km}^{2}$, desta forma, conhecida a área total da bacia (28.013,9 ha) é possível calcular sua população total e determinar então o consumo de água da bacia. 


$$
\begin{aligned}
& \left(7633 \frac{\mathrm{hab}}{\mathrm{km}^{2}}\right) \cdot\left(28,0139 \mathrm{~km}^{2}\right)=213830,1 \text { habitantes } \\
& \text { Qágua }=\frac{P . q \cdot k 1 \cdot k 2}{86400}=\frac{213830 \cdot 150 \cdot 1,2 \cdot 1,5}{86400}=668,22 \mathrm{~L} / \mathrm{s}
\end{aligned}
$$

Onde: P: população; q: consumo per capita (150L/hab.dia adotado pela SABESP); k1: coeficiente do dia de maior consumo (1,2 adotado pela SABESP); e k2: coeficiente da hora de maior consumo (1,5 adotado pela SABESP).

Determinado consumo de água, diante da taxa de retorno de esgotos adotada pela concessionária de $80 \%$ e da vazão de infiltração por metro de rede indicada pela literatura de $0,0005 \mathrm{~L} / \mathrm{s}$.m, é possível obter a vazão total de esgotos na bacia.

$$
\begin{gathered}
\text { Qesgoto }=(\text { Qágua. 80\% })+(\text { Qinfiltração. Extensão to tal de rede }) \\
\text { Qesgoto }=(668,22 \mathrm{~L} / \mathrm{s} .80 \%)+(0,0005 \mathrm{~L} / \mathrm{s} \cdot \mathrm{m} .403035,85 \mathrm{~m})=736,09 \mathrm{~L} / \mathrm{s}
\end{gathered}
$$

*Extensão total de rede coletora obtida através do cadastro SABESP.

b) Taxa linear de esgotos na bacia:

Conhecida então a vazão teórica de esgotos total da bacia é possível estimar a vazão por metro de rede.

$$
\frac{\text { Qesgoto }}{\mathrm{m}} \text { de rede }=\frac{\text { Qesgoto }}{\text { Extensão total de rede }}=\frac{736,09 \mathrm{~L} / \mathrm{s}}{403035,85 \mathrm{~m}}=0,001826 \mathrm{~L} / \mathrm{s} . \mathrm{m}
$$

Desta forma, através da metragem de redes em cada bacia (llustração 110 ), definidas com base nos trechos de rede que contribuem para cada lançamento identificado na llustração 109 , foi possível obter a vazão estimada para cada lançamento conforme mostrado na Tabela 13 . Além disso, da Tabela 13 obteve-se que dos $727,90 \mathrm{~L} / \mathrm{s}$ de esgotos teóricos gerados, atualmente $350,99 \mathrm{~L} / \mathrm{s}$ são lançados em coletores tronco e $376,91 \mathrm{~L} / \mathrm{s}$ na malha hídrica. 
Tabela 12 - Estudo da vazão de esgoto na Bacia do Jaguaré. Fonte: Elaborado pela autora.

\begin{tabular}{c|c|c|c|c|c|c|c}
\hline Bacia & $\begin{array}{c}\text { População } \\
\text { atendida }\end{array}$ & $\begin{array}{c}\text { Q água } \\
\text { (L/s) }\end{array}$ & $\begin{array}{c}\text { Q esgoto } \\
\text { (L/s) }\end{array}$ & $\begin{array}{c}\text { Infiltração } \\
\text { (Taxa: } \\
\text { 0,0005L/s.m) }\end{array}$ & $\begin{array}{c}\text { Q total na } \\
\text { rede (L/s) }\end{array}$ & $\begin{array}{c}\text { Taxa de Esgoto } \\
\text { (L/s)/m de rede }\end{array}$ & $\begin{array}{c}\text { Taxa de Esgoto } \\
\text { + Infiltração } \\
\text { (L/s.m) }\end{array}$ \\
\hline Jaguaré & 213830 & 668,22 & 534,58 & 201,52 & 736,09 & 0,001326 & 0,001826 \\
\hline
\end{tabular}

Tabela 13 - Vazão por bacia de esgotamento. Fonte: Elaborado pela autora.

\begin{tabular}{|c|c|c|c|c|c|c|c|c|}
\hline $\begin{array}{c}\text { Bacia de } \\
\text { Esgotamento } \\
\text { Sanitário }\end{array}$ & $\begin{array}{c}\text { Extensão } \\
\text { da rede } \\
(\mathrm{m})\end{array}$ & $\begin{array}{c}Q(L / s) \\
\text { lançamento }\end{array}$ & $\begin{array}{c}\text { Bacia de } \\
\text { Esgotamento } \\
\text { Sanitário }\end{array}$ & $\begin{array}{c}\text { Extensão } \\
\text { da rede } \\
\text { (m) }\end{array}$ & $\begin{array}{c}Q(L / s) \\
\text { lançamento }\end{array}$ & $\begin{array}{c}\text { Bacia de } \\
\text { Esgotamento } \\
\text { Sanitário }\end{array}$ & $\begin{array}{c}\text { Extensão } \\
\text { da rede } \\
(\mathrm{m})\end{array}$ & $\begin{array}{c}Q(\mathrm{~L} / \mathrm{s}) \\
\text { lançamento }\end{array}$ \\
\hline B1 & 1962,07 & 3,58 & B32 & 179,61 & 0,33 & B63 & 2101,38 & 3,84 \\
\hline B2 & 16975,86 & 31,00 & B33 & 2426,71 & 4,43 & B64 & 1430,88 & 2,61 \\
\hline B3 & 1089,69 & 1,99 & B34 & 14811,37 & 27,05 & B65 & 670,62 & 1,22 \\
\hline B4 & 2213,4 & 4,04 & B35 & 16070,74 & 29,35 & B66 & 746,66 & 1,36 \\
\hline B5 & 3393,72 & 6,20 & B36 & 1202,89 & 2,20 & B67 & 1171,02 & 2,14 \\
\hline B6 & 2181,35 & 3,98 & B37 & 1395,94 & 2,55 & B68 & 786,91 & 1,44 \\
\hline B7 & 987,51 & 1,80 & B38 & 362,86 & 0,66 & B69 & 1167,27 & 2,13 \\
\hline B8 & 1143,56 & 2,09 & B39 & 1753,52 & 3,20 & B70 & 666,49 & 1,22 \\
\hline B9 & 1301,53 & 2,38 & B40 & 3821,86 & 6,98 & B71 & 2020,85 & 3,69 \\
\hline B10 & 6194,9 & 11,31 & B41 & 2036,49 & 3,72 & B72 & 728,76 & 1,33 \\
\hline B11 & 188,87 & 0,34 & B42 & 686,67 & 1,25 & B73 & 263,29 & 0,48 \\
\hline B12 & 4634,27 & 8,46 & B43 & 2818,66 & 5,15 & B74 & 1396,25 & 2,55 \\
\hline B13 & 897,68 & 1,64 & B44 & 1970,09 & 3,60 & B75 & 1991,4 & 3,64 \\
\hline B14 & 1956,12 & 3,57 & B45 & 132,03 & 0,24 & B76 & 295,71 & 0,54 \\
\hline B15 & 2069,24 & 3,78 & B46 & 1873,6 & 3,42 & B77 & 5159,68 & 9,42 \\
\hline B16 & 6301,15 & 11,51 & B47 & 1296,14 & 2,37 & B78 & 411,13 & 0,75 \\
\hline B17 & 554,26 & 1,01 & B48 & 3545,32 & 6,48 & B79 & 11981,56 & 21,88 \\
\hline B18 & 1156,5 & 2,11 & B49 & 4911,44 & 8,97 & B80 & 2065,99 & 3,77 \\
\hline B19 & 1617,26 & 2,95 & B50 & 1248,03 & 2,28 & B81 & 437,57 & 0,80 \\
\hline B20 & 1860,99 & 3,40 & B51 & 1240,3 & 2,27 & B82 & 5357,91 & 9,79 \\
\hline B21 & 241,19 & 0,44 & B52 & 1230,51 & 2,25 & B83 & 2436,42 & 4,45 \\
\hline B22 & 5153,39 & 9,41 & B53 & 836,08 & 1,53 & B84 & 131,32 & 0,24 \\
\hline B23 & 3807,76 & 6,95 & B54 & 1985,81 & 3,63 & B85 & 576,89 & 1,05 \\
\hline B24 & 1565,01 & 2,86 & B55 & 935,68 & 1,71 & B86 & 918,98 & 1,68 \\
\hline B25 & 1241,97 & 2,27 & B56 & 417,65 & 0,76 & B87 & 2084,4 & 3,81 \\
\hline B26 & 601,21 & 1,10 & B57 & 115,88 & 0,21 & B88 & 1233,67 & 2,25 \\
\hline B27 & 499,28 & 0,91 & B58 & 1627,93 & 2,97 & B89 & 111,56 & 0,20 \\
\hline B28 & 1026,33 & 1,87 & B59 & 1660,04 & 3,03 & B90 & 11981,56 & 22,30 \\
\hline B29 & 2307,08 & 4,21 & $\mathrm{~B} 60$ & 1512,68 & 2,76 & B91 & 2065,99 & 3,85 \\
\hline B30 & 1096,42 & 2,00 & B61 & 837,69 & 1,53 & B92 & 437,57 & 0,81 \\
\hline B31 & 1523,5 & 2,78 & B62 & 160,55 & 0,29 & СT & 187358,32 & 342,19 \\
\hline & & & & & & TOTAL & 403035,85 & 736,09 \\
\hline
\end{tabular}

*Extensão de redes que contribuem para o Coletor tronco existente. 


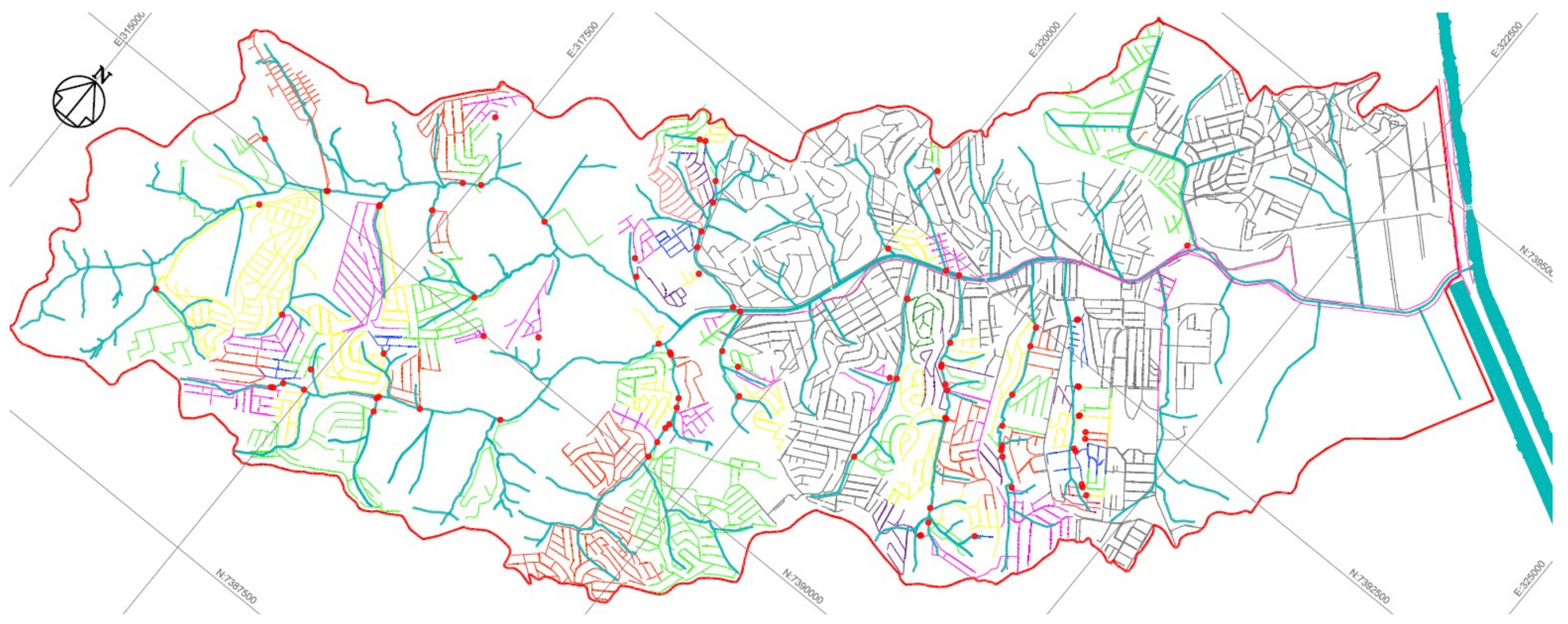

Ilustração 109 - Sistema de esgotamento sanitário existente na bacia do córrego Jaguaré. Fonte: Elaborado pela autora. 


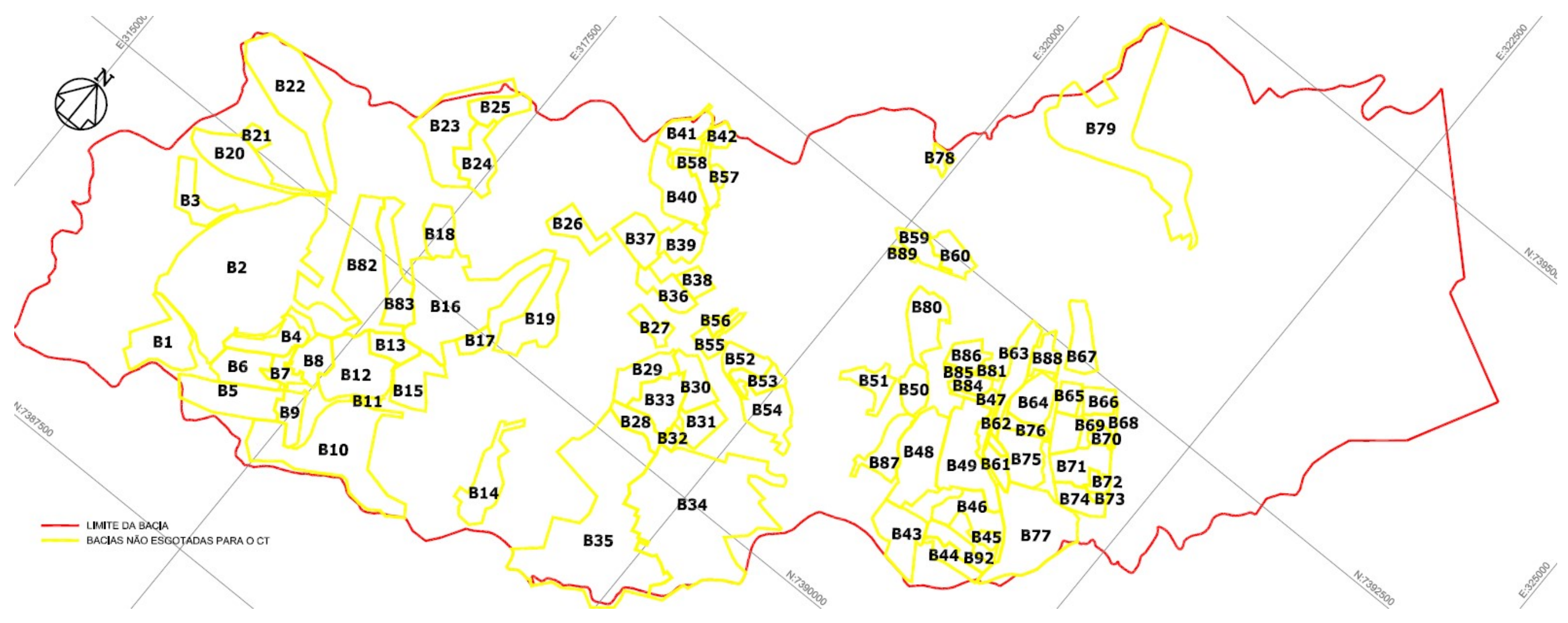

llustração 110 - Bacias não esgotadas para o coletor tronco SABESP existente na bacia do córrego Jaguaré. Fonte: Elaborado pela autora. 
Conhecidos então os pontos de cruzamento entre o sistema de esgotamento sanitário e o sistema de drenagem da bacia, foi verificado o impacto da implantação dos coletores tronco futuros previstos pela SABESP, o que resultou na llustração 111 a seguir que mostra em verde os pontos que foram solucionados pelos novos coletores troncos, ou seja, que serão coletados por estas novas redes, e em vermelho os pontos que mesmo com a implantação dos coletores tronco demandam soluções adicionais ou alternativas para serem esgotados. Além disso, foi produzida a Tabela 14 que mostra o resumo do atendimento de cada bacia de esgotamento sanitário.

Tabela 14 - Situação de cada bacia de esgotamento sanitário com a implantação dos coletores troncos previstos pela SABESP. Fonte: Elaborado pela autora.

\begin{tabular}{|c|c|c|c|}
\hline $\begin{array}{l}\text { Bacia de } \\
\text { Esgotamento } \\
\text { Sanitário }\end{array}$ & $\begin{array}{l}\text { Extensão da } \\
\text { rede }(\mathrm{m})\end{array}$ & $\begin{array}{l}\text { Atendida } \\
\text { pelos novos } \\
\text { CTs? }\end{array}$ & Observação \\
\hline B1 & 1962,07 & Sim & \\
\hline B2 & 16975,86 & Sim & Coletor do lado oposto do canal + Travessia de rodovia \\
\hline B3 & 1089,69 & Sim & Possui área de favela não atendida \\
\hline B4 & 2213,4 & Não & - \\
\hline B5 & 3393,72 & Sim & Coletor do lado oposto do canal \\
\hline B6 & 2181,35 & Sim & Coletor do lado oposto do canal \\
\hline B7 & 987,51 & Sim & Coletor do lado oposto do canal \\
\hline B8 & 1143,56 & Não & - \\
\hline B9 & 1301,53 & Sim & - \\
\hline B10 & 6194,9 & Não & Possui área de favela não atendida \\
\hline B11 & 188,87 & Sim & Coletor do lado oposto do canal \\
\hline B12 & 4634,27 & Sim & Possui área de favela não atendida \\
\hline B13 & 897,68 & Não & Possui área de favela não atendida \\
\hline B14 & 1956,12 & Sim & - \\
\hline B15 & 2069,24 & Sim & - \\
\hline B16 & 6301,15 & Não & Possui área de favela não atendida \\
\hline B17 & 554,26 & Não & - \\
\hline B18 & 1156,5 & Sim & - \\
\hline B19 & 1617,26 & Sim & - \\
\hline B20 & 1860,99 & Sim & Coletor do lado oposto do canal + Travessia de rodovia \\
\hline B21 & 241,19 & Sim & Coletor do lado oposto do canal \\
\hline B22 & 5153,39 & Sim & - \\
\hline B23 & 3807,76 & Sim & Coletor do lado oposto do canal \\
\hline B24 & 1565,01 & Sim & - \\
\hline B25 & 1241,97 & Sim & - \\
\hline B26 & 601,21 & Sim & Possui área de favela não atendida \\
\hline B27 & 499,28 & Sim & - \\
\hline B28 & 1026,33 & Sim & - \\
\hline B29 & 2307,08 & Sim & - \\
\hline
\end{tabular}




\begin{tabular}{|c|c|c|c|}
\hline $\begin{array}{l}\text { Bacia de } \\
\text { Esgotamento } \\
\text { Sanitário }\end{array}$ & $\begin{array}{l}\text { Extensão da } \\
\text { rede }(\mathrm{m})\end{array}$ & $\begin{array}{l}\text { Atendida } \\
\text { pelos novos } \\
\text { CTs? }\end{array}$ & Observação \\
\hline B30 & 1096,42 & Sim & Coletor do lado oposto do canal \\
\hline B31 & 1523,5 & Sim & - \\
\hline B32 & 179,61 & Sim & - \\
\hline B33 & 2426,71 & Sim & - \\
\hline B34 & 14811,37 & Sim & Possui área de favela não atendida \\
\hline B35 & 16070,74 & Sim & Coletor do lado oposto do canal \\
\hline B36 & 1202,89 & Não & - \\
\hline B37 & 1395,94 & Não & - \\
\hline B38 & 362,86 & Sim & Necessita de rede complementar \\
\hline B39 & 1753,52 & Sim & Coletor do lado oposto do canal + Possui área de favela não \\
\hline B40 & 3821,86 & $\operatorname{Sim}$ & Coletor do lado oposto do canal + Possui área de favela não \\
\hline B41 & 2036,49 & Não & - \\
\hline B42 & 686,67 & Não & - \\
\hline B43 & 2818,66 & Sim & - \\
\hline B44 & 1970,09 & Sim & - \\
\hline B45 & 132,03 & Não & - \\
\hline B46 & 1873,6 & Sim & Coletor do lado oposto do canal \\
\hline B47 & 1296,14 & Sim & - \\
\hline B48 & 3545,32 & Sim & - \\
\hline B49 & 4911,44 & Sim & Coletor do lado oposto do canal \\
\hline B50 & 1248,03 & Sim & Coletor do lado oposto do canal \\
\hline B51 & 1240,3 & Sim & Necessita de rede complementar \\
\hline B52 & 1230,51 & Não & - \\
\hline B53 & 836,08 & Não & - \\
\hline B54 & 1985,81 & Não & - \\
\hline B55 & 935,68 & Sim & Falta interligar no CT existente \\
\hline B56 & 417,65 & Sim & Coletor do lado oposto do canal \\
\hline B57 & 115,88 & Sim & - \\
\hline B58 & 1627,93 & Sim & - \\
\hline B59 & 1660,04 & Sim & Falta interligar no CT existente \\
\hline B60 & 1512,68 & Sim & Falta interligar no CT existente \\
\hline B61 & 837,69 & Sim & - \\
\hline B62 & 160,55 & Sim & - \\
\hline B63 & 2101,38 & Sim & \\
\hline B64 & 1430,88 & Não & Possui área de favela não atendida \\
\hline B65 & 670,62 & Sim & - \\
\hline B66 & 746,66 & Sim & Coletor do lado oposto do canal \\
\hline B67 & 1171,02 & Sim & - \\
\hline B68 & 786,91 & Sim & - \\
\hline B69 & 1167,27 & Sim & Necessita de rede complementar + Possui área de favela \\
\hline B70 & 666,49 & Sim & Necessita de rede complementar \\
\hline B71 & 2020,85 & Sim & - \\
\hline B72 & 728,76 & $\operatorname{Sim}$ & - \\
\hline B73 & 263,29 & Sim & - \\
\hline
\end{tabular}




\begin{tabular}{|c|c|c|c|}
\hline $\begin{array}{c}\text { Bacia de } \\
\text { Esgotamento } \\
\text { Sanitário }\end{array}$ & $\begin{array}{l}\text { Extensão da } \\
\text { rede }(m)\end{array}$ & $\begin{array}{c}\text { Atendida } \\
\text { pelos novos } \\
\text { CTs? }\end{array}$ & Observação \\
\hline B74 & 1396,25 & Sim & - \\
\hline B75 & 1991,4 & Sim & Coletor do lado oposto do canal \\
\hline B76 & 295,71 & Não & Possui área de favela não atendida \\
\hline B77 & 5159,68 & Sim & - \\
\hline B78 & 411,13 & Não & Possui área de favela não atendida \\
\hline B79 & 761,27 & Sim & - \\
\hline B80 & 2065,99 & $\operatorname{Sim}$ & - \\
\hline B81 & 437,57 & Sim & Coletor do lado oposto do canal \\
\hline B82 & 5357,91 & Sim & Travessia de rodovia + Possui área de favela não atendida \\
\hline B83 & 2436,42 & Sim & Travessia de rodovia + Necessita de rede complementar \\
\hline B84 & 131,32 & Sim & - \\
\hline B85 & 576,89 & Sim & Coletor do lado oposto do canal \\
\hline B86 & 918,98 & Sim & Coletor do lado oposto do canal + Possui área de favela não \\
\hline B87 & 2084,4 & Sim & Coletor do lado oposto do canal \\
\hline B88 & 1233,67 & Sim & Coletor do lado oposto do canal \\
\hline B89 & 111,56 & Não & Possui área de favela não atendida \\
\hline B90 & 11981,56 & Sim & Falta interligar no CT existente \\
\hline B91 & 108,7 & Não & - \\
\hline CT & 200973,47 & - & - \\
\hline TOTAL & 403035,85 & - & - \\
\hline
\end{tabular}

Nos pontos não atendidos pelos novos coletores tronco serão necessárias soluções adicionais para o completo esgotamento da bacia o que resultou na seguinte nomenclatura adotada neste estudo:

- Técnicas convencionais: Estação elevatória de esgotos e linhas de recalque

- Técnicas não convencionais: Sistema de tratamento individual (Bacia de evapotranspiração ou conjunto Fossa, filtro e sumidor); Sistemas de tratamento para poucas unidades (Filtro percolador ou Reator sequencial por batelada); Sistema de tratamento para pequenas comunidades (ETE's compactas ou Wetlands - Filtro de fluxo vertical). Além disso, será considerada como técnica não convencional a travessia de redes por dentro de canais.

Visando a adoção de técnicas que priorizem o tratamento local nestes pontos de difícil esgotamento, foi realizada a análise de cada um dos pontos não atendidos pelos coletores tronco a fim de identificar a melhor solução a ser adotada, o que resultou no estudo apresentado a seguir. 


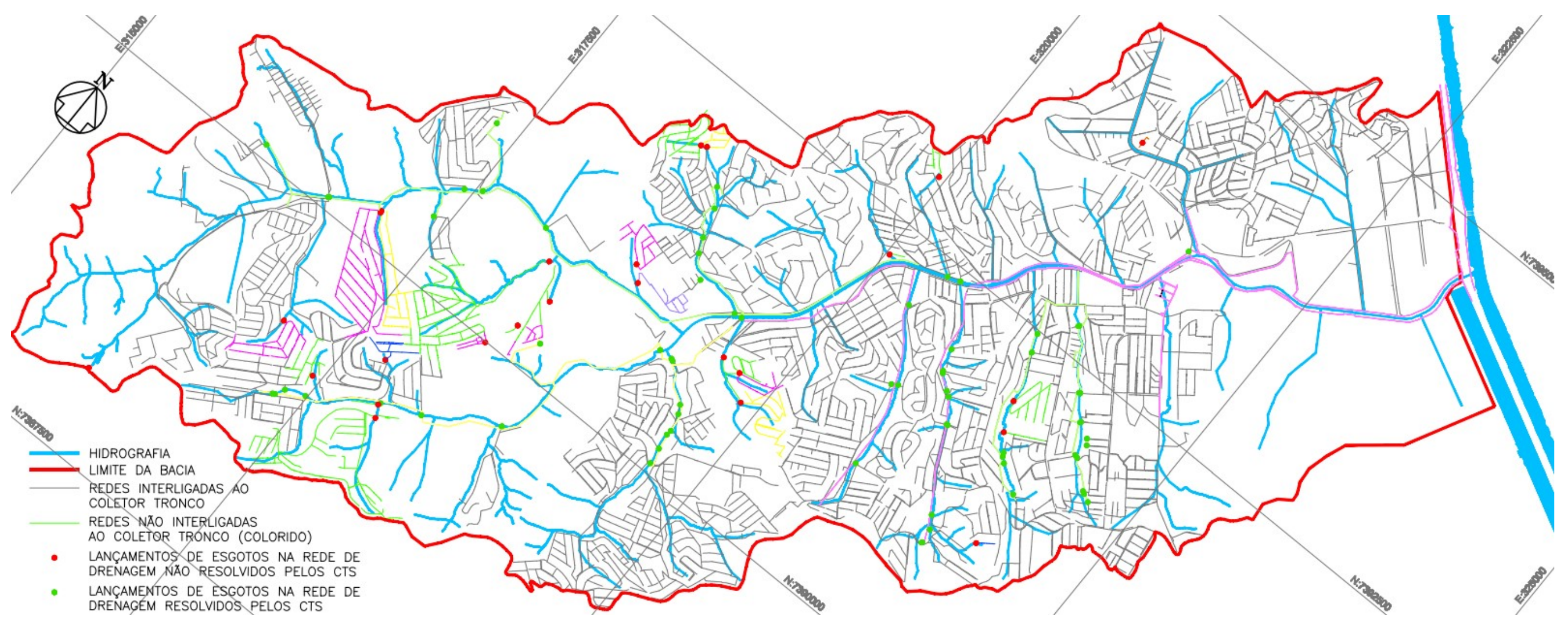

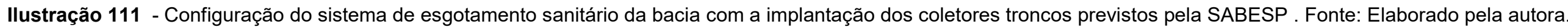




\section{Bacia 3:}

A bacia 3 será esgotada para o CT 3a Etapa BID A1 através da Bacia 2, no entanto sua área de esgotamento natural contempla a comunidade Vila Nova Esperança dentro do Parque Tizo que não é atendida por sistema de coleta de esgotos. Por tratar-se de uma área isolada na bacia, promover sua coleta através da implantação de redes coletoras que interliguem a área a um coletor tronco próximo, demandaria a implantação de uma extensão significativa de redes coletoras encarecendo sua execução. Portanto esta área será foco de estudo para verificação da viabilidade do emprego de técnicas de tratamento de esgoto locais complementares.
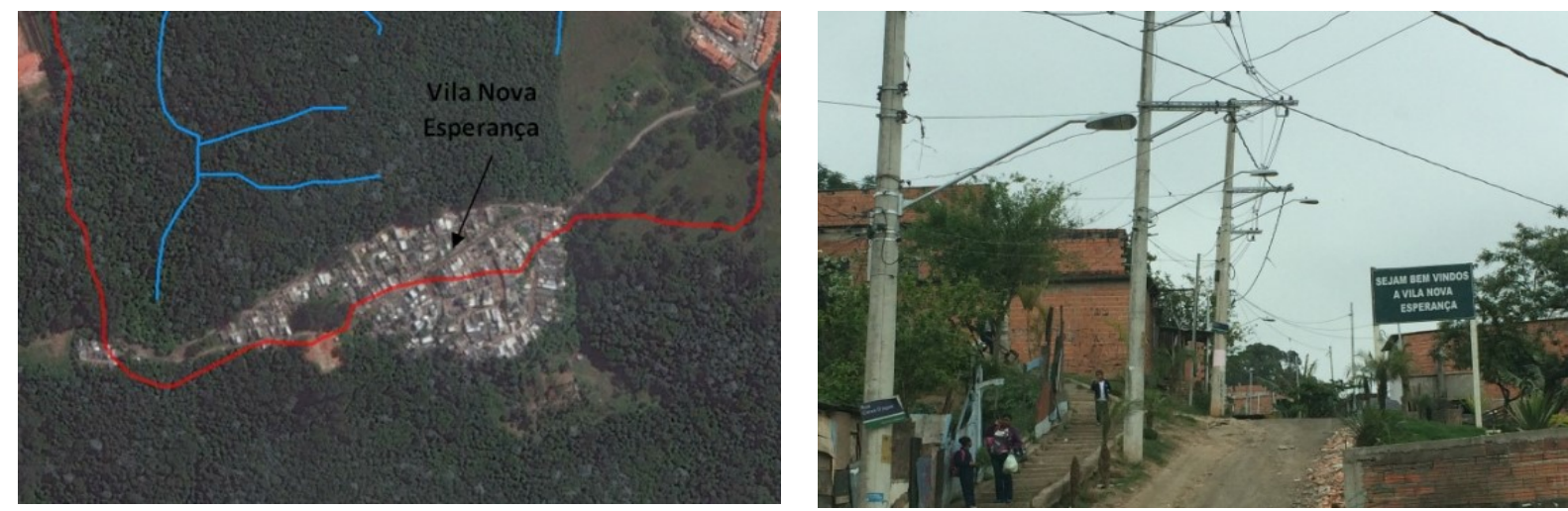

Ilustração 112 - Vila Nova Esperança na Bacia 3. Fonte: Adaptado de Google Earth e Foto da autora.

Em visita à área constatou-se que a comunidade conta com redes coletoras de esgoto instaladas pelos próprios moradores, estas tubulações vertem o esgoto a céu aberto através de canaletas no sistema viário da comunidade. Há também algumas fossas sépticas sem a devida manutenção, que acabam resultando na contaminação do solo. A llustração 113 mostra exemplos dos efluentes depositados nestas canaletas.
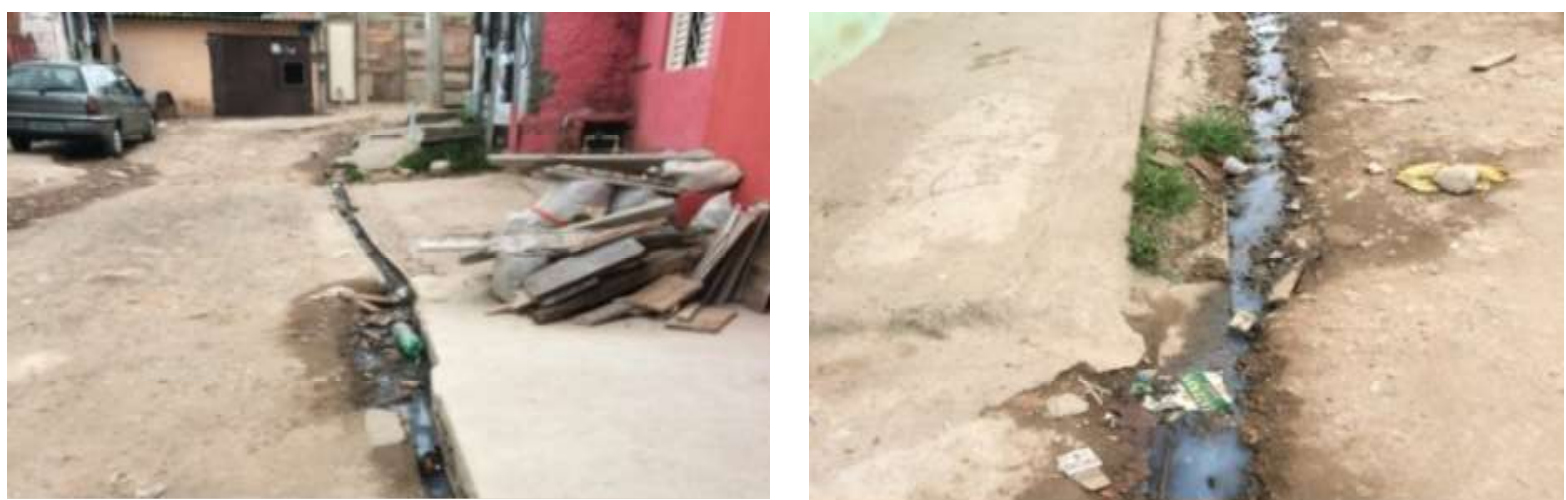

Ilustração 113 - Efluente sanitário correndo em canaletas na Vila Nova Esperança na Bacia 3. Fonte: Fotos da autora. 
Os efluentes, da parcela da comunidade que esta inserida na bacia do Jaguaré, afluem para o parque Tizo, que abriga importantes nascentes, relativamente preservadas do córrego Itaim, importante afluente do córrego Jaguaré. Esta parcela corresponde ao efluente de 120 residências de baixo padrão, totalizando uma vazão teórica de $0,30 \mathrm{~L} / \mathrm{s}$.

Como trata-se de uma pequena comunidade isolada, o tratamento mais conveniente seria o não convencional. A existência da área verde do parque propicia a implantação de um sistema coletivo de tratamento do tipo Wetland. Além disso, nos pontos isolados poderiam ser adotadas técnicas como a Bacia de Evapotranspiração e conjuntos Fossa, Filtro e Sumidor.

\section{Bacia 4:}

Não esta previsto o esgotamento da Bacia 4 na programação da SABESP. No entanto foi verificado que há a possibilidade de atender a bacia através da sua interligação com a Bacia 2 através da execução de uma rede complementar, com cerca de 120 metros e diâmetro de $150 \mathrm{~mm}$, que fará a travessia da canalização, na cota existente realizando lançamento no PV SABESP existente, implantado na cota 772,938 com $2,22 m$ de profundidade.

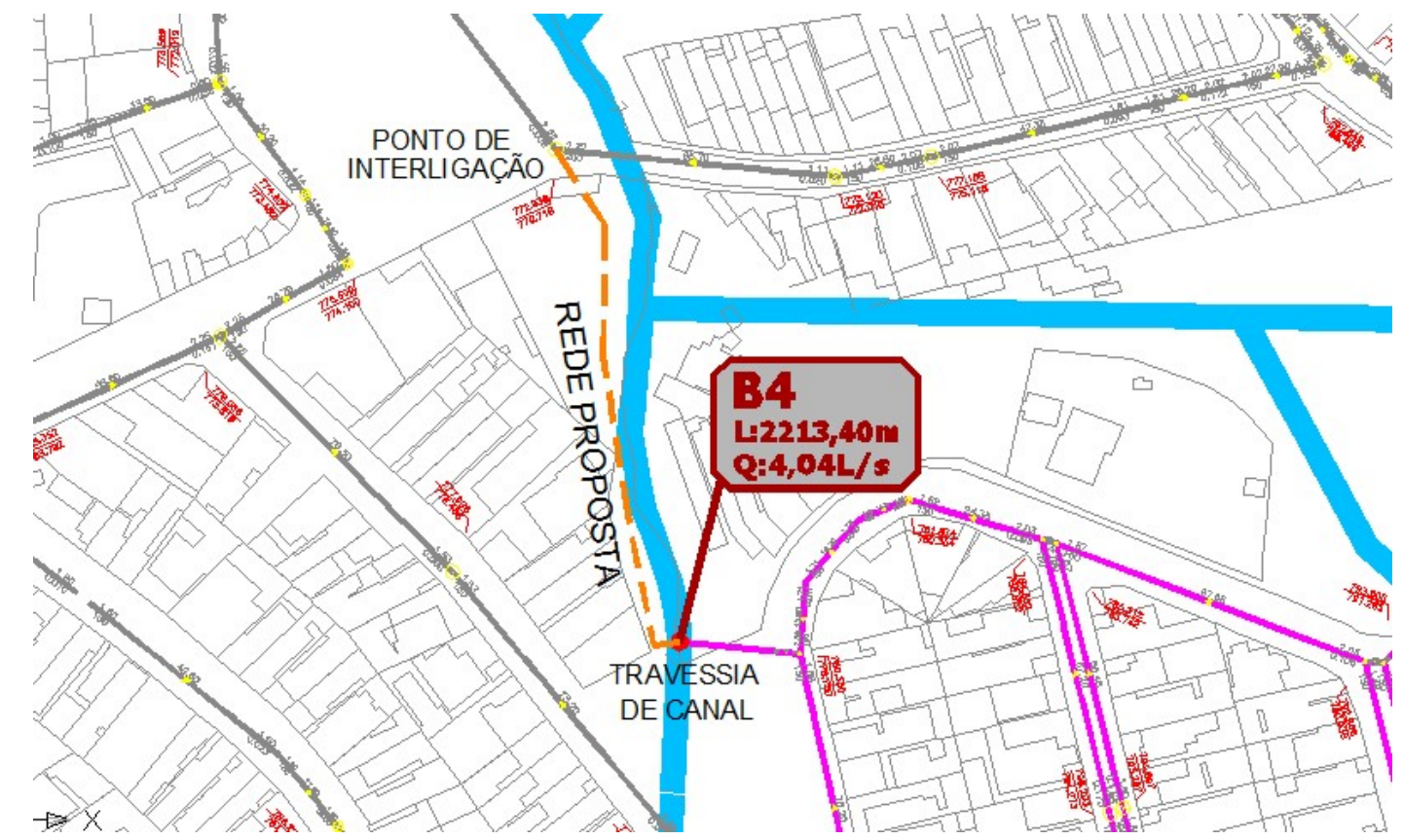

Ilustração 114 - Proposta de esgotamento da Bacia 4.

A existência de moradias junto aos corpos d'água e a necessidade de executar travessias profundas dos canais fazem com essa solução seja de difícil execução, no 
entanto como medida não convencional, pode ser adotada a solução de execução de redes no interior do canal, como já exemplificado na llustração 06 anteriormente.

\section{Bacia 8:}

Não há previsão para o esgotamento da bacia 8 bacia na programação de coletores tronco da SABESP. Este ponto é de grande importância, pois seu saneamento resultaria na melhoria da qualidade da água no Jaguaré no trecho em que o mesmo corta o CEU Uirapuru. A llustração 115 a seguir, mostra o lançamento do canal em galeria subterrânea, cujas águas encontram-se degradadas devido ao lançamento de esgotos da rede coletora em questão.
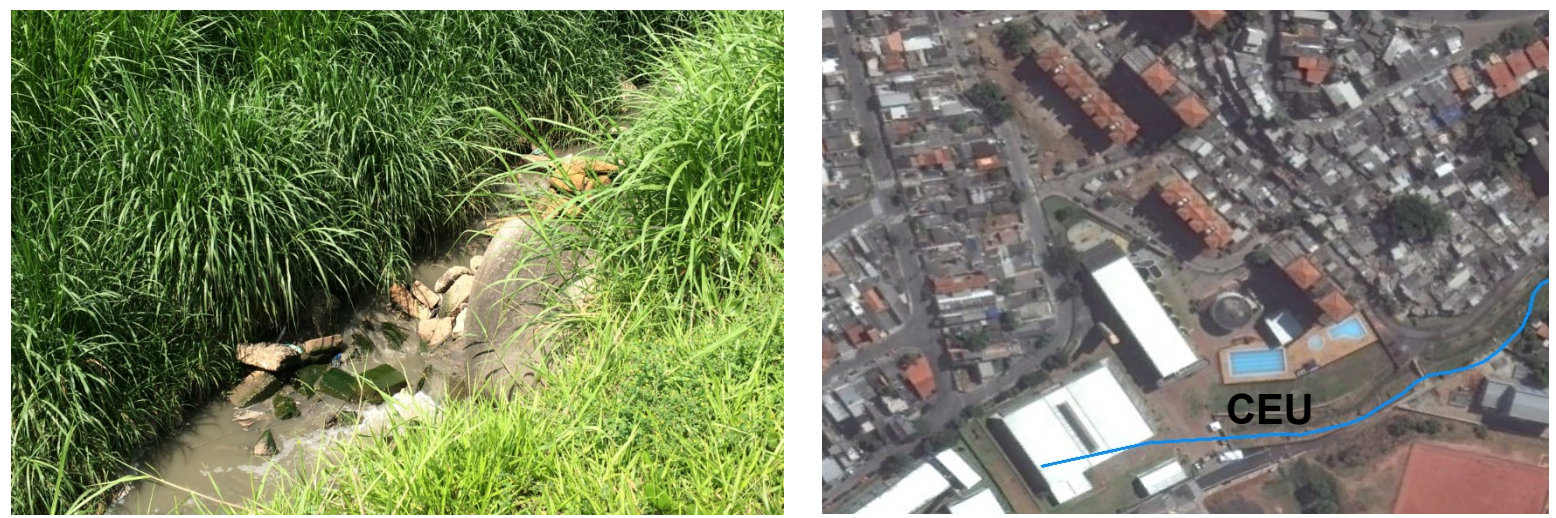

Ilustração 115 - Lançamento de esgotos no córrego Jaguaré no trecho do CEU Uirapuru.

Foi verificada neste estudo a possibilidade de atender a bacia através da sua interligação com o coletor tronco previsto 4a Etapa PAC2 - F3 através da execução de uma rede complementar, com cerca de 140 metros e diâmetro de $150 \mathrm{~mm}$, dentro da área do CEU Uirapuru, como mostrado na Ilustração 116 a seguir. No entanto tal solução demanda articulação do poder público para que seja autorizada. 


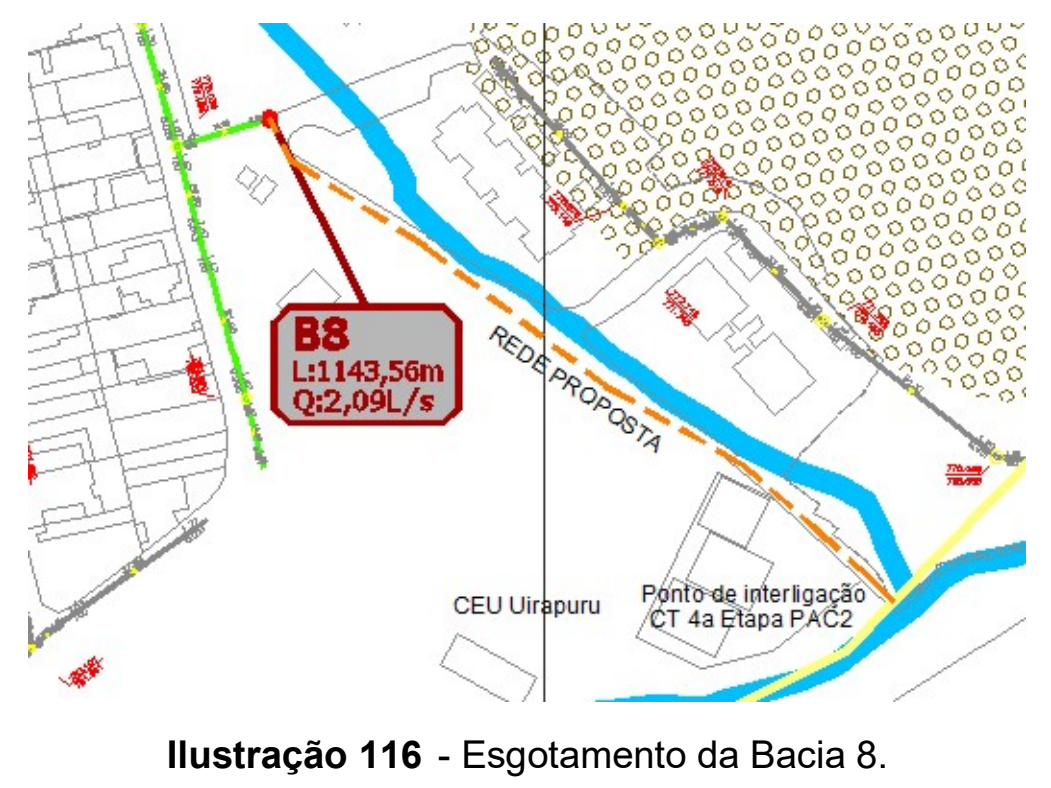

\section{Bacia 10:}

A bacia 10 além de não ser atendida diretamente pelo coletor tronco apresenta em sua área a favela Recanto da Felicidade, que não conta com sistema de coleta de esgotos. Para esgotar a bacia poderia ser realizado um complemento de rede, com cerca de 110 metros e diâmetro de $200 \mathrm{~mm}$, até o coletor tronco previsto 4a Etapa PAC2 - F3, com a execução de uma travessia no córrego Jaguaré, além disso, seria necessária a execução de redes coletoras no interior da favela e atendimento dos pontos inviáveis para esgotamento com tecnologias complementares de tratamento local. 


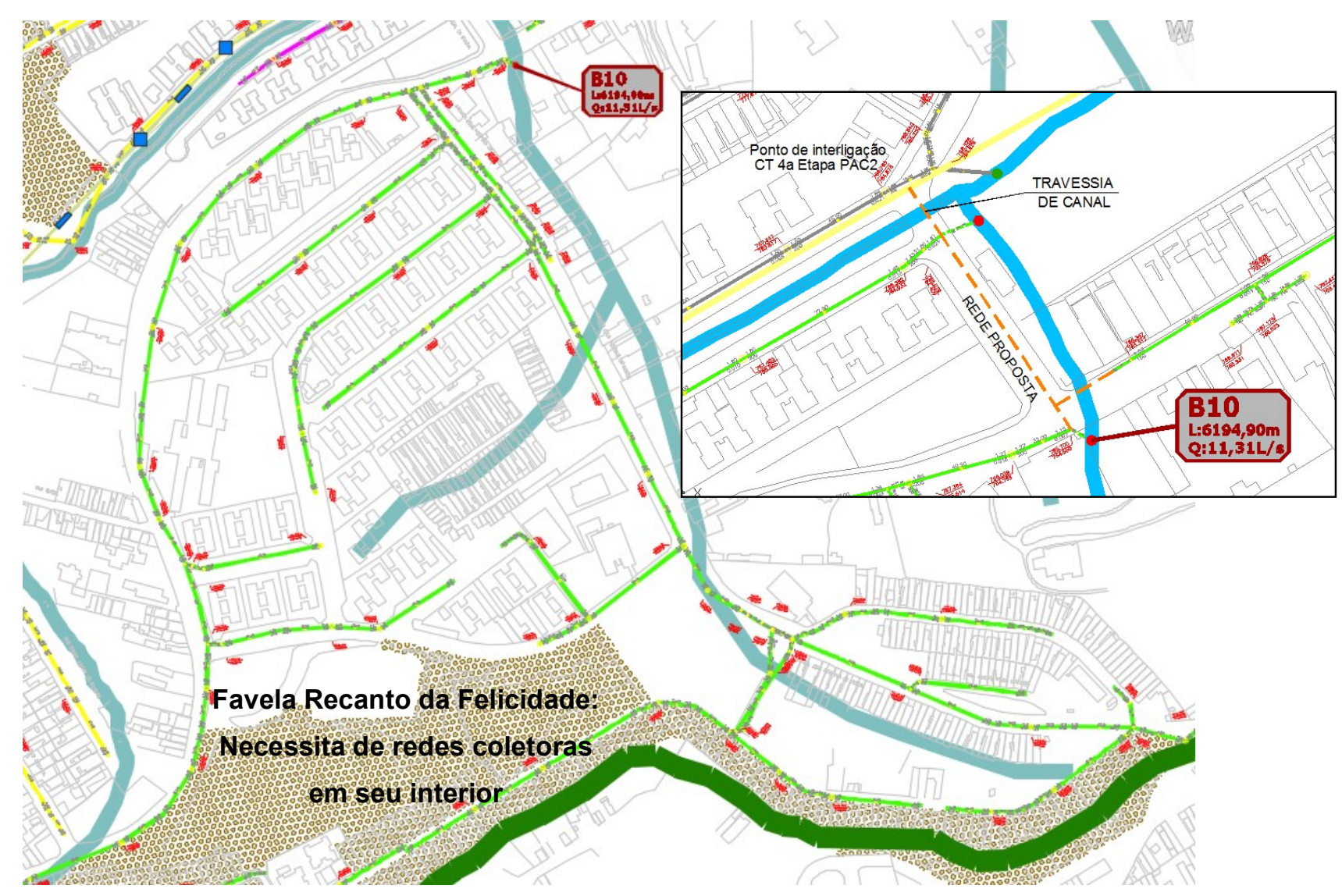

Ilustração 117 - Esgotamento da Bacia 10.

\section{Bacia 13:}

A bacia 13 além de não ser atendida pelo coletor tronco apresenta em sua área uma favela, que não conta com sistema de coleta de esgotos. Para esgotar a bacia poderia ser realizado um complemento de rede, com cerca de 130 metros e diâmetro de $150 \mathrm{~mm}$, até o poço de visita existente na bacia 12 (Indicado na llustração 118 ), com a execução de uma travessia do corpo d'água, que hoje se encontra canalizado em galeria subterrânea, e a execução de redes coletoras no interior da favela, atendendo os pontos inviáveis para esgotamento com tecnologias complementares de tratamento local. 


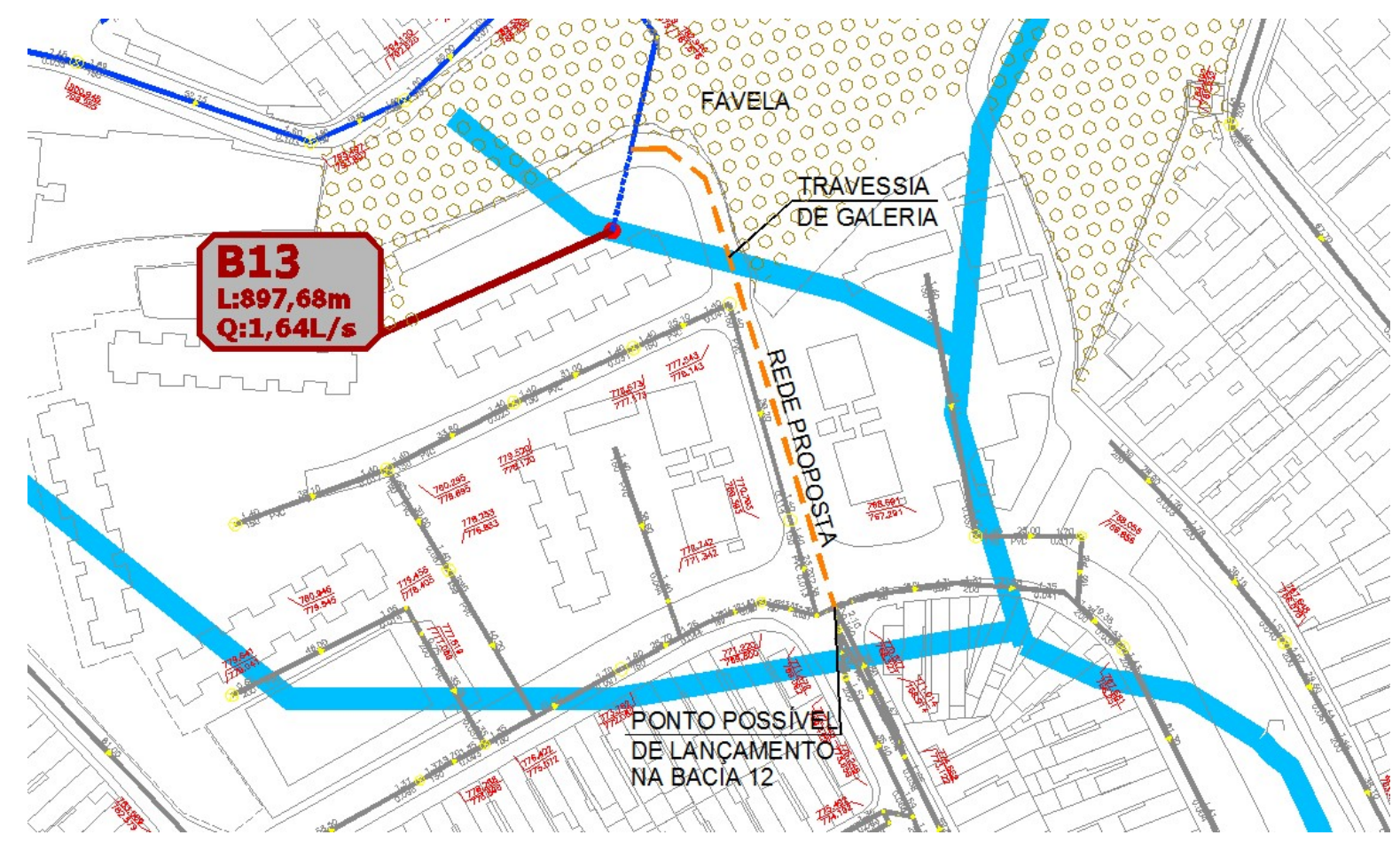

Ilustração 118 - Esgotamento da Bacia 13.

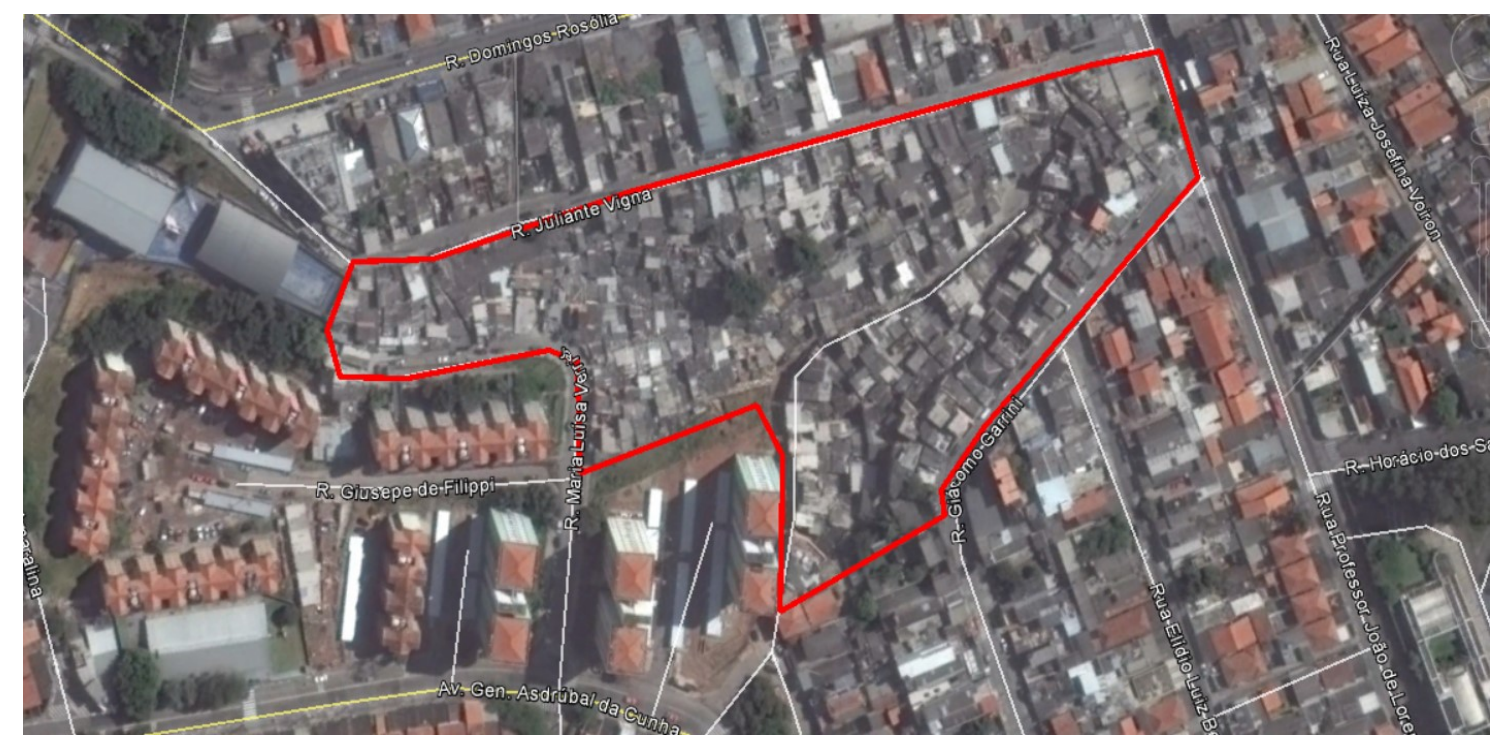

Ilustração 119 - Demanda de infraestrutura sanitária na Favela para esgotamento da Bacia 13.

\section{Bacia 16}

A bacia 16 pode ser esgotada para o CT 3a Etapa BID A1, no entanto demanda para isso a execução de redes complementares, com cerca de 150 metros e diâmetro de $200 \mathrm{~mm}$, e de uma travessia na rodovia Raposo Tavares, como mostrado na llustração 120 a seguir. Tal solução é custosa e demanda a utilização de técnicas de construção não destrutivas (MND), uma vez que se trata de uma rodovia de tráfego intenso e de grande 
importância para a região, portanto seria inviável sua interdição para execução da rede coletora em vala aberta.

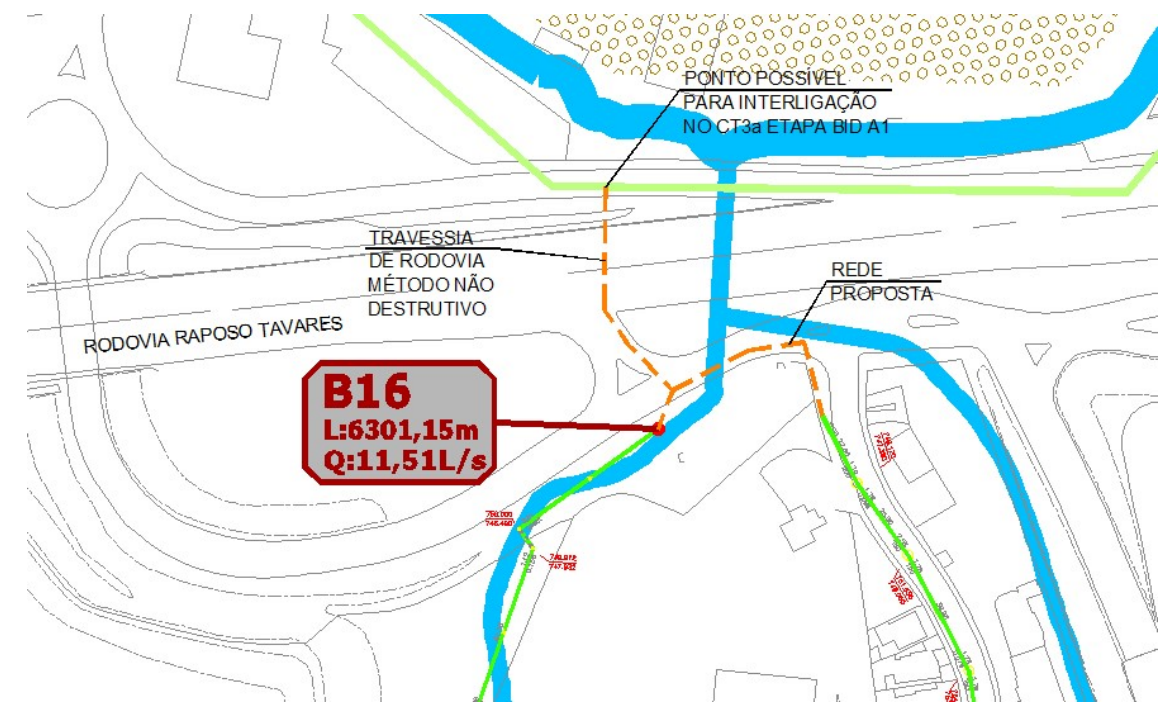

Ilustração 120 - Esgotamento da Bacia 16.

A bacia possui também uma área de favela não servida por rede coletora, demandando a execução de redes coletoras em seu interior, atendendo os pontos inviáveis para esgotamento com tecnologias complementares de tratamento local.

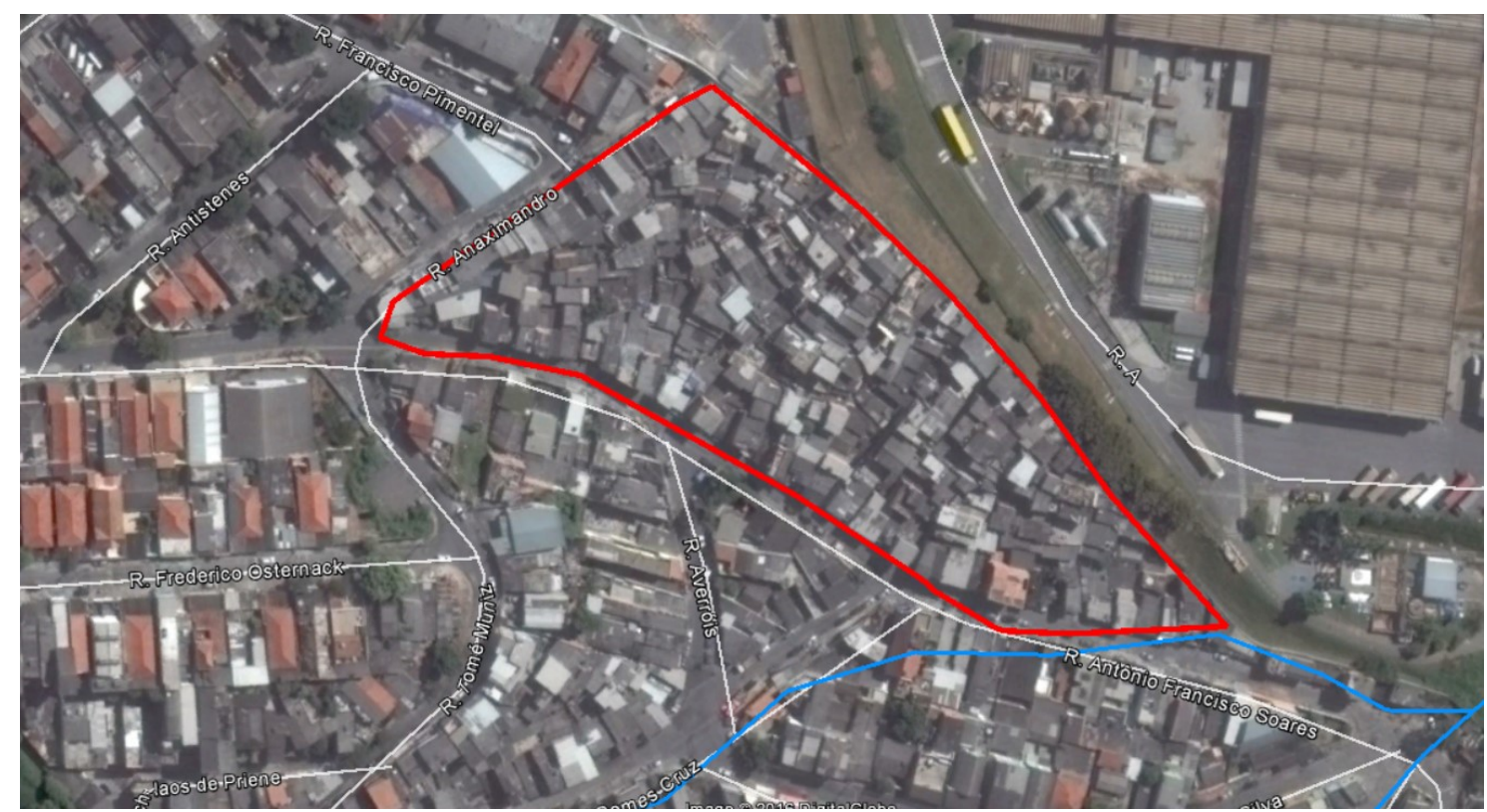

Ilustração 121 - Demanda de infraestrutura sanitária na Favela para esgotamento da Bacia 16. 
Além disso, a bacia possui dois trechos de rede de difícil esgotamento por técnicas convencionais, uma vez que demandariam a implantação de duas pequenas estações elevatórias de esgoto, o que eleva o custo do sistema, além de demandar manutenção constante.
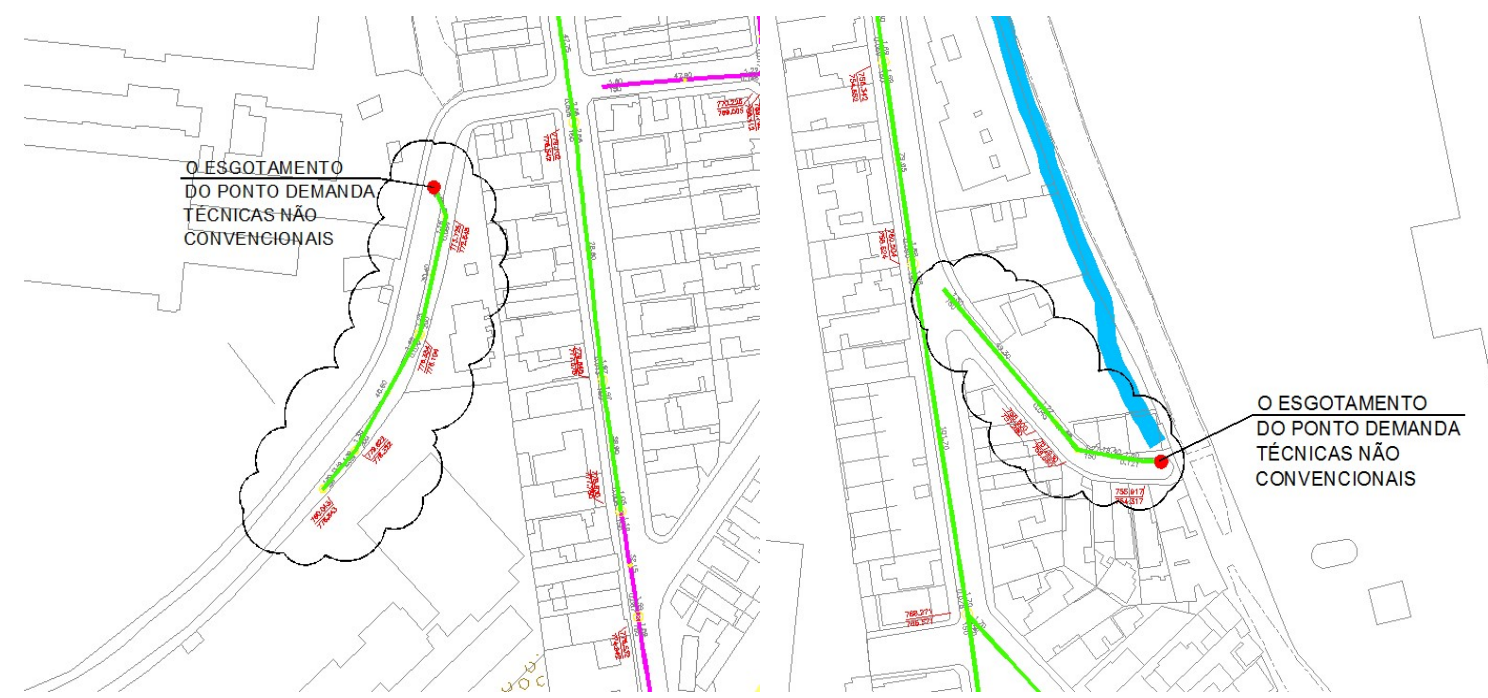

Ilustração 122 - Pontos para aplicação de técnicas de esgotamento não convencionais na Bacia 16.

\section{Bacia 17}

A bacia 17 não possui redes próximas para esgotamento por gravidade dos efluentes coletados, portanto demandaria a implantação de uma pequena estação elevatória de esgotos ou o uso de técnicas não convencionais. A área possui como ponto positivo a presença de um fragmento de área verde, que tem grande potencial para implantação de técnicas do tipo Wetlands.
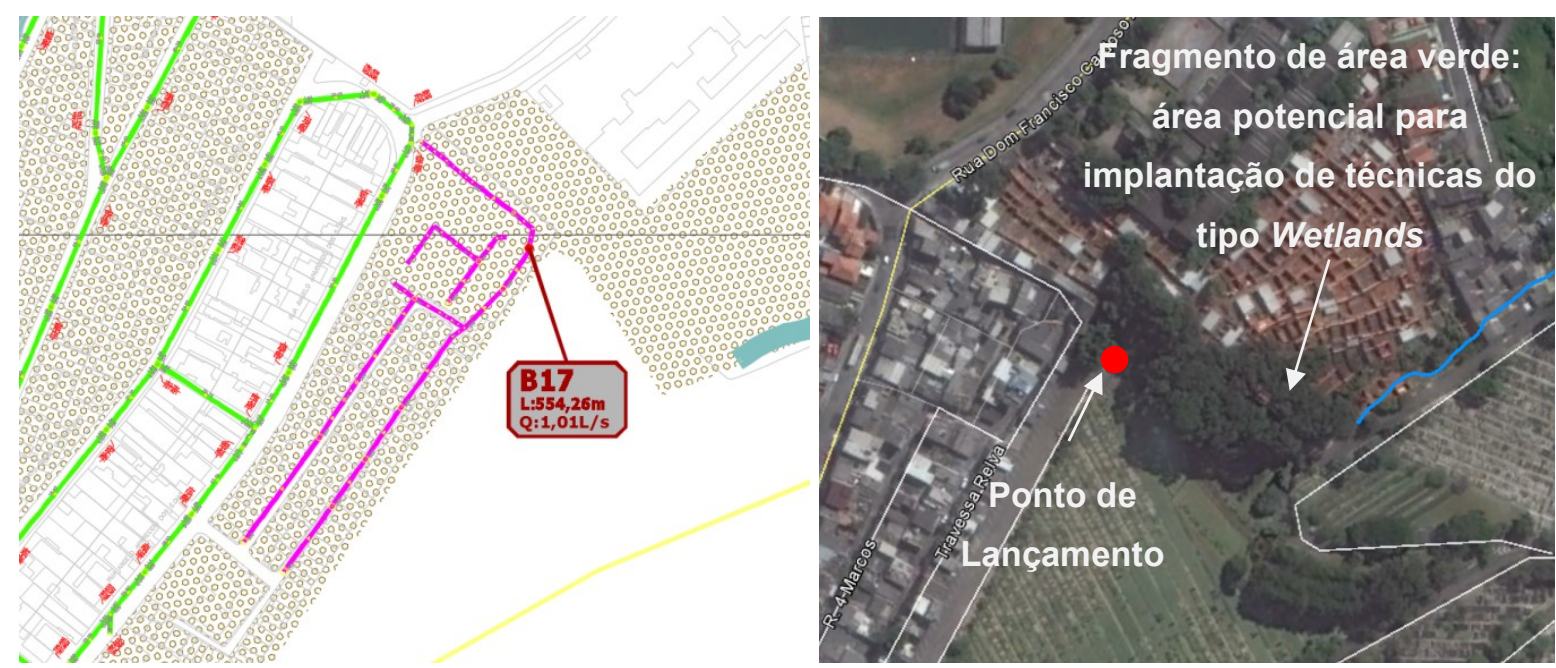

Ilustração 123 - Utilização de técnicas não convencionais para esgotamento da Bacia 17. 


\section{Bacias 36 e 37}

As bacias 36 e 37 podem ser esgotadas para o CT 4a Etapa PAC2 - F3, no entanto demandam para isso a execução de redes complementares, com cerca de 80 metros com diâmetro de $150 \mathrm{~mm}$ e 110 metros com diâmetro de 200mm, conforme mostrado na llustração 124 a seguir.

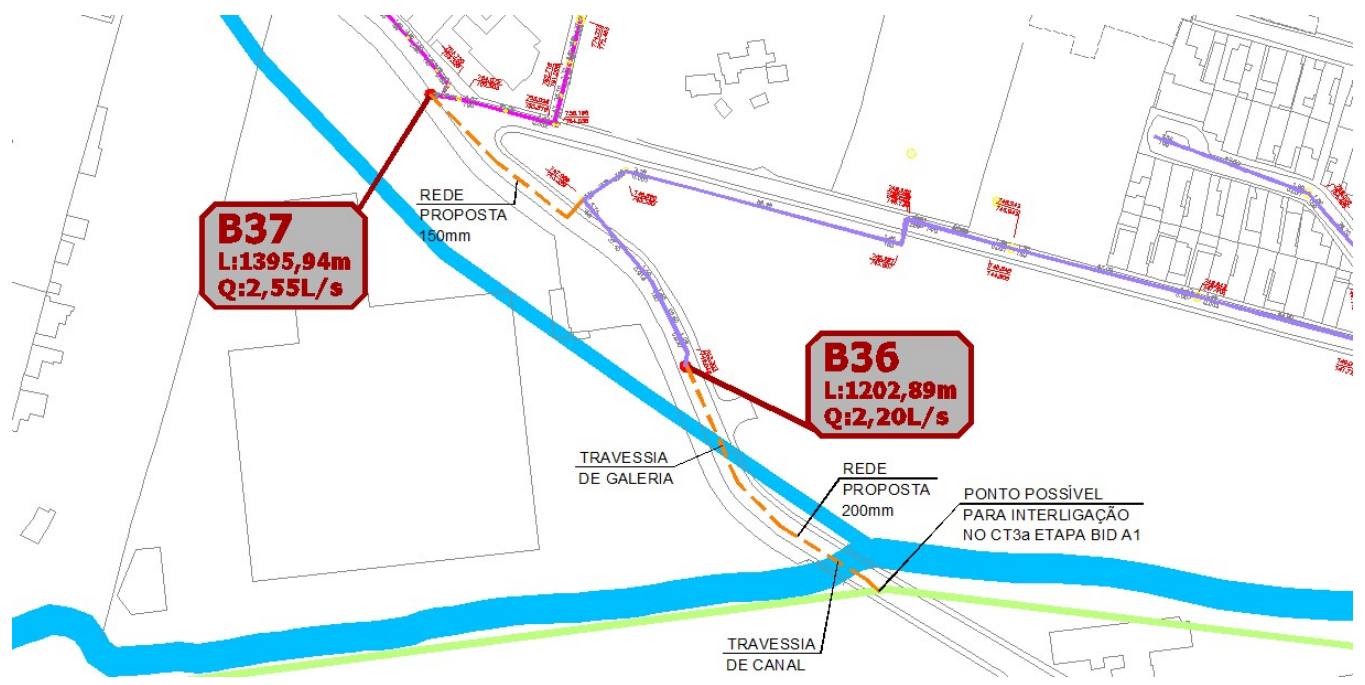

Ilustração 124 - Esgotamento das Bacias 36 e 37.

\section{Bacias 41 e 42}

As bacias 41 e 42 podem ser esgotadas para a Bacia 58 atendida pelo CT 3a Etapa BID A1, no entanto demandam adequações no sistema existente, a fim de promover o esgotamento para a Bacia 58 que é esgotada para o coletor tronco existente na Av. Escola Politécnica. Uma solução alternativa seria a adoção no local de uma estação de tratamento compacta.

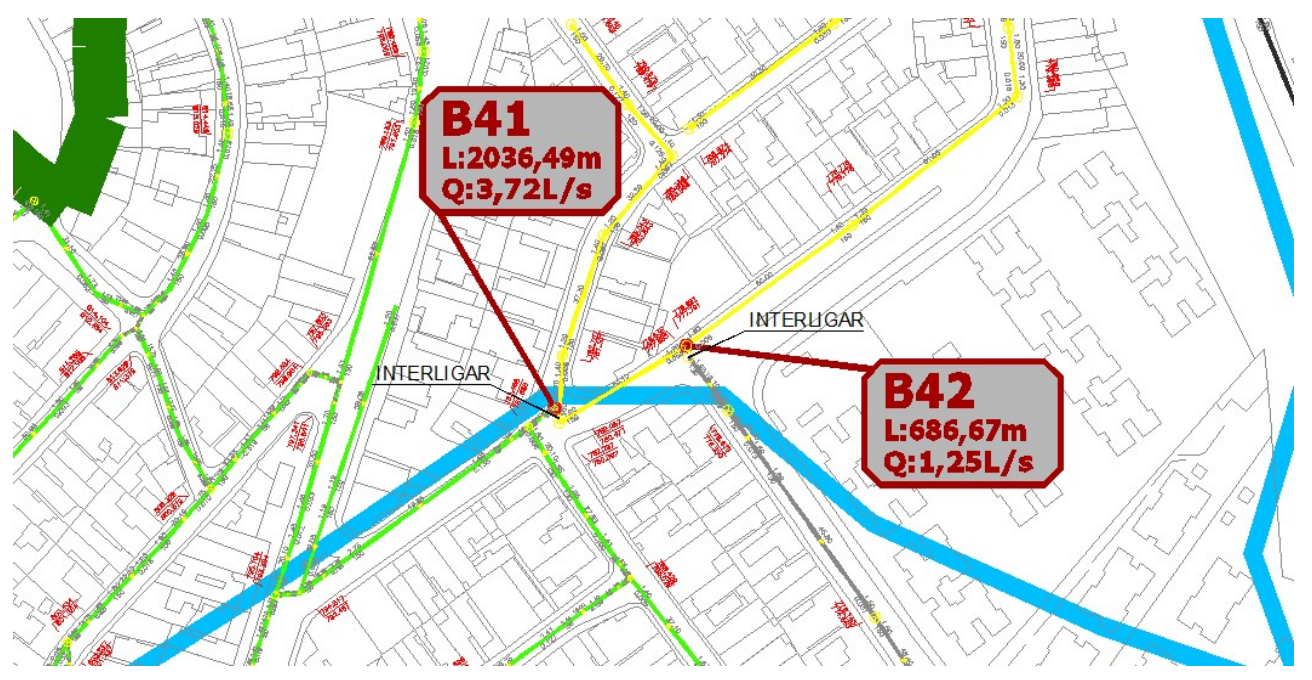

Ilustração 125 - Esgotamento das Bacias 41 e 42. 


\section{Bacia 45}

A bacia 45 não possui redes próximas para esgotamento por gravidade dos efluentes coletados, portanto demandaria a implantação de uma pequena estação elevatória de esgotos ou o uso de técnicas não convencionais. A área possui como ponto positivo a presença de um fragmento de área verde, que tem grande potencial para implantação de técnicas do tipo Wetlands.

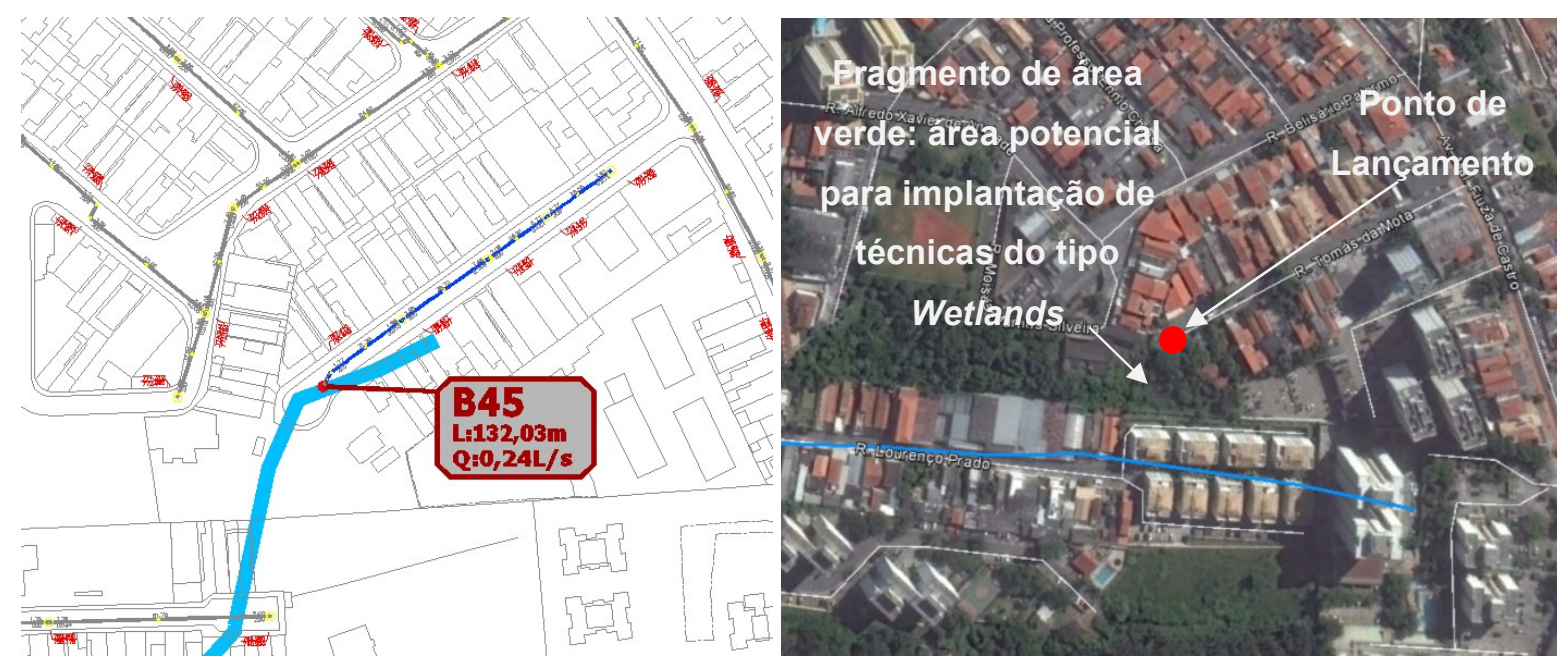

Ilustração 126 - Utilização de técnicas não convencionais para esgotamento da Bacia 45.

\section{Bacia 78}

A bacia 78 pode ser esgotada para as redes já atendidas pelo coletor tronco existente na Av. Escola Politécnica, no entanto demanda para isso a execução de redes complementares, cerca de 80 metros e diâmetro de $150 \mathrm{~mm}$.

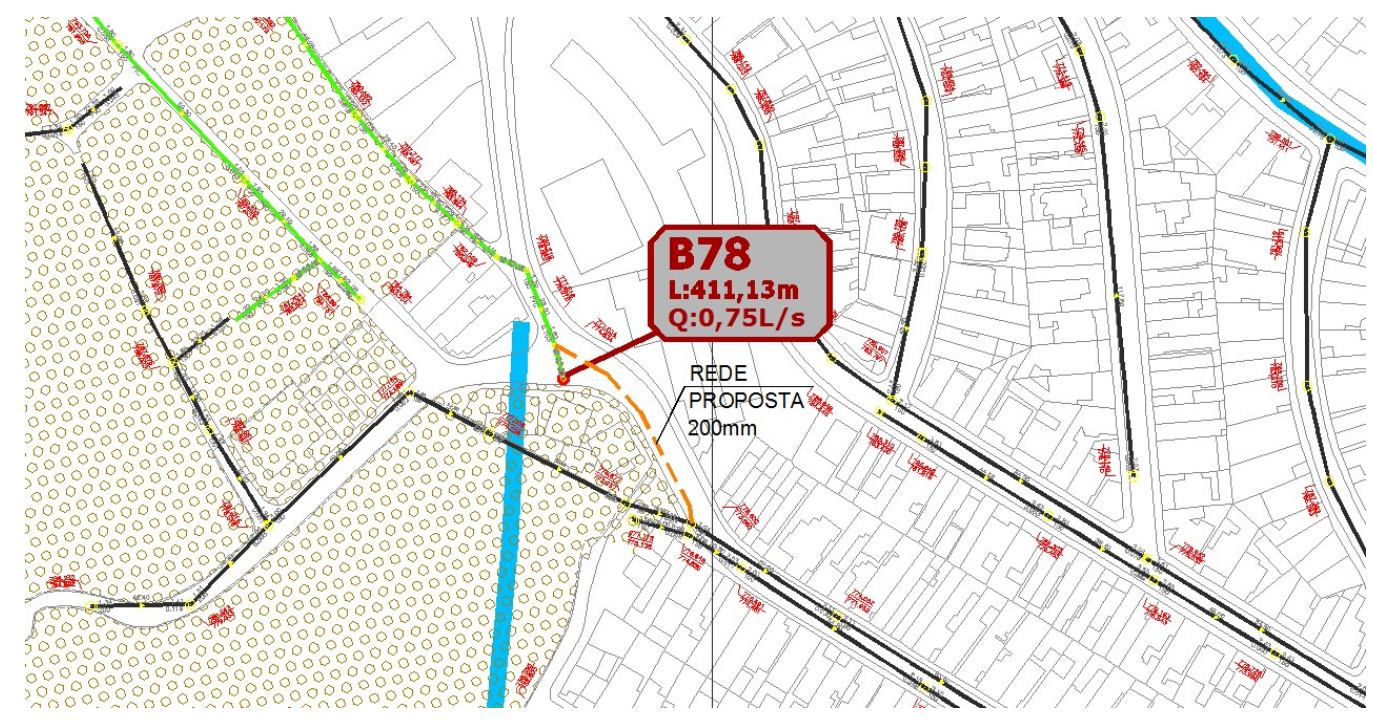

Ilustração 127 - Esgotamento da Bacia 78. 


\section{Bacias 52, 53 e 54}

As bacias 52, 53 e 54 podem ser esgotadas para o coletor tronco existente na avenida Escola Politécnica, no entanto demandam para isso a execução de diversos trechos de redes complementares, cerca de 350 metros de rede com diâmetro de $200 \mathrm{~mm}$, que unifiquem a coleta das três bacia e promovam o lançamento no CT em cota adequada.

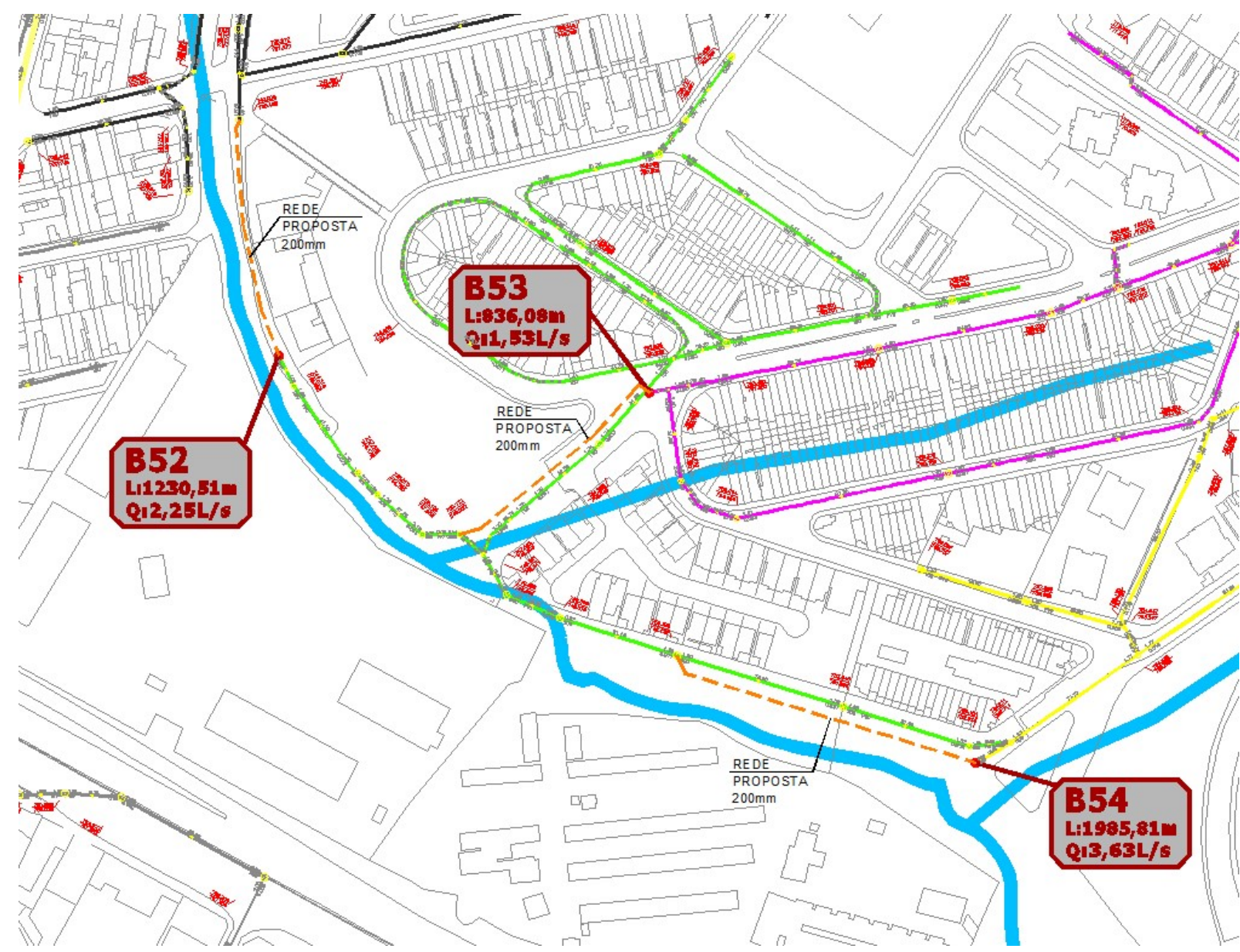

Ilustração 128 - Esgotamento das Bacias 52, 53 e 54. 


\section{Bacias 64 e 76}

As bacias 64 e 76 podem ser esgotadas para o CT 3a Etapa BID A1, no entanto demandam para isso a execução de redes complementares e de travessia do canal. Além disso, as bacias possuem uma área de favela não servida por rede coletora, demandando a execução de redes coletoras em seu interior, atendendo os pontos inviáveis para esgotamento com tecnologias complementares de tratamento local.

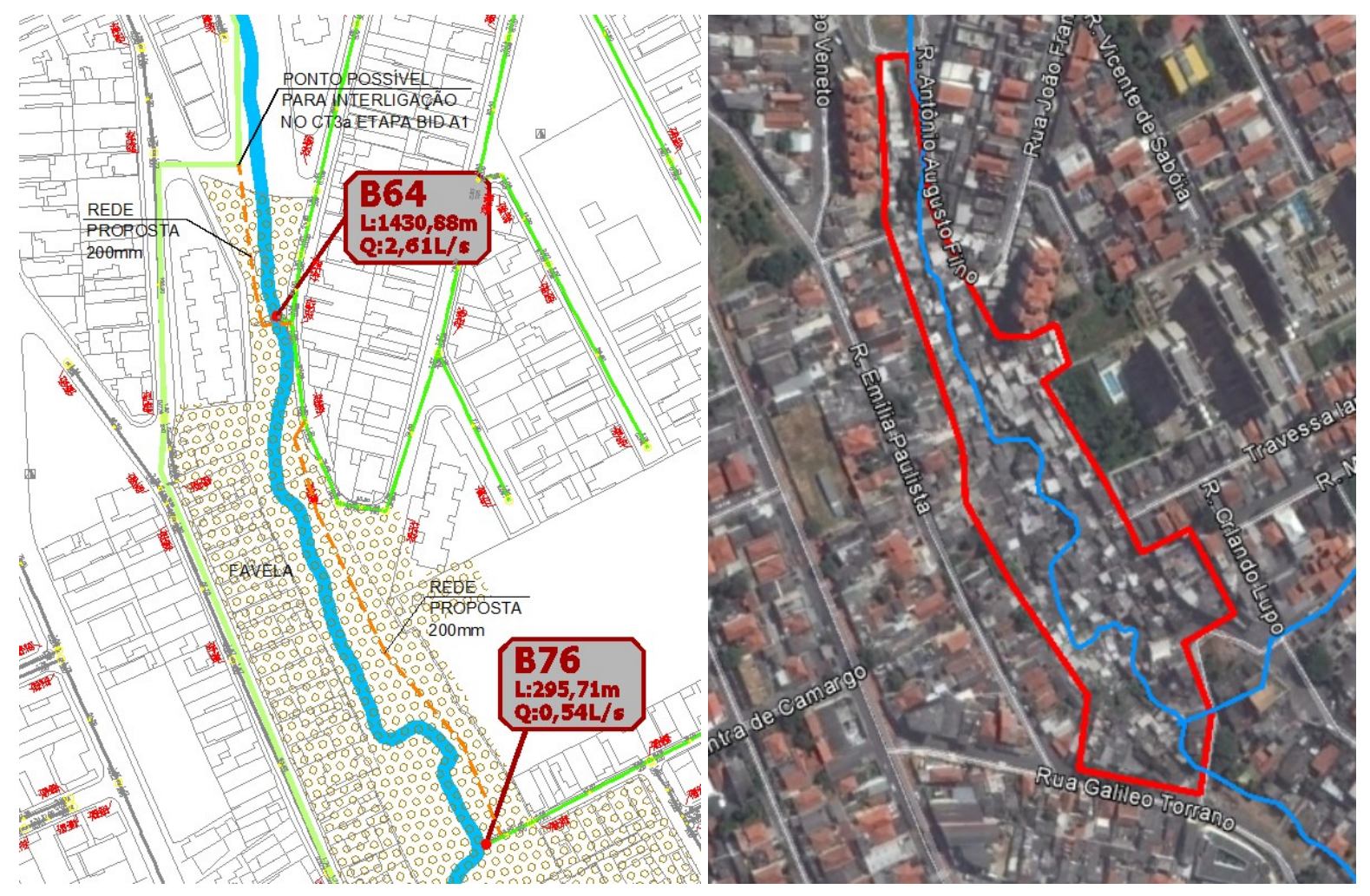

Ilustração 129 - Esgotamento e demanda de infraestrutura sanitária na Favela para esgotamento das Bacias 64 e 76.

\section{Bacia 89}

A bacia 89 pode ser esgotada para o CT 3a Etapa BID A1, no entanto demanda para isso a execução de redes complementares, cerca de 60 metros e diâmetro de 150mm. Além disso, a bacia possui uma pequena área de favela não servida por rede coletora, demandando a execução de redes coletoras em seu interior, atendendo os pontos inviáveis para esgotamento com tecnologias complementares de tratamento local. 


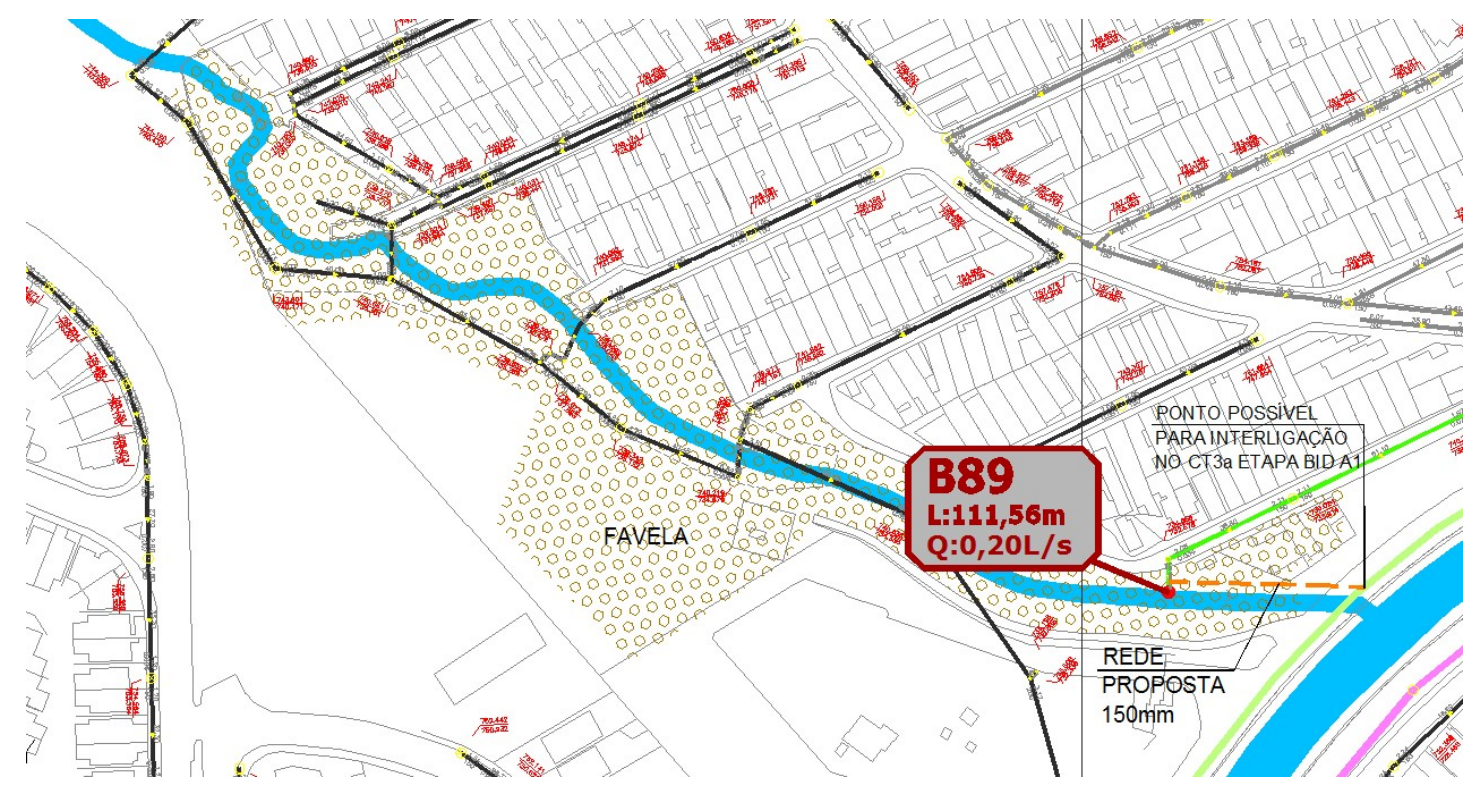

Ilustração 130 - Esgotamento da Bacia 89.

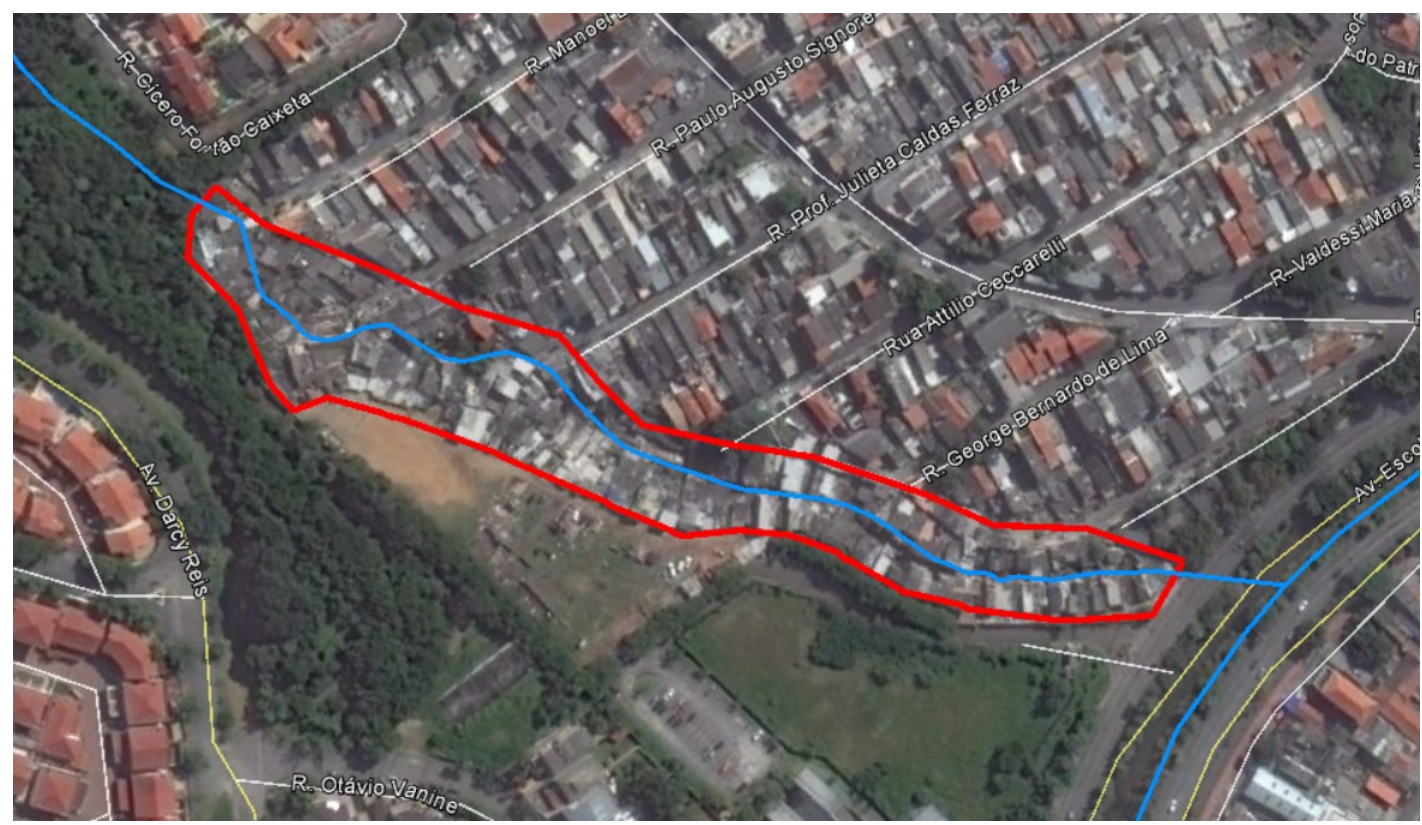

llustração 131 - Demanda de infraestrutura sanitária na Favela para esgotamento da Bacia 89.

A llustração 132 a seguir mostra o resumo das soluções propostas para a bacia para a universalização do sistema de esgotamento sanitário. 


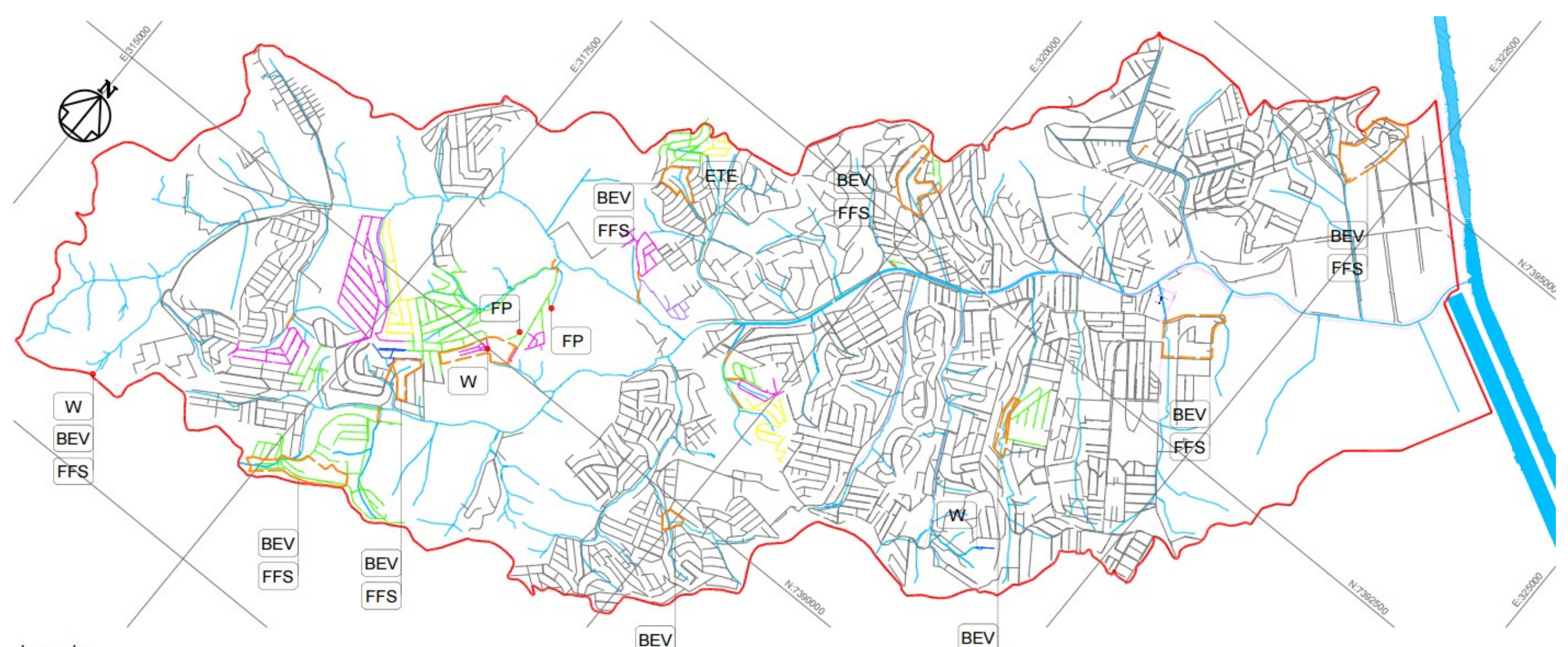

Legenda:

HIDROGRAFIA

BEV

BEV

\section{LIMITE DA BACIA}

FFS

FFS

REDES INTERLIGADAS AO COLETOR TRONCO

REDES NÃO INTERLIGADAS AO COLETOR TRONCO (COLORIDO)

- LANÇAMENTOS DE ESGOTOS NA REDE DE DRENAGEM NÃO RESOLVIDOS PELOS CTS

-- REDES COMPLEMENTARES

$\sqsubset 二 \sqsupset \quad$ ÁREAS DE OCUPAÇÃO IRREGULAR QUE DEMANDAM OBRAS DE INFRAESTRUTURA SANITÁRIA

BEV SISTEMA DE TRATAMENTO INDIVIDUAL (BACIA DE EVAPOTRANSPIRAÇÃO)

FFS SISTEMA DE TRATAMENTO INDIVIDUAL (CONJUNTO FOSSA, FILTRO E SUMIDOR)

FP DISTEMAS DE TRATAMENTO PARA POUCAS UNIDADES (FILTRO PERCOLADOR OU REATOR SEQUENCIAL POR BATELADA)

ETE SISTEMA DE TRATAMENTO PARA PEQUENAS COMUNIDADES (ETE'S COMPACTAS)

$W$ SISTEMA DE TRATAMENTO PARA PEQUENAS COMUNIDADES (WETLAND - FILTRO DE FLUXO VERTICAL)

Ilustração 132 - Soluções propostas para a universalização do esgotamento sanitário na bacia do Jaguaré . Fonte: Elaborado pela autora. 


\subsubsection{Controle de cargas difusas}

Conforme visto, Carga poluente é a quantidade de poluente, em massa ou peso, transportada, em uma unidade de tempo, a partir da fonte poluente até o corpo d'água. A estimativa das cargas poluentes que chegam a um corpo d'água é um elemento crucial para o desenvolvimento de planos de gestão de bacias hidrográficas, pois com base nestas estimativas é possível estabelecer limites para estas cargas, como por exemplo, através da adoção de um programa de carga máxima diária total (CMDT) (USEPA, 2003).

Para auxílio na elaboração do plano de intervenções para o controle de cargas difusas na bacia foi realizado o estudo teórico da geração de carga difusa com base no método da Unidade de Carga. A Unidade de Carga é um método de fácil aplicação, que representa a contribuição de poluentes por unidade de área e de tempo de cada tipo de ocupação do solo em uma determinada bacia hidrográfica, assim atribui-se pesos de produção de carga difusa para cada tipo de uso do solo através de consulta à valores referência e calcula-se o total produzido por cada parcela do solo na bacia (USEPA, 2003).

O projeto Guarapiranga, estudo pioneiro no que se refere a cargas difusas no Brasil, realizado pela SMA de São Paulo e a empresa Prime Engenharia em 2015, contemplou a quantificação das cargas poluentes aportadas para o reservatório através da aplicação do modelo MQUAL (Modelo matemático de Correlação Uso do Solo $x$ Qualidade da Água). A matriz de coeficientes de exportação de cargas para Fósforo total, Nitrogênio total, DBO, Sólidos em suspensão e Coliformes totais de diversos tipos de atividades utilizadas no programa obtidas no período chuvoso e seco são mostrados na Tabela 15 , estes coeficientes foram utilizados para gerar a produção teórica de carga difusa na bacia do Jaguaré. 
Tabela 15 - Coeficientes de exportação de cargas. Fonte: SMA/Primer, 2015.

Tempo chuvoso

\begin{tabular}{|c|c|c|c|c|c|c|c|}
\hline FONTE & Unidade & Fósforo Total & Nitrogênio & DBOc & DBOn & Sólidos em & Coliformes \\
\hline Atividade Agrícola & $\mathrm{kg} / \mathrm{km}^{2}$.dia & 0,346 & 2,95 & 7,564 & 7,315 & 230 & $1,00 E+11$ \\
\hline Reflorestamento & $\mathrm{kg} / \mathrm{km}^{2} . \mathrm{dia}$ & 0,039 & 0,6 & 1,302 & 1,197 & 20 & $1,00 E+08$ \\
\hline Mata / Capoeirão & $\mathrm{kg} / \mathrm{km}^{2}$.dia & 0,039 & 0,6 & 1,302 & 1,197 & 20 & $1,00 E+08$ \\
\hline Capoeira / Campo & $\mathrm{kg} / \mathrm{km}^{2}$.dia & 0,028 & 0,5 & 1,079 & 1,064 & 30 & $1,00 E+08$ \\
\hline Chácaras & $\mathrm{kg} / \mathrm{km}^{2} . \mathrm{dia}$ & 0,05 & 0,9 & 2 & 2,25 & 40 & $1,00 E+09$ \\
\hline Áreas Urbanas - Padrão Superior & $\mathrm{kg} / \mathrm{km}^{2} . \mathrm{dia}$ & 0,034 & 1,274 & 4 & 5,535 & 50 & $1,00 E+09$ \\
\hline Áreas Urbanas - Padrão Inferior & $\mathrm{kg} / \mathrm{km}^{2}$.dia & 0,135 & 2,548 & 8 & 11,07 & 100 & $1,00 E+09$ \\
\hline Áreas de Uso Industrial e Comercial & $\mathrm{kg} / \mathrm{km}^{2}$.dia & 0,081 & 1,784 & 5,6 & 7,749 & 70 & $1,00 E+09$ \\
\hline $\begin{array}{l}\text { População com lançamento direto de } \\
\text { esgotos nos corpos de água }\end{array}$ & kg/hab.dia & 0,00093 & 0,00775 & 0,0228 & 0,03542 & 0,0275 & $3,60 \mathrm{E}+10$ \\
\hline $\begin{array}{l}\text { População de áreas urbanizadas com } \\
\text { sistema individual de disposição de } \\
\text { esgotos - Alta Densidade }\end{array}$ & kg/hab.dia & 0,00079 & 0,00659 & 0,01482 & 0,03365 & 0,01375 & $1,80 \mathrm{E}+10$ \\
\hline $\begin{array}{l}\text { População de áreas urbanizadas com } \\
\text { sistema individual de disposição de } \\
\text { esgotos - Baixa Densidade }\end{array}$ & $\mathrm{kg} / \mathrm{h}$ & 0,0006 & 0,00388 & 0,0057 & 0,01771 & 0,0055 & $1,80 \mathrm{E}+09$ \\
\hline \multicolumn{8}{|l|}{ Tempo seco } \\
\hline FONTE & Unidade & Fósforo Total & Nitrogênio & DBOc & DBOn & Sólidos em & Coliformes \\
\hline Atividade Agrícola & $\mathrm{kg} / \mathrm{km}^{2}$.dia & 0,066 & 0,227 & 4,917 & 0,933 & 10,455 & $1,00 E+04$ \\
\hline Reflorestamento & $\mathrm{kg} / \mathrm{km}^{2}$.dia & 0,002 & 0,06 & 1,172 & 0,247 & 2,5 & $1,00 E+02$ \\
\hline Mata / Capoeirão & $\mathrm{kg} / \mathrm{km}^{2}$.dia & 0,002 & 0,06 & 1,172 & 0,247 & 2,5 & $1,00 E+02$ \\
\hline Capoeira / Campo & $\mathrm{kg} / \mathrm{km}^{2}$.dia & 0,001 & 0,05 & 1,079 & 0,206 & 3,75 & $1,00 E+02$ \\
\hline Chácaras & $\mathrm{kg} / \mathrm{km}^{2}$.dia & 0,005 & 0,09 & 3,8 & 0,37 & 8 & $1,00 E+03$ \\
\hline Áreas Urbanas - Padrão Superior & $\mathrm{kg} / \mathrm{km}^{2} . \mathrm{dia}$ & 0,136 & 0,951 & 16 & 3,913 & 0,6 & $1,00 E+02$ \\
\hline Áreas Urbanas - Padrão Inferior & $\mathrm{kg} / \mathrm{km}^{2} . \mathrm{dia}$ & 0,272 & 2,378 & 40 & 9,781 & 1,1 & $1,00 E+03$ \\
\hline Áreas de Uso Industrial e Comercial & $\mathrm{kg} / \mathrm{km}^{2}$.dia & 0,19 & 1,665 & 32 & 6,847 & 0,8 & $5,00 E+02$ \\
\hline $\begin{array}{l}\text { População com lançamento direto de } \\
\text { esgotos nos corpos de água }\end{array}$ & kg/hab.dia & 0,00151 & 0,0119 & 0,05616 & 0,04896 & 0,055 & $2,38 \mathrm{E}+09$ \\
\hline $\begin{array}{l}\text { População de áreas urbanizadas com } \\
\text { sistema individual de disposição de } \\
\text { esgotos - Alta Densidade }\end{array}$ & kg/hab.dia & 0,00121 & 0,00952 & 0,05054 & 0,03917 & 0,033 & $1,19 E+08$ \\
\hline $\begin{array}{l}\text { População de áreas urbanizadas com } \\
\text { sistema individual de disposição de } \\
\text { esgotos - Baixa Densidade }\end{array}$ & kg/hab.dia & 0,00076 & 0,00595 & 0,0337 & 0,02448 & 0,0165 & $2,38 \mathrm{E}+07$ \\
\hline
\end{tabular}

A matriz da SMA/Prime utiliza alguns usos do solo distintos dos considerados na caracterização do uso e ocupação do solo realizada neste estudo com base nas tipologias previstas pela EMPLASA, portanto para a aplicação da matriz foi necessário ajustar estes usos do solo. As adaptações realizadas são mostradas na Tabela 16 a seguir, onde, por exemplo, para o uso "Espaços verdes urbanos" da EMPLASA, adotou-se a média dos usos vegetais da matriz da SMA/Prime (Atividade agrícola, reflorestamento, mata/capoeirão, capoeira/campo e chácaras). 
Tabela 16 - Coeficientes de exportação de cargas adaptados para os usos do solo na bacia. Fonte: Adaptado de SMA/Primer, 2015.

Tempo Chuvoso

\begin{tabular}{|c|c|c|c|c|c|c|c|c|}
\hline \multicolumn{2}{|c|}{ Equivalência dos usos do solo: EMPLASA / PRIME } & \multirow{2}{*}{\begin{tabular}{|l} 
Unidade \\
$\mathrm{kg} / \mathrm{km}^{2} \cdot \mathrm{dia}$
\end{tabular}} & \multirow{2}{*}{\begin{tabular}{|c|}
$\begin{array}{c}\text { Fósforo } \\
\text { Total }\end{array}$ \\
0,039 \\
\end{tabular}} & \multirow{2}{*}{\begin{tabular}{|c|}
$\begin{array}{c}\text { Nitrogê } \\
\text { nio }\end{array}$ \\
0,6667 \\
\end{tabular}} & \multirow{2}{*}{\begin{tabular}{|l|} 
DBOc \\
1,4603
\end{tabular}} & \multirow{2}{*}{\begin{tabular}{|c|} 
DBOn \\
1,50367
\end{tabular}} & \multirow{2}{*}{\begin{tabular}{|c|}
$\begin{array}{c}\text { Sólidos } \\
\text { em }\end{array}$ \\
30 \\
\end{tabular}} & \multirow{2}{*}{\begin{tabular}{|c|}
$\begin{array}{c}\text { Coliform } \\
\text { es }\end{array}$ \\
$4,00 E+08$
\end{tabular}} \\
\hline $\begin{array}{l}\text { Espaços verdes } \\
\text { Urbanos }\end{array}$ & $\begin{array}{l}\text { Média dos usos vegetais: Mata/Capoeirão; } \\
\text { Capoeira/Campo; e Chácaras }\end{array}$ & & & & & & & \\
\hline Prédios & $\begin{array}{l}\text { População de áreas urbanizadas com } \\
\text { sistema individual de disposição de } \\
\text { esgotos - Alta Densidade }\end{array}$ & $\mathrm{kg} / \mathrm{km}^{2} \cdot \mathrm{dia}$ & 0,0008 & 0,0066 & 0,0148 & 0,03365 & 0,01375 & $1,8 \mathrm{E}+10$ \\
\hline Casas- Descontínuo & $\begin{array}{l}\text { População de áreas urbanizadas com } \\
\text { sistema individual de disposição de } \\
\text { esgotos - Baixa Densidade }\end{array}$ & $\mathrm{kg} / \mathrm{km}^{2} \cdot \mathrm{dia}$ & 0,0006 & 0,0039 & $0,0057 \mid$ & 0,01771 & 0,0055 & $1,8 \mathrm{E}+09$ \\
\hline $\begin{array}{l}\text { Comércio e Serviços } \\
\text { Descontínuo }\end{array}$ & $\begin{array}{l}\text { Média de: Áreas de Uso Industrial e } \\
\text { Comercial e Capoeira / Campo }\end{array}$ & $\mathrm{kg} / \mathrm{km}^{2} \cdot \mathrm{dia}$ & 0,0545 & 1,142 & 3,3395 & 4,4065 & 50 & $5,5 \mathrm{E}+08$ \\
\hline Favelas & $\begin{array}{l}\text { População com lançamento direto de } \\
\text { esgotos nos corpos de água }\end{array}$ & $\mathrm{kg} / \mathrm{km}^{2} \cdot \mathrm{dia}$ & 0,0009 & 0,0078 & 0,0228 & 0,03542 & 0,0275 & $3,6 \mathrm{E}+10$ \\
\hline Casas- Contínuo & $\begin{array}{l}\text { População de áreas urbanizadas com } \\
\text { sistema individual de disposição de } \\
\text { esgotos - Alta Densidade }\end{array}$ & $\mathrm{kg} / \mathrm{km}^{2} \cdot \mathrm{dia}$ & 0,0008 & 0,0066 & 0,0148 & 0,03365 & 0,01375 & $1,8 \mathrm{E}+10$ \\
\hline $\begin{array}{l}\text { Comércio e Serviços } \\
\text { Contínuo }\end{array}$ & Áreas de Uso Industrial e Comercial & $\mathrm{kg} / \mathrm{km}^{2} \cdot \mathrm{dia}$ & 0,081 & 1,784 & 5,6 & 7,749 & 70 & $1 \mathrm{E}+09$ \\
\hline Industrial - Contínuo & Áreas de Uso Industrial e Comercial & $\mathrm{kg} / \mathrm{km}^{2} . \mathrm{dia}$ & 0,081 & 1,784 & 5,6 & 7,749 & 70 & $1 \mathrm{E}+09$ \\
\hline $\begin{array}{l}\text { Industrial - } \\
\text { Descontínuo }\end{array}$ & $\begin{array}{l}\text { Média de: Áreas de Uso Industrial e } \\
\text { Comercial e Capoeira / Campo }\end{array}$ & $\mathrm{kg} / \mathrm{km}^{2} \cdot \mathrm{dia}$ & 0,0545 & 1,142 & 3,3395 & 4,4065 & 50 & $5,5 \mathrm{E}+08$ \\
\hline \multicolumn{9}{|l|}{ Tempo Seco } \\
\hline \multicolumn{2}{|c|}{ Equivalência dos usos do solo: EMPLASA / PRIME } & Unidade & \begin{tabular}{|c|}
$\begin{array}{c}\text { Fósforo } \\
\text { Total }\end{array}$ \\
\end{tabular} & \begin{tabular}{|c|}
$\begin{array}{c}\text { Nitrogê } \\
\text { nio }\end{array}$ \\
\end{tabular} & DBOc & DBOn & \begin{tabular}{|c|}
$\begin{array}{c}\text { Sólidos } \\
\text { em }\end{array}$ \\
\end{tabular} & \begin{tabular}{|c}
$\begin{array}{c}\text { Coliform } \\
\text { es }\end{array}$ \\
\end{tabular} \\
\hline $\begin{array}{l}\text { Espaços verdes } \\
\text { Urbanos }\end{array}$ & $\begin{array}{l}\text { Média dos usos vegetais: Mata/Capoeirão; } \\
\text { Capoeira/Campo; e Chácaras }\end{array}$ & $\mathrm{kg} / \mathrm{km}^{2} \cdot \mathrm{dia}$ & 0,0027 & 0,0667 & 2,017 & 0,27433 & 4,75 & $4,00 E+02$ \\
\hline Prédios & $\begin{array}{l}\text { População de áreas urbanizadas com } \\
\text { sistema individual de disposição de } \\
\text { esgotos - Alta Densidade }\end{array}$ & $\mathrm{kg} / \mathrm{km}^{2} \cdot \mathrm{dia}$ & 0,0012 & 0,0095 & 0,0505 & 0,03917 & 0,033 & $1,19 \mathrm{E}+08$ \\
\hline Casas- Descontínuo & $\begin{array}{l}\text { População de áreas urbanizadas com } \\
\text { sistema individual de disposição de } \\
\text { esgotos - Baixa Densidade }\end{array}$ & $\mathrm{kg} / \mathrm{km}^{2} \cdot \mathrm{dia}$ & 0,0008 & 0,006 & $0,0337 \mid$ & 0,02448 & 0,0165 & 23800000 \\
\hline $\begin{array}{l}\text { Comércio e Serviços } \\
\text { Descontínuo }\end{array}$ & $\begin{array}{l}\text { Média de: Áreas de Uso Industrial e } \\
\text { Comercial e Capoeira / Campo }\end{array}$ & $\mathrm{kg} / \mathrm{km}^{2} \cdot \mathrm{dia}$ & 0,0955 & 0,8575 & 16,54 & 3,5265 & 2,275 & 300 \\
\hline Favelas & $\begin{array}{l}\text { População com lançamento direto de } \\
\text { esgotos nos corpos de água }\end{array}$ & $\mathrm{kg} / \mathrm{km}^{2} \cdot \mathrm{dia}$ & 0,0015 & 0,0119 & 0,0562 & 0,04896 & 0,055 & $2,38 \mathrm{E}+09$ \\
\hline Casas- Contínuo & $\begin{array}{l}\text { População de áreas urbanizadas com } \\
\text { sistema individual de disposição de } \\
\text { esgotos - Alta Densidade }\end{array}$ & $\mathrm{kg} / \mathrm{km}^{2} \cdot \mathrm{dia}$ & 0,0012 & 0,0095 & 0,0505 & 0,03917 & 0,033 & $1,19 E+08$ \\
\hline $\begin{array}{l}\text { Comércio e Serviços } \\
\text { Contínuo }\end{array}$ & Áreas de Uso Industrial e Comercial & $\mathrm{kg} / \mathrm{km}^{2} \cdot \mathrm{dia}$ & 0,19 & 1,665 & 32 & 6,847 & 0,8 & 500 \\
\hline Industrial - Contínuo & Áreas de Uso Industrial e Comercial & $\mathrm{kg} / \mathrm{km}^{2} \cdot \mathrm{dia}$ & 0,19 & 1,665 & 32 & 6,847 & 0,8 & 500 \\
\hline $\begin{array}{l}\text { Industrial - } \\
\text { Descontínuo }\end{array}$ & $\begin{array}{l}\text { Média de: Áreas de Uso Industrial e } \\
\text { Comercial e Capoeira / Campo }\end{array}$ & $\mathrm{kg} / \mathrm{km}^{2} \cdot \mathrm{dia}$ & 0,0955 & 0,8575 & 16,54 & 3,5265 & 2,275 & 300 \\
\hline
\end{tabular}

Para aplicação do modelo de geração de carga difusa, dividiu-se a bacia do Jaguaré em 44 micro sub bacias de interesse e em 3 macro sub bacias (Itaim, alto Jaguaré e baixo Jaguaré) mostradas na llustração 133 . A composição dos usos do solo por sub-bacia é mostrada na Tabela 17 e o resultado obtido com a aplicação do modelo da unidade de carga na Tabela 1 . 


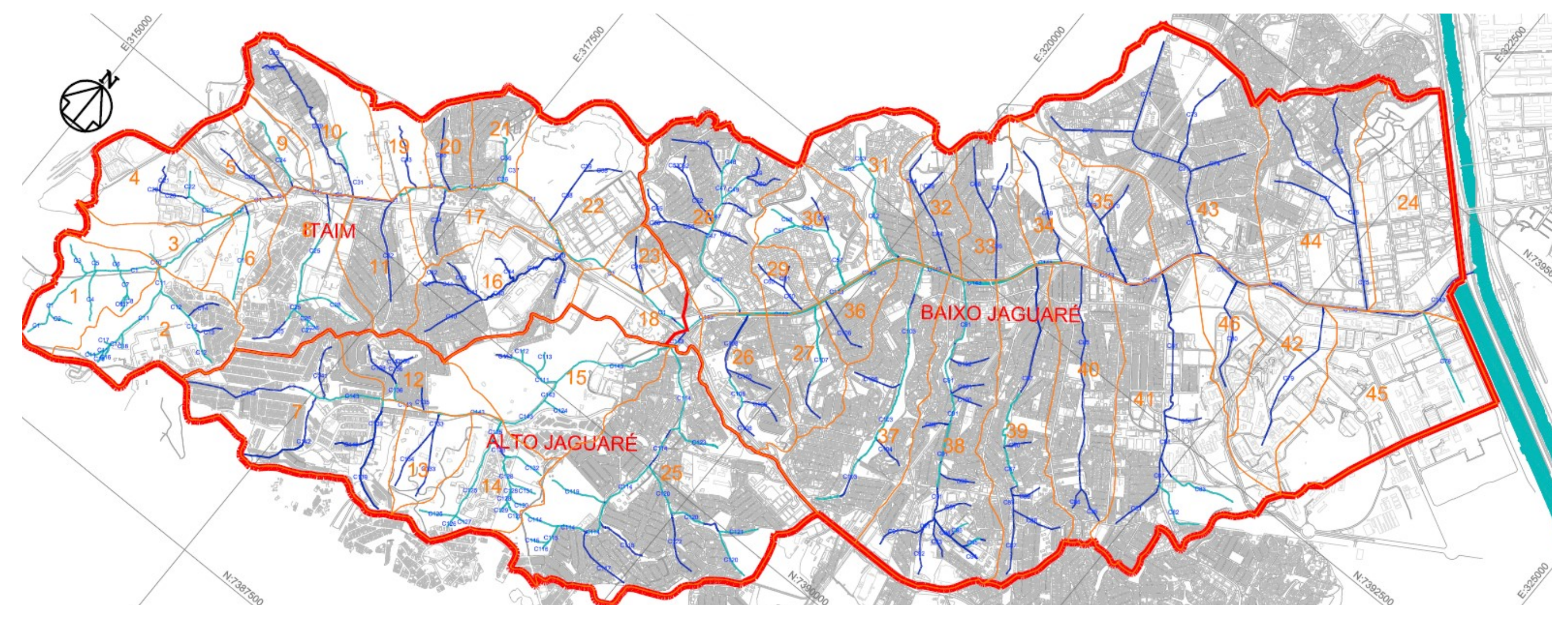

Ilustração 133 - Bacias de geração de carga difusa na bacia do córrego Jaguaré. Fonte: Elaborado pela autora. 
Tabela 17 - Composição dos usos do solo por sub bacia. Fonte: Elaborado pela autora.

\begin{tabular}{|c|c|c|c|c|c|c|c|c|c|c|c|c|c|c|c|c|c|c|c|}
\hline \multirow[b]{2}{*}{ Bacia } & \multicolumn{19}{|c|}{ Usos do solo na bacia $\left(\mathrm{km}^{2}\right)$} \\
\hline & $\begin{array}{l}\text { Espaços } \\
\text { verdes } \\
\text { Urbanos }\end{array}$ & $\%$ & Prédios & $\%$ & $\begin{array}{c}\text { Casas- } \\
\text { Descontínuo }\end{array}$ & $\%$ & $\begin{array}{c}\text { Comércio e } \\
\text { Serviços - } \\
\text { Descontínuo }\end{array}$ & $\%$ & Favelas & $\%$ & $\begin{array}{c}\text { Casas- } \\
\text { Contínuo }\end{array}$ & $\%$ & $\begin{array}{c}\text { Comércio e } \\
\text { Serviços - } \\
\text { Contínuo }\end{array}$ & $\%$ & $\begin{array}{l}\text { Industrial - } \\
\text { Contínuo }\end{array}$ & $\%$ & $\begin{array}{l}\text { Industrial - } \\
\text { Descontínuo }\end{array}$ & $\%$ & Total \\
\hline 18 & 0,12 & 44,62 & 0,05 & 16,10 & 0,02 & 6,38 & 0,04 & 13,27 & 0,00 & 0,00 & 0,02 & 5,93 & 0,00 & 1,58 & 0,02 & 8,55 & 0,01 & 3,56 & 0,28 \\
\hline 1 & 0,44 & 98,44 & 0,00 & 0,00 & 0,00 & 0,00 & 0,00 & 0,00 & 0,01 & 1,56 & 0,00 & 0,00 & 0,00 & 0,00 & 0,00 & 0,00 & 0,00 & 0,00 & 0,44 \\
\hline 3 & 0,25 & 81,17 & 0,00 & 0,00 & 0,00 & 0,00 & 0,00 & 1,07 & 0,00 & 0,00 & 0,00 & 0,00 & 0,00 & 0,00 & 0,00 & 0,00 & 0,05 & 17,76 & 0,30 \\
\hline 2 & 0,32 & 61,39 & 0,05 & 9,20 & 0,10 & 18,52 & 0,00 & 0,29 & 0,01 & 2,26 & 0,04 & 7,16 & 0,00 & 0,00 & 0,00 & 0,00 & 0,01 & 1,17 & 0,52 \\
\hline 6 & 0,16 & 67,56 & 0,00 & 0,45 & 0,03 & 13,41 & 0,02 & 8,34 & 0,00 & 0,00 & 0,01 & 4,82 & 0,00 & 0,00 & 0,00 & 0,00 & 0,01 & 5,42 & 0,24 \\
\hline 4 & 0,04 & 12,47 & 0,00 & 0,00 & 0,00 & 0,00 & 0,00 & 0,00 & 0,00 & 0,00 & 0,00 & 0,00 & 0,00 & 0,00 & 0,00 & 0,00 & 0,31 & 87,53 & 0,35 \\
\hline 5 & 0,04 & 17,69 & 0,04 & 17,66 & 0,00 & 0,00 & 0,04 & 21,98 & 0,00 & 0,00 & 0,00 & 0,00 & 0,06 & 28,57 & 0,00 & 0,00 & 0,03 & 14,10 & 0,20 \\
\hline 9 & 0,11 & 56,30 & 0,02 & 11,54 & 0,05 & 24,10 & 0,02 & 8,06 & 0,00 & 0,00 & 0,00 & 0,00 & 0,00 & 0,00 & 0,00 & 0,00 & 0,00 & 0,00 & 0,19 \\
\hline 8 & 0,17 & 29,57 & 0,01 & 1,16 & 0,19 & 33,41 & 0,01 & 2,07 & 0,00 & 0,00 & 0,13 & 22,01 & 0,00 & 0,00 & 0,01 & 1,39 & 0,06 & 10,38 & 0,57 \\
\hline 10 & 0,35 & 61,73 & 0,10 & 18,03 & 0,03 & 5,62 & 0,00 & 0,59 & 0,00 & 0,00 & 0,06 & 9,80 & 0,00 & 0,00 & 0,00 & 0,00 & 0,02 & 4,24 & 0,57 \\
\hline 11 & 0,04 & 11,90 & 0,00 & 0,00 & 0,16 & 43,01 & 0,00 & 0,00 & 0,00 & 0,49 & 0,07 & 19,32 & 0,00 & 0,75 & 0,02 & 6,33 & 0,07 & 18,20 & 0,37 \\
\hline 19 & 0,16 & 82,95 & 0,00 & 0,32 & 0,00 & 1,85 & 0,00 & 0,00 & 0,00 & 0,00 & 0,00 & 0,00 & 0,00 & 0,00 & 0,00 & 0,00 & 0,03 & 14,87 & 0,20 \\
\hline 17 & 0,027 & 8,39 & 0,037 & 11,54 & 0,055 & 17,09 & 0,049 & 15,29 & 0,000 & 0,00 & 0,020 & 6,31 & 0,000 & 0,00 & 0,018 & 5,62 & 0,115 & 35,75 & 0,3215 \\
\hline 20 & 0,018 & 11,00 & 0,014 & 8,89 & 0,091 & 56,62 & 0,007 & 4,37 & 0,000 & 0,00 & 0,031 & 19,13 & 0,000 & 0,00 & 0,000 & 0,00 & 0,000 & 0,00 & 0,1607 \\
\hline 21 & 0,036 & 17,31 & 0,002 & 1,09 & 0,078 & 37,84 & 0,000 & 0,00 & 0,000 & 0,00 & 0,091 & 43,76 & 0,000 & 0,00 & 0,000 & 0,00 & 0,000 & 0,00 & 0,2072 \\
\hline 22 & 0,509 & 69,36 & 0,000 & 0,00 & 0,005 & 0,64 & 0,082 & 11,17 & 0,015 & 2,10 & 0,006 & 0,76 & 0,000 & 0,00 & 0,038 & 5,13 & 0,080 & 10,85 & 0,7341 \\
\hline 16 & 0,077 & 12,52 & 0,000 & 0,00 & 0,114 & 18,55 & 0,244 & 39,75 & 0,125 & 20,25 & 0,022 & 3,58 & 0,000 & 0,00 & 0,033 & 5,34 & 0,000 & 0,00 & 0,6147 \\
\hline 23 & 0,041 & 32,99 & 0,000 & 0,00 & 0,028 & 22,13 & 0,000 & 0,00 & 0,000 & 0,00 & 0,002 & 1,35 & 0,003 & 2,80 & 0,000 & 0,00 & 0,051 & 40,74 & 0,1245 \\
\hline 28 & 0,122 & 15,54 & 0,076 & 9,65 & 0,400 & 50,74 & 0,035 & 4,41 & 0,057 & 7,21 & 0,095 & 12,04 & 0,001 & 0,08 & 0,000 & 0,00 & 0,003 & 0,33 & 0,7877 \\
\hline 30 & 0,153 & 39,98 & 0,000 & 0,00 & 0,223 & 58,23 & 0,007 & 1,80 & 0,000 & 0,00 & 0,000 & 0,00 & 0,000 & 0,00 & 0,000 & 0,00 & 0,000 & 0,00 & 0,3823 \\
\hline 29 & 0,016 & 12,94 & 0,000 & 0,00 & 0,109 & 87,06 & 0,000 & 0,00 & 0,000 & 0,00 & 0,000 & 0,00 & 0,000 & 0,00 & 0,000 & 0,00 & 0,000 & 0,00 & 0,1250 \\
\hline 31 & 0,197 & 41,51 & 0,005 & 1,05 & 0,219 & 46,00 & 0,003 & 0,68 & 0,016 & 3,47 & 0,035 & 7,29 & 0,000 & 0,00 & 0,000 & 0,00 & 0,000 & 0,00 & 0,4750 \\
\hline 32 & 0,009 & 3,62 & 0,000 & 0,00 & 0,113 & 47,20 & 0,010 & 4,09 & 0,060 & 24,95 & 0,048 & 20,14 & 0,000 & 0,00 & 0,000 & 0,00 & 0,000 & 0,00 & 0,2391 \\
\hline 33 & 0,083 & 22,40 & 0,003 & 0,89 & 0,268 & 72,41 & 0,012 & 3,38 & 0,000 & 0,00 & 0,003 & 0,93 & 0,000 & 0,00 & 0,000 & 0,00 & 0,000 & 0,00 & 0,3698 \\
\hline
\end{tabular}


Tabela 17 - (Continuação) Composição dos usos do solo por sub bacia. Fonte: Elaborado pela autora.

\begin{tabular}{|c|c|c|c|c|c|c|c|c|c|c|c|c|c|c|c|c|c|c|c|}
\hline \multirow[b]{2}{*}{ Bacia } & \multicolumn{19}{|c|}{ Usos do solo na bacia $\left(\mathrm{km}^{2}\right)$} \\
\hline & $\begin{array}{c}\text { Espaços } \\
\text { verdes } \\
\text { Urbanos }\end{array}$ & $\%$ & Prédios & $\%$ & $\begin{array}{c}\text { Casas- } \\
\text { Descontínuo }\end{array}$ & $\%$ & $\begin{array}{c}\text { Comércio e } \\
\text { Serviços - } \\
\text { Descontínuo }\end{array}$ & $\%$ & Favelas & $\%$ & $\begin{array}{l}\text { Casas- } \\
\text { Contínuo }\end{array}$ & $\%$ & $\begin{array}{c}\text { Comércio e } \\
\text { Serviços - } \\
\text { Contínuo } \\
\end{array}$ & $\%$ & $\begin{array}{r}\text { Industrial - } \\
\text { Contínuo }\end{array}$ & $\%$ & $\begin{array}{l}\text { Industrial - } \\
\text { Descontínuo }\end{array}$ & $\%$ & Total \\
\hline 34 & 0,1666 & 53,03 & 0,0912 & 29,04 & 0,0510 & 16,24 & 0,0038 & 1,21 & 0,0000 & 0,00 & 0,0015 & 0,47 & 0,0000 & 0,00 & 0,0000 & 0,00 & 0,0000 & 0,00 & 0,3141 \\
\hline 35 & 0,1186 & 33,19 & 0,0657 & 18,39 & 0,1317 & 36,86 & 0,0267 & 7,47 & 0,0000 & 0,00 & 0,0123 & 3,45 & 0,0023 & 0,63 & 0,0000 & 0,00 & 0,0000 & 0,00 & 0,3573 \\
\hline 43 & 0,2647 & 19,50 & 0,2471 & 18,20 & 0,3144 & 23,16 & 0,1084 & 7,98 & 0,0000 & 0,00 & 0,2297 & 16,92 & 0,1464 & 10,78 & 0,0215 & 1,58 & 0,0254 & 1,87 & 1,3575 \\
\hline 44 & 0,0497 & 5,29 & 0,1297 & 13,83 & 0,2266 & 24,15 & 0,0029 & 0,31 & 0,0123 & 1,31 & 0,0296 & 3,15 & 0,0320 & 3,41 & 0,3494 & 37,24 & 0,1061 & 11,31 & 0,9382 \\
\hline 24 & 0,0658 & 7,93 & 0,0396 & 4,77 & 0,0207 & 2,50 & 0,0117 & 1,41 & 0,0939 & 11,33 & 0,0000 & 0,00 & 0,0000 & 0,00 & 0,5974 & 72,06 & 0,0000 & 0,00 & 0,8291 \\
\hline 42 & 0,1288 & 23,17 & 0,0000 & 0,00 & 0,0000 & 0,00 & 0,4270 & 76,83 & 0,0000 & 0,00 & 0,0000 & 0,00 & 0,0000 & 0,00 & 0,0000 & 0,00 & 0,0000 & 0,00 & 0,5558 \\
\hline 41 & 0,2109 & 16,67 & 0,0956 & 7,56 & 0,2334 & 18,45 & 0,4406 & 34,83 & 0,0504 & 3,98 & 0,1128 & 8,91 & 0,0623 & 4,92 & 0,0000 & 0,00 & 0,0592 & 4,68 & 1,2652 \\
\hline 40 & 0,0464 & 7,29 & 0,0709 & 11,12 & 0,2962 & 46,48 & 0,0217 & 3,40 & 0,0224 & 3,51 & 0,1196 & 18,76 & 0,0601 & 9,43 & 0,0000 & 0,00 & 0,0000 & 0,00 & 0,6374 \\
\hline 39 & 0,0630 & 8,28 & 0,0982 & 12,92 & 0,3693 & 48,60 & 0,0170 & 2,24 & 0,0296 & 3,90 & 0,1564 & 20,59 & 0,0264 & 3,47 & 0,0000 & 0,00 & 0,0000 & 0,00 & 0,7599 \\
\hline 38 & 0,2470 & 22,82 & 0,0948 & 8,76 & 0,4493 & 41,52 & 0,1146 & 10,59 & 0,0101 & 0,94 & 0,1154 & 10,67 & 0,0407 & 3,76 & 0,0102 & 0,94 & 0,0000 & 0,00 & 1,0822 \\
\hline 37 & 0,2056 & 21,07 & 0,0540 & 5,53 & 0,5084 & 52,11 & 0,0696 & 7,13 & 0,0685 & 7,02 & 0,0562 & 5,76 & 0,0134 & 1,38 & 0,0000 & 0,00 & 0,0000 & 0,00 & 0,9758 \\
\hline 36 & 0,0274 & 18,61 & 0,0013 & 0,91 & 0,1100 & 74,72 & 0,0000 & 0,00 & 0,0000 & 0,00 & 0,0085 & 5,75 & 0,0000 & 0,00 & 0,0000 & 0,00 & 0,0000 & 0,00 & 0,1472 \\
\hline 27 & 0,0702 & 24,68 & 0,0393 & 13,79 & 0,1106 & 38,85 & 0,0099 & 3,46 & 0,0000 & 0,00 & 0,0512 & 17,98 & 0,0035 & 1,24 & 0,0000 & 0,00 & 0,0000 & 0,00 & 0,2846 \\
\hline 26 & 0,1193 & 31,98 & 0,0466 & 12,48 & 0,0679 & 18,20 & 0,0283 & 7,58 & 0,0000 & 0,00 & 0,1021 & 27,36 & 0,0090 & 2,40 & 0,0000 & 0,00 & 0,0000 & 0,00 & 0,3731 \\
\hline 15 & 0,5540 & 64,36 & 0,0022 & 0,26 & 0,1550 & 18,01 & 0,1045 & 12,14 & 0,0194 & 2,26 & 0,0084 & 0,97 & 0,0000 & 0,00 & 0,0173 & 2,01 & 0,0000 & 0,00 & 0,8608 \\
\hline 25 & 0,4617 & 26,50 & 0,0551 & 3,16 & 0,6929 & 39,76 & 0,0504 & 2,89 & 0,0265 & 1,52 & 0,3092 & 17,74 & 0,0347 & 1,99 & 0,0105 & 0,60 & 0,1018 & 5,84 & 1,7427 \\
\hline 14 & 0,3179 & 69,73 & 0,0071 & 1,56 & 0,1309 & 28,71 & 0,0000 & 0,00 & 0,0000 & 0,00 & 0,0000 & 0,00 & 0,0000 & 0,00 & 0,0000 & 0,00 & 0,0000 & 0,00 & 0,4559 \\
\hline 13 & 0,2008 & 83,19 & 0,0000 & 0,00 & 0,0343 & 14,21 & 0,0063 & 2,60 & 0,0000 & 0,00 & 0,0000 & 0,00 & 0,0000 & 0,00 & 0,0000 & 0,00 & 0,0000 & 0,00 & 0,2414 \\
\hline 12 & 0,1855 & 44,82 & 0,0260 & 6,29 & 0,1167 & 28,20 & 0,0188 & 4,55 & 0,0323 & 7,80 & 0,0345 & 8,33 & 0,0000 & 0,00 & 0,0000 & 0,00 & 0,0000 & 0,00 & 0,4138 \\
\hline 7 & 0,2053 & 21,54 & 0,1343 & 14,09 & 0,1705 & 17,89 & 0,1076 & 11,29 & 0,0960 & 10,07 & 0,2320 & 24,34 & 0,0000 & 0,00 & 0,0000 & 0,00 & 0,0075 & 0,78 & 0,9531 \\
\hline 45 & 0,2749 & 28,29 & 0,0000 & 0,00 & 0,0000 & 0,00 & 0,6967 & 71,71 & 0,0000 & 0,00 & 0,0000 & 0,00 & 0,0000 & 0,00 & 0,0000 & 0,00 & 0,0000 & 0,00 & 0,9717 \\
\hline 46 & 0,0998 & 36,76 & 0,0000 & 0,00 & 0,0000 & 0,00 & 0,1461 & 53,81 & 0,0256 & 9,43 & 0,0000 & 0,00 & 0,0000 & 0,00 & 0,0000 & 0,00 & 0,0000 & 0,00 & 0,2715 \\
\hline Jaguaré & 7,58 & & 1,70 & & 6,47 & & 3,00 & & 0,78 & & 2,25 & & 0,50 & & 1,15 & & 1,15 & & 24,57 \\
\hline Itaim & 2,9121 & 45,50 & 0,3147 & 4,92 & 0,9470 & 14,80 & 0,5189 & 8,11 & 0,1603 & 2,50 & 0,4894 & 7,65 & 0,0678 & 1,06 & 0,1436 & 2,24 & 0,8461 & 13,22 & 6,3998 \\
\hline Alto Jaguaré & 1,9253 & 41,25 & 0,2247 & 4,81 & 1,3003 & 27,86 & 0,2875 & 6,16 & 0,1742 & 3,73 & 0,5840 & 12,51 & 0,0347 & 0,74 & 0,0278 & 0,60 & 0,1092 & 2,34 & 4,6677 \\
\hline Baixo Jaguaré & 2,7387 & 20,29 & 1,1582 & 8,58 & 4,2198 & 31,26 & 2,1921 & 16,24 & 0,4457 & 3,30 & 1,1763 & 8,71 & 0,3966 & 2,94 & 0,9785 & 7,25 & 0,1933 & 1,43 & 13,4993 \\
\hline
\end{tabular}


Tabela 18 - Cargas geradas por sub-bacia. Fonte: Elaborado pela autora.

Micro bacias

\begin{tabular}{|c|c|c|c|c|c|c|c|c|c|c|c|c|}
\hline \multirow[b]{2}{*}{ Bacia } & \multicolumn{6}{|c|}{ Geração de Carga Difusa - Tempo Seco } & \multicolumn{6}{|c|}{ Geração de Carga Difusa - Tempo Chuvoso } \\
\hline & $\begin{array}{l}\text { Fósforo } \\
\text { Total } \\
\text { (Kg/dia) }\end{array}$ & $\begin{array}{c}\text { Nitrogênio } \\
\text { (Kg/dia) }\end{array}$ & $\begin{array}{c}\text { DBOc } \\
\text { (Kg/dia) }\end{array}$ & $\begin{array}{l}\text { DBOn } \\
\text { (Kg/dia) }\end{array}$ & $\begin{array}{l}\text { Sólidos em } \\
\text { Suspensão } \\
\text { (Kg/dia) }\end{array}$ & Coliformes & $\begin{array}{c}\text { Fósforo } \\
\text { Total } \\
\text { (Kg/dia) }\end{array}$ & $\begin{array}{c}\text { Nitrogênio } \\
(\mathrm{Kg} / \text { dia })\end{array}$ & $\begin{array}{c}\text { DBOc } \\
\text { (Kg/dia) }\end{array}$ & $\begin{array}{c}\text { DBOn } \\
\text { (Kg/dia) }\end{array}$ & $\begin{array}{c}\text { Sólidos em } \\
\text { Suspensão } \\
\text { (Kg/dia) }\end{array}$ & Coliformes \\
\hline$\overline{1}$ & 0,09 & 0,89 & 2,35 & 3,00 & 31,08 & $1,90 \mathrm{E}+12$ & 0,09 & 2,67 & 4,01 & 2,75 & 5,26 & $1,25 \mathrm{E}+11$ \\
\hline$\underline{2}$ & 1,07 & 8,18 & 16,70 & 38,85 & 37,46 & $1,62 \mathrm{E}+13$ & 1,48 & 11,64 & 63,43 & 47,90 & 40,18 & $3,07 \mathrm{E}+11$ \\
\hline 3 & 0,03 & 0,34 & 0,85 & 0,90 & 19,66 & $5,03 E+09$ & 0,01 & 0,07 & 1,55 & 0,30 & 1,47 & $5,75 \mathrm{E}+02$ \\
\hline 4 & 02 & 0,40 & 1,15 & 1,48 & 18,48 & $1,06 \mathrm{E}+09$ & 0,03 & 27 & 5,23 & 1,11 & 0,94 & $1,93 \mathrm{E}+02$ \\
\hline 5 & 0,23 & 2,00 & 4,65 & 9,92 & 13,72 & $4,85 \mathrm{E}+12$ & 0,34 & 2,73 & 16,73 & 11,22 & 9,30 & $3,21 \mathrm{E}+10$ \\
\hline 6 & 0,24 & 1,82 & 3,39 & 8,21 & 15,44 & $2,20 \mathrm{E}+12$ & 0,31 & 44 & 14,18 & 10,03 & 8,24 & $1,74 \mathrm{E}+10$ \\
\hline 7 & 3,70 & 29,51 & 66,49 & 144,12 & 85,46 & $7,90 \mathrm{E}+13$ & 5,49 & 43,20 & 228,72 & 177,74 & 155,42 & $2,11 \mathrm{E}+12$ \\
\hline 8 & 70 & 12,67 & 24,15 & 60,97 & 37,72 & $2,09 \mathrm{E}+13$ & 2,35 & 18,49 & 102,60 & 76,06 & 58,81 & $1,56 \mathrm{E}+11$ \\
\hline 9 & 35 & 56 & 74 & 11,99 & 12,08 & $3,59 \mathrm{E}+12$ & 0,46 & 64 & 20,45 & 14,99 & 11,73 & $2,78 \mathrm{E}+10$ \\
\hline 10 & 14 & & 0,39 & 5,17 & 43,36 & $2,23 \mathrm{E}+13$ & 1,66 & 06 & 70,84 & 53,72 & 03 & $E+11$ \\
\hline 11 & 17 & & 15,62 & 0,47 & 48 & $1,24 \mathrm{E}+13$ & 1,60 & 54 & 70,47 & 51,58 & 8,74 & $E+11$ \\
\hline 12 & 15 & & 18,10 & 40,62 & 58 & $1,88 \mathrm{E}+13$ & 1,61 & 12,66 & 67,97 & 52,11 & 44,55 & $E+11$ \\
\hline 13 & 18 & & 05 & 5,19 & 15,41 & $4,75 \mathrm{E}+11$ & 0,20 & 58 & 9,41 & 6,51 & 5,43 & $6,23 \mathrm{E}+09$ \\
\hline 14 & 67 & & 34 & 20,35 & 86 & $2,78 \mathrm{E}+12$ & 0,83 & 49 & 37,19 & 26,72 & 20,01 & $E+10$ \\
\hline 15 & 97 & & 13,24 & 30,97 & 80 & +12 & 1,24 & 75 & 55,92 & 40,10 & 61 & +11 \\
\hline 16 & 1,56 & 12,27 & 30,32 & 56,26 & 52,98 & $3,88 \mathrm{E}+13$ & 2,33 & 18,36 & 96,48 & 75,54 & 73,18 & $2,30 \mathrm{E}+12$ \\
\hline 17 & 61 & 4,76 & 9,60 & 23,10 & 19,64 & $8,64 \mathrm{E}+12$ & 0,87 & 6,84 & 39,63 & 28,14 & 21,91 & $E+10$ \\
\hline 18 & 47 & 87 & 8,39 & 18,98 & 20,03 & $8,71 \mathrm{E}+12$ & 0,68 & 38 & 30,33 & 22,16 & 18,57 & $5,92 \mathrm{E}+10$ \\
\hline 19 & 0,04 & 0,36 & 0,77 & 1,22 & 12,89 & $1,41 \mathrm{E}+11$ & 0,03 & 0,25 & 2,08 & 1,05 & 1,59 & $1,25 \mathrm{E}+09$ \\
\hline 20 & 0,69 & 4,99 & 9,12 & 23,94 & 10,10 & $7,44 \mathrm{E}+12$ & 0,94 & 7,41 & 40,93 & 30,50 & 22,91 & $5,74 \mathrm{E}+10$ \\
\hline 21 & 0,92 & 7,04 & 14,02 & 34,56 & 15,48 & $1,38 \mathrm{E}+13$ & 1,31 & 10,32 & 56,11 & 42,45 & 33,48 & $9,87 E+10$ \\
\hline 22 & 0,23 & 2,15 & 5,62 & 8,56 & 49,35 & $5,08 \mathrm{E}+12$ & 0,29 & 2,27 & 15,08 & 9,34 & 11,64 & $2,86 \mathrm{E}+11$ \\
\hline 23 & 0,14 & 1,01 & 1,69 & 4,51 & 6,90 & $6,10 \mathrm{E}+11$ & 0,18 & 1,43 & 8,78 & 5,87 & 4,23 & $6,53 \mathrm{E}+09$ \\
\hline 24 & 1,06 & 9,31 & 25,28 & 43,20 & 71,61 & $3,15 E+13$ & 1,68 & 13,36 & 80,31 & 54,95 & 52,86 & $1,75 \mathrm{E}+12$ \\
\hline 25 & 5,62 & 41,17 & 77,94 & 196,59 & 115,04 & $6,68 \mathrm{E}+13$ & 7,72 & 60,59 & 335,17 & 249,29 & 193,02 & $9,38 \mathrm{E}+11$ \\
\hline 26 & 1,22 & 9,67 & 20,23 & 47,87 & 28,61 & $2,14 E+13$ & 1,77 & 13,94 & 75,86 & 57,34 & 46,72 & $1,47 \mathrm{E}+11$ \\
\hline 27 & 1,06 & 7,92 & 15,28 & 38,43 & 19,65 & $1,39 \mathrm{E}+13$ & 1,48 & 11,61 & 63,77 & 47,78 & 37,11 & $1,02 \mathrm{E}+11$ \\
\hline 28 & 3,28 & 23,97 & 47,06 & 113,76 & 56,87 & $4,46 \mathrm{E}+13$ & 4,56 & 35,77 & 194,01 & \begin{tabular}{|l|}
147,18 \\
\end{tabular} & 117,98 & $1,26 \mathrm{E}+12$ \\
\hline 29 & 0,50 & 3,24 & 4,78 & 14,75 & 5,67 & $1,50 \mathrm{E}+12$ & 0,63 & 4,94 & 28,03 & 20,34 & 13,79 & $1,98 \mathrm{E}+10$ \\
\hline 30 & 1,04 & 6,77 & 10,11 & 30,52 & 20,08 & $3,06 \mathrm{E}+12$ & 1,29 & 10,13 & 57,75 & 41,68 & 28,88 & $4,04 \mathrm{E}+10$ \\
\hline 31 & 1,38 & & 17,38 & 44,69 & 30,36 & $1,30 \mathrm{E}+13$ & 1,83 & 14,32 & 79,08 & 58,91 & 45,49 & $3,75 \mathrm{E}+11$ \\
\hline 32 & 1,23 & 9,31 & 20,79 & 43,81 & 23,39 & $2,46 \mathrm{E}+13$ & 1,79 & 14,05 & 73,35 & 57,81 & 51,45 & $1,15 \mathrm{E}+12$ \\
\hline 33 & 1,28 & 8,37 & 12,67 & 38,19 & 18,20 & $4,60 \mathrm{E}+12$ & 1,62 & 12,67 & 71,87 & 52,12 & 35,89 & $5,47 \mathrm{E}+10$ \\
\hline 34 & 0,81 & 6,36 & 13,16 & 31,16 & 23,39 & $1,34 \mathrm{E}+13$ & 1,16 & 9,07 & 49,35 & 37,33 & 30,69 & $9,35 \mathrm{E}+10$ \\
\hline 35 & 1,09 & & 14,97 & 38,28 & 23,27 & $1,25 \mathrm{E}+13$ & 1,49 & 11,69 & 64,77 & 48,09 & 36,94 & $9,48 \mathrm{E}+10$ \\
\hline 36 & 0,57 & 3,78 & 5,97 & 17,46 & 7,51 & $2,86 \mathrm{E}+12$ & 0,73 & 5,71 & 32,15 & 23,50 & 16,48 & $2,89 \mathrm{E}+10$ \\
\hline 37 & 3,50 & 24,98 & 47,36 & 116,50 & 65,69 & $4,09 E+13$ & 4,77 & 37,42 & 204,74 & 153,97 & 121,83 & $1,44 \mathrm{E}+12$ \\
\hline 38 & 3,43 & 24,98 & 46,42 & 119,02 & & $3,78 \mathrm{E}+13$ & 4,69 & 36,81 & 205,15 & 151,45 & 115,44 & $4,57 \mathrm{E}+11$ \\
\hline 39 & 3,45 & & 50,40 & 123,77 & & $4,82 \mathrm{E}+13$ & 4,84 & 38,03 & 207,20 & 156,47 & 123,48 & $8,36 \mathrm{E}+11$ \\
\hline 40 & 2,68 & & 38,87 & 95,71 & 45,58 & & 3,75 & 29,45 & 161,69 & 121,18 & 95,05 & $6,34 \mathrm{E}+11$ \\
\hline 41 & & & & & & & & & 172,81 & 127,03 & 105,38 & $1,15 \mathrm{E}+12$ \\
\hline 42 & & & & & & & & & 7,38 & 1,56 & 1,67 & $4,19 E+02$ \\
\hline 43 & 4,36 & & 69,70 & 167,55 & & $3 E+13$ & & 49,35 & 273,04 & 203,03 & 161,58 & $4,90 \mathrm{E}+11$ \\
\hline 44 & & & & 78,43 & & $2,84 \mathrm{E}+13$ & & 23,71 & 139,12 & 97,57 & 74,64 & $4,09 \mathrm{E}+11$ \\
\hline 45 & 0,07 & & & & 53 & $E+09$ & 0,07 &, 62 & 12,19 & 2,57 & 3,08 & $8,30 E+02$ \\
\hline 46 & 0,20 & 1,79 & 5,21 & 7,83 & 19,47 & $7,04 \mathrm{E}+12$ & 0,31 & 2,46 & 13,63 & 10,12 & 11,62 & $4,65 \mathrm{E}+11$ \\
\hline
\end{tabular}

Grandes Subbacias

\begin{tabular}{l|c|c|c|c|c|c|c|c|c|c|c|c}
\hline \multirow{2}{*}{ Bacia } & \multicolumn{4}{|c|}{ Geração de Carga Difusa - Tempo Seco } & \multicolumn{4}{c}{ Geração de Carga Difusa - Tempo Chuvoso } \\
\cline { 2 - 13 } & $\begin{array}{c}\text { Fósforo } \\
\text { Total } \\
\text { (Kg/dia) }\end{array}$ & $\begin{array}{c}\text { Nitrogênio } \\
\text { (Kg/dia) }\end{array}$ & $\begin{array}{c}\text { DBOc } \\
\text { (Kg/dia) }\end{array}$ & $\begin{array}{c}\text { DBOn } \\
\text { (Kg/dia) }\end{array}$ & $\begin{array}{c}\text { Sólidos em } \\
\text { Suspensão } \\
\text { (Kg/dia) }\end{array}$ & Coliformes & $\begin{array}{c}\text { Fósforo } \\
\text { Total } \\
\text { (Kg/dia) }\end{array}$ & $\begin{array}{c}\text { Nitrogênio } \\
\text { (Kg/dia) }\end{array}$ & $\begin{array}{c}\text { DBOc } \\
\text { (Kg/dia) }\end{array}$ & $\begin{array}{c}\text { DBOn } \\
\text { (Kg/dia) })\end{array}$ & $\begin{array}{c}\text { Sólidos em } \\
\text { Suspensão } \\
\text { (Kg/dia) }\end{array}$ & Coliformes \\
\hline Itaim & 10,71 & 83,14 & 173,51 & 393,12 & 438,86 & $1,68 \mathrm{E}+14$ & 14,98 & 117,80 & 658,91 & 484,69 & 408,22 & $3,81 \mathrm{E}+12$ \\
\hline Alto Jaguaré & 12,29 & 92,20 & 185,15 & 437,84 & 331,16 & $1,77 \mathrm{E}+14$ & 17,10 & 134,28 & 734,37 & 552,46 & 452,03 & $4,13 \mathrm{E}+12$ \\
\hline Baixo Jaguaré & 37,08 & 276,99 & 548,18 & 1318,87 & 917,49 & $5,01 \mathrm{E}+14$ & 51,71 & 406,38 & 2267,25 & 1671,99 & 1328,06 & $1,10 \mathrm{E}+13$ \\
\hline
\end{tabular}

Total na bacia

\begin{tabular}{l|l|l|l|l|l|l|l|l|l|l|l|l}
\hline Jaguaré & 60,08 & 452,33 & 906,84 & 2149,83 & 1687,52 & $8,46 \mathrm{E}+14$ & 83,79 & 658,46 & 3660,54 & 2709,14 & 2188,31 & $1,89 \mathrm{E}+13$ \\
\hline
\end{tabular} 
O resultado obtido com a modelagem da produção de carga difusa na bacia revelou que há bacias com maior potencial de geração de cargas poluentes, que foram divididas em duas categorias para elaboração do plano de manejo de carga difusas na bacia, cargas associadas aos sedimentos e à matéria orgânica. Além disso, a fim de controlar potenciais cargas poluentes advindas de tipologias industriais e comerciais, foram identificados então os pontos chave de controle para estas tipologias em função do cadastro de galerias de drenagem existentes na bacia. Por fim, para promover o controle de resíduos sólidos no sistema de drenagem, será proposto para a bacia um plano de "Zero Resíduo".

Desta forma será promovido o controle das três parcelas da carga difusa: Sedimentos; Resíduos sólidos; e demais cargas difusas (Deposição úmida e seca, cargas provenientes de veículos e insumos agrícolas). A terceira parcela, das demais cargas difusas, será ainda subdividida em duas categorias, cargas oriundas de tipologias industriais e comerciais e cargas residuais nas águas pluviais. As propostas para controle das três parcelas da carga difusa serão descritas nos itens a seguir.

\subsubsection{Controle de sedimentos}

No caso da carga de sedimentos, será adotada como solução a adoção de bacias de sedimentação, cujo modelo adotado é mostrado na llustração 134 a seguir, antes da chegada das galerias de drenagem nos corpos d'água nas bacias com maior potencial poluidor, que foram aquelas que apresentaram geração diária de SST maior que $80 \mathrm{~kg} / \mathrm{dia}$., obtidas com base no modelo de geração de carga difusa para a bacia. As llustrações $130 \mathrm{e}$ 131 mostram as bacias com maior potencial de produção de sedimento nos eventos de tempo seco e chuvoso.

Os pontos propostos para bacia de sedimentação levaram em conta então as bacias com maior potencial de produção de sedimentos, indicadas pelo método da Unidade de Carga, e também as bacias com grande potencial poluidor devido à presença de pontos viciados de acumulo de resíduos de grande volume (construção civil, móveis, etc) segundo o levantamento feito pelo "Projeto Jaguaré" mostrado na llustração 103 mostrada anteriormente.

O resultado deste estudo é exibido na llustração 137 que mostra o sistema de drenagem da bacia e os pontos onde serão adotadas as bacias de sedimentação. 

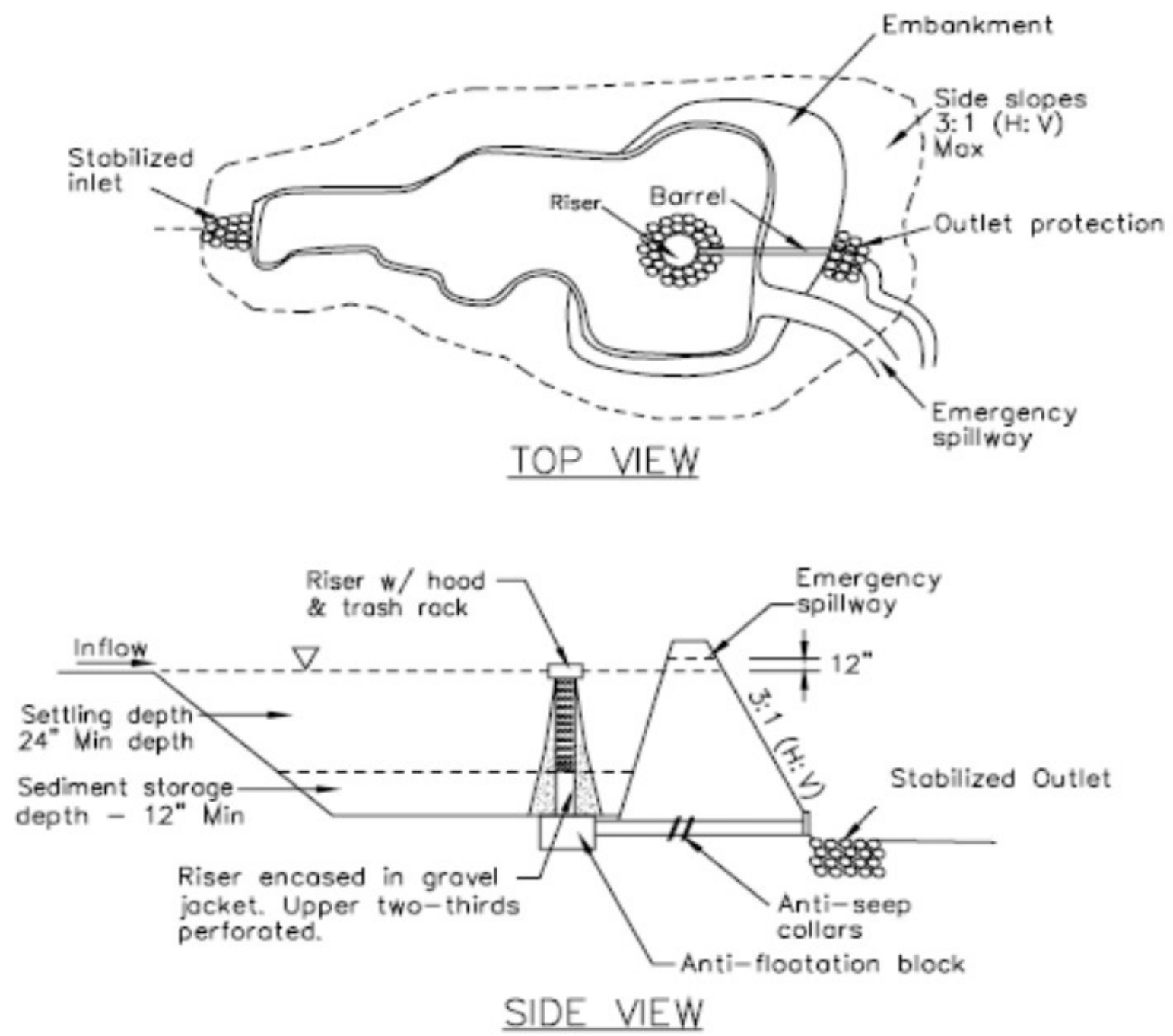

Ilustração 134 - Modelo de bacia de sedimentação. Fonte: MDEQ NPS BMP (2014). 


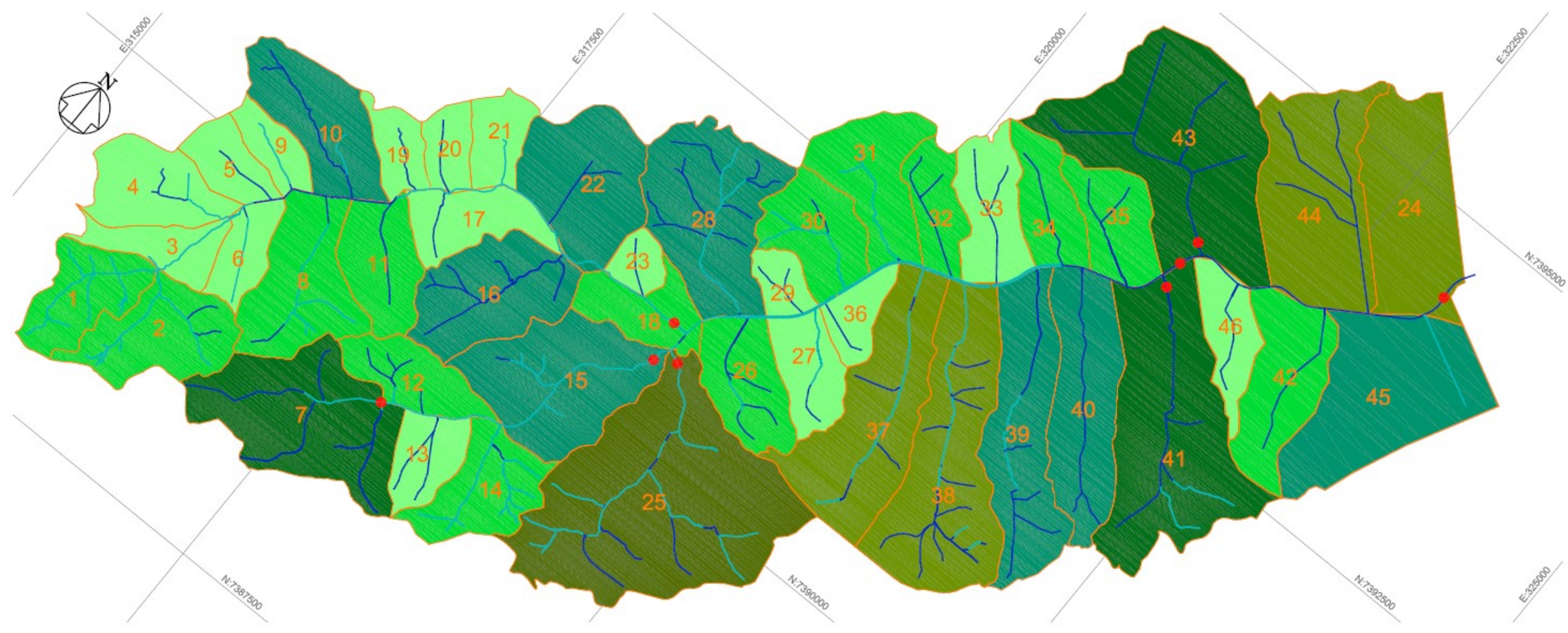

Produção de SST nas mlcrobacias nos eventos chuvosos de tempo seco:
Até $20 \mathrm{~kg}$ lia
De 101 a $120 \mathrm{~kg} / \mathrm{dla}$
- Pontos com elevada concentração de

De 21 a $40 \mathrm{~kg} / \mathrm{dla}$

De 121 a $140 \mathrm{~kg} / \mathrm{dla}$

SST que demandam BMP's

De 41 a $60 \mathrm{~kg} / \mathrm{dla}$

De 61 a $80 \mathrm{~kg} / \mathrm{dla}$

De 81 a $100 \mathrm{~kg} / \mathrm{dia}$

De 141 a $160 \mathrm{~kg} / \mathrm{dla}$

De 161 a $180 \mathrm{~kg} / \mathrm{dla}$

De 181 a $200 \mathrm{~kg} / \mathrm{dla}$

Ilustração 135 - Bacias com maior potencial de geração de carga difusa nos eventos chuvosos durante o tempo seco. Fonte: Elaborado pela autora. 


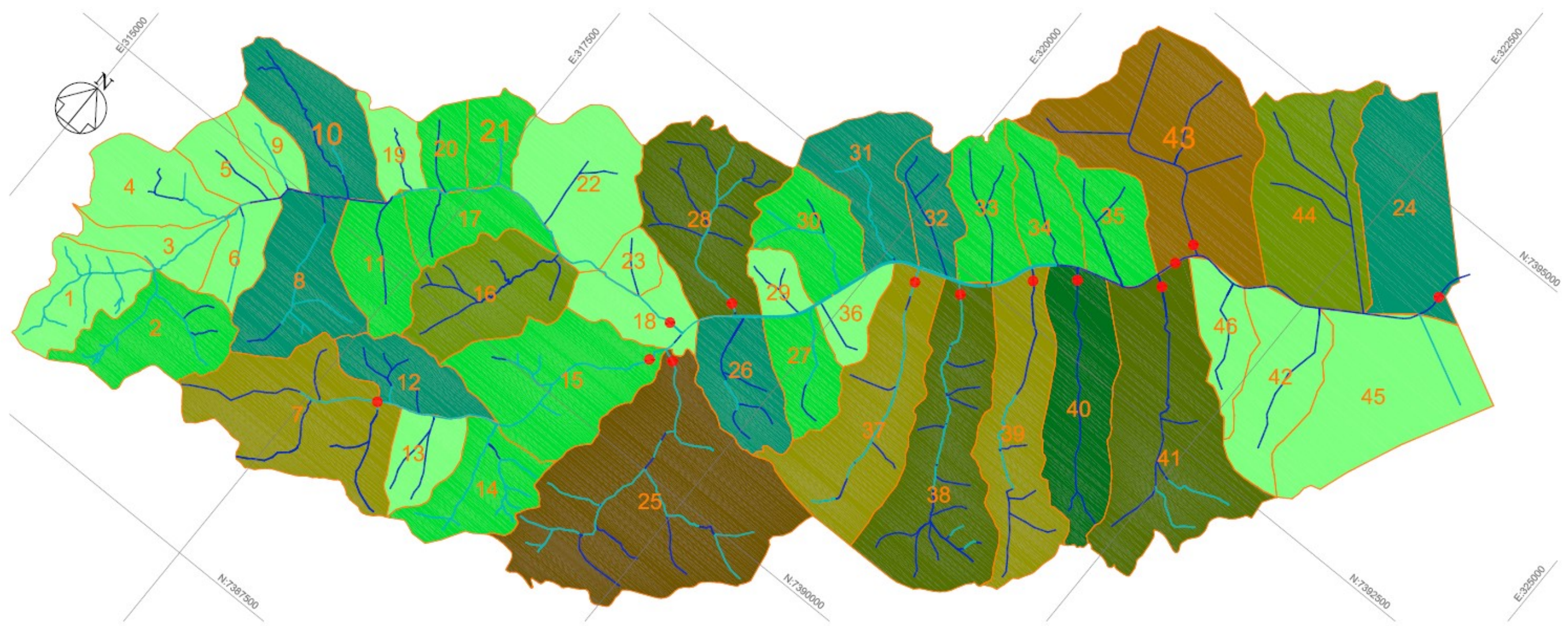

Produção de SST nas microbacias nos eventos chuvosos de tempo chuvoso:

\begin{tabular}{|c|c|c|}
\hline Até $20 \mathrm{~kg} / \mathrm{dia}$ & De 101 a $120 \mathrm{~kg} / \mathrm{dia}$ & - Pontos com elevada concentração de \\
\hline De 21 a $40 \mathrm{~kg} / \mathrm{dla}$ & De 121 a $140 \mathrm{~kg} / \mathrm{dla}$ & SST que demandam BMP's \\
\hline De 41 a $60 \mathrm{~kg} / \mathrm{dia}$ & De 141 a $160 \mathrm{~kg} / \mathrm{dia}$ & \\
\hline De 61 a $80 \mathrm{~kg} / \mathrm{dla}$ & De 161 a $180 \mathrm{~kg} / \mathrm{dla}$ & \\
\hline De 81 a $100 \mathrm{~kg} / \mathrm{dia}$ & De 181 a $200 \mathrm{~kg} / \mathrm{dia}$ & \\
\hline
\end{tabular}

Ilustração 136 - Bacias com maior potencial de geração de carga difusa nos eventos chuvosos durante o tempo chuvoso. Fonte: Elaborado pela autora. 


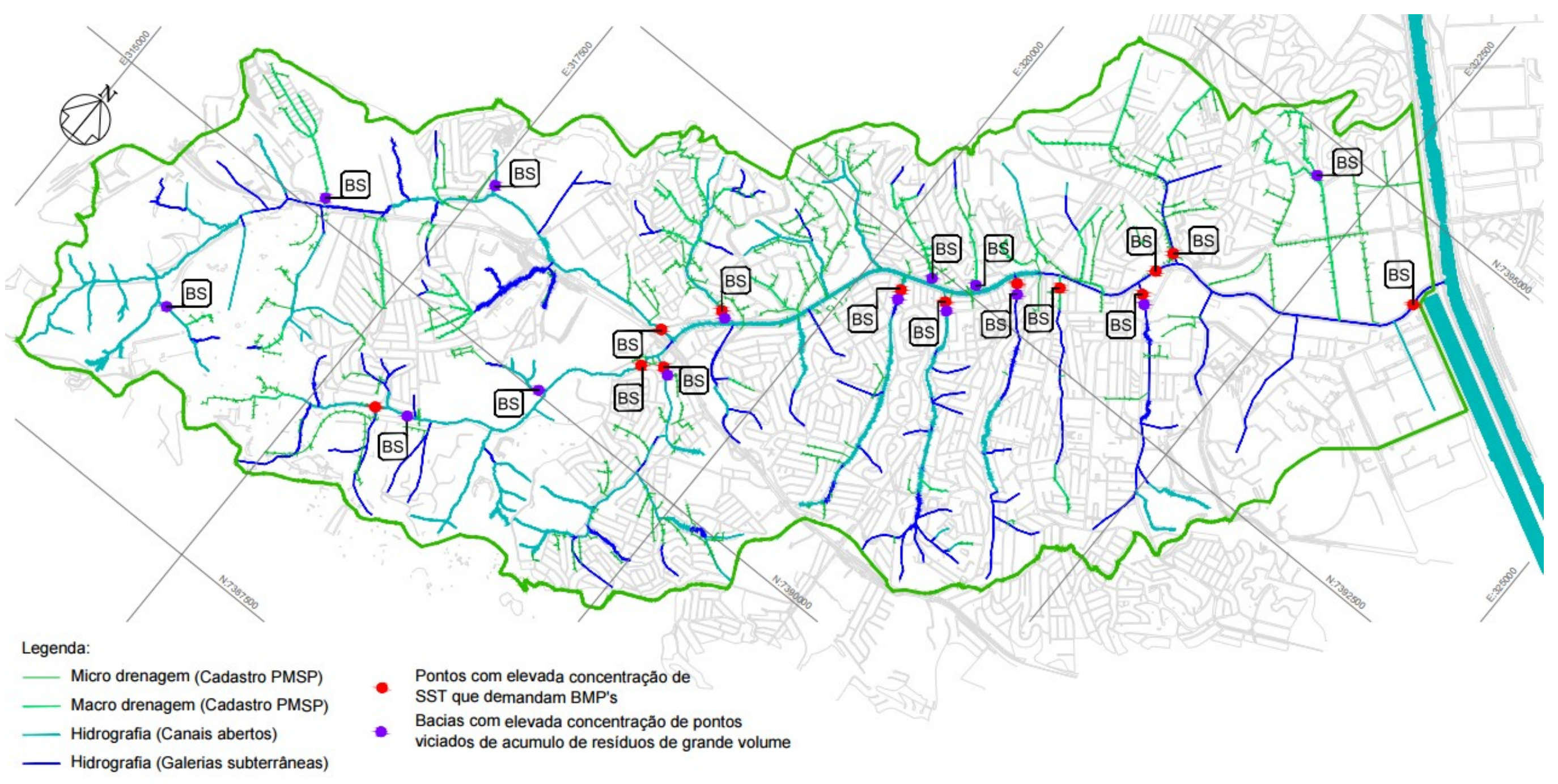

BMP's

BSP: Bacia de sedimentaçăo

Ilustração 137 - Pontos propostos para adoção de bacias de sedimentação. Fonte: Elaborado pela autora. 


\subsubsection{Controle de resíduos sólidos}

Para controle dos resíduos sólidos na bacia foram propostas um conjunto de técnicas para atingir o objetivo de "Zero Resíduo" nos cursos d'água da bacia. As medidas de controle atuarão quatro estágios de retenção: Controle no logradouro público; controle nos dispositivos de captação do escoamento superficial; controle nas galerias da microdrenagem; e por fim controle nos canais da macrodrenagem, como será apresentado a seguir.

\section{Estágio 1: Retenção no logradouro}

Para retenção de resíduos nas vias da bacia será adotada varrição mecanizada em todo o sistema viário, a fim de garantir uma melhor eficiência no processo. Seguindo o exemplo do que é feito na cidade de Los Angeles, na Califórnia, será adotado o sistema de sinalização do viário indicando os dias de operação dos caminhões da varrição mecanizada, a fim de avisar o usuário do impedimento da utilização do terço para estacionamento no período da operação de limpeza. Desta forma, o caminhão passara em dias alternados em cada lado das ruas, a fim de evitar a interdição completa da via para estacionamento de veículos.

A existência de áreas de ocupação não planejada na bacia constitui um grande desafio na implementação da varrição mecanizada, uma vez que estas áreas possuem vias com grandes declividades e com larguras variadas e fora do que exige as normas da prefeitura, no entanto tal objetivo poderá ser cumprido através da utilização de caminhões de pequeno porte, a exemplo do que já é feito no centro da cidade de São Paulo, onde é realizada a varrição mecanizada das vias estreitas com essas pequenas unidades.

Além disso, para garantir que a menor quantidade possível de resíduos aflua para dentro dos dispositivos de captação do escoamento superficial (bocas de lobo e de leão), propõe se a instalação na entrada dos dispositivos da bacia grades autooperadas, estas grades atuam impedindo a entrada de resíduos, mas quando forçadas se abrem evitando pontos de entupimento, o esquema e as fotos apresentadas na llustração 138 a seguir exemplificam o funcionamento da estrutura, 
a exemplo do que é adotado na cidade de Los Angeles.
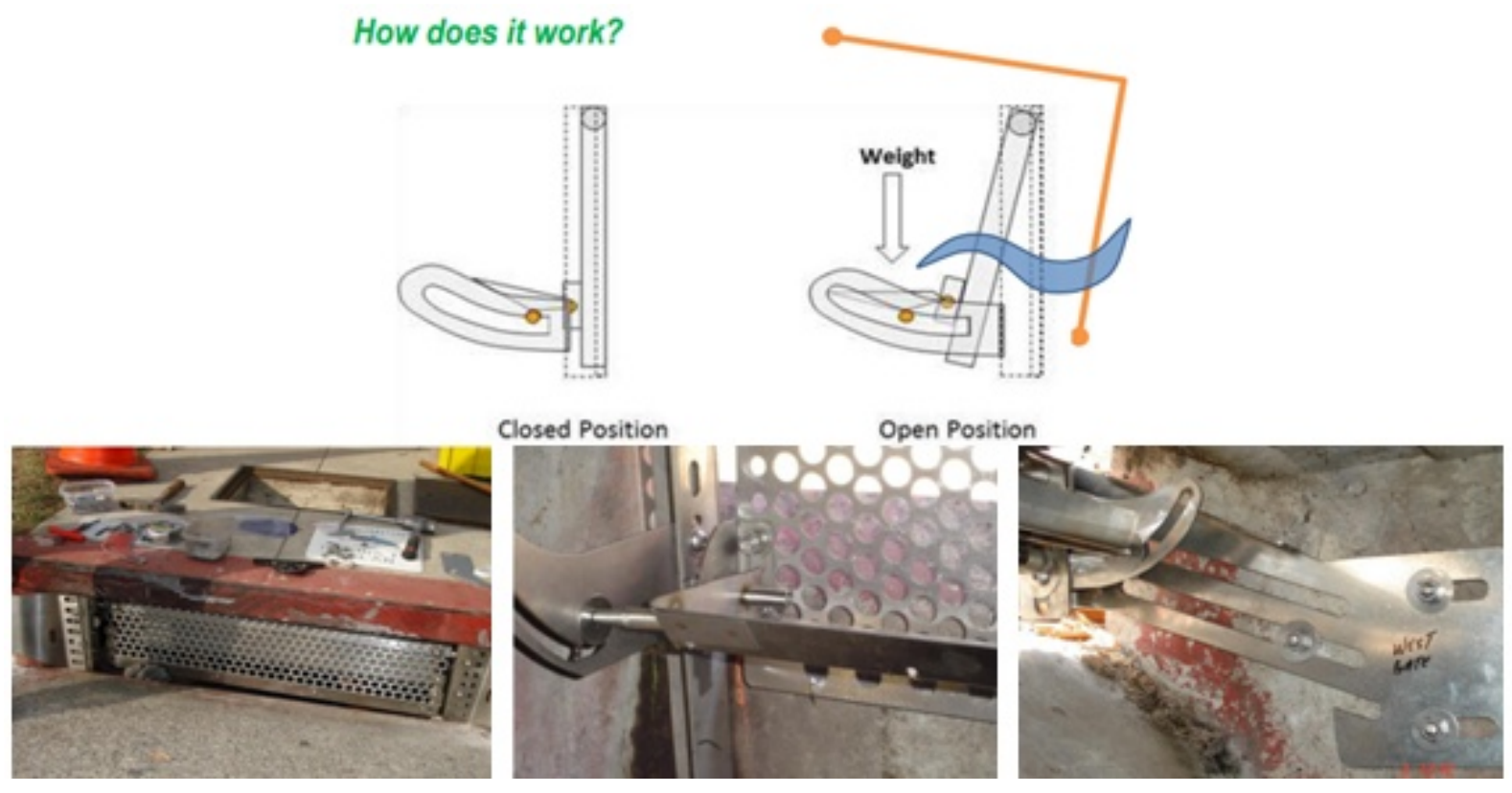

Ilustração 138 - Sistema de controle da entrada de resíduos em dispositivos de captação do escoamento superficial. Fonte: Environment LA Sanitation.

Estágio 2: Retenção no dispositivo de captação do escoamento superficial

O segundo estágio de controle de resíduos deverá ser realizado dentro dos dispositivos de captação do escoamento superficial, ou seja, bocas de lobo e de leão. Para tanto é necessário implantar dentro do dispositivo, cestos ou tecnologias similares que impeçam a passagem de resíduos para as galerias do sistema de microdrenagem, como por exemplo, os cestos metálicos adotados em Los Angeles; o SCS (Stormwater Cleaning Systems), utilizada em Springs, África do Sul; o SEPT (Side-Entry Pit Trap), utilizada em Melbourne, Austrália; ou até mesmo os cestos plásticos que tem sido adotados no centro da cidade de São Paulo, devendo ser avaliado caso a caso qual melhor dispositivo se enquadra para a realidade da parcela captada.

Atualmente, segundo o cadastro da prefeitura, existem cerca de 1800 pontos de boca de lobo ou de leão na bacia do Jaguaré, como o usual é a existência de mais de uma boca de lobo por ponto, a bacia do Jaguaré conta com cerca de 3600 bocas de lobo ou de leão a serem munidas de dispositivos de retenção. 


\section{Estágio 3: Retenção nas galerias da micro drenagem}

O terceiro estágio de retenção de resíduos consiste na retenção de resíduos nas galerias de drenagem ou nos desemboques das galerias no sistema de macro drenagem. Desta forma os resíduos que por ventura consigam afluir para o sistema de microdrenagem (passando do sistema viário para os dispositivos de captação de águas superficiais e destes dispositivos para as galerias) serão retidos.

As estruturas propostas para cumprir tal propósito são o sistema de redes de aço que podem ser implantadas no interior das galerias da microdrenagem antes do desemboque na macro drenagem como é feito na cidade de Los Angeles (llustração 47 ) e o sistema de redes de nylon como é feito em Auckland e Cape Town (llustração 43 ).

\section{Estágio 4: Retenção na macro drenagem}

Por fim, para o quarto estágio de retenção de resíduos pode ser adotado o uso de barreiras flutuantes ou ecobarreiras, que atuam na retenção de resíduos flutuantes na macrodrenagem.

Foram previstas, portanto as seguintes medidas para o córrego do Jaguaré:

- Adoção de varrição mecanizada de alta eficiência em todo o sistema viário da bacia, bem como a implantação de placas sinalizando a frequência e horários de operação do sistema. Prevendo frequência maior nos trechos onde há maior potencial de geração de resíduos;

- Instalação de sistema de controle de entrada de resíduos na entrada das bocas de lobo ou de leão da bacia, ou seja, nas cerca de 4 mil bocas de lobo existentes;

- Instalação de dispositivos de controle do tipo tela de aço ou rede de naylon nos lançamentos das galerias da microdrenagem nos canais da macrodrenagem; e

- Instalação de barreiras flutuantes ao longo dos canais da macrodrenagem.

A llustração 139 a seguir mostra a localização de algumas medidas propostas considerando as características do sistema de micro e macrodrenagem e o uso do solo na bacia. 


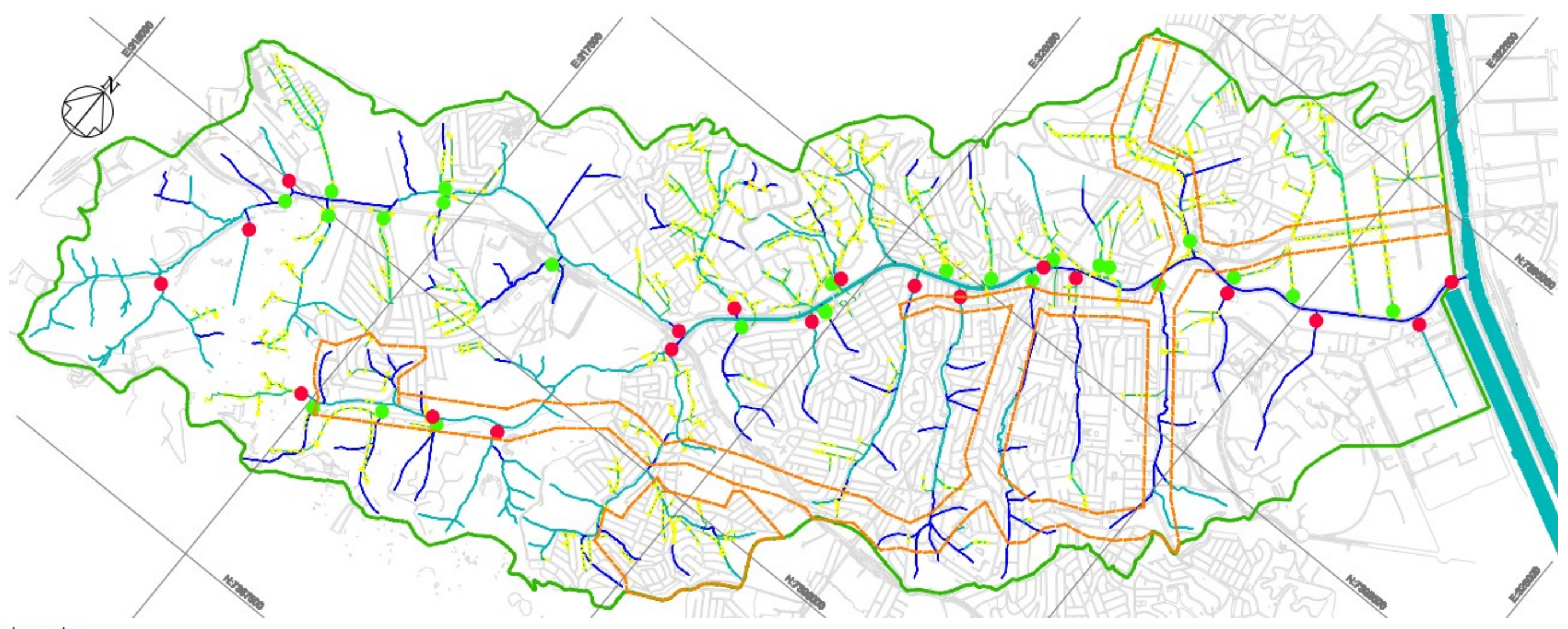

Legenda:

_ Micro drenagem (Cadastro PMSP)

Macro drenagem (Cadastro PMSP)

Hidrografia (Canais abertos)

\section{Hidrografia (Galerias subterrâneas)}

$1^{\circ}$ Estágio: Varrição mecanizada: Áreas que demandam

varriç̋̄es mais frenquentes devido ao elevado potencial de geraçăo

$2^{\circ}$ Estágio: Controle em bocas de lobo

$3^{\circ}$ Estágio: Redes de aço ou nylon para controle em galerias

- $4^{\circ}$ Estágio: Barreiras flutuantes

Ilustração 139 - Medidas de controle adotadas na bacia do Jaguaré. Laranja: Barreiras Flutuantes; Verde: Redes de aço em galerias da microdrenagem e em canais da macrodrenagem que encontram-se em galerias subterrâneas; Roxo: Zonas com alto potencial de geração de resíduos que demandam maior frequência de varrição. 


\subsubsection{Controle das demais cargas difusas}

As demais cargas são constituídas pela parcela de material fino e particulado que não é retido pelos demais dispositivos empregados, como por exemplo, a deposição seca e úmida, os poluentes provenientes da frota de veículos que trafegam pela bacia (Metais, combustível, desgaste de pneus, óleos e graxas), cargas orgânicas concentradas provenientes de feiras livres, insumos agrícolas para tratamento de áreas jardinadas e os poluentes provenientes de tipologias industriais e comerciais que variam em função da sua tipologia e dos insumos utilizados no processo produtivo. Desta forma, é proposta neste estudo uma série de medidas para controle destas cargas, como será apresentado a diante.

Para controle da deposição seca e úmida, dos poluentes da frota de veículos e de insumos agrícolas, serão adotadas em toda a bacia técnicas LID para tratamento destas cargas dispersas, como por exemplo, bio valetas, canteiros vegetados e valas de infiltração. Além disso, junto às bacias de sedimentação propostas para a bacia, serão empregadas espécies fito remediadoras a fim de promover o tratamento destas cargas poluentes.

Tabela 19 - Micro bacias de drenagem com significativas parcelas comerciais e industriais. Fonte: Elaborado pela autora.

\begin{tabular}{|c|c|c|c|c|c|c|c|}
\hline Bacia & $\begin{array}{c}\text { Total Área } \\
\text { Comercial } \\
\text { na micro } \\
\text { bacia (\%) }\end{array}$ & $\begin{array}{c}\text { Total Área } \\
\text { Industrial } \\
\text { na micro } \\
\text { bacia (\%) }\end{array}$ & $\begin{array}{c}\text { Total Área } \\
\text { Comercial } \\
\text { e Industrial } \\
\text { na micro } \\
\text { bacia (\%) } \\
\end{array}$ & Bacia & $\begin{array}{c}\text { Total Área } \\
\text { Comercial } \\
\text { na micro } \\
\text { bacia (\%) }\end{array}$ & \begin{tabular}{|c|} 
Total Área \\
Industrial \\
na micro \\
bacia (\%)
\end{tabular} & $\begin{array}{c}\text { Total Área } \\
\text { Comercial } \\
\text { e Industrial } \\
\text { na micro } \\
\text { bacia (\%) }\end{array}$ \\
\hline 1 & 0,00 & 0,00 & 0,00 & 28 & 4,48 & 0,33 & 4,82 \\
\hline 21 & 0,00 & 0,00 & 0,00 & 10 & 0,59 & 4,24 & 4,83 \\
\hline 29 & 0,00 & 0,00 & 0,00 & 39 & 5,71 & 0,00 & 5,71 \\
\hline 36 & 0,00 & 0,00 & 0,00 & 9 & 8,06 & 0,00 & 8,06 \\
\hline 14 & 0,00 & 0,00 & 0,00 & 35 & 8,11 & 0,00 & 8,11 \\
\hline 31 & 0,68 & 0,00 & 0,68 & 37 & 8,51 & 0,00 & 8,51 \\
\hline 34 & 1,21 & 0,00 & 1,21 & 26 & 9,98 & 0,00 & 9,98 \\
\hline 2 & 0,29 & 1,17 & 1,46 & 25 & 4,88 & 6,44 & 11,33 \\
\hline 30 & 1,80 & 0,00 & 1,80 & 7 & 11,29 & 0,78 & 12,07 \\
\hline 13 & 2,60 & 0,00 & 2,60 & 40 & 12,84 & 0,00 & 12,84 \\
\hline 33 & 3,38 & 0,00 & 3,38 & 6 & 8,34 & 5,42 & 13,76 \\
\hline 32 & 4,09 & 0,00 & 4,09 & 8 & 2,07 & 11,77 & 13,84 \\
\hline 20 & 4,37 & 0,00 & 4,37 & 15 & 12,14 & 2,01 & 14,14 \\
\hline 12 & 4,55 & 0,00 & 4,55 & 19 & 0,00 & 14,87 & 14,87 \\
\hline 27 & 4,70 & 0,00 & 4,70 & 38 & 14,35 & 0,94 & 15,29 \\
\hline
\end{tabular}

\begin{tabular}{c|c|c|c}
\hline Bacia & $\begin{array}{c}\text { Total Área } \\
\text { Comercial } \\
\text { na micro } \\
\text { bacia (\%) }\end{array}$ & $\begin{array}{c}\text { Total Área } \\
\text { Industrial } \\
\text { na micro } \\
\text { bacia (\%) }\end{array}$ & $\begin{array}{c}\text { Total Área } \\
\text { Comercial e } \\
\text { Industrial } \\
\text { na micro } \\
\text { bacia (\%) }\end{array}$ \\
\hline 3 & 1,07 & 17,76 & 18,83 \\
\hline 43 & 18,77 & 3,45 & 22,22 \\
\hline 11 & 0,75 & 24,53 & 25,28 \\
\hline 18 & 14,85 & 12,11 & 26,96 \\
\hline 22 & 11,17 & 15,98 & 27,14 \\
\hline 23 & 2,80 & 40,74 & 43,54 \\
\hline 41 & 39,75 & 4,68 & 44,43 \\
\hline 16 & 39,75 & 5,34 & 45,10 \\
\hline 44 & 3,72 & 48,55 & 52,27 \\
\hline 46 & 53,81 & 0,00 & 53,81 \\
\hline 17 & 15,29 & 41,37 & 56,67 \\
\hline 5 & 50,55 & 14,10 & 64,65 \\
\hline 45 & 71,71 & 0,00 & 71,71 \\
\hline 24 & 1,41 & 72,06 & 73,47 \\
\hline 42 & 76,83 & 0,00 & 76,83 \\
\hline 4 & 0,00 & 87,53 & 87,53 \\
\hline & & & \\
\hline
\end{tabular}

Para controle das cargas poluentes provenientes das tipologias industriais e comerciais que têm associadas a elas a geração de cargas de difícil remoção, como 
metais, hidrocarbonetos (Estireno, benzeno, etilbenzeno, tolueno, etc), óleos e graxas, desta forma demandam soluções pontuais para estas parcelas da bacia. Foram identificadas as micro bacias de drenagem com significativas parcelas de uso comercial e residencial, conforme mostrado na Tabela 19 e no mapa da llustração 141 a seguir.

Foram escolhido então 5 pontos chave para controle das cargas destas tipologias. A primeira Wetland proposta localiza-se na cabeceira da bacia e coletará as parcelas industriais e comerciais do Pq. Ipe e do Jd. Boa vista. A segunda e terceira Wetlands propostas localizam-se nas alças de acesso da Rodovia Raposo Tavares junto à Av. Escola Politécnica e farão a coleta das cabeceiras da bacia, recepcionando o córrego Itaim e as nascentes do Jaguaré. A quarta Wetland proposta localiza-se na rotatória do Extra Jaguaré e fará o tratamento das águas do canal no seu trecho médio. Por fim a quinta Wetland proposta localiza-se na área do Polo Tecnológico do Estado de São Paulo e tratará as águas do baixo Jaguaré.

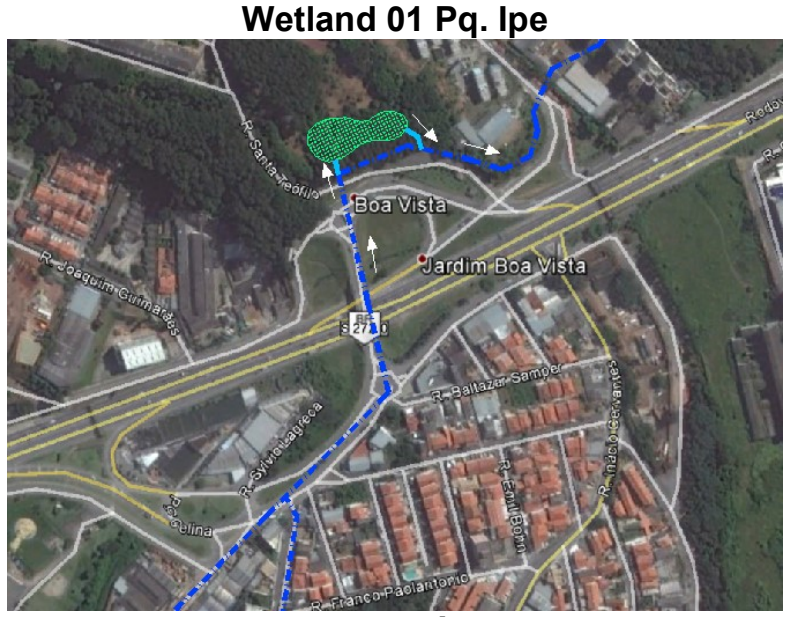

Wetland 04 Rotatória do Extra

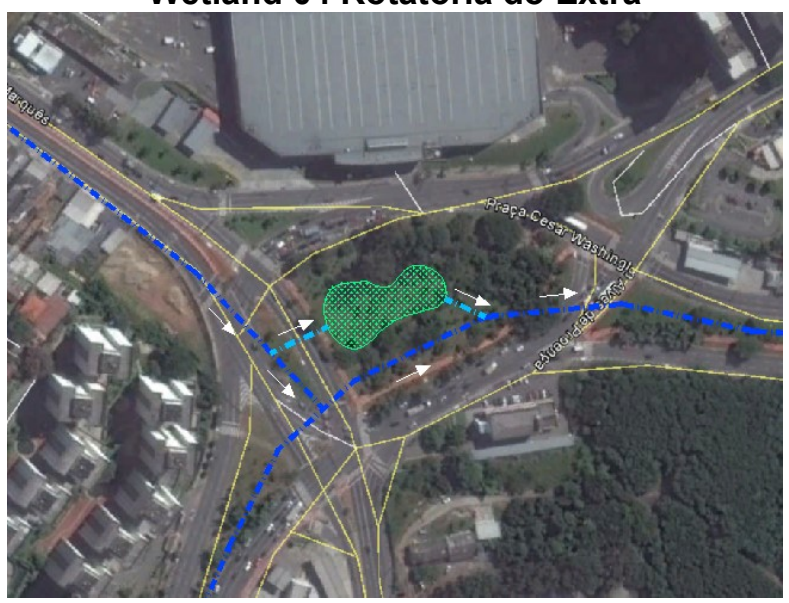

Wetland 02 e 03 Jd. Boa Vista

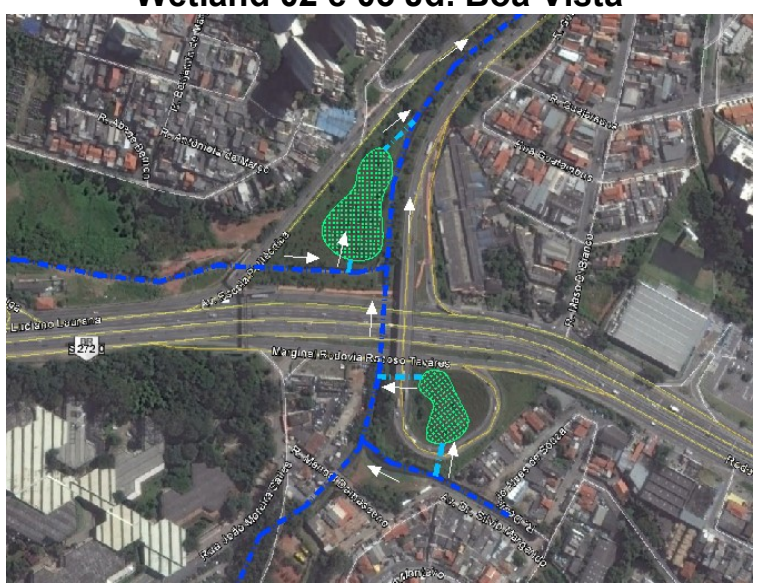

Wetland 05 Polo Tecnológico

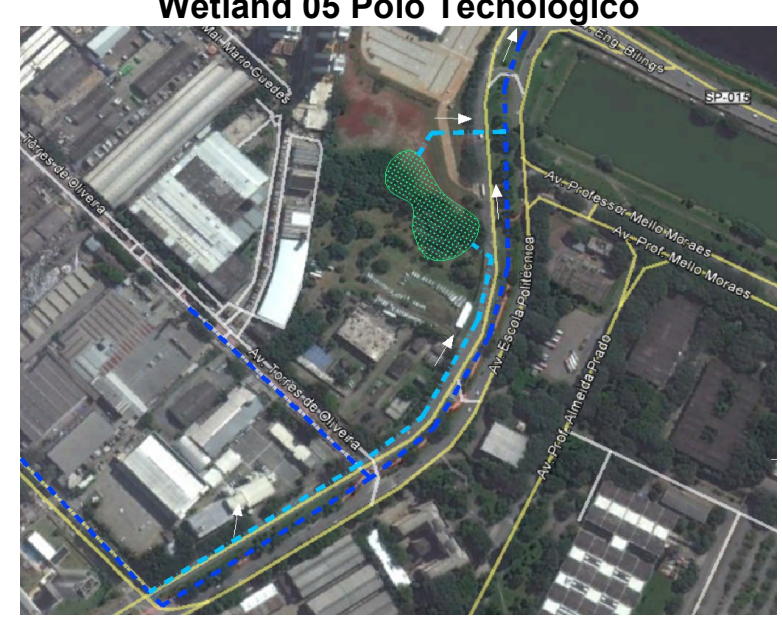

Ilustração 140 - Wetlands propostas para o controle de cargas provenientes de tipologias comerciais e industriais. Fonte: Elaborado pela autora. 


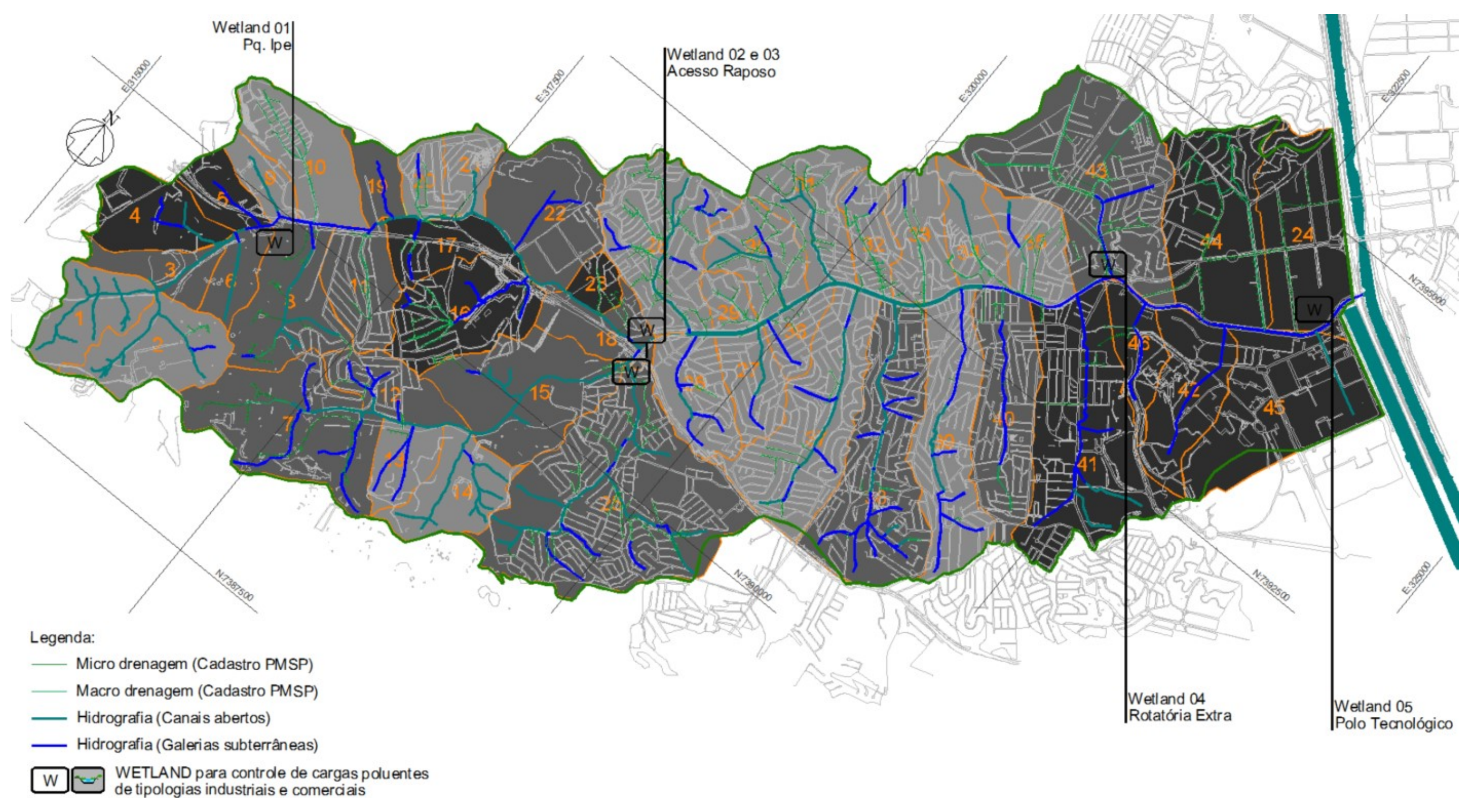

Ilustração 141 - Solução proposta para controle de cargas provenientes de tipologias comerciais e Industriais. Fonte: Elaborado pela autora. 
As Wetlands propostas tratarão as águas pluviais nos eventos chuvosos de baixa intensidade, devendo serem instaladas galerias adicionais, extravasores e saídas de fundo que conduzirão as águas dos canais afluentes para as wetlands, mas nos eventos chuvosos de alta intensidade os vertedores e as saídas de fundo redirecionarão o fluxo das águas para os canais principais, preservando a segurança hidrológica da bacia.

Nas cidades brasileiras é comum a ocorrência de feiras livres onde há a comercialização de frutas, legumes e outros produtos frescos, desta forma, estes eventos possuem grande potencial de geração de cargas poluentes para o sistema de drenagem, uma vez que depois das feiras, apesar de haver a varrição do material grosseiro, os demais poluentes soa lavados para as bocas de lobo existentes no logradouro. As águas da lavagem destas vias carregam grande quantidade de matéria orgânica tendo grande impacto sobre a DBO dos corpos d'água que recepcionam estas águas.

$\mathrm{Na}$ Bacia do Jaguaré existem atualmente 18 ruas cadastradas na PMSP que abrigam feiras de rua, representando uma carga significativa de poluentes semanais para os cursos d'água da bacia.

Tabela 20 - Feiras livres na bacia do Jaguaré. Elaborado pela autora com base em informações da PMSP.

\begin{tabular}{|c|c|c|c|c|c|c|}
\hline CÓDIGO & FEIRA & $\begin{array}{l}\text { DIA DA } \\
\text { SEMANA }\end{array}$ & ENDEREÇO & BAIRRO & $\begin{array}{l}\text { METROS } \\
\text { LINEARES }\end{array}$ & $\begin{array}{c}\text { NÚMERO DE } \\
\text { BANCAS }\end{array}$ \\
\hline 1 & Jaguaré & Terça-Feira & Rua Rolândia, S/N & Jaguaré & 149 & 27 \\
\hline 2 & Lageado & Quinta-Feira & Avenida Araicás, 254 & Jaguaré & 214 & 36 \\
\hline 3 & Vila Butantã & Sába do & Rua José Alves da Cunha Lima & Rio Pequeno & 219 & 42 \\
\hline 4 & Jardim Bonfiglioli & Terça-Feira & Avenida Octacilio Tomanik, S/N & Rio Pequeno & 595 & 107 \\
\hline 5 & Rio Pequeno & Sexta-Feira & Rua Pujais Sabaté, S/N & Rio Pequeno & 264 & 54 \\
\hline 6 & São Domingos & Domingo & Rua José joaquim Seabra, S/N & Vila Tiradentes & 521 & 100 \\
\hline 7 & Vila Dalva & Quarta-Feira & Rua Jorge Ward, 49 & Vila Dalva & 203 & 41 \\
\hline 8 & Caramuru & Quinta-Feira & Rua Padre Alarico Zacarias, S/N & Vila Maria Luiza & 130 & 28 \\
\hline 9 & Jardim Antonia & Sábado & Rua Doutor Paulo Ribeiro Coelho, S/N & Jardim Antonia & 60 & 12 \\
\hline 10 & Auriflama & Sábado & Rua Doutor Virgilio Alvin Franco, 10 & Jardim do Abril & 173 & 34 \\
\hline 11 & Vila Borges & Sexta-Feira & Rua Orestes Colombari, S/N & Vila Borges & 159 & 33 \\
\hline 12 & Jardim Guarau & Quinta-Feira & Rua Jerônimo Fernandes, S/N & Jardim Guarau & 124 & 22 \\
\hline 13 & Cohab - Educandário & Sábado & Rua Nove, S/N & Educandario Cohab & 2 & 1 \\
\hline 14 & Raposo Tavares & Domingo & Rua Gabriel de Carvalho, S/N & Jardim Boa Vista & 90 & 17 \\
\hline 15 & Jardim Arpoa dor & Domingo & Rua Adrebhal Stresser, S/N & Jardim Arpoador & 347 & 60 \\
\hline 16 & Cohab Raposo Tavares & Domingo & Rua Cachoeira do Arrependimento, S/N & Jardim Arpoador & 84 & 15 \\
\hline 17 & Jardim João XXIII & Terça-Feira & Rua Vaticano, S/N & Jardim João XXIII & 171 & 32 \\
\hline 18 & Jardim São Jorge & Quinta-Feira & Rua Professor João de Lorenzo, S/N & Jardim São Jorge & 285 & 55 \\
\hline
\end{tabular}


Desta forma, foi proposto neste estudo um sistema para envio da carga de lavagem destas áreas para o sistema de esgotamento sanitário da bacia. O sistema consiste em um sistema de bocas de lobo adicionais operadas manualmente que interceptariam a carga de lavagem dessas ruas (Indicadas na llustração 143 a seguir) e lançaria esta carga na rede coletora de esgotos. Tais bocas de lobo auxiliares devem possuir um sistema de fechamento com tranca e chave padronizadas e operadas pelo serviço de limpeza da via, permanecendo abertas somente durante os eventos de limpeza, impedindo que as mesmas recebam águas provenientes do escoamento superficial durante os eventos de chuva.

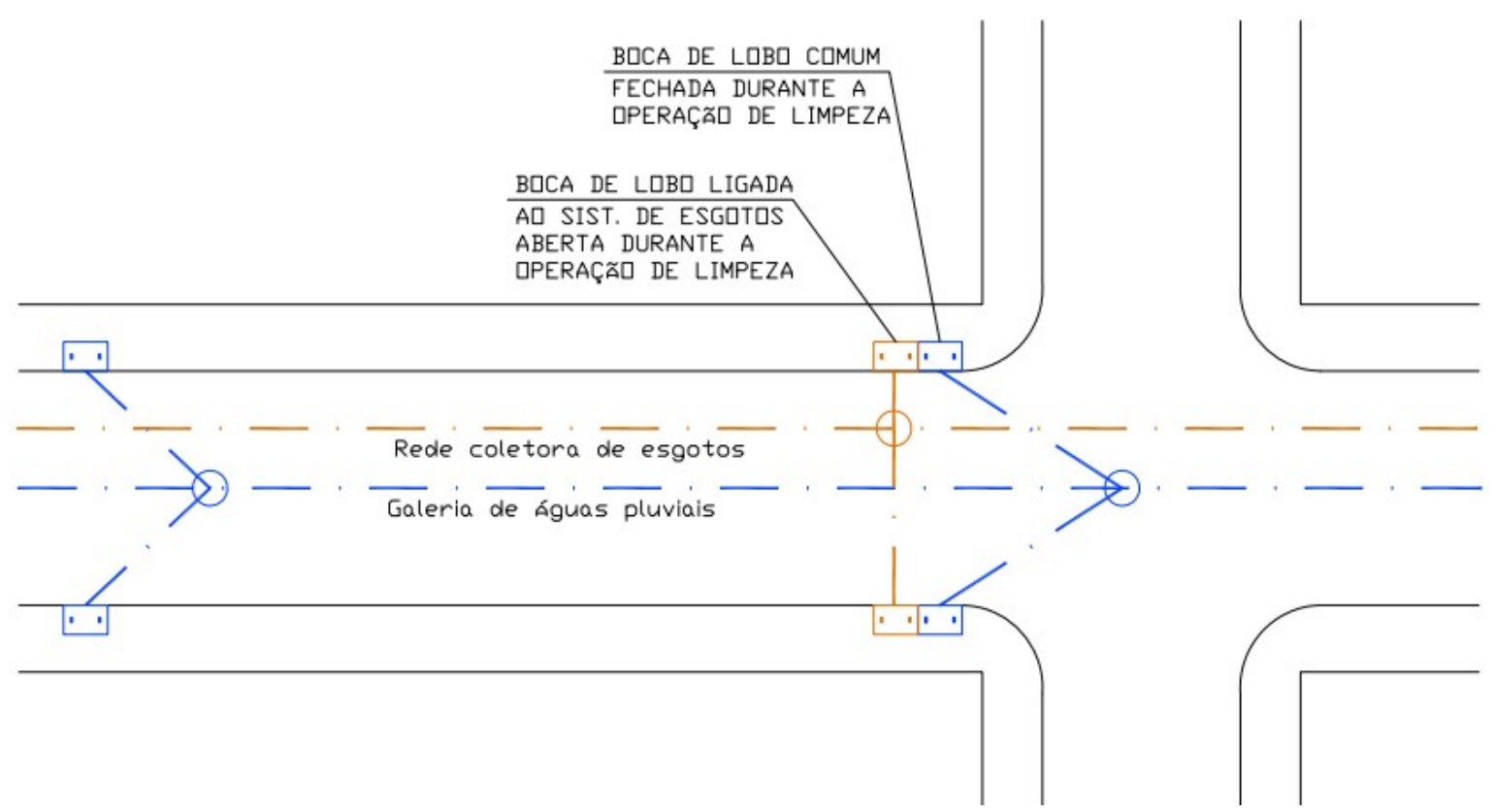

Ilustração 142 - Sistema proposto para controle de resíduos provenientes de feiras livres. Fonte: Elaborado pela autora. 


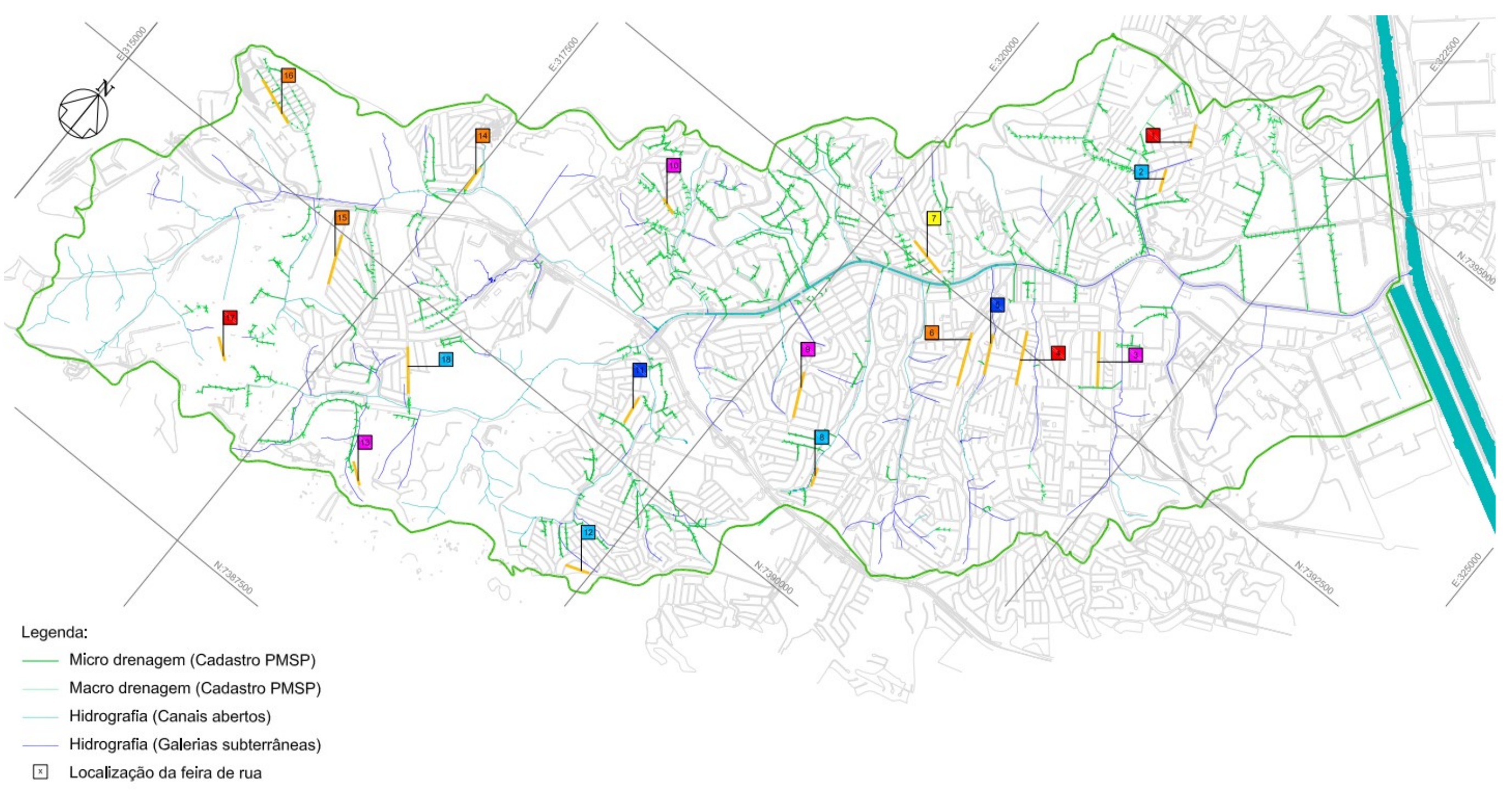

Ilustração 143 - Solução proposta para áreas de feira livre. Fonte: Elaborado pela autora. 


\subsection{Reintegração das áreas de várzea}

Nas áreas urbanas, a maioria dos rios tem suas áreas de várzea ocupadas por usos urbanos como o imobiliário e o rodoviário, e aqueles que ainda possuem suas áreas de várzea livres, as mesmas na maioria das vezes encontram-se degradadas ou sob ameaça de ocupação. Desta forma, neste estudo foram identificadas as áreas de várzea na bacia do Jaguaré a fim de avaliar qual a melhor solução para cada caso, uma vez que a bacia possui canais com diferentes graus de intervenção urbana e demandam soluções especificas.

\subsubsection{Renaturalizar, revitalizar ou recuperar?}

Como já visto, segundo Cengiz (2013), é possível dividir o manejo das águas em três categorias: Renaturalização, revitalização e recuperação, conforme resumido na Tabela 21 a seguir. As intervenções em bacias urbanas têm se pautado na maioria das vezes em ações que visam a recuperação do corpo d'água, uma vez que projetos de revitalização e renaturalização são mais caros e complexos, no entanto é crescente o interesse por essas iniciativas, a fim de promover um uso mais saudável e múltiplo da água no espaço urbano, promovendo o aumento da qualidade de vida da população nas cidades.

Tabela 21 - Renaturalização, revitalização e recuperação. Fonte: Elaborado pela autora

\begin{tabular}{c|c|c}
\hline Renaturalização & Revitalização & Recuperação \\
\hline $\begin{array}{c}\text { Restabelecer as relações entre o corpo } \\
\text { d'água e a paisagem de modo a retornar } \\
\begin{array}{c}\text { o corpo d'água a condição natural, ou o } \\
\text { mais próximo possível da condição } \\
\text { natural. }\end{array}\end{array}$ & $\begin{array}{c}\text { Restabelecer as relações entre o corpo } \\
\text { d'água e a paisagem de forma funcional, } \\
\text { ou seja, reintroduzir o canal dando } \\
\text { novamente vida a este, sem privar } \\
\text { outros usos. }\end{array}$ & $\begin{array}{c}\text { Reestabelecer condiçicas e biológicas do corpo d'água } \\
\text { manitárias satisfatórias, ou seja, garantir } \\
\text { a despoluição do corpo d'água. }\end{array}$ \\
\hline
\end{tabular}

Estas três categorias serão utilizadas para classificar o grau de intervenção que será adotado nos corpos d'água da bacia do córrego Jaguaré, a fim de propor uma metodologia para escolha de intervenções em corpos d'água em áreas urbanas. A metodologia proposta avaliou quatro aspectos, sendo eles técnicos, econômicos, biológicos e sociais, cuja pontuação para cada categoria avaliada é mostrada na Tabela 22 a seguir e os resultados obtidos são mostrados na Tabela 23 que indica o potencial para as três intervenções em função do estado atual do corpo d'água. 
Tabela 22 - Matriz de pontuação para avaliação do potencial para renaturalização, revitalização e recuperação de corpos d'água. Fonte: Elaborado pela autora.

\section{Potêncial para renaturalização}

Potêncial para revitalização

Potêncial para recuperação

Técnicos Econômicos Biológicos Sociais Total Técnicos Econômicos Biológicos Sociais Total Técnicos Econômicos Biológicos Sociais Total

\begin{tabular}{|c|c|c|c|c|c|c|c|c|c|c|c|c|c|c|c|c|}
\hline \multirow{3}{*}{$\begin{array}{c}\text { Não } \\
\text { canalizado }\end{array}$} & Dentro de fragmento florestal & 10 & 6 & 10 & 8 & 34 & 10 & 6 & 10 & 10 & 36 & 10 & 6 & 6 & 10 & 32 \\
\hline & Com faixa de vegetação nas margens & 10 & 4 & 10 & 8 & 32 & 8 & 5 & 6 & 10 & 29 & 10 & 5 & 6 & 10 & 31 \\
\hline & Em área de interesse social & 4 & 3 & 4 & 7 & 18 & 6 & 4 & 6 & 10 & 26 & 10 & 4 & 6 & 10 & 30 \\
\hline \multirow{3}{*}{$\begin{array}{c}\text { Canalizado - } \\
\text { Aberto }\end{array}$} & Com faixa de vegetação nas margens & 6 & 4 & 4 & 6 & 20 & 4 & 3 & 5 & 8 & 20 & 8 & 3 & 6 & 10 & 27 \\
\hline & Margens ocupadas por viário ou imóveis & 5 & 3 & 3 & 4 & 15 & 4 & 3 & 5 & 8 & 20 & 8 & 3 & 6 & 10 & 27 \\
\hline & Em área de interesse social & 4 & 3 & 3 & 3 & 13 & 4 & 3 & 5 & 8 & 20 & 8 & 3 & 6 & 10 & 27 \\
\hline \multirow{2}{*}{$\begin{array}{c}\text { Canalizado - } \\
\text { Fechado }\end{array}$} & Sob canteiro ou faixa de vegetação & 3 & 3 & 2 & 4 & 12 & 2 & 2 & 4 & 8 & 16 & 8 & 3 & 6 & 10 & 27 \\
\hline & Sob viário ou imóveis & 2 & 2 & 2 & 2 & 8 & 2 & 2 & 4 & 6 & 14 & 8 & 3 & 6 & 10 & 27 \\
\hline
\end{tabular}

Técnicos Quão complexa é tecnicamente a solução demandada?

Técnicos É possivel implantar a solução em pouco tempo?

Econômicos Quão custosa é a solução demandada?

Baixo/pouco/Não Médio/Talvez Muito/Alto/Sim

Econômicos Há recursos públicos disponíveis ou projeto demanda emprestimos e financiamentos?

Biológicos Considerando o entorno, quão benefica para a fauna e flora é a solução demandada?

Biológicos É possível garantir ganhos ambientais equivalentes com soluções tecnológicas?

Sociais Quão impactante positivamente é a solução adotada?

Sociais Quão impactante negativamente é a solução adotada?

\begin{tabular}{|c|c|c|c|c|}
\hline ai & ico/Nãc & Médio/Talvez & Muit & \\
\hline 5 & 4 & 3 & 2 & 1 \\
\hline 1 & 2 & 3 & 4 & 5 \\
\hline 5 & 4 & 3 & 2 & 1 \\
\hline 1 & - & $=$ & - & 5 \\
\hline 1 & 2 & 3 & 4 & 5 \\
\hline 5 & - & - & - & 1 \\
\hline 1 & 2 & 3 & 4 & 5 \\
\hline . & 4 & 3 & 2 & 1 \\
\hline
\end{tabular}

*Valores definidos para a realidade brasileira

Total possivel 40

Total / classe 13,33

Observações:

1- Considerou-se que corpos d'água não canalizados encontram se sob menor pressão antrópica, com a bacia hidrográfica menos urbanizada e impermeabilizada

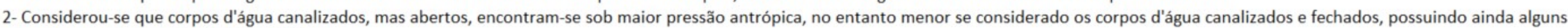

espaços permeáveis na bacia hidrográfica

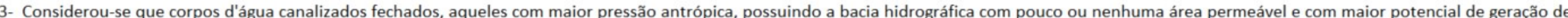
cargas poluentes 
Tabela 23 - Classificação do corpo d'água e potencial para intervenção. Fonte: Elaborado pela autora.

\begin{tabular}{l|l|c|c|c}
\hline \multicolumn{2}{c|}{ Classificação do estado atual do corpo d'água } & $\begin{array}{c}\text { Potêncial para } \\
\text { renaturalização }\end{array}$ & $\begin{array}{c}\text { Potêncial para } \\
\text { revitalização }\end{array}$ & $\begin{array}{c}\text { Potêncial para } \\
\text { recuperação }\end{array}$ \\
\hline \multirow{3}{*}{ Não canalizado } & Dentro de fragmento florestal & Alto & Alto & Alto \\
\cline { 2 - 5 } & Com faixa de vegetação nas margens & Alto & Alto & Alto \\
\cline { 2 - 5 } & Em área de interesse social & Médio & Médio & Alto \\
\hline \multirow{3}{*}{ Canalizado - Aberto } & Com faixa de vegetação nas margens & Médio & Médio & Alto \\
\cline { 2 - 5 } & Margens ocupadas por viário ou imóveis & Médio & Médio & Alto \\
\cline { 2 - 5 } & Em área de interesse social & Baixo & Médio & Alto \\
\hline \multirow{2}{*}{ Canalizado - Fechado } & Sob canteiro ou faixa de vegetação & Baixo & Médio & Alto \\
\cline { 2 - 5 } & Sob viário ou imóveis & Baixo & Médio & Alto \\
\hline
\end{tabular}

Um corpo d'água dentro de um fragmento florestal possui condições ideais para um processo de renaturalização, ao passo que um corpo d'água dentro de um contexto de forte pressão antrópica encontra maiores barreiras para uma intervenção deste tipo, possuindo, portanto um potencial menor para renaturalização e maior para outras intervenções. Para o processo de revitalização, obteve-se que áreas sob maior pressão antrópica possuem maior potencial para um processo de renaturalização, enquanto áreas sob maior pressão possuem potencial médio. Por fim, foi obtido para o processo de recuperação alto potencial para todos os cenários, uma vez que os ganhos superam as perdas em todos eles.

A classificação proposta serve para auxiliar na classificação do processo de intervenção adotado e na compreensão da viabilidade ou inviabilidade da adoção destas técnicas de manejo, uma vez que o uso de forma errônea dos termos "renaturalização, revitalização e recuperação" prejudica o avanço dos estudos e da aplicação destas técnicas.

A aplicação do método para a bacia do Jaguaré resultou no mapa da llustração 144 que mostra a intervenção escolhida em função das características de cada canal. Para montagem do mapa utilizou-se as seguintes informações: uso e ocupação do solo na várzea do canal e status do canal (Canalizado ou não e se canalizado, tipo de canalização). A partir do mapa foram selecionadas três bacias que foram utilizadas como estudo de caso para proposição de medidas para o manejo das mesmas nas três escalas de intervenção, renaturalização, revitalização e recuperação. 


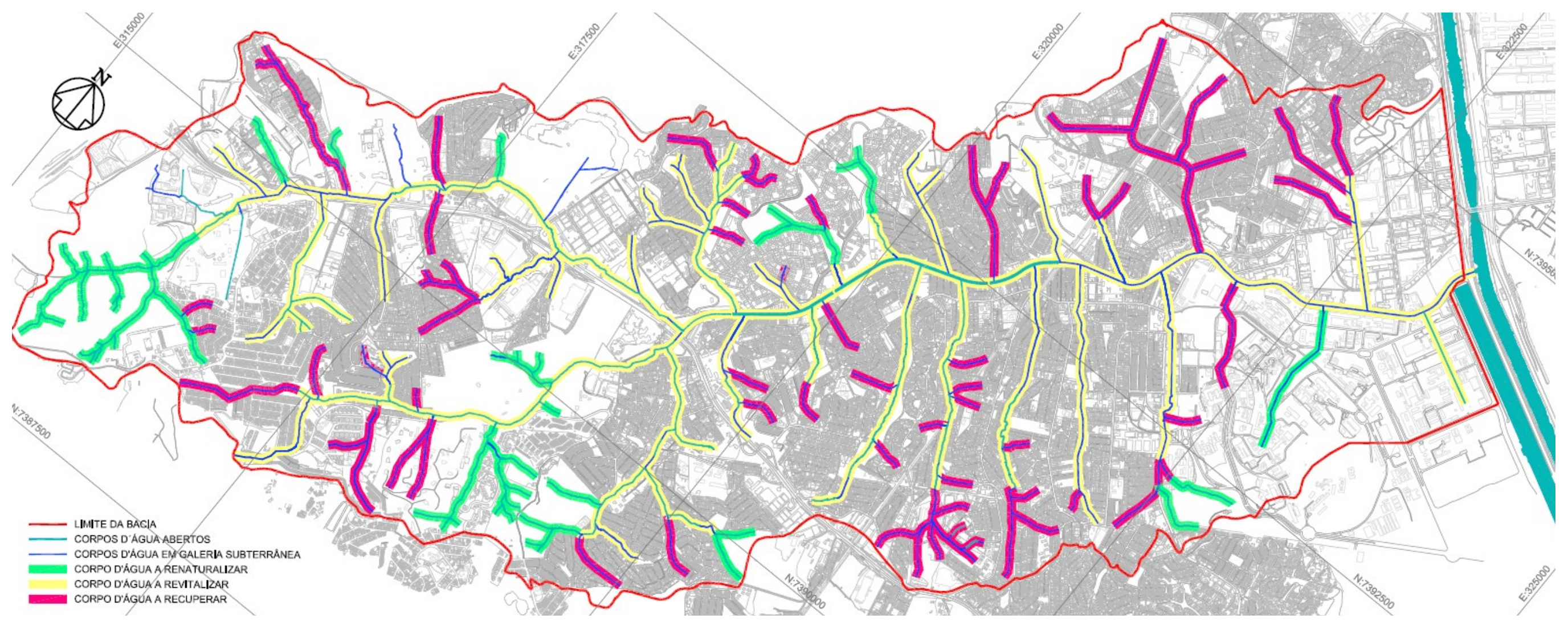

Ilustração 144 - Classificação do potencial de intervenção dos corpos d'água na bacia do Jaguaré. Fonte: Elaborado pela autora. 


\subsubsection{Renaturalizando, Revitalizando e Recuperando}

Serão propostas medidas, utilizando as técnicas vistas na revisão bibliográfica, para renaturalização, revitalização e recuperação de três sub bacias na bacia do Jaguaré: a renaturalização da bacia das nascentes do córrego Itaim $(A)$, na área que corresponde ao Parque Tizo; a revitalização da bacia do córrego da praça Evandro Valério (B); e a recuperação da bacia do córrego na Avenida Corifel de Azevedo Marques (C). A localização das bacias é mostrada na llustração 145 a seguir.

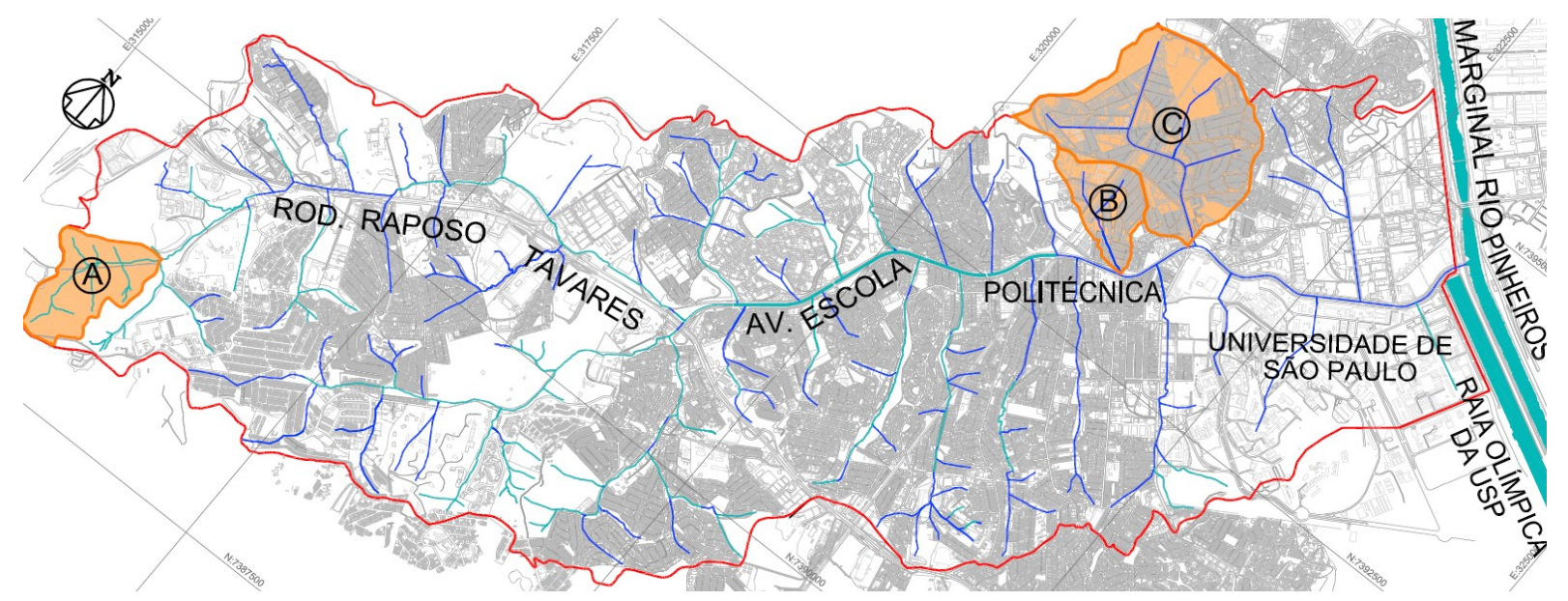

Ilustração 145 - Localização das bacias objetos de estudo para propostas de renaturalização, revitalização e recuperação na bacia do Jaguaré. Fonte: Elaborado pela autora.

As propostas elaboradas para as três sub bacias podem ser tomadas como exemplo para as demais sub bacias da bacia do Jaguaré e outras bacias hidrográficas brasileiras urbanas com características semelhantes, uma vez que as mesmas correspondem a casos emblemáticos como: córregos semi preservados em remanescentes vegetais; córregos tamponados que apresentam condições para reabertura; e córregos tamponados que devido à presença consolidada de usos urbanos em sua várzea apresentam muitos entraves à sua reabertura demandando soluções mais conservadoras. 


\subsubsection{Renaturalizando: nascentes do córrego Itaim no Parque Tizo}

Com base no que foi visto na revisão bibliográfica, propõe-se neste estudo que o processo de renaturalização de corpos d'água deve atingir as seguintes etapas:

- Controle de cargas poluentes na bacia (Pontuais e difusas);

- Retirada de moradias irregulares nas áreas de várzea;

- Requalificação da flora: Retirada de espécies exóticas invasoras e replantio de espécies nativas;

- Requalificação da estrutura física do canal: Reconstituição dos meandros ou instalação de estruturas que recriem as funções dos mesmos, demolição de revestimentos e proteções de margens e fundos que não sejam adequados à colonização da biota, controle de processos erosivos na área de várzea;

- No caso do corpo d'água estar localizado no interior de parques, criação de zonas de sacrifício com estruturas de contemplação e lazer para que a população possa acessar o corpo d'água;

- Monitoramento da evolução da qualidade da água através do uso de indicadores físico-químicos e biológicos;

- Implantação de programa de educação ambiental na bacia hidrográfica;

- Implantação de programa para pagamento por serviços ambientais (PSA) na bacia hidrográfica.

Para aplicação destas etapas e elaboração de uma proposta de renaturalização, foi escolhida a área das nascentes do córrego Itaim, maior tributário do córrego Jaguaré, que se encontra dentro do Parque Tizo. Apesar de as nascentes estarem protegidas desde a criação do parque, as mesmas sofrem influência das cargas poluentes provenientes das áreas externas, como por exemplo as cargas pontuais e difusas provenientes da Vila Nova Esperança que faz divisa com o parque na Avenida Eng. Heitor Antônio Eiras Garcia. A llustração 146 mostra a localização da área do parque Tizo em verde e as nascentes do córrego Itaim dentro do parque. 


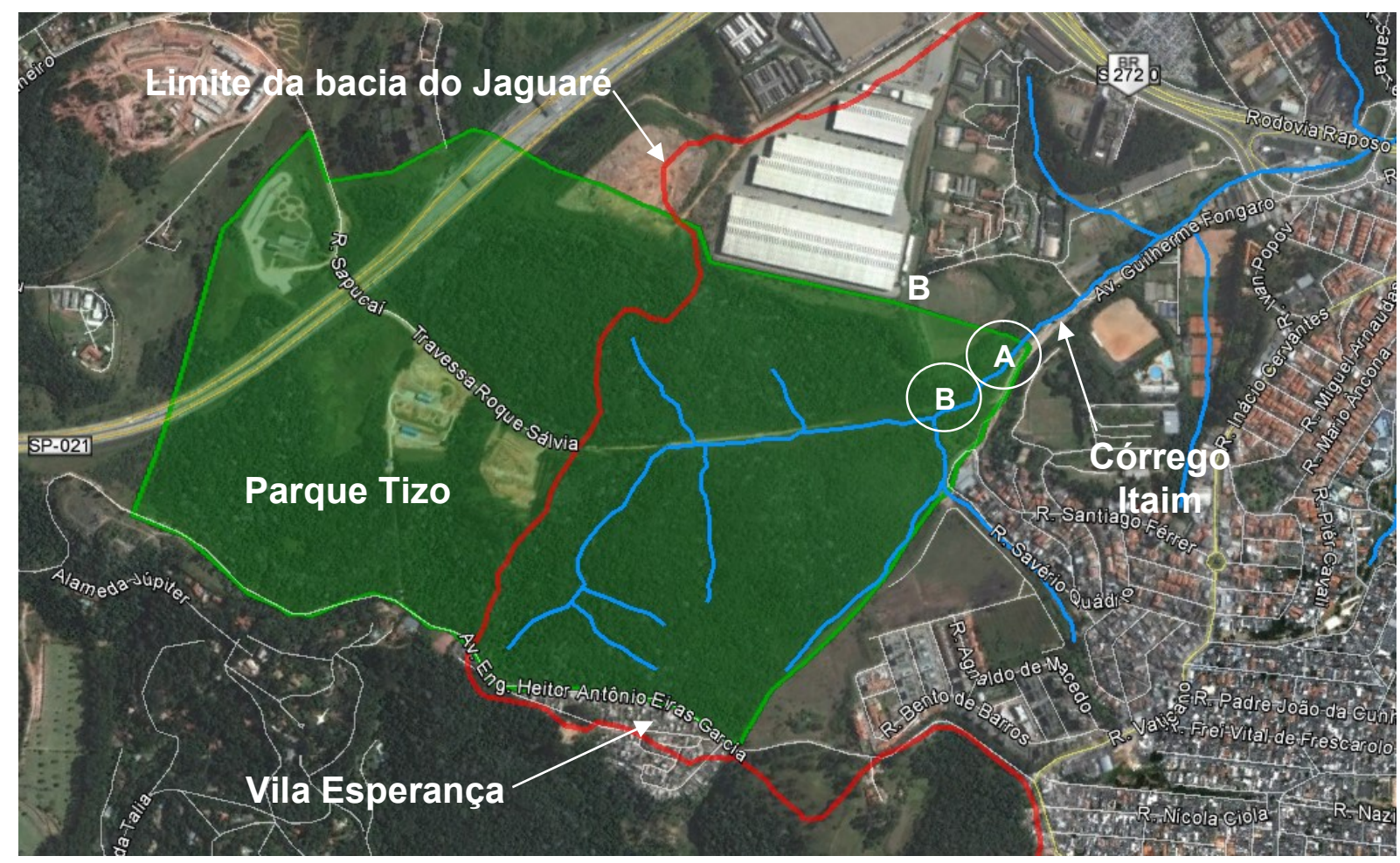

Ilustração 146 - Localização das nascentes do córrego Itaim no Parque Tizo. Fonte: Elaborado pela autora a partir de Google Earth Pro.

Além das ameaças devido ao lançamento de cargas poluidoras, os canais dentro do parque não estão em condições totalmente naturais, nem tão pouco integrados à população que frequenta o parque. $O$ trecho próximo à entrada do parque tem suas margens tomadas por capim, o que impede o acesso e até mesmo a visualização do canal, como mostrado na Foto A da llustração 147 . Já a Foto B da mesma llustração mostra um segundo trecho do canal cujo acesso é possível, mas que apresenta as margens sem vegetação e erodida.
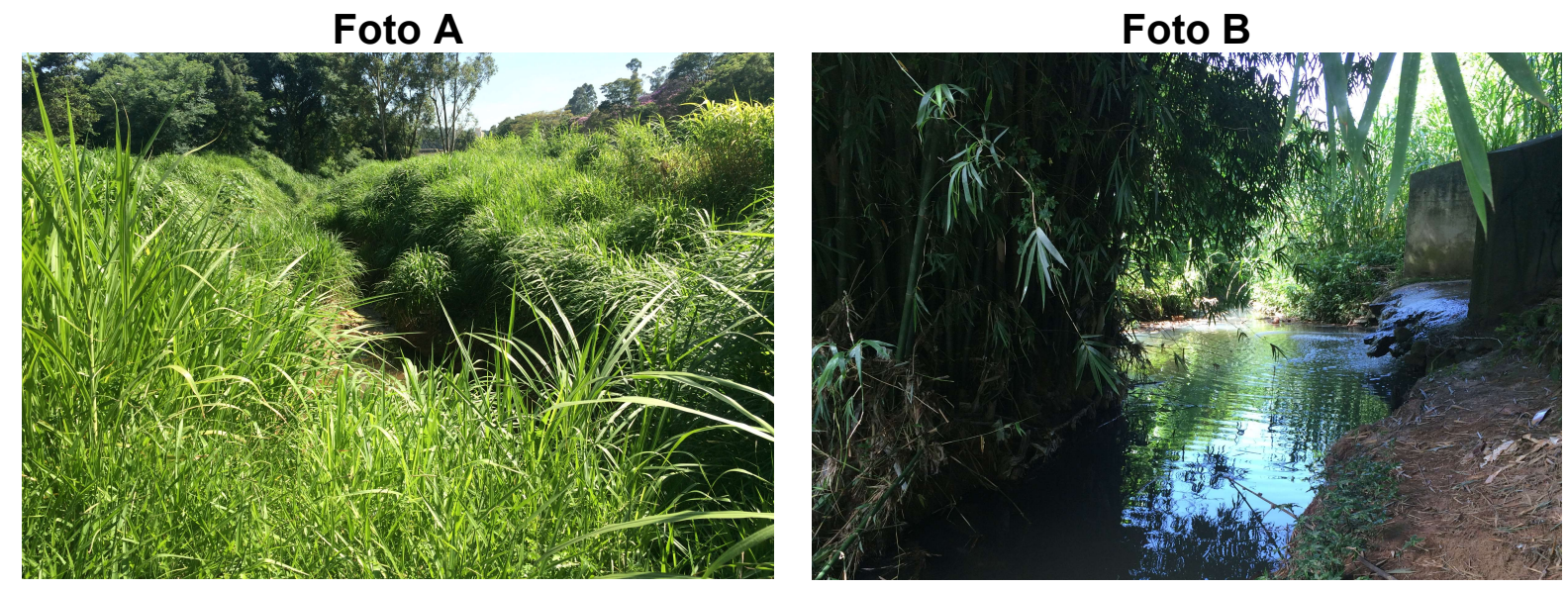

Ilustração 147 - Trechos da nascente do córrego Itaim no Parque Tizo. Fonte: Fotos da autora. 
As nascentes do Itaim possuem enorme potencial para revitalização, uma vez que estão inseridas em um contexto de remanescente vegetal sob proteção, desta forma foram propostas uma série de medidas para renaturalização das nascentes, a fim de atender o conjunto de técnicas detalhadas, conforme apresentado no corte da llustração 148 e na Ilustração 149 a seguir.

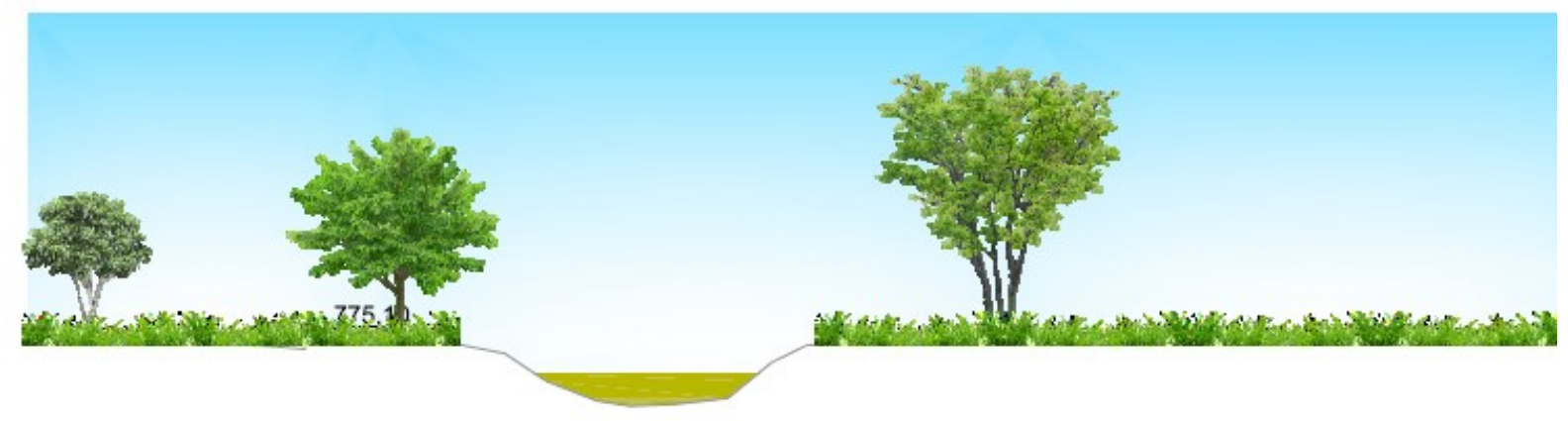

\section{NASCENTE DO CÓRREGO ITAIM - ATUAL}

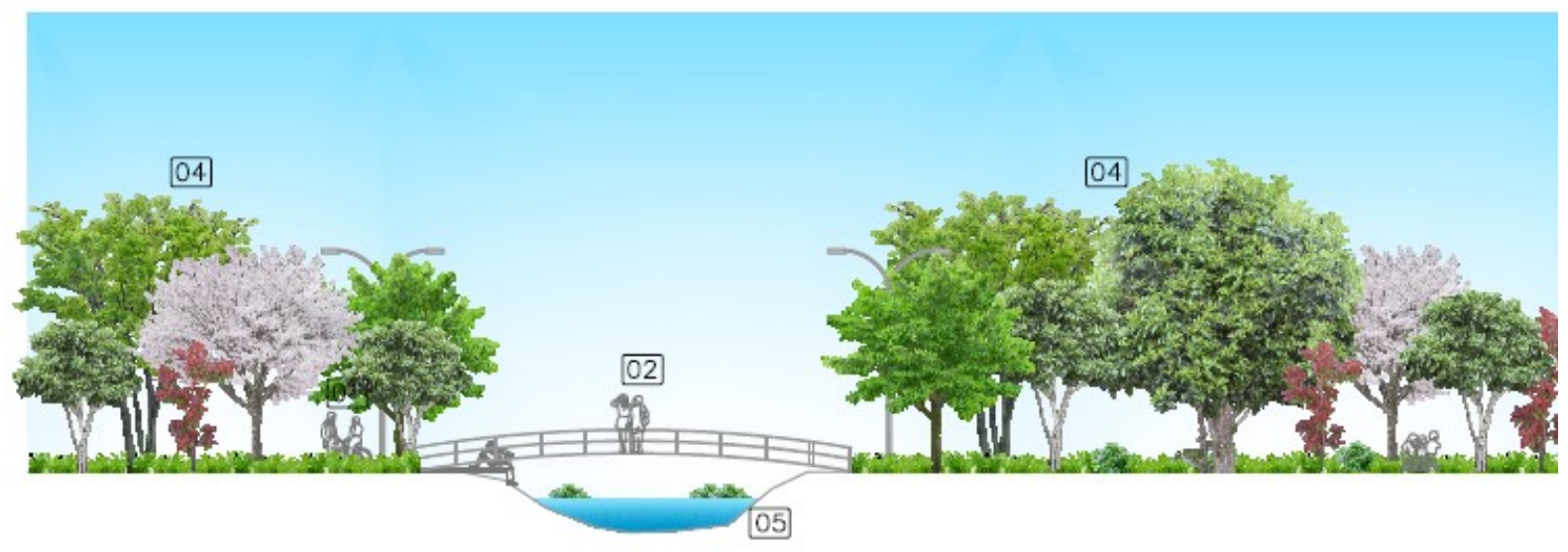

NASCENTE DO CÓRREGO ITAIM - PROPOSTO

\section{LEGENDA}

01 INTEGRAÇÃO DA POPULAÇÃO USUÁRIA DO PARQUE COM AS ÁGUAS

02 PONTE PARA TRAVESSIA DE PEDESTRES

03 USO DE ESPÉCIES VEGETAIS FITO REMEDIADORAS PARA TRATAMENTO DAS ÁGUAS

04 PLANTIO DE ESPĖCIES ADEQUADAS NAS VÁRZEAS

05 REGULARIZAÇÃO DE MARGENS E FUNDO COM TÉCNICAS SUSTENTÁVEIS

llustração 148 - Corte do cenário existente e proposto para a nascente do córrego Itaim no Parque Tizo. Fonte: Elaborado pela autora. 


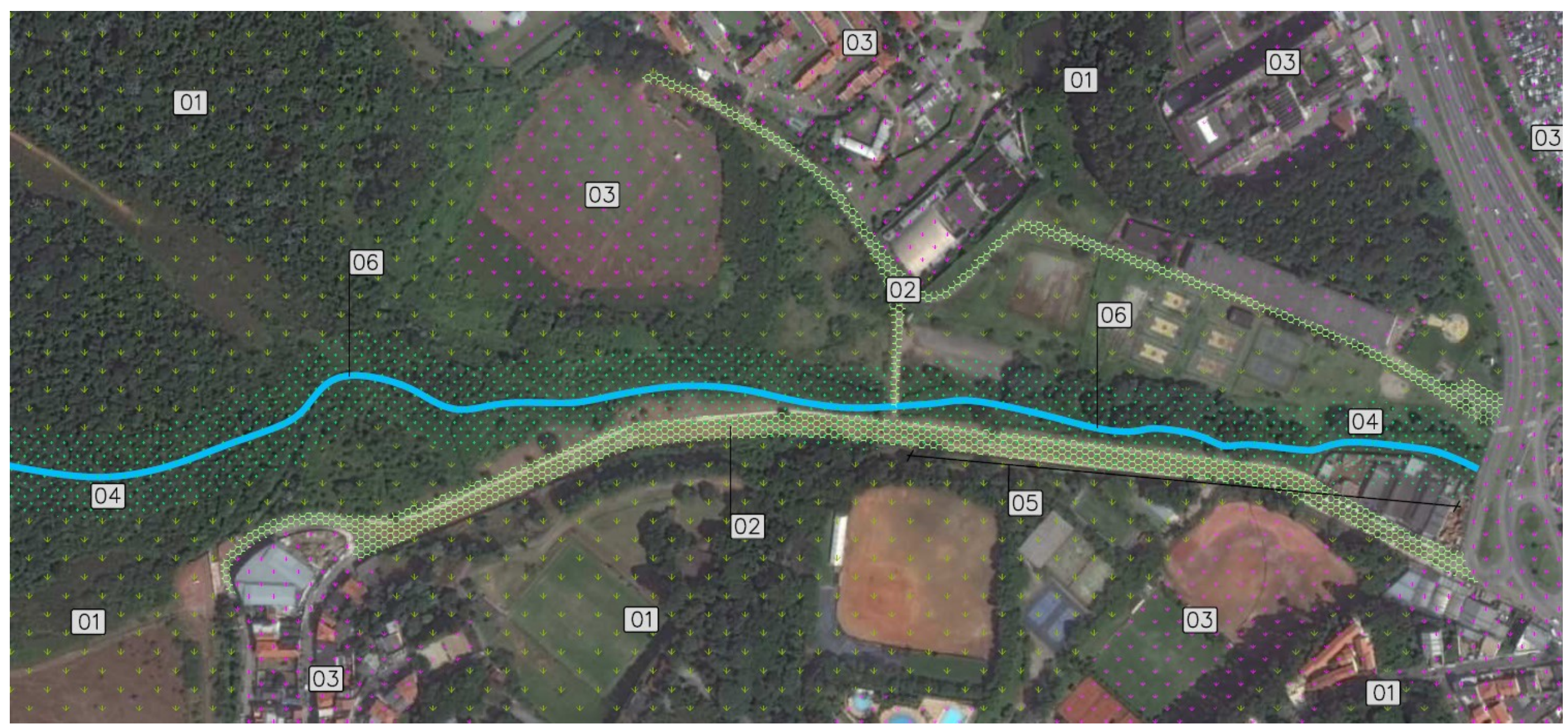

\section{LEGENDA}

01 ZONA QUE DEMANDA ENRIQUECIMENTO AMBIENTAL

02 VIÁRIO QUE DEMANDA APLICAÇÃO DE INFRAESTRUTURA VERDE

03 EDIFICAÇÖES E INSTALAÇÖES

04 REQUALIFICAÇÄO DA ÁREA DE VÁRZEA

05 ZONA PRÓXIMA À ÁREA DE VISITAÇÃO: DEMANDA EQUIPAMENTOS PARA OBSERVAÇ̃̃O

06 REQUALIFICAÇÃO DO CANAL

Ilustração 149 - Proposta para renaturalização das nascentes do Itaim no Parque Tizo. Fonte: Elaborado pela autora. 
O sistema de pagamento por serviços ambientais prestados pela população da bacia no caso de bacias em renaturalização deve ser pautado principalmente em ações que visem a preservação das áreas verdes e da qualidade da água:

- Incentivos fiscais para a manutenção de áreas verdes em propriedades privadas;

- Incentivos fiscais aos usuários que procederem com o cadastro de novas ligações de esgoto junto à concessionária;

- Sistema de recompensa para denuncias de lançamentos irregulares de cargas poluidoras no sistema de drenagem e nos corpos d'água da bacia;

- Incentivos fiscais para a adoção de técnicas de infraestrutura verde na escala do lote para controle de cargas poluentes e da vazão de pico.

O sistema de monitoramento de qualidade da água neste caso deve ser rigoroso a fim de aferir se a qualidade da água apresentada pelo corpo d'água atende as demandas do ecossistema aquático, devendo ser realizado no mínimo mensalmente e utilizando indicadores físico-químicos e biológicos. 


\subsubsection{Revitalização do córrego da Praça Evandro Valério e Padre Campos}

Com base no que foi visto na revisão bibliográfica, propõe-se neste estudo que o processo de revitalização de corpos d'água deve atingir as seguintes etapas:

- Controle de cargas poluentes na bacia (Pontuais e difusas);

- Retirada de moradias irregulares nas áreas de várzea;

- Requalificação da flora: Plantio de espécies que auxiliem na regulação hidrológica e que atuem no controle de poluentes;

- Requalificação da estrutura física do canal: Emprego de revestimento e proteções de margens e fundo que comportem crescimento vegetal.

- Implantação de estruturas de lazer ao longo do curso d'água como decks de observação, pistas de caminhada, ciclo vias, bancos, equipamentos esportivos, etc;

- Implantação de zonas de serviços como restaurantes, quiosques, etc;

- Monitoramento da evolução da qualidade da água através do uso de indicadores físico-químicos e biológicos;

- Implantação de programa de educação ambiental na bacia hidrográfica;

- Implantação de programa para pagamento por serviços ambientais (PSA) na bacia hidrográfica.

As praças Evandro Valério e Padre Campos, apesar de apresentarem condições propícias para a manutenção de um corpo d'água, abrigam um córrego canalizado em galeria subterrânea. Segundo os moradores do entorno das praças, o córrego foi tamponado em atendimento aos pedidos da própria população, já que o mesmo encontrava-se poluído gerando uma série de inconvenientes, como a presença de pragas urbanas (Insetos e ratos) e a exalação de odores provenientes dos esgotos depositados indevidamente no canal. A llustração 150 mostra a bacia contribuinte (Laranja), a área das praças (Verde), a localização dos corpos d'água da bacia e a localização do memorial fotográfico. A bacia possui ainda uma área sujeita a alagamentos, que será objeto de discussão adiante. 


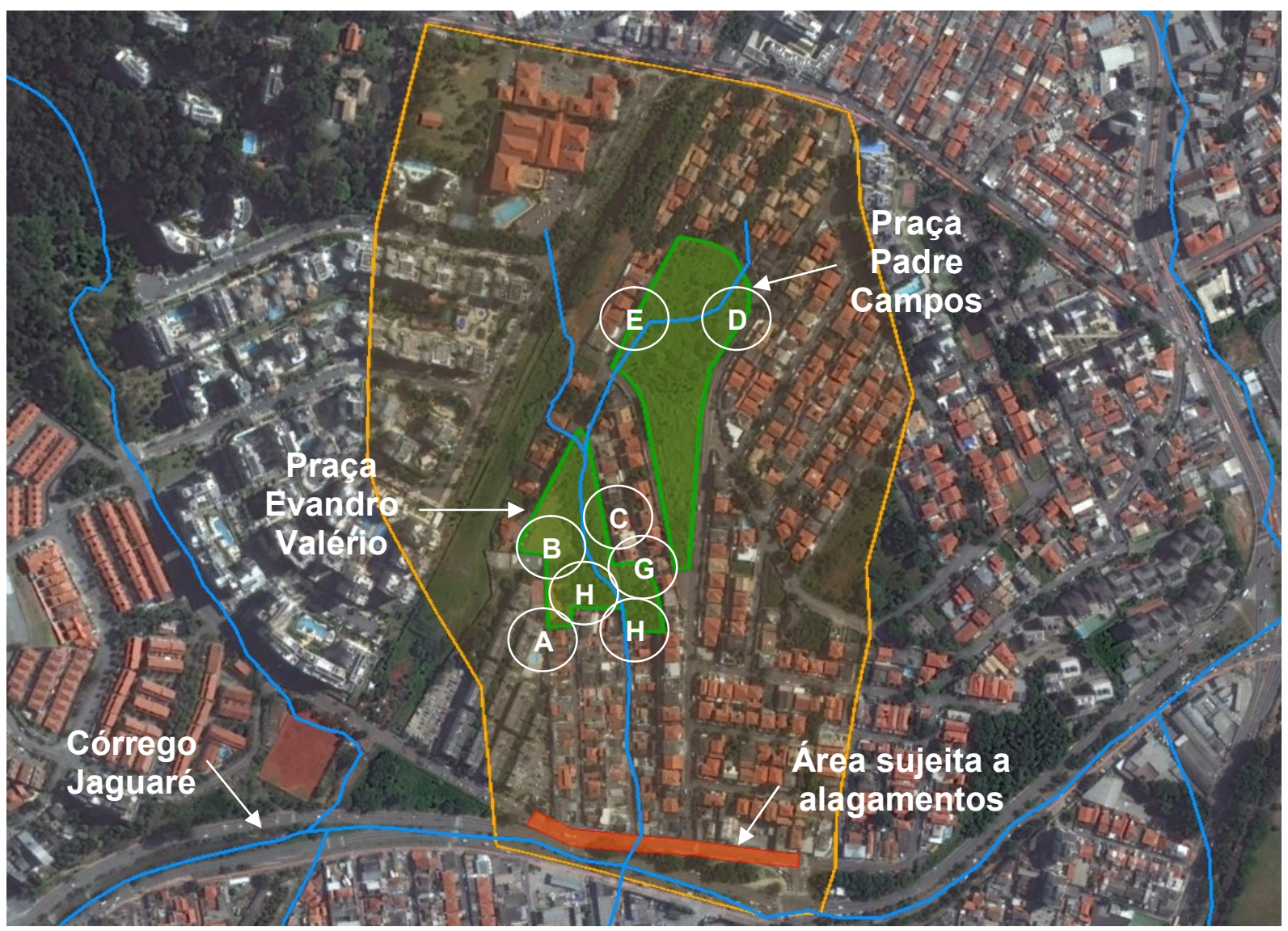

Ilustração 150 - Localização da praça Evandro Valério na bacia do córrego Jaguaré. Fonte: Elaborado pela autora a partir de Google Earth Pro.

A llustração 151 mostra pontos emblemáticos das praças. A Foto A mostra um campo de futebol instalado pela população; As Fotos B, C1 e E ilustram a densidade da vegetação existente em diferentes pontos; A Foto C2 mostra a falta de manutenção existente em um dos trechos, onde a vegetação invade a calçada, que acaba incentivando o depósito inadequado de resíduos pela população; e a Foto $D$ mostra um trecho que possui equipamentos públicos para práticas esportivas.
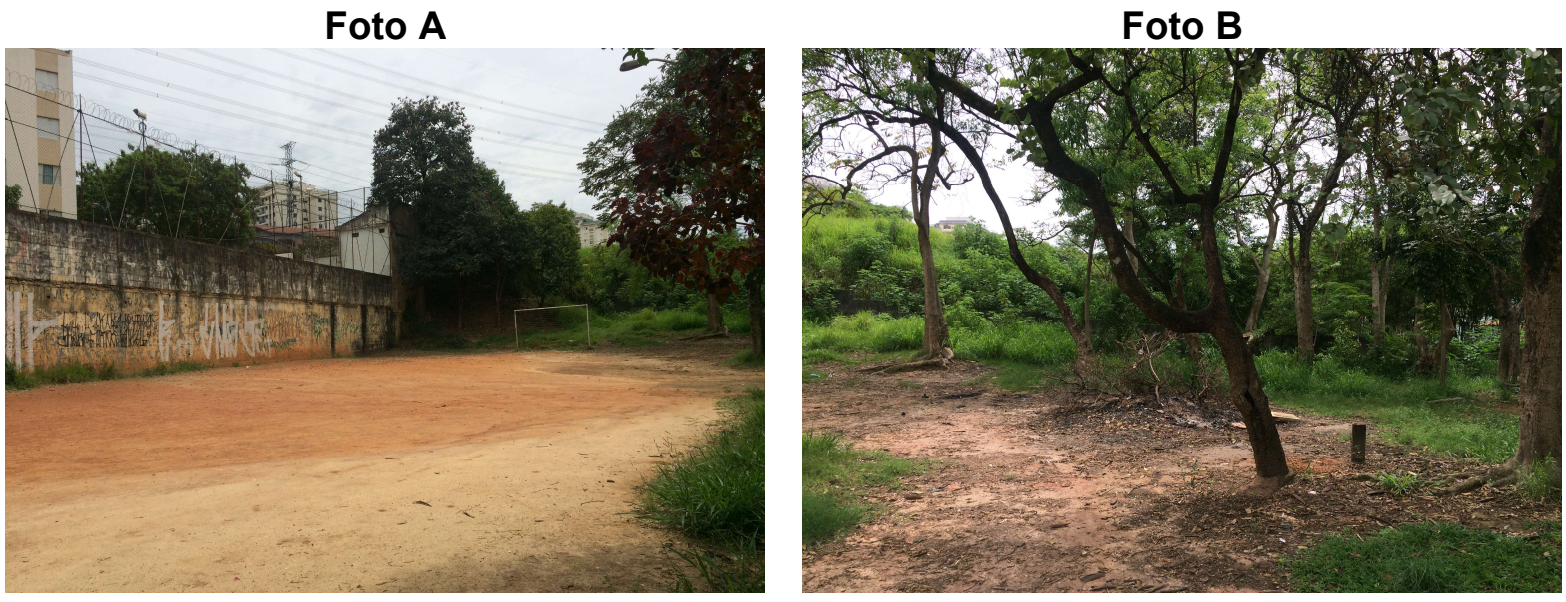


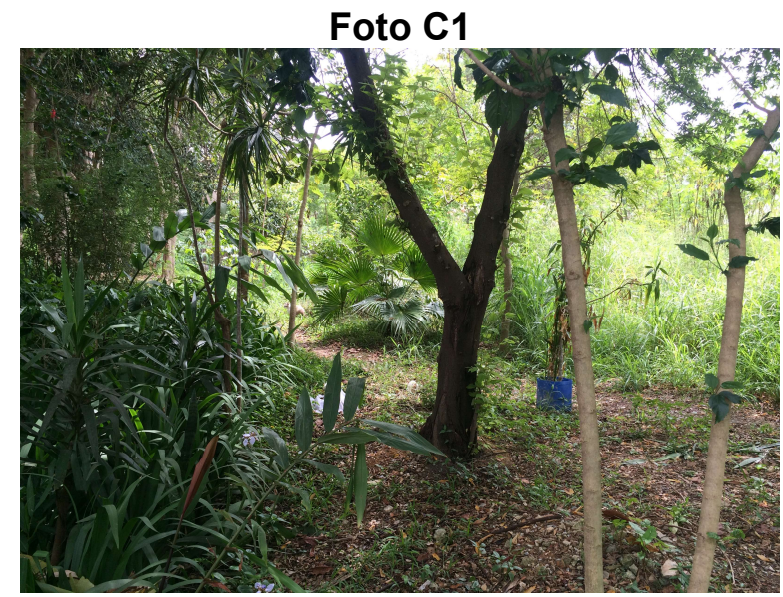

Foto D
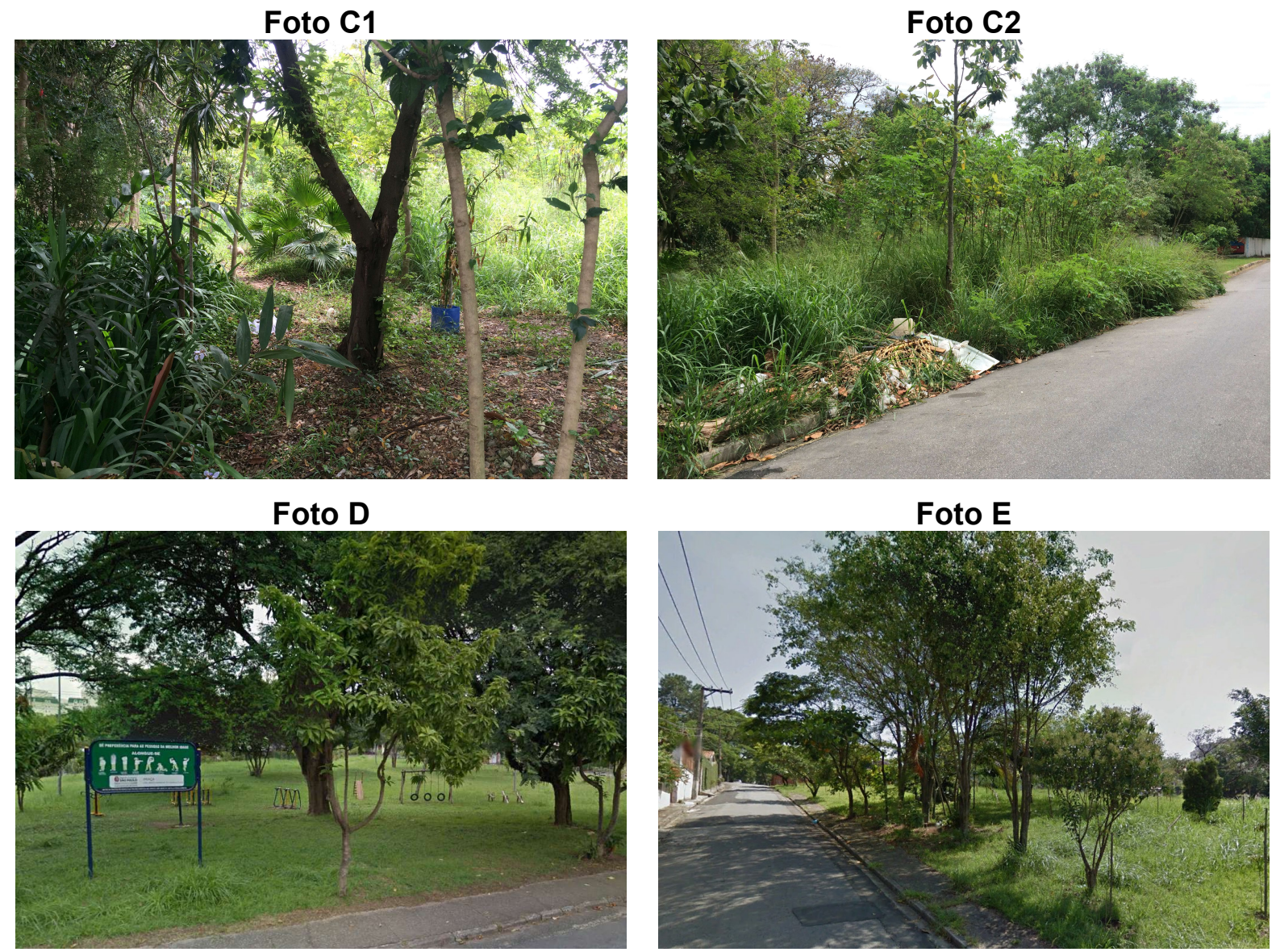

Foto $\mathrm{E}$

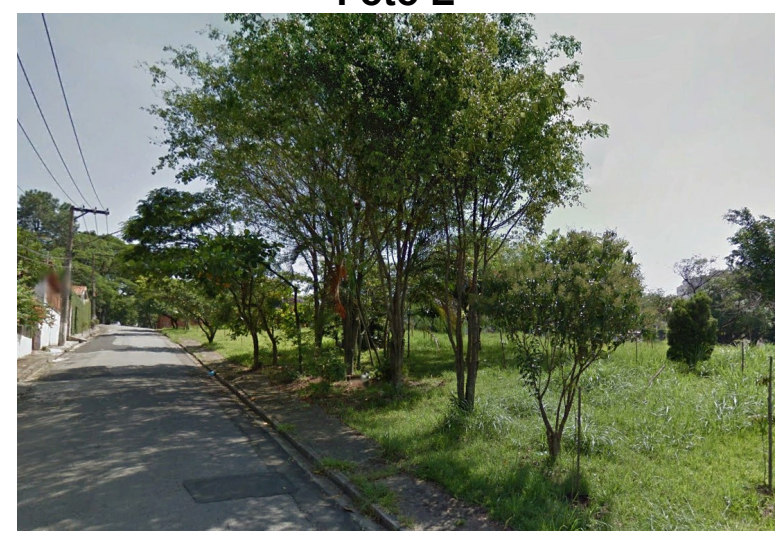

Ilustração 151 - Praça Evandro Valério na bacia do córrego Jaguaré. Fonte: Fotos da autora.

A llustração 152 mostra um dos poucos sinais de existência de água na praça, um poço de inspeção e uma caixa acoplada a uma boca de lobo.
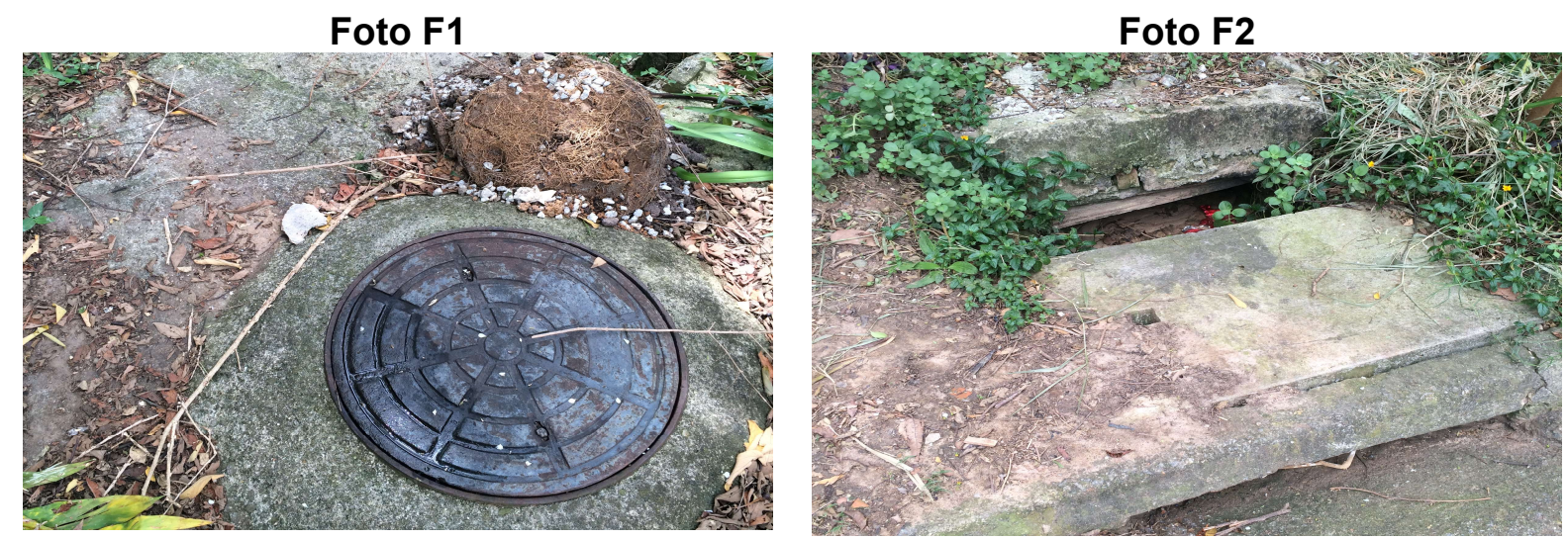

Ilustração 152 - Córrego canalizado sob a Praça Evandro Valério na bacia do córrego Jaguaré. Fonte: Fotos da autora.

A praça abriga ainda uma nascente que possui contribuição do aquífero subterrâneo, uma vez que se mantém na paisagem com vazão significativa mesmo nos períodos de estiagem (Vazão volumétrica em 10/08/2015 =0,33L/s), que é 
usada intensamente pela população do entorno para captação de água para usos não potáveis. Em um período de 30 minutos de observação da nascente em um sábado, pode-se registrar 8 usuários visitando a nascente para coleta de água (Captação de água através de galões) e para lavagem de automóveis. A área de afloramento natural da nascente (Foto $G$ ) foi tratada pela prefeitura através da construção de uma vala com brita, segundo relato de um morador da bacia, que direcionou as água até um ponto de captação, onde a população capta as águas da nascente (Foto $\mathrm{H} 2$ ).

A praça recepciona o fundo de alguns lotes com soleira negativa (Ponto baixo do lote voltado para o fundo do mesmo) o que resultava no lançamento dos esgotos destes lotes na praça; A mobilização da população que faz uso do local e principalmente das águas da nascente, resultou na execução de uma caixa coletora destes esgotos (Foto H1) que direciona indevidamente os efluentes coletados para uma boca de lobo próxima da nascente, mesmo havendo um poço de inspeção da rede coletora de esgotos há poucos metros da boca de lobo (Foto H3). O local demanda intervenções para consolidação do sistema de esgotamento sanitário a fim de garantir a preservação das águas da nascente, uma vez que a demanda por suas águas pela população é elevada e a inexistência do manejo adequado pode representar grande risco a saúde da mesma. As fotos dos pontos são mostradas na llustração 153 a seguir.
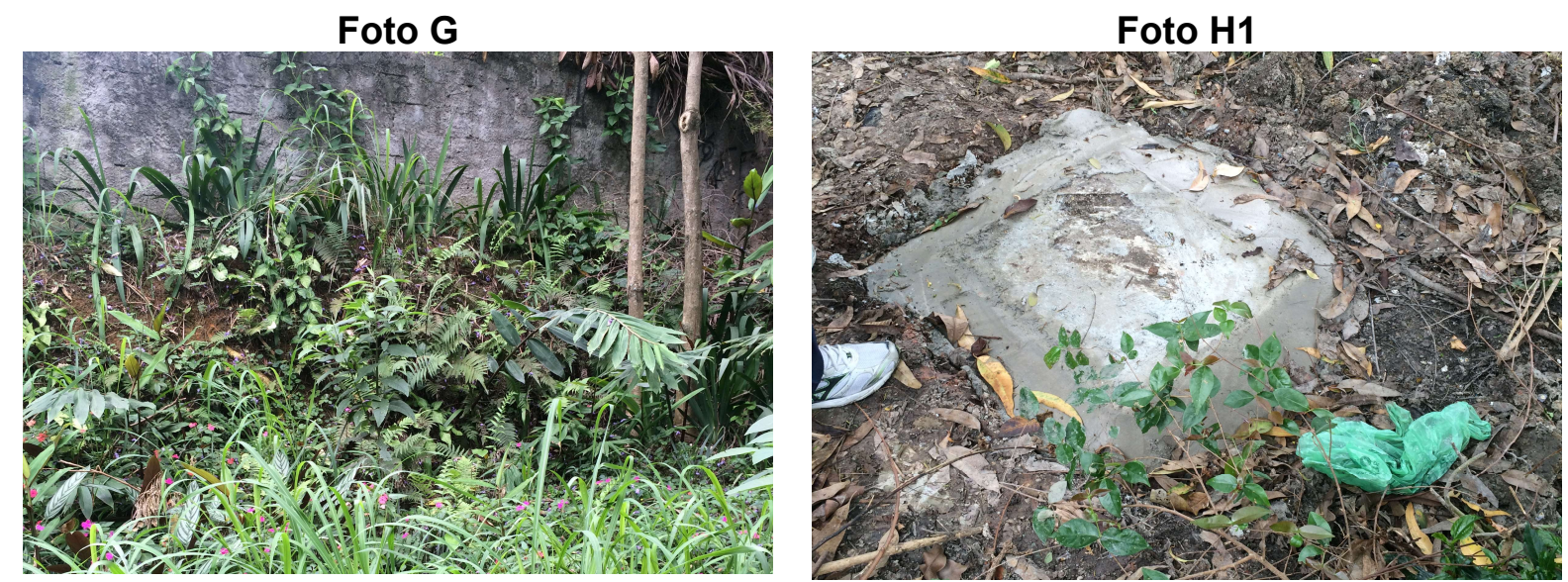

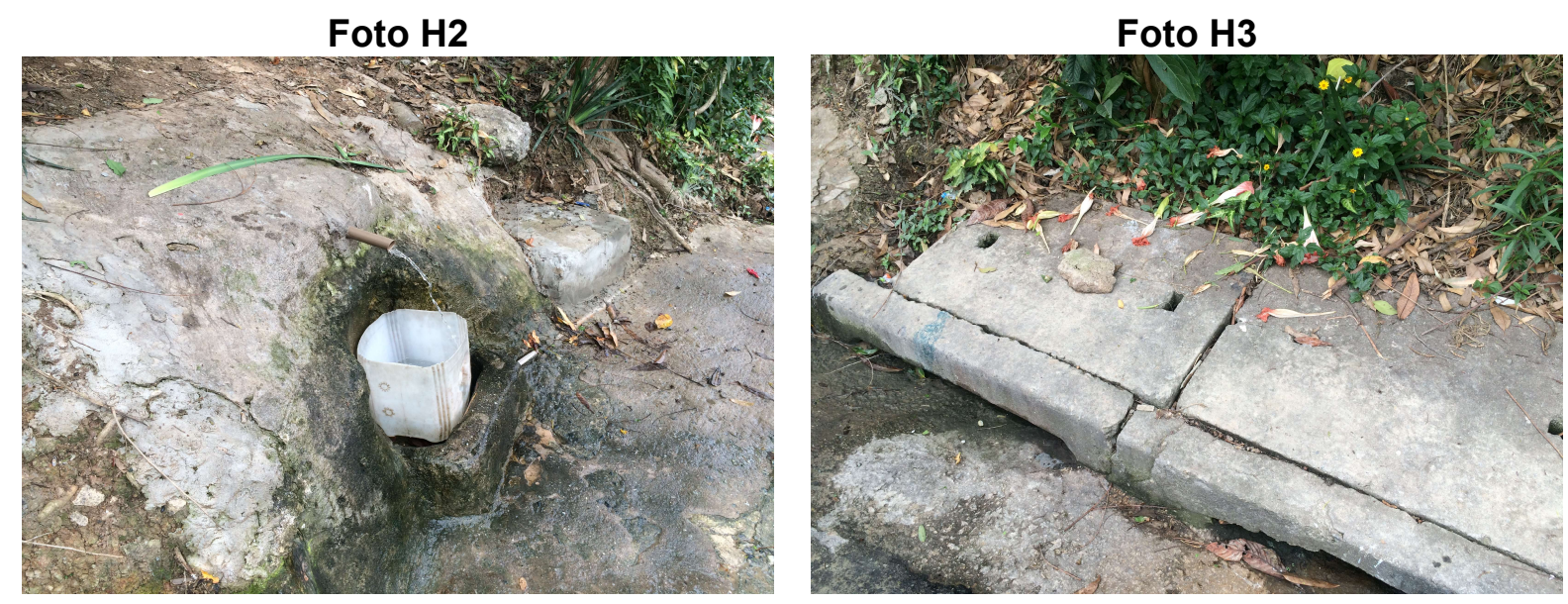

Ilustração 153 - Nascente na Praça Evandro Valério na bacia do córrego Jaguaré. Fonte: Fotos da autora.

O córrego das praças, apelidado neste estudo de córrego da nascente, recebe parte do escoamento superficial do condomínio Vila de São Francisco, complexo de prédios residenciais e comerciais de alto padrão. O condomínio foi construído antes da lei municipal 13.276 de 2002 que torna obrigatório a implantação de reservatórios de detenção de águas pluviais em empreendimentos com área construída maior que $500 \mathrm{~m}^{2}$, portanto não possui nenhuma medida para auxiliar no controle da vazão de pico. Se construído hoje, o empreendimento que tem cerca de $260 \mathrm{mil} \mathrm{m}^{2}$ demandaria um volume de detenção de $1404 \mathrm{~m}^{3}$ (Considerando $60 \%$ de área construída). Da área total do condomínio, a parcela de $75 \mathrm{mil} \mathrm{m}^{2}$ contribui para o córrego da nascente, computando um volume de detenção necessário de $405 \mathrm{~m}^{3}$. A retenção deste volume aliviaria o sistema de drenagem nos períodos de chuva intensa reduzindo o risco de alagamentos na região, desta forma neste estudo propõe-se a criação de áreas para retenção deste volume nas praças Evandro Valério e Padre Campos, conforme mostrado na llustração 154 a seguir. 


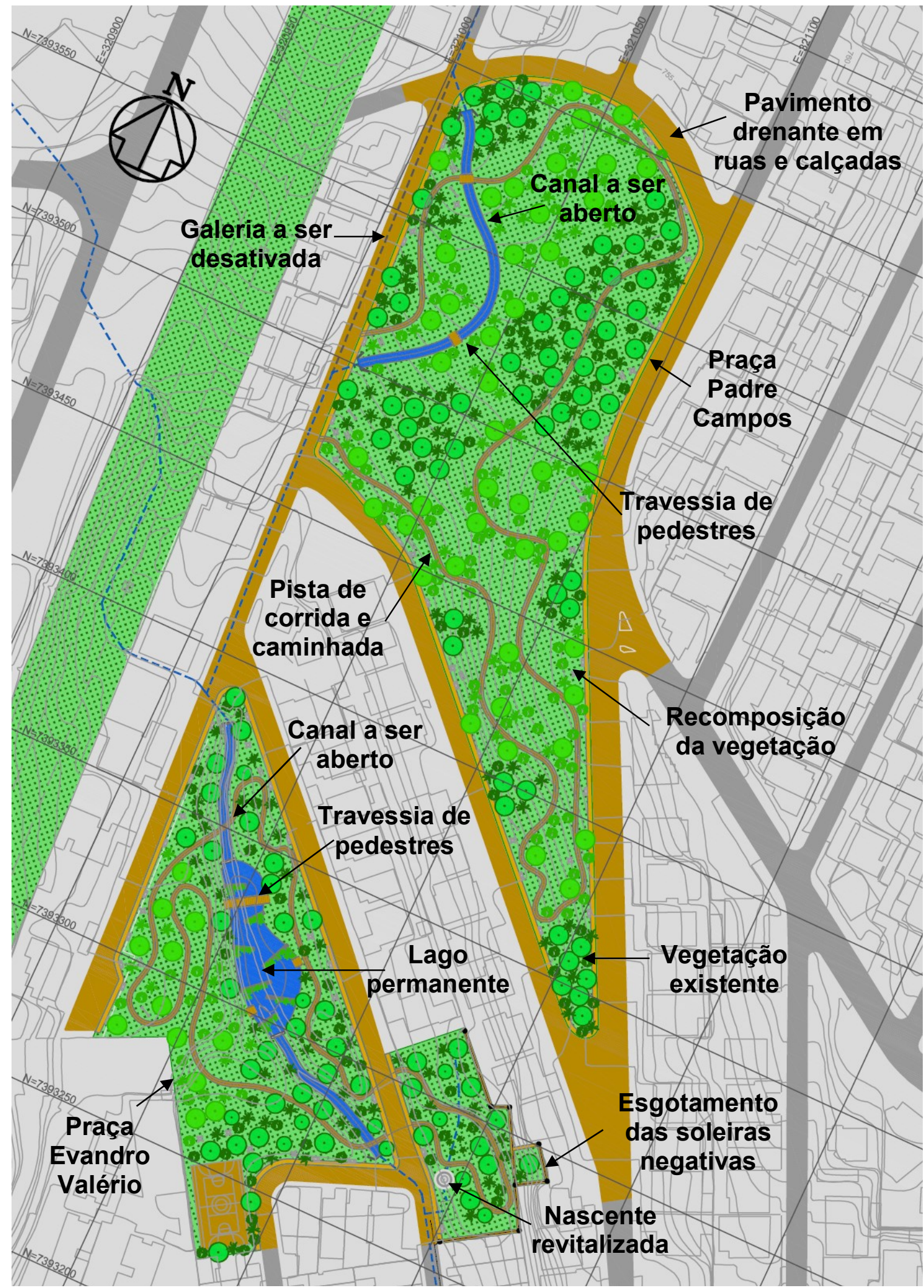

Ilustração 154 - Proposta de revitalização do córrego da nascente - Planta de implantação. Fonte: Elaborado pela autora. 
A Ilustração 155 mostra imagens referência das estruturas previstas na proposta de revitalização do canal da nascente e das áreas das praças. Foi proposta a implantação de um lago permanente com vegetação para tratamento das águas e barreiras de gabião para propiciar a vida aquática através da criação de abrigos; Implantação de decks de observação e travessias de pedestres; Abertura do canal; e Revitalização da nascente, propiciando o uso adequado de suas águas.
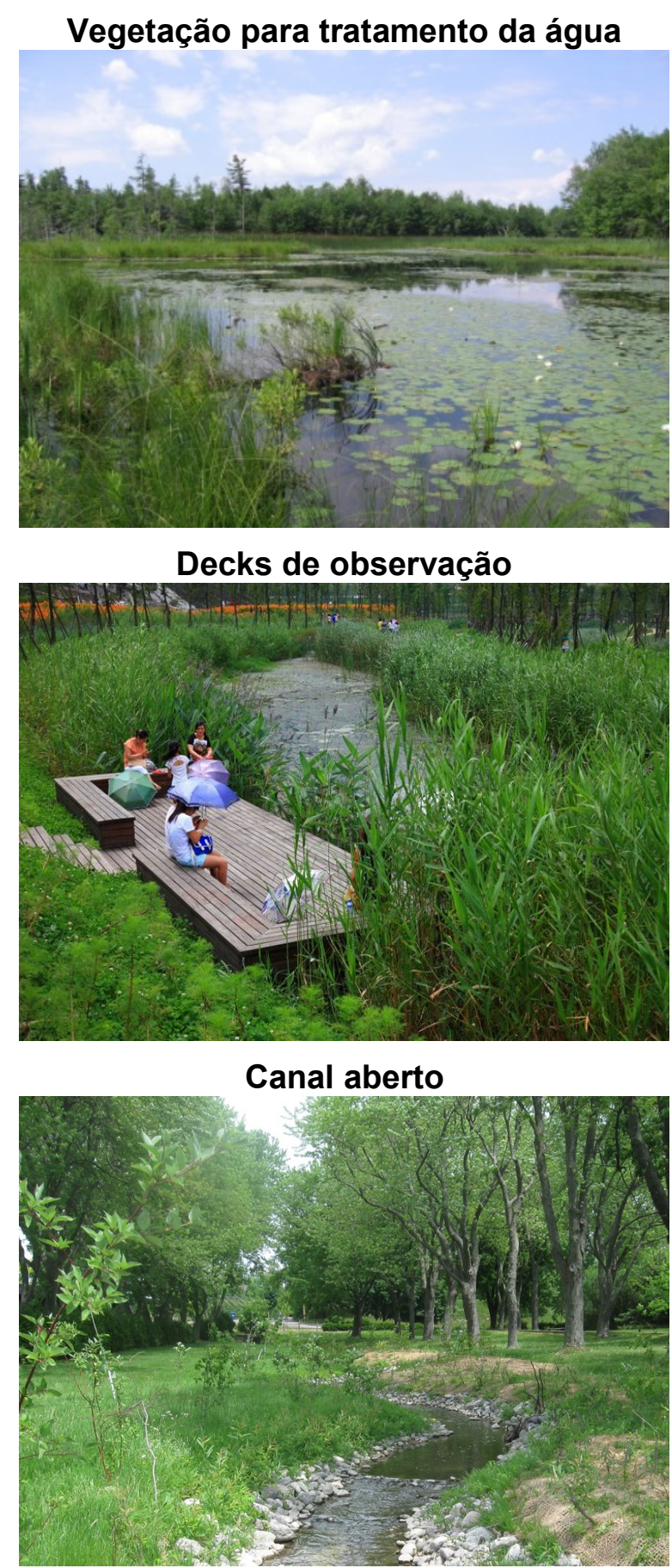

Barreiras para a flora e a fauna
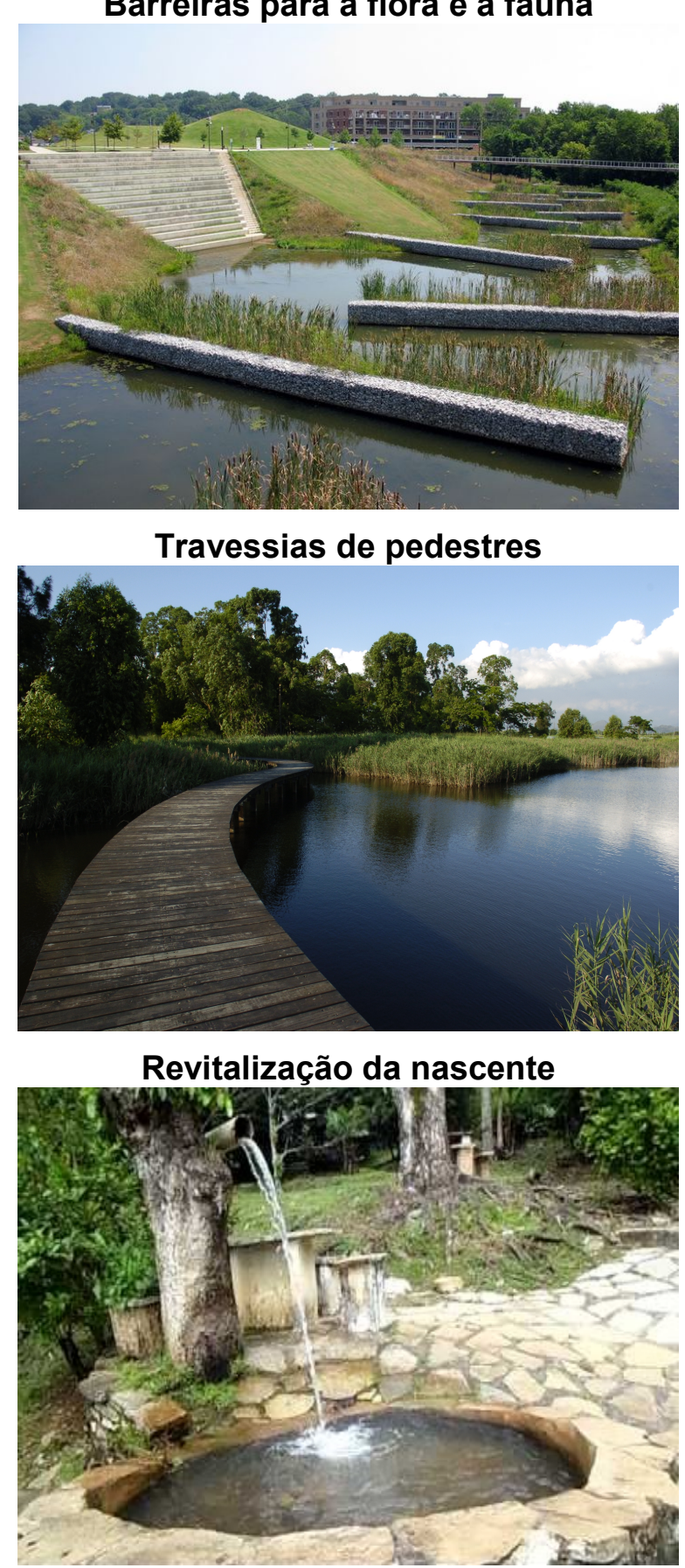

Ilustração 155 - Referências das estruturas previstas na proposta. Fonte: Maine/ Hargreaves/ Ramsar/ Itishk/ Otanabee. 
Apesar da presença de vegetação nas praças, há trechos que demandam manejo, portanto incluí-se na proposta a recomposição da vegetação em determinados trechos (Representados na llustração 154 pela vegetação em tom de verde mais claro). Para tanto devem ser selecionadas espécies adequadas, como por exemplo, aquelas que promovam o controle da erosão e preservem a qualidade das águas. O manual de arborização de áreas urbanas da SVMA (Barbedo et al., 2011) identifica 253 espécies nativas do município de São Paulo, extraídas da portaria 61/SVMA/2011, que podem ser utilizadas em programas de recomposição vegetal em áreas urbanas; são espécies adequadas ao manejo urbano pois apresentam características anatômicas e fisiológicas que propiciam a convivência harmoniosa com os elementos urbanos.

Das 253 espécies, 49 são espécies higrófitas, ou seja, adaptadas a solos e ambientes com muita umidade e zonas alagadas, ideais para propostas de revitalização de áreas de várzea no município de São Paulo. A lista apresentada na Tabela 24 mostra as 49 espécies higrófitas e suas principais características, como os nomes científico e popular das espécies; a permanência das folhas ao longo do ano (Decídua: perde as folhas em um período; Semidecídua: perde parcialmente as folhas; Perenifólia: mantém sua folhagem o ano todo); cor das flores e época da floração; atratividade dos frutos e época da frutificação; e Porte (PP: pequeno porte; MP: médio porte; GP: grande porte).

O sistema de esgotamento sanitário encontra-se consolidado na bacia, ou seja, existem redes coletoras em todas as ruas e todas elas são recepcionadas pelo coletor tronco existente na Av. Escola Politécnica, no entanto, para consolidar o sistema é necessário averiguar se todas as residências da bacia encontram-se ligadas à rede pública e se não há ligações cruzadas entre o sistema coletor de esgotos e o sistema de drenagem. 
Tabela 24 - Espécies higrófitas nativas do município de São Paulo. Fonte: Elaborado pela autora a partir de Barbedo et al., 2011.

\begin{tabular}{|c|c|c|c|c|c|c|c|c|}
\hline Nome científico & Nome popular & Folhas & Flores & Época & Frutificação & Época & Porte & Fisio. \\
\hline Allophilus edulis & Chal-chal & Semidecidua & & & Atrai Avifauna & & PP & $\mathrm{SH}$ \\
\hline $\begin{array}{l}\text { Campomanesia } \\
\text { guazumifolia }\end{array}$ & $\begin{array}{l}\text { Sete } \\
\text { capotes }\end{array}$ & Decídua & Brancas e grandes & out-nov & Atrai Fauna & mar-mai & PP & $\mathrm{H}$ \\
\hline Campomanesia & Cambuci & Semidecidua & Brancas e grandes & ago-nov & Alim. Humana & jan-fev & PP & $\mathrm{SH}$ \\
\hline Casearia sylvestirs & Guaçatonga & Perenifólia & & & Atrai Avifauna & set-nov & PP & $\mathrm{SH}$ \\
\hline Erythrina crista-galli & Crista de galo & Decídua & $\begin{array}{l}\text { Róseas ou vermelhas } \\
\text { / Atrai Avifauna }\end{array}$ & set-dez & & & PP & $\mathrm{SH}$ \\
\hline Erytrina speciosa & Eritrina candelabro & Decídua & $\begin{array}{l}\text { Róseas ou vermelhas } \\
\text { / Atrai Avifauna }\end{array}$ & jun-set & & & PP & $\mathrm{SH}$ \\
\hline $\begin{array}{l}\text { Erythroxylum } \\
\text { deciduum }\end{array}$ & Cocão & Decídua & & & Atrai Fauna & out-jan & PP & $\mathrm{SH}$ \\
\hline Eugenia Involucrata & Cereja do Rio Grande & Perenifólia & & & Alim. Humana & out-dez & PP & $\mathrm{SH}$ \\
\hline Eugenia pyriformis & Uvaia & Semidecidua & & & Alim. Humana & set-jan & PP & $\mathrm{SH}$ \\
\hline Eugenia uniflora & Pitangueira & Semidecidua & & & Alim. Humana & out-jan & PP & $\mathrm{SH}$ \\
\hline Garcinia gardneriana & Bacupari & Perenifólia & & & Alim. Humana & dez-fev & PP & $\mathrm{SH}$ \\
\hline Ilexparaguariensis & Erva Mate & Perenifólia & & & Atrai Avifauna & jan-mar & PP & $\mathrm{SH}$ \\
\hline Myrcia rostrata & Guamirim da folha fina & Semidecidua & & & Atrai Fauna & jan-mar & PP & $\mathrm{SH}$ \\
\hline Posoqueria & Baga de macaco & Perenifólia & & & Atrai Fauna & jun-ago & PP & $\mathrm{SH}$ \\
\hline Psidium cattelanum & Araça & Perenifólia & & & Alim. Humana & set-mar & PP & $\mathrm{SH}$ \\
\hline Psidium guajava & Goiabeira & Semidecidua & Brancas & set-nov & Alim. Humana & dez-mar & PP & $\mathrm{SH}$ \\
\hline Andira fraxinifolia & Angelim doce & Decídua & Rosadas & nov-dez & Atrai Fauna & fev-abr & MP & $\mathrm{SH}$ \\
\hline Cecropia glaziovi & Embaúba vermelha & Perenifólia & & & Atrai Fauna & nov-fev & MP & $\mathrm{SH}$ \\
\hline Cecropia & Emabaúba & Perenifólia & & & Atrai Fauna & jun & MP & $\mathrm{SH}$ \\
\hline Cordia ecalyculata & Café de bugre & Perenifólia & & & Atrai Fauna & jan-mar & MP & SU \\
\hline Cordia superba & Babosa branca & Semidecidua & Brancas & out-fev & Atrai Fauna & set-nov & MP & $\mathrm{SH}$ \\
\hline Croton urucurana & Sangra d'água & Semidecidua & Meliferas & dez-jun & & & MP & $\mathrm{SH}$ \\
\hline Eugenia brasiliensis & Grumixama & Perenifólia & & & Alim. Humana & nov-dez & MP & $\mathrm{SH}$ \\
\hline Genipa americana & Jenipapo & Semidecidua & & & Alim. Humana & nov-dez & MP & $\mathrm{SH}$ \\
\hline Inga vera & Ingá do brejo & Semidecidua & Branas polistemones & ago-nov & Atrai Fauna & dez-fev & MP & $\mathrm{SH}$ \\
\hline Myrciaria floribunda & Cambuí & Semidecidua & & & Atrai Fauna & dez-jan & MP & $\mathrm{SH}$ \\
\hline Plinia edulis & Cambucá & Perenifólia & & & Alim. Humana & dez-jan & MP & $\mathrm{SH}$ \\
\hline Ropanea ferruginea & Capororoca & Perenifólia & & & Atrai Avifauna & out-dez & MP & $\mathrm{SH}$ \\
\hline Tapirira guianensis & Peito de pombo & Perenifólia & & & Atrai Fauna & jan-mar & MP & SU \\
\hline $\begin{array}{l}\text { Campomanesia } \\
\text { xanthocarpa }\end{array}$ & Guabiroba & Decídua & Brancas & set-nov & Alim. Humana & nov-dez & GP & $\mathrm{SH}$ \\
\hline Cariniana estrlensis & Jequitibá branco & Semidecidua & & & Atrai Fauna & jun-set & GP & $\mathrm{SH}$ \\
\hline Cedrela fissilis & Cedro & Decídua & & & & & GP & SU \\
\hline $\begin{array}{l}\text { Citharexylum } \\
\text { myrianthum }\end{array}$ & Pau viola & Decídua & $\begin{array}{l}\text { Cacho de flores } \\
\text { brancas pequenas }\end{array}$ & out-dez & Atrai Fauna & jan-mar & GP & $\mathrm{SH}$ \\
\hline $\begin{array}{l}\text { Cryptocarya } \\
\text { aschersoniana }\end{array}$ & Canela batalha & Perenifólia & & & Atrai Fauna & fev-abr & GP & $\mathrm{SH}$ \\
\hline Cupania vernalis & Camboatá & Semidecidua & & & Atrai Fauna & set-nov & GP & $\mathrm{SH}$ \\
\hline Erythrina falcata & Eritrina falcata & Decídua & $\begin{array}{l}\text { Vermelho tijolo / } \\
\text { Atrai Avifauna }\end{array}$ & jun-nov & & & GP & $\mathrm{SH}$ \\
\hline Euplassa cantareirae & Carvalho da serra & Perenifólia & Meliferas & nov-dez & Atrai Fauna & fev-mar & GP & $\mathrm{SH}$ \\
\hline Ficus insipida & Figueira do brejo & Semidecidua & & & Atrai Fauna & jan-fev & GP & $\mathrm{SH}$ \\
\hline Guarea guidonia & Marinheiro & Perenifólia & & & Atrai Fauna & nov-dez & GP & $\mathrm{SH}$ \\
\hline $\begin{array}{l}\text { Handroanthus } \\
\text { umbellatus }\end{array}$ & Ipê amarelo do brejo & Decídua & Amarelas & ago-out & & & GP & $\mathrm{H}$ \\
\hline Inga sessilis & Ingá ferradura & Semidecidua & & & Alim. Humana & ago-jan & GP & $\mathrm{SH}$ \\
\hline Luehea divaricata & Açoita cavalo & Decídua & Rosadas & dez-fev & & & GP & $\mathrm{SH}$ \\
\hline Magnolia ovata & Pinha do brejo & Perenifólia & Brancas & out-dez & Atrai Fauna & ago-set & GP & $\mathrm{SH}$ \\
\hline Phytolacca dioica & Ceboleiro & Decídua & & & Atrai Fauna & jan-fev & GP & $\mathrm{SH}$ \\
\hline $\begin{array}{l}\text { Platymiscium } \\
\text { floribundum }\end{array}$ & Sacambu & Semidecidua & Amarelas & mar-abr & & & GP & $\mathrm{SH}$ \\
\hline Pouteria calmito & Abiu & Perenifólia & & & Alim. Humana & mar-abr & GP & $\mathrm{SH}$ \\
\hline $\begin{array}{l}\text { Pseudobombax } \\
\text { grandiforum }\end{array}$ & Embiruçu & Decídua & Brancas & jun-set & Atrai Avifauna & set-out & GP & SU \\
\hline $\begin{array}{l}\text { Schizolobium } \\
\text { parahyba }\end{array}$ & Guapuruvu & Decídua & Amarelas & ago-out & & & GP & $\mathrm{SH}$ \\
\hline
\end{tabular}




\subsubsection{Recuperação do córrego da Av. Corifeu de Azevedo Marques}

Com base no que foi visto na revisão bibliográfica, propõe-se neste estudo que o processo de recuperação de corpos d'água deve atingir as seguintes etapas:

- Controle de cargas poluentes na bacia (Pontuais e difusas);

- Monitoramento da evolução da qualidade da água através do uso de indicadores físico-químicos;

- Implantação de programa de educação ambiental na bacia hidrográfica;

- Implantação de programa para pagamento por serviços ambientais (PSA) na bacia hidrográfica.

O córrego sob a Av. Corifeu de Azevedo Marques, afluente do córrego Jaguaré, e seus afluentes sob as ruas do entorno da avenida apresentam baixo potencial para um processo de revitalização que incluísse a abertura das galerias subterrâneas, uma vez que a avenida possui trafego intenso e sua implantação tomou totalmente a várzea do canal, havendo apenas um pequeno canteiro central dividindo os dois sentidos da via. A abertura do corpo d'água principal da Avenida Corifeu de Azevedo Marques demandaria a desconstrução completa da avenida, que é um importante eixo de circulação, que coneta o Butantã ao município de Osasco e mais a frente ao Rodoanel Mario Covas, havendo hoje duas faixas de rolamento para carros, uma fixa de ônibus e uma faixa para bicicleta em cada um dos sentidos da via. A situação atual da via é de saturação, mesmo havendo diferentes modais nela, portanto a reabertura do corpo d'água tornaria ainda mais caótica a situação do tráfego na região. Além disso, os afluentes do corpo d'água estão sob ruas estreitas e sua abertura impediria o tráfego de veículos completamente nestas vias. A localização dos corpos d'água e a situação das vias são mostradas nas Ilustração 156 e llustração 157 respectivamente.

Córregos nessa situação demandam, pelo menos em curto prazo, soluções mais conservadoras, como é o caso da recuperação. Para a recuperação do canal é necessário controlar as cargas poluidoras existentes que afluem para o mesmo. 0 cadastro da rede coletora existente da concessionária revela que a bacia em 
questão não encontra-se completamente esgotada para o coletor tronco existente, ou seja, há trechos que contribuem diretamente para o sistema de drenagem, resultando em dois lançamentos, como mostrado na llustração 158 .

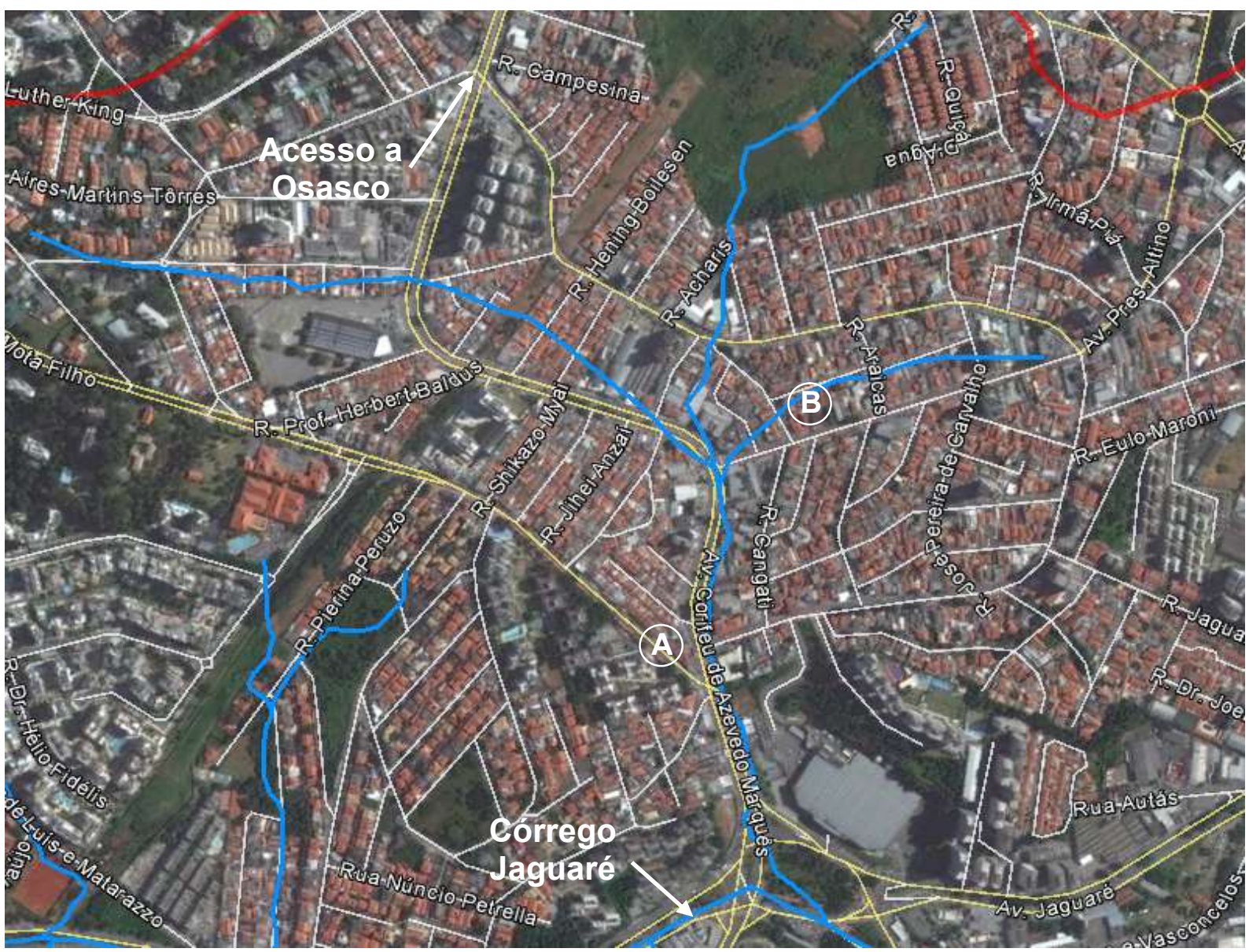

Ilustração 156 - Localização do córrego canalizado sob a Avenida Corifeu de Azevedo Marques. Fonte: Elaborado pela autora a partir de Google Earth Pro.

Foto A

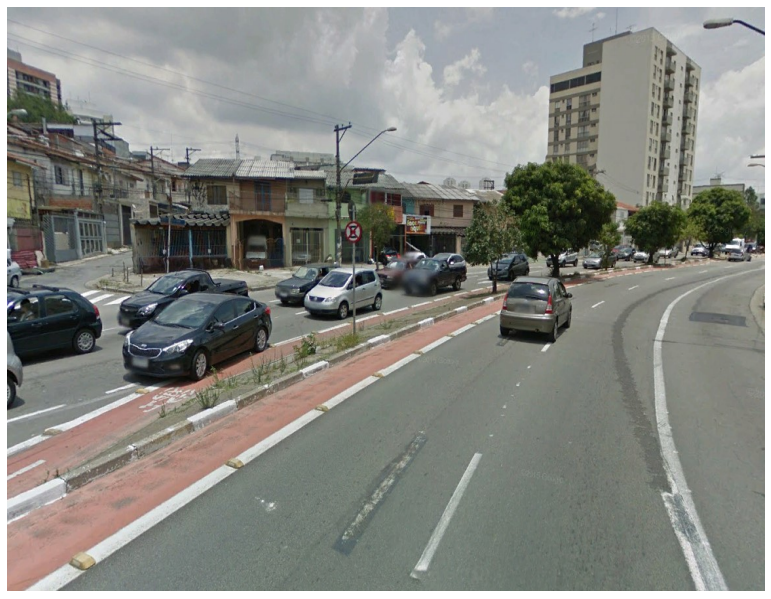

Foto B

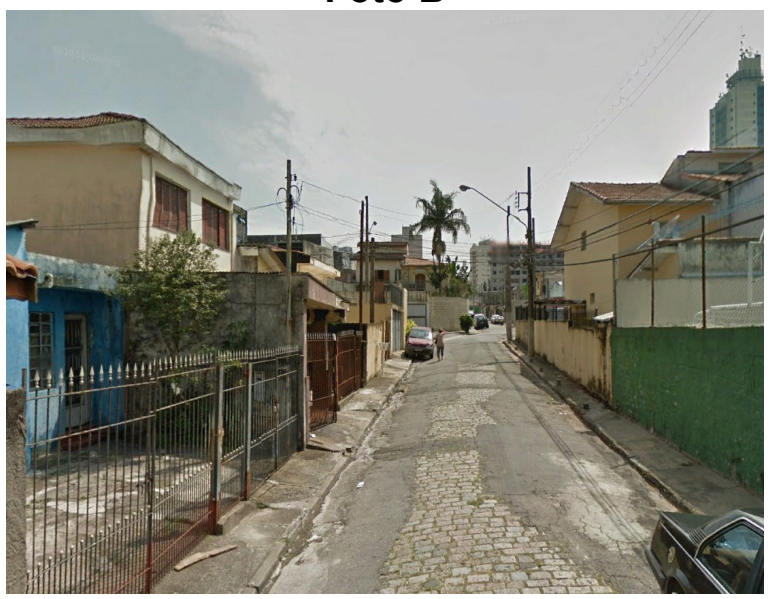

Ilustração 157 - Córrego canalizado sob a Avenida Corifeu de Azevedo Marques na bacia do córrego Jaguaré. Fonte: Fotos da autora. 


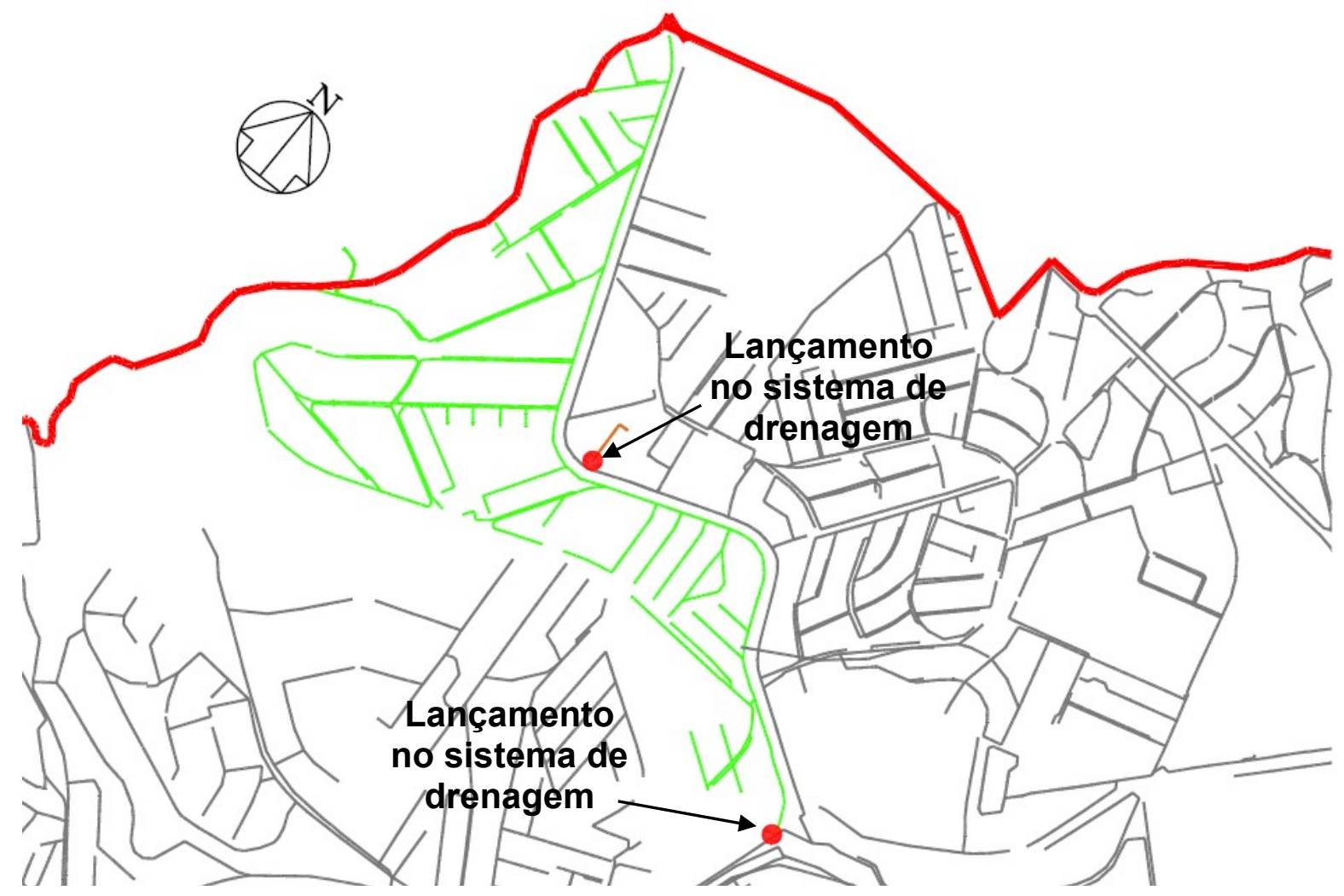

Ilustração 158 - Sistema coletor da bacia do córrego sob a Av. Corifel de Azevedo Marques. Fonte: Elaborado pela autora a partir do cadastro SABESP.

A resolução para estes dois pontos de lançamento é simples uma vez que ambos têm condições topográficas de serem recepcionados pelas redes já implantadas, bastante apenas a construção de dois trechos de rede que realizem tais ligações. No entanto para consolidação completa do sistema de esgotamento sanitário é necessário medidas adicionais que garantam o isolamento total entre o sistema de esgotamento sanitário e o de drenagem urbana. Seguindo as técnicas utilizadas no programa "Córrego limpo", as redes de esgoto devem passar pelas seguintes etapas:

- Varredura completa das redes com o auxílio de equipamento guiado remotamente para identificação de tubulações rompidas e posterior execução de reparos;

- Aplicação de corante nas redes trecho a trecho para rastreamento de ligações cruzadas e posterior desativação das ligações cruzadas;

- Na presença de áreas com ocupação irregular que não possuam infraestrutura sanitária, proceder com a regularização e implantação da infraestrutura necessária ou desapropriação. 
O sistema de pagamento por serviços ambientais prestados pela população da bacia no caso de bacias em recuperação deve ser pautado principalmente em ações de controle da carga poluidora como os destacados a seguir:

- Incentivos fiscais aos usuários que procederem com o cadastro de novas ligações de esgoto junto à concessionária;

- Sistema de recompensa para denuncias de lançamentos irregulares de cargas poluidoras no sistema de drenagem e nos corpos d'água da bacia;

- Incentivos fiscais para a adoção de técnicas de infraestrutura verde na escala do lote para controle de cargas poluentes.

O sistema de monitoramento de qualidade da água neste caso pode ser mais simplificado, pautando se apenas em variáveis chaves, como por exemplo, DBO, $\mathrm{DQO}, \mathrm{OD}$, turbidez, condutividade e $\mathrm{pH}$. Além disso, a frequência do monitoramento pode ser menos frequente, como por exemplo, o monitoramento mensal.

O programa de educação ambiental na bacia deve ser pautado principalmente no controle de cargas poluentes e na importância do cadastramento de novas ligações domiciliares junto à concessionária que opera o sistema esgotamento sanitário na bacia. 


\subsubsection{Repensando as várzeas do córrego Jaguaré}

O córrego Jaguaré ao longo de sua extensão apresenta distintos tratamentos em suas várzeas, demandando, portanto, estudos específicos para cada trecho a fim de promover a recuperação das mesmas, como mostram a llustração 159 e a Ilustração 160 que apresentam respectivamente a planta com os diferentes trechos (Verde: canal aberto com diferentes tratamentos e ocupação das margens; Vermelho: canal aberto com as margens ocupadas pela avenida escola politécnica; e Laranja: canal fechado em galeria subterrânea sob canteiro central e margens ocupadas pela avenida escola politécnica) e fotos ilustrativas dos mesmos.

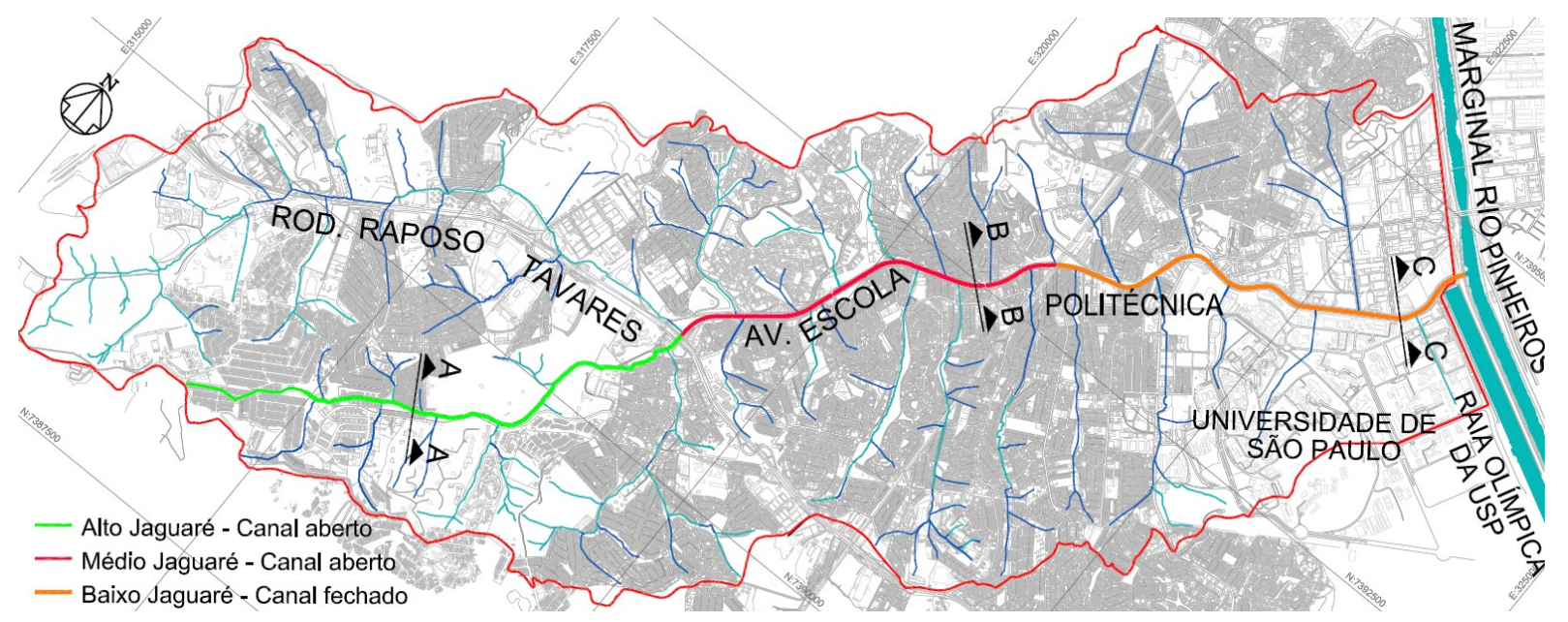

Ilustração 159 - Localização dos trechos do córrego Jaguaré e dos cortes dos cenários existentes e propostos. Fonte: Elaborado pela autora.
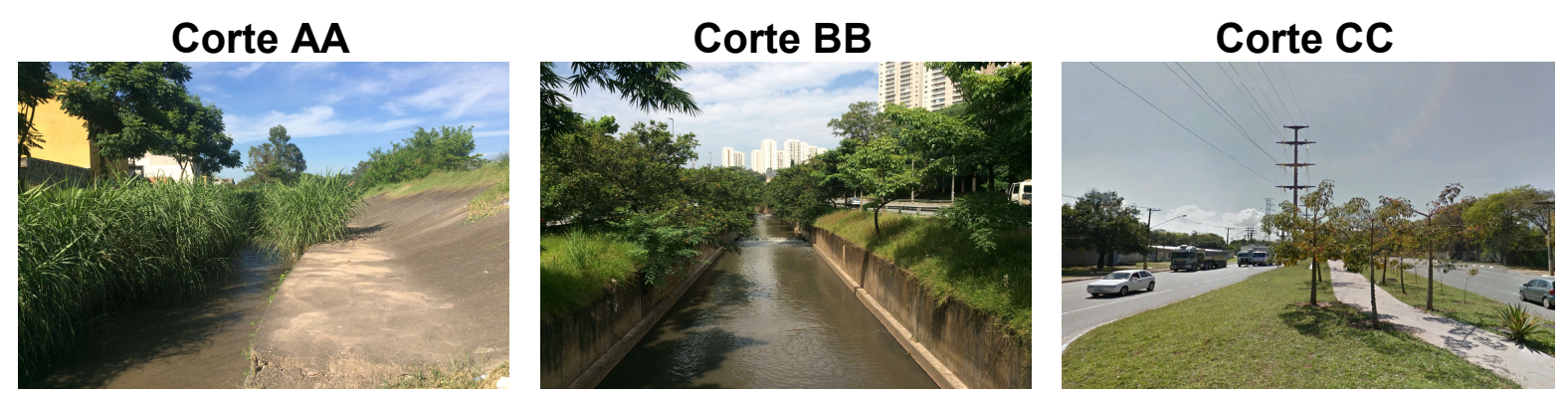

Ilustração 160 - Trechos do córrego Jaguaré e dos cortes dos cenários existentes e propostos. Fonte: Elaborado pela autora.

Foi realizado, portanto o estudo de 6 seções do canal, ao longos dos três trechos, a fim de propor uma nova concepção de uso do corpo d'água e de suas margens, com base nas técnicas e conceitos vistos na revisão bibliográfica. A llustração 161 a seguir mostra a localização das seções estudadas que são mostradas em seguida. 


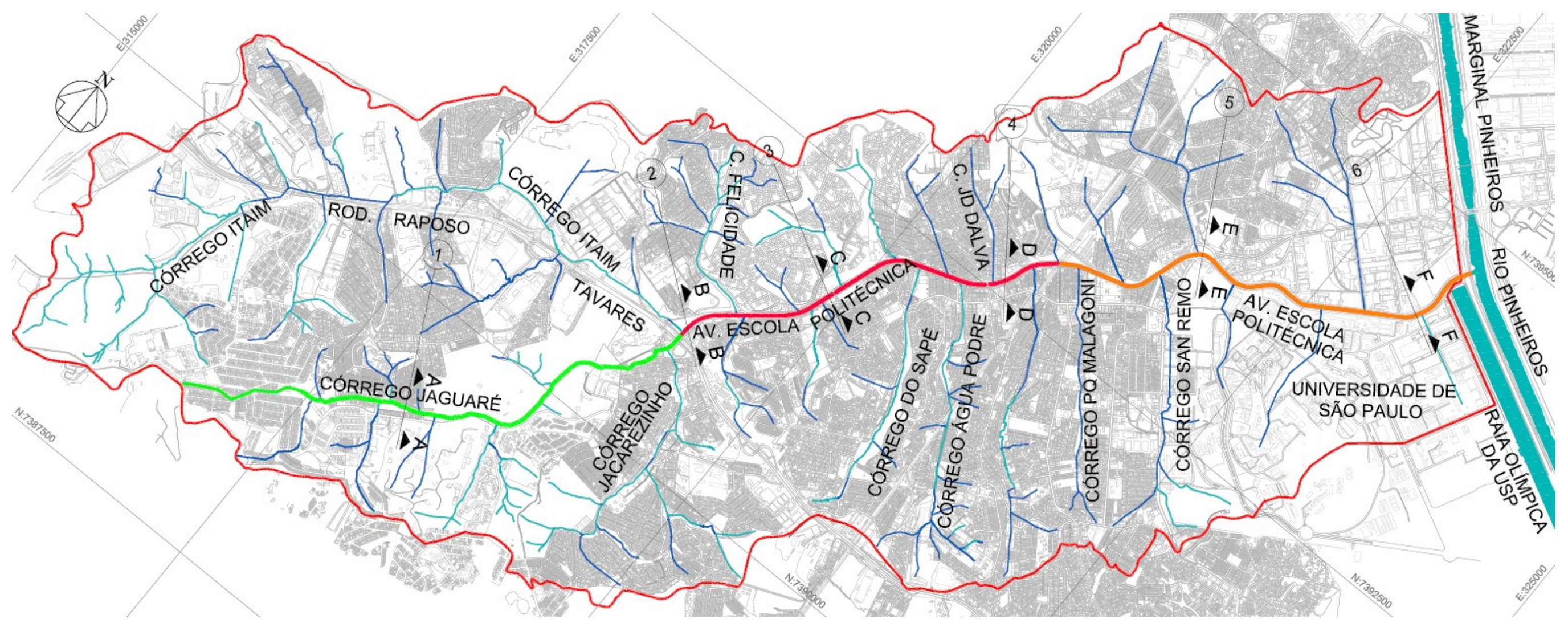

Ilustração 161 - Seções estudadas na bacia do Jaguaré. Fonte: Elaborado pela autora. 


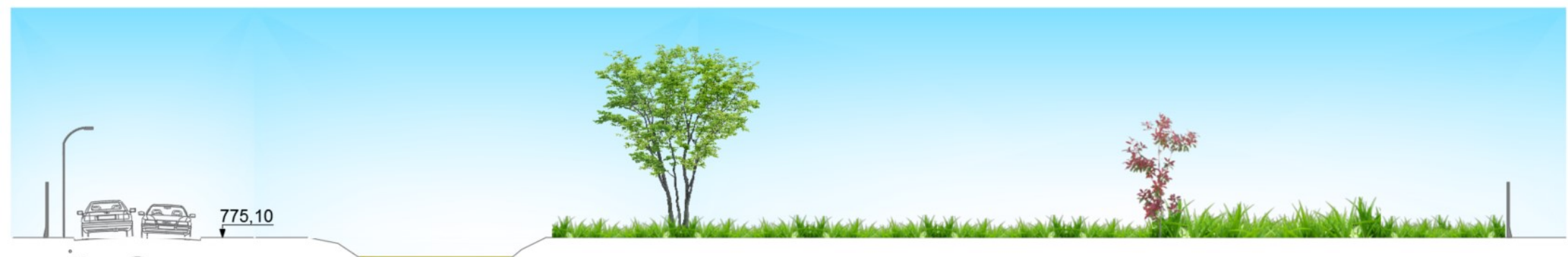

\section{NASCENTE DO CÓRREGO JAGUARÉ - ATUAL}

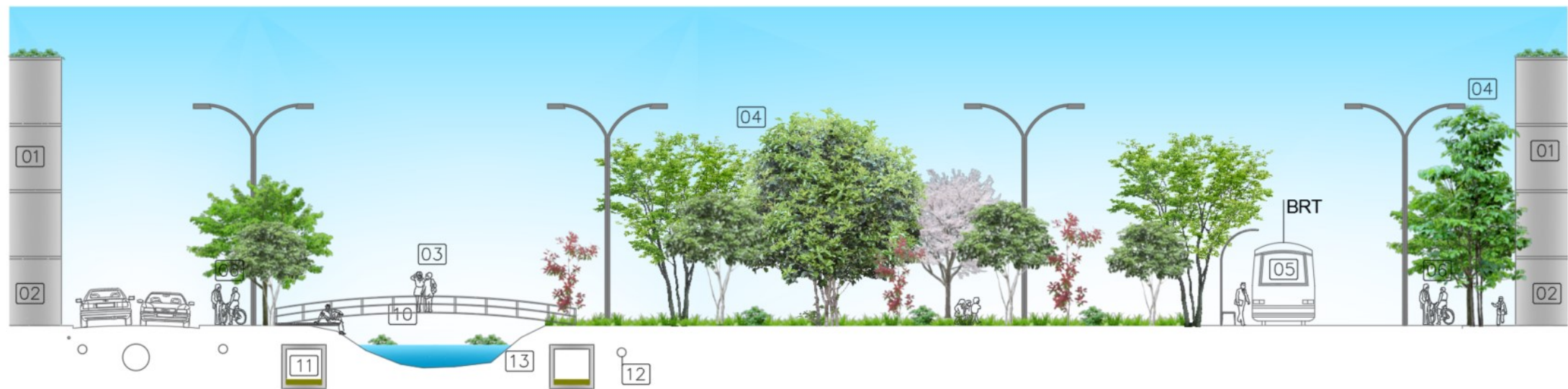

\section{NASCENTE DO CÓRREGO JAGUARÉ - PROPOSTO}

\section{LEGENDA}

\section{USO MÚLTIPLO}

02 TÉRREO VIVO (COMÉRCIO DE RUA)

03 PONTE PARA TRAVESSIA DE PEDESTRES

04 PLANTIOO DE ESPÉCIES ADEQUADAS

05 BRT

06 CICLOVIA

07 REDUÇ̃̃o DO NÚMERO DE FAIXAS DE RODAGEM
08 CANAL EM TERRAÇO
09 ABERTURA DE GALERIAS SUBTERRÂNEAS - ÁGUAS PLUVIAIS CONTROLADAS
10 USO DE ESPÉCIES VEGETAIS FITO REMEDIADORAS PARA TRATAMENTO DAS ÁGUAS
11 GALERIAS AUXILIARES - ÁGUAS PLUVIIAIS NÃO CONTROLADAS / ÁGUAS DA PRIMEIRA CHUVA
12 IMPLANTAÇÃO DE INFRAESTRUTURA SANITÁRIA
13 REGULARIZAÇÃO DE MARGENS E FUNDO COM TÉCNICAS SUSTENTÁVEIS
14 ILUMINAÇÃO ADEQUADA PARA USO NOTURNO DAS ESTRUTURAS DE LAZER

Ilustração 162 - Corte AA - Repensando a várzea do Jaguaré. Fonte: Elaborado pela autora. 


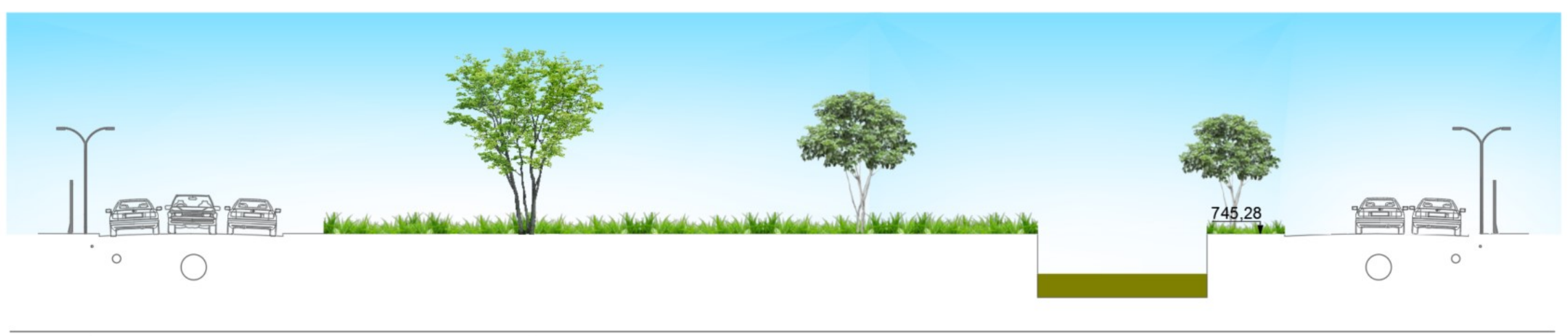

CONFLUÊNCIA ENTRE O CÓRREGO ITAIM E O JAGUARÉ - ATUAL

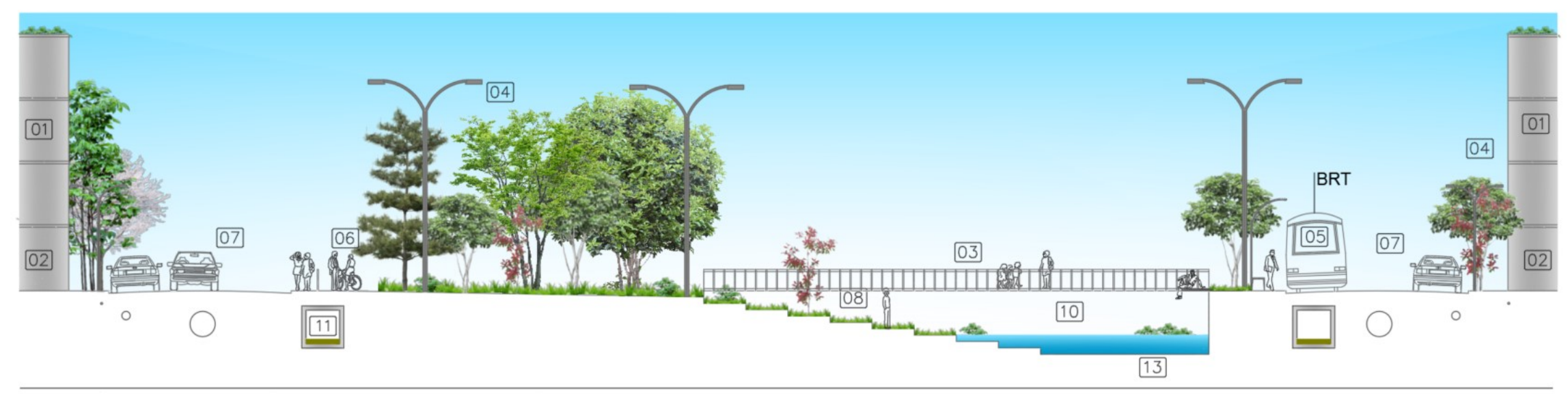

CONFLUÊNCIA ENTRE O CÓRREGO ITAIM E O JAGUARÉ - PROPOSTO

\section{LEGENDA}

01 USO MÚLTIPLO

02 TÉRREO VIVO (COMÉRCIO DE RUA)

03 PONTE PARA TRAVESSIA DE PEDESTRES

04 PLANTIO DE ESPÉCIES ADEQUADAS

05 BRT

06 CICLOVIA

07 REDUÇÃO DO NÚMERO DE FAIXAS DE RODAGEM
08 CANAL EM TERRAÇO

09 ABERTURA DE GALERIAS SUBTERRÂNEAS - ÁGUAS PLUVIAIS CONTROLADAS

10 USO DE ESPÉCIES VEGETAIS FITO REMEDIADORAS PARA TRATAMENTO DAS ÁGUAS

11 GALERIAS AUXILIARES - ÁGUAS PLUVIAIS NÃO CONTROLADAS / ÁGUAS DA PRIMEIRA CHUVA

12 IMPLANTAÇ̃̃o DE INFRAESTRUTURA SANITÁRIA

13 REGULARIZAÇÃO DE MARGENS E FUNDO COM TÉCNICAS SUSTENTÁVEIS

14 ILUMINAÇÃO ADEQUADA PARA USO NOTURNO DAS ESTRUTURAS DE LAZER

Ilustração 163 - Corte BB - Repensando a várzea do Jaguaré. Fonte: Elaborado pela autora. 


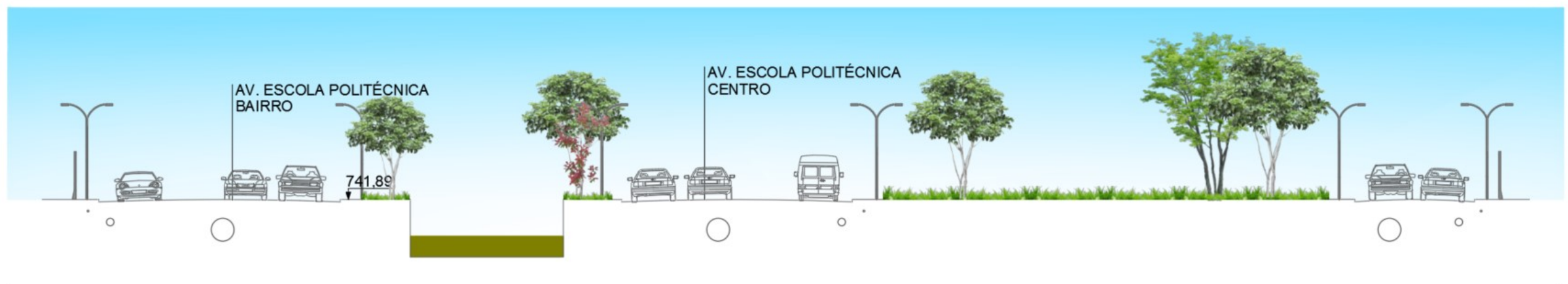

\section{CÓRREGO JAGUARÉ - ATUAL}

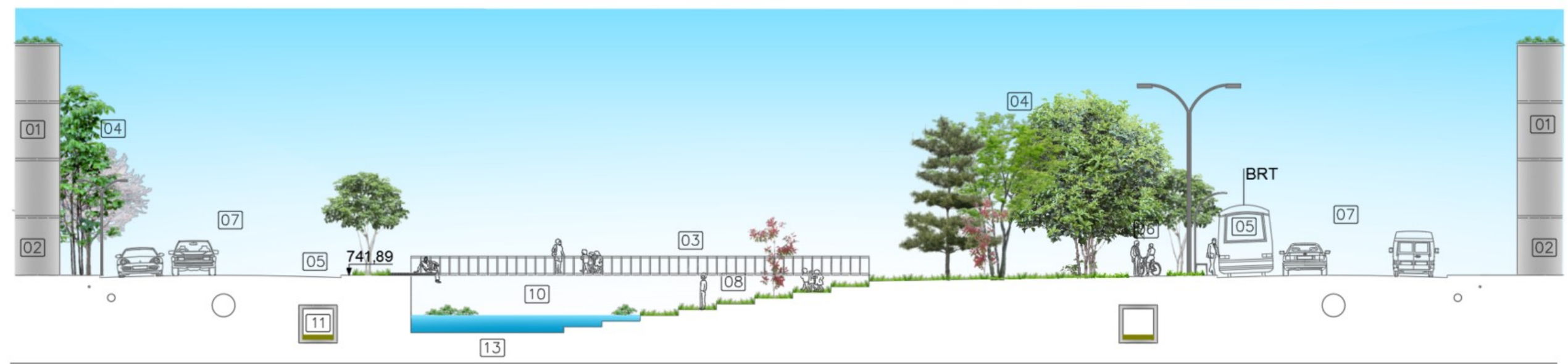

\section{CÓRREGO JAGUARÉ - PROPOSTO}

\section{LEGENDA}

01 USO MÚLTIPLO

02 TÉRREO VIVO (COMÉRCIO DE RUA)

03 PONTE PARA TRAVESSIA DE PEDESTRES

04 PLANTIO DE ESPÉCIES ADEQUADAS

05 BRT

06 CICLOVIA

07 REDUÇÃo DO NÚMERO DE FAIXAS DE RODAGEM
08 CANAL EM TERRAÇO
09 ABERTURA DE GALERIAS SUBTERRÂNEAS - ÁGUAS PLUVIAIS CONTROLADAS
10 USO DE ESPÉCIES VEGETAIS FITO REMEDIADORAS PARA TRATAMENTO DAS ÁGUAS
11 GALERIAS AUXILIARES - ÁGUAS PLUVIAIS NÃO CONTROLADAS / ÁGUAS DA PRIMEIRA CHUVA
12 IMPLANTAÇÃO DE INFRAESTRUTURA SANITÁRIA
13 REGULARIZAÇÃO DE MARGENS E FUNDO COM TÉCNICAS SUSTENTÁVEIS
14 ILUMINAÇÃO ADEQUADA PARA USO NOTURNO DAS ESTRUTURAS DE LAZER

Ilustração 164 - Corte CC - Repensando a várzea do Jaguaré. Fonte: Elaborado pela autora. 


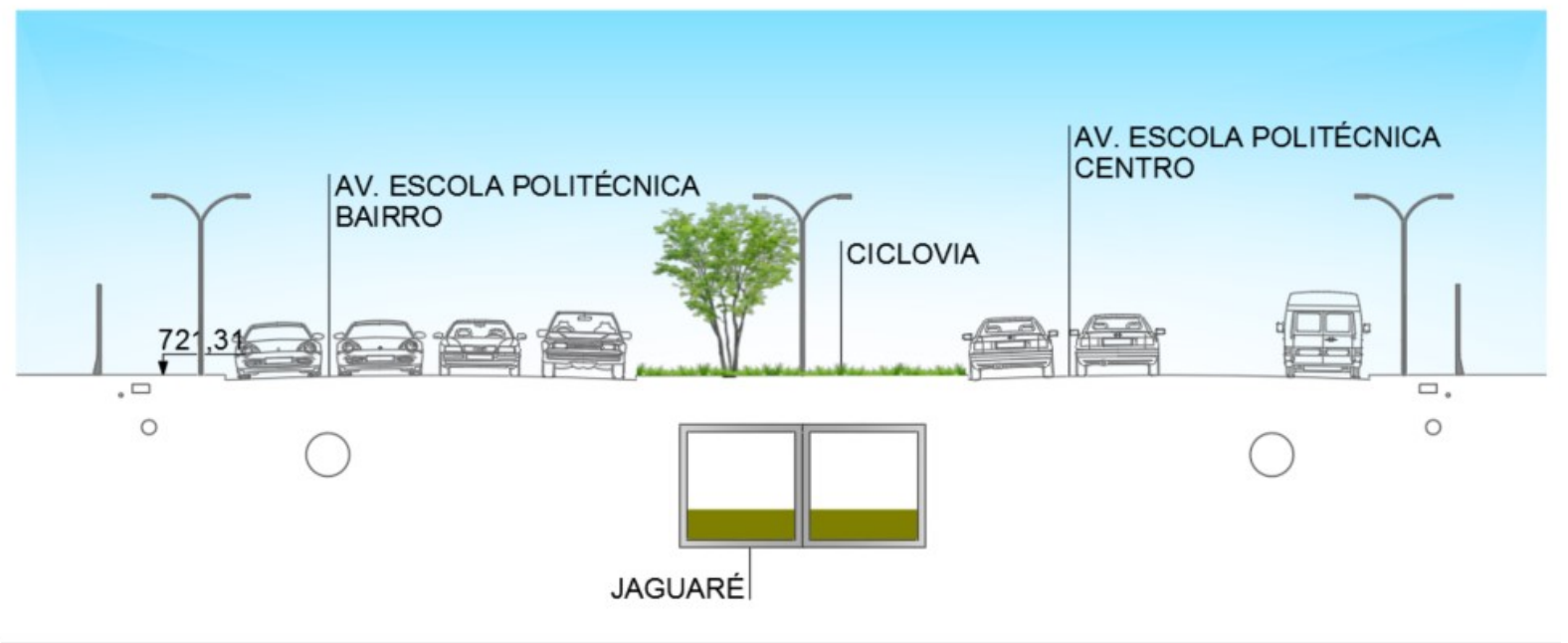

CÓRREGO JAGUARÉ - ATUAL

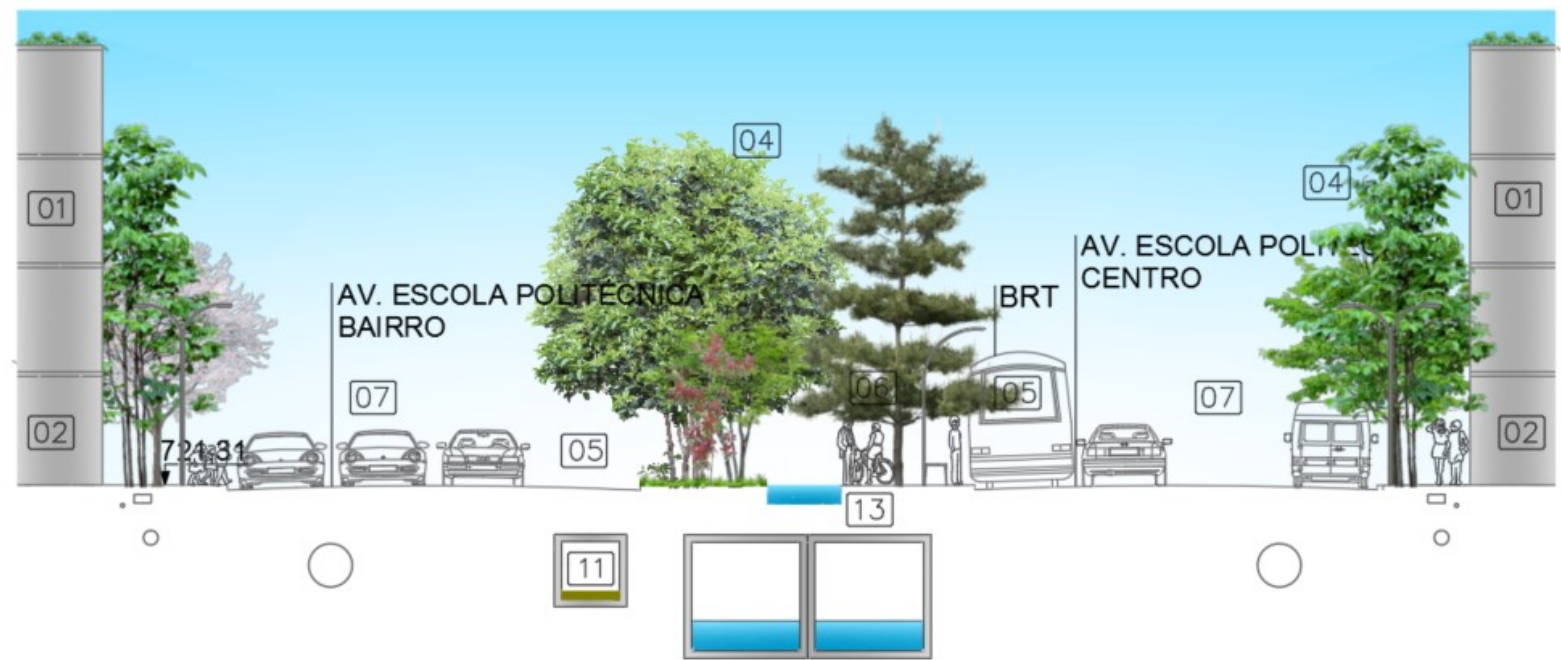

\section{CÓRREGO JAGUARÉ - PROPOSTO}

\section{LEGENDA}

01 USO MÚLTIPLO

02 TÉRREO VIVO (COMÉRCIO DE RUA)

03 PONTE PARA TRAVESSIA DE PEDESTRES

04 PLANTIO DE ESPÉCIES ADEQUADAS

05 BRT

06 CICLOVIA

07 REDUÇÃO DO NÚMERO DE FAIXAS DE RODAGEM

08 CANAL EM TERRAÇO

09 CANAL COM ÁGUAS PLUVIAIS CONTROLADAS

10 USO DE ESPÉCIES VEGETAIS FITO REMEDIADORAS PARA TRATAMENTO DAS ÁGUAS

11 GALERIAS AUXILIARES - ÁGUAS PLUVIAIS NÃO CONTROLADAS I ÁGUAS DA PRIMEIRA CHUVA

12 IMPLANTAÇÃO DE INFRAESTRUTURA SANITÁRIA

13 REGULARIZAÇÃO DE MARGENSE FUNDO COM TÉCNICAS SUSTENTÁVEIS

14 ILUMINAÇÃO ADEQUADA PARA USO NOTURNO DAS ESTRUTURAS DE LAZER

Ilustração 165 - Corte DD - Repensando a várzea do Jaguaré. Fonte: Elaborado pela autora. 


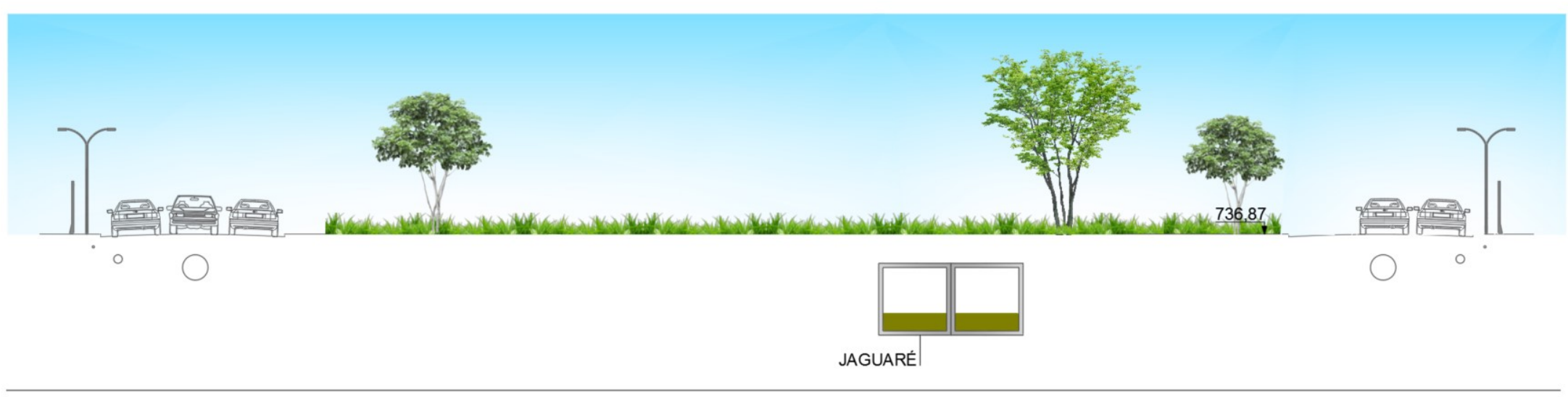

ROTATÓRIA DO JAGUARÉ - ATUAL

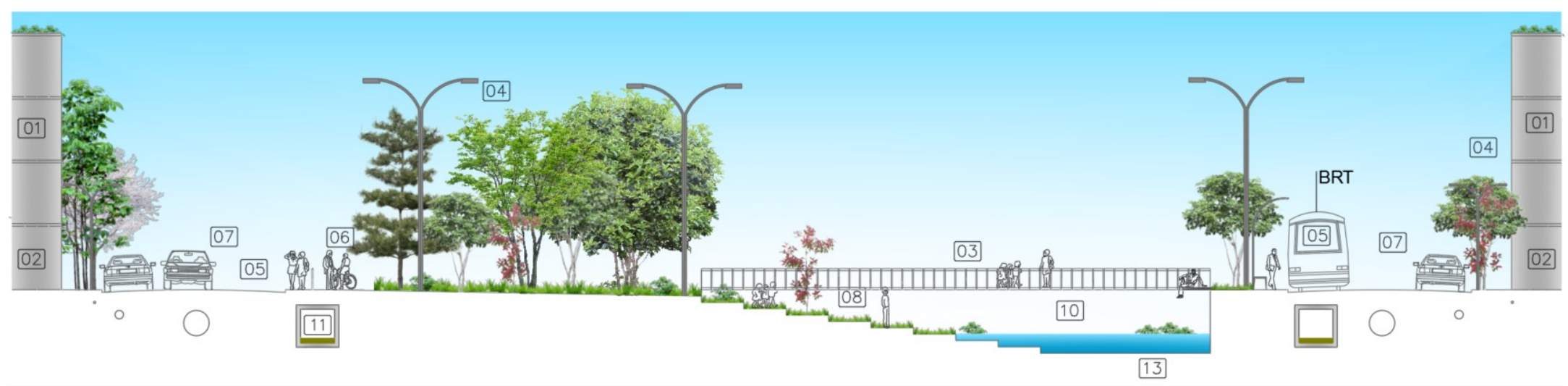

ROTATÓRIA DO JAGUARÉ - PROPOSTO

LEGENDA

01 USO MÚLTIPLO

02 TÉRREO VIVO (COMÉRCIO DE RUA)

03 PONTE PARA TRAVESSIA DE PEDESTRES

04 PLANTIO DE ESPÉCIES ADEQUADAS

05 BRT

06 CICLOVIA

07 REDUÇ̃̃o DO NÚMERO DE FAIXAS DE RODAGEM
08 CANAL EM TERRAÇO

09 ABERTURA DE GALERIAS SUBTERRÂNEAS - AGUAS PLUVIAIS CONTROLADAS

10 USO DE ESPÉCIES VEGETAIS FITO REMEDIADORAS PARA TRATAMENTO DAS ÁGUAS

11 GALERIAS AUXILIARES - ÁGUAS PLUVIAIS NÃO CONTROLADAS / ÁGUAS DA PRIMEIRA CHUVA

12 IMPLANTAÇÃo DE INFRAESTRUTURA SANITÁRIA

13 REGULARIZAÇÃO DE MARGENS E FUNDO COM TÉCNICAS SUSTENTÁVEIS

14 ILUMINAÇÃO ADEQUADA PARA USO NOTURNO DAS ESTRUTURAS DE LAZER

Ilustração 166 - Corte EE - Repensando a várzea do Jaguaré. Fonte: Elaborado pela autora. 


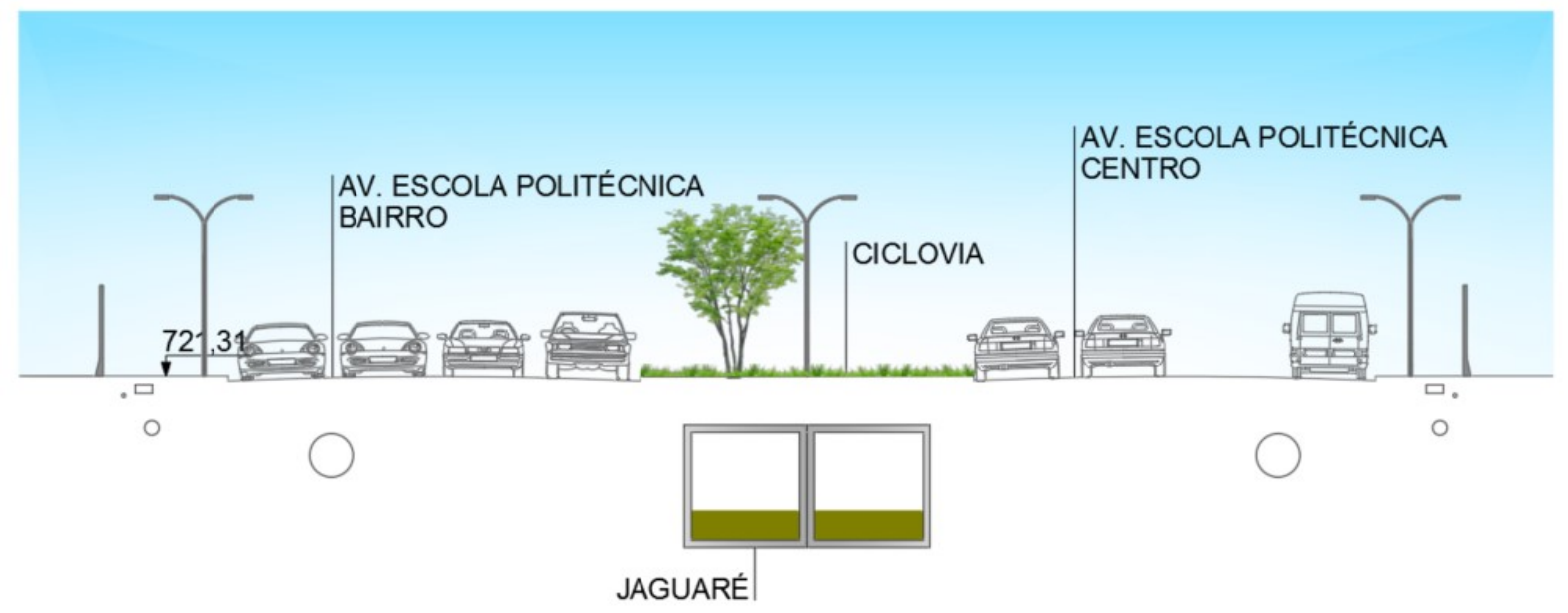

CÓRREGO JAGUARÉ - ATUAL

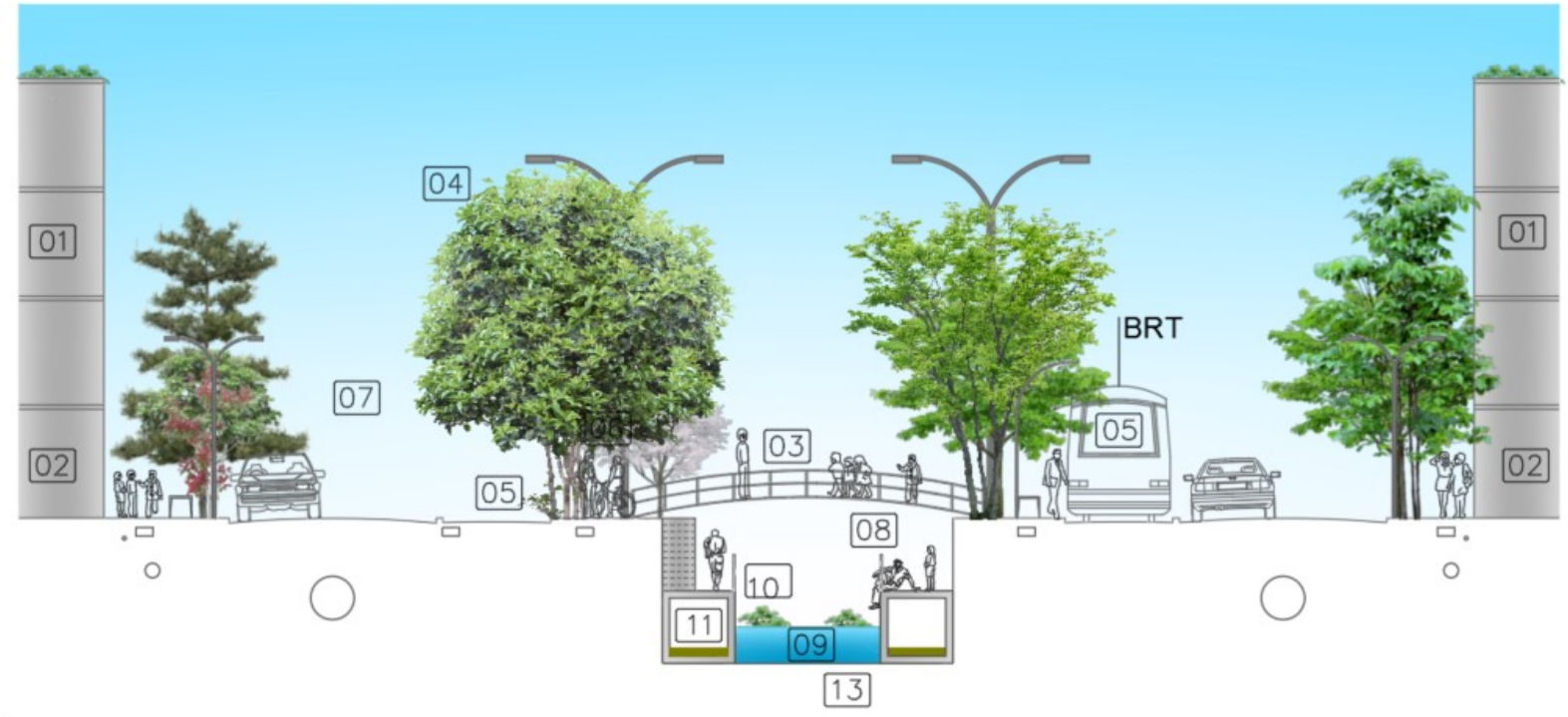

CÓRREGO JAGUARÉ - PROPOSTO

\section{LEGENDA}

01 USO MÚLTIPLO

02 TÉRREO VIVO (COMÉRCIO DE RUA)

03 PONTE PARA TRAVESSIA DE PEDESTRES

04 PLANTIO DE ESPÉCIES ADEQUADAS

05 BRT

06 CICLOVIA

07 REDUÇÃO DO NÚMERO DE FAIXAS DE RODAGEM

08 CANAL EM TERRAÇO

09 CANAL COM ÁGUAS PLUVIAIS CONTROLADAS

10 USO DE ESPÉCIES VEGETAIS FITO REMEDIADORAS PARA TRATAMENTO DAS ÁGUAS

11 GALERIAS AUXILIARES - ÁGUAS PLUVIAIS NÃO CONTROLADAS I ÁGUAS DA PRIMEIRA CHUVA

12 IMPLANTAÇÃO DE INFRAESTRUTURA SANITÁRIA

13 REGULARIZAÇÃO DE MARGENS E FUNDO COM TÉCNICAS SUSTENTÁVEIS

14 ILUMINAÇÃO ADEQUADA PARA USO NOTURNO DAS ESTRUTURAS DE LAZER

Ilustração 167 - Corte FF - Repensando a várzea do Jaguaré. Fonte: Elaborado pela autora. 
No cenário proposto é prevista a abertura de algumas galerias subterrâneas (09) que conduzirão somente fontes controladas de águas pluviais, como águas pluviais provenientes de reservatórios piscininha (Lei13.276/2002), de nascentes da bacia e da segunda parcela das chuvas, sendo propostas a manutenção de galerias subterrâneas auxiliares para condução das águas da primeira chuva, que carrega a maior parte da carga poluente. As águas das galerias auxiliares devem ser destinadas para a uma estação de tratamento nos períodos secos, já que representam um volume menor viabilizando o seu tratamento.

Além disso, no cenário proposto há ampliação de canteiros, com diminuição do número de faixas de rodagem em algumas vias (07), implantação de ciclovias (06), na margem do córrego Jaguaré foi proposta uma faixa para circulação de transporte coletivo, como o BRT (05), que circulara por toda a Avenida Escola Politécnica. Apesar de a avenida ser uma via de acesso importante que conecta diversos bairros à Marginal do rio Pinheiros e à USP, a avenida não conta com linhas suficientes de transporte público coletivo, portanto a implantação de uma linha de BRT, por exemplo, aumentaria o número de pedestres circulando na via e proporcionaria mais uma opção de transporte para a população do entorno. A bacia do Jaguaré é residida por muitos alunos e funcionários da USP, o que inclui o entorno da Avenida Escola Politécnica, portanto é notória a demanda por mais opções de transporte público coletivo.

Foi proposta ainda a implantação de pontes para travessia de pedestres (03) na altura das ruas marginas, a fim de proporcionar uma maior interação da população com o canal, com o mesmo intuito foi proposto em diversos pontos a implantação de margens em terraço (08) para que durante as estações secas o canal possa ser utilizado como pista de caminhada, corrida e área de contemplação. Para proporcionar o conforto térmico e enriquecimento ambiental da área, foi proposto o plantio de espécies adequadas (04) nas áreas de várzea, que convivam de forma harmônica com as infraestruturas instaladas, de acordo com a Tabela 24 de espécies higrófitas nativas do município de São Paulo.

Foi proposta a promoção da ocupação do entorno dos corpos d'água com unidades que priorizem o uso múltiplo (01) e vivo da avenida (02), por exemplo, com 
a instalação de unidades comerciais no pavimento térreo das edificações voltadas para a avenida, a fim de promover a circulação de pedestres na área. Para ampliar as horas de uso da infraestrutura proposta, foi proposta a implantação de iluminação adequada (14) em todo o parque linear resultante da proposta de revitalização do córrego Jaguaré.

Por fim, é prevista a requalificação de margens e fundo com técnicas sustentáveis (13) que promovam o desenvolvimento da fauna e da flora do corpo d'água sem comprometer a função estrutural e geotécnica da contenção. Além disso, adotou se o uso de espécies vegetais fito remediadoras (10) para tratamento das águas do canal.

Para que a implantação do cenário proposto seja viável é necessário a implantação prévia de todas as medidas de controle de cargas poluentes descritas anteriormente. Além disso, é fundamental que a população da bacia esteja integrada no processo e que participe de forma ativa de seu planejamento, implantação e operação. Neste estudo foi realizada uma consulta pública a fim de verificar a aceitação por parte da população das medidas propostas para revitalização das várzeas do córrego Jaguaré, sendo o resultado obtido é apresentado no item "Percepção da população sobre uma proposta de revitalização para as várzeas do Jaguaré". 


\subsection{Impacto da perda de áreas verdes na bacia do córrego Jaguaré}

$\mathrm{Na}$ bacia do Jaguaré é possível distinguir dois tipos de remanescentes vegetais, aqueles localizados em áreas públicas (Parques, praças e canteiros), sendo considerados neste estudo como protegidos, já que existem instrumentos legais que priorizam sua manutenção como áreas verdes; e aqueles em áreas privadas, considerados neste estudo como desprotegidos, já que a qualquer momento podem ser convertidos em outros usos do solo. As áreas verdes públicas, apesar de protegidas por instrumentos legais, encontram-se sujeitas, se mal geridas, à ocupação irregular, como ocorre na maioria das áreas urbanas brasileiras em fundos de vale e encostas, onde predominam os remanescentes vegetais, demandando atenção especial do poder público. O mapa da llustração 168 mostra a bacia do Jaguaré e seus remanescentes vegetais protegidos (áreas públicas) e desprotegidos (áreas privadas).

Para verificar a relevância da manutenção destes fragmentos vegetais em bacias hidrográficas urbanas foram realizadas simulações hidrológicas na bacia do córrego Jaguaré, variando o uso do solo em quatro cenários:

- Cenário 1: Existente, conforme detalhamento do uso do solo na bacia com base em imagens aéreas de março de 2016;

- Cenário 2: Considerando a perda das áreas verdes desprotegidas (privadas) e conversão destas áreas em uso residencial descontínuo, onde os lotes possuem áreas permeáveis;

- Cenário 3: Considerando a perda das áreas verdes desprotegidas (privadas) e conversão destas áreas em uso residencial contínuo, onde os lotes não possuem áreas permeáveis;

- Cenário 4: Considerando a perda das áreas verdes desprotegidas (privadas) e conversão destas áreas em uso residencial contínuo e a perda das áreas verdes protegidas (públicas) e conversão destas áreas em favelas.

As simulações hidrológicas foram realizadas verificando a vazão de pico na bacia através do método SCS (Soil Conservation Service), considerando uma chuva com período de retorno de 100 anos. 


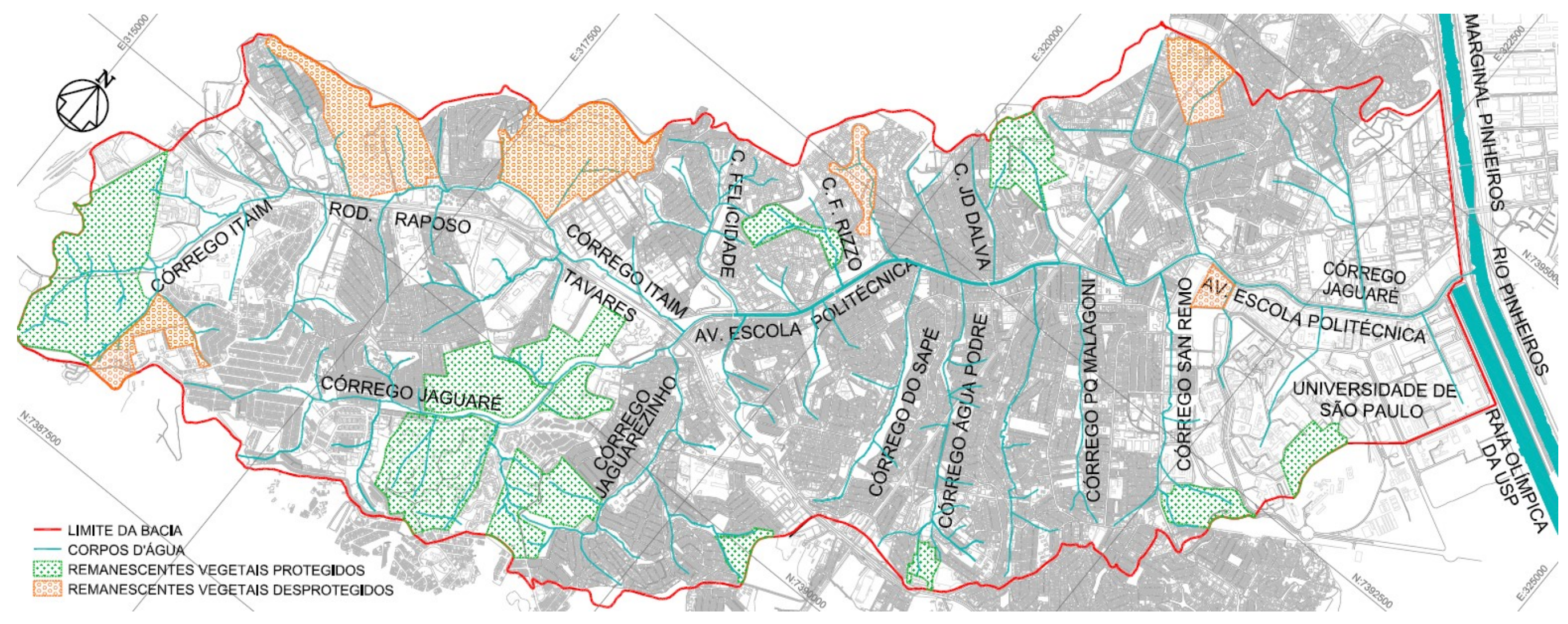

Ilustração 168 - Remanescentes vegetais protegidos e desprotegidos na bacia do Jaguaré. Fonte: Elaborado pela autora. 
Uma das formas de amortecer a vazão de pico de uma bacia é a adoção de reservatórios de detenção que detém certo volume do escoamento superficial trazido pelo sistema de drenagem e lança este volume de água no corpo d'água depois do evento de chuva, salvaguardando a bacia da ocorrência de inundações. Estas estruturas são de custo elevado e têm associadas a elas, da forma como são construídas atualmente, diversos malefícios como a retenção de resíduos, mal cheiro e a desvalorização paisagística. Neste estudo será verificado o custo de implantação destas estruturas para cada cenário simulado, para tanto será calculado o volume de reservação necessário em cada cenário, como descrito a seguir.

O volume necessário para a implantação de um reservatório de detenção convencional, do tipo piscinão, a fim de mitigar o volume excedente resultante da ocupação urbana na bacia pode ser determinado segundo Porto (2006) usando a função gama, onde o volume é dado pela seguinte equação:

$$
\text { Vol }=\left(2 \frac{\pi}{n}\right)^{0,5} i_{p} t_{p}
$$

Equação 1 (Porto, 2006).

Onde: Vol: Volume estimado do reservatório de detenção $\left(m^{3}\right) ; n$ : fator de aspecto, onde adota-se 8 ; ip: vazão máxima do hidrograma de entrada $\left(\mathrm{m}^{3} / \mathrm{s}\right)$; e tp: tempo de pico do hidrograma afluente.

Para determinação da vazão para cada cenário e para posterior determinação do volume de detenção necessário foi utilizado o método SCS (Soil Conservation Service) indicado para bacias hidrográficas com área superior a 100 hectares. Já para obtenção dos parâmetros de alimentação da equação de intensidade-duraçãofrequência da chuva foi utilizado o software Pluvio 2.1, sendo os parâmetros apresentados pelo programa os seguintes: $K=1999,992 ; a=0,108 ; b=20,206$; e $c=0,838$.

Segundo Tomaz (2002), o custo de implantação por $\mathrm{m}^{3}$ de um piscinão aberto em São Paulo é de $R \$ 136 / \mathrm{m}^{3}$ e para o fechado, tomando como base o piscinão do Pacaembu, o custo é de $R \$ 432 / \mathrm{m}^{3}$. Segundo estudo realizado por Pereira (2014) a média do custo de implantação dos reservatórios abertos na bacia do Pirajussara foi 
de $R \$ 152 / m^{3}$. Estes valores foram utilizados como referência para cálculo do custo de implantação dos reservatórios hipotéticos dimensionados para cada cenário verificado.

Tabela 25 - Resultados obtidos para os cenários estudados. Fonte: Elaborado pela autora.

\begin{tabular}{|c|c|c|c|c|c|c|c|c|}
\hline & \multicolumn{4}{|c|}{ Cenário 1: Atual } & \multicolumn{4}{|c|}{$\begin{array}{l}\text { Cenário 2: Perda da vegetação } \\
\text { des protegida e conversão em uso } \\
\text { residencial des contínuo }\end{array}$} \\
\hline & $\begin{array}{c}\text { Argiloso } \\
\operatorname{raso}\left(\mathbf{K m}^{2}\right)\end{array}$ & $\mathrm{CN}$ & $\begin{array}{l}\text { Argilo arenoso } \\
\text { profundo }\left(\mathbf{K m}^{2}\right)\end{array}$ & $\mathbf{C N}$ & $\begin{array}{c}\text { Argiloso } \\
\operatorname{raso}\left(\mathbf{K m}^{2}\right)\end{array}$ & $\mathrm{CN}$ & $\begin{array}{l}\text { Argilo arenoso } \\
\text { profundo }\left(\mathbf{K m}^{2}\right)\end{array}$ & $\mathbf{C N}$ \\
\hline Bosques ou zonas florestais & 3,3786 & 55 & 0,9351 & 25 & 2,2103 & 55 & 0,6063 & 25 \\
\hline Espaços verdes Urbanos & 1,4589 & 80 & 1,8036 & 61 & 1,4589 & 80 & 1,8036 & 61 \\
\hline Cas as - Contínuo & 1,0734 & 98 & 1,1763 & 98 & 1,0734 & 98 & 1,1763 & 98 \\
\hline Cas as - Des contínuo & 2,2473 & 90 & 4,2198 & 85 & 3,4156 & 90 & 4,5486 & 85 \\
\hline Prédios & 0,5394 & 90 & 1,1582 & 85 & 0,5394 & 90 & 1,1582 & 85 \\
\hline Favelas & 0,3345 & 98 & 0,4457 & 98 & 0,3345 & 98 & 0,4457 & 98 \\
\hline Comércio e Serviços - Contínuo & 0,1025 & 95 & 0,3966 & 92 & 0,1025 & 95 & 0,3966 & 92 \\
\hline Comércio e Serviços - Descontínuo & 0,8064 & 85 & 2,1921 & 70 & 0,8064 & 85 & 2,1921 & 70 \\
\hline Industrial - Contínuo & 0,1714 & 93 & 0,9785 & 88 & 0,1714 & 93 & 0,9785 & 88 \\
\hline Industrial - Des contínuo & 0,9553 & 85 & 0,1933 & 70 & 0,9553 & 85 & 0,1933 & 70 \\
\hline \multirow[t]{7}{*}{ Viário } & 1,3492 & 100 & 2,2972 & 100 & 1,3492 & 100 & 2,2972 & 100 \\
\hline & $\mathrm{CN}$ médio & $=$ & 77,58 & & $\mathrm{CN}$ médio & $=$ & 80,04 & \\
\hline & $\mathbf{Q}_{\text {sCs }}$ & $=$ & 86,39 & $\mathrm{~m}^{3} / \mathrm{s}$ & Q scs & $=$ & 98,33 & $\mathrm{~m}^{3} / \mathrm{s}$ \\
\hline & Vol retardo & $=$ & 339955,44 & $\mathrm{~m}^{3}$ & Vol retardo & $=$ & 386955,20 & $\mathrm{~m}^{3}$ \\
\hline & $\mathbf{R S}$ & $=$ & 46233939,85 & & RS & $=$ & 52625906,97 & \\
\hline & \multicolumn{4}{|c|}{$\begin{array}{l}\text { Cenário 3: Perda da vegetação } \\
\text { desprotegida e conversão em uso } \\
\text { residencial contínuo }\end{array}$} & \multicolumn{4}{|c|}{$\begin{array}{c}\text { Cenário 4: Perda da vegetação } \\
\text { des protegida e conversão em uso } \\
\text { residencial contínuo e perda da } \\
\text { vegetação protegida e conversão em }\end{array}$} \\
\hline & $\begin{array}{c}\text { Argiloso } \\
\operatorname{raso}\left(\mathbf{K m}^{2}\right) \\
\end{array}$ & $\mathbf{C N}$ & $\begin{array}{l}\text { Argilo arenoso } \\
\text { profundo }\left(\mathrm{Km}^{2}\right) \\
\end{array}$ & $\mathbf{C N}$ & $\begin{array}{c}\text { Argiloso } \\
\operatorname{raso}\left(\mathbf{K m}^{2}\right) \\
\end{array}$ & $\mathbf{C N}$ & $\begin{array}{l}\text { Argilo arenoso } \\
\text { profundo }\left(\mathbf{K m}^{2}\right)\end{array}$ & $\mathbf{C N}$ \\
\hline Bosques ou zonas florestais & 2,2103 & 55 & 0,6063 & 25 & 0,0000 & 55 & 0,0000 & 25 \\
\hline Espaços verdes Urbanos & 1,4589 & 80 & 1,8036 & 61 & 1,4589 & 80 & 1,8036 & 61 \\
\hline Casas - Contínuo & 2,2417 & 98 & 1,5051 & 98 & 2,2417 & 98 & 1,5051 & 98 \\
\hline Casas - Des contínuo & 2,2473 & 90 & 4,2198 & 85 & 2,2473 & 90 & 4,2198 & 85 \\
\hline Prédios & 0,5394 & 90 & 1,1582 & 85 & 0,5394 & 90 & 1,1582 & 85 \\
\hline Favelas & 0,3345 & 98 & 0,4457 & 98 & 2,5448 & 98 & 1,0521 & 98 \\
\hline Comércio e Serviços - Contínuo & 0,1025 & 95 & 0,3966 & 92 & 0,1025 & 95 & 0,3966 & 92 \\
\hline Comércio e Serviços - Descontínuo & 0,8064 & 85 & 2,1921 & 70 & 0,8064 & 85 & 2,1921 & 70 \\
\hline Indus trial - Contínuo & 0,1714 & 93 & 0,9785 & 88 & 0,1714 & 93 & 0,9785 & 88 \\
\hline Industrial - Descontínuo & 0,9553 & 85 & 0,1933 & 70 & 0,9553 & 85 & 0,1933 & 70 \\
\hline \multirow[t]{5}{*}{ Viário } & 1,3492 & 100 & 2,2972 & 100 & 1,3492 & 100 & 2,2972 & 100 \\
\hline & CN médio & $=$ & 80,60 & & $\mathrm{CN}$ médio & $=$ & 86,27 & \\
\hline & Q scs & $=$ & 101,17 & $\mathrm{~m}^{3} / \mathrm{s}$ & Q sCs & $=$ & 133,66 & $\mathrm{~m}^{3} / \mathrm{s}$ \\
\hline & Vol retardo & $=$ & 398102,59 & $\mathrm{~m}^{3}$ & Vol retardo & $=$ & 525986,35 & $\mathrm{~m}^{3}$ \\
\hline & RS & $=$ & 54141952,65 & & RS & $=$ & 71534143,30 & \\
\hline
\end{tabular}


Confirmou-se com este estudo a relevância dos remanescentes vegetais em áreas urbanas no controle da vazão de pico de bacia hidrográficas, já que, mesmo diante das características geológicas desfavoráveis à retenção da água no solo da bacia (presença de solo argiloso raso na cabeceira da bacia do Jaguaré, onde encontram-se a maioria dos remanescentes vegetais), no cenário crítico simulado (perda completa dos remanescentes vegetais, convertidos em favelas) a vazão de pico saltou dos atuais $86,39 \mathrm{~m}^{3} / \mathrm{s}$ para $133,66 \mathrm{~m}^{3} / \mathrm{s}$.

Todos os cenários simulados resultaram em incrementos significativos na vazão de pico da bacia que resultaram na necessidade do aumento da dimensão atual da calha do córrego Jaguaré, o que por sua vez resulta em gastos públicos elevados para realizar tais intervenções. Além disso, a aplicação da função gama para determinação do volume de detenção necessário para amortização da vazão de pico revelou a necessidade de implantação de piscinões em todos os cenários, resultando na necessidade de investimentos elevados para essa implantação ( $R \$ 71534143,30$ no cenário mais crítico) ressaltando a importância econômica da manutenção de áreas verdes em bacias hidrográficas.

Estas áreas verdes poderiam ainda, além de serem mantidas, serem enriquecidas com a adoção de infraestruturas verdes, tornando o sistema de drenagem mais sustentável, resultando na redução da vazão de pico atual da bacia e reduzindo o risco de inundações. Além disso, como verificado no levantamento de Costa (2006), tais remanescentes são importantes refúgios de espécies da mata atlântica, bioma que tem sido gravemente afetado pela expansão da mancha urbana. 


\subsection{Infraestrutura verde e azul na bacia do córrego Jaguaré}

\subsubsection{Infraestrutura verde e azul: Escala da bacia}

Seguindo os conceitos da drenagem sustentável e da infraestrutura verde, foi proposta para a bacia do Jaguaré a interligação das áreas verdes da bacia a fim de propagar as zonas úmidas, criando um corredor ecológico urbano que seja difusor de espécies da fauna e da flora, promovendo o enriquecimento ambiental, a valorização paisagística e o bem estar da população. Para tanto foram utilizadas as várzeas dos corpos d'água da bacia para conectar estas áreas verdes, sendo, portanto tais corredores ecológicos chamados de corredores verdes e azuis.

A zona das cabeceiras da bacia do Jaguaré possui importantes fragmentos florestais que abrigam representantes importantes da mata Atlântica, tanto da flora, como foi levantado por Costa (2006) (Tabela 10 ), quanto da fauna, desta forma os corredores verdes e azuis propostos funcionam como difusores destas espécies para as demais áreas verdes da bacia, chegando até o parque Villa Lobos.

A avifauna tem grande importância ecológica em áreas verdes, uma vez que desempenham um serviço ecossistêmico valioso ao efetuarem a dispersão de sementes. Segundo a SVMA (2012) no parque Tizo podem ser encontrados facilmente as seguintes espécies da avifauna: Bem-te-vi (Pitangus sulphuratus), Tucano do bico verde (Ramphastos dicolorus), Caracara (Caracara plancus), Picapau do campo (Colaptes campestris), Irerê (Dendrocygna viduata), Sabiá Laranjeira (Turdus rufiventris) e Frango d'água comum (Gallinula chloropus). Já no parque Villa Lobos foram, segundo Komesu (2012) foram avistadas 51 espécies de aves, apresentadas na Tabela 26 a seguir. Os corredores verdes e azuis propostos além de ampliarem as possibilidades de abrigo e alimentação para a avifauna, tem grande importância no equilíbrio das populações já que propicia a troca gênica entre as populações presentes nos fragmentos florestais.

Para traçado dos corredores verdes e azuis da bacia foi utilizado o mapa com as áreas delimitadas pela SVMA (llustração 106 ), o resultado obtido é mostrado na Ilustração 170 a seguir. 


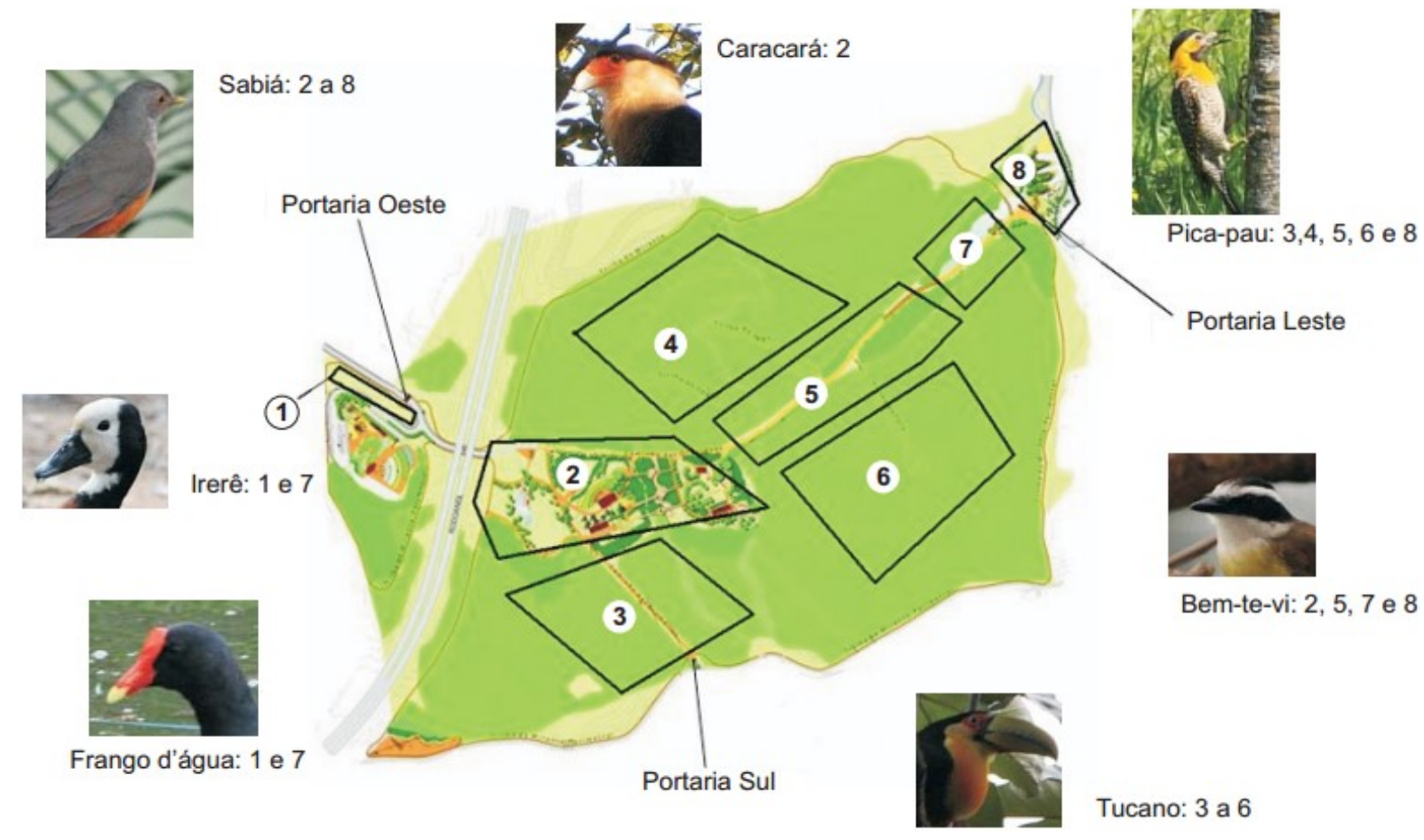

Ilustração 169 - Locais de avistamento de avifauna no parque Tizo. Fonte: SVMA, 2012.

Tabela 26 - Avifauna avistada no Parque Villa Lobos. Fonte: Addaptado de komesu (2012).

\begin{tabular}{|c|c|c|c|}
\hline Espécie & Nome popular & Dryocopus lineatus & pica-pau-de-banda-branca \\
\hline Accipiter striatus & gavião-miúdo & Aratinga leucophthalma & periquitão-maracanã \\
\hline Streptoprocne zonaris & taperuçu-de-coleira-branca & Brotogeris tirica & periquito-rico \\
\hline Syrigma sibilatrix & maria-faceira & Diopsittaca nobilis & maracanã-pequena \\
\hline Coragyps atratus & urubu-de-cabeça-preta & Forpus xanthopterygius & tuim \\
\hline Vanellus chilensis & quero-quero & Athene cunicularia & coruja-buraqueira \\
\hline Coereba flaveola & cambacica & Rhinoptynx clamator & coruja-orelhuda \\
\hline Columba livia & pombo-doméstico & Conirostrum speciosum & figuinha-de-rabo-castanho \\
\hline Patagioenas picazuro & pombão & Thlypopsis sordida & saí-canário \\
\hline Zenaida auriculata & pomba-de-bando & Thraupis sayaca & sanhaçu-cinzento \\
\hline Pyroderus scutatus & pavó & Trichothraupis melanops & tiê-de-topete \\
\hline Piaya cayana & alma-de-gato & Theristicus caudatus & curicaca \\
\hline Paroaria dominicana & cardeal-do-nordeste & Amazilia lactea & beija-flor-de-peito-azul \\
\hline Sicalis flaveola & canário-da-terra- & Eupetomena macroura & beija-flor-tesoura \\
\hline Zonotrichia capensis & tico-tico & Troglodytes musculus & corruíra \\
\hline Estrilda astrild & bico-de-lacre & Turdus flavipes & sabiá-una \\
\hline Falco femoralis & falcão-de-coleira & Turdus leucomelas & sabiá-barranco \\
\hline Carduelis magellanica & pintassilgo & Turdus rufiventris & sabiá-laranjeira \\
\hline Furnarius rufus & joão-de-barro & Fluvicola nengeta & lavadeira-mascarada \\
\hline Molothrus bonariensis & vira-bosta & Machetornis rixosa & suiriri-cavaleiro \\
\hline Basileuterus culicivorus & pula-pula & Myiodynastes maculatus & bem-te-vi-rajado \\
\hline Passer domesticus & pardal & Pitangus sulphuratus & bem-te-vi \\
\hline Phalacrocorax brasilianus & biguá & Pyrocephalus rubinus & príncipe \\
\hline Celeus flavescens & pica-pau-de-cabeça- & Serpophaga subcristata & alegrinho \\
\hline Colaptes campestris & pica-pau-do-campo & Xolmis cinereus & primavera \\
\hline Colaptes melanochloros & pica-pau-verde-barrado & Cyclarhis gujanensis & pitiguari \\
\hline
\end{tabular}




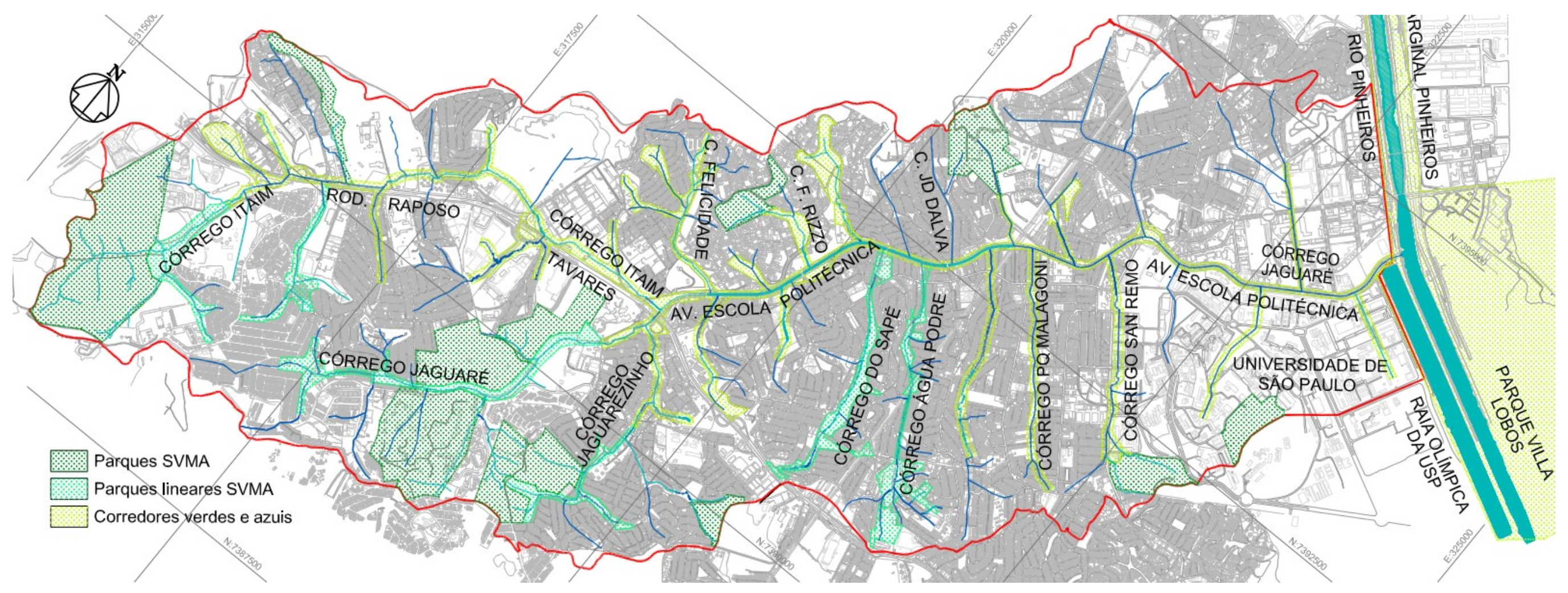

Ilustração 170 - Proposta de infraestrutura verde e azul. Fonte: Elaborado pela autora. 


\subsubsection{Infraestrutura verde e azul: Escala do sistema viário}

Foi verificado o impacto da adoção de medidas da infraestrutura verde e azul aplicadas ao sistema viário na vazão de pico da bacia. Para tanto foi computada a capacidade de retenção da instalação de 3 medidas: Estruturas de biorretenção (Canteiros vegetados e valas de infiltração), passeios e viários permeáveis. Segundo Moura, Pellegrino e Martins (2014) uma estrutura de biorretenção com 0,15m de brita graduada simples e 0,60 de macadame hidráulico (Brita 3 ) tem capacidade de retenção por $\mathrm{m}^{2}$ de $0,47 \mathrm{~m}^{3}$, enquanto passeios e viários permeáveis com $0,15 \mathrm{~m}$ de brita graduada simples e 0,15 de macadame hidráulico (Brita 3) tem capacidade de retenção por $\mathrm{m}^{2}$ de $0,0945 \mathrm{~m}^{3}$.

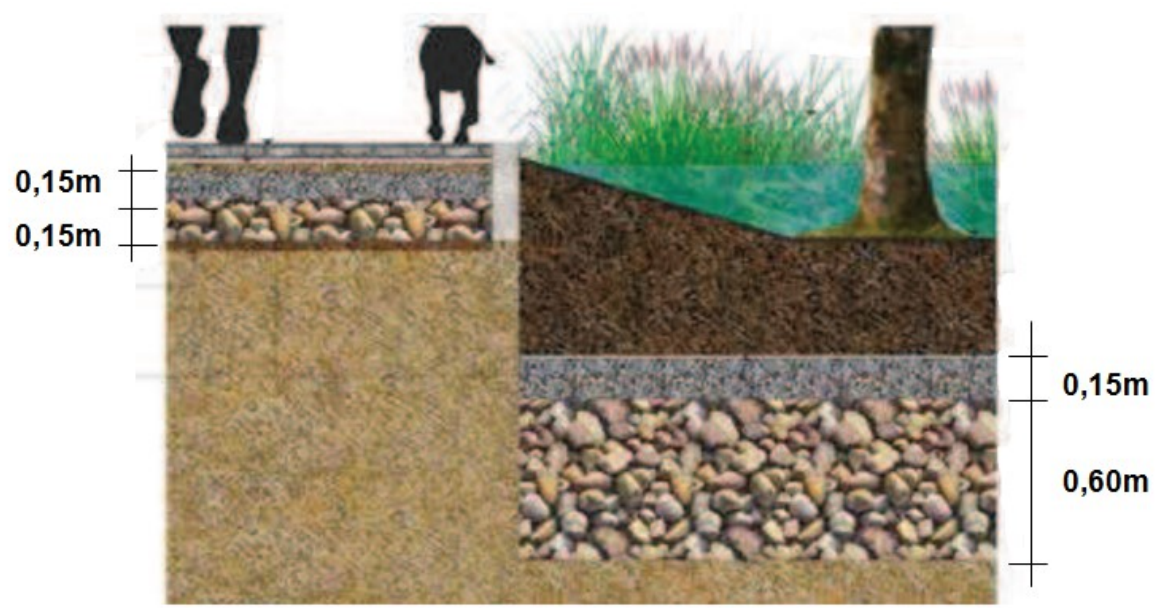

Ilustração 171 - Estrutura de biorretenção. Fonte: Adaptado de Moura, Pellegrino e Martins, 2014.

Foi então realizado um estudo para a caracterização do sistema viário na bacia, distinguindo 4 tipos de viário (llustração 172 ) Rodovia, Avenidas (Onde foram inseridas as ruas que apesar de possuírem a denominação rua apresentavam características de avenida, como via e passeios largos), Ruas e Vielas, obtendo as seguintes extensões na bacia, apresentadas na Tabela 27 a seguir.

Tabela 27 - Composição do sistema viário na bacia. Fonte: Elaborado pela autora.

\begin{tabular}{lllr}
\hline Viário tipo 1 & rodovia & $14047,09 \mathrm{~m}$ & $4 \%$ \\
\hline Viário tipo 2 & avenida & $68770,42 \mathrm{~m}$ & $17 \%$ \\
\hline Viário tipo 3 & rua & $300350,9 \mathrm{~m}$ & $75 \%$ \\
\hline Viário tipo 4 & viela & $17629,31 \mathrm{~m}$ & $4 \%$ \\
\hline Total & & $\mathbf{4 0 0 7 9 7 , 7 ~ m}$ & $\mathbf{1 0 0 \%}$ \\
\hline
\end{tabular}




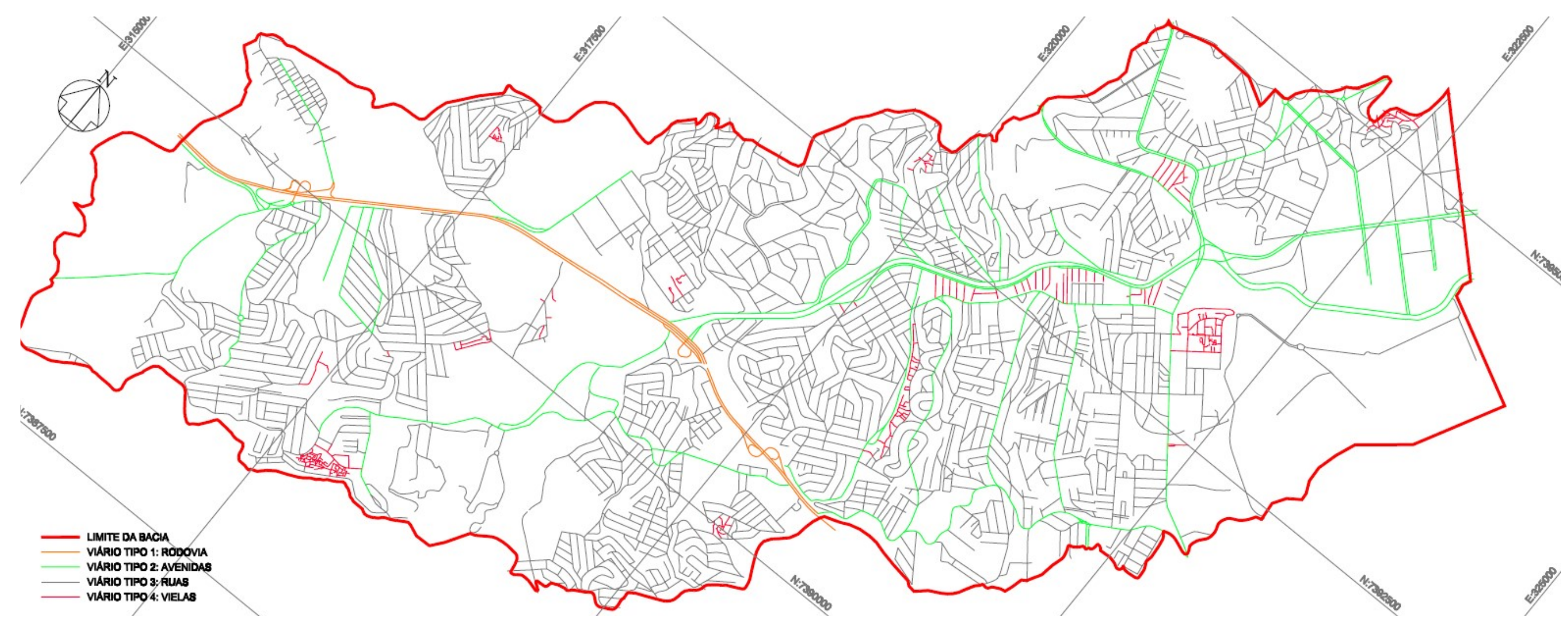

Ilustração 172 - Tipos de viário na bacia do Jaguaré. Fonte: Elaborado pela autora. 
Foram estabelecidas então intervenções típicas para os quatro tipos de viário em questão. Para o viário tipo 1 (Rodovia), não foi adotada infraestrutura verde, já que rodovias tem tráfego de alta velocidade e de veículos pesados, havendo solicitação elevada dos materiais empregados no pavimento; Tem sido testados materiais drenantes para emprego em rodovias, que possibilitem a retenção da água do escoamento superficial sem redução da sua resistência mecânica, no entanto a ciência ainda esta em desenvolvimento, desta forma não será adotado nenhum tipo de infraestrutura verde na rodovia deste estudo. Para o tipo 2 (Avenida) e 3 (Rua) e 4 (Viela) serão adotadas as 3 medidas de infraestrutura verde, estruturas de biorretenção (Canteiros vegetados e valas de infiltração), passeios e viários permeáveis, seguindo a distribuição típica mostrada na llustração 173 .

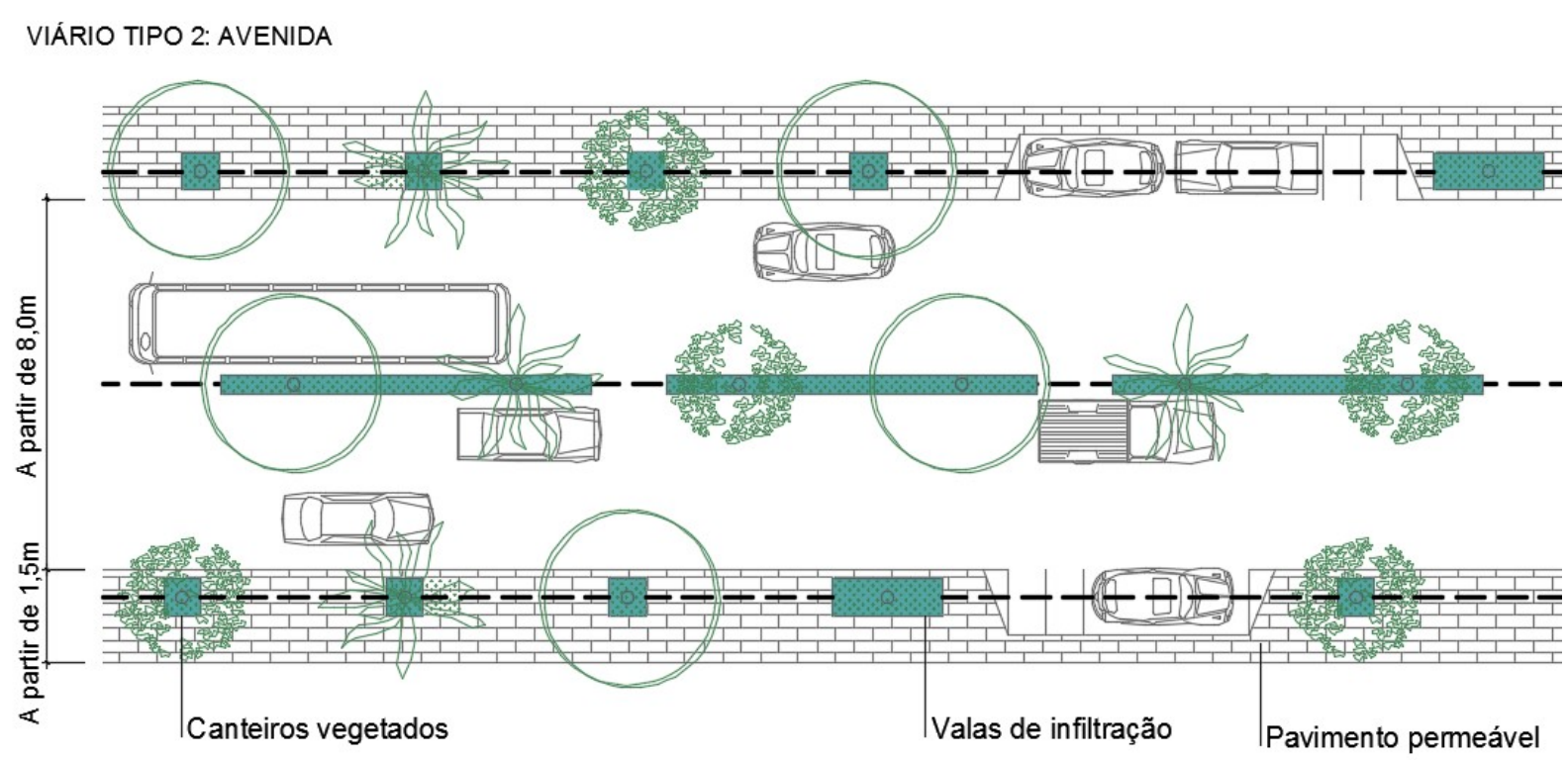

VIÁRIO TIPO 3: RUA

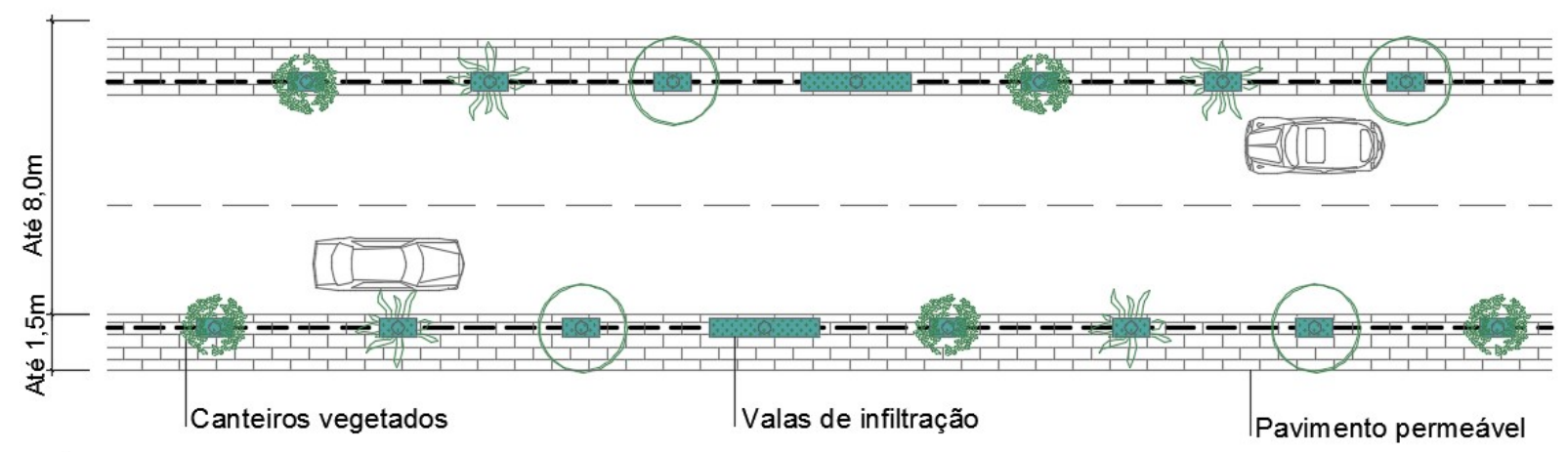

VIÁRIO TIPO 4: VIELA

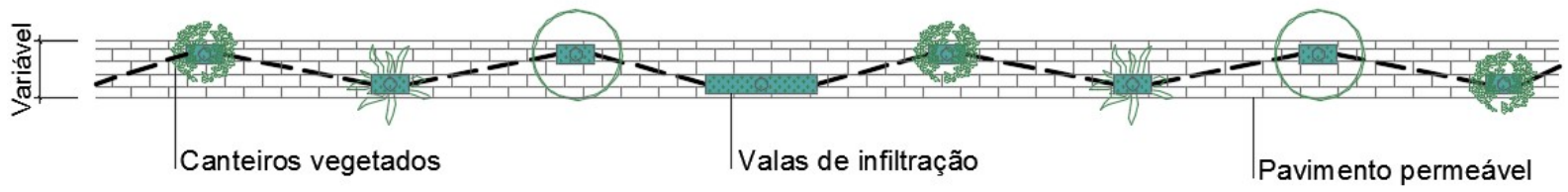

Ilustração 173 - Tratamento típico do viário. Fonte: Elaborado pela autora. 
O tratamento proposto prevê a implantação de estruturas de biorretenção a cada 5 metros de passeio e pavimento drenante nos passeios. Além disso a adoção de pavimento asfáltico drenante nas faixas de rodagem. Considerando estas tipologias, cada metro linear de viário teria as seguintes áreas de estrutura de biorretenção: Tipo $2=0,8 \mathrm{~m}^{2}$; Tipo $3=0,3 \mathrm{~m}^{2}$; e Tipo $4=0,1 \mathrm{~m}^{2}$. Para o cálculo da área de pavimento permeado nos passeios e viário adotou-se a metragem mínima para largura (Avenida: passeio 1,5m e viário 8,0m / Rua: passeio 1,0m e viário 6,0m) e para vielas considerou-se largura de 1,0m. Considerando as premissas descritas, a implantação da infraestrutura verde na bacia do Jaguaré, considerando um cenário conservador, resultaria nas possíveis capacidades de retenção na bacia, mostradas na Tabela 28 a seguir.

Tabela 28 - Volumes retidos com a implantação da infraestrutura verde. Fonte: Elaborado pela autora.

\begin{tabular}{|c|c|c|c|c|c|}
\hline & & & & & \\
\hline & & $\begin{array}{l}\text { Estrutura de } \\
\text { biorretenção }\end{array}$ & $\begin{array}{c}\text { Passeio } \\
\text { permeável }\end{array}$ & $\begin{array}{c}\text { Viário } \\
\text { permeável }\end{array}$ & Total \\
\hline Viário tipo 1 & rodovia & $0 \mathrm{~m}^{3}$ & $0 \mathrm{~m}^{3}$ & $0 \mathrm{~m}^{3}$ & $0 \mathrm{~m}^{3}$ \\
\hline Viário tipo 2 & avenida & $25857,68 \mathrm{~m}^{3}$ & $9748,21 \mathrm{~m}^{3}$ & $51990,44 \mathrm{~m}^{3}$ & $87596,32 \mathrm{~m}^{3}$ \\
\hline Viário tipo 3 & rua & $42349,47 \mathrm{~m}^{3}$ & $28383,16 \mathrm{~m}^{3}$ & $170298,94 \mathrm{~m}^{3}$ & $241031,57 \mathrm{~m}^{3}$ \\
\hline Viário tipo 4 & viela & $828,58 \mathrm{~m}^{3}$ & $1665,97 \mathrm{~m}^{3}$ & $0 \mathrm{~m}^{3}$ & $2494,55 \mathrm{~m}^{3}$ \\
\hline Total & & $69035,73 \mathrm{~m}^{3}$ & $39797,33 \mathrm{~m}^{3}$ & $222289,38 \mathrm{~m}^{3}$ & $331122,44 \mathrm{~m}^{3}$ \\
\hline
\end{tabular}

Desta forma, o volume de retardo necessário para o cenário atual, calculado no item anterior, de $339955,44 \mathrm{~m}^{3}$ poderia ser parcialmente retido em estruturas da infraestrutura verde, mediante estudo de viabilidade do custo de implantação das mesmas. O cenário descrito a seguir, com adoção de estruturas de biorretenção na bacia, resultaria na retenção mostrada na Tabela 29 .

- Aplicação de estruturas de biorretenção (Canteiros vegetados e valas de infiltração) e passeios permeáveis em todas as calçadas das avenidas da bacia;

- Aplicação de estruturas de biorretenção (Canteiros vegetados e valas de infiltração) e passeios permeáveis nas calçadas de 1/4 das ruas da bacia;

- Aplicação de estruturas de biorretenção (Canteiros vegetados e valas de infiltração) e passeios permeáveis em todas as vielas (Vielas são favoráveis à implantação de infraestrutura verde, uma vez que boa parte delas encontram-se em áreas de interesse social, que já demandam programas de requalificação, portanto esta requalificação poderia ser feita com base no conceito LID); e 
- Aplicação de pavimento permeável em 1/4 das ruas.

Tabela 29 - Proposta de retenção com infraestrutura verde. Fonte: Elaborado pela autora.

\begin{tabular}{l|l|r|l}
\hline \multirow{4}{*}{$\begin{array}{c}\text { Solução de } \\
\text { retenção com } \\
\text { infraestrutura } \\
\text { verde }\end{array}$} & Biorretenção em avenidas & 25857,68 & $\mathrm{~m}^{3}$ \\
\cline { 2 - 4 } & Passeio permeável em avenidas & 9748,21 & $\mathrm{~m}^{3}$ \\
\cline { 2 - 4 } & Passeio permeável em vielas & 1665,97 & $\mathrm{~m}^{3}$ \\
\cline { 2 - 4 } & Passeio permeável em 1/4 das ruas & 7095,79 & $\mathrm{~m}^{3}$ \\
\cline { 2 - 4 } & Viário permeável em 1/4 das ruas & 42574,74 & $\mathrm{~m}^{3}$ \\
\cline { 2 - 4 } & Retenção total & $\mathbf{8 6 9 4 2 , 3 8}$ & $\mathrm{m}^{\mathbf{3}}$ \\
\hline
\end{tabular}

Segundo Tomaz (2002), o custo de implantação por $\mathrm{m}^{3}$ de um piscinão aberto em São Paulo é de $\mathrm{R} \$ 136 / \mathrm{m}^{3}$ e para o fechado, tomando como base o piscinão do Pacaembu, o custo é de $R \$ 432 / \mathrm{m}^{3}$. Segundo estudo realizado por Pereira (2014) a média do custo de implantação dos reservatórios abertos na bacia do Pirajussara foi de $R \$ 152 / \mathrm{m}^{3}$. Já o custo da implantação das 3 medidas da infraestrutura verde foram calculados com base na tabela de custos da PMSP de 2016, obtendo-se os seguintes custos de implantação: $R \$ 281,15 / \mathrm{m}^{2}$ de canteiro vegetado ou vala de infiltração (Tabela 23); $R \$ 185,20 / \mathrm{m}^{2}$ de passeio permeável (Tabela 24); e $\mathrm{R} \$ 270,05 / \mathrm{m}^{2}$ de viário permeável (Tabela 25$)$.

Comparando então o custo de implantação das medidas de infraestrutura verde na bacia com a implantação de um piscinão, teríamos a seguinte relação, apresentada na Tabela 26.

Tabela 30 - Custo de implantação de estruturas de biorretenção. Fonte: Elaborado pela autora com base em PMSP, 2016.

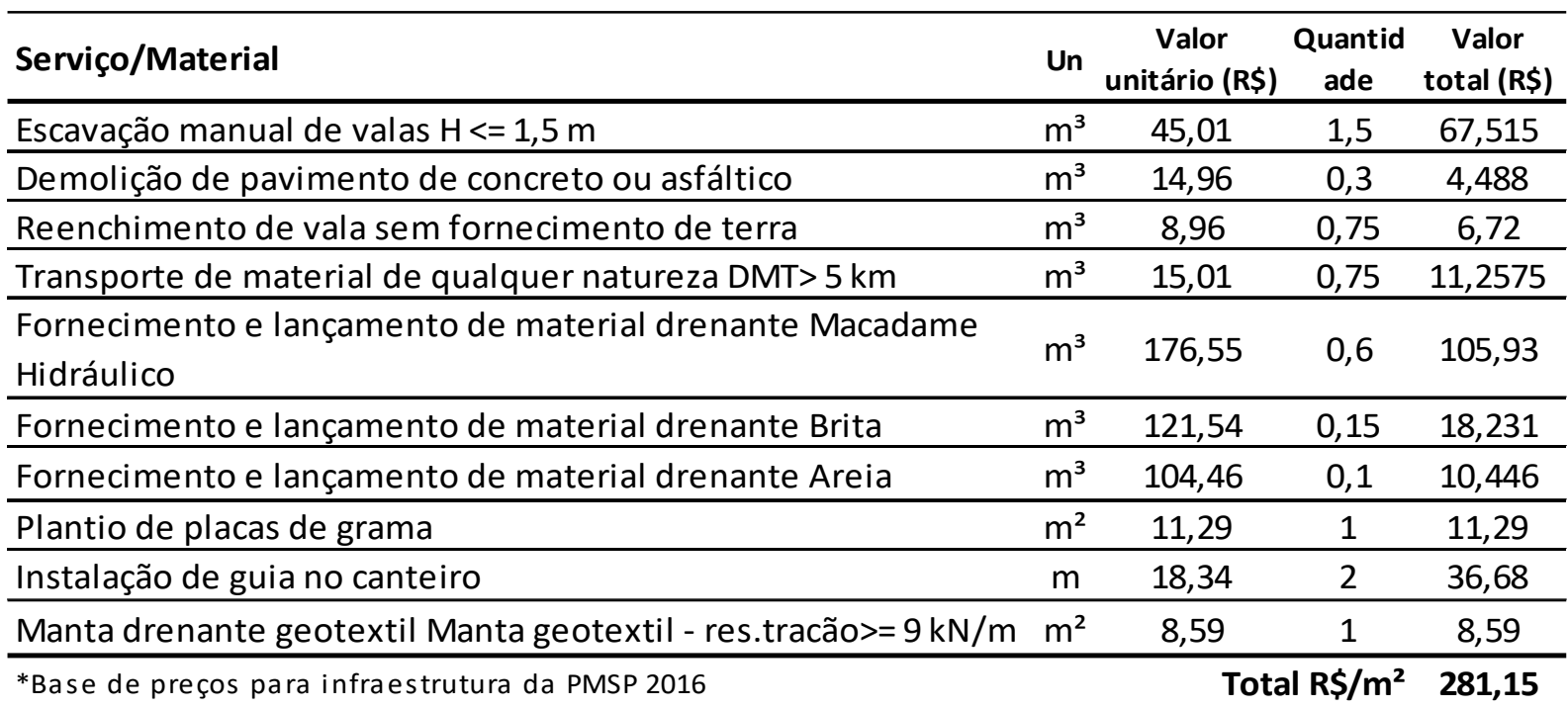


Tabela 31 - Custo de implantação de passeio permeável. Fonte: Elaborado pela autora com base em PMSP, 2016.

\begin{tabular}{lcccc}
\hline Serviço/Material & Un & $\begin{array}{c}\text { Valor } \\
\text { unitário (R\$̦) }\end{array}$ & $\begin{array}{c}\text { Quantid } \\
\text { ade }\end{array}$ & $\begin{array}{c}\text { Valor } \\
\text { total (R\$) }\end{array}$ \\
\hline Escavação manual de valas $\mathrm{H}<=1,5 \mathrm{~m}$ & $\mathrm{~m}^{3}$ & 45,01 & 0,4 & 18,004 \\
\hline Demolição de pavimento de concreto ou asfáltico & $\mathrm{m}^{3}$ & 14,96 & 0,1 & 1,496 \\
\hline Transporte de material de qualquer natureza DMT>5 km & $\mathrm{m}^{3}$ & 15,01 & 0,4 & 6,004 \\
\hline $\begin{array}{l}\text { Fornecimento e lançamento de material drenante Macadame } \\
\text { Hidráulico }\end{array}$ & $\mathrm{m}^{3}$ & 176,55 & 0,15 & 26,4825 \\
\hline Fornecimento e lançamento de material drenante Brita & $\mathrm{m}^{3}$ & 121,54 & 0,15 & 18,231 \\
\hline Fornecimento e lançamento de material drenante Areia & $\mathrm{m}^{3}$ & 104,46 & 0,1 & 10,446 \\
\hline Pavimento drenante para passeios e estacionamentos & $\mathrm{m}^{2}$ & 95,95 & 1 & 95,95 \\
\hline Manta drenante geotextil Manta geotextil - res.tracão>=9 $\mathrm{kN} / \mathrm{m}^{2}$ & $\mathrm{~m}^{2}$ & 8,59 & 1 & 8,59 \\
\hline
\end{tabular}

*Base de preços para infraestrutura da PMSP 2016

Total $\mathbf{R} \$ / \mathrm{m}^{2} \quad 185,20$

Tabela 32 - Custo de implantação de viário permeável. Fonte: Elaborado pela autora com base em PMSP, 2016.

\begin{tabular}{lcccc}
\hline Serviço/Material & Un & $\begin{array}{c}\text { Valor } \\
\text { unitário (R\$) }\end{array}$ & $\begin{array}{c}\text { Quantid } \\
\text { ade }\end{array}$ & $\begin{array}{c}\text { Valor } \\
\text { total (R\$) }\end{array}$ \\
\hline Escavação manual de valas $\mathrm{H}<=1,5 \mathrm{~m}$ & $\mathrm{~m}^{3}$ & 45,01 & 0,6 & 27,006 \\
\hline Demolição de pavimento de concreto ou asfáltico & $\mathrm{m}^{3}$ & 14,96 & 0,3 & 4,488 \\
\hline Transporte de material de qualquer natureza DMT>5 km & $\mathrm{m}^{3}$ & 15,01 & 0,6 & 9,006 \\
\hline $\begin{array}{l}\text { Fornecimento e lançamento de material drenante Macadame } \\
\text { Hidráulico }\end{array}$ & $\mathrm{m}^{3}$ & 176,55 & 0,15 & 26,4825 \\
\hline Fornecimento e lançamento de material drenante Brita & $\mathrm{m}^{3}$ & 121,54 & 0,15 & 18,231 \\
\hline Fornecimento e lançamento de material drenante Areia & $\mathrm{m}^{3}$ & 104,46 & 0,1 & 10,446 \\
\hline Pavimento drenante para viário & $\mathrm{m}^{2}$ & 165,8 & 1 & 165,8 \\
\hline Manta drenante geotextil Manta geotextil - res.tracão>=9 $9 \mathrm{kN} / \mathrm{m}^{2}$ & $\mathrm{~m}^{2}$ & 8,59 & 1 & 8,59 \\
\hline *Base de preços para infraestrutura da PMSP 2016 & & Total $\mathbf{R S} / \mathbf{m}^{\mathbf{2}}$ & $\mathbf{2 7 0 , 0 5}$
\end{tabular}

Tabela 33 - Custo de implantação das medidas de infraestrutura ver e de um piscinão. Fonte: Elaborado pela autora.

\begin{tabular}{|c|c|c|c|}
\hline \multirow{6}{*}{$\begin{array}{l}\text { Solução de } \\
\text { retenção com } \\
\text { infraestrutura } \\
\text { verde }\end{array}$} & Biorretenção em avenidas & \begin{tabular}{l|l|l}
25857,68 & $\mathrm{~m}^{3}$ \\
\end{tabular} & $\mathrm{R} \$ 15.467 .705,33$ \\
\hline & Passeio permeável em avenidas & $9748,21 \mathrm{~m}^{3}$ & $\mathrm{R} \$ 19.104 .783,72$ \\
\hline & Passeio permeável em vielas & $1665,97 \mathrm{~m}^{3}$ & $R \$ 3.265 .009,91$ \\
\hline & Passeio permeável em 1/4 das ruas & \begin{tabular}{l|l|l}
7095,79 & $\mathrm{~m}^{3}$ \\
\end{tabular} & $\mathrm{R} \$ 13.906 .508,09$ \\
\hline & Viário permeável em $1 / 4$ das ruas & $42574,74 \mathrm{~m}^{3}$ & $\mathrm{R} \$ 83.439 .048,53$ \\
\hline & Retenção total & $86942,38 \mathrm{~m}^{3}$ & $\mathrm{R} \$ 119.715 .350,25$ \\
\hline \multirow{2}{*}{$\begin{array}{l}\text { Retenção em } \\
\text { piscinão }\end{array}$} & Aberto & $339955,44 \mathrm{~m}^{3}$ & $\mathrm{R} \$ 46.233 .939,85$ \\
\hline & Fechado & $339955,44 \mid \mathrm{m}^{3}$ & $\mathrm{R} \$ 146.860 .750,12$ \\
\hline
\end{tabular}

Observa-se que a infraestrutura verde tem custo mais elevado de implantação, no entanto considerando os benefícios adicionais que estas medidas trazem para a bacia, como a retenção de poluentes do escoamento superficial e a valorização paisagística, as mesmas podem ser trabalhadas como uma ferramenta auxiliar. 

diferentes idades, escolaridade, formação, faixa social e sexo.

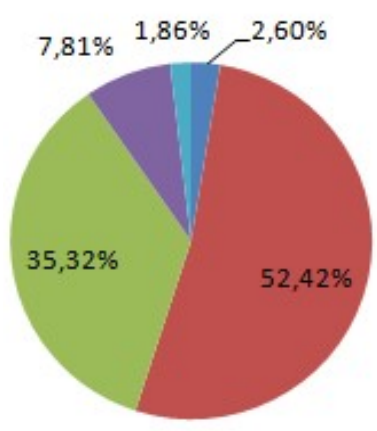

Até 17 anos.

De 18 a 24 anos.

De 25 a 35 anos.

De 36 a 50 anos.

A partir de 51 anos.
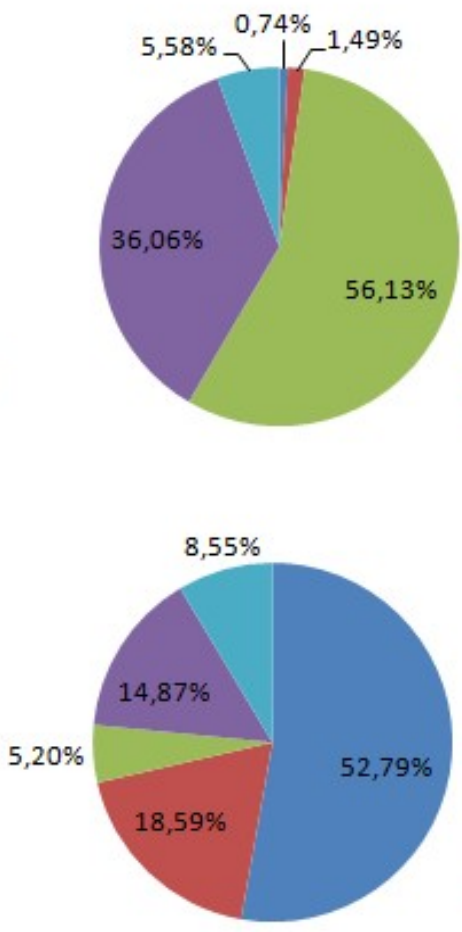

Nenhuma escolaridade.

Ensino fundamental completo.

Ensino médio completo.

Ensino superior completo.

口ós-graduação completo.

Exatas.

- Humanas.

Biológicas (Área da saúde)

Biológicas (Outras Áreas).

- Outra.

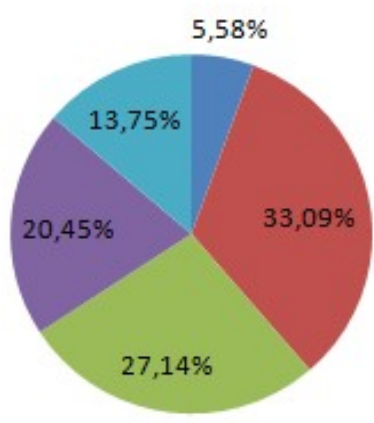

Feminino

Masculino
Até um salário mínimo (RS 724,00).

पMais de 1 até 3 salários mínimos (R\$̣ 724,00 até R\$ 2.172,00).

Mais de 3 até 6 salários mínimos (R\$ 2.172,00 até R\$̣ 4.344).

—Mais de 6 até 10 salários mínimos (R\$ 4.344,00 até R\$̦ 7.240,00).

- Mais de 10 salários mínimos (Acima de R\$ 7.240,00).

Ilustração 174 - Perfil dos entrevistados. Fonte: Elaborado pela autora.

Quando questionados sobre a interação com os rios no seu dia a dia e a percepção individual sobre a proximidade com os rios a maioria dos entrevistados $(98,51 \%)$ indicou a existência de rios de levemente poluído a gravemente poluído nas proximidades em que reside; $75,46 \%$ dos entrevistados se mostraram favoráveis a viver próximo de corpos d'água. 
Há quantos anos você reside em seu bairro atual?

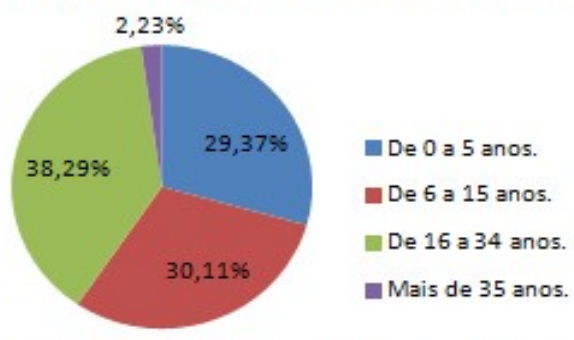

Há algum rio próximo da área em que você reside?

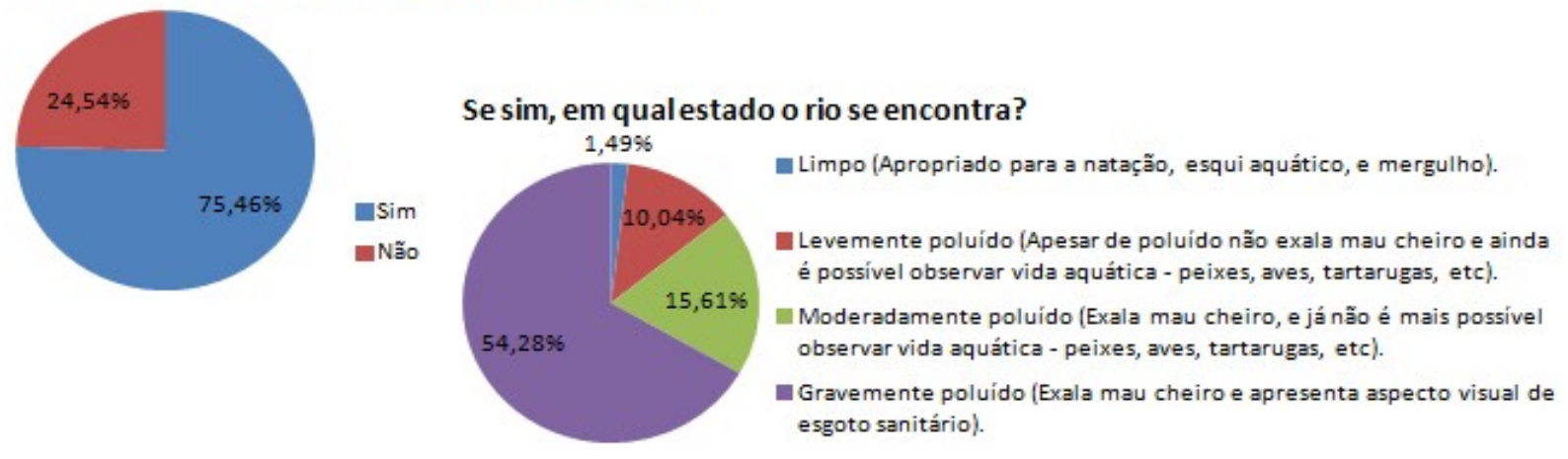

Você gosta ou gostaria de morar próximo a um rio?

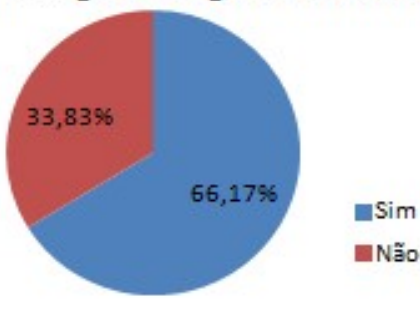

Se não, por quê?

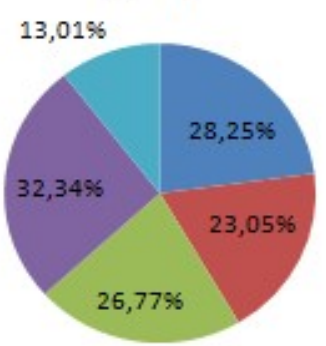

Se sim, por quê?

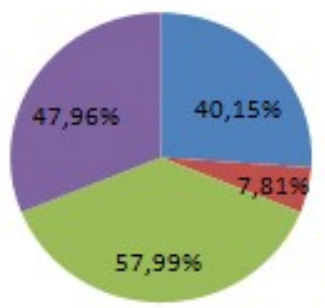

- Valorização paisagística (Ter vista para o rio). Evalorização Imobiliária.

aresença da fauna/flora (Pássaros, peixes, vegetação, etc). - Melhor qualidade do ar.

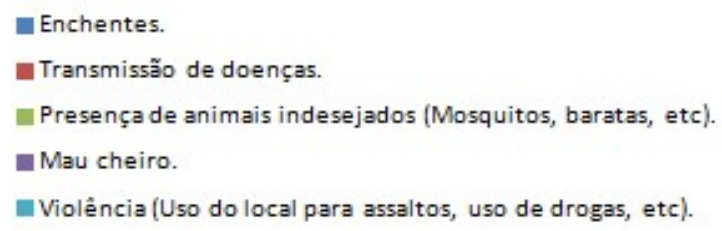

Ilustração 175 - Resultados questionário específico: parte 1. Fonte: Elaborado pela autora.

O questionário específico revelou ainda que os entrevistados se mostram em sua grande maioria favorável a intervenções no meio urbano que priorizem áreas de lazer e que promovam o bem estar da fauna e da flora e o aumento da qualidade de vida da população, como mostrado nas llustrações seguintes, $74,7 \%$ dos entrevistados indicaram como preferência para rios urbanos aqueles que possuam parques em suas margens, que possam ser utilizados para recreação e lazer. Além disso, quando questionados sobre a possibilidade de abrir canais que atualmente 
estão canalizados em galerias subterrâneas, $84 \%$ dos entrevistados se mostraram favoráveis.

Considerando um rio que corta uma cidade, pensando no seu estilo de vida e em suas preferências, qual das realidades descritas abaixo mais o agrada?

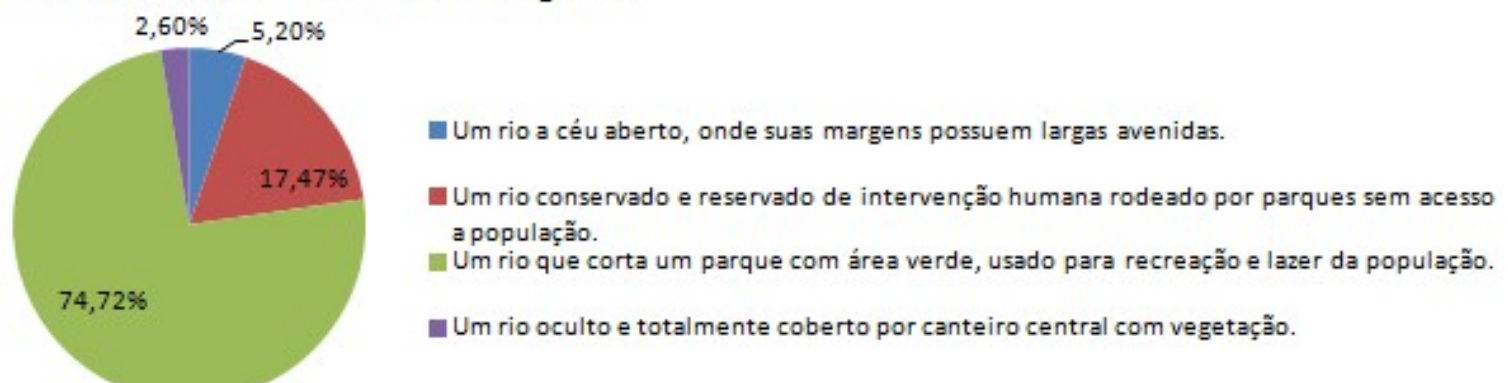

Na sua opinião qual o PRINCIPAL fator responsável pela situação atual dos rios nas grandes cidades?

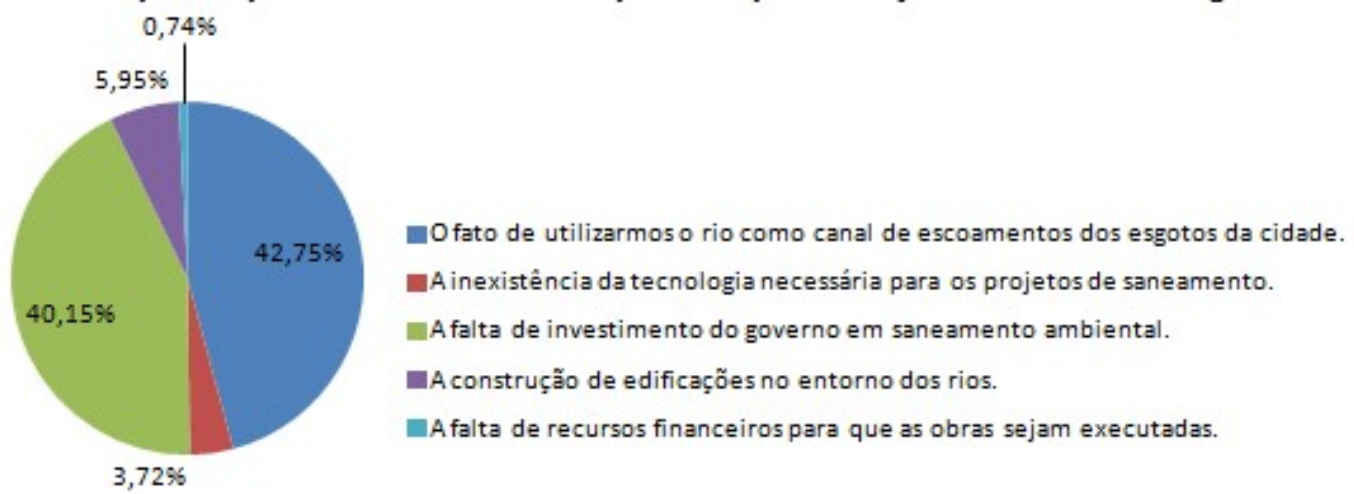

Canalizações fechadas são aquelas em que o rio fica totalmente oculto na paisagem, através de galerias subterrâneas. Você acredita que esta é uma boa metodologia considerando a situação atual dos rios em sua cidade?
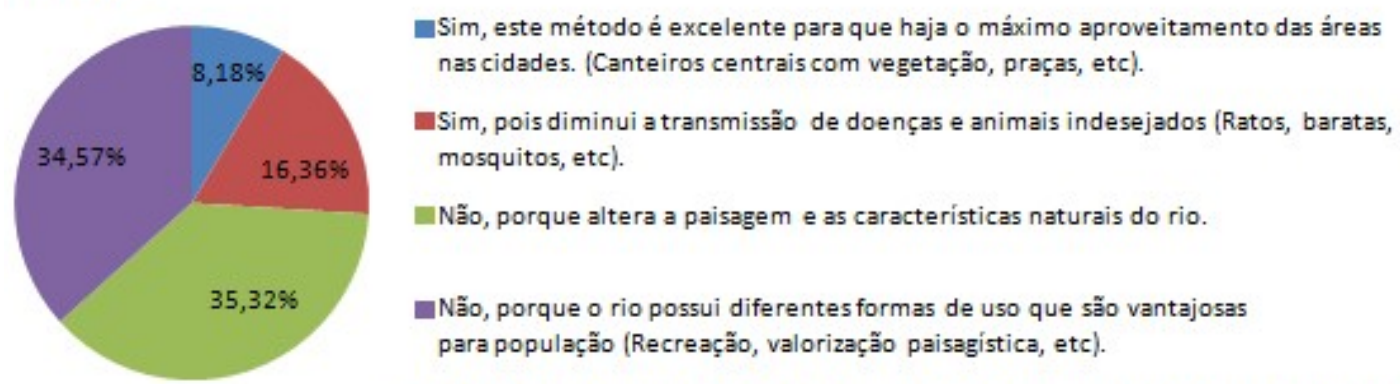

Considerando a questão anterior, se o rio em avaliação fosse limpo, sua opinião seria a mesma?

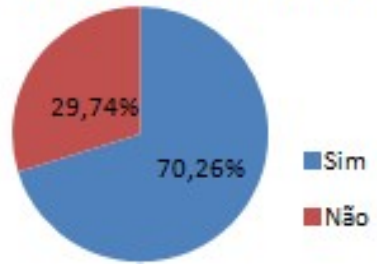

Ilustração 176 - Resultados questionário específico: parte 2. Fonte: Elaborado pela autora.

O questionário revelou também que muitos desconhecem a existência de importantes corpos d'água que hoje residem sob avenidas famosas, mostrando o 
quão fraca é a relação da população com os rios da cidade, apesar da importância histórica que os mesmos tiveram para a construção da metrópole.

Você sabia que grande parte das principais avenidas da cidade de São Paulo (Avenida Nove de Julho, Bandeirantes e Pacaembu) foram criadas em cima de rios que foram canalizados em galerias subterrâneas?

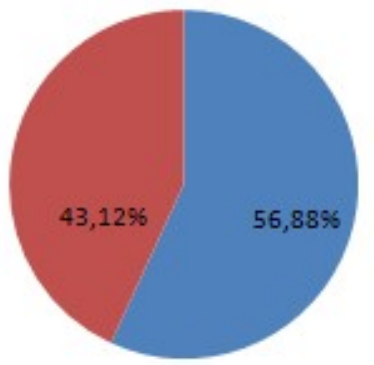

$$
\begin{aligned}
& \text { "Sim } \\
& \text { = Não }
\end{aligned}
$$

Considerando o caso dos rios citados na questão anterior, se houvesse um projeto para traze-los de voltaà paisagem, ou seja, transformar esses rios subterrâneos em rios abertos novamente, dentro de um contexto que priorizasse o uso do espaço pela população, você seria a favor?

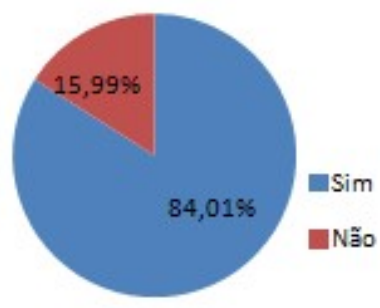

Considerando a situação atual dos rios de sua cidade, se houvesse uma hidrovia para transporte de pessoas, você a utilizaria?

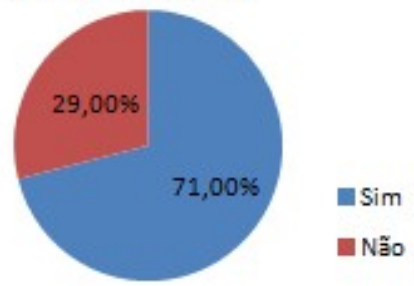

Ilustração 177 - Resultados questionário específico: parte 3. Fonte: Elaborado pela autora.

Quando questionados sobre o porquê da ocorrência de enchentes, onde era possível atribuir mais de uma escolha na resposta, $65,06 \%$ dos entrevistados atribuíram a culpa à falta de investimento público; 78,07\% indicaram que se deve ao lançamento de resíduos e $76,21 \%$ indicaram a impermeabilização do solo.

Na sua opinião, as enchentes ocorrem devido a(o):

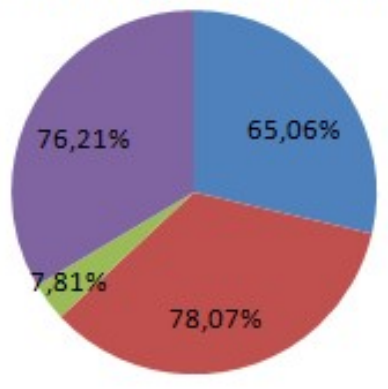

- Mau investimento do governo em obras para melhorias no sistema de drenagem das águas de chuva.

Grande quantidade de lixo gerado e mal descartado pela população, que acaba entupindo os sistemas de drenagem.

Chuvas atípicas que não estavam previstas no projeto.

- Impermeabilização do solo (a parcela da água que deveria infiltrar no solo, escorre pela ruas, aumentando assim o volume de água que vai para os rios).

Ilustração 178 - Resultados questionário específico: parte 4. Fonte: Elaborado pela autora. 


\subsection{Percepção da população sobre uma proposta de revitalização para}

as várzeas do córrego Jaguaré

Após a conclusão dos cenários propostos para a revitalização das várzeas do córrego Jaguaré para a bacia do Jaguaré, foi realizada uma consulta pública à população da bacia a fim de validar o cenário proposto e averiguar as demandas existentes. Para tanto foi adotada a seguinte metodologia:

- Exposição das soluções propostas em prancha e em linguagem acessível;

- Coleta de avaliações sendo 3 avaliações possíveis: favorável, desfavorável e reticente; e

- Coleta de sugestões, relatos e observações.

A consulta pública foi realizada em 4 pontos da bacia: o primeiro na saída do Carrefour da Raposo Tavares na região das cabeceiras; o segundo na Av. Rio Pequeno, rua de comercio na bacia onde há grande circulação de pedestres; o terceiro na entrada do Extra Jaguaré; e o quarto no campus da Cidade Universitária, no terminal de ônibus próximo à Av. Escola Politécnica. A llustração 179 a seguir mostra fotos da realização da consulta pública.
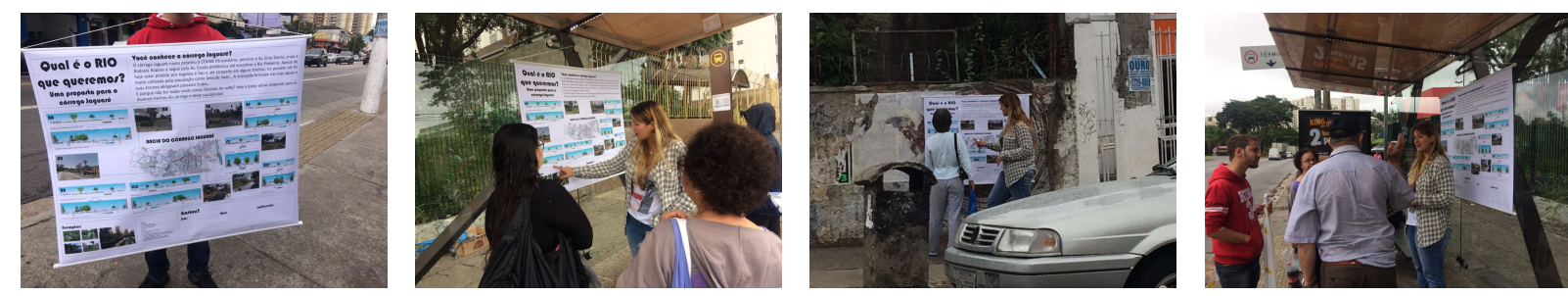

Ilustração 179 - Consulta pública realizada na bacia do córrego Jaguaré. Fonte: Fotos da autora.

Obteve-se um total de 189 respostas, sendo $89 \%$ favoráveis às medidas adotadas, $6 \%$ desfavoráveis e $5 \%$ reticentes, como mostrado em detalhe na Tabela 34 a seguir. 
Tabela 34 - Resultado da pesquisa de campo. Fonte: Elaborado pela autora.

\begin{tabular}{l|c|c|c|c|c|c|c|c|c|c}
\hline Resposta & $\begin{array}{c}\text { Carrefour } \\
\text { Raposo }\end{array}$ & $\%$ & $\begin{array}{c}\text { Rio } \\
\text { Pequeno }\end{array}$ & $\%$ & Extra & $\%$ & $\begin{array}{c}\text { Ponto de } \\
\text { ônibus da } \\
\text { USP }\end{array}$ & $\%$ & $\begin{array}{c}\text { Total } \\
\text { Geral }\end{array}$ & $\%$ \\
\hline Favorável & 57 & $88 \%$ & 46 & $90 \%$ & 5 & $83 \%$ & 81 & $89 \%$ & $\mathbf{1 8 9}$ & $\mathbf{8 9 \%}$ \\
\hline Desfavorável & 6 & $9 \%$ & 3 & $6 \%$ & 1 & $17 \%$ & 3 & $3 \%$ & $\mathbf{1 3}$ & $\mathbf{6 \%}$ \\
\hline Reticente & 2 & $3 \%$ & 2 & $4 \%$ & 0 & $0 \%$ & 7 & $8 \%$ & $\mathbf{1 1}$ & $\mathbf{5 \%}$ \\
\hline Total & $\mathbf{6 5}$ & & $\mathbf{5 1}$ & & $\mathbf{6}$ & & $\mathbf{9 1}$ & & $\mathbf{2 1 3}$ & \\
\hline
\end{tabular}

Durante as entrevistas com a população da bacia constataram-se os seguintes anseios da população:

- Muitos manifestaram sua preocupação com relação à segurança pública, uma vez que os corpos d'água em áreas urbanas carregam o estigma de serem áreas degradadas do ponto de vista social;

- Foi relatada também a preocupação com a poluição das águas e se fazia parte da proposta da retirada de lixos e esgotos do canal;

- Além disso, muitos manifestaram sua preocupação com a manutenção do espaço citando como exemplo a má conservação das praças do bairro;

- Alguns relataram sua preocupação quanto ao financiamento para implantação da iniciativa; e

- Houve também questionamentos sobre a necessidade de desapropriação para a implantação do projeto.

Apesar destes anseios, todos os entrevistados favoráveis se mostraram entusiasmados com a possibilidade de uso da várzea do corpo d'água como área de lazer. Aqueles que se mostram desfavoráveis alegaram que um projeto deste tipo nunca daria certo no Brasil. Os reticentes se mostraram favoráveis a ideia, mas não tinham certeza se seria viável.

Muitos entrevistados no ponto 4, na cidade Universitária, apesar de serem moradores da bacia, desconheciam o fato de que o córrego Jaguaré estava tamponado em uma galeria subterrânea no trecho da Av. Escola Politécnica próximo à USP. 

recuperação ambiental de bacias hidrográficas em áreas urbanas através da revisão bibliográfica; Foi proposta uma metodologia para consolidação do esgotamento sanitário aliando técnicas convencionais à técnicas complementares aplicada à bacia do Jaguaré; Foi realizado o estudo das melhores medidas de controle de cargas difusas (Estruturais e não estruturais) para redução do potencial poluidor, sendo realizado uma proposta de controle aplicada à bacia do Jaguaré; Foi proposta uma metodologia para identificação da melhor técnica para requalificação do corpo d'água em função das características da bacia hidrográfica em estudo; Foi realizada a verificação da relevância da manutenção de áreas verdes em bacias hidrográficas e da importância do emprego da infraestrutura verde no controle da vazão de pico, através do estudo da bacia do Jaguaré; Foi feito um estudo junto à população visando integra-la às propostas feitas para a bacia. Por fim todos estes estudos resultaram em um plano de manejo completo para a bacia do córrego Jaguaré.

O levantamento de trabalhos sobre o tema efetuado na revisão bibliográfica apresentada neste estudo mostrou que, apesar da importância que tem o recurso água para a sociedade, no Brasil os serviços ecossistêmicos prestados pelas águas nas áreas urbanas são ainda pouco explorados, se comparado ao que já é feito em países como os EUA, Austrália e diversos outros da Europa. Nas áreas urbanas brasileiras ainda predomina a relação conflituosa entre água e sociedade.

Apesar do contexto em que estão inseridos os cursos d'água dos países desenvolvidos seja na maioria das vezes diferente do contexto a que estão expostos os cursos d'água Brasileiros, é importante observar o processo histórico dos projetos de requalificação nestes países para que possamos atingir maior eficiência nos projetos locais, uma vez que as interações básicas existentes no curso d'água são as mesmas no mundo todo, como por exemplo a relação intima entre curso d'água e bacia hidrográfica. Além disso, o fator humano é o principal responsável para que um projeto obtenha sucesso, portanto buscar entender como se deu a conciliação da população com as águas nestes projetos de sucesso é de grande importância.

A existência de poucos manuais bem consolidados baseados em técnicas LID no Brasil, que auxiliem os usuários das bacias hidrográficas na adoção de medidas que auxiliem no controle da vazão de pico e no tratamento das águas pluviais, torna 
o processo de manejo das águas urbanas ainda mais complexo.

Através do estudo de caso apresentado neste trabalho foi possível constatar quais são os principais aspectos e desafios envolvidos no processo de requalificação de bacias hidrográficas brasileiras, que vai muito além de atuar na despoluição das águas, compreende também a atuação na estrutura social, política e econômica da bacia. A questão das águas nas áreas urbanas brasileiras está intimamente ligada ao déficit habitacional e à divisão desigual de renda, que resultam na ocupação das áreas livres - no sentido de não edificadas - da cidade que na maioria das vezes são áreas de grande importância ambiental, como por exemplo, as áreas de várzea, as encostas e áreas de proteção de mananciais. A criação de uma nova cultura de gestão sustentável das águas urbanas passa antes pela resolução dos conflitos sociais, políticos e econômicos existentes dentre das cidades.

Ao longo deste trabalho esbarrou-se na falta de consenso prático na utilização de algumas terminologias quando se trata de requalificação de corpos d'água, desta forma foi realizada uma pesquisa extensa a fim de sacramentar o uso dos termos "renaturalização", "revitalização" e "recuperação", sendo obtidas definições claras para cada um destes termos a fim de auxiliar os técnicos atuantes na área de gestão das águas.

Desta forma, foi proposta uma metodologia de simples utilização para escolha do tipo de requalificação a ser adotada em um curso d'água: a renaturalização, a revitalização ou a recuperação. A metodologia proposta e os parâmetros utilizados foram obtidos com base na experiência adquirida durante a construção do presente trabalho, portanto a metodologia pode ser replicada com a utilização de parâmetros de outras fontes.

Além disso, com relação aos tipos de cargas poluidoras que afluem para os corpos d'água, apesar de existir um consenso na separação nos grupos "cargas pontuais" e "cargas difusas", dentro do grupo "cargas difusas" há no campo prático uma confusão no detalhamento dos tipos de poluentes que o compõe, desta forma foi proposto neste estudo o agrupamento destas cargas em três categorias: sedimentos, resíduos sólidos e demais cargas. Essa proposta de separação se deu 
em função da forma de geração destas cargas na bacia e do tipo de tratamento aplicado para cada caso.

Concluiu-se com este estudo que são essenciais para a requalificação de corpos d'água em bacias urbanizadas no âmbito da renaturalização, da revitalização e da recuperação o atendimento das seguintes frentes: despoluição das águas, controle do uso do solo na bacia e principalmente das áreas de várzea e requalificação das características físicas do canal. No processo de renaturalização, como se almeja alcançar o estado natural do curso d'água é necessário utilizar ferramentas que garantam a recomposição dos seus elementos naturais. No processo de revitalização, além das atividades voltadas à recuperação da qualidade das águas, é necessário entender o contexto da bacia e as demandas dos atores envolvidos no processo para que se propicie o uso múltiplo do recurso hídrico, garantindo ao processo durabilidade e efetividade. O processo de recuperação é obrigatoriamente uma etapa dos processos de renaturalização e revitalização, no entanto o grau de recuperação do curso d'água depende dos resultados paisagísticos que se deseja obter.

Verificou-se neste estudo que para despoluição das águas é essencial o controle tanto de cargas pontuais quanto difusas e para tanto são necessárias não somente técnicas que atuem na escala da bacia, mas também de técnicas que atuem na escala do lote, do bairro e da microbacia. O controle do uso do solo é de extrema importância para o controle da vazão de pico, da requalificação paisagística da bacia bem como para promover a integração da população com a água, uma vez que o uso das várzeas impacta diretamente na forma como a população irá interagir com o corpo d'água. Por fim a requalificação das características físicas do canal tem fundamental importância para o reestabelecimento das funções ecossistêmicas do mesmo e da integração paisagística e ambiental do canal, através do emprego de técnicas que recriem as funções dos antigos meandros e que requalifiquem as funções ecológicas de margens e fundo.

Diante da compreensão de que o processo de manejo das águas é multidisciplinar, neste estudo buscou-se reunir técnicas advindas de diversas áreas do conhecimento como a engenharia, a arquitetura, a gestão ambiental, a economia 
e a ecologia. Desta forma fica claro que qualquer processo de manejo de águas e requalificação de bacias hidrográficas que almeje ser bem-sucedido e que seus resultados sejam duradouros, deve ser multidisciplinar.

Por fim, como é certo que o que é cunhado na academia não deve ser tido como verdade absoluta, buscou-se junto à comunidade obter um pouco da sua percepção sobre as águas no meio urbano e também sua percepção sobre a proposta elaborada para revitalização das áreas de várzea do córrego Jaguaré. Esta experiência foi muito enriquecedora para este trabalho uma vez que expôs as fragilidades de toda ação voltada às áreas públicas urbanas: degradação social, falta de manutenção e falta de investimento público.

Este estudo teve como intuito contribuir para o melhor entendimento das técnicas envolvidas no processo de requalificação de cursos d'água em bacias hidrográficas urbanizadas, sendo sua principal contribuição a aplicação destas técnicas ao contexto brasileiro, em que o controle da carga pontual não é efetivo, há pouca integração da população na gestão das águas e há dificuldades financeiras e políticas para a execução de intervenções. Além disso, espera-se que a matriz de identificação do potencial de cursos d'água para renaturalização, revitalização e recuperação possa ser utilizada para nortear trabalhos futuros, tanto na academia quanto no campo prático, auxiliando os gestores e planejadores das águas urbanas a conceber projetos mais efetivos. 

bacias urbanas. Tese de Doutorado. Universidade de São Paulo, 2012.

Baker, S.; Eckerberg, K. - A Policy Analysis Perspective on Ecological Restoration. Ecology and Society, 18(2): 17, 2013.

Bayley, P. B. - Understanding large river: floodplain ecosystems.BioScience, 153$158,1995$.

Barbedo, A. S., Bianchi, C. G., Keller, L. R., Ortega, M. G., \& Ortega, S. E. H. Manual técnico de arborização urbana. Secretaria Municipal do Verde e do Meio Ambiente, 45, 2a Edição, 2011.

Benedict, M. A.; McMahon, E. T. Green Infrastructure - Linking Landscapes and Communities. Island Press, Washington, 2006.

Benjamin, A. M. Bacia de evapotranspiração: tratamento de efluentes domésticos e de produção de alimentos. Dissertação de mestrado apresentada à Universidade Federal de Lavras, Programa de Pós-graduação em Engenharia Agrícola, 2013.

Biomatrix - Sistema de tratamento ecológico recupera rios poluídos e cria jardins flutuantes - Disponível em:< http://planetasustentavel.abril.com.br/blog/blog-daredacao/sistema-ecologico-recupera-rios-poluidos-e-cria-jardins-flutuantes/> e <http://www.biomatrixwater.com/river-restoration/> Acessado em 31/04/2014.

Blignaut, J.; Aronson, J.; WIT, M. - The economics of restoration: looking back and leaping forward. Annals of the New York Academy of Sciences, 2014.

Brighetti, G. et al. Revestimentos de Canais e Cursos D'água. Manual Técnico. FCTH, 1999.

Brooks, S. S.; Lake, P. S. - River restoration in Victoria, Australia: change is in the wind, and none too soon. Restoration Ecology, v. 15, n. 3, p. 584-591, 2007.

Buijs, A. E. - Public support for river restoration. A mixed-method study into local residents' support for and framing of river management and ecological restoration in the Dutch floodplains. Journal of Environmental management, 90(8), 2680-2689, 2009. 
Cardoso, A.S.; Baptista, M. B. - Metodologia multicriterial para orientação de processos decisórios relativos a intervenções em cursos de água em áreas urbanas. Revista REGA - Vol. 10, no. 1, p. 51-67, jan./jun. 2013.

Cardoso, A. S.; Baptista, M. B. - Metodologia para Avaliação de Alternativas de Intervenção em Cursos de Água em Áreas Urbanas - RBRH - Revista Brasileira de Recursos Hídricos Volume 16 n.1 129-139, Jan/Mar, 2011.

Calmon, A. P. S.; Souza, J. C.; Reis,J. A. T.; Mendonça, A. S. F. - Subsídios para o Enquadramento dos Cursos de Água da Bacia Hidrográfica do Rio Itapemirim Considerando Aportes de Esgotos Sanitários. RBRH - Revista Brasileira de Recursos Hídricos, v19 n.1 -Jan/Mar, 255-270, 2014.

Cechin, A. D., \& Veiga, J. E. D. A economia ecológica e evolucionária de GeorgescuRoegen. Revista de Economia Política, v. 30, n. 3, p. 438-454, 2010.

Cengiz, B. - Urban River Landscapes. Advances in Landscape Architecture", book edited by Murat Özyavuz, ISBN, p. 978-953, 2013.

Cha, S.; Ham, Y.; Ki, S.; Lee, S.; Cho, K.; Park, Y.; Kim, J. - Evaluation of pollutants removal efficiency to achieve successful urban river restoration. Water Science \& Technology, 59.11, 2009.

Chin, A. \& Gregory, K. J. - Managing urban river channel adjustments Geomorphology 69 (2005) 28- 45 - Received 14 November 2003; received in revised form 8 September 2004; accepted 8 October 2004 Available online 13 January, 2005.

Schneider, K. - Donghao Chung, Guangzhou's Daylighted Water Refuge - Circle of blue, 2015. Disponível em < http://www.circleofblue.org/2015/world/donghao-chungd-water-refuge/> Acessado em 27/01/2017.

CONAMA 357. Resolução CONAMA n 357, de 17 de Março de 2005. Conselho Nacional do Meio Ambiente - CONAMA, v. 357, 2005.

CONAMA 377. Resolução CONAMA n 377, de 09 de outubro de 2006. Dispõe Sobre Licenciamento Ambiental Simplificado de Sistemas de esgotamento 
Sanitário. Diário Oficial da União no 195, de 10 out. de 2006, Seção 1, página 56, Brasília, DF. Disponível em: <http://www.mma.gov.br/port/conama/ legiabre.cfm?codlegi=507>, acesso em: 19 jun. 2014.

Córrego limpo - Informações, mapas, planilhas e fotos obtidas junto à coordenação do programa "Córrego Limpo" durante a elaboração da pesquisa e outras informações disponíveis em: <http://www.corregolimpo.com.br> Acessado em 18/02/2011.

Condepefi, Conselho de defesa Parque Estadual Fontes do Ipiranga - Córrego Piranungaua - Afluente do Riacho Ipiranga - antes da revitalização. Disponível em: < http://www.condepefi.sp.gov.br/noticias/80_anos_botanico/jardim_botanico_80_anos .htm>. Acessado em: 02/04/2016.

CONTEMAR - A CONTEMAR. Disponível em: <http://www.contemar.com.br/ contemar-ambiental.php>. Acesso em 10/09/2014.

Costa, R. - Impactos sobre remanescentes de florestas de mata atlântica na zona oeste da Grande São Paulo: um estudo de caso da mata da Fazenda TIZO. Dissertação de Mestrado apresentada à Faculdade de Filosofia, Letras e Ciências Humanas da Universidade de São Paulo, São Paulo, 2006.

CPRM - Serviço Geológico do Brasil - Aquíferos. Disponível em: <http://www.cprm.gov.br/publique/cgi/cgilua.exe/sys/start.htm?infoid=1377\&sid=129> . Acessado em 14/12/2014.

Cruz, Marcus Aurélio Soares; Tucci, Carlos Eduardo Morelli. Avaliação dos Cenários de Planejamento na Drenagem Urbana. Revista Brasileira de Recursos Hídricos, v. 13, n. 3, p. 59-71, 2008.

Cybis, Luiz Fernando de Abreu; Santos, Altemar Vilar dos; Gehling, Gino Roberto. Eficiência do reator sequencial em batelada (RSB) na remoção de nitrogênio no tratamento de esgoto doméstico com DQO baixa. Eng. sanit. ambient, v. 9, n. 3, p. 260-264, 2004.

DAEE, Departamento de Águas e Energia Elétrica - Governo do Estado de São 
Paulo - Equações de Chuvas Intensas do Estado de São Paulo, Convênio DAEE USP, 1999.

Das Neves, M. G. F. P.; Tucci, C. E. M. - Gerenciamento Integrado em Drenagem Urbana: Quantificação e Controle de Resíduos Sólidos, 2003.

Davis, S.N. \& Dewiest, R.J.M.. Hydrogeology - John Wiley \& Sons, 1966.

De Oliveira, e. M.; Soares, m. C.; Bonzi, r. S. - Aplicação do desenho ambiental para a bacia do córrego das corujas: Potencialidades e limitações na implantação de um parque linear. Revista LABVERDE, n. 4, p. 31-62, 2012.

Discovery life. Catálogo biológico eletrônico - Fotos de espécies utilizadas em wetlands. Disponível em: <http://www.discoverlife.org>. Acessado em 10/01/2016.

DOC. Department of Conservation. Te Papa Atawbai. Why wetlands are important. Disponível em: <http://www.doc.govt.nz/nature/habitats/wetlands/why-wetlands-areimportant/>. Acessado em 09/03/2017.

DRENURBS - Iniciativas inspiradoras - Programa DRENURBS: Uma concepção inovadora no meio urbano, Belo Horizonte - MG, 2013. Disponível em: <http://www.solucoesparacidades.com.br/wp-content/uploads/2013/09/AF_DREN NURBS_WEB.pdf> Acessado em 01/02/2016.

Duarte, C. A. M. - Influência do tipo de chuvada e da forma da encosta no escoamento superficial e processos de transporte de sedimento - Dissertação de Mestrado - Faculdade de Ciências e Tecnologia da Universidade de Coimbra, 2008.

DWSUD. Draft Water Sensitive Urban Design, Engineering Guidelines. Sedimentation Basins. Disponível em: https://www.brisbane.qld.gov.au/sites/default/files/wsud_chapt4.1_to_4.3.3_sediment ation_basins.pdf>. Acessado em 09/03/2017.

EMAE - Usina Elevatória de Traição - Disponível em: < http://www.emae.sp.gov.br /elevatorias2.htm>. Acessado em 10/05/2015.

ESA - Ecological society of America - Living in a city within a park, 2010. Disponível 
em: <http://www.esa.org/esablog/research/conservation/living-in-a-city-within-apark/>. Acessado em 26/01/2016.

Esteves, F. A. - Fundamentos de limnologia, Rio de Janeiro, 3a Edição- Editora Interciência Ltda. - 2011.

Fernandes, F. - Ainda em teste, mecanização da coleta de lixo avança. 02/2014. Disponível em: <http://myfuncity.uol.com.br/ainda-em-teste-mecanizacao-da-coletade-lixo-avanca/>. Acessado em: 15/09/2014.

Ferraz, A. - Varrição das ruas muda, mas SP é suja ou muito suja para 3 em 4 paulistanos. 09/2012. Disponível em: <http://sao-paulo.estadao.com.br/noticias/geral, varricao-das-ruas-muda-mas-sp-e-suja-ou-muito-suja-para-3-em-4-paulistanos-imp,840972>. Acessado em: 15/09/2014.

Findlay, S. J.; Taylor, M. P. - Why rehabilitate urban river systems?. Area, v. 38, n. 3, p. 312-325, 2006.

Flipper - Estações de tratamento de esgotos compactas. Disponível em: <http://www.flipper.ind.br/> Acessado em 07/02/2016.

Francis, R. A.; Hoggart, S. PG. - Urban river wall habitat and vegetation: observations from the River Thames through central London.Urban ecosystems, v. 12, n. 4, p. 465-485, 2009.

Freire, A. P.; Castro, E. C. - Análise da Correlação do uso e Ocupação do Solo e da Qualidade da Água. RBRH - Revista Brasileira de Recursos Hídricos, v 19 n.1 Jan/Mar, 41-49, 2014.

Forman, R. T. Land Mosaics: The Ecology of Landscapes and Regions. Island Press, 1995.

Galeria da Arquitetura - Projeto de recuperação do córrego do Antonico. Disponível em: <http://www.galeriadaarquitetura.com.br/projeto/mmbb-arquitetos_/projeto-urban o-corrego-do-antonico/1358> Acessado em 01/03/2016.

Gebler, L.; Louzada, J. A. S.; Bertol, I.; Ramos, R. R.; Miquelluti, D. J.; \& Schrammel, 
B. M. - Adaptação metodológica no cálculo de cargas contaminantes de fósforo em bacias hidrográficas gaúchas - Revista Brasileira de Engenharia Agrícola e Ambiental, v.16, n.7, p.769-776, 2012.

GESAD - Grupo de estudos em sistemas wetlands construídos aplicados ao tratamento de águas residuárias. Disponível em: <http://gesad.ufsc.br/> Acessado em 08/02/2016.

Global wetlands - Filtros Wetland Construídos de Fluxo Vertical - Disponível em: $<$ http://www.globalwetlands.com/pt/filtros-wetland-construidos/\#verticaal>. Acessado em 15/02/2016.

Guedes, Fátima Becker; Seehusen, Susan Edda. Pagamentos por Serviços Ambientais na Mata Atlânica: lições aprendidas e desafios. Ministério do Meio Ambiente-MMA, 2011.

Groffman, P. M.; Bain, D. J.; Band, L. E.; Belt, K. T.; Brush, G. S., Grove, J. M.; Zipperer, W. C. - Down by the riverside: urban riparian ecology. Frontiers in Ecology and the Environment, 1(6), 315-321, 2003.

Guia Ecológico - Processo de autodepuração em corpos d'água - Disponível em < http://guiaecologico.files.wordpress.com/2011/07/imagem1.jpg>. Acessado em 13/01/2014.

Hagen, D.; Svavarsdottir, K.; Nilsson, C.; Tolvanen, A. K.; Raulund-Rasmussen, K.; Aradòttir, À. L.; Halldorsson, G. - Ecological and social dimensions of ecosystem restoration in the nordic countries. Ecology and Society, 18(4), 2003.

Hargreaves. Imagens de barreiras para colonização da fauna aquatica - Disponível em: <http://www.hargreaves.com/projects/Waterfronts/ChattanoogaRenaissance/>. Acessado em 08/10/2015.

Herzog, C. P.; Rosa, L. Z. - Infraestrutura Verde: Sustentabilidade e resiliência para a paisagem urbana. Revista LABVERDE, São Paulo, n. 1, p. 92-115, sep. 2010. ISSN 2179-2275. Disponível em: <http://www.revistas.usp.br/revistalabverde/article/ view/61281/64217>. Acesso em: 26/01/2017. 
Hill, M. T.; Platts, W. S. - Ecosystem restoration: a case study in the Owens River Gorge, California. Fisheries, v. 23, n. 11, p. 18-27, 1998.

Hoffmann, H., Wolff, D. B., Platzer, C., \& da Costa, R. H. R. Propostas para o saneamento descentralizado no Brasil. ICTR 2004 - Congresso Brasileiro de Ciência e Tecnologia em Resíduos e Desenvolvimento Sustentável. Costão do Santinho, Florianópolis - Santa Catarina, 2004.

Itishk - Imagens de travessias sobre corpos d'água - Disponível em: <http://www.itishk.com/2015/03/hong-kong-wetland-park-bird-watching/>. Acessado em 08/10/2015.

Komesu, Claudia. Avifauna avistada no Parque Villa Lobos, 2012. Disponível em: <http://virtude-ag.com/pa-villa-lobos-geral-cko/> Acessado em 11/03/2017.

Kondolf, G. M. - River restoration and meanders. Ecology and Society, v. 11, n. 2, p. 42, 2006.

Kondolf, G. M.; Anderson, S.; Lave, R.; Pagano, L.; Merenlender, A.; Bernhardt, E. S. - Two decades of river restoration in California: what can we learn?. Restoration ecology, 15(3), 516-523, 2007.

LabSid - Manual Acquanet - Texto de auxílio ao usuário para utilização do LabSid AquaNet 2013. Disponível em: < http://www.labsid.com.br/arquivos.php?id=140>. Acessado em 10/01/2015.

Lee, Y. N. - Cheonggyechon restoration and urban development. 2005. Disponível em: <https://ssms.jp/wp-content/uploads/PDF/ssms2005/SMS05-002_Lee.pdf>. Acesso em 03/06/2015.

Lei $n^{\circ} 6.938$ de 31 de agosto de 1981. Dispõe sobre a Política Nacional do Meio Ambiente, seus fins e mecanismos de formulação e aplicação, e dá outras providencias. Senado Federal. Brasília, DF. V. I, 1981.

LOGA - Logística Ambiental de São Paulo - Coleta Mecanizada de Superfície. Disponível em: < http://www.loga.com.br/content.asp?CP=LOGA\&cod=1179>. 
Acessado em: 21/09/2014.

Maccaferri - MacSoil - Manual Técnico, Módulo 1 - Dimensionamento e considerações gerais. Edição Maccaferri. Disponível em <http://www.maccaferri. com.br/downloads/manuais-tecnicos/16429-1.html> Acessado em 10/11/2013.

Macedo, D. R.; Magalhães, A. P. - Percepção Social no Programa de Restauração de cursos d'água urbanos em Belo Horizonte - Sociedade \& Natureza, Uberlândia, 23 (1): 51-63, abr., 2011

Machado, A. T. G. M.; Lisboa, A. H.; Alves, C. B. M.; Lopes, D. A.; Goulart, E. M. A.; Leite, F. A.; Polignano, M. V. - Revitalização de rios no mundo: América, Europa e Ásia. Projeto Manuelzão. 1ª Edição, Instituto Guaicuy, Belo Horizonte, 2010.

Maine - Imagens de Wetlands - Disponível em: <http://www.maine.gov/dep/water/ wetlands/images/wetland-photo.jpg>. Acessado em 08/10/2015.

Martín-vide, J. P. Restoration of an urban river in Barcelona, Spain.Environmental Engineering and Policy, v. 2, n. 3, p. 113-119, 1999.

Marques, J. F.; Comunne, A. E. Quanto vale o meio ambiente: interpretações sobre o valor econômico ambiental. In: Encontro Nacional de Economia, 23., Salvador, 1995. Anais. Rio de Janeiro: Anpec, 1995. v. 1, p 633-652.

Manuel, Patricia M. - Cultural perceptions of small urban wetlands: Cases from the Halifax regional municipality, Nova Scotia, Canada. Wetlands, v. 23, n. 4, p. 921-940, 2003.

Mendes, B. \& Oliveira, J.F.S.- Qualidade da água para consumo humano - Lidel, Edições Técnicas, Lda, Lisboa - 2004.

Mendiondo, E. M.. Challenging issues of urban biodiversity related to ecohydrology.Braz. J. Biol., São Carlos, v. 68, n. 4, supl. p. 983-1002, Nov. 2008 . Available from <http://www.scielo.br/scielo.php?script=sci_arttext\&pid=S151969842008000500007\&lng=en\&nrm=iso>. access on 15 Aug. 2017. http://dx.doi.org/10.1590/S1519-69842008000500007. 
Mitsch, W. J.; Day JR, J. W. - Restoration of wetlands in the Mississippi-OhioMissouri (MOM) River Basin: Experience and needed research. Ecological Engineering, v. 26, n. 1, p. 55-69, 2006.

MDEQ NPS BMP Manual. Sediment Basin. https://www.michigan.gov/documents/ deq/nps-sediment-basin_332133_7.pdf>. Acessado em: 05/03/2017.

Monteiro, M.D.; Gurgueira, M.D.; Rocha, H.C. - Geologia da região metropolitana de São Paulo. In Twin Cities - Solos das cidades de São Paulo e Curitiba. ABMS, São Paulo, 2012.

Moura, Newton Celio Becker ; Pellegrino, Paulo Renato Mesquita ; Martins, José Rodolfo Scarati . Transição em infraestruturas urbanas de controle pluvial: uma estratégia paisagística de adaptação às mudanças climáticas. Paisagem e Ambiente, v. 1, p. 107-128, 2014.

Nakamura, K.; Tockner, K.; Amano, K. - River and wetland restoration: lessons from Japan. BioScience, v. 56, n. 5, p. 419-429, 2006.

Nam-choon, K. - Ecological restoration and revegetation works in Korea. Landscape and Ecological Engineering, v. 1, n. 1, p. 77-83, 2005.

NBR9649 - Projeto de rede coletora de esgoto, 1986.

Newson, M. D.; Large, A. R. G. - 'Natural' rivers, 'hydromorphological quality' and river restoration: a challenging new agenda for applied fluvial geomorphology - Earth Surface Processes and Landforms - Earth Surf. Process. Landforms 31, 1606-1624, 2006.

Nilsson, C; Aradóttir, Á. L. - Ecological and social aspects of ecological restoration: new challenges and opportunities for northern regions. Ecology \& society, v. 18, n. 4, p. 35, 2013.

Novotny, V.; Olem, H. - Water quality: Prevention, identi fication and management of diffuse pollution - New York: Van Nostrand Reinhold, 1994.

Novotny, V. - Integrating diffuse/nonpoint pollution control and water body restoration 
into watershed management1. Journal of the American Water Resources Association, volume 35, issue 4, 717-727, 1999.

Novotny, V. - Water quality: Diffuse pollution and watershed management $-2^{\mathrm{a}}$ Edição - New York: J. Wiley, 2003.

Otanabee - Imagens de córregos revitalizados - Disponível em: $<$ http://www.otonabee.com/otonabee-conservation-launches-peterborough-urbanshoreline-project/> Acessado em 08/10/2015.

Otto,B.; McCormick, K.; Leccese, M. - Ecological Riverfront Design:Restoring Rivers, Connecting Communities - American Planning Association Planning Advisory Service Report Number 518-519, 2004.

Palmer, M. A., Bernhardt, E. S., Allan, J. D., Lake, P. S., Alexander, G., Brooks, S., Sudduth, E. - Standards for ecologically successful river restoration. Journal of applied ecology, v. 42, n. 2, p. 208-217, 2005.

Palmer, M. A.; Bernhardt, E. S. - Hydroecology and river restoration: Ripe for research and synthesis. Water Resources Research, v. 42, n. 3, 2006.

Palmer, M.; Allan, J. D.; Meyer, J.; Bernhardt, E. S. - River restoration in the twentyfirst century: data and experiential knowledge to inform future efforts. Restoration Ecology, 15(3), 472-481, 2007.

Palmer, M. A.; Menninger, H. L.; Bernhardt, E. S. - River restoration, habitat heterogeneity and biodiversity: a failure of theory or practice?. Freshwater biology, v. 55, n. s1, p. 205-222, 2010.

PDESP - Plano Diretor Estratégico de São Paulo, 2014. Disponível em: <http://gestaourbana. prefeitura.sp.gov.br/marco-regulatorio/plano-diretor/>. Acessado em 13/02/2017.

PDMAT3 - Terceiro Plano Diretor de Macrodrenagem da Bacia do Alto Tietê, 2013. Disponível em: < http://www.daee.sp.gov.br/index.php?option=com_content\&view=ar ticle\&id=1364\&ltemid=77>. Acessado em 10/01/2016. 
Pearce, D. W.; Turner, R. K. Economia dos Recursos Naturais e o Meio Ambiente. 2. ed. Baltimore: Johns Hopkins Univ. Press, 1990.

Pereira, A. L. - Princípios da restauração de ambientes aquáticos continentais. Boletim da Associação Brasileira de Limnologia, 39(2), 1-21, 2001.

Pereira, I. L. V. - Estudos de Revitalização de Cursos de Água - Trecho Experimental no Rio das Velhas. Dissertação de mestrado apresentada ao Programa de Pós-graduação em Saneamento, Meio Ambiente e Recursos Hídricos da Universidade Federal de Minas Gerais, 2008.

Pereira, M. C. S. - Relação de eficiência e custos dos reservatórios de detenção e pavimento permeável na bacia hidrográfica do rio Pirajussara. Dissertação de mestrado apresentada para o programa de pós graduação em engenharia civil da Escola Politécnica da Universidade de São Paulo, 2014.

Petts, J. - Learning about learning: lessons from public engagement and deliberation on urban river restoration. The Geographical Journal, v. 173, n. 4, p. 300-311, 2007.

PGIRSSP - Plano de gestão integrada de resíduos sólidos da cidade de São Paulo, 2014 - Plano de gestão integrada de resíduos sólidos da cidade de São Paulo. Disponível em: <http://www.prefeitura.sp.gov.br /cidade/secretarias/upload/servicos/ arquivos/PGIRS-2014.pdf>. Acessado em 15/04/2015.

Philippi, L., Sezerino, P., Olijnyk, D. P., \& Kossatz, b. - Eficácia dos sistemas de tratamento de esgoto doméstico e de água para consumo humano utilizando wetlands considerando períodos diferentes de instalação e diferentes substratos e plantas utilizados. Relatório Final. Florianópolis: Universidade Federal de Santa Catarina, Grupo de Estudos em Saneamento Descentralizado, 2007.

Pinheiro, A \& Deschamps, F. C. - Transporte de ortofosfato e de nitrato na microbacia do Ribeirão da Fortuna, SC. Revista Brasileira de Engenharia Agrícola e Ambiental, v.12, n.3, p.318-325, 2008.

Pocinho, Margarida. Estatística II - Teoria e exercícios passo a passo, 2010 Disponível em:< http://docentes.ismt.pt/ m_pocinho/Sebenta_estatistica_II_com_ 
anexos_2010.pdf> - Acessado em 18/02/2017.

Poleto, C. \& Martinez, L. L. G. - Sedimentos Urbanos: Ambiente e Água - Holos Environment, v.11, n.1, 2011.

Poleto, C. - SUDS (Sustainable Urban Drainage Systems): Uma Contextualização Histórica. Revista Thema, v. 8, n. 1, 2011.

Porto, M. F. - Aspectos qualitativos do escoamento superficial em áreas urbanas. Tucci, C. E. M; Porto, R. L.; Barros, M. T. B. (Org.). Drenagem Urbana. In:. Porto Alegre: ABRH e Editora da UFRGS, 1995 - 387-414p.

Porto, R. M. . Hidráulica Básica 4a edição. 4. ed. São Paulo: Rettec Gráfica e Editora, 2006. v. 2500. 529 p.

Postel, S. L., and Barton H. T. - Watershed protection: Capturing the benefits of nature's water supply services. Natural Resources Forum. Vol. 29. No. 2. p. 98-108. Blackwell Publishing, Ltd., 2005.

PMSP, Prefeitura do Município de São Paulo - Tabelas de custo - Disponível em: <http://www.prefeitura.sp.gov.br/cidade/secretarias/infraestrutura/tabelas_de_custos/ index.php?p=215107> Acessado em 20/04/2016.

PMSP, Prefeitura do Município de São Paulo - Dados Demográficos dos Distritos pertencentes as Subprefeituras. Disponível em: $<$ http://www.prefeitura.sp.gov.br/cidade/secretarias/subprefeituras /subprefeituras/dados_demograficos/index.php?p=12758>. Acesso em: 15/09/2014.

PMSP, Prefeitura do Município de São Paulo - Histórico. Disponível em: < http://www.prefeitura. sp.gov.br/cidade/secretarias/subprefeituras/butanta/historico/>. Acesso em: 15/09/2014.

PMSP - Projeto de Lei dos Planos Regionais Estratégicos das Subprefeituras e da Disciplina do Uso e Ocupação do Solo do Município de São Paulo, Fevereiro de 2014.

Projeto Arroyo Dilúvio. Informações sobre o projeto disponíveis em: 
$<$ http://www.ufrgs.br/arroiodiluvio>.

Ramsar - Imagens de decks em projetos de wetlands - Disponível em: <http://ramsar.rgis.ch/cda/en/ramsar-media-sites-photo-essay-some-17053/main/ ramsar/1-25-34\%5E17053_4000_0_>. Acessado em 08/10/2015.

SABESP - Companhia de Saneamento Básico da Estado de São Paulo - Relatório de sustentabilidade 2014. Disponível em: < http://site.sabesp.com.br/uploads /file/sociedade_meioamb/rs_2014.pdf>. Acesso em 10/08/2015.

SAISP, Sistema de Alerta a Inundações de São Paulo - Histórico de precipitação para Zona Oeste no período de janeiro de 2007 a março de 2012 - FCTH Fundação Centro Tecnológico de Hidráulica.

Salati, Eneas; Salati Filho, Eneas; Salati, Eneida. Utilização de sistemas de wetlands construídas para tratamento de águas. Biológico, São Paulo, v. 65, n. 1/2, p. 113116, 2003.

Samuel, P. R. da S. Alternativas sustentáveis de tratamento de esgotos sanitários urbanos, através de sistemas descentralizados, para municípios de pequeno porte. Dissertação de mestrado apresentada na Escola de Engenharia da Universidade Federal do Rio Grande do Sul, 2011.

Seidl, R.; Stauffacher, M. - Evaluation of river restoration by local residents. Water Resources Research, v. 49, n. 10, p. 7077-7087, 2013.

Silva, J. C. A.; Porto, M. F. A. . Estudo da influência do tipo de tratamento de canais sobre a qualidade ambiental de corpos d'água. Córrego Ibiraporã e do Sapé. $X$ Encontro Nacional de Águas Urbanas, 2014, São Paulo.

Silva, J. C. A.; Porto, M. F. D. A. - Recuperação de córregos urbanos através do controle de cargas pontuais e Difusas. Córrego Ibiraporã, SP. RBRH - Revista Brasileira de Recursos Hídricos, v20 n.1 -Jan/Mar 2014.

Silva, J. C. A.; Porto, M. F. D. A.; Brandimarte, A. L.; Martins, J. R. S. - Utilização de índices físicos, químicos e biológicos para avaliação da qualidade de corpos d-água em processo de recuperação - Córrego Ibiraporã, SP. RBRH - Revista Brasileira de 
Recursos Hídricos, v20 n.4 - Out/Dez 2015.

Silva, R. T.; Porto, M. F. D. A. - Gestão urbana e gestão das águas: caminhos da integração. Estudos Avançados, v. 17, n. 47, p. 129-145, 2003.

SMA/PRIME ENGENHARIA - Diagnóstico Limnológico e ecológico do reservatório do Guarapiranga. Relatório Síntese. 93p, 2015.

SVMA. Avifauna do Parque Tizo. Disponível em: <http://arquivos.ambiente.sp.gov.br /parquejequitiba/2012/03/avifauna.pdf> Acessado em 11/03/2017.

SNIS - Sistema Nacional de Informações de Saneamento - Diagnóstico dos Serviços de Água e Esgoto 2013. Disponível em: <http://www.snis.gov.br/diagnostico-agua-eesgotos/diagnostico-ae-2013>. Acesso em 10/08/2015.

Souza, V. C. B. Goldenfum, J. A. - "Trincheiras de infiltração como controle de escoamento superficial: um estudo experimental”, 2000.

Stromberg, J. C. - Restoration of riparian vegetation in the south-western United States: importance of flow regimes and fluvial dynamism.Journal of Arid Environments, 49(1), 17-34, 2001.

Teixeira, C. A.; Porto, R. L. L. - Modelo matemático para gerenciamento de quantidade e qualidade da água em rios. Um estudo de caso: bacia do rio piracicaba. Revista de ciências ambientais, v. 2, n. 2, p. p. 79-104, 2008.

Tetra Tech - Los Angeles River Revitalization Master Plan, 2007.

Tomaz, P. Livro: Poluição Difusa - Editora Navegar - São Paulo - $1^{\text {a }}$ Edição Publicação: 2006. Cap. 3.

Tomaz, P. - Livro: Cálculos hidrológicos e hidráulicos para obras municipais: piscinões, galerias, bueiros, canais; métodos SCS, Denver, Santa Bárbara, Racional, TR-55. Navegar, 2002.

TNEPSC. Tennessee Erosion Prevention and Sediment Control. Exemplo de bacia de sedimentação no Tennessee. Disponível em: <http://tnepsc.org/page.asp?ID=5>. 
Acessado em: 08/03/2017.

Tonetti, A. L., Coraucci Filho, B., Bertoncini, E. I., Oliveira, R. A., \& Stefanutti, R. (2010). Avaliação de um sistema simplificado de tratamento de esgotos visando a utilização em áreas rurais. Revista Brasileira de Engenharia Agrícola e Ambiental, v. 14, n. 2, p. 227-234, 2010.

Travassos, L.; Schult, S. I. M. - Recuperação socioambiental de fundos de vale urbanos na cidade de São Paulo, entre transformações e permanências. Cadernos Metrópole. ISSN (impresso) 1517-2422;(eletrônico) 2236-9996, v. 15, n. 29, p. 289312, 2013.

Trein, C. M., Pelissari, C., Hoffmann, H., Platzer, C. J., \& Sezerino, P. H. Tratamento descentralizado de esgotos de empreendimentos comercial e residencial empregando a ecotecnologia dos wetlands construídos. Ambiente Construído, v. 15, n. 4 , p. 351-367, 2015.

Tucci, Carlos EM. Águas urbanas. Estudos avançados, v. 22, n. 63, p. 97-112, 2008.

Tucci, C. M. - Drenagem Urbana - Editora da Universidade - UFRGS, Porto Alegre, 1995.

UACDC - LID, Low Impact Development a design manual for urban areas. UACDC, Fayetteville, Arkansas, 2010 http://uacdc.uark.edu.

UDFCD. Urban Drainage and Flood Control District. Urban Storm Drainage Criteria Manual Volume 3. Disponível em <http://udfcd.org/wpcontent/uploads/2014/07/Chapter-2-BMP-Selection.pdf>. Acessado em: 09/03/2017.

UFPE - Agência de notícias da UFPE - " Bem-vindo ao futuro Parque Capibaribe". Disponível em: <https://www.ufpe.br/agencia/clipping/index.php?option=com_content \&view=article\&id=16767: bem-vindo-ao-futuro-parque-capibaribe\&catid=34\&Itemid $=122>$. Acessado em 05/02/2016.

USDA. United States Department of Agriculture. Natural Resources Conservation Service Conservation. Practice Standard. Sediment Basin. Disponível em: <https://www.nrcs.usda.gov/Internet/FSE_DOCUMENTS/nrcs143_025942.pdf>. 
Acessado em: 08/03/2017.

USEPA, United States Environmental Protection Agency, National Management Measures to Control Nonpoint Source Pollution from Agriculture, EPA 841-B-03-004, 2003.

USEPA, United States Environmental Protection Agency - Texto: Wet Ponds Disponível em:< http://cfpub.epa.gov/npdes/stormwater/menuofbmps/index.cfm? action=factsheet_results\&view=specific\&bmp=68> Acessado em 31/10/2012.

USEPA, United States Environmental Protection Agency - Storm Water Management Model (SWMM) - Disponível em: <https://www.epa.gov/waterresearch/storm-water-management-model-swmm> Acessado em 27/02/2016.

Urbanisten - "Water Squares" - Disponível em <http://www.urbanisten.nl/wp/?port folio=waterpleinen $>$.Acesso em 02/11/2012.

Walsh, C. J.; Fletcher, T. D.; Ladson, A. R. - Stream restoration in urban catchments through redesigning stormwater systems: looking to the catchment to save the stream. Journal of the North American Benthological Society, v. 24, n. 3, p. 690-705, 2005.

Ward, J. V., Tockner, K., Uehlinger, U., \& Malard, F. - Understanding natural patterns and processes in river corridors as the basis for effective river restoration. Regulated Rivers: Research \& Management, 17(4-5), 311-323, 2001.

WIDNR. Wisconsin Department of Natural Resources. Sediment Basin. Disponível em <http://dnr.wi.gov/topic/stormWater/documents/SedimentBasin_1064.pdf>. Acessado em: 09/03/2017.

Yamamoto, Y. - Measures to mitigate urban heat islands. Science and Technology Trends Quarterly Review, v. 18, n. 1, p. 65-83, 2006. 


\section{Capítulo 7}

\section{Anexos}

\section{ANEXO I \\ Percepção da população sobre a água no ambiente urbano}

* Required
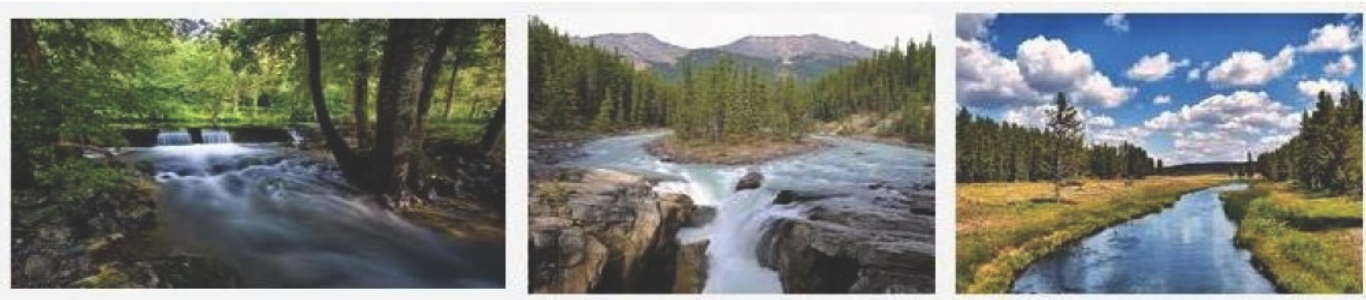

Os rios são fonte de um dos recursos naturais vitais aos seres vivos: a água, que é utilizada em larga escala pela população em abastecimento público, industrial, comercial, agrícola e para a geração de energia.

Ou seja, dependemos da água para viver, no entanto muitas vezes nos esquecemos do quanto ela é essencial para nossa sobrevivência, o que se reflete na situação atual dos nossos rios e nascentes.

Pensando nisso, esse formulário busca dados que ajudem a solucionar esta questão.

\section{Questionário sócio econômico:}

1) Qual a sua faixa etária? *

Até 17 anos.

De 18 a 24 anos.

- De 25 a 35 anos.

De 36 a 50 anos.

A partir de 51 anos.

2) Qual o seu sexo? *

$\bigcirc$ Feminino

Masculino

3) Qual a faixa de renda mensal por pessoa em sua família? *

Até um salário mínimo (R\$ 724,00).

Mais de 1 até 3 salários mínimos (R\$ 724,00 até $R \$ 2.172,00$ ).

Mais de 3 até 6 salários mínimos ( $R \$ 2.172,00$ até $R \$ 4.344$ ).

Mais de 6 até 10 salários mínimos ( $R \$ 4.344,00$ até $R \$ 7.240,00$ ). 


\title{
4) Qual seu grau de escolaridade? *
}

Nenhuma escolaridade.

Ensino fundamental completo.

Ensino médio completo.

Ensino superior completo.

Pós-graduação completo.

5) Qual sua área profissional? *

Exatas.

Humanas.

Biológicas (Área da saúde).

Biológicas (Outras Áreas).

Other:

\section{Questionário específico:}

\author{
6) Há quantos anos você reside em seu bairro atual? * \\ De 0 a 5 anos. \\ De 6 a 15 anos. \\ De 16 a 34 anos. \\ Mais de 35 anos.
}

7) Há algum rio próximo da área em que você reside? *

Sim

Não

8) Se sim, em qual estado o rio se encontra?

Limpo (Apropriado para a natação, esqui aquático, e mergulho).

Levemente poluído (Apesar de poluído não exala mau cheiro e ainda é possível observar vida aquática - peixes, aves, tartarugas, etc).

Moderadamente poluído (Exala mau cheiro, e já não é mais possível observar vida aquática peixes, aves, tartarugas, etc).

$\bigcirc$ Gravemente poluído (Exala mau cheiro e apresenta aspecto visual de esgoto sanitário).

9) Você gosta ou gostaria de morar próximo a um rio? *

Sim

Não

10) Se sim, por quê?

Você pode escolher mais de uma alternativa!

Valorização paisagística (Ter vista para o rio). 
Valorização Imobiliária.

Presença da fauna/flora (Pássaros, peixes, vegetação, etc).

Melhor qualidade do ar.

Other:

\section{1) Se não, por quê?}

Você pode escolher mais de uma alternativa!

Enchentes.

Transmissão de doenças.

Presença de animais indesejados (Mosquitos, baratas, etc).

Mau cheiro.

Violência (Uso do local para assaltos, uso de drogas, etc).

Other:

12) Considerando um rio que corta uma cidade, pensando no seu estilo de vida e em suas preferências, qual das realidades descritas abaixo mais o agrada? *

Um rio a céu aberto, onde suas margens possuem largas avenidas.

Um rio conservado e reservado de intervenção humana rodeado por parques sem acesso a população.

Um rio que corta um parque com área verde, usado para recreação e lazer da população.

Um rio oculto e totalmente coberto por canteiro central com vegetação.

13) Na sua opinião qual o PRINCIPAL fator responsável pela situação atual dos rios nas grandes cidades? *

O fato de utilizarmos o rio como canal de escoamentos dos esgotos da cidade.

A inexistência da tecnologia necessária para os projetos de saneamento.

A falta de investimento do governo em saneamento ambiental.

A construção de edificações no entorno dos rios.

A falta de recursos financeiros para que as obras sejam executadas.

Other:

14) Canalizações fechadas são aquelas em que o rio fica totalmente oculto na paisagem, através de galerias subterrâneas. Você acredita que esta é uma boa metodologia considerando a situação atual dos rios em sua cidade? *

Sim, este método é excelente para que haja o máximo aproveitamento das áreas nas cidades. (Canteiros centrais com vegetação, praças, etc).

Sim, pois diminui a transmissão de doenças e animais indesejados (Ratos, baratas, mosquitos, etc).

Não, porque altera a paisagem e as características naturais do rio.

Não, porque o rio possui diferentes formas de uso que são vantajosas para população (Recreação, valorização paisagística, etc).

Other:

15) Considerando a questão anterior, se o rio em avaliação fosse limpo, sua opinião seria 
a mesma? *

Sim

Não

16) Você sabia que grande parte das principais avenidas da cidade de São Paulo (Avenida Nove de Julho, Bandeirantes e Pacaembu) foram criadas em cima de rios que foram canalizados em galerias subterrâneas? *

Sim

Não

17) Considerando o caso dos rios citados na questão anterior, se houvesse um projeto para traze-los de volta à paisagem, ou seja, transformar esses rios subterrâneos em rios abertos novamente, dentro de um contexto que priorizasse o uso do espaço pela população, você seria a favor? *

Sim

Não

Se não, por quê?

18) Considerando a situação atual dos rios de sua cidade, se houvesse uma hidrovia para transporte de pessoas, você a utilizaria? *

Sim

Não

Se não, por quê?

19) Você acredita que os projetos de educação ambiental influenciam nas atitudes da população? *

Sim, o conhecimento adquirido nesses projetos levaria a população à ter atitudes mais conscientes.

Não, apesar dos projetos serem importantes, cabe primeiramente ao governo implantar obras estruturais (Recuperação dos rios, parques, lixões, etc). Assim a população zelaria pelos patrimônios públicos e naturais.

Other:

20) Na sua opinião, as enchentes ocorrem devido a(o): * Você pode escolher mais de uma alternativa!

Mau investimento do governo em obras para melhorias no sistema de drenagem das águas de chuva.

Grande quantidade de lixo gerado e mal descartado pela população, que acaba entupindo os sistemas de drenagem.

Chuvas atípicas que não estavam previstas no projeto.

Impermeabilização do solo (a parcela da água que deveria infiltrar no solo, escorre pela ruas, aumentando assim o volume de água que vai para os rios).

Other:

\section{Obrigado por sua participação!}

\section{Submit}

Never submit passwords through Google Forms. 